\title{
DIMENSÕES JURÍDICAS DA PROTEÇÃO DA VIDA E O ABORTO DO FETO ANENCÉFALO
}

\author{
DISSERTAÇÃO DE MESTRADO \\ ORIENTADOR: Prof. Associado Dr. André de Carvalho Ramos
}

UNIVERSIDADE DE SÃO PAULO

FACULDADE DE DIREITO

São Paulo

2012 
DANIELA BUCCI OKUMURA

Dimensões Jurídicas da Proteção da Vida e o Aborto do Feto Anencéfalo

Dissertação apresentada à Faculdade de Direito da Universidade de São Paulo, sob a orientação do Prof. Associado Dr. André de Carvalho Ramos, como exigência parcial para obtenção do título de Mestre em Direitos Humanos.

\section{São Paulo}


Bucci Okumura, Daniela.

Dimensões Jurídicas da Proteção da Vida e o Aborto de Feto Anencéfalo / Daniela Bucci Okumura; orientador André de Carvalho Ramos. - São Paulo, 2012.

$303 \mathrm{f}$.

Dissertação (Mestrado) - Faculdade de Direito da Universidade de São Paulo, 2012.

1. Aborto. 2. Anencefalia. 3. Constituição. 4. Direitos Fundamentais. 5. Direitos Humanos. I. Carvalho Ramos, André de. II. Dimensões Jurídicas da Proteção da Vida e o Aborto de Feto Anencéfalo. 


\section{FOLHA DE APROVAÇÃO}

Nome: BUCCI OKUMURA, Daniela.

Título: Dimensões Jurídicas da Proteção da Vida e o Aborto de Feto Anencéfalo.

Dissertação apresentada à Faculdade de Direito da Universidade de São Paulo, sob a orientação do Prof. Associado Dr. André de Carvalho Ramos, como exigência parcial para obtenção do título de Mestre em Direitos Humanos.

Aprovada em:

Banca Examinadora

Prof. Dr. Instituição:

Julgamento: Assinatura:

Prof. Dr. Instituição:

Julgamento: Assinatura:

Prof. Dr. Instituição: Assinatura: 


\section{DEDICATÓRIA}

Dedico o presente trabalho ao meu pai, Nelson Bucci (in memoriam), por tudo. 


\section{AGRADECIMENTOS}

Ao Professor Associado Doutor André de Carvalho Ramos, meu orientador, pela generosidade de partilhar sua vasta cultura jurídica, pelos valiosos ensinamentos, e pelo incentivo constante, meu eterno agradecimento.

Ao Professor Associado Doutor Geraldo Miniuci Ferreira Junior e ao Professor Doutor Guilherme Assis de Almeida, pelas orientações durante a Banca de Qualificação e ao longo do curso.

Aos Professores Claudio Cohen, Eduardo Carlos Bianca Bittar, Reinaldo Ayer de Oliveira, Virgílio Afonso da Silva, e Wagner Menezes pelas aulas, reflexões, e conversas.

Aos funcionários da Faculdade de Direito da Universidade de São Paulo, do Departamento de Direito Internacional e da Secretaria de Pós-graduação, especialmente ao Claudia Regina Koga, Fernanda de Jesus Santos Targino, Maria de Fátima Silva Cortinha, Mário Sérgio de Oliveira e Silva, e Mário Paulino, pela presteza e cordialidade de sempre.

Aos amigos Alessandra Cristina Guedes Pellini, Daniel Kalansky, David Olson, Denise Carvalho, Dirce Massaoka Okumura, Jefferson Nascimento, Karen Bucci, Maria Okumura, e Vicente Gomes de Oliveira Filho, pelas relevantes informações para a pesquisa.

Aos amigos Águida Arruda Barbosa, José Blanes Sala e Luís Renato Vedovato pelo incentivo e pelo exemplo.

A todos os amigos da São Francisco, especialmente, Edinaldo César Santos Júnior, Rafael Santos Morais, Luiz Fabrício Vergueiro, Eloísa Machado, Guilherme Madeira, Anamara Osório, e Luis Pardí, pela companherismo diário e profícuas discussões.

Ao amigo Coordenador do Curso de Direito da Universidade Municipal de São Caetano do Sul, Professor Doutor Vander Ferreira de Andrade, pela oportunidade de conduzir as atividades do Observatório de Direitos Humanos da universidade.

Aos alunos e ex-alunos do Observatório de Direitos Humanos da Universidade Municipal de São Caetano do Sul, pelo reconhecimento, apoio, e entusiasmo.

À minha família, especialmente minha mãe, Edna, e minha sogra, Dag, e também à minha grande amiga Lilian Garcia, por compreenderem minhas ausências constantes.

Ao meu marido, Andre, agradeço imensamente pelo amor, apoio, e encorajamento incondicionais, e por servir de exemplo de cárater, disciplina, e determinação. 
Agregado infeliz de sangue e cal, Fruto rubro de carne agonizante, Filho da grande força fecundante De minha brônzea trama neuronial

Que poder embriológico fatal Destruiu, com a sinergia de um gigante, A tua morfogênese de infante,

A minha morfogênese ancestral?!

Porção de minha plásmica substância, Em que lugar irás passar a infância, Tragicamente anônimo, a feder?!...

Ah! Possas tu dormir feto esquecido, Panteisticamente dissolvido Na noumenalidade do NÃO SER!

\section{Augusto dos Anjos}

Soneto dedicado ao primeiro filho, nascido morto, com 7 meses incompletos, em 2 fevereiro 1911. 


\section{RESUMO}

BUCCI OKUMURA, Daniela. Dimensões Jurídicas da Proteção da Vida e o Aborto do Feto Anencéfalo. 2012. 314 f. Dissertação (Mestrado) - Faculdade de Direito, Universidade de São Paulo, São Paulo, 2012.

A constitucionalidade de abortar-se um feto anencéfalo foi, durante vários anos, controversa no Brasil, e não havia uniformidade nas decisões judiciais a respeito do tema, até o Supremo Tribunal Federal (STF) responder ao questionamento, quando do julgamento da Arguição de Preceito Fundamental (ADPF) 54. A solução tomada foi favorável ao direito de a gestante abortar a gravidez de feto anencáfalo, mas também foi particularmente difícil em vista dos direitos humanos e fundamentais em conflito no caso. Neste contexto, a dissertação analisa o que é anencefalia, como a legislação e a doutrina têm entendido o aborto do feto anencéfalo, o conceito de vida, o direito à vida, e suas dimensões vertical e horizontal, e objetiva e subjetiva, apontando interpretações aplicáveis à restrição do direito à vida em face de outros direitos fundamentais, especialmente, do direito à dignidade da pessoa humana, à saúde, à autonomia individual, à liberdade, à integridade física e psíquica, e aos direitos reprodutivos da mulher. O Direito Internacional dos Direitos Humanos é essencial ao se interpretar o direito à vida e outros direitos fundamentais, e a dissertação aborda também como tratados internacionais de direitos humanos são incorporados ao ordenamento brasileiro. A dissertação elenca as principais jurisprudências, doutrinas, e soluções adotadas no plano internacional com relação ao aborto em geral e à proteção dos direitos fundamentais em conflito. Analisa como interpretar-se a lei em situações de conflitos de princípios e direitos fundamentais, destacando limites imanentes, sopesamento e proporcionalidade. Comenta o papel que cabe ao Judiciário no estado democrático de direito, especialmente com relação à efetivação dos direitos humanos. Propõe quatro modelos possíveis de interpretação constitucional sobre o aborto do feto anencéfalo: $\mathrm{O}$ modelo da proibição absoluta interpreta a Constituição como garantindo o direito à vida absolutamente; o modelo da livre disposição defende que a Constituição garante a liberdade da mulher de dispor do próprio corpo, também absolutamente; o modelo da liberdade limitada, que parte da premissa da prevalência da liberdade de escolha da mulher, que só pode ser restringida de modo que não seja arbitrário; e o modelo da exceção permitida, que parte da premissa da primazia da vida, que só pode ser limitada em situações razoáveis, após cuidadoso sopesamento e ponderação dos princípios envolvidos. A dissertação segue com um teste de consistência dos modelos sugeridos, com base nos argumentos que o STF utilizou no julgamento da ADPF 54 e da Ação Direta de Inconstitucionalidade (ADI) 3510, que versou sobre a lei que regulamenta pesquisas com células-tronco embrionárias humanas. Conclui-se pelo modelo da exceção permitida em vista das evidências apresentadas de que, no Brasil, a análise constitucional geralmente parte do pressuposto de que o direito à vida deve ter primazia sobre os demais direitos fundamentais, podendo, apenas excepcionalmente, ser limitado, e de modo razoável e proporcional às circunstâncias fáticas. Finalmente, sugerem-se medidas que o Legislativo poderia tomar visando à maior efetivação possível dos direitos fundamentais em conflito no caso.

Palavras-chave: Aborto. Anencefalia. Constituição. Direitos Fundamentais. Direitos Humanos. 


\begin{abstract}
BUCCI OKUMURA, Daniela. Legal Dimensions of Protection of Life and Abortion of Anencephalic Fetus. 2012. 314 f. Dissertação (Mestrado) - Faculdade de Direito, Universidade de São Paulo, São Paulo, 2012.

The constitutionality of aborting an anencephalic fetus in Brazil has been, for many years, surrounded by controversy, and there was no case law uniformity on the matter until the Supreme Federal Court ("STF") ruled the issue in the Claim of Breach of Fundamental Precept 54 ("ADPF 54"). The solution to the case was favorable to the right of women to abort anencephalic fetuses, but it was also particularly difficult in view of the conflicting human and fundamental rights involved. Within this context, this dissertation analyses what is anencephaly, how the law and jurisprudence have been treating the abortion of the anencephalic fetus, the definition of life, the right to life and its vertical-horizontal and objective-subject dimensions, pointing out constructions applicable to the restriction of the right to life in view of other fundamental rights, in particular, the right to dignity of human person, the right to health, to the individual autonomy, to liberty, to physical and mental integrity, and to the reproductive rights of women. As the International Human Rights Law is essential to construe the right to life and other fundamental rights, this dissertation also addresses how international human rights treaties are incorporated into the Brazilian legal system. This dissertation also gathers the most important international case law, jurisprudence, and solutions regarding abortion in general and the competing protections of fundamental rights. It reviews how the law should be construed in cases involving conflicting fundamental rights, with focus on immanent limitations, balancing of principles, and proportionality analysis. It further comments the role of courts in a democracy rooted in the rule of law, specially in connection with the implementation of human rights. Furthermore, it proposes four models of constitutional interpretation on the abortion of the anencephalic fetus: The model of absolute prohibition of abortion, through which the Constitution is construed to protect the right to life absolutely; the model of free control over one's own body, which asserts that the Constitution protects the right of women to control their own bodies absolutely; the model of abortion as a limitable freedom, which starts with the premise of the prevalence of the freedom of choice of women, but acknowledges that such freedom may be restricted in certain cases, provided it is not restricted in an arbitrary way; and the model of abortion as a permitted exception, which starts with the premise of the preeminence of the right to life, which may only be limited in reasonable circumstances, after a careful balancing and weighing the competing principles involved. This dissertation progresses with a test of consistency of the suggested models, based on the arguments the STF used in the rulings of the ADPF 54 and of the Direct Claim of Unconstitutionality (ADI) 3510, which debated the law regulating human embryonic stem cells research. The analysis concludes for the model of the abortion as a permitted exception, by virtue of the evidences that, in Brazil, the constitutional construction generally starts with the premise that the right to life shall take precedence over the other fundamental rights, but that it may be exceptionally limited in a way that is reasonable and proportional to the actual circumstances. Finally, the dissertation suggests legislative measures that may be taken to protect society through guarantees aiming at the greatest possible effectiveness of the competing fundamental rights involved in the case.
\end{abstract}

Keywords: Abortion. Anencephaly. Constitution. Fundamental Rights. Human Rights. 


\section{SUMÁRIO}

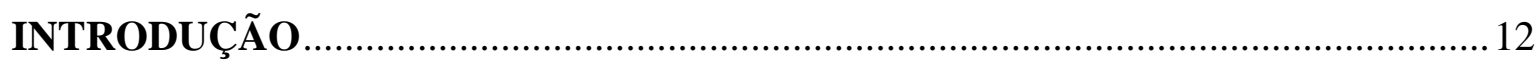

PARTE I - PROTEÇÃO DA VIDA E O ABORTO......................................................15

1 O DIREITO À VIDA E SEUS DIVERSOS SENTIDOS.............................................. 15

2 DIMENSÕES VERTICAL E HORIZONTAL DO DIREITO À VIDA E SUA PROTEÇÃO NO DIREITO NO DIREITO INTERNACIONAL ..................................25

3 RESTRIÇÕES OU LIMITES À VIDA EM RAZÃO DA EXISTÊNCIA DE

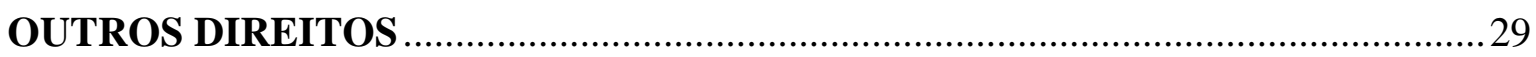

3.1 INTERPRETAÇÕES OBSERVADAS QUANTO AO ÂMBITO DE PROTEÇÃO DO

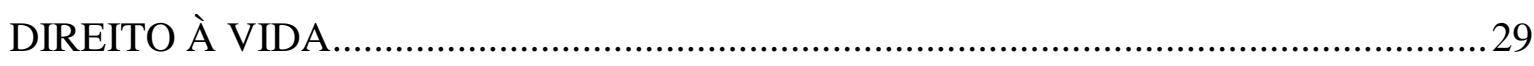

3.2 DIMENSÃO OBJETIVA DO DIREITO À VIDA.............................................................

3.2.1 Obrigações de Respeito e de Garantia e a Responsabilização Internacional do Estado em Caso de Violação do Direito à Vida ...............................................................35

3.3 O DIREITO À VIDA NAS CORTES INTERNACIONAIS DE DIREITOS

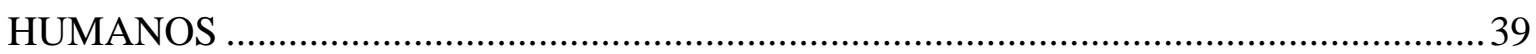

3.4 DIREITO À VIDA EM CONFLITO COM OUTROS DIREITOS ................................54

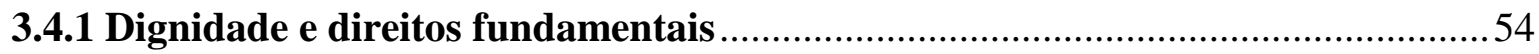

3.4.2 Direito à vida relativizado

3.4.3 Valores, princípios, regras e o direito à vida …………………………………......62

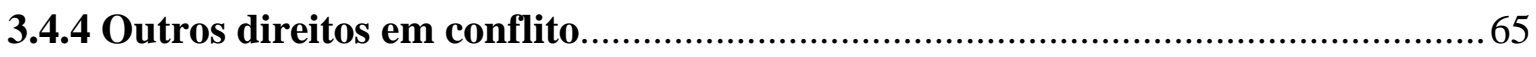

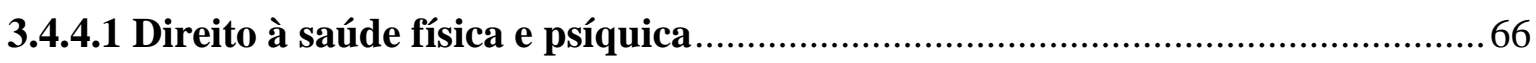

3.4.4.2 Direitos reprodutivos e sexuais da mulher ………………………….............69

3.4.4.2.1 Liberdade, dignidade, autonomia individual, disposição sobre o próprio corpo, igualdade de gêneros, e privacidade …………………………………………....69

4 ANÁLISE DO ABORTO NO BRASIL …………………............................................

4.1 TERMINOLOGIAS, CONCEITOS E CLASSIFICAÇÕES...........................................77

4.2 LEGISLAÇÃOE DOUTRINA BRASILEIRA SOBRE ABORTO ………..................8

4.2.1 O aborto e a Constituição Federal.......................................................................... 81

4.2.2 A incorporação e hierarquia das normas de direitos humanos no Brasil ............82

4.2.3 O Código Civil e o direito de personalidade ..........................................................

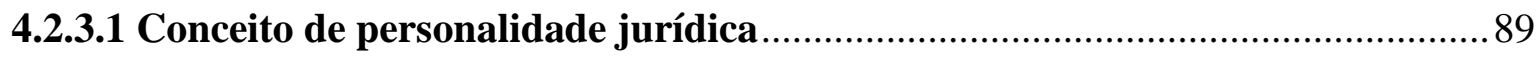

4.2.3.1.1 Teorias sobre a personalidade jurídica ............................................................ 89 
4.2.4 A criminalização do aborto

PARTE II - O ABORTO DO FETO ANENCÉFALO ............................................. 102

1 CONTROVÉRSIAS SOBRE A PROTEÇÃO DO DIREITO À VIDA NO CASO DE ABORTO EM DECORRÊNCIA DE INVIABILIDADE DA VIDA

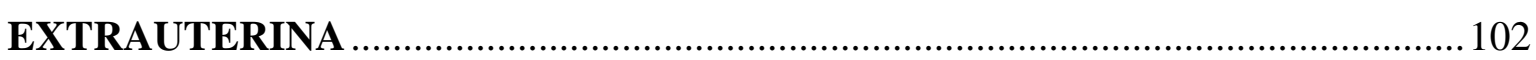

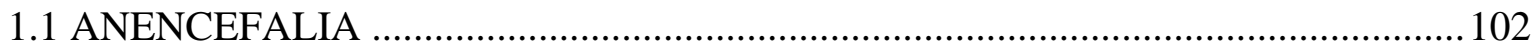

1.2 PRINCIPAIS ASPECTOS ÉTICO-JURÍDICOS NO CASO DA ANENCEFALIA.. 104

1.3 DIREITOS FUNDAMENTAIS NAS RELAÇÕES ENTRE PARTICULARES ........110

2 ANÁLISE DA ARGUIÇÃO DE PRECEITO FUNDAMENTAL (ADPF) No $54 \ldots 115$

2.1 PRINCIPAIS ARGUMENTOS SOBRE ANENCEFALIA NA JURISPRUDÊNCIA BRASILEIRA.

2.2 ARGUIÇÃO DE DESCUMPRIMENTO DE PRECEITO FUNDAMENTAL (ADPF) $\mathrm{N}^{\mathrm{0}} 54$

2.2.1 Origens do caso 121

2.2.2 Argumentos do arguente 122

2.2.3 Argumentos da Procuradoria Geral de República 126

2.3 ANÁLISE DOS VOTOS DA MEDIDA LIMINAR 128

2.3.1 Voto do Ministro Marco Aurélio 128

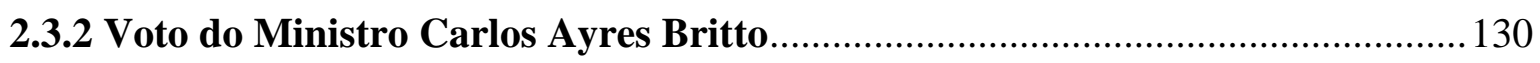

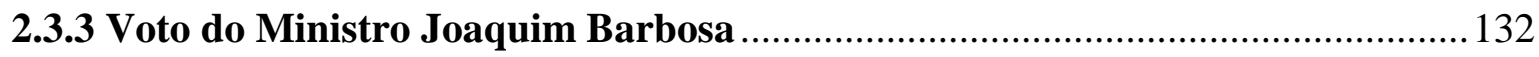

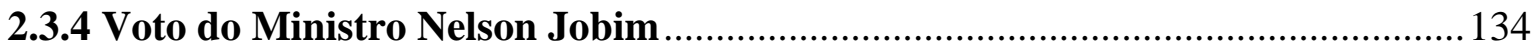

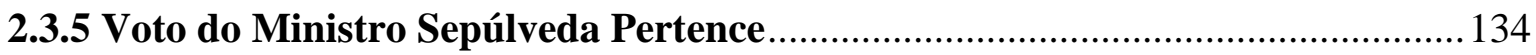

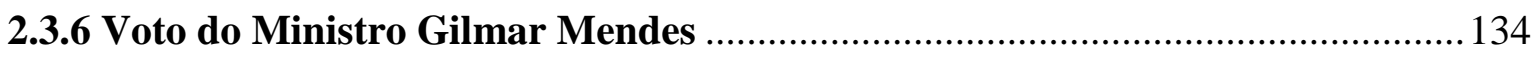

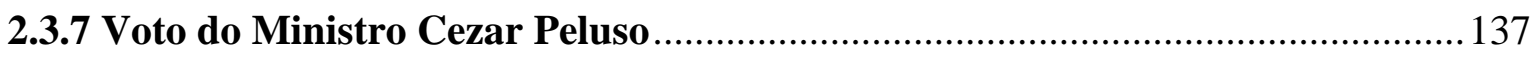

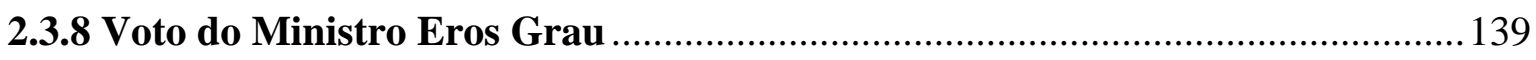

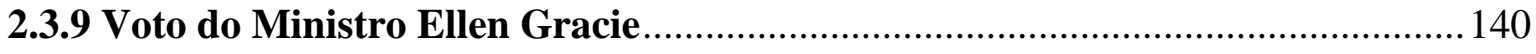

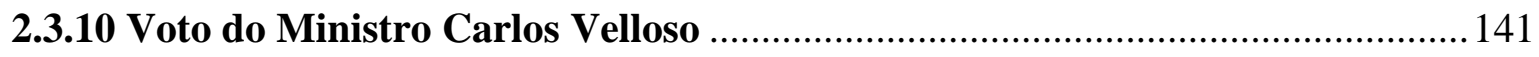

2.4 ARGUMENTOS APRESENTADOS EM AUDIÊNCIA PÚBLICA .......................... 141

2.5 ALEGAÇÕES FINAIS DO MINISTÉRIO PÚBLICO FEDERAL, DA ADVOCACIA GERAL DA UNIÃO, E DO ARGUENTE.................................................................... 160

2.6 ANÁLISE DOS VOTOS NA ADPF 54 - MÉRITO .................................................. 165

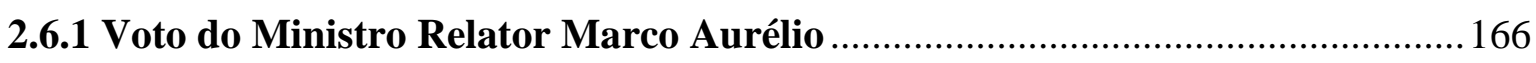

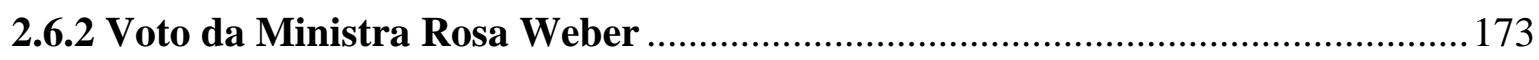

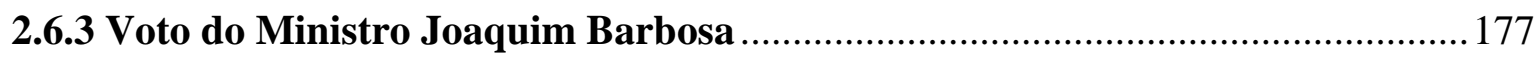




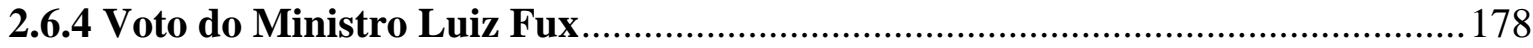

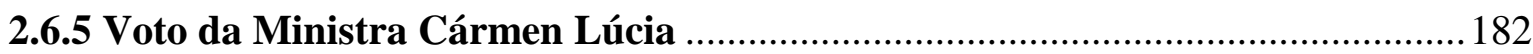

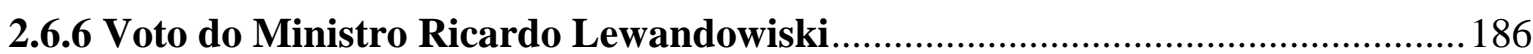

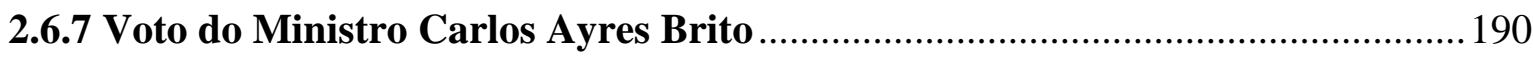

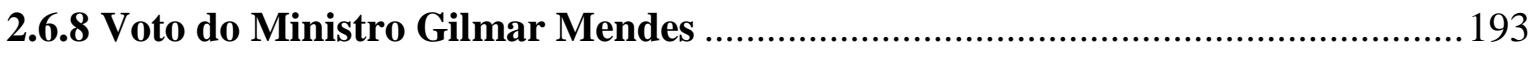

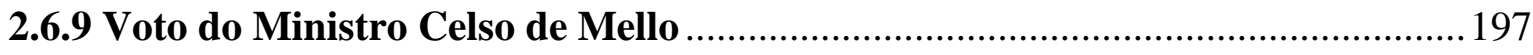

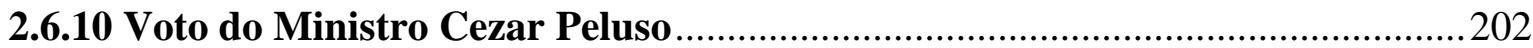

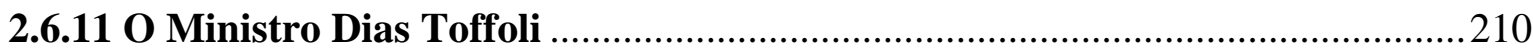

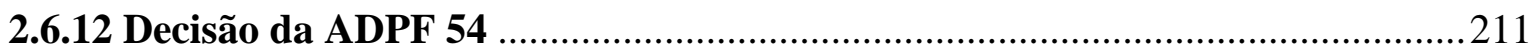

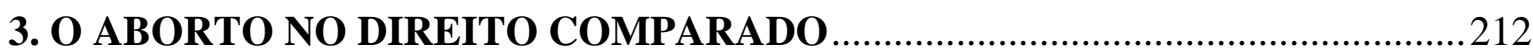

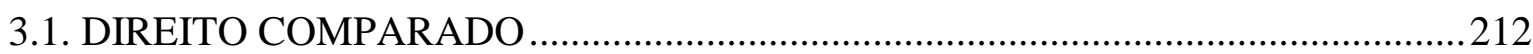

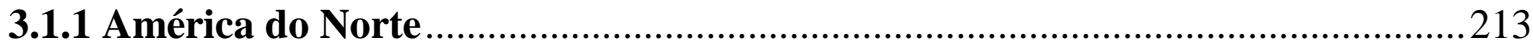

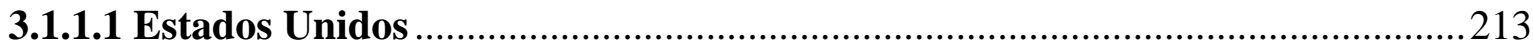

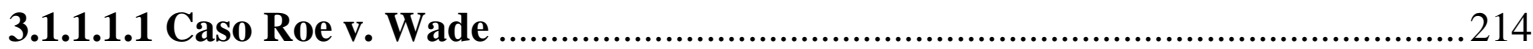

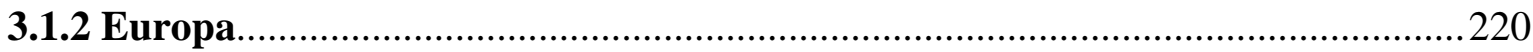

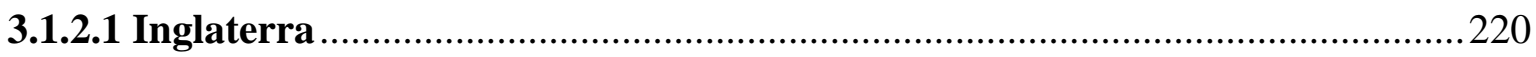

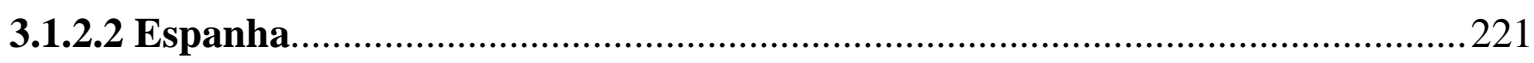

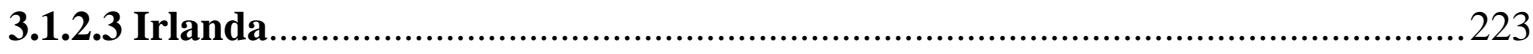

3.2 INTERPRETAÇÃO DOS TRIBUNAIS INTERNACIONAIS A RESPEITO DO

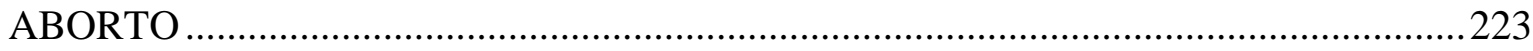

3.2.1 A Corte Européia de Direitos Humanos e o aborto ...........................................223

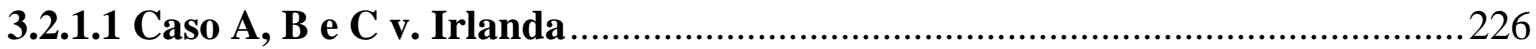

3.2.2 A Corte Interamericana de Direitos Humanos e o aborto …...............................2235

4. TEORIAS APLICADAS SOBRE RESTRIÇÃO AO DIREITO À VIDA .............237

4.1 CONFLITOS E LIMITES DE DIREITOS FUNDAMENTAIS ................................237

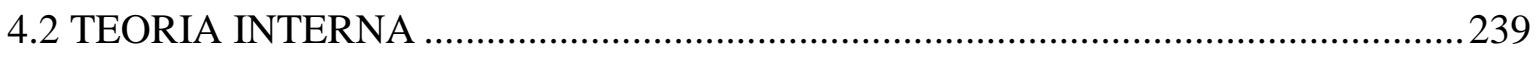

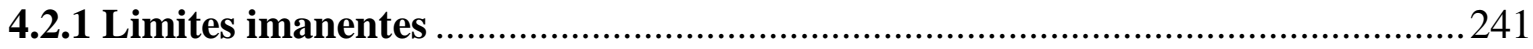

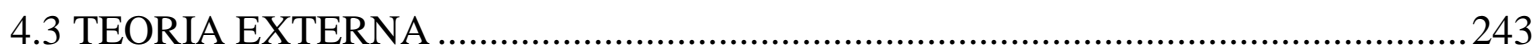

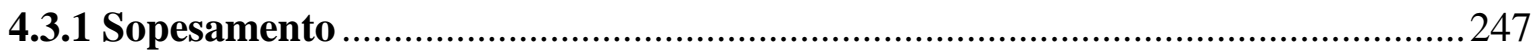

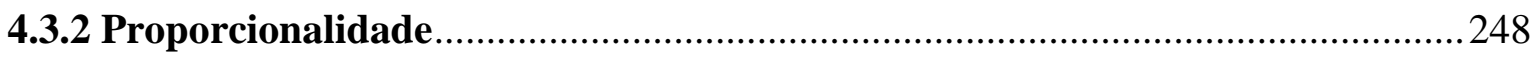

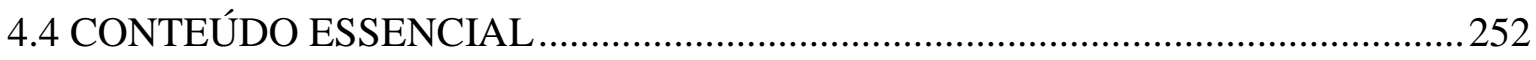

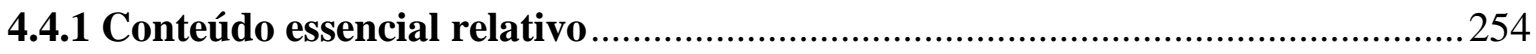

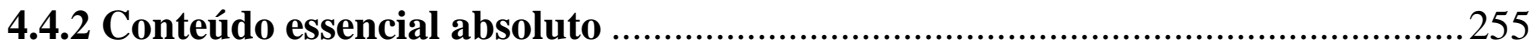


PARTE III - O ABORTO DO FETO ANENCÉFALO E O TRATAMENTO

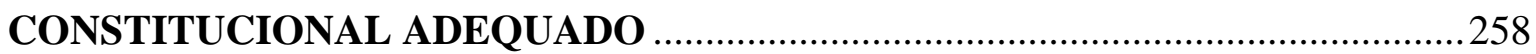
1 QUATRO MODELOS POSSÍVEIS DE INTERPRETAÇÃO DA CONSTITUIÇÃO FEDERAL BRASILEIRA 258

1.1 O MODELO DE INTERPRETAÇÃO CONSTITUCIONAL DE PROIBIÇÃO ABSOLUTA DO ABORTO DE FETO ANENCÉFALO. 260

1.2 O MODELO DE INTERPRETAÇÃO CONSTITUCIONAL DA LIVRE DISPOSIÇÃO.

1.3 O MODELO DE INTERPRETAÇÃO CONSTITUCIONAL DO ABORTO DE FETO ANENCÉFALO COMO LIBERDADE LIMITADA

$1.4 \mathrm{O}$ MODELO DE INTERPRETAÇÃO CONSTITUCIONAL DA EXCEÇÃO PERMITIDA AO ABORTO DE FETO ANENCÉFALO

2 O MODELO DE INTERPRETAÇÃO CONSTITUCIONAL MAIS ADEQUADO À REALIDADE JURÍDICA BRASILEIRA: UMA TENTATIVA DE DEFINIÇÃO.. 269 2.1 MODELOS A PRIORI INADEQUADOS À REALIDADE JURÍDICA ATUAL DO BRASIL. .269

2.2 O FETO ANENCÉFALO E O PAPEL DO JUDICIÁRIO 270

2.3 DISCUSSÕES SOBRE DECISÕES E OS PRINCIPAIS MODELOS DE

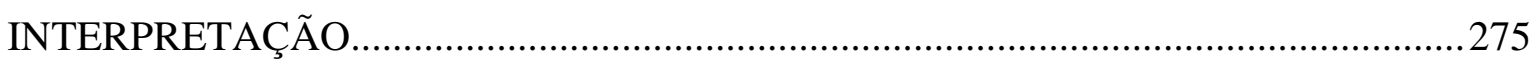

2.3.1 Argumentos no sentido de que o direito à vida não é absoluto.........................276

2.3.2 Argumentos envolvendo a brevidade da vida do feto ....................................279

2.3.3 Argumentos envolvendo o estado, a igreja, e valores ......................................2. 281

2.3.4 Argumentos envolvendo a personalidade do feto ….......................................282

2.3.5 Argumentos sobre a vida na concepção e o Pacto de San José............................285

2.3.6 Argumentos sobre a vida e a personalidade a partir da fecundação .................286

2.3.7 Argumentos envolvendo a morte encefálica ...................................................228

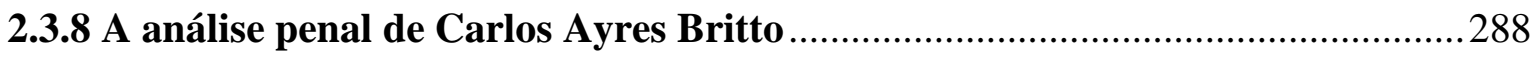

2.3.9 Argumentos invocando a iniciativa do Poder Legislativo …..............................2290

2.3.10 Conclusão sobre o modelo de interpretação constitucional aparentemente aplicável ao Brasil .

3 SOBRE A POSSIBILIDADE DE SE CONDICIONAR O ABORTO DO FETO ANENCÉFALO A FIM DE GARANTIR DIREITOS ..............................................292

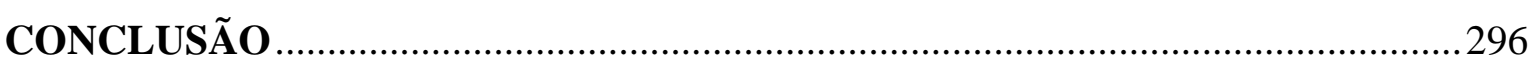

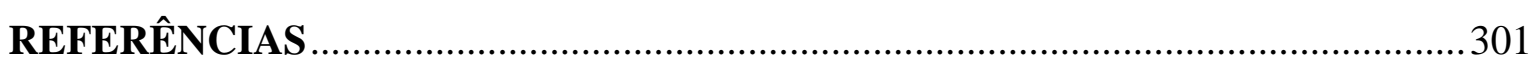




\section{INTRODUÇÃO}

Esta dissertação visa a analisar o aborto do feto anencéfalo à luz do ordenamento jurídico brasileiro, levando em consideração a tutela do direito à vida em face do Direito Internacional dos Direitos Humanos, elencando as principais jurisprudências, doutrinas, e soluções adotadas no plano internacional com relação ao tema, analisando a interpretação da lei em situações de conflitos de princípios e direitos fundamentais, comentando o papel do Judiciário no estado democrático de direito, especialmente com relação à efetivação dos direitos humanos, e, finalmente, propondo quatro modelos de interpretação constitucional aplicáveis ao aborto do feto anencéfalo, tendo como pano de fundo a decisão do Supremo Tribunal Federal a respeito do tema na Arguição de Preceito Fundamental (ADPF) 54, cuja análise servirá como um teste de consistência dos modelos propostos.

Na primeira parte da pesquisa, traçaremos um arcabouço teórico sobre o direito à vida, abordando o conceito de vida, os diversos sentidos atribuídos ao direito à vida, suas dimensões vertical e horizontal, e objetiva e subjetiva; apontando possíveis interpretações que podem ser aplicadas para compreensão de uma restrição ou limitação da vida ou do direito à vida, especialmente quando se tem em jogo outros direitos, como, por exemplo, a dignidade da pessoa humana, o direito à saúde, o direito à autonomia individual, o direito à liberdade, $\mathrm{o}$ direito à integridade física e psíquica da gestante, e os direitos reprodutivos da mulher, entre outros.

Impossível no mundo atual falar-se em direito à vida e outros direitos fundamentais sem se levar em conta o Direito Internacional dos Direitos Humanos. Portanto, ainda nesta primeira parte do trabalho, abordaremos também como se dá a incorporação de tratados internacionais no ordenamento jurídico brasileiro, enfatizando os tratados internacionais de direitos humanos, e seu impacto na compreensão do direito à vida e suas limitações em nosso direito interno. Ainda alimentando esse arcabouço teórico, trataremos sobre o aborto no Brasil, analisando como a legislação e a doutrina têm debatido e entendido o tema, abordando as principais teorias sobre a matéria.

$\mathrm{Na}$ segunda parte do trabalho, direcionaremos o foco de nosso estudo ao caso do aborto do anencéfalo. Explicaremos exatamente o que é a anencefalia, para ter uma base sólida factual sobre a qual refletir a respeito do problema, e traçaremos e analisaremos, então, 
as mais relevantes controvérsias sobre a proteção do direito à vida no caso de aborto do feto anencéfalo, aplicando o arcabouço teórico anteriormente analisado, e debatendo como serão tratados os direitos fundamentais, em especial o direito à vida, no caso prático em tela, lembrando também que o aborto, inclusive, envolve relações entre particulares, o que traz importantes implicações a um estado democrático de direito.

Levaremos em conta discussões éticas e filosóficas que servirão como pano de fundo para nossa análise, e buscaremos construir - a partir desses debates éticos, filosóficos, e jurídicos - uma teoria capaz de auxiliar o intérprete quando houver conflito entre a proteção do direito à vida de um lado, e a liberdade, a dignidade, e outros princípios e direitos fundamentais conflitantes, de outro. Analisaremos como tem sido tratada a situação do aborto do feto anencéfalo no Brasil, abordando especialmente as decisões e a jurisprudência a respeito, destacando, a ADPF 54, que versa especificamente sobre a matéria, e que foi julgada pelo Supremo Tribunal Federal em 11 e 12 abril de 2012, depois de tramitar por quase 8 anos, tendo sido originalmente proposta em 2004.

Em um segundo momento, ainda nesta parte do trabalho, buscaremos elencar as principais doutrinas e soluções adotadas no plano internacional com relação ao aborto, que possam ajudar a embasar o estudo deste tema no nosso direito interno. Além disso, destacaremos as normas estrangeiras e internacionais que têm sido invocadas e estudadas com relação à proteção dos direitos em conflito no caso, especialmente o direito à vida, à dignidade, à vida digna, à liberdade, à saúde, à autonomia, à igualdade, e aos direitos reprodutivos e sexuais, através de um estudo de direito comparado das legislações de alguns países onde a discussão está particularmente desenvolvida, e da interpretação dos tribunais internacionais de direitos humanos sobre a matéria, confrontando as referidas legislações, doutrinas e jurisprudências em face do nosso ordenamento jurídico, procurando analisar as soluções encontradas e propostas, com especial ênfase no Sistema Interamericano de proteção aos Direitos Humanos, do qual o Brasil faz parte, levantando as mais importantes teorias e argumentos sobre o tema.

No final desta parte do trabalho, trataremos das principais teorias aplicadas com relação às restrições ao direito à vida, analisando os critérios e circunstâncias em que o direito à vida poderia ser restringido ou limitado, demonstrando a possibilidade e a existência de gradações dessa proteção quando se tem outros direitos fundamentais envolvidos, com destaque aos limites imanentes, sopesamento e proporcionalidade, cuja compreensão será essencial para uma conclusão final sobre como o tema do aborto do feto anencéfalo é tratado no Brasil. 
Por fim, na terceira parte deste trabalho, apresentaremos um teste de consistência, ou seja, munidos das análises teóricas e estudos jurisprudenciais desenvolvidos nas duas partes anteriores do texto, passaremos a aplicá-las efetivamente ao caso concreto julgado na ADPF 54.

Tendo em vista que a decisão final sobre a constitucionalidade do aborto do anencéfalo coube ao nosso Supremo Tribunal Federal, e que a lei é silente sobre a matéria (ainda que não o seja sobre o aborto em geral), em primeiro lugar, brevemente, comentaremos o papel que cabe ao Judiciário em um estado democrático de direito, especialmente com relação à efetivação dos direitos humanos.

Passaremos, a seguir, à proposição de quatro modelos cabíveis de interpretação constitucional sobre o caso do feto anencéfalo, explicando as diferenças e consequências da adoção de cada um desses modelos por nossa corte suprema. O teste de consistência proposto concretizar-se-á com uma análise final detalhada dos principais argumentos aplicáveis ao caso que o Supremo Tribunal Federal efetivamente utilizou no julgamento da liminar e do mérito da ADPF 54, levando-se em conta também o julgamento do STF da Ação Direta de Inconstitucionalidade (ADI) 3510, que tratou da constitucionalidade de se realizar pesquisas com células-tronco embrionárias humanas. Em vista dessa análise, poderemos então verificar se algum dos modelos de interpretação constitucional propostos poderia se aplicar de fato ao caso, e qual seria esse modelo.

Assim, fecharemos nosso trabalho verificando qual a opção de interpretação constitucional o Brasil adotou para o caso do aborto do feto anencéfalo, e discutiremos quais medidas o legislador poderia ainda vir a tomar para contribuir com uma solução razoavelmente satisfatória ao tema, revestindo a situação com uma carapaça protetora que visasse a garantir, ao máximo possível, a maior efetivação de todos direitos fundamentais em jogo, procurando encontrar, assim, o máximo denominador comum desses direitos para a sempre trágica e difícil situação do feto acometido de anencefalia. 


\section{PARTE I - PROTEÇÃO DA VIDA E O ABORTO}

\section{DIREITO À VIDA E SEUS DIVERSOS SENTIDOS}

Para Nietzsche "o valor da vida não pode ser estimado", e, ademais, "juízos de valor acerca da vida, contra ou a favor, nunca podem ser verdadeiros" ${ }^{\prime 2}$. Mas qual o significado de vida? Qual o objeto daquilo que é pressuposto de todos direitos ${ }^{3}$ e tem causado inúmeros debates? É possível atribuir à vida humana um valor intrínseco que a garanta plenamente? Ou sobre a vida se constrói apenas um juízo de valor?

Muitos são os significados atribuídos à vida. Vida ordinariamente é entendida como sendo o período compreendido entre o nascimento e a morte, caracterizando o que denominamos de existência ${ }^{4}$. Consiste em um "estado" - estar, de algum modo, vivo pressupõe não estar morto, pressupõe estar em determinada situação em que seja possível estar ativo. Mas nem a definição mais simples de vida está além de controvérsias - apenas a título de exemplo, as concepções acima, retiradas do dicionário, são claramente insuficientes, uma vez que, por exemplo, não faltará quem entenda que a vida tem início na concepção (em oposição ao nascimento), e não resta dúvidas de que um ser pode estar vivo, ainda que esteja em situação em que não lhe seja possível "estar ativo".

Para José Afonso da Silva, o significado de vida trazido no artigo $5^{\circ}$ da Constituição Federal não abarca apenas "seu sentido biológico",

(...) Vida, no texto constitucional (art. $5^{\circ}$, caput), não será considerada apenas no seu sentido biológico de incessante auto-atividade funcional, peculiar à matéria orgânica, mas na sua acepção biográfica mais compreensiva. Sua riqueza significativa é algo de difícil apreensão, porque é

\footnotetext{
${ }^{1}$ NIETZSCHE, Friedrich. O Crepúsculo dos Ídolos - ou como se filosofa com um martelo. Trad. Paulo César de Souza. São Paulo: Companhia das Letras, 2006, p. 18.

${ }^{2}$ NIETZSCHE, Friedrich. O Crepúsculo dos Ídolos - ou como se filosofa com um martelo. Trad. Paulo César de Souza. São Paulo: Companhia das Letras, 2006, p. 18.

${ }^{3}$ Por exemplo, DINIZ, Maria Helena. O Estado Atual do Biodireito. São Paulo: Saraiva, 2009, p. 21.

${ }^{4}$ Vida: "1. Conjunto de propriedades e qualidades graças às quais animais e plantas se mantém em contínua atividade; existência. 2. A vida humana. 3. O espaço de tempo que vai do nascimento à morte; existência”. FERREIRA, Aurélio Buarque de Holanda. Miniaurélio Eletrônico versão 5.12. 6a. edição, revista e atualizada, do Minidicionário Aurélio, da Língua Portuguesa. Edição eletrônica autorizada à Positivo Informática Ltda.XXX: Editora Positivo, 2004.

5 SILVA, José Afonso da. Curso de Direito Constitucional Positivo. 24a edição, ver. atual. São Paulo: Malheiros, 2005, p. 197.
} 
algo dinâmico, que se transforma incessantemente sem perder sua própria identidade. É mais um processo (processo vital), que se instaura com a concepção (ou germinação vegetal), transforma-se, progride, mantendo sua identidade, até que muda de qualidade, deixando, então, de ser vida para ser morte. Tudo que interfere em prejuízo deste fluir espontâneo e incessante contraria a vida.

A vida, na visão de José Afonso da Silva, portanto, é dinâmica, está em constante atividade e, diante de suas características únicas, exige respeito. Esse existir dinâmico em constante processo, no entanto, não é atributo exclusivo do ser humano. Os animais e plantas também são considerados seres vivos. Então, o que diferencia e caracteriza a vida humana, tornando-a digna de ser protegida?

Sob um prisma subjetivo de vida, Marco Segre e Gabriela Guz definem que a essência da vida seria baseada na "percepção"6 de como cada indivíduo a entende e a define. Sugerem que esse conceito subjetivo de vida está ligado à capacidade do homem de atribuir à vida um sentido individual ${ }^{7}$. Tal concepção da essencialidade da vida, no entanto, não é científica.

A partir de concepções científicas da vida, várias são as teorias sobre seu significado. Renata da Rocha, por exemplo, trata a vida como "prefixo de ciência e tecnologia" 8 . Sob uma perspectiva mais moderna e tecnológica, a autora reduz o sentido atribuído à vida a duas categorias: a vida vista como um "código", e a vida vista como um "produto"10.

No primeiro caso, a vida é valorada dentro do contexto do código genético, em especial, porque a partir da descoberta do ácido desoxirribonucléico - DNA - foi possível desenvolver pesquisas e tecnologias de engenharia genética ${ }^{11}$ com o objetivo de "identificar e isolar os genes responsáveis por milhares de doenças genéticas que acometem os seres humanos"12.

Com relação à segunda situação, Renata da Rocha examina a vida sob o ponto de vista do Projeto Genoma Humano, que parte da decodificação do genoma, sequenciando "as bases de DNA da espécie humana"13, e destacando a corrida pelo patenteamento do genoma

\footnotetext{
6 “A essência da vida está na subjetividade, na forma como cada um a percebe e, portanto, ela é indefinível, e sua experiência, inefável. Se nos louvarmos nas religiões, a vida precede a concepção e o nascimento e ultrapassa a morte - todos fenômenos biológicos percebidos "de fora'". SEGRE, Marco; GUZ, Gabriela. Início da vida e células-tronco embrionárias. Disponível em: <http://www.jornaldaciencia.org.br/Detalhe.jsp?id=29790>. Acesso em: 04 mai. 2011.

7 SEGRE, Marco; GUZ, Gabriela. Início da vida e células-tronco embrionárias. Disponível em: <http://www.jornaldaciencia.org.br/Detalhe.jsp?id=29790>. Acesso em: 04 mai. 2011.

${ }^{8}$ ROCHA, Renata da. Direito à vida e a pesquisa em células-tronco. Rio de Janeiro: Elsevier, 2008, p. 5.

${ }^{9}$ ROCHA, Renata da. Direito à vida e a pesquisa em células-tronco. Rio de Janeiro: Elsevier, 2008, p. 21-26.

${ }^{10}$ ROCHA, Renata da. Direito à vida e a pesquisa em células-tronco. Rio de Janeiro: Elsevier, 2008, p. 26-34.

${ }^{11}$ ROCHA, Renata da. Direito à vida e a pesquisa em células-tronco. Rio de Janeiro: Elsevier, 2008, p. 24.

${ }^{12}$ ROCHA, Renata da. Direito à vida e a pesquisa em células-tronco. Rio de Janeiro: Elsevier, 2008, p. 25.

${ }^{13}$ ROCHA, Renata da. Direito à vida e a pesquisa em células-tronco. Rio de Janeiro: Elsevier, 2008, p. 26.
} 
humano ${ }^{14}$. Para a autora, tais situações, em especial o que diz respeito à patente, consagram “a associação definitiva entre vida, ciência e técnica" ${ }^{15}$.

Certamente essa "redução" do significado de vida somente foi possível por causa da descoberta de novas técnicas capazes de verificar situações até então inimagináveis para o homem, como, por exemplo, constatar a viabilidade do feto e tratar doenças ainda dentro do útero $^{16}$. Essas novas perspectivas tornam ainda mais relevante o debate sobre o direito à vida, especialmente em vista do risco de que tal "redução" nos leve a categorizar a vida como um objeto $^{17}$, um produto, um código.

Além disso, velhos valores são questionados e novos valores são agregados ao debate, exigindo reflexões mais acuradas sobre os sentidos atribuídos à própria vida e sobre os limites do direito à vida:

O Direito, como mecanismo regulador de condutas, e por encontrar-se indissoluvelmente atrelado às transformações que experimentam os diferentes comportamentos humanos, transformações essas que podem ter como origem significativas modificações da ideologia dominante em uma determinada sociedade, ou, como no caso em questão, espetaculares avanços científicos, que ameaçam conceitos que se revestiam, até bem pouco tempo, da qualidade de certezas incontestes, não pode se furtar a atender o chamado de sua vocação genuína, qual seja, assegurar o pleno desenvolvimento da vida humana ${ }^{18}$.

Independentemente dos avanços tecnológicos, muitos estudiosos, entre eles filósofos e juristas, afirmam que a vida deve ser entendida como um valor, e é em razão disso que ela se encontraria protegida, como veremos ao longo deste trabalho.

Habermas destaca o valor intrínseco da vida quando debate o direito à vida nos casos de interrupção de gravidez. Afirma o filósofo que, no debate sobre o aborto, por décadas "fracassa toda tentativa de alcançar uma descrição ideologicamente neutra, e, portanto, sem

\footnotetext{
${ }^{14}$ ROCHA, Renata da. Direito à vida e a pesquisa em células-tronco. Rio de Janeiro: Elsevier, 2008, p. 27.

${ }^{15}$ ROCHA, Renata da. Direito à vida e a pesquisa em células-tronco. Rio de Janeiro: Elsevier, 2008, p. 29.

${ }^{16}$ REY MARTÍNEZ, Fernando. Eutanasia y Derechos Fundamentales. Madrid: Centro de Estúdios Políticos Y Constitucionales, 2008, p. 12.

17 Por outro lado, vale lembrar que Kant defende a não-coisificação do ser humano, no sentido de que o ser humano não é uma coisa (res) e não pode ser usado como se fosse mero objeto. Ele é um fim em si, investido, portanto, de uma dignidade que lhe é própria. KANT, Immanuel. Foundation of the Methaphysics of Morals. In: Ethical Theories. New York: Prentice Hall; 1950, p. 231.

${ }^{18}$ ROCHA, Renata da. Direito à vida e a pesquisa em células-tronco. Rio de Janeiro: Elsevier, 2008, p. 72.
} 
prejulgamentos, do status moral da vida humana prematura, que seja aceitável, para todos os cidadãos de uma sociedade secular" ${ }^{, 19}$.

Para Habermas, tem-se uma perspectiva de que o embrião "no estágio prematuro de desenvolvimento" ${ }^{20}$ constitui um "amontoado de células",21, em contraposição à pessoa do recém-nascido, "a quem compete primeiramente a dignidade humana no sentido estritamente moral",22.

Além disso, Habermas afirma que, embora não se dê ao feto o "status de um sujeito de direitos", é possível considerar que "todo exemplar biologicamente determinável da espécie" é uma pessoa em potencial e, em razão disso, é "portador de direitos fundamentais inalienáveis" ${ }^{23}$.

Para o autor, algo pode ser tido como indisponível sem que seja necessário atribuir-se ao indivíduo beneficiado por esse direito fundamental status de sujeito de direitos ${ }^{24}$. Todavia, qualquer tentativa de estabelecer um limite específico e "moralmente relevante em algum ponto entre a fecundação ou a junção de gametas, de um lado, e o nascimento, de outro",25 seria arbitrária ${ }^{26}$.

Assim, na concepção de Habermas, é difícil estabelecer um início absoluto e definitivo da vida, e, no entanto, "ninguém duvida do valor intrínseco da vida humana antes do

\footnotetext{
${ }^{19}$ Ao debater sobre a dignidade humana v. dignidade da vida humana, Habermas traça uma diferença entre aborto devido à rejeição de células-tronco de um aborto decorrente da interrupção da gravidez. HABERMAS, Jürgen. O futuro da natureza humana: a caminho de uma eugenia liberal? Trad. Karina Jannini; revisão da tradução Eurides Avance de Souza. São Paulo: Martins Fontes, 2004, p. 44. Vide também Fernando Rey Martínez, que afirma que o problema da eutanásia tem sido debatido de modo mais agudo onde há meios técnicos melhores e uma concepção social da vida mais secularizada. Para ele, em sociedades mais tecnologicamente limitadas, ou mais profundamente religiosas, o debate não chega a se desenvolver. REY MARTÍNEZ, Fernando. Eutanasia y Derechos Fundamentales. Madrid: Centro de Estúdios Políticos Y Constitucionales, 2008, p. 38.

${ }^{20}$ HABERMAS, Jürgen. O futuro da natureza humana: a caminho de uma eugenia liberal? Trad. Karina Jannini; revisão da tradução Eurides Avance de Souza. São Paulo: Martins Fontes, 2004, p. 44.

${ }^{21}$ HABERMAS, Jürgen. O futuro da natureza humana: a caminho de uma eugenia liberal? Trad. Karina Jannini; revisão da tradução Eurides Avance de Souza. São Paulo: Martins Fontes, 2004, p. 44.

${ }^{22}$ HABERMAS, Jürgen. O futuro da natureza humana: a caminho de uma eugenia liberal? Trad. Karina Jannini; revisão da tradução Eurides Avance de Souza. São Paulo: Martin Fontes, 2004, p. 44.

${ }^{23}$ HABERMAS, Jürgen. O futuro da natureza humana: a caminho de uma eugenia liberal? Trad. Karina Jannini; revisão da tradução Eurides Avance de Souza. São Paulo: Martins Fontes, 2004, p. 44.

${ }^{24}$ HABERMAS, Jürgen. O futuro da natureza humana: a caminho de uma eugenia liberal? Trad. Karina Jannini; revisão da tradução Eurides Avance de Souza. São Paulo: Martins Fontes, 2004, p. 44. Pois, para o autor, é possível limitar direitos por motivos morais, sem por isso ser "intangível no sentido dos direitos fundamentais em vigor de forma irrestrita e absoluta". HABERMAS, Jürgen. O futuro da natureza humana: a caminho de uma eugenia liberal? Trad. Karina Jannini; revisão da tradução Eurides Avance de Souza. São Paulo: Martins Fontes, 2004, p. 44.

${ }^{25}$ HABERMAS, Jürgen. O futuro da natureza humana: a caminho de uma eugenia liberal? Trad. Karina Jannini; revisão da tradução Eurides Avance de Souza. São Paulo: Martins Fontes, 2004, p. 45.

${ }^{26}$ HABERMAS, Jürgen. O futuro da natureza humana: a caminho de uma eugenia liberal? Trad. Karina Jannini; revisão da tradução Eurides Avance de Souza. São Paulo: Martins Fontes, 2004, p. 45.
} 
nascimento" 27 . Vale dizer que o ser no útero não é uma "pessoa pronta" e também não age no contexto de interação com outras pessoas ${ }^{28}$. Esse ser, porém, é considerado um de nós, e já goza de proteção legal. Para o autor, a vida humana evoca a "dignidade humana" e, por isso, exige respeito $^{29}$. Assim, o embrião precisa ser protegido, e é digno dessa proteção ${ }^{30}$.

Em uma linha semelhante, Dworkin afirma que "a vida humana tem um valor intrínseco e inviolável" ${ }^{31}$. Ele avalia ${ }^{32}$ a vida atribuindo-lhe três sentidos para evidenciar a sua "sacralidade" ${ }^{33}$ - os sentidos instrumental, intrínseco e subjetivo ${ }^{34}$.

A instrumentalidade nos remete à ideia de se avaliar a vida observando como "serviu aos interesses dos outros" ${ }^{35}$.

A subjetividade, por sua vez, é medida levando-se em conta o valor que a pessoa atribui à própria vida ${ }^{36}$. O quanto significaria a alguém estar vivo? Trata-se de um "valor pessoal"37. Para Dworkin, é esse valor pessoal que "o governo tenta proteger, como fundamentalmente importante, quando reconhece e faz vigorar o direito das pessoas à vida ${ }^{38}$. ${ }^{27}$ HABERMAS, Jürgen. O futuro da natureza humana: a caminho de uma eugenia liberal? Trad. Karina
Jannini; revisão da tradução Eurides Avance de Souza. São Paulo: Martins Fontes, 2004, p. 46 .
${ }^{28}$ HABERMAS, Jürgen. O futuro da natureza humana: a caminho de uma eugenia liberal? Trad. Karina
Jannini; revisão da tradução Eurides Avance de Souza. São Paulo: Martins Fontes, 2004, p. Habermas, p. 49 . O
autor admite a forma de "socialização por integração", em que haveria uma interação entre o feto e o pai da
criança. HABERMAS, Jürgen. O futuro da natureza humana: a caminho de uma eugenia liberal? Trad. Karina
Jannini; revisão da tradução Eurides Avance de Souza. São Paulo: Martins Fontes, 2004, p. 50-51.
${ }_{29}$ HABERMAS, Jürgen. O futuro da natureza humana: a caminho de uma eugenia liberal? Trad. Karina
Jannini; revisão da tradução Eurides Avance de Souza. São Paulo: Martins Fontes, 2004, p. 52.
${ }^{30}$ HABERMAS, Jürgen. O futuro da natureza humana: a caminho de uma eugenia liberal? Trad. Karina
Jannini; revisão da tradução Eurides Avance de Souza. São Paulo: Martins Fontes, 2004, p. 54.
31 DWORKIN, Ronald. Domínio da Vida: aborto, eutanásia e liberdades individuais. Trad. Jefferson Luiz
Camargo; rev. da tradução Silvana Vieira. São Paulo: Martins Fontes, 2003, p. 37.
32 Defende Ronald Dworkin que no debate sobre o aborto o que se discute são os valores intrínsecos e não os
direitos ou interesses do feto. DWORKIN, Ronald. Domínio da Vida: aborto, eutanásia e liberdades individuais.
Trad. Jefferson Luiz Camargo; rev. da tradução Silvana Vieira. São Paulo: Martins Fontes, 2003, p. 48.
33 Nesse sentido, o autor elucida que se entende sagrado como sinônimo de inviolável e não no sentido teísta,
como comumente é empregado. DWORKIN, Ronald. Domínio da Vida: aborto, eutanásia e liberdades
individuais. Trad. Jefferson Luiz Camargo; rev. da tradução Silvana Vieira. São Paulo: Martins Fontes, 2003 , p.
33 .

${ }^{34}$ DWORKIN, Ronald. Domínio da Vida: aborto, eutanásia e liberdades individuais. Trad. Jefferson Luiz Camargo; rev. da tradução Silvana Vieira. São Paulo: Martins Fontes, 2003, p. 99.

${ }^{35}$ DWORKIN, Ronald. Domínio da Vida: aborto, eutanásia e liberdades individuais. Trad. Jefferson Luiz Camargo; rev. da tradução Silvana Vieira. São Paulo: Martins Fontes, 2003, p. 101. Dworkin afirma que o dinheiro, por exemplo, tem um valor essencialmente instrumental porque não tem outro valor além de comprar coisas que as pessoas desejam ou precisam. Vide DWORKIN, Ronald. Domínio da Vida: aborto, eutanásia e liberdades individuais. Trad. Jefferson Luiz Camargo; rev. da tradução Silvana Vieira. São Paulo: Martins Fontes, 2003, p. 99.

${ }^{36}$ DWORKIN, Ronald. Domínio da Vida: aborto, eutanásia e liberdades individuais. Trad. Jefferson Luiz Camargo; rev. da tradução Silvana Vieira. São Paulo: Martins Fontes, 2003, p. 99.

${ }^{37}$ DWORKIN, Ronald. Domínio da Vida: aborto, eutanásia e liberdades individuais. Trad. Jefferson Luiz Camargo; rev. da tradução Silvana Vieira. São Paulo: Martins Fontes, 2003, p. 101.

${ }^{38}$ DWORKIN, Ronald. Domínio da Vida: aborto, eutanásia e liberdades individuais. Trad. Jefferson Luiz Camargo; rev. da tradução Silvana Vieira. São Paulo: Martins Fontes, 2003, p. 101. Vale dizer que daí decorre a importância, para o autor de se verificar se o feto tem direitos e interesses próprios. DWORKIN, Ronald. Domínio da Vida: aborto, eutanásia e liberdades individuais. Trad. Jefferson Luiz Camargo; rev. da tradução 
Já o caráter intrínseco da vida diz respeito à ideia de que algo deve ser respeitado e protegido "por sua qualidade inerente" 39 , independentemente do valor atribuído a ela por alguém, ou de se ter atendido aos interesses dos outros; simplesmente, "por ser maravilhosa em si mesmo"40, de modo que, porque existe, é inviolável ${ }^{41}$; pelo que "representa ou incorpora" ${ }^{, 42}$, é inviolável. Assim, também para Dworkin, a vida deve ser protegida por sua qualidade inerente e intrínseca.

Fernando Rey Martínez defende que a vida é um bem jurídico indisponível ${ }^{43}$, expondo sua dimensão objetiva, já que independe da vontade de seu titular - se dependesse, transformar-se-ia a vida em um direito subjetivo. Afirma Rey Martínez que a perspectiva jurídica tradicional considerou a vida como "um bem claramente indisponível”, consagrando um verdadeiro dever de viver ${ }^{44}$.

A Constituição Federal de 1988 estabelece, em seu artigo $5^{\circ}$, caput $^{45}$, a inviolabilidade do direito à vida, posicionando-o dentre os direitos individuais e coletivos, constituindo-o como um direito fundamental a todos.

Destacamos dois sentidos que podem, em princípio, ser inferidos do texto constitucional que são interessantes para o trabalho em tela: o direito à vida como direito à

\footnotetext{
Silvana Vieira. São Paulo: Martins Fontes, 2003, p. 101. Ainda para Dworkin, "Ninguém pode afirmar, com coerência, que um feto tem o direito de não ser morto e, ao mesmo tempo, sustentar que é errado que o governo proteja esse direito através das leis penais. Afinal, a responsabilidade fundamental do governo consiste em proteger os interesses de todos os membros da comunidade, particularmente os interesses daqueles que não podem proteger-se por conta própria". DWORKIN, Ronald. Domínio da Vida: aborto, eutanásia e liberdades individuais. Trad. Jefferson Luiz Camargo; rev. da tradução Silvana Vieira. São Paulo: Martins Fontes, 2003 , p. 18 e "Não é importante que existam mais pessoas, mas, uma vez que uma vida humana tenha começado, é muito importante que floresça e não se perca”. DWORKIN, Ronald. Domínio da Vida: aborto, eutanásia e liberdades individuais. Trad. Jefferson Luiz Camargo; rev. da tradução Silvana Vieira. São Paulo: Martins Fontes, 2003 , p. 102.

${ }^{39}$ Ronald Dworkin se refere à obra de arte que deve ser protegida e respeitada independentemente de se as pessoas a apreciem ou querem vê-la. DWORKIN, Ronald. Domínio da Vida: aborto, eutanásia e liberdades individuais. Trad. Jefferson Luiz Camargo; rev. da tradução Silvana Vieira. São Paulo: Martins Fontes, 2003 , p. 100 .

${ }^{40}$ DWORKIN, Ronald. Domínio da Vida: aborto, eutanásia e liberdades individuais. Trad. Jefferson Luiz Camargo; rev. da tradução Silvana Vieira. São Paulo: Martins Fontes, 2003, p. 102.

${ }^{41}$ DWORKIN, Ronald. Domínio da Vida: aborto, eutanásia e liberdades individuais. Trad. Jefferson Luiz Camargo; rev. da tradução Silvana Vieira. São Paulo: Martins Fontes, 2003, p. 102.

${ }^{42}$ DWORKIN, Ronald. Domínio da Vida: aborto, eutanásia e liberdades individuais. Trad. Jefferson Luiz Camargo; rev. da tradução Silvana Vieira. São Paulo: Martins Fontes, 2003, p. 102.

${ }^{43}$ Fernando Rey Martínez entende que o direito à vida é indisponível em razão de sua íntima relação com a conservação do núcleo social, mas não acredita que seja um bem jurídico exclusivo da comunidade, nem exclusivamente individual. REY MARTÍNEZ, Fernando. Eutanasia y Derechos Fundamentales. Madrid: Centro de Estúdios Políticos Y Constitucionales, 2008, p. 155.

${ }^{44}$ REY MARTÍNEZ, Fernando. Eutanasia y Derechos Fundamentales. Madrid: Centro de Estúdios Políticos Y Constitucionales, 2008, p. 135.

${ }^{45}$ BRASIL. Constituição (1988). Constituição da República Federativa do Brasil. Brasília, DF: Senado, 1988.
} 
própria existência, e o direito à vida sob o prisma do mínimo existencial ou vida digna, como defende Alexandre de Moraes ${ }^{46}$.

$\mathrm{O}$ direito à vida no sentido de direito à própria existência estaria ligado à não interrupção dos processos humanos vitais ${ }^{47}$, seja por terceiros, seja pelo Estado. É o direito de estar e continuar vivo ${ }^{48}$ até que o processo vital se encerre espontaneamente ${ }^{49}$.

Esse sentido atribuído ao direito à vida nos remete ao estudo sobre a classificação das gerações de direitos humanos ${ }^{50}$, podendo ser o direito à vida inserido nos direitos de primeira geração. Os direitos de primeira geração ${ }^{51}$ ou dimensão estariam ligados aos direitos de

\footnotetext{
${ }^{46}$ Afirma o autor que a Constituição Federal assegura o direito à vida em sua dupla acepção: "sendo a primeira relacionada ao direito de continuar vivo e a segunda de se ter vida digna quanto à subsistência". MORAES, Alexandre de. Direitos Humanos Fundamentais: teoria geral, comentários aos arts. $1^{\circ}$ a $5^{\circ}$ da Constituição da República Federativa do Brasil, doutrina e jurisprudência. 9. ed. São Paulo: Atlas, 2011, p. 80.

${ }^{47}$ Para Dimitri Dimoulis, a inviolabilidade do direito à vida de que trata o artigo $5^{\circ}$ da Constituição Federal do Brasil de 1988 diz respeito ao "direito de permanecer vivo, proibindo-se interferências nos processos vitais que possam resultar em morte”. DIMOULIS, Dimitri. Vida (Direito à). In: DIMOULIS, Dimitri (Coordenador Geral). TAVARES, André Ramos; DIMOULIS, Dimitri; BERCOVICI, Gilberto; SILVA, Guilherme Amorim Campos da; FRANCISCO, José Carlos; ANJOS FILHO, Robério Nunes dos; ROTHENBURG, Walter Claudius (org.). Dicionário Brasileiro de Direito Constitucional. São Paulo: Saraiva, 2007, p. 397.

${ }^{48}$ Vide MORAES, Alexandre de. Direitos Humanos Fundamentais: teoria geral, comentários aos arts. $1^{\circ}$ a $5^{\circ}$ da Constituição da República Federativa do Brasil, doutrina e jurisprudência. 9. ed. São Paulo: Atlas, 2011, p. 80. Ainda nessa linha, afirma José Afonso da Silva que é em razão disso "que se considera legítima a defesa contra qualquer agressão à vida, bem como se reputa legítimo até mesmo tirar a vida de outrem em estado de necessidade da salvação da própria". SILVA, José Afonso da. Curso de Direito Constitucional Positivo. 24 edição, ver. atual. São Paulo: Malheiros, 2005, p. 198.

49 "Consiste no direito de estar vivo, de lutar pelo viver, de defender a própria vida, de permanecer vivo. É o direito de não ter interrompido o processo vital senão pela morte espontânea e inevitável. Existir é o movimento espontâneo contrário ao estado morte". SILVA, José Afonso da. Curso de Direito Constitucional Positivo. 24 edição, ver. atual. São Paulo: Malheiros, 2005, p. 198.

${ }^{50}$ Karel Vasak classificou o conteúdo dos direitos humanos em três gerações: os direitos humanos de primeira geração corresponderiam aos direitos de liberdade; os de segunda geração, aos direitos de igualdade e os de terceira geração, direitos de solidariedade, abrangendo o direito ao desenvolvimento e à autodeterminação. CARVALHO RAMOS, André de. Teoria Geral dos Direitos Humanos na Ordem Internacional. Rio de Janeiro: Renovar, 2005, p. 82. Alguns autores mencionam, ainda, os direitos de quarta geração ou dimensão abrangendo direitos resultantes da globalização dos direitos humanos. CARVALHO RAMOS, André de. Teoria Geral dos Direitos Humanos na Ordem Internacional. Rio de Janeiro: Renovar, 2005, p. 86. Sobre o desenvolvimento das fases dos direitos dos homens, interessante a leitura da obra clássica de Norberto Bobbio. BOBBIO, Norberto. A Era dos Direitos. Tradução Carlos Nelson Coutinho. Apresentação de Celso Lafer. $6^{a}$ reimpressão. Rio de Janeiro: Elsevier, 2004, p. 32-33.

${ }^{51}$ [N.R.] Há autores que criticam esse conceito, entendendo que seu uso sugeriria a substituição de uma geração por outra, quando na verdade somar-se-iam. Os direitos fundamentais representam a historicidade dos direitos que foram conquistados com o tempo. Nesse sentido, Antonio Cançado Trindade, ao exemplificar alguns dogmas do passado que devem ser questionados, afirma que "o quarto exemplo diz respeito à fantasia das chamadas 'gerações de direitos', à qual corresponde uma visão atomizada ou fragmentada destes últimos no tempo. A noção simplista das chamadas 'gerações de direitos', histórica e juridicamente infundada, tem prestado um desserviço ao pensamento mais lúcido a inspirar a evolução do direito internacional dos direitos humanos. Distintamente do que a infeliz invocação da imagem antológica da 'sucessão generacional' pareceria supor, os direitos humanos não se 'sucedem' ou 'substituem' uns aos outros, mas antes se expandem, se acumulam e fortalecem, interagindo os direitos individuais e sociais (tendo esses últimos inclusive precedidos os primeiros no plano internacional, a exemplo das primeiras convenções internacionais do trabalho). O que testemunhamos é o fenômeno não de uma sucessão, mas antes da expansão, cumulação e fortalecimento dos direitos humanos consagrados, a revelar a natureza complementar de todos os direitos humanos". CANÇADO TRINDADE, Antonio. In: PIOVESAN FLÁVIA. Direitos Humanos e o Direito Constitucional Internacional. $10^{a}$ edição, revista e atualizada. São Paulo: Saraiva, 2009, p. XXXVII.
} 
liberdade, isto é, garantindo uma atuação individual ${ }^{52}$ dentro de uma esfera de liberdade, contra os abusos e arbitrariedades cometidos pelos Estados.

Por outro lado, poderíamos verificar que a incolumidade do direito à vida de que trata a lei constitucional brasileira não é absoluta e possui exceções, a exemplo da pena de morte ${ }^{53}$, que também é prevista na Constituição Federal, artigo $5^{\circ}$, XLVII, $a^{54}$. André Ramos Tavares, no mesmo sentido, nos lembra de que em vista de uma "necessidade de coerência, de unidade [...] a interpretação constitucional haverá de ser consciente de que nenhum direito, nenhuma garantia, nenhuma liberdade poderá ser tomada como absoluta" ${ }^{\natural 5}$. Como veremos em maiores detalhes mais a frente, se entendido como um mandamento de otimização ${ }^{56}$, o direito à vida está sujeito a restrições ${ }^{57}$.

Além disso, a legislação também exige que se estabeleça um momento a partir do qual a vida deve estar protegida. Em geral, a vida estaria protegida desde a concepção ${ }^{58}$ e se encerraria observando o conceito de morte encefálica ${ }^{59,60}$.

Quanto a isso, vale lembrar que, ao estabelecer o momento em que a vida termina através do critério legal de morte encefálica, inadvertidamente, o legislador acabou criando o potencial de se importar este critério à discussão do aborto, especialmente, à discussão do aborto do anencéfalo, pois, analogamente, é possível entender-se que o início da vida dar-se-

\footnotetext{
52 São denominados de direitos individuais, pois correspondem aos direitos dos indivíduos. A doutrina os denomina também de liberdades públicas e corresponderiam a "direitos subjetivos", "reconhecidos e protegidos pela ordem jurídica a todos os seres humanos". FERREIRA FILHO, Manoel Gonçalves. Direitos Humanos Fundamentais. 10 ed. São Paulo: Saraiva, 2008, p. 28.

${ }^{53}$ Há quem entenda o aborto como pena de morte do nascituro. MARTINS, Ives Gandra da Silva. O direito do ser humano à vida. In: MARTINS, Ives Gandra da Silva; MARTINS, Roberto Vidal da Silva; MARTINS FILHO, Ives Gandra da Silva. A Questão do Aborto: Aspectos Jurídicos Fundamentais. São Paulo: Quartier Latin, 2008, p. 108.

${ }^{54}$ In verbis: "Não haverá pena de morte, salvo em caso de guerra declarada, nos termos do artigo 84, XIX.". ${ }^{54}$ BRASIL. Constituição (1988). Constituição da República Federativa do Brasil. Brasília, DF: Senado, 1988.

${ }^{55}$ TAVARES, André Ramos. Interpretação Constitucional. In: DIMOULIS, Dimitri (Coordenador Geral). TAVARES, André Ramos; DIMOULIS, Dimitri; BERCOVICI, Gilberto; SILVA, Guilherme Amorim Campos da; FRANCISCO, José Carlos; ANJOS FILHO, Robério Nunes dos; ROTHENBURG, Walter Claudius (org.). Dicionário Brasileiro de Direito Constitucional. São Paulo: Saraiva, 2007, p. 195.

56 ALEXY, Robert. Teoria dos Direitos Fundamentais. Tradução de Virgílio Afonso da Silva da $5^{\text {a }}$ edição alemã. São Paulo: Malheiros, 2008, p. 90.

57 ALEXY, Robert. Teoria dos Direitos Fundamentais. Tradução de Virgílio Afonso da Silva da $5^{\mathrm{a}}$ edição alemã. São Paulo: Malheiros, 2008, p. 90.

${ }^{58}$ Nos termos do art. $4^{\circ}$, I, CADH in verbis: "toda pessoa tem o direito de que se respeite sua vida. Esse direito deve ser protegido pela lei e, em geral, desde o momento da concepção. Ninguém pode ser privado da vida arbitrariamente". Disponível em: <http://www.cidh.oas.org/Basicos/ Portugues/c.Convencao_Americana.htm>. Acesso em: 10 out. 2010.

${ }^{59}$ Vide artigo $3^{\circ}$ da Lei $9434 / 97$ que substituiu as regulamentações anteriores (lei 8.489/92 e o Decreto 879/93) e a Lei 10.211/2001 que alterou seu texto. A lei estabelece que para a retirada de órgãos e tecidos para transplante é necessário o diagnóstico de morte encefálica.

60 "Uma vez que entramos nesse mundo simbólico, apenas a morte cerebral pode fazer-nos sair dele". SUPIOT, Alain. Homus juridicus: Ensaio sobre a função antropológica do Direito. Trad. Maria Ermantina de Almeida Prado Galvão. São Paulo: Martins Fontes, 2007, p. 5.
} 
ia apenas a partir do funcionamento cerebral regular, já que o inverso determina o fim da vida $^{61}$.

Ademais, no que tange a eventuais restrições, também é importante refletir se o direito à própria existência poderia ser limitado por conta da relação entre particulares. O indivíduo poderia dispor de sua própria vida? No que se refere ao direito à vida como direito à existência, relembrando os conceitos filosóficos de Dworkin, se entendermos o direito à existência como um "valor intrínseco", em princípio não seria possível dispor da vida ou sequer restringi-la, uma vez que o que se protege é a vida em si mesma. Mais uma vez, vale lembrar a lição de Rey Martínez de que, tradicionalmente, considera-se a vida um bem indisponível $^{62}$.

Já com relação ao mínimo existencial ou vida digna, Alexandre de Moraes afirma que o direito à vida "deve ser entendido como direito a um nível de vida adequado com a condição humana, ou seja, direito à alimentação, vestuário, assistência médico-odontológica, educação, cultura, lazer e demais condições vitais" ${ }^{\prime 63}$, criando uma dupla obrigação ao Estado: uma de cuidado ${ }^{64}$ e outra de concretização ${ }^{65}$.

No entanto, esse sentido de direito à vida poderia ser inserido no contexto da segunda dimensão (ou geração) de direitos ${ }^{66}$. Nesse contexto, os direitos humanos protegidos surgem de um cenário de lutas sociais em prol da igualdade, garantindo a todos os chamados direitos

\footnotetext{
${ }^{61}$ [N.R.] O tema será abordado cuidadosamente adiante.

${ }^{62}$ REY MARTÍNEZ, Fernando. Eutanasia y Derechos Fundamentales. Madrid: Centro de Estúdios Políticos Y Constitucionales, 2008, p. 135.

${ }^{63}$ Cf. MORAES, Alexandre de. Direitos Humanos Fundamentais: teoria geral, comentários aos arts. $1^{\circ}$ a $5^{\circ}$ da Constituição da República Federativa do Brasil, doutrina e jurisprudência. 9a . Ed. São Paulo: Atlas, 2011, p. 8081. Nesse sentido, considera Dimoulis que "além da proteção da existência física, o direito à vida abrange a pretensão a certa qualidade de vida, excluindo ações e omissões do Estado que agridam a dignidade humana e privem a pessoa do acesso aos meios de subsistência, isto é, da reprodução adequada da própria vida (alimentação, vestuário, moradia, atendimento médico etc)". DIMOULIS, Dimitri. Vida (Direito à). In: DIMOULIS, Dimitri (Coordenador Geral). TAVARES, André Ramos; DIMOULIS, Dimitri; BERCOVICI, Gilberto; SILVA, Guilherme Amorim Campos da; FRANCISCO, José Carlos; ANJOS FILHO, Robério Nunes dos; ROTHENBURG, Walter Claudius (org.). Dicionário Brasileiro de Direito Constitucional. São Paulo: Saraiva, 2007, p. 397.

${ }^{64}$ No primeiro caso, cuidar para que todos aqueles que não possam obter recursos suficientes e que não os tenham, ainda assim, possam ter seus direitos garantidos. MORAES, Alexandre de. Direitos Humanos Fundamentais: teoria geral, comentários aos arts. $1^{\circ}$ a $5^{\circ}$ da Constituição da República Federativa do Brasil, doutrina e jurisprudência. $9^{\mathrm{a}}$. Ed. São Paulo: Atlas, 2011, p. 80.

${ }^{65}$ DIMOULIS, Dimitri. Vida (Direito à). In: DIMOULIS, Dimitri (Coordenador Geral). TAVARES, André Ramos; DIMOULIS, Dimitri; BERCOVICI, Gilberto; SILVA, Guilherme Amorim Campos da; FRANCISCO, José Carlos; ANJOS FILHO, Robério Nunes dos; ROTHENBURG, Walter Claudius (org.). Dicionário Brasileiro de Direito Constitucional. São Paulo: Saraiva, 2007, p. 397.

${ }^{66}$ Como vimos, essa situação demonstra a evolução da proteção dos direitos humanos, de modo que uma geração não substitui a outra, mas se complementam. CARVALHO RAMOS, André de. Teoria Geral dos Direitos Humanos na Ordem Internacional. Rio de Janeiro: Renovar, 2005, p. 84-85. Vide também notas 50-51.
} 
sociais que englobam o direito à saúde e à habitação, entre outros ${ }^{67}$. Sob essa perspectiva, 0 direito à vida está relacionado a um conceito de vida digna ${ }^{68}$ : não basta estar vivo - é preciso um mínimo existencial para que a vida do indivíduo possa ser considerada digna de existir.

Vale dizer que a interação entre o direito à vida e a dignidade da pessoa humana será um dos principais pontos de tensão do debate sobre o aborto do feto anencéfalo. No entanto, é importante ressaltar que nosso objetivo é analisar o âmbito de proteção do direito à vida e as restrições a esse direito que poderiam justificar concretamente a legitimidade do aborto de feto anencéfalo, já que admiti-lo meramente com fundamento na dignidade da pessoa humana esvaziaria o debate, na medida em que seria possível defender tanto uma autorização quanto uma proibição do aborto sustentando, em ambos os casos, a dignidade da pessoa humana ${ }^{69}$ (o que, inclusive, ocorre com frequência).

José Afonso da Silva, por outro lado, critica e não acolhe o conceito de existência digna $^{70}$, pois, para ele, o termo - que "consubstancia aspectos generosos de natureza material e moral" $"$ - poderia justificar o desligamento de equipamentos médico-hospitalares de alguém que estivesse vivendo artificialmente, a prática da eutanásia, e, até mesmo, poderia vir a justificar a eliminação de um portador de deficiência "se viesse a concluir que não teria uma existência humana digna",72. Por fim, mais adiante analisaremos com detalhes os dois sentidos jurídicos atribuídos ao direito à vida, e também o desenvolvimento da proteção do direito à vida, observando que tanto o direito à própria existência, quanto o direito a uma vida digna, serão protegidos, ainda que as violações ocorram no âmbito das relações particulares.

\footnotetext{
${ }^{67}$ Os direitos econômicos e sociais foram especialmente consagrados pela Constituição Mexicana de 1917 e pela Constituição Alemã de Weimar de 1919.

${ }^{68}$ Para Fernando Rey Martínez, talvez seja mais correto falar em qualidade de vida do que vida digna. REY MARTÍNEZ, Fernando. Eutanasia y Derechos Fundamentales. Madrid: Centro de Estúdios Políticos Y Constitucionales, 2008, p. 28.

${ }^{69}$ REY MARTÍNEZ, Fernando. Eutanasia y Derechos Fundamentales. Madrid: Centro de Estúdios Políticos Y Constitucionales, 2008, p. 163.

70 Em sentido contrário, Paulo Hamilton e Miguel Oliveira defendem que "o valor fundamental do texto constitucional é a vida digna. Esse fato dota a vida humana de um valor fundamental e superior: dignidade da pessoa humana”. SIQUEIRA JÚNIOR, Paulo Hamilton; OLIVEIRA, Miguel Augusto Machado de. Direitos Humanos e Cidadania. $3^{\text {a }}$ ed. rev. e atual. São Paulo: Editora Revista dos Tribunais, 2010, p. 220.

${ }^{71}$ SILVA, José Afonso da. Curso de Direito Constitucional Positivo. $24^{a}$ edição, rev. atual. São Paulo: Malheiros, 2005, p. 198-199.

${ }^{72}$ SILVA, José Afonso da. Curso de Direito Constitucional Positivo. 24 edição, rev. atual. São Paulo: Malheiros, 2005, p. 198-199. Nessa linha, Fernando Rey Martínez ao tratar da eutanásia afirma que, por existirem diferentes concepções de dignidade em uma sociedade multicultural, a descriminalização da eutanásia é a maneira de autorizar todas as opções sem obrigar ninguém a reconhecer que todos têm o direito de levar a cabo as decisões mais íntimas e pessoais relacionadas a sua noção de dignidade e autonomia pessoal. REY, Fernando Martínez. Eutanasia y Derechos Fundamentales. Madrid: Centro de Estúdios Políticos Y Constitucionales, 2008, p. 4.
} 


\section{DIMENSÕES VERTICAL E HORIZONTAL DO DIREITO À VIDA E SUA PROTEÇÃO NO DIREITO INTERNACIONAL}

Quando falamos de direito à vida, percebemos que possui "diversas facetas"73 que alcançam, essencialmente, as diversas discussões sobre o começo e o fim da vida, abrangendo temas como eutanásia, ortotanásia, eugenia, suicídio assistido, aborto, pesquisas com célulastronco, e clonagem ${ }^{74}$ reprodutiva e terapêutica, cada qual estimulando importantes debates.

Diante disso, André de Carvalho Ramos constata a necessidade de se dividir a proteção da vida em uma dimensão vertical e uma dimensão horizontal ${ }^{75}$.

A dimensão vertical da proteção à vida versa sobre a proteção da vida nas "diferentes fases do desenvolvimento humano" "76 , e a dimensão horizontal da proteção à vida envolve os debates sobre a vida digna, realçando "qualidade de vida, mínimo existencial e facetas sociais"77. Essas dimensões ficam mais evidentes porque os diplomas normativos de direito internacional (e muitas vezes, de direito interno) não estabelecem marcos temporais claros da vida, mas apenas, marcos protetivos ${ }^{78}$.

Especialmente nos diplomas internacionais, podemos facilmente constatar que a proteção do direito à vida alcança a dimensão vertical e horizontal.

\footnotetext{
${ }^{73}$ CARVALHO RAMOS, André de. O direito à vida e a pena de morte. In: PETERKE, Sven (coord). Manual prático de direitos humanos internacionais. Brasília: Escola Superior do Ministério Público da União, 2009, p. 223.

${ }^{74}$ Vale notar que Alain Supiot critica ferozmente a clonagem humana, para tanto, utilizando vocabulário fortemente influenciado por valores religiosos: "A clonagem humana não é, porém, um projeto técnico como um outro. Não visa deslocar os limites que cerceiam a ação do homem sobre a natureza, mas apagar os limites constitutivos do ser humano. Se fosse pensar em um antecedente histórico, é mais na eugenia do que na aviação que cumpriria pensar [...]. Sob a égide das "leis da Ciência", a humanidade se divide então entre produtores de homens e homens produzidos. Produzindo o homem à sua imagem, o homem realizaria enfim seu mais louco sonho: ocupar o lugar de Deus Pai, do Pai absoluto que não é filho nem esposo de ninguém, e escapar assim a todos os limites que definem a condição humana”. SUPIOT, Alain. Homus juridicus: Ensaio sobre a função antropológica do Direito. Trad. Maria Ermantina de Almeida Prado Galvão. São Paulo: Martins Fontes, 2007, p. 11-12.

${ }^{75}$ CARVALHO RAMOS, André de. O direito à vida e a pena de morte. In: PETERKE, Sven (coord). Manual prático de direitos humanos internacionais. Brasília: Escola Superior do Ministério Público da União, 2009, p. 223.

${ }^{76}$ CARVALHO RAMOS, André de. O direito à vida e a pena de morte. In: PETERKE, Sven (coord). Manual prático de direitos humanos internacionais. Brasília: Escola Superior do Ministério Público da União, 2009, p. 223.

${ }^{77}$ CARVALHO RAMOS, André de. O direito à vida e a pena de morte. In: PETERKE, Sven (coord). Manual prático de direitos humanos internacionais. Brasília: Escola Superior do Ministério Público da União, 2009, p. 223.

${ }^{78}$ CARVALHO RAMOS, André de. O direito à vida e a pena de morte. In: PETERKE, Sven (coord). Manual prático de direitos humanos internacionais. Brasília: Escola Superior do Ministério Público da União, 2009, p. 224.
} 
Destacamos a Declaração Universal dos Direitos Humanos (DUDH) ${ }^{79}$ que, em 1948, já dispunha em seu artigo III sobre a proteção do direito à vida, garantindo esse direito a todos os seres humanos ${ }^{80}$, abrangendo, inclusive, a proteção ao mínimo existencial para uma vida digna $^{81}$.

Posteriormente, em 1966, o Pacto Internacional de Direitos Civis e Políticos ${ }^{82}$ e o Pacto Internacional relativo aos Direitos Econômicos, Sociais e Culturais ${ }^{83}$ também versaram sobre o direito à vida. No primeiro, a privação arbitrária da vida é proibida e regulada ${ }^{84}$, e, no segundo, há uma preocupação maior com a qualidade e condições de vida do indivíduo, o que corrobora o texto da Declaração Universal de Direitos Humanos, visando ainda a uma

\footnotetext{
${ }^{79}$ Aprovado pela Assembleia Geral da Organização das Nações Unidas (ONU). Resolução 217, A, III, de 10 de dzembro de 1948.

${ }^{80}$ Vide o artigo III da DUDH in verbis: "Todo ser humano tem direito à vida, à liberdade e à segurança pessoal". Disponível em: http://unicrio.org.br/img/DeclU_D_HumanosVersoInternet.pdf>. Acesso em: 10 out. 2010. Vale dizer que a Declaração Americana de Direitos e Deveres do Homem também abarca a proteção da vida. Artigo I "Todo ser humano tem direito à vida, à liberdade e à segurança de sua pessoa". A Declaração Americana foi aprovada na IX Conferência Internacional Americana em Bogotá, em 1948. Disponível em: <http://www.cidh.oas.org/Basicos/Portugues/b.Declaracao_Americana.htm>. Acesso: 10 out. 2010. CARVALHO RAMOS, André de. O direito à vida e a pena de morte. In: PETERKE, Sven (coord). Manual prático de direitos humanos internacionais. Brasília: Escola Superior do Ministério Público da União, 2009, p. 224.

${ }^{81}$ Vide o artigo XXV da DUDH: "1. Todo ser humano tem direito a um padrão de vida capaz de assegurar-lhe, e a sua família, saúde e bem-estar, inclusive alimentação, vestuário, habitação, cuidados médicos e os serviços sociais indispensáveis, e direito à segurança em caso de desemprego, doença, invalidez, viuvez, velhice ou outros casos de perda dos meios de subsistência em circunstâncias fora de seu controle". Disponível em: 〈http://unicrio.org.br/img/DeclU_D_HumanosVersoInternet.pdf〉. Acesso em: 10 out. 2010.

${ }^{82}$ O Pacto Internacional de Direitos Civis e Políticos foi adotado e aberto à assinatura, ratificação e adesão pela Assembleia Geral das Nações Unidas pela Resolução N. ${ }^{\circ}$ 2200-A (XXI), de 16 de Dezembro de 1966. Entrou em vigor em 1976. O Decreto-Legislativo n. 226, de 12 de dezembro de 1991, depositando a Carta de Adesão na Secretaria Geral da Organização das Nações Unidas em 24 de janeiro de 1992, entrando em vigor em 24 de abril do mesmo ano. Vide também Decreto 592 de 06 jul. 1992.

${ }^{83}$ O Pacto Internacional de Direitos Econômicos, Sociais e Culturais foi adotado e aberto à assinatura, ratificação e adesão pela Assembleia Geral das Nações Unidas na sua Resolução N. ${ }^{\circ}$ 2200-A (XXI), de 16 de dezembro de 1966.

${ }^{84}$ Vide especialmente o artigo $6^{\circ}$ in verbis: "O direito à vida é inerente à pessoa humana. Este direito está protegido por lei. Ninguém pode ser arbitrariamente privado da vida. 1. Nos países que não tenham abolido a pena capital, só pode ser imposta a pena de morte para os crimes mais graves, em conformidade com a legislação em vigor no momento em que se cometeu o crime, e que não seja contrária às disposições do presente Pacto nem da Convenção para a prevenção e punição do crime de genocídio. Esta pena só poderá ser aplicada em cumprimento de sentença definitiva de um tribunal competente. 2. Quando a privação da vida constituir crime de genocídio entende-se que nada do disposto neste artigo eximirá os Estados-Signatários do cumprimento de qualquer das obrigações assumidas em virtude das disposições da Convenção para a prevenção e punição do crime de genocídio. 3 . Toda a pessoa condenada à morte terá direito a solicitar o indulto ou a comutação da pena. A anistia, o indulto ou a comutação da pena capital poderão ser concedidos em todos os casos. 4. A pena de morte não poderá ser imposta por crimes cometidos por pessoas com menos de 18 anos de idade, nem se aplicará a mulheres grávidas. 5. Nenhuma disposição deste artigo poderá ser invocada por um Estado-Signatário no presente Pacto para retardar ou impedir a abolição da pena capital. Disponível em: <http://www.dhnet.org.br/direitos/sip/onu/doc/pacto2.htm>. Acesso em: 10 out. 2010.
} 
"melhoria contínua" da vida humana em geral ${ }^{85}$, tendo em vista o reconhecimento de que tais direitos "derivam da dignidade inerente à pessoa humana" 86 .

A proteção da vida é reafirmada, também, em âmbitos regionais internacionais pela Convenção Europeia de Direitos Humanos $(\mathrm{CEDH})^{87}$, e pela Convenção Americana de Direitos Humanos (CADH) ${ }^{88}$.

A Convenção Europeia, em seu artigo $11^{89}$, buscou proteger a vida trazendo, no entanto, algumas ressalvas a esse direito ${ }^{90}$.

O artigo $4^{\mathrm{o}}$ da Convenção Americana de Direitos Humanos ${ }^{91}$, por sua vez, garante o respeito à vida, inclusive proibindo os Estados de reinstituírem a pena de morte se já a aboliram, e incentivando os demais Estados a não a instituirem ${ }^{92}$.

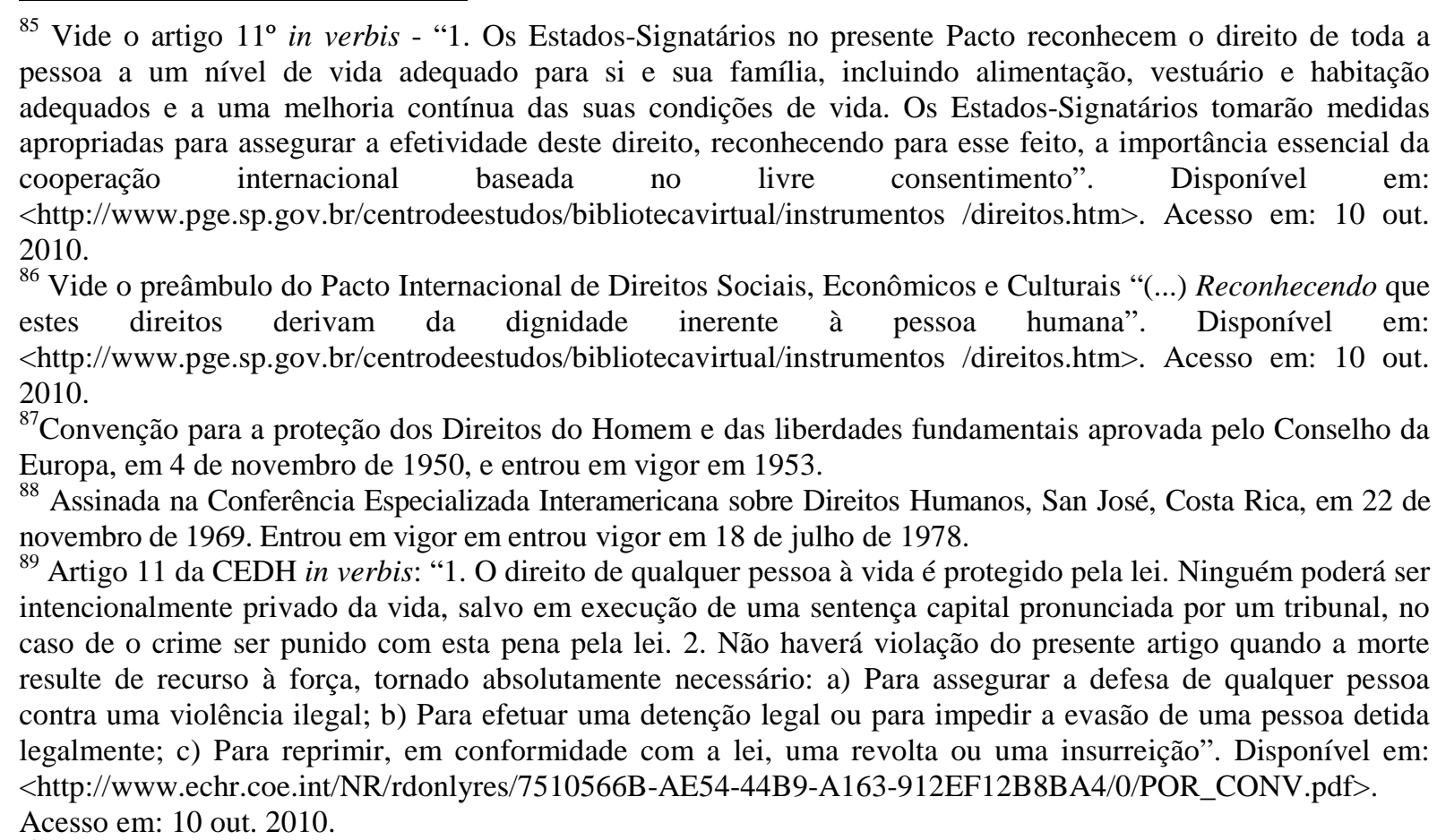

${ }^{90}$ Vide texto da Convenção na nota de rodapé acima.

${ }^{91}$ Artigo 4 da CADH in verbis: "1. Toda pessoa tem o direito de que se respeite sua vida. Esse direito deve ser protegido pela lei e, em geral, desde o momento da concepção. Ninguém pode ser privado da vida arbitrariamente; 2. Nos países que não houverem abolido a pena de morte, esta só poderá ser imposta pelos delitos mais graves, em cumprimento de sentença final de tribunal competente e em conformidade com lei que estabeleça tal pena, promulgada antes de haver o delito sido cometido. Tampouco se estenderá sua aplicação a delitos aos quais não se aplique atualmente; 3 . Não se pode restabelecer a pena de morte nos Estados que a hajam abolido; 4. Em nenhum caso pode a pena de morte ser aplicada por delitos políticos, nem por delitos comuns conexos com delitos políticos; 5. Não se deve impor a pena de morte a pessoa que, no momento da perpetração do delito, for menor de dezoito anos, ou maior de setenta, nem aplicá-la a mulher em estado de gravidez; 6. Toda pessoa condenada à morte tem direito a solicitar anistia, indulto ou comutação da pena, os quais podem ser concedidos em todos os casos. Não se pode executar a pena de morte enquanto o pedido estiver pendente de decisão ante a autoridade competente". Disponível em: <http://www.cidh.oas.org/Basicos/ Portugues/c.Convencao_Americana.htm>. Acesso em: 10 out. 2010.

${ }^{92}$ Vide texto da Convenção na nota de rodapé acima. 
Em seguida, estudaremos a possibilidade de restrições ou limites ao direito à vida em razão da existência de conflitos com outros direitos que também devem ser considerados na análise sobre o âmbito de proteção conferido à vida. 


\section{RESTRIÇÕES OU LIMITES À VIDA EM RAZÃO DA EXISTÊNCIA DE OUTROS DIREITOS}

\subsection{INTERPRETAÇÕES OBSERVADAS QUANTO AO ÂMBITO DE PROTEÇÃO DO DIREITO À VIDA}

A doutrina afirma que a pré-existência do direito à vida é essencial para que outros direitos fundamentais possam existir ${ }^{93}$. Nessa linha, Maria Helena Diniz afirma que o direito à vida "condiciona" outros direitos da personalidade ${ }^{94}$, e que "deve ser protegido contra tudo e contra todos", 95 , constituindo um verdadeiro "direito absoluto erga omnes"

Alguns autores entendem que, ao afirmar que o direito à vida constitui um direito supremo, ou o mais básico e fundamental de todos, se sugere implicitamente uma hierarquia entre direitos fundamentais ${ }^{97}$.

André de Carvalho Ramos apresenta outros dois aspectos que devem ser considerados para se estabelecer o âmbito de proteção do direito à vida: Para o autor, o caráter irreversível ${ }^{98}$ e irreparável da violação do direito à vida, bem como o "desconforto" de se estabelecer o início e o fim da vida, configuram seu caráter diferenciado em relação aos demais direitos fundamentais ${ }^{99}$.

Com base nisso, vale dizer que a vida não pode ser considerada uma "concessão jurídico-estatal" ${ }^{\prime 100}$, pois é indisponível, não cabendo ao titular, e tampouco ao estado,

\footnotetext{
${ }^{93}$ DINIZ, Maria Helena. O Estado Atual do Biodireito. São Paulo: Saraiva, 2009, p. 21.

${ }^{94}$ DINIZ, Maria Helena. O Estado Atual do Biodireito. São Paulo: Saraiva, 2009, p. 21.

${ }^{95}$ Para a autora, a vida deve prevalecer sobre qualquer outro direito, como por exemplo, a liberdade religiosa, constituindo autêntico "princípio do primado do mais relevante". DINIZ, Maria Helena. O Estado Atual do Biodireito. São Paulo: Saraiva, 2009, p. 25.

${ }^{96}$ DINIZ, Maria Helena. O Estado Atual do Biodireito. São Paulo: Saraiva, 2009, p. 21.

${ }^{97}$ KRATOCHVIL, Jan. The Rigth to Life in the Perspective of The Human Rights Committee and the European Court of Human Rights. Disponível em: 〈http://ssm.com/abstract=951225>, p. 1. Acesso em: 10 jun. 2010.

${ }_{98}$ Nesse sentido, Fernando Rey Martínez trata das singularidades do direito à vida como pressuposto lógico e ontológico dos demais direitos e seu caráter de irreversibilidade, pois a morte implica o desaparecimento de seu titular. REY MARTÍNEZ, Fernando. La Protección Jurídica de La Vida: Un Derecho em Transformación Y Expansión (art. 2 CEDH y Protocolos $6^{\circ}$ y $13^{\circ}$ ). In: GARCIA ROCA, Javier e SANTOLAYA, Pablo (coords). La Europa de Los Derechos: El Convenio Europeo de Derechos Humanos. Madrid: Centro de Estúdios Políticos Y Constitucionales, 2005, p. 71.

${ }^{99}$ CARVALHO RAMOS, André de. O direito à vida e a pena de morte. In: PETERKE, Sven (coord). Manual prático de direitos humanos internacionais. Brasília: Escola Superior do Ministério Público da União, 2009, p. 221.

${ }^{100}$ DINIZ, Maria Helena. O Estado Atual do Biodireito. São Paulo: Saraiva, 2009, p. 22.
} 
restringir o direito ou impedi-lo de ser exercido ${ }^{101}$, de modo que o estado deve proteger o direito à vida, além de garanti-lo.

Nesse sentido, também ensina Daniel Sarmento que essas obrigações do estado decorrem da ideia do "wellfare state"102, isto é, de uma concepção político-social do estado, que adota uma previsão de restrições às atividades estatais, ao lado da prestação de atividades, que sejam garantidoras de direitos fundamentais ${ }^{103}$. Nessa esteira, “o Estado Democrático de Direito é o modelo de organização que objetiva concretizar a justiça social" 104 .

Para demonstrar o desenvolvimento da proteção do direito à vida, André de Carvalho Ramos elenca quatro fases que marcaram a evolução do âmbito de proteção do direito à vida na esfera internacional ${ }^{105}$. Para ele, a primeira fase buscou proteger a vida contra sua violação arbitrária $^{106}$, em especial no que diz respeito à imposição de pena de morte. A segunda fase estabeleceu obrigações aos estados, no sentido de zelar pela vida de seus jurisdicionados ${ }^{107}$, dando destaque a casos de desaparecimentos forçados, torturas e uso desproporcionado da força cometido pelo estado por meio de seus agentes públicos ${ }^{108}$. Nas relações entre particulares ou relações privadas ${ }^{109}$, quando referidos desaparecimentos ou torturas fossem cometidos por grupos armados, por exemplo, surge a terceira fase do desenvolvimento do

${ }^{101}$ Para Maria Helena Diniz “a vida não é domínio da vontade livre”. DINIZ, Maria Helena. O Estado Atual do Biodireito. São Paulo: Saraiva, 2009, p. 25

${ }^{102}$ SARMENTO, Daniel. Direitos Fundamentais e Relações Privadas. Rio de Janeiro: Editora Lúmen Júris, 2008, p. 129.

${ }^{103}$ [N.R.]Trata-se do que se denomina dimensão objetiva dos direitos humanos que será estudado mais adiante.

${ }^{104}$ FRANCISCO, José Carlos. Estado Democrático de Direito. In: DIMOULIS, Dimitri (Coordenador Geral). TAVARES, André Ramos; DIMOULIS, Dimitri; BERCOVICI, Gilberto; SILVA, Guilherme Amorim Campos da; FRANCISCO, José Carlos; ANJOS FILHO, Robério Nunes dos; ROTHENBURG, Walter Claudius (org.). Dicionário Brasileiro de Direito Constitucional. São Paulo: Saraiva, 2007, p. 149.

${ }^{105}$ CARVALHO RAMOS, André de. O direito à vida e a pena de morte. In: PETERKE, Sven (coord). Manual prático de direitos humanos internacionais. Brasília: Escola Superior do Ministério Público da União, 2009, p. 226.

${ }^{106}$ CARVALHO RAMOS, André de. O direito à vida e a pena de morte. In: PETERKE, Sven (coord). Manual prático de direitos humanos internacionais. Brasília: Escola Superior do Ministério Público da União, 2009, p. 226.

${ }^{107}$ CARVALHO RAMOS, André de. O direito à vida e a pena de morte. In: PETERKE, Sven (coord). Manual prático de direitos humanos internacionais. Brasília: Escola Superior do Ministério Público da União, 2009, p. 226.

${ }^{108}$ André de Carvalho Ramos destaca que nessa fase buscou-se combater: “a) uso desproporcionado da força por parte dos agentes públicos; b) os desaparecimentos forçados e ataques clandestinos à vida por parte dos agentes públicos; c) torturas e mortes nas prisões e dependências policiais". CARVALHO RAMOS, André de. O direito à vida e a pena de morte. In: PETERKE, Sven (coord). Manual prático de direitos humanos internacionais. Brasília: Escola Superior do Ministério Público da União, 2009, p. 226. Carvalho Ramos menciona a jurisprudência da Corte Interamericana de Direitos Humanos nos casos Velásquez Rodriguez e Godínez Cruz e para maiores detalhes sugiro a leitura complementar de mesma autoria em que analisa minuciosamente os dois casos: CARVALHO RAMOS, André de. Direitos Humanos em juízo: comentários aos casos contenciosos e consultivos da Corte Interamericana de Direitos Humanos e estudo da implementação dessas decisões no Direito Brasileiro. São Paulo: Max Limonad, 2001, p. 118-162.

${ }^{109}$ CARVALHO RAMOS, André de. O direito à vida e a pena de morte. In: PETERKE, Sven (coord). Manual prático de direitos humanos internacionais. Brasília: Escola Superior do Ministério Público da União, 2009, p. 226. 
âmbito de proteção ao direito à vida ${ }^{110}$. A quarta e última fase abrangeria um espectro maior daquilo que podemos entender como direito à vida - abarcaria também condições mínimas de existência digna ${ }^{111}$.

Para atestarmos a incidência e relevância desses estágios de desenvolvimento de proteção do direito à vida, vale lembrar que o Brasil ainda enfrenta muitos temas que estão inseridos em diversas fases de desenvolvimento do âmbito de proteção da vida. Podemos destacar, por exemplo, as recentes discussões sobre o direito à vida no caso de células-tronco embrionárias na decisão do Supremo Tribunal Federal na Ação Direta de Inconstitucionalidade $3510^{112}$, bem como a recente responsabilização do Estado brasileiro pela Corte Interamericana de Direitos Humanos ${ }^{113}$ em relação a desaparecimentos e torturas cometidos por agentes estatais no período de ditadura militar, e até mesmo a manifestação do Supremo Tribunal Federal na Arguição de Descumprimento de Preceito Fundamental sobre a descriminalização do aborto de feto anencéfalo $54^{114}$, objeto deste trabalho.

Diante de tais discussões, restam, pois, claras a atualidade e a relevância do tema, bem como a certeza de que não há uma superação do tema ao longo do tempo, mas, como afirma André de Carvalho Ramos, um "maior ou menor foco sobre tais âmbitos de proteção"115.

Ante o exposto, vamos tratar da dimensão objetiva do direito à vida, e, individualmente, das obrigações positivas e negativas que dela decorrem, para que possamos,

\footnotetext{
${ }^{110} \mathrm{O}$ autor menciona as hipóteses de "combate aos esquadrões da morte e execuções extrajudiciais por parte de agentes privados", de modo que esse âmbito de proteção abarcaria "grupos vulneráveis" como ocorre, por exemplo, na "violência de gênero, contra crianças e por discriminação odiosa". Vide CARVALHO RAMOS, André de. O direito à vida e a pena de morte. In: PETERKE, Sven (coord). Manual prático de direitos humanos internacionais. Brasília: Escola Superior do Ministério Público da União, 2009, p. 226.

${ }^{111}$ CARVALHO RAMOS, André de. O direito à vida e a pena de morte. In: PETERKE, Sven (coord). Manual prático de direitos humanos internacionais. Brasília: Escola Superior do Ministério Público da União, 2009, p. 226. Sugere-se a leitura dos comentários feitos por André de Carvalho Ramos sobre a interpretação extensiva atribuída ao direito à vida pelos tribunais internacionais e a valoração do conteúdo social desse direito. CARVALHO RAMOS, André de. Processo Internacional de Direitos Humanos. 2. ed. São Paulo: Saraiva, 2012, p. 310-312.

${ }^{112}$ Ação Direta de Inconstitucionalidade (ADI) 3510-0, na qual se analisa a constitucionalidade do artigo $5^{\circ}$ da Lei de Biossegurança ${ }^{\circ}$ 11.105/2005, declarado constitucional pelo Supremo. Acórdão disponível no website do Supremo Tribunal Federal http://www.stf.jus.br.

${ }^{113}$ Corte IDH. Caso Gomes Lund y otros (Guerrilha do Araguaia) v. Brasil. Excepciones Preliminares, Fondo, Reparaciones y Costas. Sentencia de 24 de noviembre de 2010 Serie C No. 219. Vide ainda artigo que analisa os votos da ADPF 153 julgada em 28 abr. 2010 pelo Supremo Tribunal Federal e o Caso Gomes Lundi. CARVALHO RAMOS, André de. A ADPF 153 e a Corte Interamericana de Direitos Humanos. In: GOMES, Luiz Flávio; MAZZUOLI, Valério de Oliveira (Orgs.). Crimes da Ditadura Militar: uma análise à luz da jurisprudência atual da Corte Interamericana de Direito Humanos: Argentina, Brasil, Chile, Uruguais. São Paulo: Editora Revistas dos Tribunais, 2011, p. 174-225.

${ }^{114}$ ADPF 54. Vide em: http://www.stf.jus.br

${ }^{115}$ CARVALHO RAMOS, André de. O direito à vida e a pena de morte. In: PETERKE, Sven (coord). Manual prático de direitos humanos internacionais. Brasília: Escola Superior do Ministério Público da União, 2009, p. 227.
} 
assim, entender melhor o âmbito de proteção do direito à vida no campo do Direito Internacional.

\subsection{DIMENSÃO OBJETIVA DO DIREITO À VIDA}

A proteção jurídica da vida foi intensificando-se a partir da crescente necessidade de o estado não violar o direito à vida, bem como o dever de o estado proteger o direito à vida em relação a terceiros ${ }^{116}$, estabelecendo o que se denomina dimensão objetiva dos direitos humanos $^{117}$.

Assim, a dimensão objetiva ${ }^{118}$ do direito à vida não é apenas conferida ao titular desse direito, mas deve ser entendida como "um conjunto de regras impositivas de comportamento voltadas à proteção e satisfação do direito à vida dos indivíduos"119, acarretando as obrigações positivas e negativas de proteção ao direito à vida, em geral, atribuídas ao estado ${ }^{120}$, que, em caso de descumprimento, poderá ser responsabilizado internacionalmente.

\footnotetext{
${ }^{116}$ Para Sarlet, “[...] todos os órgãos, funções e atividades estatais encontram-se vinculados ao princípio da dignidade da pessoa humana, impondo-se-lhes um dever de respeito e proteção, que se exprime tanto na obrigação por parte do Estado de abster-se de ingerências na esfera individual que sejam contrárias à dignidade pessoal, quanto no dever de protegê-la (a dignidade pessoal de todos os indivíduos) contra agressões oriundas de terceiros, seja qual for a procedência, vale dizer, inclusive contra agressões oriundas de outros particulares, especialmente - mas não exclusivamente - dos assim denominados poderes sociais (ou poderes privados)". SARLET, Ingo Wolfgang. A Dignidade da Pessoa Humana e os Direitos Fundamentais na Constituição Federal e 1988. São Paulo: Livraria do Advogado, 2008, p. 113.

${ }^{117}$ CARVALHO RAMOS, André de. O direito à vida e a pena de morte. In: PETERKE, Sven (coord). Manual prático de direitos humanos internacionais. Brasília: Escola Superior do Ministério Público da União, 2009, p. 223. Nessa linha, Daniel Sarmento ensina que "A teoria contemporânea dos direitos fundamentais afirma que o Estado deve não apenas abster-se de violar tais direitos, tendo também de proteger seus titulares diante de lesões e ameaças provenientes de terceiros". SARMENTO, Daniel. Direitos Fundamentais e Relações Privadas. Rio de Janeiro: Editora Lúmen Júris, 2008, p. 129.

${ }^{118}$ Para André de Carvalho Ramos tem caráter "complementar à visão dos direitos humanos subjetivos públicos ou sob uma ótica de direito individual”. CARVALHO RAMOS, André de. Teoria Geral dos Direitos Humanos na Ordem Internacional. Rio de Janeiro: Renovar, 2005, p. 238.

${ }^{119}$ CARVALHO RAMOS, André de. O direito à vida e a pena de morte. In: PETERKE, Sven (coord). Manual prático de direitos humanos internacionais. Brasília: Escola Superior do Ministério Público da União, 2009, p. 223.Vide também CARVALHO RAMOS, André de. Teoria Geral dos Direitos Humanos na Ordem Internacional. Rio de Janeiro: Renovar, 2005, p. 237.

${ }^{120}$ Conforme André de Carvalho Ramos, em geral, ao Estado são atribuídas "regras de imposição de deveres" a fim de garantir a "implementação e desenvolvimento dos direitos individuais". CARVALHO RAMOS, André de. Teoria Geral dos Direitos Humanos na Ordem Internacional. Rio de Janeiro: Renovar, 2005, p. 237.
} 
Para Daniel Sarmento, a dimensão objetiva ${ }^{121}$ dos direitos fundamentais está vinculada ao fato de que tais direitos consagram "os valores mais importantes em uma comunidade",122, pois constituem os "valores nucleares de uma ordem jurídica democrática"123. Seus efeitos não podem depender de sua positivação por parte do estado em seu ordenamento e estão, em razão disso, sujeitos à "limitação jurídica do poder estatal" "124. Esses direitos se irradiam para "todos os campos do ordenamento jurídico"125, exigindo a atuação de todos os órgãos do estado. É o reconhecimento da relevância do conteúdo desses valores aliado à exigência de prestações por parte dos estados que comprovam sua dimensão objetiva ${ }^{126}$.

Assim, é possível afirmar que os direitos fundamentais têm uma dupla dimensão: constituem, ao mesmo tempo, fonte de direitos subjetivos ${ }^{127}$ e objetivos ${ }^{128}$.

Por outro lado, os direitos fundamentais ou individuais correspondem às "prestações negativas", ou seja, pressupõem uma não-intervenção do estado ${ }^{129}$ na medida em que este

\footnotetext{
${ }^{121} \mathrm{O}$ autor explica que na teoria liberal os direitos fundamentais eram tidos como limitadores do poder do Estado que tinha o "dever jurídico da abstenção" trazendo ao Direito Constitucional "a categoria de direito subjetivo", observando as pretensões do indivíduo em face do Estado em razão de "um direito positivado na sua ordem jurídica". Porém, com o Estado Social pós-guerra, mais os direitos fundamentais foram positivados internamente, exigindo uma "nova leitura". SARMENTO, Daniel. Direitos Fundamentais e Relações Privadas. $2^{\mathrm{a}}$ ed., $2^{\mathrm{a}}$ tiragem. Rio de Janeiro: Editora Lumen Júris, 2008, p. 105.

${ }^{122}$ Conforme o autor, determinam prestações aos Estados. SARMENTO, Daniel. Direitos Fundamentais e Relações Privadas. $2^{\text {a }}$. Ed., 2 ${ }^{\mathrm{a}}$. tiragem. Rio de Janeiro: Editora Lumen Júris, 2008, p. 105.

${ }^{123}$ SARMENTO, Daniel. Direitos Fundamentais e Relações Privadas. $2^{\mathrm{a}}$ ed., $2^{\mathrm{a}}$ tiragem. Rio de Janeiro: Editora Lumen Júris, 2008, p. 106.

${ }^{124}$ SARMENTO, Daniel. Direitos Fundamentais e Relações Privadas. $2^{\mathrm{a}}$ ed., $2^{\mathrm{a}}$ tiragem. Rio de Janeiro: Editora Lumen Júris, 2008, p. 106.

${ }^{125}$ SARMENTO, Daniel. Direitos Fundamentais e Relações Privadas. $2^{\mathrm{a}}$ ed., $2^{\mathrm{a}}$ tiragem. Rio de Janeiro: Editora Lumen Júris, 2008, p. 106.

${ }^{126}$ Além disso, correspondem aos valores essenciais de certa comunidade política, de modo que não é só dever do Estado, mas de toda a sociedade garanti-lo. SARMENTO, Daniel. Direitos Fundamentais e Relações Privadas. $2^{\mathrm{a}}$ ed., $2^{\mathrm{a}}$ tiragem. Rio de Janeiro: Editora Lumen Júris, 2008, p. 106.

${ }^{127}$ Para Daniel Sarmento, a dimensão subjetiva justifica que tais direitos "podem ser reclamados em juízo e as bases fundamentais da ordem jurídica, que se expandem para todo o direito positivo". SARMENTO, Daniel. Direitos Fundamentais e Relações Privadas. $2^{\mathrm{a}}$ ed., $2^{\mathrm{a}}$ tiragem. Rio de Janeiro: Editora Lumen Júris, 2008, p.107. Dimitri Dimoulis e Leonardo Martins afirmam que a dimensão subjetiva corresponde à visão clássica de que o "conteúdo normativo refere-se ao direito de seu titular de resistir à intervenção estatal em sua esfera de liberdade individual", aparecendo também no caso em que o indivíduo adquire um status de liberdade positiva, pressupondo ação estatal. DIMOULIS, Dimitri, MARTINS, Leonardo. Teoria Geral dos Direitos Fundamentais. $2^{a}$. ed. rev., atual. e ampl. São Paulo: Editora Revista dos Tribunais, 2009, p. 110-111. Vide também ALEXY, Robert. Teoria dos Direitos Fundamentais. Tradução de Virgílio Afonso da Silva. São Paulo: Malheiros, 2008, p. 180-193.

${ }^{128}$ SARMENTO, Daniel. Direitos Fundamentais e Relações Privadas. $2^{\mathrm{a}}$ ed., $2^{\mathrm{a}}$ tiragem. Rio de Janeiro: Editora Lumen Júris, 2008, p. 107. Vide também. CARVALHO RAMOS, André de. Teoria Geral dos Direitos Humanos na Ordem Internacional. Rio de Janeiro: Renovar, 2005, p. 237-238.

${ }^{129}$ Vale esclarecer que após a Revolução Industrial e o movimento do iluminismo, teorizava-se a busca de uma mínima interferência do Estado nas relações sociais, garantindo ao máximo a liberdade dos indivíduos. DINIZ, Geilza Fátima Cavalcanti. Aspectos Jurídicos da Clonagem Reprodutiva de Seres Humanos. $2^{\mathrm{a}}$. ed. Curitiba: Juruá, 2008, p. 52.
} 
deve proteger e garantir a "esfera de autonomia do indivíduo"130, correspondendo aos direitos de defesa ${ }^{131}$ (também denominados de direitos civis e políticos ${ }^{132}$ ).

Ademais, Fernando Rey Martínez menciona que, além dessa proibição, que vincula o estado de modo negativo, proibindo a ele causar a morte de um indivíduo por meio de agentes estatais, a importância do direito à vida faz com que os estados estejam também obrigados a proteger esse direito em seus ordenamentos internos, ficando assim vinculados também de modo positivo ${ }^{133}$. É nesse sentido que seria possível avaliar a conduta estatal e sua omissão ${ }^{134}$.

Isso quer dizer que, em suma, o estado deve abster-se de violar o direito à vida, e também garantir que tais direitos sejam protegidos ${ }^{135}$, já que o homem seria detentor desse direito e poderia exercê-lo livremente.

Daniel Sarmento acrescenta ainda que o estado deverá assegurar "condições mínimas para o exercício efetivo das liberdades constitucionais"136, devendo "formatar seus órgãos e os respectivos procedimentos" $" 137$ para proteger e garantir os direitos fundamentais.

É interessante pensar na proteção do direito à vida nesse contexto de dimensão objetiva. Isso porque, quando admitimos que o direito fundamental à vida está inserido neste cenário, a sua garantia não corresponde mais a apenas uma obrigação estatal. Toda a sociedade deve "agir em sua defesa"138. Daniel Sarmento afirma que a dimensão objetiva se

\footnotetext{
${ }^{130}$ CARVALHO RAMOS, André de. Teoria Geral dos Direitos Humanos na Ordem Internacional. Rio de Janeiro: Renovar, 2005, p. 82.

${ }^{131}$ REY MARTÍNEZ, Fernando. La Protección Jurídica de La Vida: Un Derecho em Transformación Y Expansión (art. 2 CEDH y Protocolos $6^{\circ}$ y $13^{\circ}$ ). In: GARCIA ROCA, Javier e SANTOLAYA, Pablo (coords). La Europa de Los Derechos: El Convenio Europeo de Derechos Humanos. Madrid: Centro de Estúdios Políticos Y Constitucionales, 2005, p. 71.

${ }^{132}$ CARVALHO RAMOS, André de. Teoria Geral dos Direitos Humanos na Ordem Internacional. Rio de Janeiro: Renovar, 2005, p. 82.

${ }^{133}$ REY MARTÍNEZ, Fernando. La Protección Jurídica de La Vida: Un Derecho em Transformación Y Expansión (art. $2 \mathrm{CEDH}$ y Protocolos $6^{\circ}$ y $13^{\circ}$ ). In: GARCIA ROCA, Javier e SANTOLAYA, Pablo (coords). La Europa de Los Derechos: El Convenio Europeo de Derechos Humanos. Madrid: Centro de Estúdios Políticos Y Constitucionales, 2005, p. 71.

${ }^{134}$ REY MARTíNEZ, Fernando. La Protección Jurídica de La Vida: Un Derecho em Transformación Y Expansión (art. 2 CEDH y Protocolos $6^{\circ}$ y $13^{\circ}$ ). In: GARCIA ROCA, Javier e SANTOLAYA, Pablo (coords). La Europa de Los Derechos: El Convenio Europeo de Derechos Humanos. Madrid: Centro de Estúdios Políticos Y Constitucionales, 2005, p. 71.

${ }^{135}$ CARVALHO RAMOS, André de. Teoria Geral dos Direitos Humanos na Ordem Internacional. Rio de Janeiro: Renovar, 2005, p. 84.

${ }^{136}$ SARMENTO, Daniel. Direitos Fundamentais e Relações Privadas. $2^{\mathrm{a}}$ ed., $2^{\mathrm{a}}$ tiragem. Rio de Janeiro: Editora Lumen Júris, 2008, p. 107.

${ }^{137}$ SARMENTO, Daniel. Direitos Fundamentais e Relações Privadas. $2^{\mathrm{a}}$ ed., $2^{\mathrm{a}}$ tiragem. Rio de Janeiro: Editora Lumen Júris, 2008, p. 107.

${ }^{138}$ Daniel Sarmento afirma ainda que "não só através dos instrumentos pertinentes, mas também no espaço público, através de mobilizações sociais, da atuação em ONG’s e outras entidades, do exercício responsável do direito de voto". SARMENTO, Daniel. Direitos Fundamentais e Relações Privadas. $2^{\mathrm{a}}$ ed., $2^{\mathrm{a}}$ tiragem. Rio de Janeiro: Editora Lumen Júris, 2008, p. 106-107.
} 
espalha, inclusive, no "âmbito das relações privadas"139, dificultando a plena autonomia do indivíduo, mas garantindo a máxima ${ }^{140}$ proteção do direito fundamental da pessoa humana ${ }^{141}$, no caso, o direito à vida.

A que correspondem essas obrigações positivas e negativas?

\subsubsection{Obrigações de Respeito e de Garantia e a Responsabilização Internacional do Estado em Caso de Violação do Direito à Vida}

Como vimos, a obrigação de proteger a vida, em geral, é atribuída aos estados, que podem ser responsabilizados internacionalmente, caso violem os compromissos assumidos em defesa dos direitos humanos.

Explica André de Carvalho Ramos que a responsabilidade internacional do estado por violação de direitos humanos está ligada diretamente à ideia de proteção internacional desses direitos, já que a "negação dessa responsabilidade acarreta a negação do caráter jurídico da norma internacional" ${ }^{\prime 42}$. Significa dizer que medidas que buscam prevenir futuras violações ou medidas que visem a responsabilizar o estado infrator garantiriam uma maior proteção dos direitos humanos, consolidando a "juridicidade das normas internacionais"143 e "o desenvolvimento das relações entre os Estados"144.

Os estados, neste contexto internacional, aderem a diversos diplomas jurídicos de proteção (convenções, declarações e tratados internacionais de proteção de direitos humanos,

\footnotetext{
139 SARMENTO, Daniel. Direitos Fundamentais e Relações Privadas. $2^{\mathrm{a}}$ ed., $2^{\mathrm{a}}$ tiragem. Rio de Janeiro: Editora Lumen Júris, 2008, p. 108.

${ }^{140}$ Vale dizer que Daniel Sarmento alerta para o fato de que a dimensão objetiva dos direitos fundamentais tem sido usada para justificar a limitação desses direitos em relação aos interesses da coletividade. SARMENTO, Daniel. Direitos Fundamentais e Relações Privadas. $2^{a}$ ed., $2^{a}$ tiragem. Rio de Janeiro: Editora Lumen Júris, 2008, p. 108.

${ }^{141}$ SARMENTO, Daniel. Direitos Fundamentais e Relações Privadas. $2^{\mathrm{a}}$ ed., $2^{\mathrm{a}}$ tiragem. Rio de Janeiro: Editora Lumen Júris, 2008, p.107.

${ }^{142}$ CARVALHO RAMOS, André de. Responsabilidade Internacional do Estado por Violação de Direitos Humanos. In: Revista do CEJ, Brasília, n. 29, p. 53-63, abr/jun 2005, p. 55. Para Casella a responsabilidade constituiria o verdadeiro princípio fundamental da justiça. ACCIOLY, Hildebrando; G. E. do Nascimento e Silva e; CASELLA, Paulo Borba. Manual de Direito Internacional Público. 18 ed., de acordo com o Decreto 7030 , de 14-12-2009, e a Lei 12.134, 18-12-2009. São Paulo: Saraiva, 2010, p. 364-365.

${ }^{143}$ CARVALHO RAMOS, André de. Responsabilidade Internacional do Estado por Violação de Direitos Humanos. In: Revista do CEJ, Brasília, n. 29, p. 53-63, abr/jun 2005, p. 55.

144 Responsabilidade Internacional do Estado porViolação de Direitos Humanos. In: Revista do CEJ, Brasília, n. 29, p. 53-63, abr/jun 2005, p. 55.
} 
por exemplo), que estabelecem "mecanismos de supervisão e controle do respeito, pelo Estado, desses mesmos direitos protegidos" ${ }^{\prime 45}$.

Especificamente no Sistema da Convenção Americana de Direitos Humanos (CADH), ao qual está submetido o Brasil ${ }^{146}$, o artigo $1.1^{147}$ obriga o estado a respeitar os direitos e liberdades reconhecidos pela Convenção e a garantir o livre e pleno exercício desses $\operatorname{direitos}^{148}$.

Surgem as obrigações de respeito e obrigações de garantia ${ }^{149}$ : a obrigação de respeito corresponderia a uma obrigação de não-fazer, enquanto que a obrigação de garantia corresponderia a uma obrigação de fazer ${ }^{150}$.

É simples: no primeiro caso, o Estado não deve cometer atos que violem os direitos humanos $^{151}$, sendo, deste modo, um dever negativo por parte do Estado ${ }^{152}$; no segundo caso, diferentemente, o Estado tem o dever positivo de criar mecanismos para "prevenir, investigar

145 CARVALHO RAMOS, André de. Responsabilidade Internacional por Violação de Direitos Humanos: seus elementos, a reparação devida e sanções possíveis: teoria e prática do direito internacional. Rio de Janeiro: Renovar, 2004, p. 34.

${ }^{146}$ A Convenção foi aprovada na Conferência de São José da Costa Rica em 22 nov. 1969, mas o Brasil somente aderiu à Convenção em 1992, por meio do Decreto 678 de 6 nov. 1992.

${ }^{147}$ Artigo $1^{\circ}$ - Obrigação de respeitar os direitos, in verbis: 1. Os Estados-partes nesta Convenção comprometemse a respeitar os direitos e liberdades nela reconhecidos e a garantir seu livre e pleno exercício a toda pessoa que esteja sujeita à sua jurisdição, sem discriminação alguma, por motivo de raça, cor, sexo, idioma, religião, opiniões políticas ou de qualquer outra natureza, origem nacional ou social, posição econômica, nascimento ou qualquer outra condição social. (negrito nosso) Disponível em: <http://www.cidh.oas.org/Basicos/ Portugues/c.Convencao_Americana.htm>. Acesso em: 10 out. 2010.

${ }^{148}$ A Corte Interamericana de Direitos Humanos entendeu, na Opinião Consultiva 14/94, que os artigos 1 e 2 da Convenção estabelecem um compromisso com os Estados de respeitar os direitos e liberdades reconhecidos por ela, garantindo seu livre e pleno exercício, devendo ser adotadas medidas legislativas ou de outra natureza necessárias para efetivar esses direitos e garantias. Assim, para a Corte, se o Estado contraiu uma obrigação de adotar as medidas necessárias para efetivar esses direitos, com maior razão, o Estado não deve adotar medidas que contrariem o objeto e a finalidade da Convenção. Corte IDH. Responsabilidad Internacional por Expedición y Aplicación de Leyes Violatorias de la Convención (arts. 1 y 2 Convención Americana sobre Derechos Humanos). Opinión Consultiva OC-14/94 del 9 de diciembre de 1994. Serie A No. 14, p. 11-12. Tradução nossa.

${ }^{149}$ Sarlet afirma que o "princípio da dignidade da pessoa humana não apenas impõe um dever de abstenção (respeito), mas também condutas positivas tendentes a efetivar e proteger a dignidade dos indivíduos". SARLET, Ingo Wolfgang. A Dignidade da Pessoa Humana e os Direitos Fundamentais na Constituição Federal e 1988. São Paulo: Livraria do Advogado, 2008, p. 113.

${ }^{150}$ CARVALHO RAMOS, André de. Responsabilidade Internacional por Violação de Direitos Humanos: seus elementos, a reparação devida e sanções possíveis: teoria e prática do direito internacional. Rio de Janeiro: Renovar, 2004, p. 41. Vide também CARVALHO RAMOS, André de. Processo Internacional de Direitos Humanos: análise dos sistemas de apuração de violações dos direitos humanos e a implementação das decisões no Brasil. Rio de Janeiro: Renovar, 2002, p. 224-225. CARVALHO RAMOS, André. Teoria Geral dos Direitos Humanos na Ordem Internacional. Rio de Janeiro: Renovar, 2005, p. 239.

${ }^{151}$ CARVALHO RAMOS, André de. Responsabilidade Internacional por Violação de Direitos Humanos: seus elementos, a reparação devida e sanções possíveis: teoria e prática do direito internacional. Rio de Janeiro: Renovar, 2004, p. 41. CARVALHO RAMOS, André. Teoria Geral dos Direitos Humanos na Ordem Internacional. Rio de Janeiro: Renovar, 2005, p. 239.

${ }^{152}$ CARVALHO RAMOS, André. Teoria Geral dos Direitos Humanos na Ordem Internacional. Rio de Janeiro: Renovar, 2005, p. 240. 
e mesmo punir toda violação, pública ou privada, dos direitos fundamentais da pessoa humana, mostrando a faceta objetiva ${ }^{153}$ desses mesmos direitos" ${ }^{\text {"154 }}$.

Para Fernando Rey Martínez, essa dimensão positiva obrigaria os estados a estabelecer "um sistema de proteção (inclusive penal) que sancionasse qualquer agressão à vida independentemente de sua origem pública ou privada"155. Ainda para o autor, "diante de certos tipos de riscos contra a vida de terceiros", exige-se dos estado o estabelecimento de um sistema de normas que efetivamente protejam a vida ou permitam uma reparação suficiente" 156 à vítima. Seria nessa dimensão positiva de uma obrigação do estado de se proteger a vida que se discute a questão da tutela estatal da eutanásia e do aborto.

A obrigação de não-fazer surge da obrigação de o estado respeitar os direitos humanos, que se "traduz na limitação do poder público"157 em decorrência dos "atributos inerentes à dignidade humana e em consequência, superiores ao poder do Estado" ${ }^{158}$. Isto significa dizer que o estado, por meio de seus agentes, não deve agir no sentido de privar indivíduos de seu

\footnotetext{
${ }^{153}$ A interpretação no regime objetivo das normas internacionais de direitos humanos deve ser feita em favor dos indivíduos e não dos estados que contraem as obrigações por tratados internacionais, não sendo exigida uma contraprestação. Sobre o tema ler mais as obras de CARVALHO RAMOS, André de. Responsabilidade Internacional por Violação de Direitos Humanos: seus elementos, a reparação devida e sanções possíveis: teoria e prática do direito internacional. Rio de Janeiro: Renovar, 2004, p. 36-40, Processo Internacional de Direitos Humanos: análise dos sistemas de apuração de violações dos direitos humanos e a implementação das decisões no Brasil. Rio de Janeiro: Editora Renovar, 2002, p. 25-38 e Teoria Geral dos Direitos Humanos na Ordem Internacional. Rio de Janeiro: Renovar, 2005, p. 237-242. Ler também SARMENTO, Daniel. Direitos Fundamentais e Relações Privadas. Rio de Janeiro: Editora Lúmen Júris, 2008, p. 129-138.

${ }^{154}$ CARVALHO RAMOS, André de. Responsabilidade Internacional por Violação de Direitos Humanos: seus elementos, a reparação devida e sanções possíveis: teoria e prática do direito internacional. Rio de Janeiro: Renovar, 2004, p. 41.

${ }^{155}$ REY MARTÍNEZ, Fernando. La Protección Jurídica de La Vida: Un Derecho em Transformación Y Expansión (art. $2 \mathrm{CEDH}$ y Protocolos $6^{\circ}$ y $13^{\circ}$ ). In: GARCIA ROCA, Javier e SANTOLAYA, Pablo (coords). La Europa de Los Derechos: El Convenio Europeo de Derechos Humanos. Madrid: Centro de Estúdios Políticos Y Constitucionales, 2005, p. 74 (tradução nossa).

${ }^{156}$ REY MARTíNEZ, Fernando. La Protección Jurídica de La Vida: Un Derecho em Transformación Y Expansión (art. $2 \mathrm{CEDH}$ y Protocolos $6^{\circ}$ y $13^{\circ}$ ). In: GARCIA ROCA, Javier e SANTOLAYA, Pablo (coords). La Europa de Los Derechos: El Convenio Europeo de Derechos Humanos. Madrid: Centro de Estúdios Políticos Y Constitucionales, 2005, p. 74 (tradução nossa).

${ }^{157}$ CARVALHO RAMOS, André de. O direito à vida e a pena de morte. In: PETERKE, Sven (coord). Manual prático de direitos humanos internacionais. Brasília: Escola Superior do Ministério Público da União, 2009, p. 227 e CARVALHO RAMOS, André. Teoria Geral dos Direitos Humanos na Ordem Internacional. Rio de Janeiro: Renovar, 2005, p. 239.

${ }^{158}$ CARVALHO RAMOS, André de. O direito à vida e a pena de morte. In: PETERKE, Sven (coord). Manual prático de direitos humanos internacionais. Brasília: Escola Superior do Ministério Público da União, 2009, p. 227 e CARVALHO RAMOS, André. Teoria Geral dos Direitos Humanos na Ordem Internacional. Rio de Janeiro: Renovar, 2005, p. 239.
} 
direito à vida arbitrariamente ou com o uso excessivo de força ${ }^{159}$, mesmo em caso de "ruptura" da ordem pública ${ }^{160}$.

Se o estado agir em dissonância com o dever de respeitar, responderá, portanto, por sua conduta comissiva. As jurisprudências das Cortes Internacionais de Direitos Humanos Europeia e Interamericana seguem nesse sentido, responsabilizando o estado quando este age excessivamente ou arbitrariamente contra a vida, ainda que seja para garantir a ordem interna do país ou nos casos da "guerra contra o terror"161.

Além da obrigação de respeito, existem as obrigações de garantia que correspondem às obrigações de fazer. Nesse caso, cabe aos estados criar mecanismos e instrumentos ${ }^{162}$, a fim de prevenir, investigar e punir toda violação de direito humanos.

A Corte tem entendido tal obrigação como um verdadeiro "dever preventivo" a ser realizado pelo estado ${ }^{163}$, exigindo não só a defesa dos direitos humanos, mas também, uma vez que tais direitos sejam violados, que o estado garanta a indenização das vítimas e a punição dos culpados. Assim, o estado também responderá se for omisso no sentido de prevenir e reparar a violação dos direitos garantidos, em especial, o direito à vida ${ }^{164}$.

Podemos afirmar ainda que as obrigações de garantia alcançam um patamar bem mais extenso porque exigem do estado uma estrutura coerente com a prevenção do direito à vida e reparação no caso desse direito ser violado. É necessário, portanto, que essa estrutura tenha a participação do estado no âmbito administrativo, legislativo e jurídico ${ }^{165}$, o que, na visão de André de Carvalho Ramos, abarcaria "todas aquelas medidas de caráter jurídico, político, administrativo e cultural" 166 .

\footnotetext{
${ }^{159}$ CARVALHO RAMOS, André de. O direito à vida e a pena de morte. In: PETERKE, Sven (coord). Manual prático de direitos humanos internacionais. Brasília: Escola Superior do Ministério Público da União, 2009, p. 227.

${ }^{160}$ Nesse sentido, ensina André de Carvalho Ramos. CARVALHO RAMOS, André de. O direito à vida e a pena de morte. In: PETERKE, Sven (coord). Manual prático de direitos humanos internacionais. Brasília: Escola Superior do Ministério Público da União, 2009, p. 227.

${ }^{161}$ Explicam Andrew Clapham e Susan Marks que atualmente existe um grave perigo relacionado ao terrorismo e ao contra-terrorismo já que nesse último caso, muitos abusos se têm feito aos direitos humanos em nome da luta contra o terror, até mesmo em decorrência da subjetividade do conceito de terrorismo. Ler mais em: CLAPHAM, Andrew e MARKS, Susan. International Human Rights Lexicon. New York: Oxford University Press, 2005, p. 345-346.

${ }_{162}$ Para André de Carvalho Ramos essa obrigação invoca a "criação de procedimentos e estruturas que previnam a ocorrência de violações de direitos protegidos". CARVALHO RAMOS, André. Teoria Geral dos Direitos Humanos na Ordem Internacional. Rio de Janeiro: Renovar, 2005, p. 240.

${ }_{163}$ Corte IDH. Caso Velásquez Rodríguez v. Honduras. Fondo. Sentencia de 29 de julio de 1988. Serie C no 4. ${ }^{164}$ Vide [N.R.] 151 a 154.

${ }^{165}$ Nesse sentido. CARVALHO RAMOS, André de. Responsabilidade Internacional do Estado por Violação de Direitos Humanos. In: Revista do CEJ, Brasília, n. 29, p. 53-63, abr/jun 2005, p. 55.

${ }^{166}$ CARVALHO RAMOS, André. Teoria Geral dos Direitos Humanos na Ordem Internacional. Rio de Janeiro: Renovar, 2005, p. 241.
} 
Observando, assim, as obrigações de fazer e de não-fazer às quais estão submetidos os estados, nota-se que esses poderiam ser responsabilizados por sua conduta comissiva ou por sua conduta omissiva no que tange ao direito à vida. Significa afirmar que o estado pode ser responsabilizado internacionalmente, quer por ter cometido atos que violem o direito à vida, quer por ter deixado de prevenir ou punir tais atos ${ }^{167}$.

Todavia, é importante ressaltar que nem todo ato ensejará a responsabilidade do estado $^{168}$, mesmo quando o direito em questão versar sobre a vida. Um argumento bastante utilizado no campo do Direito Internacional Público aponta que a responsabilidade do estado decorre do descumprimento de um compromisso ou norma internacional ao qual o estado se vinculou voluntariamente por meio de tratados ou costumes internacionais ${ }^{169}$.

Nesse sentido, Paulo Borba Casella explica que a responsabilidade do estado decorre de "todo ato ou omissão que lhe seja imputável e do qual resulte a violação de uma norma jurídica internacional ou de suas obrigações internacionais" ${ }^{170}$, de modo que somente a conduta comissiva ou omissiva que efetivamente viole um compromisso internacional firmado pelo estado pode ensejar a sua responsabilidade no âmbito internacional ${ }^{171}$.

Ademais, como ensina André de Carvalho Ramos, a responsabilidade internacional do estado possui três elementos ${ }^{172}$ : existência de um fato internacionalmente ilícito, o resultado lesivo, e o nexo causal ${ }^{173}$. Dessa forma, o primeiro elemento, para o autor, decorre de uma conduta comissiva ou omissiva de uma prévia obrigação internacional estabelecida pela ordem jurídica ${ }^{174}$, porém "a imputabilidade é o elemento que vincula a conduta do agente do Estado responsável" ${ }^{, 175}$. Assim, não basta ter-se violado o direito à vida: é necessário que o ato

\footnotetext{
${ }^{167}$ Vide [N.R.] 151 a 154.

${ }^{168}$ Vide CASSESE, Antonio. International Law. New York: Oxford University Press, 2005, p. 243.

${ }^{169}$ CASSESE, Antonio. International Law. New York: Oxford University Press, 2005, p. 242.

170 ACCIOLY, Hildebrando; G. E. do Nascimento e Silva e; CASELLA, Paulo Borba. Manual de Direito Internacional Público. 18 ed., de acordo com o Decreto 7030, de 14 dez. 2009, e a Lei 12.134, 18 dez. 2009. São Paulo: Saraiva, 2010, p. 365.

${ }^{171}$ No caso "A Última tentação de Cristo" a Corte Interamericana de Direitos Humanos entendeu que o descumprimento de uma norma obrigatória assumida pelo Estado gera a responsabilidade, ainda que não houve a culpa do agente ou que ocorra um dano. Corte IDH. Caso "La Última Tentación de Cristo" (Olmedo Bustos y otros) v. Chile. Fondo, Reparaciones y Costas. Sentencia de 5 de febrero de 2001. Serie C No. 73, $§ 72$.

172 As pré-condições da responsabilidade do estado para Cassese seriam: 1) elementos subjetivos: a) imputabilidade da conduta omissiva ou comissiva ao estado de um indivíduo contrária à uma obrigação internacional e em alguns casos a culpa de um agente estatal executando o ato ilícito; 2) elementos objetivos: a) inconsistência de uma conduta particular em relação à uma obrigação internacional, b) danos morais ou materiais causados à outro sujeito internacional, c) ausência de qualquer uma das várias circunstâncias excludentes de ilicitude. CASSESE, Antonio. International Law. New York: Oxford University Press, 2005, p. 245-246.

${ }^{173}$ CARVALHO RAMOS, André de. Responsabilidade Internacional por Violação de Direitos Humanos: seus elementos, a reparação devida e sanções possíveis: teoria e prática do direito internacional. Rio de Janeiro: Renovar, 2004, p. 107-111, em especial, p. 107.

${ }^{174}$ International Law.New York: Oxford University Press, 2005, p. 108.

${ }^{175}$ International Law.New York: Oxford University Press, 2005, p. 111.
} 
seja considerado ilícito, resulte em lesão, e que haja nexo causal entre o ato lesivo e o mal provocado.

Além disso, a conduta omissiva ou comissiva em questão não precisa ser "cometida" exclusivamente por agentes do estado. Um particular também poderia gerar responsabilidade do estado em decorrência do caráter objetivo do direito à vida. Daí porque, em se tratando de respeito e prevenção do direito à vida, o tema ganha amplitude, exigindo uma postura mais atuante do estado, inclusive nas relações privadas. $\mathrm{O}$ estado, por exemplo, poderia ser responsabilizado na hipótese de um particular matar alguém ${ }^{176}$. São claras as possíveis implicações disso com relação até mesmo ao aborto.

\subsection{O DIREITO À VIDA NAS CORTES INTERNACIONAIS DE DIREITOS HUMANOS}

Há diversos diplomas internacionais que cuidam da proteção do direito à vida, como já dito anteriormente. A Declaração Universal dos Direitos do Homem (DUDH), que garante a todo ser humano o direito à vida em seu artigo III $^{177}$, como vimos, estende a proteção desse direito à luz de um significado mais amplo de vida, entendido como a garantia do mínimo existencial para uma vida digna, garantindo saúde, bem-estar, alimentação e habitação, entre $\operatorname{outros}^{178}$.

Além da DUDH, os Pactos Internacionais de Direitos Civis e Políticos ${ }^{179}$ e o de Direitos Econômicos, Sociais e Culturais ${ }^{180,181}$ garantem ainda mais a possibilidade de se

\footnotetext{
${ }^{176}$ CARVALHO RAMOS, André de. Responsabilidade Internacional por Violação de Direitos Humanos: seus elementos, a reparação devida e sanções possíveis: teoria e prática do direito internacional. Rio de Janeiro: Renovar, 2004, p. 107-111, em especial, p. 107.

${ }^{177}$ Estabelece o artigo III da DUDH in verbis: "Todo ser humano tem direito à vida, à liberdade e à segurança pessoal”. Disponível em: 〈http://unicrio.org.br/img/DeclU_D_HumanosVersoInternet.pdf〉. Acesso em: 10 out. 2010.

${ }^{178}$ Vide o artigo XXV da DUDH in verbis: "1. Todo ser humano tem direito a um padrão de vida capaz de assegurar-lhe, e a sua família, saúde e bem-estar, inclusive alimentação, vestuário, habitação, cuidados médicos e os serviços sociais indispensáveis, e direito à segurança em caso de desemprego, doença, invalidez, viuvez, velhice ou outros casos de perda dos meios de subsistência em circunstâncias fora de seu controle". Disponível em: 〈http://unicrio.org.br/img/DeclU_D_HumanosVersoInternet.pdf〉. Acesso em: 10 out. 2010.

${ }^{179}$ O Pacto Internacional de Direitos Civis e Políticos foi adotado e aberto à assinatura, ratificação e adesão pela Assembleia Geral das Nações Unidas pela Resolução N. ${ }^{\circ}$ 2200-A (XXI), de 16 de Dezembro de 1966.

${ }^{180} \mathrm{O}$ Pacto Internacional relativo aos Direitos Econômicos, Sociais e Culturais foi adotado e aberto à assinatura, ratificação e adesão pela Assembleia Geral das Nações Unidas na sua Resolução N. ${ }^{\circ}$ 2200-A (XXI), de 16 de Dezembro de 1966. Guilherme Assis de Almeida ensina que "a Carta da ONU, de 1945, a Declaração Universal dos Direitos Humanos, de 1948, o Pacto Internacional de Direitos Civis e Políticos (foi adotado em 1966 e entrou em vigor em 1976; atualmente tem 137 ratificações), e o Pacto Internacional de Direitos Econômicos, Sociais e Culturais (foi adotada em 1966 e entrou em vigor em 1976; atualmente conta com 140 ratificações)
} 
proteger a vida humana, não só regulando e coibindo uma conduta que arbitrariamente prive um indivíduo de sua vida ${ }^{182}$, como, nos casos de pena de morte ${ }^{183}$, destacando sua proibição em caso de menores de 18 anos e grávidas. Garantem, ainda, uma "melhoria contínua"184 na qualidade de vida do ser humano ${ }^{185}$, tendo em vista que o reconhecimento de tais direitos "derivam da dignidade inerente à pessoa humana"186.

No âmbito regional, tanto na Convenção Europeia de Direitos Humanos - $\mathrm{CEDH}^{187}$ quanto na Convenção Americana de Direitos Humanos - $\mathrm{CADH}^{188}$, o indivíduo não pode ser

formam em conjunto, a Carta da ONU de Direitos Humanos, documento básico do DIDH”. ALMEIDA, Guilherme Assis de. Direitos humanos e não-violência. São Paulo: Atlas, 2001, p. 61

${ }^{181}$ Ensinam Vladmir Oliveira da Silveira e Maria Mendez Rocasolano que "a diferença básica entre os dois pactos está no fato de que, enquanto o Pacto de Direitos Civis e Políticos criou predominantemente direitos para os indivíduos, o Pacto de Direitos Econômicos, Sociais e Culturais estabeleceu obrigações coletivas para os Estados-partes, tais como garantir trabalho, qualidade de vida, educação, moradia, saúde e previdência, entre outros. SILVEIRA, Vladmir Oliveira da; ROCASOLANO, Maria Mendez. Direitos humanos: conceitos, significados e funções. São Paulo: Saraiva, 2010, p. 158.

${ }^{182}$ Vide especialmente o artigo 6. ${ }^{\circ}$ do Pacto Internacional de Direitos Civis e Políticos, in verbis: "O direito à vida é inerente à pessoa humana. Este direito está protegido por lei. Ninguém pode ser arbitrariamente privado da vida. 1. Nos países que não tenham abolido a pena capital, só pode ser imposta a pena de morte para os crimes mais graves, em conformidade com a legislação em vigor no momento em que se cometeu o crime, e que não seja contrária às disposições do presente Pacto nem da Convenção para a prevenção e punição do crime de genocídio. Esta pena só poderá ser aplicada em cumprimento de sentença definitiva de um tribunal competente. 2. Quando a privação da vida constituir crime de genocídio entende-se que nada do disposto neste artigo eximirá os Estados-Signatários do cumprimento de qualquer das obrigações assumidas em virtude das disposições da Convenção para a prevenção e punição do crime de genocídio. 3 . Toda a pessoa condenada à morte terá direito a solicitar o indulto ou a comutação da pena. A anistia, o indulto ou a comutação da pena capital poderão ser concedidos em todos os casos. 4. A pena de morte não poderá ser imposta por crimes cometidos por pessoas com menos de 18 anos de idade, nem se aplicará a mulheres grávidas. 5. Nenhuma disposição deste artigo poderá ser invocada por um Estado-Signatário no presente Pacto para retardar ou impedir a abolição da pena capital". Disponível em: 〈http://www.dhnet.org.br/direitos/sip/onu/doc/pacto2.htm>. Acesso em: 10 out. 2010.

${ }_{183}$ CLAPHAM, Andrew e MARKS, Susan. International Human Rights Lexicon. New York: Oxford University Press, 2005, p. 50-52.

${ }^{184}$ Vide o artigo 11 do Pacto Internacional de Direitos Econômicos, Sociais e Culturais in verbis: "1 - Os Estados-Signatários no presente Pacto reconhecem o direito de toda a pessoa a um nível de vida adequado para si e sua família, incluindo alimentação, vestuário e habitação adequados e a uma melhoria contínua das suas condições de vida. Os Estados-Signatários tomarão medidas apropriadas para assegurar a efetividade deste direito, reconhecendo para esse feito, a importância essencial da cooperação internacional baseada no livre consentimento". Disponível em: <http://www.pge.sp.gov.br/centrodeestudos/bibliotecavirtual/instrumentos /direitos.htm>. Acesso em: 10 out. 2010.

${ }^{185}$ Nos lembra Cláudia Perrone-Moisés que o Pacto Internacional relativo aos Direitos Econômicos, Sociais e Culturais "reconhece o direito de toda pessoa a um nível de vida adequado para si próprio e para a sua família, incluindo-se a alimentação, vestimenta e moradia, assim como a melhoria contínua de suas condições de vida, e determina que o Estados Partes devem tomar medidas apropriadas para assegurar a consecução desse direito". PERRONE-MOISÉS, Cláudia. Direitos Humanos e Desenvolvimento: A Contribuição das Nações Unidas. PERRONE-MOISÉS, Cláudia. (Org.); AMARAL JUNIOR, A. (Org.). O Cinqüentenário da Declaração Universal dos Direitos do Homem. São Paulo: EDUSP, 1999, p. 180.

${ }^{186}$ Vide o preâmbulo do Pacto Internacional de Direitos Sociais, Econômicos e Culturais "[...] Reconhecendo que estes direitos derivam da dignidade inerente à pessoa humana". Disponível em: <http://www.pge.sp.gov.br/centrodeestudos/bibliotecavirtual/instrumentos /direitos.htm>. Acesso em: 10 out. 2010.

${ }^{187}$ Artigo $2^{\circ}$ da CEDH in verbis: "1. O direito de qualquer pessoa à vida é protegido pela lei. Ninguém poderá ser intencionalmente privado da vida, salvo em execução de uma sentença capital pronunciada por um tribunal, no caso de o crime ser punido com esta pena pela lei. 2. Não haverá violação do presente artigo quando a morte resulte de recurso à força, tornado absolutamente necessário: a) Para assegurar a defesa de qualquer pessoa contra uma violência ilegal; b) Para efetuar uma detenção legal ou para impedir a evasão de uma pessoa detida 
privado arbitrariamente de sua vida. Assim, a Corte Europeia de Direitos Humanos, e a Corte Interamericana têm trazido parâmetros para estabelecer o alcance do âmbito de proteção do direito à vida ${ }^{189}$.

Com relação à obrigação negativa do estado, ou seja, obrigação de abster-se de violar direitos humanos, em especial, o direito à vida, trazemos à baila o caso da pena de morte, cuja atualidade e relevância persistem até hoje. A interpretação versa sobre o que se entende por "arbitrariamente".

$\mathrm{O}$ artigo $2^{\circ}$ da Convenção Europeia ${ }^{190}$ estabelece que o direito à vida de toda pessoa está protegido por lei, não podendo qualquer indivíduo ser privado de sua vida arbitrariamente, exceto em caso de pena de morte imposta por um tribunal, e em situações em que o uso da força será permitido, desde que absolutamente necessário ${ }^{191}$.

A privação da vida por agentes estatais ${ }^{192}$ é, particularmente, uma grave violação do direito à vida ${ }^{193}$. A Convenção Europeia de Direitos Humanos não enumera situações em que

legalmente;c) Para reprimir, em conformidade com a lei, uma revolta ou uma insurreição". Disponível em: http://www.echr.coe.int/NR/rdonlyres/7510566B-AE54-44B9-A163-912EF12B8BA4/0/POR_CONV.pdf>.

Acesso em: 10 out. 2010.

${ }^{188}$ Artigo 4 da CADH in verbis: "1. Toda pessoa tem o direito de que se respeite sua vida. Esse direito deve ser protegido pela lei e, em geral, desde o momento da concepção. Ninguém pode ser privado da vida arbitrariamente; 2 . Nos países que não houverem abolido a pena de morte, esta só poderá ser imposta pelos delitos mais graves, em cumprimento de sentença final de tribunal competente e em conformidade com lei que estabeleça tal pena, promulgada antes de haver o delito sido cometido. Tampouco se estenderá sua aplicação a delitos aos quais não se aplique atualmente; 3. Não se pode restabelecer a pena de morte nos Estados que a hajam abolido; 4. Em nenhum caso pode a pena de morte ser aplicada por delitos políticos, nem por delitos comuns conexos com delitos políticos; 5. Não se deve impor a pena de morte a pessoa que, no momento da perpetração do delito, for menor de dezoito anos, ou maior de setenta, nem aplicá-la a mulher em estado de gravidez; 6 . Toda pessoa condenada à morte tem direito a solicitar anistia, indulto ou comutação da pena, os quais podem ser concedidos em todos os casos. Não se pode executar a pena de morte enquanto o pedido estiver pendente de decisão ante a autoridade competente". Disponível em: 〈http://www.cidh.oas.org/Basicos/ Portugues/c.Convencao_Americana.htm〉. Acesso em: 10 out. 2010.

${ }^{189}$ Fernando Rey Martínez extrai do artigo $2^{\mathbf{o}}$ da Convenção Europeia três situações que exigirão uma análise da interpretação dada pela Corte Europeia de Direitos Humanos sobre o tema. A primeira estaria ligada à privação da vida devido ao uso da força por agentes estatais; a segunda, sobre o término e início da vida; e, a terceira, sobre a proteção estatal para determinados tipos de riscos à vida. REY MARTÍNEZ, Fernando. La Protección Jurídica de La Vida: Un Derecho em Transformación Y Expansión (art. 2 CEDH y Protocolos $6^{\circ}$ y $13^{\circ}$ ). In: GARCIA ROCA, Javier e SANTOLAYA, Pablo (coords). La Europa de Los Derechos: El Convenio Europeo de Derechos Humanos. Madrid: Centro de Estúdios Políticos Y Constitucionales, 2005, p. 75.

${ }^{190} 1$. O direito de qualquer pessoa à vida é protegido pela lei. Ninguém poderá ser intencionalmente privado da vida, salvo em execução de uma sentença capital pronunciada por um tribunal, no caso de o crime ser punido com esta pena pela lei. 2. Não haverá violação do presente artigo quando a morte resulte de recurso à força, tornado absolutamente necessário: a) Para assegurar a defesa de qualquer pessoa contra uma violência ilegal; $b$ ) Para efectuar uma detenção legal ou para impedir a evasão de uma pessoa detida legalmente; c) Para reprimir, em conformidade com a lei, uma revolta ou uma insurreição. Disponível em: <http://www.echr.coe.int/NR/rdonlyres/7510566B-AE54-44B9-A163-912EF12B8BA4/0/POR_CONV.pdf〉.

Acesso em: 10 out. 2010.

${ }^{191}$ Nota-se que, apesar de o Human Right Commitee afirmar que o direito à vida é um direito supremo, ao mesmo tempo, admite possíveis exceções. Ler mais a respeito: KRATOCHVIL, Jan. The Rigth to Life in the Perspective of The Human Rights Committee and the European Court of Human Rights. Disponível em: $\langle$ http://ssm.com/abstract=951225, p. 2>. Acesso em: 10 jun. 2010.

${ }^{192}$ André de Carvalho Ramos, ao tratar da responsabilidade internacional do estado por violação de direitos humanos, afirma que o estado é responsável por atos ou omissões cometidos pela conduta do Poder Executivo, 
privar o indivíduo de sua vida é permitida, mas proíbe qualquer forma "arbitrária" de privação da vida ${ }^{194}$.

No entanto, Jan Kratochvil aponta uma dificuldade para aplicar o dispositivo: A necessidade de se analisar a interpretação que se pretende atribuir ao termo "arbitrariamente"195.

Kratochvil explica que a força usada pelo agente estatal que viola o direito à vida deve ser desproporcional e ilegítima para que possa implicar alguma responsabilidade ao estado. Para ele, tem-se entendido que o termo "arbitrariamente" está ligado ao exercício desproporcional a uma situação legítima ${ }^{196}$, o que exige uma análise pontual, verificando-se as peculiaridades de cada caso.

Nesse sentido, André de Carvalho Ramos afirma que há responsabilidade internacional do estado quando o agente estatal atua de modo ultra vires, ou seja, quando o agente estatal, embora imbuído da necessidade de agir, age de forma abusiva e arbitrária ${ }^{197}$, violando o direito à vida do indivíduo. Assim, a conduta do estado deve restar limitada diante dos direitos dos indivíduos ${ }^{198}$.

Além disso, mesmo em circunstâncias em que o uso da força está autorizado, tem-se entendido que ele deve ser realizado somente se estritamente necessário ${ }^{199}$, a fim de não se colocar em risco o efetivo exercício do direito à vida ${ }^{200}$.

Legislativo e Judiciário. CARVALHO RAMOS, André de. Responsabilidade Internacional do Estado por Violação de Direitos Humanos. In: R.CEJ, Brasília, n. 29, p. 53-63, abr/jun 2005, p. 55.

${ }^{193}$ KRATOCHVIL, Jan. The Rigth to Life in the Perspective of The Human Rights Committee and the European Court of Human Rights. Disponível em: 〈http://ssm.com/abstract=951225, p. 3〉. Acesso em: 10 jun. 2010.

${ }^{194}$ KRATOCHVIL, Jan. The Rigth to Life in the Perspective of The Human Rights Committee and the European Court of Human Rights. Disponível em: 〈http://ssm.com/abstract=951225, p. 3〉. Acesso em: 10 jun. 2010.

${ }^{195}$ KRATOCHVIL, Jan. The Rigth to Life in the Perspective of The Human Rights Committee and the European Court of Human Rights. Disponível em: 〈http://ssm.com/abstract=951225, p. 3〉. Acesso em: 10 jun. 2010.

${ }^{196}$ KRATOCHVIL, Jan. The Rigth to Life in the Perspective of The Human Rights Committee and the European Court of Human Rights. Disponível em: 〈http://ssm.com/abstract=951225, p. 4〉. Acesso em: 10 jun. 2010.

${ }^{197}$ CARVALHO RAMOS, André de. Responsabilidade Internacional do Estado por Violação de Direitos Humanos. In: R.CEJ, Brasília, n. 29, p. 53-63, abr/jun 2005, p. 55.

${ }^{198}$ CARVALHO RAMOS, André de. O direito à vida e a pena de morte. In: PETERKE, Sven (coord). Manual prático de direitos humanos internacionais. Brasília: Escola Superior do Ministério Público da União, 2009, p. 227.

${ }^{199}$ KRATOCHVIL, Jan. The Rigth to Life in the Perspective of The Human Rights Committee and the European Court of Human Rights. Disponível em: 〈http://ssm.com/abstract=951225, p. 4〉. Acesso em: 10 jun. 2010.

${ }^{200}$ CARVALHO RAMOS, André de. O direito à vida e a pena de morte. In: PETERKE, Sven (coord). Manual prático de direitos humanos internacionais. Brasília: Escola Superior do Ministério Público da União, 2009, p. $227-228$ 
Fernando Rey Martínez, por sua vez, critica esse dispositivo e explica que esse artigo foi perdendo a força, pois, em 1983, com o surgimento do Protocolo $\mathrm{n}^{\mathrm{o}} 6^{201}$, foram estabelecidas algumas circunstâncias em que seria possível aplicar a pena de morte, como em caso de guerra, por exemplo ${ }^{202}$.

Para Rey Martínez, o Protocolo $n^{\circ} 6$ constitui um diferenciado diploma internacional, pois obriga os estados a abolirem a pena de morte, aproximando-se mais de uma norma interna que uma norma internacional ${ }^{203}$. Além disso, o autor afirma que tal dispositivo “outorga um direito subjetivo aos particulares de não serem condenados a tal pena e, muito menos, a serem executados" 204 , e, por fim, ao tentar estabelecer regras sobre a "legalidade penal e certas garantias processuais" ${ }^{, 205}$, o Protocolo $\mathrm{n}^{\circ} 6$ acabou evoluindo e originando o Protocolo 13 da Convenção Europeia, a partir do qual seria possível até mesmo impedir que as circunstâncias anteriores, que previam e permitiam a pena de morte, fossem sustentadas, devendo, a partir de então, também estas, ser abolidas ${ }^{206}$.

Já com relação ao sistema regional interamericano, extraímos do artigo $6^{\circ}$ da Convenção Americana de Direitos Humanos alguns pontos relevantes e semelhantes às críticas avençadas. Seria possível afirmar que o que se protege igualmente é a impossibilidade de privação da vida do indivíduo de modo arbitrário. No entanto, a Convenção também é

\footnotetext{
201 Protocolo adicional à Convenção para a Proteção dos Direitos do Homem e das Liberdades Fundamentais, Relativo à Abolição da pena de morte. Disponível em: <http://www.hrea.org/erc/Library/hrdocs/coe/echr_pt.pdf>. Acesso em: 10 out. 2010.

${ }^{202}$ Visa à abolição da pena de morte, sem excluir casos de ameaça de iminência de guerra ou em caso de atos cometidos em tempo de guerra. Disponível em: <http://www.hrea.org/erc/Library/hrdocs/coe/echr_pt.pdf>. Acesso em: 15 jun. 2011. Vide também REY MARTÍNEZ, Fernando. La Protección Jurídica de La Vida: Un Derecho em Transformación Y Expansión (art. 2 CEDH y Protocolos $6^{\circ}$ y $13^{\circ}$ ). In: GARCIA ROCA, Javier e SANTOLAYA, Pablo (coords). La Europa de Los Derechos: EI Convenio Europeo de Derechos Humanos. Madrid: Centro de Estúdios Políticos Y Constitucionales, 2005, p. 68.

203 REY MARTÍNEZ, Fernando. La Protección Jurídica de La Vida: Un Derecho em Transformación Y Expansión (art. $2 \mathrm{CEDH}$ y Protocolos $6^{\circ}$ y $13^{\circ}$ ). In: GARCIA ROCA, Javier e SANTOLAYA, Pablo (coords). La Europa de Los Derechos: El Convenio Europeo de Derechos Humanos. Madrid: Centro de Estúdios Políticos Y Constitucionales, 2005, p. 68.

${ }^{204}$ REY MARTÍNEZ, Fernando. La Protección Jurídica de La Vida: Un Derecho em Transformación Y Expansión (art. 2 CEDH y Protocolos $6^{\circ}$ y $13^{\circ}$ ). In: GARCIA ROCA, Javier e SANTOLAYA, Pablo (coords). La Europa de Los Derechos: El Convenio Europeo de Derechos Humanos. Madrid: Centro de Estúdios Políticos Y Constitucionales, 2005, p. 68 (tradução nossa).

205. REY MARTÍNEZ, Fernando. La Protección Jurídica de La Vida: Un Derecho em Transformación Y Expansión (art. 2 CEDH y Protocolos $6^{\circ}$ y $13^{\circ}$ ). In: GARCIA ROCA, Javier e SANTOLAYA, Pablo (coords). La Europa de Los Derechos: El Convenio Europeo de Derechos Humanos. Madrid: Centro de Estúdios Políticos Y Constitucionales, 2005, p. 69 (tradução nossa).

206. REY MARTÍNEZ, Fernando. La Protección Jurídica de La Vida: Un Derecho em Transformación Y Expansión (art. 2 CEDH y Protocolos $6^{\circ}$ y $13^{\circ}$ ). In: GARCIA ROCA, Javier e SANTOLAYA, Pablo (coords). La Europa de Los Derechos: El Convenio Europeo de Derechos Humanos. Madrid: Centro de Estúdios Políticos Y Constitucionales, 2005, p. 69 (tradução nossa).
} 
omissa no que tange ao rol de exceções ao direito à vida, deixando, ainda, a critério dos estados e de seus intérpretes estabelecerem as restrições do direito à vida ${ }^{207}$.

A jurisprudência da Corte Interamericana de Direitos Humanos, no entanto, tem estabelecido parâmetros de interpretação do significado de "arbitrário", observando o contexto do artigo $6^{\circ}$ da Convenção Americana de Direitos Humanos, como no caso Suarez de Guerrero v. Colombia, por exemplo ${ }^{208}$.

Conforme ensina Renata Cenedesi Rodrigues ${ }^{209}$, no Caso Hilarie, Constantine e Benjamin e outros, julgado pela Corte Interamericana, Trinidad \& Tobago $^{210}$ foi responsabilizado internacionalmente, pois o estado tinha previsão para pena de morte em caso de homicídio doloso, e a Corte entendeu que este dispositivo interno violava o direito à vida, previsto no artigo $4^{\circ}$ da $\mathrm{CADH}$.

A pena de morte, portanto, é vista para alguns como exceção do direito à vida, mas, como bem salienta André de Carvalho Ramos, avança em direção a seu "completo banimento no globo" 211 . E, no entanto, ela tem sido aplicada ao longo da história ${ }^{212}$. Algumas garantias e salva-guardas foram estabelecidas contra a pena de morte, como, por exemplo, a restrição à

\footnotetext{
${ }^{207}$ Vide [N.R.] 188, com o texto integral do artigo $4^{\circ}$ da Convenção Americana de Direitos Humanos.

${ }^{208}$ André de Carvalho Ramos relembra também o caso da Penitenciária El Frontón em que o Peru foi condenado pelo uso da força de modo excessivo. CARVALHO RAMOS, André de. O direito à vida e a pena de morte. In: PETERKE, Sven (coord). Manual prático de direitos humanos internacionais. Brasília: Escola Superior do Ministério Público da União, 2009, p. 227-228.

${ }^{209}$ RODRIGUES, Renata Cenedesi Bom Costa. El Nuevo Concepto del Derecho a la vida en la Jurisprudencia de la Corte Interamericana de Derechos Humanos. p. 91. Disponível em: <http://www.idpc.es/archivo/1213281758FCI9RCB.pdf >. Acesso em: 10 out. 2010.

${ }^{210}$ Corte IDH. Caso Hilaire, Constantine y Benjamin y otros Vs. Trinidad y Tobago. Fondo, Reparaciones y Costas. Sentencia de 21 de junio de 2002. Serie C No. 94

${ }^{211}$ CARVALHO RAMOS, André de. O direito à vida e a pena de morte. In: PETERKE, Sven (coord). Manual prático de direitos humanos internacionais. Brasília: Escola Superior do Ministério Público da União, 2009, p. 248.

${ }_{212}$ Ainda com relação à pena de morte em face dos direitos humanos internacionais, vale lembrar que André de Carvalho Ramos aponta três fases do tratamento recebido pela pena de morte: i) convivência tolerada, em que há permissão da pena de morte, mas sujeita aos limites estabelecidos pelo artigo $6^{\circ}$ do Pacto Internacional de Direitos Civis e Políticos, sendo que, nesta fase, os Estados signatários não poderiam aplicar a pena de morte em casos não previstos quando da ratificação desses tratados internacionais, exigindo-se uma decisão judicial e a possibilidade de previsão de indulto, anistia ou comutação de pena, além de ser vedada a sua aplicação às grávidas, menores e maiores de 70 anos; ii) banimento com exceções, fase em que somente é possível aplicar a pena de morte para crimes militares, nos termos do $2^{\circ}$ Protocolo Facultativo do Pacto Internacional sobre Direitos Civis e Políticos e do Protocolo Adicional à Convenção Americana de Direitos Humanos relativo à Pena de Morte; e, finalmente, iii) banimento da pena de morte em qualquer circunstância nos termos do Protocolo 13 à Convenção Europeia de Direitos Humanos, que taxativamente veda a aplicação da pena de morte e não aceita reserva de seu texto. CARVALHO RAMOS, André de. O direito à vida e a pena de morte. In: PETERKE, Sven (coord). Manual prático de direitos humanos internacionais. Brasília: Escola Superior do Ministério Público da União, 2009, p. 248-250. Vide também Andrew Clapham e Susan Marks que explicam que a Comissão Interamericana entendeu tratar-se de violação de normas de ius cogens a imposição de pena de morte à menores. CLAPHAM, Andrew e MARKS, Susan. International Human Rights Lexicon. New York: Oxford University Press, 2005, p. 53-54.
} 
possibilidade de se aplicar a pena de morte somente nos casos em que há previsão na lei e uma decisão condenatória proferida por um tribunal ${ }^{213}$.

Protocolos adicionais e a Convenção Americana de Direitos Humanos ${ }^{214}$ foram agregando mais rigor à aplicação da pena, em alguns casos, possível somente para crimes mais graves ou crimes de natureza militar ${ }^{215}$. Tais diplomas internacionais de direitos humanos têm também estimulado os estados a abolir a pena de morte, impedindo aqueles que a tenham abolido de voltar a institui-la, ou, ainda, proibindo estados que já não a prescrevem de criar novas hipóteses de aplicação ${ }^{216}$.

Além disso, outro aspecto interessante envolvendo a pena de morte é o fenômeno do corredor da morte ${ }^{217}$, que tem sido amplamente comentado pela doutrina. Tem-se entendido que a espera no corredor da morte viola a dignidade humana, constituindo um tratamento cruel e degradante, como, por exemplo, também já foi decidido no caso Söering v. Reino Unido $^{218}$.

Vale lembrar que André de Carvalho Ramos salienta que "o termo 'arbitrariamente' possibilitaria a contrario sensu, a existência de justificativas legais para o término da vida, como, por exemplo, a legítima defesa, o estado de necessidade, a eutanásia, entre outros"219, podendo ser reconhecida uma legitimidade de se tirar a vida de outra pessoa na defesa de sua própria $^{220}$.

Outra interpretação importante frequentemente utilizada é a de que existe uma responsabilidade do estado pela proteção do direito à vida, ainda que a ação que tenha violado

${ }^{213}$ Vale relembrar também, como o faz André de Carvalho Ramos, que mesmo a pena máxima prevista no Estatuto de Roma, atualmente aplicada pelo Tribunal Penal Internacional - que pune crimes contra a humanidade, como o genocídio, por exemplo - é a prisão perpétua, e não a pena de morte. CARVALHO RAMOS, André de. O direito à vida e a pena de morte. In: PETERKE, Sven (coord). Manual prático de direitos humanos internacionais. Brasília: Escola Superior do Ministério Público da União, 2009, p. 249-250.

${ }^{214}$ Vide artigo $4^{\circ}$ da Convenção Americana de Direitos Humanos e Opinião Consultiva 3/83 emitida pela Corte Interamericana de Direitos Humanos.

${ }^{215}$ Cf. KRATOCHVIL, Jan. The Rigth to Life in the Perspective of The Human Rights Committee and the European Court of Human Rights. Disponível em: 〈http://ssm.com/abstract=951225, p. 11〉. Acesso em: 10 jun. 2010.

${ }^{216}$ Vide Opinião Consultiva 14/94 emitida pela Corte Interamericana de Direitos Humanos

${ }^{217}$ KRATOCHVIL, Jan. The Rigth to Life in the Perspective of The Human Rights Committee and the European Court of Human Rights. Disponível em: <http://ssm.com/abstract=951225, p. 14-16>. Acesso em: 10 jun. 2010. Vide também CLAPHAM, Andrew e MARKS, Susan. International Human Rights Lexicon. New York: Oxford University Press, 2005, p. 55-56.

${ }^{218}$ Soëring v. The United Kingdow (Application no. 14038/88). Julgamento em 07 jul. 1989. Corte Europeia de Direitos Humanos. Disponível em: <http://cmiskp.echr.coe.int/tkp197/view.asp?item= $1 \&$ portal=hbkm\&action $=$ html\&highlight $=$ soering\&sessionid=72256788\&skin=hudoc-en $>$. Acesso em: 15 jun. 2010.

${ }^{219}$ CARVALHO RAMOS, André de. O direito à vida e a pena de morte. In: PETERKE, Sven (coord). Manual prático de direitos humanos internacionais. Brasília: Escola Superior do Ministério Público da União, 2009, p. 226.

${ }^{220}$ Nesse sentido, SILVA, José Afonso da. Curso de Direito Constitucional Positivo. $24^{\text {a }}$ edição, ver. atual. São Paulo: Malheiros, 2005, p. 198. 
esse direito tenha sido cometida por particulares. Em outras palavras, a proteção do direito à vida se estende não somente à mortes causadas por agentes públicos; o estado responde por atos praticados por seus agentes ${ }^{221}$ e por particulares ${ }^{222}$, desde que possa ser imputável a ele e $^{223}$ tal conduta. Neste caso, a responsabilidade do estado seria indireta ${ }^{224}$. Em outras palavras, a responsabilidade nasceria da inércia do estado em garantir as obrigações assumidas internacionalmente por ele $\mathrm{e}^{225}$.

Ademais, o estado poderá ser responsabilizado não só na ação, mas também na omissão do agente na proteção do direito à vida ${ }^{226}$. Como vimos, trata-se da obrigação de respeito e da obrigação de garantia. O estado não deve tirar a vida arbitrariamente do indivíduo (obrigação de não fazer), e deve garantir que o direito à vida seja plenamente exercido, devendo o estado também tomar todas as medidas cabíveis para que isso aconteça $^{227}$.

A situação de responsabilização do estado é mais fácil de ser visualizada quando a conduta violadora for praticada por agentes do próprio estado ${ }^{228}$, ocupantes de cargos oficiais.

\footnotetext{
${ }^{221}$ Nesse sentido, o autor traz alguns casos em que Estados foram responsabilizados por atos de seus agentes, tais como Mallén, Youmans e Caire. CASSESE, Antonio. International Law. New York: Oxford University Press, 2005, p. 246-247.

${ }^{222}$ No entanto, vale lembrar que Luísa Neto, abordando um assunto correlato, explica que "[...] quanto aos que por contrato dispõem do próprio corpo, em termos de renúncia genérica e não especificamente abrangida por casos de legítima defesa ou estado de necessidade, nem o direito internacional nem o direito nacional obriga a evitar que estranhos percam a vida". NETO, Luísa. O direito fundamental à disposição do próprio corpo (a relevância da vontade na configuração do seu regime). Coimbra: Coimbra Editora, 2004, p. 448.

${ }^{223}$ Imputável ao governo para ACCIOLY, Hildebrando; G. E. do Nascimento e Silva e; CASELLA, Paulo Borba. Manual de Direito Internacional Público. 18 ed., de acordo com o Decreto 7030, de 14-12-2009, e a Lei 12.134, 18-12-2009. São Paulo: Saraiva, 2010, p. 365.

${ }^{224}$ ACCIOLY, Hildebrando; G. E. do Nascimento e Silva e; CASELLA, Paulo Borba explicam que "Em rigor, contudo, poderia dizer-se que a responsabilidade do estado será sempre indireta, porque somente pode praticar atos por meio de seus agentes, e quando responde por atos de particulares não é por tê-los praticado" (negrito dos autores). Manual de Direito Internacional Público. 18 ed., de acordo com o Decreto 7030, de 14-12-2009, e a Lei 12.134, 18-12-2009. São Paulo: Saraiva, 2010, p. 365.

${ }^{225}$ Manual de Direito Internacional Público. 18 ed., de acordo com o Decreto 7030, de 14-12-2009, e a Lei 12.134, 18-12-2009. São Paulo: Saraiva, 2010, p. 374.

${ }^{226}$ Vide [N.R.] 151 a 154.

${ }^{227}$ Vide [N.R.] 151 a 154.

${ }^{228}$ [N.R.] O Sistema de proteção da Convenção Americana de Direitos Humanos (CADH)abrange somente países signatários ou que aderiram à Convenção, determinando os mecanismos de controle e supervisão internacionais de direitos humanos. A Convenção foi aprovada na Conferência de São José da Costa Rica em 22 nov. 1969, mas o Brasil somente aderiu à Convenção em 1992, através do Decreto 678 de 6 nov. 1992. A Corte Interamericana de Direitos Humanos já se pronunciou nesse sentido na Opinião Consultiva 14 de 1994. A consulta realizada pela Comissão Interamericana considerou que a incorporação do artigo 140 da nova constituição do Peru, mediante a qual se ampliavam os casos de aplicação da pena de morte (isto é, além do delito de traição à pátria em caso de guerra já previsto no artigo 235 da anterior Constituição Peruana de 1979, a nova Constituição pretendia estabelecer a pena de morte também no caso de terrorismo), contrariava o disposto no artigo 4, parágrafos $2^{\circ}$ e $3^{\circ}$, da Convenção Americana de Direitos Humanos. Embora a Opinião consultiva tenha representado um marco no que tange à relação de direito interno e direito internacional, uma das perguntas formuladas à Corte foi destinada à análise das responsabilidades e obrigações de agentes ou funcionários do estado que ao cumprir a lei editada por esse estado poderia violar o disposto na Convenção Americana de Direitos Humanos. Apesar da curiosa manifestação do estado brasileiro, com relação à pergunta formulada pela
} 
Neste caso, tanto na conduta comissiva quanto na omissiva que viole o direito à vida, o estado responde. No entanto, fica mais difícil compreender como o estado poderia ser responsabilizado se o particular viola direito à vida já que, nesse caso, os indivíduos não agem em nome do estado e nem estão vinculados diretamente a ele ${ }^{229}$.

Em princípio, poderíamos afirmar que o estado não poderia ser responsabilizado por atos de particulares que violam direitos humanos, até mesmo porque o estado não poderia, da mesma maneira, fiscalizar os atos de particulares como o pode fazer com relação aos atos de seus agentes ${ }^{230}$. No entanto, ensina André de Carvalho Ramos que "a responsabilização internacional do estado por ato de particulares é observado tanto no caso de conduta de agentes estatais agindo a título privado (ou seja, como particulares) quanto no caso de conduta de agentes estatais no momento do ato de particulares" 231 .

$\mathrm{O}$ estado não responde pelo ato do particular em si. Na verdade, o resultado lesivo decorre da inércia de o estado promover ações que normalmente ${ }^{232}$ deveriam ter sido praticadas a fim de proteger os direitos humanos, seja corrigindo violações já ocorridas, seja antecipando atos de modo a evitar que eles ocorram.

Assim, para garantir a efetividade do direito à vida, por exemplo, o estado não deve apenas agir de forma a não violar esse direito, mas também deve tomar medidas de prevenção, de proteção, e garantir que referidas condutas violatórias não se repitam.

Comissão concluindo pela submissão dos funcionários dos estados aos ditames constitucionais, não podendo sequer invocar convenções internacionais para descumpri-los, a Corte entendeu que o estado é responsável por atos de seus agentes ou funcionários que apliquem leis violadoras da Convenção, já que a Comissão e a Corte analisam a conduta dos estados. (Isso não exclui a possibilidade de um indivíduo ser julgado, entretanto, pelo Tribunal Penal Internacional, na hipótese de delito internacional previsto, tais como crimes contra a paz, contra a humanidade, genocídio etc.). Corte IDH. Responsabilidad Internacional por Expedición y Aplicación de Leyes Violatorias de la Convención (arts. 1 y 2 Convención Americana sobre Derechos Humanos). Opinión Consultiva OC-14/94 del 9 de diciembre de 1994. Serie A No. 14. Sobre a atuação ultra vires ler CARVALHO RAMOS, André de. Responsabilidade Internacional por Violação de Direitos Humanos: seus elementos, a reparação devida e sanções possíveis: teoria e prática do direito internacional. Rio de Janeiro: Renovar, 2004, p. 157-161, especialmente, p. 159-161. A respeito ler também interessantes casos da Corte Internacional de Justiça indicados por SHAW, Malcom N. Internacional Law. Cambridge: Cambridge University Press, 2003, p. 700.

${ }^{229}$ Nesse diapasão, CASSESE também explica que é "very difficult to prove that a State is responsible for acts performed by individuals not having the status os State officials. Indeed, it becomes necessary to prove that every single action contrary to International Law has been the subject of specific instructions by the State". CASSESE, Antonio. International Law. New York: Oxford University Press, 2005, p. 250.

${ }^{230}$ ACCIOLY, Hildebrando; G. E. do Nascimento e Silva e; CASELLA, Paulo Borba. Manual de Direito Internacional Público. 18 ed., de acordo com o Decreto 7030, de 14-12-2009, e a Lei 12.134, 18-12-2009. São Paulo: Saraiva, 2010, p. 374.

${ }^{231}$ Para o autor, é preciso ser cauteloso para estabelecer a responsabilidade do Estado. CARVALHO RAMOS, André de. Responsabilidade Internacional por Violação de Direitos Humanos: seus elementos, a reparação devida e sanções possíveis: teoria e prática do direito internacional. Rio de Janeiro: Renovar, 2004, p. 162-163.

232 ACCIOLY, Hildebrando; G. E. do Nascimento e Silva e; CASELLA, Paulo Borba. Manual de Direito Internacional Público. 18 ed., de acordo com o Decreto 7030, de 14 dez. 2009, e a Lei 12.134, 18 dez. 2009. São Paulo: Saraiva, 2010, p. 375. 
No entanto, é importante analisar quais parâmetros poderiam ser estabelecidos a fim de constatarmos a omissão do estado na ocasião do non-state actor ${ }^{233}$ e sua consequente responsabilidade, especialmente no tocante ao direito à vida: como determinar quais ações poderiam ser consideradas normais ou razoáveis, e como determinar quais ações deveriam ter sido praticadas para impedir a violação de direitos humanos ou para corrigir conduta lesiva aos direitos humanos?

Podemos extrair dois exemplos muito citados pela doutrina em que a Corte Interamericana de Direitos Humanos ${ }^{234}$ responsabilizou o estado por violação de direito à vida por atos de particulares: Velásquez Rodrigues ${ }^{235}$ e Godínez $\mathrm{Cruz}^{236}$, ambos envolvendo a responsabilidade do estado de Honduras. Nestes casos, houve a responsabilização por ato de particulares em decorrência de o estado "falhar em prevenir ou adequadamente responder pelo desaparecimento" 237 de pessoas e assassinatos de testemunhas.

\footnotetext{
${ }^{233}$ Susan Marks e Andrew Clapham afirmam que embora, via de regra, o ato cometido por particulares no Direito Internacional não enseja a responsabilidade do estado, no caso de uso de armas individualmente, por exemplo, acaba tornando-se armas de destruição em massa e, nesse caso, apesar de não ser atribuída responsabilidade diretamente ao Estado, este poderia ser responsabilizado por não regular a conduta individual do uso de armas. MARKS, Susan e CLAPHAM, Andrew. International Human Rights Lexicon. New York: Oxford University Press, 2005, p. 8-9.

${ }^{234}$ A Corte Interamericana é o órgão judicial autônomo cabendo a ela aplicar e interpretar a Convenção Americana de Direitos Humanos, com competência para reconhecer qualquer caso que lhe seja submetido, desde que os Estados Membros envolvidos no caso tenham reconhecido sua jurisdição. Vide artigos $1^{\circ}$ e $2^{\circ}$ do Estatuto da Corte Interamericana de Direitos Humanos e artigos 33 e 62 da Convenção Americana de Direitos Humanos.

${ }^{235}$ Corte IDH. Caso Velásquez Rodríguez v. Honduras. Fondo. Sentencia de 29 de julio de 1988 . Serie C no 4 . O caso foi encaminhado à Comissão em 1981, que, após analisá-lo, encaminhou-o para a Corte Interamericana de Direitos Humanos em 24 abr. 86. Angel Manfredo Velásquez Rodrigues, sob a acusação de ter praticado crimes políticos, foi detido para interrogatório sem ordem judicial pela DNI e pelas Forças Armadas de Honduras, e, conforme declarou a Comissão Interamericana, foi submetido à sessões de tortura e restou desaparecido. Não bastasse a atuação ultra vires de policiais e militares hondurenhos durante o processo, algumas testemunhas foram ameaçadas e mortas (antes e depois de terem prestado depoimento). Em certo ponto, a morte de uma das testemunhas, que veio a ocorrer, no entanto, foi atribuída a um grupo de guerrilheiros hondurenhos chamado "Cinchonero". A falta de prevenção na morte da testemunha por parte do Estado, acabou culminando na condenação de Honduras em janeiro de 1989, especialmente, a violação do direito à vida por ato de particulares. Vide importantes comentários feitos ao caso por CARVALHO RAMOS, André de. Direitos Humanos em juízo: comentários aos casos contenciosos e consultivos da Corte Interamericana de Direitos Humanos e estudo da implementação dessas decisões no Direito Brasileiro. São Paulo: Max Limonad, 2001, p. 118-145.

${ }^{236}$ Corte IDH. Caso Godínez Cruz v. Honduras. Fondo. Sentencia de 20 de enero de 1989. Serie C No. 5. No caso do professor escolar Saul Godínez Cruz, que desapareceu em 22 jul. 1982 após ter sido capturado por três homens, dentre os quais, um vestindo um uniforme militar. Durante o processo, algumas testemunhas também foram assassinadas. Nesse caso, a omissão sem justificativa do Estado ensejou na sua responsabilização. Vide CARVALHO RAMOS, André de. Direitos Humanos em juízo: comentários aos casos contenciosos e consultivos da Corte Interamericana de Direitos Humanos e estudo da implementação dessas decisões no Direito Brasileiro. São Paulo: Max Limonad, 2001, p. 145-162.

${ }^{237}$ MARKS, Susan e CLAPHAM, Andrew. International Human Rights Lexicon. New York: Oxford University Press, 2005, p. 9, 126-128.
} 
Também em relação à responsabilização por atos de particulares, vale ressaltar ainda a atuação da Comissão Interamericana ${ }^{238}$ em um caso envolvendo a responsabilização do Brasil: o Caso José Pereira ${ }^{239}$.

Dentre as acusações, o estado brasileiro teria violado direito à vida, à liberdade, à segurança, e à integridade pessoal, o direito ao trabalho e a uma justa remuneração, e o direito à proteção contra a detenção arbitrária, entre outros, especialmente porque deixou de tomar medidas de proteção e de garantia, permitindo a ocorrência de reiterados casos semelhantes na região, demonstrando ineficácia nas investigações e punições, bem como nos processos referentes aos assassinos e os responsáveis pela exploração do trabalho que, por muitos anos, arrastaram-se sem qualquer resposta ${ }^{240}$.

Outra interpretação relevante diz respeito à ampliação do conceito de vida. A ampliação do conceito de vida tem sido aplicada frequentemente pela Corte Interamericana nos casos de desaparecimento forçado, por exemplo, que tem sido entendido como uma vulnerabilidade do direito à vida em que o estado viola de forma continuada diversos direitos reconhecidos por tratados internacionais ${ }^{241}$. Na América do Sul, a prática ocorreu principalmente nos anos setentas, época de muitas ditaduras nos países latino-americanos.

\footnotetext{
${ }^{238}$ [N.R.] A Comissão atua com atribuições diferentes, ora como órgão da OEA e ora como órgão da Convenção Americana de Direitos Humanos, verificando a existência de violação de direitos humanos que uma vez confirmada poderá ou não encaminhar o caso diretamente à Corte; pode, ainda, apresentar recomendações aos estados no sentido de que estes adotem medidas progressivas em prol dos direitos humanos, a elaboração de relatórios, solicitação de informações dos estados sobre as medidas adotadas em matéria de direitos humanos, e visitas aos estados com sua anuência ou mediante seu convite. Vide artigo 41 da Convenção Americana de Direitos Humanos e artigo 18 do Estatuto da Comissão Interamericana de Direitos Humanos.

${ }^{239}$ CARVALHO RAMOS, André de. Responsabilidade Internacional do Estado por Violação de Direitos Humanos in Revista do CEJ, Brasília, n. 29, p. 56. Vide também o RELATÓRIO N 95/03 - CASO 11.289 SOLUÇÃO AMISTOSA - JOSÉ PEREIRA x BRASIL. 24 de outubro de 2003. Disponível em: <http://www.cidh.oas.org/annualrep/2003port/Brasil.11289.htm>. Acesso em: 05 dez. 2010.

${ }^{240}$ Nesse caso, a denúncia apresentada pelas organizações não-governamentais, América Watch e Centro pela Justiça e o Direito Internacional (CEJIL), foi recebida pela Comissão em 22 de fevereiro de 1994, e relatava que José Pereira, à época com 17 anos de idade, e outros 60 trabalhadores, trabalhavam em condições análogas à de escravo, sendo forçados a laborar sem remuneração e em condições desumanas e ilegais. Em 1989, ao tentarem escapar da Fazenda "Espírito Santo", a vítima e outro trabalhador foram perseguidos por pistoleiros da fazenda. José Pereira foi alvejado por tiros de fuzil; sobreviveu, mas sofreu lesões permanentes no olho e na mão direitos. RELATÓRIO No 95/03 - CASO 11.289 - SOLUÇÃO AMISTOSA - JOSÉ PEREIRA x BRASIL. 24 de outubro de 2003. Disponível em: <http://www.cidh.oas.org/annualrep/2003port/Brasil.11289.htm〉. Acesso em: 05 dez. 2010.

241 RODRIGUES, Renata Cenedesi Bom Costa. El Nuevo Concepto del Derecho a la vida en la Jurisprudencia de la Corte Interamericana de Derechos Humanos. p. 93. Disponível em: <http://www.idpc.es/archivo/1213281758FCI9RCB.pdf>. Acesso em: 10 out. 2010. Como prefere Jan Kratochvil, "uma dificuldade vis-à-vis do direito à vida". KRATOCHVIL, Jan. The Rigth to Life in the Perspective of The Human Rights Committee and the European Court of Human Rights. Disponível em: <http://ssm.com/abstract=951225, p. 16>. Acesso em: 10 jun. 2010.
} 
Nesses casos, o que gera especial desconforto, é a incerteza quanto a se as vítimas foram ou não privadas de suas vidas ${ }^{242}$.

No plano internacional, foi consagrada nesses casos a responsabilidade do estado no descumprimento de investigar os crimes e punir os culpados ${ }^{243}$. A Corte Interamericana tem decidido a respeito desses desaparecimentos neste sentido desde o caso Velásques Rodrigues $^{244}$, que foi a primeira decisão da Corte sobre o assunto. A propósito, vale ainda mencionar que a Corte também tem entendido que o estado não pode criar e aplicar leis de anistia, a fim de evitar sua obrigação de responsabilizar os culpados por violações de direitos humanos ${ }^{245}$.

Nessa linha, recente decisão contra o Brasil foi proferida pela Corte Interamericana, em que o estado brasileiro foi responsabilizado ${ }^{246}$. A Corte pretende, com isso, evitar que as leis de anistia gerem uma situação de impunidade ${ }^{247}$, evitando a persecução penal dos acusados e impedindo a investigação, a identificação e o julgamento dos culpados ${ }^{248}$, além da reparação das vítimas.

\footnotetext{
${ }^{242}$ KRATOCHVIL, Jan. The Rigth to Life in the Perspective of The Human Rights Committee and the European Court of Human Rights. Disponível em: 〈http://ssm.com/abstract=951225, p. 16>. Acesso em: 10 jun. 2010.

${ }^{243}$ CARVALHO RAMOS, André de. O direito à vida e a pena de morte. In: PETERKE, Sven (coord). Manual prático de direitos humanos internacionais. Brasília: Escola Superior do Ministério Público da União, 2009, p. 235-238.

${ }^{244}$ Corte IDH. Caso Velásquez Rodríguez Vs. Honduras. Fondo. Sentencia de 29 de julio de 1988. Serie C No. 4.

${ }^{245}$ Vide também Corte IDH. Caso Godínez Cruz Vs. Honduras. Fondo. Sentencia de 20 de enero de 1989. Serie C No. 5 e Corte IDH. Caso Aloeboetoe y otros Vs. Surinam. Fondo. Sentencia de 4 de diciembre de 1991. Serie C No. 11

${ }^{246}$ Corte IDH. Caso Gomes Lund y otros (Guerrilha do Araguaia) Vs. Brasil. Excepciones Preliminares, Fondo, Reparaciones y Costas. Sentencia de 24 de noviembre de 2010, Serie C No. 219. A respeito ler importante trabalho. CARVALHO RAMOS, André de. A ADPF 153 e a Corte Interamericana de Direitos Humanos. In: GOMES, Luiz Flávio; MAZZUOLI, Valério de Oliveira (Orgs.). Crimes da Ditadura Militar: uma análise à luz da jurisprudência atual da Corte Interamericana de Direito Humanos: Argentina, Brasil, Chile, Uruguais. São Paulo: Editora Revistas dos Tribunais, 2011, p. 174-225.

${ }^{247}$ André de Carvalho Ramos entende que "o afastamento da tutela penal" é um verdadeiro filtro que viola "o tratamento isonômico", privilegiando uns em detrimento de outros. Além disso, para o autor, a impunidade configura um "câncer" na proteção de direitos humanos, pois incentiva a repetição dos mesmos atos violatórios. CARVALHO RAMOS, André de. O direito à vida e a pena de morte. In: PETERKE, Sven (coord). Manual prático de direitos humanos internacionais. Brasília: Escola Superior do Ministério Público da União, 2009, p. 241-242.

${ }^{248}$ RODRIGUES, Renata Cenedesi Bom Costa. El Nuevo Concepto del Derecho a la vida en la Jurisprudencia de la Corte Interamericana de Derechos Humanos. p. 97-98. Disponível em: http://www.idpc.es/archivo/1213281758FCI9RCB.pdf>. Acesso em: 10 out. 2010. André de Carvalho Ramos lembra do Caso Suarez Rosero em que a Corte determinou que o Estado do Equador investigasse e punisse os violadores de direitos humanos, ato denominado pelo autor de obrigações processuais. CARVALHO RAMOS, André de. $\mathrm{O}$ direito à vida e a pena de morte. In: PETERKE, Sven (coord). Manual prático de direitos humanos internacionais. Brasília: Escola Superior do Ministério Público da União, 2009, p. 238/239.
} 
Como esclarece Jan Kratochvil ${ }^{249}$, os casos de desaparecimentos forçados envolvem a violação da obrigação positiva de proteção do direito à vida, de modo que, nesses casos, a morte presumida é o principal elemento para determinar a violação do artigo que protege o direito à vida da Convenção Americana.

Conforme ensina André de Carvalho Ramos, o direito à vida alcança também as "condições materiais mínimas de existência"250.

Nesta linha, explica Renata Cenesi, o Caso Villagrán Morales ${ }^{251}$, mais conhecido como Niños de la Calle ${ }^{252}$. Neste caso, a Corte entendeu que o direito à vida é um direito fundamental, e que este é um pré-requisito para os demais, de modo que o Estado (a Guatemala, no caso) deveria garantir uma existência digna, e não deveria impedir ou dificultar o acesso dos indivíduos a essas condições mínimas. Neste caso, os meninos de rua tinham sido vítimas de uma agressão dupla: i) violação de sua vida e de sua integridade física, psíquica e moral; e ii) o estado não impediu que as crianças fossem lançadas à miséria e, em razão disso, foram privadas de condições mínimas para uma vida digna e pleno desenvolvimento de sua personalidade ${ }^{253}$.

André de Carvalho Ramos afirma que o direito à vida realça a ideia de vida com dignidade, tendo a Corte, no Caso Villagrán Morales, efetuado "o reconhecimento de que havia risco à vida pelo Estado de abandono social" 254 em face da situação em que estavam os meninos de rua, de modo que a violação do direito à vida se deu no caso em razão não só dos homicídios a que estavam sujeitos, mas também "da negação do direito de viver com dignidade" 255 decorrente de sua situação de marginalização social.

\footnotetext{
${ }^{249}$ KRATOCHVIL, Jan. The Rigth to Life in the Perspective of The Human Rights Committee and the European Court of Human Rights. Disponível em: http://ssm.com/abstract=951225, p. 17>. Acesso em: 10 jun. 2010.

${ }^{250}$ CARVALHO RAMOS, André de. O direito à vida e a pena de morte. In: PETERKE, Sven (coord). Manual prático de direitos humanos internacionais. Brasília: Escola Superior do Ministério Público da União, 2009, p. 244.

${ }^{251}$ Para André de Carvalho Ramos esse caso é "o giro copernicano na proteção do direito à vida". CARVALHO RAMOS, André de. O direito à vida e a pena de morte. In: PETERKE, Sven (coord). Manual prático de direitos humanos internacionais. Brasília: Escola Superior do Ministério Público da União, 2009, p. 244.

${ }^{252}$ RODRIGUES, Renata Cenedesi Bom Costa. El Nuevo Concepto del Derecho a la vida en la Jurisprudencia de la Corte Interamericana de Derechos Humanos. p. 100. Disponível em: <http://www.idpc.es/archivo/1213281758FCI9RCB.pdf>. Acesso em: 10 out. 2010.

${ }_{253}$ RODRIGUES, Renata Cenedesi Bom Costa. El Nuevo Concepto del Derecho a la vida en la Jurisprudencia de la Corte Interamericana de Derechos Humanos. p. 100. Disponível em: <http://www.idpc.es/archivo/1213281758FCI9RCB.pdf>. Acesso em: 10 out. 2010.

${ }^{254}$ CARVALHO RAMOS, André de. O direito à vida e a pena de morte. In: PETERKE, Sven (coord). Manual prático de direitos humanos internacionais. Brasília: Escola Superior do Ministério Público da União, 2009, p. 245.

${ }^{255}$ CARVALHO RAMOS, André de. O direito à vida e a pena de morte. In: PETERKE, Sven (coord). Manual prático de direitos humanos internacionais. Brasília: Escola Superior do Ministério Público da União, 2009, p. 245.
} 
Além desse conceito de mínimo existencial, a Corte reconheceu outro sentido ao direito à vida: a destruição do projeto de vida também viola o direito à vida ${ }^{256}$.

No caso Loyaza Tamayo ${ }^{257}$, a Sra. Tamayo foi presa, torturada e obrigada a confessar sua participação no grupo Sendero Luminoso, atuante no Peru. Foi condenada a vinte anos de prisão. Nesse caso, a Sra. Tamayo teve seu projeto de vida frustrado, ou seja, sua realização pessoal, suas aspirações e expectativas foram anuladas. A Sra. Tamayo não teve opção de conduzir sua vida e desenvolver-se plenamente ${ }^{258}$.

Situação semelhante ocorreu no caso Cantoral Benavides ${ }^{259}$ v. Peru em que a Corte Interamericana condenou o estado por não ter garantido os estudos universitários de Benavides e, com isso, ter impedido-o de se realizar integralmente, já que foi torturado e encarcerado por quatro anos, na época em que cursava a universidade.

Poderíamos mencionar, ainda, que a dignidade da vida também tem sido entendida como "direito à vida sustentável",260, de modo a se considerar também que a proteção do meio ambiente garante a sobrevivência da espécie humana e do planeta ${ }^{261}$. Esse conceito ganha relevância especialmente diante dos acidentes atômicos e petrolíferos que colocam em risco o meio ambiente e destroem a natureza ${ }^{262}$.

Além disso, também é importante mencionar que se tem argumentado que até mesmo o direito a morrer deveria ser considerado parte do direito à vida ${ }^{263}$. Explica Fernando Rey Martínez que o estado deve proteger a vida e que este direito está assegurado pelas obrigações

\footnotetext{
256 RODRIGUES, Renata Cenedesi Bom Costa. El Nuevo Concepto del Derecho a la vida en la Jurisprudencia de la Corte Interamericana de Derechos Humanos. p. 101. Disponível em: <http://www.idpc.es/archivo/1213281758FCI9RCB.pdf>. Acesso em: 10 out. 2010.

${ }^{257}$ Corte IDH. Caso Loayza Tamayo Vs. Perú. Fondo. Sentencia de 17 de septiembre de 1997. Serie C No. 33

${ }^{258}$ RODRIGUES, Renata Cenedesi Bom Costa. El Nuevo Concepto del Derecho a la vida en la Jurisprudencia de la Corte Interamericana de Derechos Humanos. p. 101. Disponível em: <http://www.idpc.es/archivo/1213281758FCI9RCB.pdf>. Acesso em: 10 out. 2010. CARVALHO RAMOS, André de. $\mathrm{O}$ direito à vida e a pena de morte. In: PETERKE, Sven (coord). Manual prático de direitos humanos internacionais. Brasília: Escola Superior do Ministério Público da União, 2009, p. 245.

${ }^{259}$ Corte IDH. Caso Benavides Cevallos Vs. Ecuador. Fondo, Reparaciones y Costas. Sentencia de 19 de junio de 1998. Serie C No. 38.

${ }^{260}$ CARVALHO RAMOS, André de. O direito à vida e a pena de morte. In: PETERKE, Sven (coord). Manual prático de direitos humanos internacionais. Brasília: Escola Superior do Ministério Público da União, 2009, p. 247.

${ }^{261}$ CARVALHO RAMOS, André de. O direito à vida e a pena de morte. In: PETERKE, Sven (coord). Manual prático de direitos humanos internacionais. Brasília: Escola Superior do Ministério Público da União, 2009, p. 248.

${ }^{262}$ Vide Casos L. C. B. V. Reino Unido e Caso Oneryldiz v. Turquia. REY MARTínEZ, Fernando. La Protección Jurídica de La Vida: Un Derecho em Transformación Y Expansión (art. 2 CEDH y Protocolos $6^{\circ}$ y $13^{\circ}$ ). In: GARCIA ROCA, Javier e SANTOLAYA, Pablo (coords). La Europa de Los Derechos: El Convenio Europeo de Derechos Humanos. Madrid: Centro de Estúdios Políticos Y Constitucionales, 2005, p. 90.

${ }^{263}$ REY MARTíNEZ, Fernando. La Protección Jurídica de La Vida: Un Derecho em Transformación Y Expansión (art. $2 \mathrm{CEDH}$ y Protocolos $6^{\circ}$ y $13^{\circ}$ ). In: GARCIA ROCA, Javier e SANTOLAYA, Pablo (coords). La Europa de Los Derechos: El Convenio Europeo de Derechos Humanos. Madrid: Centro de Estúdios Políticos Y Constitucionales, 2005, p. 84.
} 
positivas e negativas que o estado deve cumprir ${ }^{264}$. Mas será que o direito à vida incluiria um "direito à morte"?

No caso Pretty v. Reino Unido, uma mulher com enfermidade neurológica grave e degenerativa, sem cura e com expectativa de menos de um ano de vida, pediu à Corte Europeia a autorização para realizar um suicídio assistido ${ }^{265}$. Rey Martínez destaca, em linhas gerais, que o argumento mais importante usado pela Sra. Pretty foi o de que o direito à vida previsto no artigo $2^{\circ}$ da Convenção Europeia protegeria também o direito de escolher continuar ou não vivendo e não somente a vida em $\mathrm{si}^{266}$. No entanto, o Tribunal Europeu entendeu que o direito à vida é pressuposto para a existência de todos os demais direitos, e que afirmar que o artigo $2^{\circ}$ garantiria também o direito a morrer seria uma distorção da linguagem, valorizando mais a morte do que o próprio direito a viver ${ }^{267}$.

\subsection{DIREITO À VIDA EM CONFLITO COM OUTROS DIREITOS}

É mister lembrar que a análise do âmbito de proteção do direito à vida deve ser considerado levando-se em conta princípios, regras e outros direitos. Por essa razão, vamos estudar a relação do direito à vida e o princípio da dignidade da pessoa humana. Vamos buscar entender se é possível pensar em um direito à vida relativizado e se o direito à vida é entendido como um princípio, uma regra ou um valor, observando, no caso do aborto especialmente do feto anencéfalo - o próprio princípio da dignidade da pessoa humana e a existência de outros direitos fundamentais que podem - e entram - em conflito quando falamos em proteção à vida ou proteção do direito à vida.

${ }^{264}$ REY MARTÍNEZ, Fernando. La Protección Jurídica de La Vida: Un Derecho em Transformación Y Expansión (art. 2 CEDH y Protocolos $6^{\circ}$ y $13^{\circ}$ ). In: GARCIA ROCA, Javier e SANTOLAYA, Pablo (coords). La Europa de Los Derechos: El Convenio Europeo de Derechos Humanos. Madrid: Centro de Estúdios Políticos Y Constitucionales, 2005, p. 84.

${ }^{265}$ REY MARTíNEZ, Fernando. La Protección Jurídica de La Vida: Un Derecho em Transformación Y Expansión (art. 2 CEDH y Protocolos $6^{\circ}$ y $13^{\circ}$ ). In: GARCIA ROCA, Javier e SANTOLAYA, Pablo (coords). La Europa de Los Derechos: El Convenio Europeo de Derechos Humanos. Madrid: Centro de Estúdios Políticos Y Constitucionales, 2005, p. 83.

${ }^{266}$ REY MARTíNEZ, Fernando. La Protección Jurídica de La Vida: Un Derecho em Transformación Y Expansión (art. 2 CEDH y Protocolos $6^{\circ}$ y $13^{\circ}$ ). In: GARCIA ROCA, Javier e SANTOLAYA, Pablo (coords). La Europa de Los Derechos: El Convenio Europeo de Derechos Humanos. Madrid: Centro de Estúdios Políticos Y Constitucionales, 2005, p. 84.

${ }^{267}$ REY MARTÍNEZ, Fernando. La Protección Jurídica de La Vida: Un Derecho em Transformación Y Expansión (art. 2 CEDH y Protocolos $6^{\circ}$ y $13^{\circ}$ ). In: GARCIA ROCA, Javier e SANTOLAYA, Pablo (coords). La Europa de Los Derechos: El Convenio Europeo de Derechos Humanos. Madrid: Centro de Estúdios Políticos Y Constitucionales, 2005, p. 85. 


\subsubsection{Dignidade e direitos fundamentais}

Depois de termos estudado os principais aspectos sobre o âmbito de proteção à vida e sobre as principais interpretações que lhe tem sido conferidas pelos tribunais internacionais de direitos humanos, não poderíamos admitir que um feto tenha o direito de não ser morto e, ao mesmo tempo, entender que o estado não deva proteger esse direito juridicamente, já que é seu dever proteger o interesse de todos, especialmente daqueles que não podem defender-se sozinhos $^{268}$.

Ingo Wolfgang Sarlet busca aproximar a dignidade da pessoa humana dos direitos fundamentais $^{269}$. Porém, para o autor, o conceito de dignidade humana é aberto, o que dificulta encontrar-lhe uma definição mais específica. Sarlet defende que a dignidade decorre de uma "qualidade tida como inerente a todo e qualquer ser humano",270, e que vem sendo tratada como “"o valor próprio’ que o identifica, o caracteriza”271. Essa qualidade deve ser respeitada e protegida e sua existência não depende de ser reconhecida pelo direito ${ }^{272}$.

Sarlet explica ainda que a noção de dignidade funda-se, por outro lado, na autonomia e no direito de autodeterminação da pessoa ${ }^{273}$, mas que a liberdade (autonomia) é considerada em abstrato ${ }^{274}$, na medida em que o indivíduo pode autodeterminar sua conduta ${ }^{275}$. Para o autor, o nascituro também está protegido e o indivíduo sofre os reflexos desta dignidade

\footnotetext{
268 DWORKIN, Ronald. Domínio da Vida: aborto, eutanásia e liberdades individuais. Trad. Jefferson Luiz Camargo; rev. da tradução Silvana Vieira. São Paulo: Martins Fontes, 2003, p. 18.

${ }^{269}$ Para Luísa Neto, a dignidade da pessoa impõe ao Estado o reconhecimento da personalidade jurídica. NETO, Luísa. $\mathrm{O}$ direito fundamental à disposição do próprio corpo (a relevância da vontade na configuração do seu regime). Coimbra: Coimbra Editora, 2004, p. 496.

${ }^{270}$ SARLET, Ingo Wolfgang. A Dignidade da Pessoa Humana e os Direitos Fundamentais na Constituição Federal e 1988. São Paulo: Livraria do Advogado, 2008, p. 40. Nesse mesmo sentido, REY MARTÍNEZ, Fernando. Eutanasia y Derechos Fundamentales. Madrid: Centro de Estúdios Políticos Y Constitucionales, 2008 , p. 164.

${ }^{271}$ SARLET, Ingo Wolfgang. A Dignidade da Pessoa Humana e os Direitos Fundamentais na Constituição Federal e 1988. São Paulo: Livraria do Advogado, 2008, p. 40.

${ }^{272}$ SARLET, Ingo Wolfgang. A Dignidade da Pessoa Humana e os Direitos Fundamentais na Constituição Federal e 1988. São Paulo: Livraria do Advogado, 2008, p. 43.

${ }^{273}$ SARLET, Ingo Wolfgang. A Dignidade da Pessoa Humana e os Direitos Fundamentais na Constituição Federal e 1988. São Paulo: Livraria do Advogado, 2008, p. 46.

${ }^{274}$ SARLET, Ingo Wolfgang. A Dignidade da Pessoa Humana e os Direitos Fundamentais na Constituição Federal e 1988. São Paulo: Livraria do Advogado, 2008, p. 46.

${ }^{275}$ SARLET, Ingo Wolfgang. A Dignidade da Pessoa Humana e os Direitos Fundamentais na Constituição Federal e 1988. São Paulo: Livraria do Advogado, 2008, p. 46.
} 
mesmo depois da morte ${ }^{276}$, embora haja entendimentos de que a dignidade não seja diretamente inerente à natureza humana ${ }^{277}$.

Afirma ainda Sarlet que a dignidade possui função dúplice ${ }^{278}$, como "condição limite e tarefa dos poderes estatais" 279 , e como "paralela e conexa dimensão defensiva e prestacional da dignidade" 280 . No primeiro caso, a dignidade é de cada um, e deixando de existir não existiria mais qualquer limite a ser respeitado ${ }^{281}$. No segundo caso, como tarefa prestacional, o indivíduo exigiria do estado a preservação e promoção de sua dignidade ${ }^{282}$. Para Sarlet, os direitos fundamentais não possuem o encargo de assegurar a dignidade, mas sim trazer condições para a realização da prestação ${ }^{283}$. Assim, para o autor, a dimensão dúplice da dignidade é considerar ao mesmo tempo a "expressão da autonomia da pessoa humana" aqui entendida com base na autodeterminação individual ${ }^{284}$, e a "necessidade de sua proteção", tanto pelo estado ${ }^{285}$ quanto pela sociedade ${ }^{286}$.

De maneira muito singela, Fernando Rey Martínez assevera que a construção jurídica do conceito de dignidade encontra três barreiras: i) quanto ao contéudo ambíguo do termo e a

${ }^{276}$ SARLET, Ingo Wolfgang. A Dignidade da Pessoa Humana e os Direitos Fundamentais na Constituição Federal e 1988. São Paulo: Livraria do Advogado, 2008, p. 46.

${ }^{277}$ SARLET, Ingo Wolfgang. A Dignidade da Pessoa Humana e os Direitos Fundamentais na Constituição Federal e 1988. São Paulo: Livraria do Advogado, 2008, p. 47.

${ }^{278}$ SARLET, Ingo Wolfgang. A Dignidade da Pessoa Humana e os Direitos Fundamentais na Constituição Federal e 1988. São Paulo: Livraria do Advogado, 2008, p. 50. Vide também Luísa Neto. "O respeito e a protecção da dignidade da pessoa implicam que seja respeitada. Mas não têm só obrigação de respeitar a dignidade. Devem também protegê-la inclusive face à própria pessoa". NETO, Luísa. O direito fundamental à disposição do próprio corpo (a relevância da vontade na configuração do seu regime). Coimbra: Coimbra Editora, 2004, p. 496-497.

${ }^{279}$ SARLET, Ingo Wolfgang. A Dignidade da Pessoa Humana e os Direitos Fundamentais na Constituição Federal e 1988. São Paulo: Livraria do Advogado, 2008, p. 50.

${ }^{280}$ SARLET, Ingo Wolfgang. A Dignidade da Pessoa Humana e os Direitos Fundamentais na Constituição Federal e 1988. São Paulo: Livraria do Advogado, 2008, p. 50.

${ }^{281}$ SARLET, Ingo Wolfgang. A Dignidade da Pessoa Humana e os Direitos Fundamentais na Constituição Federal e 1988. São Paulo: Livraria do Advogado, 2008, p. 48.

${ }^{282}$ SARLET, Ingo Wolfgang. A Dignidade da Pessoa Humana e os Direitos Fundamentais na Constituição Federal e 1988. São Paulo: Livraria do Advogado, 2008, p. 48.

${ }^{283}$ SARLET, Ingo Wolfgang. A Dignidade da Pessoa Humana e os Direitos Fundamentais na Constituição Federal e 1988. São Paulo: Livraria do Advogado, 2008, p. 49.

${ }^{284}$ Luísa Neto afirma que "o princípio da dignidade da pessoa, que prescreve que os homens devem ser tratados segundo as suas decisões, intenções ou manifestações de consentimento, parece ser tão básico que resulta quase vago como directiva de moralidade social". NETO, Luísa. O direito fundamental à disposição do próprio corpo (a relevância da vontade na configuração do seu regime). Coimbra: Coimbra Editora, 2004, p. 497.

${ }^{285}$ Para Luísa Neto é dever do Estado garantir a dignidade da pessoa e esse "não pode ser neutral antes os actos por libérrimos que sejam - de degradação da pessoa". NETO, Luísa. O direito fundamental à disposição do próprio corpo (a relevância da vontade na configuração do seu regime). Coimbra: Coimbra Editora, 2004, p. 497.

286 "Fechado o parêntese e na perspectiva já sinalizada (dignidade como limite e tarefa), sustenta-se que uma dimensão dúplice da dignidade manifesta-se enquanto simultaneamente expressão da autonomia da pessoa humana (vinculada à ideia de autodeterminação no que diz com as decisões essenciais a respeito da própria existência), bem como da necessidade de sua proteção (assistência) por parte da comunidade e do Estado, especialmente quando fragilizada ou até mesmo - e principalmente - quando ausente a capacidade de autodeterminação". SARLET, Ingo Wolfgang. A Dignidade da Pessoa Humana e os Direitos Fundamentais na Constituição Federal e 1988. São Paulo: Livraria do Advogado, 2008, p. 50. 
necessidade de harmonização com outros valores e com o pluralismo das sociedades democráticas; ii) quanto a temporalidade do termo que está em constante evolução; e iii) quanto à ligação do termo com a qualidade inerente ao ser humano, com aquilo que o identifica $^{287}$. Essa última barreira caracteriza a impossibilidade de utilizar o conceito de dignidade de modo taxativo, já que poderia ser empregado "a favor de qualquer das partes em detrimento das demais" 288 .

Diante disso, é possível afirmar que o conceito de dignidade não é absoluto ${ }^{289}$, admite relativização, e, é óbvio, encontrará pontos de colisão com outros valores.

Para verificar se houve violação da dignidade da pessoa humana, Sarlet parte de uma fórmula alemã da instrumentalização do indivíduo: isto é, toda vez que a pessoa for tratada como um objeto, que "venha a ser descaracterizada e desconsiderada como sujeito de direitos"290, haveria violação. Todavia, este método não elimina a dificuldade de se estabelecer o limite para saber se, em cada caso concreto, o indivíduo teria ou não sido considerado mero instrumento ${ }^{291}$.

Sob outra perspectiva, em uma tentativa de aproximar os direitos fundamentais do princípio da dignidade da pessoa humana, afirma Sarlet que o princípio da dignidade da pessoa humana é o alfa e ômega do sistema das liberdades constitucionais previstas no

\footnotetext{
287 “A construção jurídica do [conceito de dignidade] se vê rodeada de três dificuldades específicas. A primeira é que a ideia de dignidade é um ideia axiológica aberta que deve harmonizar-se com a diversidade de valores e o pluralismo que se manifestam nas complexas sociedades democráticas contemporâneas. De modo que se trata de uma cláusula afetada por uma 'profunda ambiguidade' em relação aos seus usos jurídicos concretos. [...] a dignidade pode ser simples ideologia camuflada sob um pseudônimo jurídico respeitável. A segunda dificuldade é que a ideia de dignidade também se encontra não só em seu conteúdo, mas também no tempo. Se trata de um conceito em permanente processo de desenvolvimento e construção. Outra dificuldade é que a dignidade diferente do que ocorre com outros bens como a liberdade, intimidade, integridade etc, não cuida de aspectos mais ou menos particulares da existência humana, mas de uma qualidade tida como inerente, de modo que é o valor próprio que identifica o ser humano como tal, daí que se trata de um conceito excessivamente radical ou taxativo para ser empregado em qualquer disputa jurídica sem fechá-la de imediato a favor de qualquer das partes em detrimento das demais". REY MARTÍNEZ, Fernando. Eutanasia y Derechos Fundamentales. Madrid: Centro de Estúdios Políticos Y Constitucionales, 2008, p. 164, (tradução nossa).

${ }^{288}$ REY MARTíNEZ, Fernando. Eutanasia y Derechos Fundamentales. Madrid: Centro de Estúdios Políticos Y Constitucionales, 2008, p. 164, (tradução nossa).

${ }^{289}$ Nesse sentido, André Ramos Tavares afirma que "Não se pode, equivocamente, inferir do conteúdo da dignidade da pessoa humana que se trataria de um direito ou princípio absoluto". TAVARES, André Ramos. Direito Constitucional Econômico. $3^{\mathrm{a}}$ ed. Rio de Janeiro: Forense; São Paulo: Método, 2011, p. 130. O autor propõe como "compreensão do alcance da dignidade como princípio a tese da consubstancialidade", isto é, se a dignidade da pessoa humana poderia ser entendida como um "substratum básico de todo e qualquer direito fundamental". TAVARES, André Ramos. Direito Constitucional Econômico. $3^{\mathrm{a}}$ ed. Rio de Janeiro: Forense; São Paulo: Método, 2011, p. 131.

${ }^{290}$ SARLET, Ingo Wolfgang. A Dignidade da Pessoa Humana e os Direitos Fundamentais na Constituição Federal e 1988. São Paulo: Livraria do Advogado, 2008, p. 59.

${ }^{291}$ [N.R.] No caso de uma gestação de feto com anencefalia, a mãe poderia ser considerada um instrumento para preservar a vida - no sentido abstrato - do feto.
} 
ordenamento jurídico brasileiro ${ }^{292}$, de modo que tais direitos fundamentais encontram "fundamento direto, imediato e igual na dignidade da pessoa humana, do qual seriam concretizações"293. Para o autor, a relação não é subsidiária, mas de "substancial fundamentalidade" ${ }^{294}$, de forma que é exigido o reconhecimento e a proteção de todos os direitos fundamentais, pois, ao negar aos seres humanos direitos que lhes são inerentes, negase também a própria dignidade ${ }^{295}$.

Nessa esteira, ensina Ingo Sarlet que a dignidade está relacionada a "um direito geral ao livre desenvolvimento da personalidade, mas também aos direitos de personalidade em geral" 296 .

No que tange ao direito à vida, que está estreitamente relacionado com a dignidade da pessoa, sua relação tem sido entendida "no sentido de que onde há vida há dignidade, e a violação de um, por via de consequência, implica a violação do outro bem jurídico constitucionalmente tutelado" 297 .

Ao lado dessa aproximação da dignidade e do direito à vida, Sarlet afirma que a dignidade humana também está assentada na autonomia pessoal ${ }^{298}$, ou seja, na liberdade, uma vez que, se essa não for reconhecida e assegurada, não há que se falar em dignidade ${ }^{299}$.

Além disso, é possível encontrar conexão da dignidade humana com o reconhecimento e proteção da identidade pessoal, destacando, como faz Sarlet, o respeito à privacidade, à intimidade, etc ${ }^{300}$. Ademais, a dignidade humana também encontra conexão com o direito geral de igualdade e com o respeito e proteção da integridade física e psíquica ${ }^{301}$.

\footnotetext{
292 SARLET, Ingo Wolfgang. A Dignidade da Pessoa Humana e os Direitos Fundamentais na Constituição Federal e 1988. São Paulo: Livraria do Advogado, 2008, p. 79.

${ }^{293}$ SARLET, Ingo Wolfgang. A Dignidade da Pessoa Humana e os Direitos Fundamentais na Constituição Federal e 1988. São Paulo: Livraria do Advogado, 2008, p. 81.

${ }^{294}$ SARLET, Ingo Wolfgang. A Dignidade da Pessoa Humana e os Direitos Fundamentais na Constituição Federal e 1988. São Paulo: Livraria do Advogado, 2008, p. 87.

${ }^{295}$ SARLET, Ingo Wolfgang. A Dignidade da Pessoa Humana e os Direitos Fundamentais na Constituição Federal e 1988. São Paulo: Livraria do Advogado, 2008, p. 87.

${ }^{296}$ SARLET, Ingo Wolfgang. A Dignidade da Pessoa Humana e os Direitos Fundamentais na Constituição Federal e 1988. São Paulo: Livraria do Advogado, 2008, p. 88-89.

${ }^{297}$ SARLET, Ingo Wolfgang. A Dignidade da Pessoa Humana e os Direitos Fundamentais na Constituição Federal e 1988. São Paulo: Livraria do Advogado, 2008, p. 88-89

${ }^{298}$ Para Luísa Neto a relação entre dignidade da pessoa e o princípio da autonomia não é muito claro, seguindo a linha de que o princípio da dignidade prevaleceria sobre o da autonomia. NETO, Luísa. O direito fundamental à disposição do próprio corpo (a relevância da vontade na configuração do seu regime). Coimbra: Coimbra Editora, 2004, p. 498.

${ }^{299}$ SARLET, Ingo Wolfgang. A Dignidade da Pessoa Humana e os Direitos Fundamentais na Constituição Federal e 1988. São Paulo: Livraria do Advogado, 2008, p. 87.

${ }^{300}$ SARLET, Ingo Wolfgang. A Dignidade da Pessoa Humana e os Direitos Fundamentais na Constituição Federal e 1988. São Paulo: Livraria do Advogado, 2008, p. 87.

${ }^{301}$ SARLET, Ingo Wolfgang. A Dignidade da Pessoa Humana e os Direitos Fundamentais na Constituição Federal e 1988. São Paulo: Livraria do Advogado, 2008, p. 88-90.
} 
A crítica mais contundente ao uso da noção de dignidade na argumentação em geral é a formulada por Fernando Rey Martínez, que alerta para o fato de que, sob o pretexto da "dignidade individual", é possível chegar aos mais diversos resultados interpretativos, não apenas distintos, mas até "diametralmente opostos". Para o autor, isso invalidaria quase por completo o uso desse argumento no debate. $\mathrm{O}$ argumento da dignidade, portanto, se reduziria a mera retórica ${ }^{302}$.

Ensina ainda Ingo Sarlet que, se não existir o respeito à vida, à integridade física ${ }^{303}$, e à limitação do poder, não haverá espaço para a dignidade. É preciso que os direitos fundamentais sejam "reconhecidos e minimamente asssegurados",304.

Esta concepção de dignidade está intimamente relacionada a de direitos fundamentais clássicos $^{305}$, que surgiram da necessidade de se limitar o poder do estado, estabelecendo para tanto princípios e direitos essenciais para o funcionamento de um estado democrático de direito $^{306}$. Referidos direitos seriam, conforme Alexandre de Moraes

${ }^{302}$ REY MARTÍNEZ, Fernando. Eutanasia y Derechos Fundamentales. Madrid: Centro de Estúdios Políticos Y Constitucionales, 2008, p. 163. Nessa linha, Ingo Sarlet ensina que o alto grau de indeterminação da dignidade humana pode constituir como caminho mais fácil para a arbitrariedade do intérprete "Isto, contudo, não significa que uma eventual ofensa a determinado direito fundamental não possa constituir também, simultaneamente, violação do âmbito de proteção da dignidade da pessoa humana, de modo que esta poderá sempre servir de fundamento autônomo para o reconhecimento de um direito subjetivo, neste caso de cunho defensivo". SARLET, Ingo Wolfgang. A Dignidade da Pessoa Humana e os Direitos Fundamentais na Constituição Federal e 1988. São Paulo: Livraria do Advogado, 2008, p. 106-107. André Ramos Tavares traz um exemplo desse conflito na seara econômica: "no campo econômico, poder-se-á cogitar do conflito entre categorias ou pessoas distintas, mas envolvendo, para ambos os lados, a mesma ideia de dignidade da pessoa humana. Nesse sentido é a discussão orçamentária atual sobre a prestação de saúde, especificamente de certos tratamentos de alto custo, para poucas pessoas, deixando ao desabrigo (insuficiência de recursos para todas as necessidades) um grande contingente de pessoas que necessitam de tratamentos mais simples e de custo reduzidíssimo. É, mais do que um dilema econômico, um dilema moral para o estado e uma dificuldade operacional grande, especialmente em razão da fragmentação judicial das decisões adotadas em benefício exclusivo dos que procuram o Poder Judiciário". TAVARES, André Ramos. Direito Constitucional Econômico. $3^{\mathrm{a}}$ ed. Rio de Janeiro: Forense; São Paulo: Método, 2011, p. 131.

${ }^{303}$ Para Luísa Neto, o direito à integridade física também não é absoluto, vez tratar-se de direito parcialmente disponível. Exemplifica com o artigo 143 do Código Penal Português que considera o crime de ofensas corporais simples excusável com o consentimento do ofendido, respeitado os limites determinados pelo direito à vida, bons costumes, ordem pública etc. NETO, Luísa. O direito fundamental à disposição do próprio corpo (a relevância da vontade na configuração do seu regime). Coimbra: Coimbra Editora, 2004, p. 576-577.

304 "onde não houver respeito pela vida e pela integridade física e moral do ser humano, onde as condições mínimas para uma existência digna não forem asseguradas, onde não houver limitação do poder, enfim, onde a liberdade e a autonomia, a igualdade (em direitos e dignidade) e os direitos fundamentais não forem reconhecidos e minimamente assegurados, não haverá espaço para a dignidade da pessoa humana e esta (a pessoa), por sua vez, poderá não passar de mero objeto de arbítrio e injustiças". SARLET, Ingo Wolfgang. A Dignidade da Pessoa Humana e os Direitos Fundamentais na Constituição Federal e 1988. São Paulo: Livraria do Advogado, 2008, p. 61.

${ }^{305}$ A doutrina traz diversas definições e diferenças ao termo, vide [N.R.] 52.

${ }^{306}$ MORAES, Alexandre de. Direitos Humanos Fundamentais: teoria geral, comentários aos arts. $1^{\circ}$ a $5^{\circ}$ da Constituição Federal da República Federativa do Brasil, doutrina e jurisprudência. 9. ed. São Paulo: Atlas, 2011, p. 3. Para José Carlos Francisco, o Estado Democrático de Direito é uma "modalidade do Estado de Direito, representando a evolução do Estado Liberal e do Estado Social sendo aparelhado por instrumentos constitucionais para concretizar a justiça social". FRANCISCO, José Carlos. Estado Democrático de Direito. In: DIMOULIS, Dimitri (Coordenador Geral). TAVARES, André Ramos; DIMOULIS, Dimitri; BERCOVICI, 
o conjunto institucionalizado de direitos e garantias do ser humano que tem por finalidade básica o respeito a sua dignidade, por meio de sua proteção contra o arbítrio do poder estatal, e o estabelecimento de condições mínimas de vida e desenvolvimento da personalidade humana ${ }^{307}$.

É, pois, incontestável a relevância, o valor e a estatura da dignidade da pessoa humana na arena jurídica de nossos dias. Mais adiante, analisaremos como a dignidade e o direito à vida podem colidir em várias circunstâncias, inclusive no caso do aborto do feto anencefálico.

\subsubsection{O Direito à vida relativizado}

Há quem afirme que o direito à vida é o mais relevante dos direitos, pois é considerado pré-requisito para a existência e exercício de todos demais direitos ${ }^{308}$. Por outro lado, como ensina Sarlet, até mesmo a vida deve ser vivida com dignidade, destacando o caráter hierárquico da dignidade da pessoa humana ${ }^{309}$.

Fernando Rey Martínez não nega que exista um interesse da sociedade em proteger a vida, pois, apesar de ela ser um bem individual, englobaria também um componente coletivo, em virtude da importância que tem a vida de cada indivíduo em relação ao tecido social ${ }^{310}$. Portanto, em razão da importância que tem para a sociedade, não nega tampouco o autor que a vida deva ser protegida independentemente da vontade de seu titular, em razão do que, o direito à vida não poderia ser entendido como meramente um direito subjetivo ${ }^{311}$. $\mathrm{O}$ direito à

Gilberto; SILVA, Guilherme Amorim Campos da; FRANCISCO, José Carlos; ANJOS FILHO, Robério Nunes dos; ROTHENBURG, Walter Claudius (org.). Dicionário Brasileiro de Direito Constitucional. São Paulo: Saraiva, 2007, p. 148.

${ }^{307}$ MORAES, Alexandre de. Direitos Humanos Fundamentais: teoria geral, comentários aos arts. $1^{\circ}$ a $5^{\circ}$ da Constituição Federal da República Federativa do Brasil, doutrina e jurisprudência. 9. ed. São Paulo: Atlas, 2011, p. 20-21.

${ }^{308}$ Neste sentido, Paulo Hamilton Siqueira Júnior e Miguel Augusto Machado de Oliveira, "a vida é o valor fundamental do ser humano, pois todos os outros direitos e características da personalidade surgem do bem vida". SIQUEIRA JÚNIOR, Paulo Hamilton; OLIVEIRA, Miguel Augusto Machado de. Direitos Humanos e Cidadania. $3^{a}$ ed. rev. e atual. São Paulo: Editora Revista dos Tribunais, 2010, p. 218.

${ }^{309}$ SARLET, Ingo Wolfgang. A Dignidade da Pessoa Humana e os Direitos Fundamentais na Constituição Federal e 1988. São Paulo: Livraria do Advogado, 2008, p. 85.

${ }^{310}$ REY MARTÍNEZ, Fernando. Eutanasia y Derechos Fundamentales. Madrid: Centro de Estúdios Políticos Y Constitucionales, 2008, p. 136.

${ }^{311}$ Afirma o autor que no caso Pretty v. Reino Unido, a Corte entendeu que o direito à vida é um bem jurídico indisponível e que deverá ser protegida com independência da vontade de seu titular. Para o autor, o direito à vida está além do direito subjetivo. REY MARTÍNEZ, Fernando. La Protección Jurídica de La Vida: Un Derecho em Transformación Y Expansión (art. 2 CEDH y Protocolos $6^{\circ}$ y $13^{\circ}$ ). In: GARCIA ROCA, Javier e 
vida, assim, pertence para Rey Martínez ao núcleo duro dos direitos fundamentais ${ }^{312}$. Deste modo, o direito à vida deve ser protegido pelo estado, embora não seja absoluto ${ }^{313}$, podendo ser relativizado, assim como a própria dignidade da pessoa humana ${ }^{314}$.

Como ensina Rey Martínez, não seria legítimo que um estado tivesse interesse de preservar a vida de seus cidadãos todo o tempo e sob todas as circunstâncias ${ }^{315}$. Seria uma proteção de um valor meramente abstrato ${ }^{316}$.

Vale ainda lembrar que, sob uma pespectiva jurídica tradicional, como bem esclarece Rey Martínez, a vida é considerada "um bem claramente indisponível para o direito positivo", constituindo verdadeiro dever de viver ${ }^{317}$. No entanto, outros direitos fundamentais devem também ser levados em conta quando conflitam com o direito à vida, especialmente quando falamos de dignidade de vida, ou, como preferem alguns, qualidade de vida ${ }^{318}$.

Ensina Rey Martínez que a ideia de santidade da vida ou intangibilidade decorre de uma visão idealista de que a vida humana seria um bem jurídico absoluto, pois "não consiste nem se esgota nas suas manisfestações biológicas" 319 , uma vez que possui um "sentido único e é constitutivamente intangível" 320 . Ao contrário, o postulado da "qualidade da vida", de caráter empirista, não opera a priori, mas a posteriori em relação à experiência. $\mathrm{O}$ critério religioso da santidade da vida é metafísico e cientificamente indemonstrável, como assevera Rey Martínez ${ }^{321}$. A realidade e a ciência, por outro lado, descobrem na vida humana

SANTOLAYA, Pablo (coords). La Europa de Los Derechos: El Convenio Europeo de Derechos Humanos. Madrid: Centro de Estúdios Políticos Y Constitucionales, 2005, p. 72.

$312 \mathrm{O}$ autor afirma que o direito à vida das pessoas está protegido por lei, de modo que não se pode assegurar a vida sem a proteção jurídica da vida. REY MARTÍNEZ, Fernando. La Protección Jurídica de La Vida: Un Derecho em Transformación Y Expansión (art. 2 CEDH y Protocolos $6^{\circ}$ y $13^{\circ}$ ). In: GARCIA ROCA, Javier e SANTOLAYA, Pablo (coords). La Europa de Los Derechos: El Convenio Europeo de Derechos Humanos. Madrid: Centro de Estúdios Políticos Y Constitucionales, 2005, p. 72-73.

313 [N.R.] Interessante as observações feitas no capítulo 3 da parte deste trabalho sobre as interpretações dadas pelos tribunais internacionais de direitos humanos com relação ao âmbito de proteção à vida, os termos "geralmente", vida digna, a legítima defesa e outros argumentos demonstram que o direito à vida não é absoluto, ou não tem sido interpretado dessa maneira.

${ }^{314}$ REY MARTÍNEZ, Fernando. Eutanasia y Derechos Fundamentales. Madrid: Centro de Estúdios Políticos Y Constitucionales, 2008, p. 124.

315 REY MARTÍNEZ, Fernando. Eutanasia y Derechos Fundamentales. Madrid: Centro de Estúdios Políticos Y Constitucionales, 2008, p. 124.

${ }^{316}$ REY MARTÍNEZ, Fernando. Eutanasia y Derechos Fundamentales. Madrid: Centro de Estúdios Políticos Y Constitucionales, 2008, p. 40-41.

${ }^{317}$ REY MARTÍNEZ, Fernando. Eutanasia y Derechos Fundamentales. Madrid: Centro de Estúdios Políticos Y Constitucionales, 2008, p. 135.

${ }^{318}$ REY MARTÍNEZ, Fernando. Eutanasia y Derechos Fundamentales. Madrid: Centro de Estúdios Políticos Y Constitucionales, 2008, p. 136.

319 REY MARTÍNEZ, Fernando. Eutanasia y Derechos Fundamentales. Madrid: Centro de Estúdios Políticos Y Constitucionales, 2008, p. 136.

${ }^{320}$ REY MARTÍNEZ, Fernando. Eutanasia y Derechos Fundamentales. Madrid: Centro de Estúdios Políticos Y Constitucionales, 2008, p. 136, (tradução nossa).

${ }^{321}$ REY MARTÍNEZ, Fernando. Eutanasia y Derechos Fundamentales. Madrid: Centro de Estúdios Políticos Y Constitucionales, 2008, p. 136. 
"processos biológicos, fases diferenciais, segmentos existenciais" "322, com "peculiaridades biológicas divergentes suscetíveis de considerações éticas e jurídicas diferenciadas" ${ }^{\text {323 }}$.

No Brasil, podemos tomar como exemplo de como a vida humana pode não ser absoluta, a recente decisão do Supremo Tribunal Federal sobre as células-tronco (ADI ${ }^{324}$ 3510-0), e também a exceção legal do aborto em decorrência de estupro, prevista no artigo 128, II, do Código Penal Brasileiro. Nestes casos, fica patente que, diante do direito à saúde ou da incolumidade física e moral da mulher, e, ainda, da liberdade sexual da mulher, o direito à vida nem sempre prevalece em nosso ordenamento jurídico.

Nesse mesmo sentido, destacamos o caso Roe v. Wade ${ }^{325}$, decidido pela Suprema Corte Americana. Neste caso, foi reconhecido o direito da mulher ao aborto nos Estados Unidos, sendo que a Suprema Corte, neste caso, assegurou às mulheres o direito de dispor do próprio corpo, o direito à privacidade e à liberdade individual, além do direito de reprodução.

\subsubsection{Valores, princípios, regras e o direito à vida}

Vimos que o direito à vida, apesar de fundamental, normalmente não é tratado como absoluto. No entanto, em se tratando da colisão de direitos fundamentais, sempre será necessária uma análise do caso concreto, de modo que as peculiaridades de cada caso possam ser avaliadas e ponderadas pelo intérprete da lei, buscando-se evitar abusos e arbitrariedades.

Daniel Sarmento defende que, no caso específico de conflitos envolvendo o direito à vida intrauterina, seria possível conceber tal direito como um princípio, e não como uma regra $^{326}$. Seria o direito à vida considerado, então, um valor, um princípio, ou uma regra?

\footnotetext{
${ }^{322}$ REY MARTÍNEZ, Fernando. Eutanasia y Derechos Fundamentales. Madrid: Centro de Estúdios Políticos Y Constitucionales, 2008, p. 136.

${ }^{323}$ REY MARTíNEZ, Fernando. Eutanasia y Derechos Fundamentales. Madrid: Centro de Estúdios Políticos Y Constitucionales, 2008, p. 136, (tradução nossa).

${ }^{324}$ Conforme André Ramos Tavares a Ação Direta de Inconstitucionalidade (ADI) é a "denominação da técnica constitucional brasileira pós-1988 para identificar o instrumento do processo objetivo tendente a realizar o controle abstrato-concentrado da constitucionalidade dos atos normativos". TAVARES, André Ramos. Ação Direta de Inconstitucionalidade. In: DIMOULIS, Dimitri (Coordenador Geral). TAVARES, André Ramos; DIMOULIS, Dimitri; BERCOVICI, Gilberto; SILVA, Guilherme Amorim Campos da; FRANCISCO, José Carlos; ANJOS FILHO, Robério Nunes dos; ROTHENBURG, Walter Claudius (org.). Dicionário Brasileiro de Direito Constitucional. São Paulo: Saraiva, 2007, p. 5.

${ }^{325}$ Este caso será estudado cuidadosamente na segunda parte do trabalho.

${ }^{326} \mathrm{O}$ autor afirma que a proteção do nascituro constitui um mandado de otimização, sujeito à outros princípios constitucionais e que pode ser relativizado em determinadas circunstâncias. SARMENTO, Daniel. Legalização do Aborto e constituição. In: SARMENTO, Daniel; PIOVESAN, Flávia (coordenadores). Nos Limites da Vida. Rio de Janeiro: Lúmen Júris, 2006, p. 35.
} 
$\mathrm{O}$ primeiro ponto a ser tratado refere-se à diferença entre valores e princípios formulada por Robert Alexy. Alexy ensina que, nesse quadro de colisões, existe uma relação muito próxima entre valores e direitos fundamentais, e que a realização gradual dos princípios corresponde à realização gradual dos valores ${ }^{327}$. O autor admite a colisão e o sopesamento entre princípios, bem como a colisão e sopesamento entre valores, e afirma que a diferença entre princípios e valores decorre de características estruturais gerais e elementares dos valores $^{328}$.

De forma sucinta, Alexy afirma que, apesar dessa proximidade entre valores e princípios, eles possuem natureza diversa. Enquanto que os princípios são mandamentos de otimização e pertencem ao âmbito deôntico, isto é, do dever-ser, os valores pertencem ao âmbito axiológico, ou seja, ligados ao conceito de bom ${ }^{329}$. Assim, para o autor, "aquilo que no modelo de valores, é prima facie o melhor é, no modelo de princípios, prima facie devido; e aquilo que é, no modelo de valores, definitivamente o melhor; é, no modelo de princípios, definitivamente devido" ${ }^{, 330}$. Embora, para o autor, ambos os conceitos sejam importantes, assegura que no direito o que interessa é o dever-ser, e que o conceito de princípios traz “menos interpretações equivocadas" que o conceito de valores ${ }^{331}$.

Em vista do que nos explica Alexy, fica claro que o direito à vida deve ser entendido como princípio, e não, valor. O direito à vida pertence ao âmbito do dever-ser; não está ligado per se ao que se possa ser axiologicamente entendido como bom.

Tendo em vista a sutil diferença entre princípio e valor, de outro lado, é importante mencionar, agora, as diferenças entre princípios e regras.

Segundo ensina Virgílio Afonso da Silva, o principal aspecto que diferencia regras e princípios é a estrutura de direitos que essas regras podem garantir - elementos da teoria dos princípios também proposta por Robert Alexy. No caso das regras, garantem-se direitos definitivos; e, no caso de princípios, garantem-se direitos prima facie $^{332}$. Significa dizer que o

\footnotetext{
327 ALEXY, Robert. Teoria dos Direitos Fundamentais. Tradução de Virgílio Afonso da Silva. São Paulo: Malheiros, 2008, p. 144.

328 ALEXY, Robert. Teoria dos Direitos Fundamentais. Tradução de Virgílio Afonso da Silva. São Paulo: Malheiros, 2008, p. 147.

${ }^{329}$ ALEXY, Robert. Teoria dos Direitos Fundamentais. Tradução de Virgílio Afonso da Silva. São Paulo: Malheiros, 2008, p. 144.

330 ALEXY, Robert. Teoria dos Direitos Fundamentais. Tradução de Virgílio Afonso da Silva. São Paulo: Malheiros, 2008, p. 153.

331 ALEXY, Robert. Teoria dos Direitos Fundamentais. Tradução de Virgílio Afonso da Silva. São Paulo: Malheiros, 2008, p. 153.

332 ALEXY, Robert. Teoria dos Direitos Fundamentais. Tradução de Virgílio Afonso da Silva. São Paulo: Malheiros, 2008, p. 103-104. SILVA, Virgílio Afonso da. Direitos Fundamentais: conteúdo essencial, restrições e eficácia. São Paulo: Malheiros, 2009, p. 45.
} 
direito garantido pela regra deve ser cumprido integralmente ${ }^{333}$, enquanto que no direito assegurado pelo princípio nem sempre haverá a realização integral como dispõe a norma. Há uma diferença, portanto, entre o que é garantido definitivamente e o que é garantido prima facie.

Como vimos, Robert Alexy afirma que os princípios correspondem a mandamentos de otimização, isto é, normas que devem ser aplicadas na maior medida possível, diante das possibilidades fáticas e jurídicas existentes ${ }^{334}$, e que podem ser cumpridas em "diversos graus" 335 .

O problema surge quando se tem mais de um mandamento de otimização ou mais de uma regra presentes no mesmo caso concreto. E, nessa situação, é preciso estabelecer qual mandamento de otimização - ou qual regra - deve prevalecer em relação ao outro.

Para Dworkin, os princípios teriam sempre uma dimensão de peso, de importância, que as regras não possuem na medida em que podem ou não exercer função importante ${ }^{336}$.

Quando há conflitos entre regras, é preciso estabelecer que uma dessas regras é válida total ou parcialmente, pois, caso contrário, será violado o caráter de definitividade contida na regra $^{337}$.

É possível, ainda, que tenhamos conflitos entre princípios, e, nesse caso, não é possível declarar a invalidade de um ou de outro, mas é preciso verificar se, no caso concreto, haverá a prevalência de um sobre o outro ${ }^{338}$. Em outras palavras, se há conflito entre princípios, poderá um princípio prevalecer sobre os demais - sem que se invalidem os princípios restringidos.

Mas há ainda outra possibilidade de conflitos: o conflito entre regras e princípios. Virgílio Afonso da Silva assevera que esse ponto é muito complexo e pouco discutido na teoria dos princípios, e que seria possível duas respostas distintas ${ }^{339}$ : i) a solução se dá por

\footnotetext{
${ }^{333}$ Embora possa ter exceções. SILVA, Virgílio Afonso da. Direitos Fundamentais: conteúdo essencial, restrições e eficácia. São Paulo: Malheiros, 2009, p. 45.

${ }^{334}$ ALEXY, Robert. Teoria dos Direitos Fundamentais. Tradução de Virgílio Afonso da Silva. São Paulo: Malheiros, 2008, p. 90.

${ }_{335}$ ALEXY, Robert. Teoria dos Direitos Fundamentais. Tradução de Virgílio Afonso da Silva. São Paulo: Malheiros, 2008, p. 90. SILVA, Virgílio Afonso da. Direitos Fundamentais: conteúdo essencial, restrições e eficácia. São Paulo: Malheiros, 2009, p. 46.

${ }^{336}$ DWORKIN, Ronald. Levando os Direitos a Sério. Trad. Jefferson Luiz Camargo; 2a . ed. São Paulo: Martins Fontes, 2007. (justiça e direito), p. 42.

${ }^{337}$ SILVA, Virgílio Afonso da. Direitos Fundamentais: conteúdo essencial, restrições e eficácia. São Paulo: Malheiros, 2009, p. 46-47. Nesse sentido, Dworkin, afirma que o sistema jurídico é capaz de determinar qual regra deve prevalecer, como, por exemplo, regra mais nova, hierarquicamente superior etc. DWORKIN, Ronald. Levando os Direitos a Sério. Trad. Jefferson Luiz Camargo; ${ }^{\text {a }}$. ed. São Paulo: Martins Fontes, 2007. (justiça e direito), p. 43.

${ }^{338}$ SILVA, Virgílio Afonso da. Direitos Fundamentais: conteúdo essencial, restrições e eficácia. São Paulo: Malheiros, 2009, p. 50-51.

${ }^{339}$ SILVA, Virgílio Afonso da. Direitos Fundamentais: conteúdo essencial, restrições e eficácia. São Paulo: Malheiros, 2009, p. 51.
} 
meio do sopesamento para saber se a regra ou o princípio irá prevalecer - porém, isso pode afastar a aplicação de um direito definitivo (regra), e somente poderia ser realizado um sopesamento entre normas com a mesma "dimensão de peso" - fato que não se observa nas regras $^{340}$; ou ii) a solução é verificada pelo plano de validade - neste caso, o princípio que der lugar a uma outra norma deve ser excluído do ordenamento jurídico, violando o conceito de que um princípio continua válido no ordenamento jurídico, ainda que, em certo caso concreto, seja restringido. Enfim, Virgílio conclui que não há conflitos entre regras e princípios, mas um produto de sopesamento que resultará em uma relação de restrição, e não de colisão ${ }^{341}$.

Já havíamos concluído, à luz dos ensinamentos de Alexy, que a natureza do direito à vida é de princípio, em oposição a de valor. Agora, em vista dos esclarecimentos minuciosos de Virgílio Afonso da Silva, resta patente que o direito à vida, de fato, é princípio, e não regra, pois o direito à vida é claramente prima facie, relativizável, ainda que sempre importante; e não goza do grau de definição exigido por uma regra. Ao refletir sobre esta questão, não pudemos evitar pensar que, talvez, o único modo de se entender o direito à vida como regra fosse atribuindo-lhe um valor absoluto - que já vimos que não tem - o que, mais uma vez, reforçou nossa conclusão a respeito de sua natureza de princípio.

\subsubsection{Outros direitos em conflito}

Cançado Trindade, ao tratar de limitações, restrições ou derrogações permissíveis ao exercício dos direitos humanos consagrados, como, por exemplo, o direito à vida, afirma que estas restrições devem ser interpretadas restritivamente, devem ser previstas em lei, e somente devem ser usadas em situações absolutamente necessárias ${ }^{342}$. Além disso, para o autor, as limitações deverão ser realizadas em nome do interesse geral da coletividade, atentando-se aos "requisitos de uma sociedade democrática e, respeitando o princípio da proporcionalidade" 343 .

\footnotetext{
${ }^{340}$ SILVA, Virgílio Afonso da. Direitos Fundamentais: conteúdo essencial, restrições e eficácia. São Paulo: Malheiros, 2009, p. 51.

${ }^{341}$ SILVA, Virgílio Afonso da. Direitos Fundamentais: conteúdo essencial, restrições e eficácia. São Paulo: Malheiros, 2009, p. 52.

342 CANÇADO TRINDADE, Antônio Augusto. A Proteção Internacional dos Direitos Humanos: fundamentos jurídicos e instrumentos básicos. São Paulo: Saraiva, 1991, p. 16.

343 CANÇADO TRINDADE, Antônio Augusto. A Proteção Internacional dos Direitos Humanos: fundamentos jurídicos e instrumentos básicos. São Paulo: Saraiva, 1991, p. 16.
} 
Nessa linha, Alexandre de Moraes ensina que os direitos humanos fundamentais, no Brasil, não podem ser arguidos na defesa de atividades ilícitas ${ }^{344}$, e também não são ilimitados, pois encontram limites em outros direitos igualmente protegidos pela Constituição Federal. $^{345}$ É o que o autor denomina de princípio da relatividade ou convivência das liberdades públicas ${ }^{346}$.

Assim, para uma análise mais completa dos conflitos relativos ao aborto, é necessário analisar quais direitos podem ser suscitados neste debate ${ }^{347}$. Por exemplo, poderíamos considerar o direito à vida da mulher ${ }^{348}$, o direito à sua saúde - englobando o direito à saúde psíquica e física -, o direito à liberdade, à privacidade e à autonomia individual ${ }^{349}$, destacando também os direitos reprodutivos e sexuais da mulher.

\subsubsection{Direito à saúde física e psíquica ${ }^{350}$}

\footnotetext{
${ }^{344}$ Para o autor "os direitos humanos fundamentais não podem ser utilizados como um escudo protetivo da prática de atividades ilícitas, nem tampouco como argumento para afastamento ou diminuição da responsabilidade civil ou penal por atos criminosos, sob pena de total consagração ao desrespeito a um verdadeiro Estado de Direito." MORAES, Alexandre de. Direitos Humanos Fundamentais: teoria geral, comentários aos arts. $1^{\circ}$ a $5^{\circ}$ da Constituição Federal da República Federativa do Brasil, doutrina e jurisprudência. 6. ed. São Paulo:Atlas, 2005 (Coleção Temas Jurídicos:3), p. 27.

${ }^{345}$ MORAES, Alexandre de. Direitos Humanos Fundamentais: teoria geral, comentários aos arts. $1^{\circ}$ a $5^{\circ}$ da Constituição Federal da República Federativa do Brasil, doutrina e jurisprudência. 6. ed. São Paulo:Atlas, 2005 (Coleção Temas Jurídicos:3), p. 27.

${ }^{346}$ Quanto a liberdades públicas, Manoel Gonçalves Ferreira Filho afirma que "por muito tempo a elas se chamou no Brasil, os direitos individuais, [e] constituem o núcleo dos direitos fundamentais. A eles - é certo se agregaram primeiro os direitos econômicos e sociais, depois os direitos de solidariedade, mas esses outros direitos não renegam essas liberdades, visam antes a completá-las”. FERREIRA FILHO, Manoel Gonçalves. Direitos Humanos Fundamentais. 10 ed. São Paulo: Saraiva, 2008, p. 28. MORAES, Alexandre de. Direitos Humanos Fundamentais: teoria geral, comentários aos arts. $1^{\circ}$ a $5^{\circ}$ da Constituição Federal da República Federativa do Brasil, doutrina e jurisprudência. 6. ed. São Paulo:Atlas, 2005 (Coleção Temas Jurídicos:3), p. 27.

${ }^{347}$ SARMENTO, Daniel. Legalização do Aborto e Constituição. In: SARMENTO, Daniel; PIOVESAN, Flávia (coordenadores). Nos Limites da Vida. Rio de Janeiro: Lúmen Júris, 2006, p. 36.

348 NETO, Luísa. O direito fundamental à disposição do próprio corpo (a relevância da vontade na configuração do seu regime). Coimbra: Coimbra Editora, 2004, p. 605.

349 Sugere-se a leitura do interessante texto sobre conflito dos direitos da mãe e do feto. Para Steinbock, os direitos da mãe e do feto devem ser considerados: “In resolving mother-fetus conflicts, women's rights to privacy, bodily integrity and autonomy must be considered along with the welfare of the fetus and surviving child'. STEINBOCK, Bonnie. Mother-fetus conflict. In: A Companion to Bioethics. KUHSE, Helga. SINGER, Peter (Blackwell Companion to Philosophy). Massachusetts, EUA. Blackwell Publishing, 1998, p. 135-145.

${ }^{350}$ Aponta a "enorme relevância deste direito fundamental para a garantia da vida humana digna", tendo em vista que "a proteção à saúde é muitas vezes um imperativo necessário à manutenção do próprio direito à vida, bem como da integridade física e psíquica das pessoas humanas." SARMENTO, Daniel. Legalização do Aborto e Constituição. In: SARMENTO, Daniel; PIOVESAN, Flávia (coordenadores). Nos Limites da Vida. Rio de Janeiro: Lúmen Júris, 2006, p. 37.
} 
No caso do aborto, a proteção do direito à vida do feto, em alguns casos, poderia violar o direito à saúde física da mulher. Dessa forma, o aborto seria permitido se a continuidade da gravidez pudesse, de algum modo, colocar em risco a saúde da mãe. Esse argumento tem sido bastante utilizado e já tem sido admitido na legislação e jurisprudência internacionais ${ }^{351}$.

A Organização Mundial de Saúde (OMS) reconhece que "saúde é o estado de completo bem-estar físico, mental e social, e não apenas a ausência de doença ou enfermidade" (negrito nosso) ${ }^{352}$. Assim, quando falamos em direito à saúde, tratamos do direito à saúde física, mental e social. Logo, não se trata apenas da saúde física.

Além disso, ensina Daniel Sarmento que esse direito possui duas dimensões: defensiva e prestacional ${ }^{353}$. A primeira impediria que o estado ou terceiros violem esse direito; e a segunda determina obrigações de formular políticas públicas para a sua promoção ${ }^{354}$. Para Sarmento, o direito à saúde é ao mesmo tempo um direito positivo e um direito negativo ${ }^{355}$.

Dessa forma, Daniel Sarmento afirma que a criminalização do aborto ${ }^{356}$, especialmente como tipificada na legislação brasileira ${ }^{357}$, violaria "duplamente" o direito à saúde da mulher: na esfera individual porque não há previsão legal para o aborto no caso de risco à saúde da

\footnotetext{
${ }^{351}$ Vide casos e jurisprudência citados no capítulo 3 da primeira parte deste trabalho.

${ }^{352} 20$ parágrafo preambular in verbis: "Health is a state of complete physical, mental and social well-being and not merely the absence of disease or infirmity". Constitucion of the World Health Organization de 22 jul. 1946 (tradução nossa). Disponível em: <http://whqlibdoc.who.int/hist/official_records/constitution.pdf>. Acesso em: 09 jan. 2012.

${ }^{353}$ SARMENTO, Daniel. Legalização do Aborto e Constituição. In: SARMENTO, Daniel; PIOVESAN, Flávia (coordenadores). Nos Limites da Vida. Rio de Janeiro: Lúmen Júris, 2006, p. 38.

${ }^{354} \mathrm{O}$ Estado tem deveres comissivos devendo "formular e implementar políticas públicas visando à promoção da saúde das pessoas, bem como fornecer prestações materiais aos cidadãos correlacionadas à saúde, tais como atendimento médico e medicamentos." SARMENTO, Daniel. Legalização do Aborto e Constituição. In: SARMENTO, Daniel; PIOVESAN, Flávia (coordenadores). Nos Limites da Vida. Rio de Janeiro: Lúmen Júris, 2006, p. 38. O autor esclarece, ainda, que há discussões sobre os limites das prestações positivas, especialmente, em razão do ônus financeiro e escassez de verbas destinadas à saúde, destacando o debate sobre reserva do possível e mínimo existencial. SARMENTO, Daniel. Legalização do Aborto e Constituição. In: SARMENTO, Daniel; PIOVESAN, Flávia (coordenadores). Nos Limites da Vida. Rio de Janeiro: Lúmen Júris, 2006, p. 3738. Vide comentários sobre o direito a tratamento médico e críticas sobre as condições da saúde no Brasil formuladas por Maria Helena Diniz. DINIZ, Maria Helena. O Estado Atual do Biodireito. São Paulo: Saraiva, 2009, p. 155-156.

${ }^{355}$ SARMENTO, Daniel. Legalização do Aborto e Constituição. In: SARMENTO, Daniel; PIOVESAN, Flávia (coordenadores). Nos Limites da Vida. Rio de Janeiro: Lúmen Júris, 2006, p. 39.

${ }^{356}$ Piovesan também questiona a efetividade da legislação penal brasileira que dispõe sobre a criminalização do aborto. PIOVESAN, Flávia. Direitos Sexuais e Reprodutivos: Aborto Inseguro como Violação aos Direitos Humanos. In: SARMENTO, Daniel; PIOVESAN, Flávia (coordenadores). Nos Limites da Vida. Rio de Janeiro: Lúmen Júris, 2006, p. 66.

${ }^{357}$ Os artigos $6^{\circ}$ e 196 a 200 da Constituição Brasileira dispõem sobre o direito à saúde. Destacamos, porém, dois artigos in verbis: Art. $6^{\circ}$ - São direitos sociais a educação, a saúde, a alimentação, o trabalho, a moradia, o lazer, a segurança, a previdência social, a proteção à maternidade e à infância, a assistência aos desamparados, na forma desta Constituição"; Art. 196 - "A saúde é direito de todos e dever do Estado, garantido mediante políticas sociais e econômicas que visem à redução do risco de doença e de outros agravos e ao acesso universal e igualitário às ações e serviços para sua promoção, proteção e recuperação". BRASIL. Constituição da República Federativa do Brasil. Brasília, DF: Senado, 1988.
} 
mulher, seja física ou psíquica ${ }^{358}$, e, na esfera coletiva ${ }^{359}$, porque, em decorrência da proibição do aborto, muitas mulheres realizam abortos "clandestinos", sem higiene e segurança, estando sujeitas a riscos a sua saúde e sua vida ${ }^{360}$ como um verdadeiro "efeito colateral" 361 dessa criminalização.

Assim, para Sarmento, comprovado o risco à saúde da mulher, é preciso garantir que a mulher escolha ou não pelo aborto ${ }^{362}$. Para o autor, a realidade do aborto clandestino expõe ainda mais a mulher a riscos à saúde e à vida, e a criminalização não impede essa prática ${ }^{363}$.

\footnotetext{
${ }^{358}$ Para o autor, violaria a dimensão negativa, pois a norma penal que proíbe o aborto viola o direito à saúde da mulher nos casos em que a gravidez coloca em risco à sua saúde física e psíquica, sendo necessário diminuir o poder do Estado na ação contra as mulheres, médicos e enfermeiros. SARMENTO, Daniel. Legalização do Aborto e Constituição. In: SARMENTO, Daniel; PIOVESAN, Flávia (coordenadores). Nos Limites da Vida. Rio de Janeiro: Lúmen Júris, 2006, p. 39. A saúde psíquica têm sido abordada nos casos de aborto em razão de estupro ou no casos em que seja constatado a inviabilidade extrauterina do feto. Esse direito associado aos direitos reprodutivos da mulher são hoje considerados os mais relevantes para permitir a realização do aborto. Vide item 3.4.4.1 da primeira parte deste trabalho.

${ }^{359}$ Para o autor, violaria a dimensão positiva já que não bastaria eliminar o dispositivo legal que proíbe o aborto, seria preciso garantir a realização do aborto no sistema público de saúde, caso contrário as mulheres de baixa renda manteriam-se sujeitas aos mesmos riscos do aborto clandestino. SARMENTO, Daniel. Legalização do Aborto e Constituição. In: SARMENTO, Daniel; PIOVESAN, Flávia (coordenadores). Nos Limites da Vida. Rio de Janeiro: Lúmen Júris, 2006, p. 39.

${ }^{360}$ Para o autor, centenas de milhares de gestantes praticam o aborto por ano em razão do "principal efeito prático das normas repressivas em vigor". SARMENTO, Daniel. Legalização do Aborto e Constituição. In: SARMENTO, Daniel; PIOVESAN, Flávia (coordenadores). Nos Limites da Vida. Rio de Janeiro: Lúmen Júris, 2006, p. 36-37, especialmente, p. 36.

${ }^{361}$ SARMENTO, Daniel. Legalização do Aborto e Constituição. In: SARMENTO, Daniel; PIOVESAN, Flávia (coordenadores). Nos Limites da Vida. Rio de Janeiro: Lúmen Júris, 2006, p. 36.

362 Já que a vida do nascituro não seria assegurada "com a mesma intensidade do que a assegurada pela Lei Maior aos indivíduos já nascidos". SARMENTO, Daniel. Legalização do Aborto e Constituição. In: SARMENTO, Daniel; PIOVESAN, Flávia (coordenadores). Nos Limites da Vida. Rio de Janeiro: Lúmen Júris, 2006, p. 40. Nesse sentido, avaliando a capacidade de interesse do feto (teoria do non-conscious, non-sentient), o feto seria menos protegido porque incapaz de sentir. Ler a respeito: STEINBOCK, Bonnie. Mother-fetus conflict. In: A Companion to Bioethics. KUHSE, Helga. SINGER, Peter (Blackwell Companion to Philosophy). Massachusetts, EUA. Blackwell Publishing, 1998, p. 136.

${ }^{363} \mathrm{O}$ autor entende que medidas como "ampliação dos investimentos em planejamento familiar e educação sexual para redução do número de gestações indesejadas; a garantia do direito à creche e o combate ao preconceito contra a mulher grávida no ambiente de trabalho" e o "fortalecimento da rede de segurança social" são mais eficazes e trazem menos "efeitos colaterais" que a repressão criminal do aborto. SARMENTO, Daniel. Legalização do Aborto e Constituição. In: SARMENTO, Daniel; PIOVESAN, Flávia (coordenadores). Nos Limites da Vida. Rio de Janeiro: Lúmen Júris, 2006, p. 40-41. O autor ainda traz dados de pesquisa realizada entre 1999 e 2002 para demonstrar que são realizados entre 705.600 e 1.008 .000 abortos anuais, com cerca de 518 óbitos ocorridos no mesmo período, decorrentes de abortos no Brasil. As vítimas são na grande maioria, mulheres de baixa renda e negras. $\mathrm{O}$ autor indica que o preço cobrado por clínicas de aborto nos centros das capitais brasileiras variam entre $\mathrm{R} \$ 1.500,00$ a $\mathrm{R} \$ 3.500,00$, de modo que o acesso a essas clínicas também não abrangeria todas as mulheres, pois não tendo condições de pagar pelo procedimento, sujeitam-se à métodos piores daqueles utilizados nas clínicas, com menos condições ainda de segurança e higiene. Ler mais a respeito. SARMENTO, Daniel. Legalização do Aborto e Constituição. In: SARMENTO, Daniel; PIOVESAN, Flávia (coordenadores). Nos Limites da Vida. Rio de Janeiro: Lúmen Júris, 2006, p. 41. Piovesan alerta para o fato de que a defesa da inviolabilidade do direito à vida acaba gerando a "morte seletiva de mulheres", pois o aborto aparece como a " $4^{\mathrm{a}}$ causa de morte materna no Brasil" atingindo especialmente mulheres de baixa renda e que milhares de mulheres foram internadas após a realização de abortos clandestinos. PIOVESAN, Flávia. Direitos Sexuais e Reprodutivos: Aborto Inseguro como Violação aos Direitos Humanos. In: SARMENTO, Daniel; PIOVESAN, Flávia (coordenadores). Nos Limites da Vida. Rio de Janeiro: Lúmen Júris, 2006, p. 67.
} 
Uma recente Pesquisa Nacional de Aborto (PNA) ${ }^{364}$ revelou que uma em cada cinco mulheres entrevistadas (em torno de 22\%) já fez um aborto até completar 40 (quarenta) anos, e $6 \%$ já o realizou com idade entre 18 e 19 anos, o que indica que o aborto é um "fenômeno comum na vida reprodutiva das mulheres" ${ }^{\text {"365 }}$, e que constitui, atualmente - pelos resultados que provoca - um problema de saúde pública no Brasil ${ }^{366}$. Ademais, revela ainda a pesquisa que em torno de $8 \%$ das mulheres já foram internadas em decorrência de um aborto ${ }^{367}$.

Nesse sentido, Daniel Sarmento defende que o aborto deveria ser tratado como um "problema de saúde pública"368, e que, para que o princípio constitucional do "atendimento integral" ${ }^{369}$ contido na Constituição Federal brasileira possa ser atendido, deveria ser garantida, inclusive, a realização do procedimento pelo sistema público de saúde ${ }^{370}$.

\footnotetext{
${ }^{364}$ A pesquisa entrevistou 2002 mulheres nos centros urbanos em 2010. A pesquisa diz respeito ao número de mulheres que praticaram aborto e não sobre o número de abortos realizados por elas que, na prática, podem realizar mais de um aborto cada uma. DINIZ, Debora e MEDEIROS, Marcelo. Aborto no Brasil: uma pesquisa domiciliar com técnica de urna. Associação Brasileira de Pós-Graduação em Saúde Coletiva versão impressa ISSN 1413-8123Ciência \& saúde coletiva. Vol.15 supl.1. Rio de Janeiro jun. 2010. Disponível em: <http://dx.doi.org/10.1590/S1413-81232010000700002>. Acesso em: 10 jan. 2012. Texto integral disponível em: <http://www.scielo.br/scielo.php?script=sci_arttext\&pid=S1413- 81232010000700002 \&lng=pt\&nrm =iso>. Acesso em: 10 jan. 2012.

${ }^{365}$ DINIZ, Debora e MEDEIROS, Marcelo. Aborto no Brasil: uma pesquisa domiciliar com técnica de urna. Ciência, saúde coletiva. Vol.15 supl.1. Rio de Janeiro jun. 2010. Disponível em: <http://dx.doi.org/10.1590/S1413-81232010000700002>. Acesso em: 10 jan. 2012. Texto integral disponível em: <http://www.scielo.br/scielo.php?script=sci_arttext\&pid=S1413- $81232010000700002 \quad$ \&lng=pt\&nrm =iso>. Acesso em: 10 jan. 2012.

${ }^{366}$ Para Debora Diniz e Marcelo Medeiros: "Os níveis de internação pós-aborto são elevados e colocam o aborto como um problema de saúde pública no Brasil. Cerca de metade das mulheres que fizeram aborto recorreram ao sistema de saúde e foram internadas por complicações relacionadas ao aborto, o que corresponde a $8 \%$ das mulheres entrevistadas. Boa parte dessa internação poderia ter sido evitada se o aborto não fosse tratado como atividade clandestina e o acesso aos medicamentos seguros para aborto fosse garantido". DINIZ, Debora e MEDEIROS, Marcelo. Aborto no Brasil: uma pesquisa domiciliar com técnica de urna. Ciência, saúde coletiva. Vol.15 supl.1. Rio de Janeiro jun. 2010. Disponível em: http://dx.doi.org/10.1590/S141381232010000700002>. Acesso em: 10 jan. 2012. Texto integral disponível em: <http://www.scielo.br/scielo.php?script=sci_arttext\&pid=S1413- $81232010000700002 \quad \& \operatorname{lng}=$ pt\&nrm $=i s o>$. Acesso em: 10 jan. 2012.

${ }^{367}$ DINIZ, Debora e MEDEIROS, Marcelo. Aborto no Brasil: uma pesquisa domiciliar com técnica de urna. Ciência, saúde coletiva. Vol.15 supl.1. Rio de Janeiro jun. 2010. Disponível em: <http://dx.doi.org/10.1590/S1413-81232010000700002>. Acesso em: 10 jan. 2012. Texto integral disponível em: http://www.scielo.br/scielo.php?script=sci_arttext\&pid=S1413-81232010000700002 \&lng=pt\&nrm =iso>. Acesso em: 10 jan. 2012.

${ }^{368}$ SARMENTO, Daniel. Legalização do Aborto e Constituição. In: SARMENTO, Daniel; PIOVESAN, Flávia (coordenadores). Nos Limites da Vida. Rio de Janeiro: Lúmen Júris, 2006, p. 42.

${ }^{369}$ Art. 198, II, CF. Vide também art. 7, IV, Lei 8080/90. Para Daniel Sarmento, o Estado gasta muito para tratar das complicações resultantes de abortos clandestinos. Ler mais a respeito. SARMENTO, Daniel. Legalização do Aborto e Constituição. In: SARMENTO, Daniel; PIOVESAN, Flávia (coordenadores). Nos Limites da Vida. Rio de Janeiro: Lúmen Júris, 2006, p. 42.

${ }^{370} \mathrm{O}$ autor conclui no sentido de reformar a legislação brasileira com a legalização do aborto e a interrupção da gravidez no seu início pelo sistema público de saúde (Sistema Único de Saúde - SUS). SARMENTO, Daniel. Legalização do Aborto e Constituição. In: SARMENTO, Daniel; PIOVESAN, Flávia (coordenadores). Nos Limites da Vida. Rio de Janeiro: Lúmen Júris, 2006, p. 42.
} 


\subsubsection{2 - Direitos reprodutivos e sexuais da mulher ${ }^{371}$}

\subsubsection{1 - Liberdade, dignidade e autonomia individual; a disposição sobre o próprio corpo, igualdade de gêneros, e privacidade}

Destacamos dentre os direitos que conflitam com o direito à vida, especialmente no caso de aborto, os direitos reprodutivos e sexuais da mulher.

Alguns defendem que o controle sobre o corpo e a sexualidade da mulher poderiam ser considerados uma forma de sexismo ${ }^{372}$ ou de submissão, e que, uma vez regulados, violariam a privacidade e a liberdade de escolha da mulher ${ }^{373}$.

Como podemos perceber, há uma relação muito próxima da autonomia reprodutiva com a dignidade da pessoa humana ${ }^{374}$ e os direitos è liberdade e privacidade ${ }^{375}$.

\footnotetext{
${ }^{371}$ Explicam Piovesan e Gonçalves que as teorias feministas de gênero se aprofundaram na década de 90 com a publicação de Judith Butler da obra: "Gênero: feminismo e subversão da identidade", com a reformulação de uma política não tradicional, orientada pela nova realidade social, refletindo na esfera do Direito. PIOVESAN, Flávia; GONÇALVES, Tamara Amoroso. Gênero no Supremo Tribunal Federal. In: SARMENTO, Daniel e SARLET, Ingo Wolfgang (coords). Direitos Fundamentais no Supremo Tribunal Federal: Balanço e Crítica. p. 367-374. Daniel Sarmento lembra que os direitos reprodutivos também dizem respeito aos homens, mas "as questões de saúde reprodutiva são muito mais críticas para o gênero feminino". SARMENTO, Daniel. Legalização do Aborto e Constituição. In: SARMENTO, Daniel; PIOVESAN, Flávia (coordenadores). Nos Limites da Vida. Rio de Janeiro: Lúmen Júris, 2006, p. 39.

372 Afirma Carl Sagan que "as proibições legislativas sobre o aborto despertam a suspeita de que sua real intenção é controlar a indepedência e a sexualidade das mulheres. Por que os legisladores teriam algum direito de dizer às mulheres o que fazer com os seus corpos? Ser privado da liberdade de reprodução é humilhante. As mulheres já estão fartas de receber ordens." SAGAN, Carl. Bilhões e bilhões: reflexões sobre vida e morte na virada do milênio. Tradução Rosaura Eichemberg. São Paulo: Companhia das Letras, 1998, p. 183. Daniel Sarmento critica o Código Penal brasileiro entendendo que no começo dos anos 40, a sociedade era machista e o "momento político autoritário", daí o desrespeito pela liberdade. SARMENTO, Daniel. Legalização do Aborto e Constituição. In: SARMENTO, Daniel; PIOVESAN, Flávia (coordenadores). Nos Limites da Vida. Rio de Janeiro: Lúmen Júris, 2006, p. 45.

${ }^{373}$ Carl Sagan expõe que há dois aspectos nesse debate: pró-vida e pró-escolha. No primeiro caso, há um dever moral de proteção desde a concepção, pois há vida e o aborto equivaleria a um homicídio. No segundo, o Estado não tem o direito de intervir na decisão, que caberia somente à mulher. SAGAN, Carl. Bilhões e bilhões: reflexões sobre vida e morte na virada do milênio. Tradução Rosaura Eichemberg. São Paulo: Companhia das Letras, 1998, p. 181. Ainda nessa esteira, Steinbock entende que existe uma diferença entre a obrigação moral para com o feto no caso de uma mulher que aborta e de outra que não aborta, de forma que nesse último, os efeitos de seu comportamento afetarão não apenas o feto, mas também a futura criança: "In my view, this ignores an important difference between the behaviour of a pregnant woman who is going to term and the behaviour of a pregnant woman who aborts her pregnancy. If a woman does not abort, her conduct during pregnancy may have adverse effects not simply on the fetus, but on the future child. Whatever the status of the fetus, children have interests and rights, including the fundamental moral and legal right not to be injured". STEINBOCK, Bonnie. Mother-fetus conflict. In: A Companion to Bioethics. KUHSE, Helga. SINGER, Peter (Blackwell Companion to Philosophy). Massachusetts, EUA. Blackwell Publishing, 1998, p. 136-137, especialmente, p. 137.

${ }^{374}$ Como vimos no capítulo 3 da primeira parte deste trabalho.
} 
A respeito dessa aproximação, Daniel Sarmento afirma que a decisão de engravidar, para a mulher, traz consequências durante e após a gestação ${ }^{376}$, razão pela qual, porque o feto é gerado dentro do corpo da mulher, recairíamos na esfera do direito à privacidade - capaz de "excluir intervenções heterônomas sobre o corpo do seu titular","377, uma vez que o "reconhecimento da dignidade da pessoa humana pressupõe que se respeite a esfera de autodeterminação de cada mulher ou homem,378, devendo cada um decidir sobre suas próprias vidas, sem a intervenção do Estado ou terceiros ${ }^{379}$. Assim, deveria existir um poder de a mulher decidir livremente sobre seu próprio corpo ${ }^{380}$ e, consequentemente, ter autonomia de decidir sobre sua própria vida ${ }^{381}$.

Nesta linha, vemos que, para Luísa Neto, os direitos reprodutivos e sexuais da mulher estão na esfera da liberdade individual ${ }^{382}$. A autora ainda ressalta a necessidade de se compreender o que seria "nosso próprio corpo", trazendo como exemplo ilustrativo da importância o caso de Janel Daoud, preso na penitenciária de Avignon: Janel cortou a falange superior do seu dedo auricular direito para chamar atenção das autoridades para o seu caso, mas a polícia confiscou-a, entendendo tratar-se de "objecto susceptível de confisco pelas autoridades penitenciárias" ${ }^{383}$.

Também neste sentido, vale ainda mencionar um interessante argumento utilizado pelos defensores do aborto, introduzido por Judith Jarvis Thomson, e comentado por Peter Singer: Um dia, um cidadão acorda no hospital, ligado a um violinista famoso, com grave problema renal, inconsciente, e descobre que foi sequestrado por uma sociedade de amantes

375 Como ensina Daniel Sarmento. SARMENTO, Daniel. Legalização do Aborto e Constituição. In: SARMENTO, Daniel; PIOVESAN, Flávia (coordenadores). Nos Limites da Vida. Rio de Janeiro: Lúmen Júris, 2006, p. 43-44.

${ }^{376}$ Nesse diapasão, Luísa Neto reconhece que a gestante tem uma "participação mais intensa no processo de filiação, o que lhe deve dar um direito prevalecente, em caso de conflito com a vontade do homem". NETO, Luísa. O direito fundamental à disposição do próprio corpo (a relevância da vontade na configuração do seu regime). Coimbra: Coimbra Editora, 2004, p. 569.

377 Especialmente a de manter uma gestação até o final: "Se o direito à privacidade envolve o poder de excluir intervenções heterônomas sobre o corpo de alguém, como a imposição à gestante de que mantenha uma gravidez, por nove meses, contra a vontade”. SARMENTO, Daniel. Legalização do Aborto e Constituição. In: SARMENTO, Daniel; PIOVESAN, Flávia (coordenadores). Nos Limites da Vida. Rio de Janeiro: Lúmen Júris, 2006, p. 44.

${ }^{378}$ SARMENTO, Daniel. Legalização do Aborto e Constituição. In: SARMENTO, Daniel; PIOVESAN, Flávia (coordenadores). Nos Limites da Vida. Rio de Janeiro: Lúmen Júris, 2006, p. 43.

${ }^{379}$ SARMENTO, Daniel. Legalização do Aborto e Constituição. In: SARMENTO, Daniel; PIOVESAN, Flávia (coordenadores). Nos Limites da Vida. Rio de Janeiro: Lúmen Júris, 2006, p. 43.

${ }^{380}$ NETO, Luísa. O direito fundamental à disposição do próprio corpo (a relevância da vontade na configuração do seu regime). Coimbra: Coimbra Editora, 2004, p. 461.

381 Nesse mesmo sentido. SARMENTO, Daniel. Legalização do Aborto e Constituição. In: SARMENTO, Daniel; PIOVESAN, Flávia (coordenadores). Nos Limites da Vida. Rio de Janeiro: Lúmen Júris, 2006, p. 44.

382 NETO, Luísa. O direito fundamental à disposição do próprio corpo (a relevância da vontade na configuração do seu regime). Coimbra: Coimbra Editora, 2004, p. 461.

383 NETO, Luísa. O direito fundamental à disposição do próprio corpo (a relevância da vontade na configuração do seu regime). Coimbra: Coimbra Editora, 2004, p. 423. 
da música porque é a única pessoa no mundo com o mesmo tipo sanguíneo do músico. Seria possível desligar-se do músico - mas ele morreria. Por outro lado, permanecendo ligado ao músico por apenas nove meses, o músico estaria recuperado e sobreviveria. Explica Singer que, neste exemplo, não se pretendeu negar a inocência do músico, e sequer que ele tenha um direito à vida, mas demonstrar que esse direito à vida do músico não implica o direito de usar o corpo de outrem. Por analogia, Thomson e Singer destacam que desligar-se do músico corresponderia a abortar um feto não viável, e que, se concordássemos com Thompson que não existe uma "obrigação moral" do cidadão de permanecer ligado ao músico por nove meses para que ele possa sobreviver, igualmente não haveria uma obrigação moral de se levar ao fim uma gravidez, independentemente de sua viabilidade ou não ${ }^{384}$.

Ainda no sentido de traçar uma aproximação entre os direitos, Flávia Piovesan afirma que o conceito de direitos sexuais e reprodutivos versam sobre dois aspectos ${ }^{385}:$ i) liberdade e autodeterminação individual, e ii) a saúde sexual e reprodutiva garantida por políticas públicas. O primeiro corresponderia ao livre exercício da sexualidade e reprodução humana, respeitando a privacidade e intimidade do indivíduo, livre da intervenção do Estado ${ }^{386}$, e o segundo corresponderia ao direito do indivíduo de lhe ser assegurado o "acesso a informações, a meios e recursos seguros, disponíveis e acessíveis” ${ }^{\text {387, }}$, com a necessária intervenção estatal $^{388}$.

Neste sentido, Luísa Neto afirma ainda que o próprio corpo humano pode ser entendido como "enquadramento condicionante ao direito", reconhecido como princípio inviolável ${ }^{389}$, observando a capacidade de o indivíduo se "autoregular". 390 Portanto, o

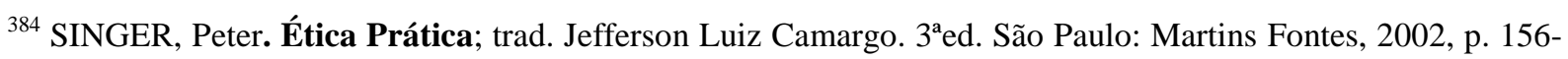
159.

385 PIOVESAN, Flávia. Direitos Sexuais e Reprodutivos: Aborto Inseguro como Violação aos Direitos Humanos. In: SARMENTO, Daniel; PIOVESAN, Flávia (coordenadores). Nos Limites da Vida. Rio de Janeiro: Lúmen Júris, 2006, p. 55.

${ }^{386}$ PIOVESAN, Flávia. Direitos Sexuais e Reprodutivos: Aborto Inseguro como Violação aos Direitos Humanos. In: SARMENTO, Daniel; PIOVESAN, Flávia (coordenadores). Nos Limites da Vida. Rio de Janeiro: Lúmen Júris, 2006, p. 55.

387 PIOVESAN, Flávia. Direitos Sexuais e Reprodutivos: Aborto Inseguro como Violação aos Direitos Humanos. In: SARMENTO, Daniel; PIOVESAN, Flávia (coordenadores). Nos Limites da Vida. Rio de Janeiro: Lúmen Júris, 2006, p. 55.

388 PIOVESAN, Flávia. Direitos Sexuais e Reprodutivos: Aborto Inseguro como Violação aos Direitos Humanos. In: SARMENTO, Daniel; PIOVESAN, Flávia (coordenadores). Nos Limites da Vida. Rio de Janeiro: Lúmen Júris, 2006, p. 55.

${ }^{389}$ NETO, Luísa. O direito fundamental à disposição do próprio corpo (a relevância da vontade na configuração do seu regime). Coimbra: Coimbra Editora, 2004, p. 421 e 445. A autora excetua os casos de doação de órgãos que não podem constituir objeto de direito patrimonial e casos de necessidade terapêutica. NETO, Luísa. O direito fundamental à disposição do próprio corpo (a relevância da vontade na configuração do seu regime). Coimbra: Coimbra Editora, 2004, p. 445.

${ }^{390}$ NETO, Luísa. O direito fundamental à disposição do próprio corpo (a relevância da vontade na configuração do seu regime). Coimbra: Coimbra Editora, 2004, p. 447.
} 
indivíduo teria direito de dispor sobre ${ }^{391}$ seu próprio corpo ${ }^{392}$, desde que não violasse sua integridade física ${ }^{393}$ e não fosse contrário à lei ou aos bons costumes ${ }^{394}$. Explica Neto que o direito de dispor sobre o próprio corpo ${ }^{395}$ estaria vinculado à integridade física, que "vai além da existência" ${ }^{396}$, sendo capaz de atingir o bem da vida ${ }^{397}$. Assim, o corpo humano estaria protegido, pois se confundiria com a própria pessoa ${ }^{398}$.

Maria Helena Diniz, por sua vez, entende que somente o planejamento familiar responsável é um direito reprodutivo 399 . Mas, para a autora, não se trata de "uma liberdade procriadora exercida de qualquer maneira, mas de uma liberdade responsável" ${ }^{400}$. Para Diniz, os direitos reprodutivos não são absolutos ${ }^{401} \mathrm{e}$, portanto, seria necessário conciliar a "liberdade para criar a vida, mas não para destrui-la",402.

${ }^{391}$ E não direito de dispor $\underline{\text { do }}$ próprio corpo. NETO, Luísa. O direito fundamental à disposição do próprio corpo (a relevância da vontade na configuração do seu regime). Coimbra: Coimbra Editora, 2004, p. 423.

${ }^{392} \mathrm{Em}$ tese, poderia recusar determinado tratamento médico ou poderia por fim à própria vida. NETO, Luísa. O direito fundamental à disposição do próprio corpo (a relevância da vontade na configuração do seu regime). Coimbra: Coimbra Editora, 2004, p. 454-455.

${ }^{393}$ Luísa Neto apresenta possibilidade de proibir a disposição de um indivíduo ao próprio corpo. Para a autora, é necessário compreender o conceito dessa proibição a partir de dois aspectos: i) direito subjetivo - facultado ao indivíduo o exercício e defesa; ii) faculdade de dispor - limitado pelo poder de disposição sobre direitos alheios. NETO, Luísa. O direito fundamental à disposição do próprio corpo (a relevância da vontade na configuração do seu regime). Coimbra: Coimbra Editora, 2004, p. 455-456. [N.R.] Vale dizer que, no caso da manutenção de uma gravidez de feto anencéfalo, poderia se falar em violação do direito à integridade física e moral da mulher.

${ }^{394}$ Para Luísa Neto, a ordem pública pode ser um limite ou fundamento para dispor sobre o próprio corpo. NETO, Luísa. O direito fundamental à disposição do próprio corpo (a relevância da vontade na configuração do seu regime). Coimbra: Coimbra Editora, 2004, p. 475. Ensina ainda a autora que a ordem pública e os bons costumes têm papeis similares, vez que há bens jurídicos irrenunciáveis. NETO, Luísa. O direito fundamental à disposição do próprio corpo (a relevância da vontade na configuração do seu regime). Coimbra: Coimbra Editora, 2004, p. 478.

${ }^{395}$ Para Luísa Neto, poderiam ser extraídas da doutrina, ainda, duas facetas: o direito do indíviduo com relação ao seu corpo e o direito à proteção. No primeiro caso, o direito estaria ligado ao aspecto patrimonial e, no segundo, aplicado aos direitos de personalidade. NETO, Luísa. $\mathbf{O}$ direito fundamental à disposição do próprio corpo (a relevância da vontade na configuração do seu regime). Coimbra: Coimbra Editora, 2004, p. 439. Atualmente, busca-se esvaziar a ideia de que o corpo humano tenha um valor meramente patrimonial, apesar de a autora não o considerar um bem "individual, inalienável e intangível". NETO, Luísa. O direito fundamental à disposição do próprio corpo (a relevância da vontade na configuração do seu regime). Coimbra: Coimbra Editora, 2004, p. 440.

${ }^{396} \mathrm{O}$ bem integridade física que, para a autora, consiste na incolumidade física, atinge o bem vida. NETO, Luísa. O direito fundamental à disposição do próprio corpo (a relevância da vontade na configuração do seu regime). Coimbra: Coimbra Editora, 2004, p. 422.

397 Nesse sentido, Daniel Sarmento. SARMENTO, Daniel. Legalização do Aborto e Constituição. In: SARMENTO, Daniel; PIOVESAN, Flávia (coordenadores). Nos Limites da Vida. Rio de Janeiro: Lúmen Júris, 2006, p. 37.

${ }^{398}$ A autora expõe a visão de René Dekkers que entende que tudo é coisa, exceto o ser humano. NETO, Luísa. O direito fundamental à disposição do próprio corpo (a relevância da vontade na configuração do seu regime). Coimbra: Coimbra Editora, 2004, p. 426. Ler mais a respeito. NETO, Luísa. O direito fundamental à disposição do próprio corpo (a relevância da vontade na configuração do seu regime). Coimbra: Coimbra Editora, 2004, p. 421-432.

${ }^{399}$ DINIZ, Maria Helena. O Estado Atual do Biodireito. São Paulo: Saraiva, 2009, p. 140.

${ }^{400}$ DINIZ, Maria Helena. O Estado Atual do Biodireito. São Paulo: Saraiva, 2009, p. 140.

${ }^{401}$ Para a autora, os direitos dos filhos e o bem comum determinam os limites do direito reprodutivo. DINIZ, Maria Helena. O Estado Atual do Biodireito. São Paulo: Saraiva, 2009, p. 140.

${ }^{402}$ DINIZ, Maria Helena. O Estado Atual do Biodireito. São Paulo: Saraiva, 2009, p. 140. 
Todavia, Flávia Piovesan e Wilson Pirotta ensinam que direitos reprodutivos "correspondem ao conjunto de direitos básicos relacionados ao livre exercício da sexualidade e da reprodução humana" 403 . Além da "liberdade" de procriar, conforme os autores, a igualdade "de fato" e "de direito" entre os gêneros só seria garantida com o "reconhecimento e o exercício" 404 , e que o conceito dos direitos reprodutivos abrangeria a reprodução e a sexualidade humanas, entendendo-os como direitos humanos ${ }^{405}$, incluindo também o direito à saúde sexual ${ }^{406}$. Assim, para Piovesan e Pirotta, os direitos reprodutivos abrangem o direito de decidir sobre a reprodução, sobre o número de filhos e intervalo entre as gestações, e o direito a ter acesso à informação e à saúde reprodutiva ${ }^{407}$, compreendendo o "direito a ter controle sobre seu próprio corpo" 408 , e o direito à privacidade, dentre outros ${ }^{409}$.

Desta forma, aproximar os direitos reprodutivos e sexuais da mulher da dignidade da pessoa humana, da liberdade e da autonomia individual, possibilitando a ela a disposição sobre seu próprio corpo, também é uma afirmação pela igualdade de gênero.

Daniel Sarmento, insere neste cenário a necessidade ao respeito pela igualdade de gênero - especialmente dos grupos vulneráveis, dentre os quais, as mulheres - que, para ele, não se limita "à isonomia formal" ${ }^{410}$. Daniel Sarmento admite que a criminalização do aborto gera um "impacto desproporcional sobre as mulheres" ${ }^{411}$, pois aos homens não se exige "sacrifício comparável"

\footnotetext{
${ }^{403}$ PIOVESAN, Flávia e PIROTTA, Wilson Ricardo Buquetti. Temas de Direitos Humanos. $4^{\text {a }}$. ed. São Paulo: Saraiva, 2010, p. 308.

${ }^{404}$ PIOVESAN, Flávia e PIROTTA, Wilson Ricardo Buquetti. Temas de Direitos Humanos. $4^{\mathrm{a}}$. ed. São Paulo: Saraiva, 2010, p. 308.

${ }^{405}$ PIOVESAN, Flávia e PIROTTA, Wilson Ricardo Buquetti. Temas de Direitos Humanos. $4^{a}$. ed. São Paulo: Saraiva, 2010, p. 308-310. Conforme Conferência Internacional do Cairo sobre População e Desenvolvimento do Cairo de 1994. Ler mais a respeito, PIOVESAN, Flávia e PIROTTA, Wilson Ricardo Buquetti. Temas de Direitos Humanos. 4ª ed. São Paulo: Saraiva, 2010, p. 308-309.Vide também PIOVESAN, Flávia. Direitos Humanos e o Direito Constitucional Internacional. 10a . ed. rev., ampl. e atual. São Paulo: Saraiva, 2009, p. 201. Nesse sentido, DINIZ, Maria Helena. O Estado Atual do Biodireito. São Paulo: Saraiva, 2009, p. 139.

${ }^{406}$ Conforme Declaração de Beijing resultante da $4^{\mathrm{a}}$. Conferência Mundial sobre a Mulher. Vide mais a respeito. PIOVESAN, Flávia e PIROTTA, Wilson Ricardo Buquetti. Temas de Direitos Humanos. $4^{a}$. ed. São Paulo: Saraiva, 2010, p. 312-313. Destaca Maria Helena Diniz que a declaração de Beijing garante serviços médicos seguros e higiênicos no caso de aborto legal. DINIZ, Maria Helena. O Estado Atual do Biodireito. São Paulo: Saraiva, 2009, p. 139.

${ }^{407}$ PIOVESAN, Flávia e PIROTTA, Wilson Ricardo Buquetti. Temas de Direitos Humanos. $4^{\mathrm{a}}$. ed. São Paulo: Saraiva, 2010, p. 313-314.

${ }^{408}$ PIOVESAN, Flávia e PIROTTA, Wilson Ricardo Buquetti. Temas de Direitos Humanos. ${ }^{a}$. ed. São Paulo: Saraiva, 2010, p. 314.

${ }^{409}$ Nesse sentido, Lei 9029 de 13 de abril de 1995. BRASIL. Lei n 9.029, de 13 de abril de 1995. Dispõe sobre a proibição da exigência de atestados de gravidez e esterilização, e outras práticas discriminatórias, para efeitos admissionais ou de permanência da relação jurídica de trabalho, e dá outras providências.

${ }^{410}$ SARMENTO, Daniel. Legalização do Aborto e Constituição. In: SARMENTO, Daniel; PIOVESAN, Flávia (coordenadores). Nos Limites da Vida. Rio de Janeiro: Lúmen Júris, 2006, p. 47-48.

${ }^{411} \mathrm{O}$ autor explica que a jurisprudência adotou o disparage impact, isto é, o "reconhecimento da inconstitucionalidade de normas que, aparentemente regulares, causem um ônus desproporcional para determinados grupos em situação de inferioridade", destacando o caso Griggs v. Duke Power de 1971.
} 
Em razão desses conflitos, Flávia Piovesan e Wilson Pirotta destacam a importância de uma "mudança de paradigmas" direitos conquistados no plano internacional ${ }^{414}$ também no âmbito interno. Para os autores, o

SARMENTO, Daniel. Legalização do Aborto e Constituição. In: SARMENTO, Daniel; PIOVESAN, Flávia (coordenadores). Nos Limites da Vida. Rio de Janeiro: Lúmen Júris, 2006, p. 46 e 48.

${ }^{412}$ SARMENTO, Daniel. Legalização do Aborto e Constituição. In: SARMENTO, Daniel; PIOVESAN, Flávia (coordenadores). Nos Limites da Vida. Rio de Janeiro: Lúmen Júris, 2006, p. 48.

${ }^{413}$ PIOVESAN, Flávia e PIROTTA, Wilson Ricardo Buquetti. Temas de Direitos Humanos. 4a ed. São Paulo: Saraiva, 2010, p. 301. A fim de ilustrar a necessidade de uma mudança de paradigma, segue o relatório de 2005 sobre o Brasil: "HUMAN RIGHTS COMMITTEE CONSIDERATION OF REPORTS SUBMITTED BY STATES PARTIES UNDER ARTICLE 40 OF THE COVENANT Second periodic report BRAZIL* [15 November 2004] GENERAL CCPR/C/BRA/2004/2 11 April 2005 Original: ENGLISH 42. Another issue that warrants consideration involves reproductive rights. The current government has committed itself to undertake a review of the repressive legislation governing abortion so that the principle of free choice in the exercise of individual sexuality is fully respected. It is not the purview of the State to interfere in this area of individual autonomy, although it does have a duty to offer all necessary information and assure access to the various methods of contraception in order to ensure people are provided with the ideal conditions to prevent unwanted pregnancies. The 1988 Federal Constitution recognized the universality of the right to healthcare and mandated CCPR/C/BRA/2004/2 Page 14 that the State provide services in this area at no charge. It also guarantees the right to family planning, thereby anticipating the recommendation of the World Conference on Population and Development held in Cairo. The right to family planning was officially ordered by Federal Law, in 1898, with the introduction of the principle of full healthcare for women in all stages of their lives, assuring, in this way access to reversible contraceptive methods and recognizing the right to tubal ligations and vasectomies. The same legislation set out guarantees against abuses and imposed or manipulative sterilization practices. 43. However, the autonomy assured by the Law with regard to a woman's decision to not bear children has yet to be fully implemented. Difficulties in access to contraception and the small number of services available to assist women who have been the victims of sexual violence play a role in the problem of unwanted pregnancies and back-alley abortions, which, in turn, predispose women to maternal death. Abortion is currently the fifth leading cause of maternal death in Brazil. 44. The Brazilian Penal Code dates to 1940. Despite the reforms that have been introduced in the Code, some discriminatory clauses persist, such as subsection VII of article 107, which provides for waiving punishment when the sexual aggressor is married to the victim. That same legislation, meanwhile, mandates stiff penalties for abortion, except in cases of imminent risk to the mother and pregnancy induced by rape. 45. Brazilian legislation has not yet been adjusted to conform to the recommendation of the Plan of Action of the 1995 World Conference on Women, held in Beijing, in which abortion was defined as a public health issue. The Brazilian government is hopeful that the National Congress will consider one of the draft bills now in Congress aimed at correcting the repressive manner in which abortion is today addressed. 46. Through the Special Secretariat for Women's Pol icies and the Ministry of Health, the Brazilian government has carried out several actions to reduce morbimortality caused by abortion. A specific protocol was introduced requiring notification in the event of maternal death; reviving the National Commission against Maternal Mortality (Comissão Nacional Contra a Mortalidade Materna); implementing prevention Committees in all state capitals and municipalities with more than 100,000 residents; establishing the "Dial Women's Health" hotline designed to provide access to information on existing services; and mobilizing the country for a debate on sexual and reproductive rights with an emphasis on family planning and conscious and involved paternity". Disponível em:

bin/texis/vtx/refworld/rwmain?page=search\&amp;docid=43f2ff6a0\&amp;skip=0\&

$<$ http://www.unhcr.org/cgiamp;query=abortion>. Acesso em: 10 nov. 2011.

${ }^{414}$ Interessante análise contida no World Report e Amnesty International Annual Report, ambos de 2011 referente ao direito reprodutivo no Brasil. "Reproductive Health Rights. Raids on family planning clinics and aggressive prosecution of abortion limited women's access to reproductive health services in 2010. In May a bill to prioritize the human rights of a fertilized ovum over those of the pregnant woman carrying it was voted favorably out of the Family and Social Security Commission of the Brazilian House of Representatives. The bill is still pending at this writing". Disponível em: <http://www.unhcr.org/cgibin/texis/vtx/refworld/rwmain?page=search\&amp;docid=4d3e80171a\&amp;skip=0\&amp;query=abortion>.

Acesso em: 10 nov. 2011. "Amnesty International Annual Report 2011 - Brazil. Head of state and government: Luiz Inácio Lula da Silva; Death penalty: abolitionist for ordinary crimes;Population: 195.4 million ;Life expectancy: 72.9 years;Under-5 mortality (m/f): 33/25 per 1,000;Adult literacy: 90 per cent;13 May 2011; President Lula approved a modified version of the Third National Human Rights Plan in May, amid criticisms 
direito constitucional brasileiro protege o direito reprodutivo ao assegurar o princípio da igualdade e da inviolabilidade da intimidade e da vida privada ${ }^{415}$, mas é o parágrafo $7^{0416}$, do artigo 226 da Constituição Federal que lhe atribui caráter constitucional, garantindo o disposto nos instrumentos internacionais de direitos humanos ${ }^{417}$.

Em seguida, vamos compreender como o aborto é tratado no Brasil, para depois, estudarmos a situação do aborto do feto anencéfalo, especificamente.

that references to the decriminalization of abortion, mediation in agrarian conflicts and sections relating to crimes committed during the military regime (1964-85) had been removed. Vale a pena comparar com o contéudo dos relatórios em 2003: Reproductive Rights In Brazil, abortion is legal only when performed by a medical doctor in order to save the life of the pregnant woman or when the pregnancy is the result of rape. Criminal investigations into women's health clinics in Mato Grosso do Sul, Sao Paulo, and Rio Grande do Sul have raised serious privacy concerns. In an ongoing 2007 criminal case from Mato Grosso do Sul, for months private medical records of thousands of women were reportedly made accessible to members of the public upon request to judicial authorities". Disponível em: <http://www.unhcr.org/cgiin/texis/vtx/refworld/rwmain?page=search\&amp;docid=49705faa78\&amp;skip=0\&amp;query=abortion>.

Acesso em: 10 nov. 2011. "Transparency International ranked Ireland 23rd on its 2002 Corruption Perceptions Index, better than only France, Portugal, and Italy among EU-member states. Discrimination against women in the workplace is unlawful, but inequalities persist regarding pay and promotions in both the public and private sectors. Abortion is legal only when a woman's life is in danger; an estimated 6,500 women travel to Britain annually to obtain abortions. Distr. GENERAL E/C.12/1/Add.87 26 June 2003 COMMITTEE ON ECONOMIC, SOCIAL AND CULTURAL RIGHTS Thirtieth session 5-23 May 2003 27. The Committee notes with concern the high rate of maternal mortality from illegal abortions, particularly in the northern regions where women have insufficient access to health care facilities. The Committee is also concerned about the persistence of forced sterilization. 28. The Committee is concerned that some articles of the Penal Code discriminate against women. In particular, it is concerned that article 215 of the Code requires the victim of a $\mathrm{m}$ 51. The Committee requests the State party to undertake legislative and other measures, including a review of its present legislation, to protect women from the effects of clandestine and unsafe abortion and to ensure that women do not resort to such harmful procedures. The Committee requests the State party to provide in its next periodic report detailed information, based on comparative data, about maternal mortality and abortion in Brazil". Disponível em: <http://www.unhcr.org/cgi-bin/texis/vtx/refworld/rwmain?page=search\&amp;docid=473c5431c\&amp;skip=0\& amp;query=abortion>. Acesso em: 10 nov. 2011.

${ }^{415}$ Nos termos dos artigos $5^{\circ}$, I e X, da CF. Os autores ainda ensinam que o título VIII da Constituição Federal de 1988 assegura os direitos reprodutivos ao garantir o direito à saúde e ao planejamento familiar, reconhecendo a igualdade de gêneros, nos termos dos artigo 226, parágrafo $5^{\circ}$. PIOVESAN, Flávia e PIROTTA, Wilson Ricardo Buquetti. Temas de Direitos Humanos. $4^{\text {a }}$. ed. São Paulo: Saraiva, 2010, p. 315. Alexandre de Moraes explica que o conceito de intimidade e de vida privada são diferentes, mas interligados. O primeiro estaria voltado às "relações subjetivas e de trato íntimo da pessoa humana, suas relações familiares e de amizade" e o segundo, "envolve todos os relacionamentos da pessoa, inclusive os objetivos". MORAES, Alexandre de. Direitos Humanos Fundamentais: teoria geral, comentários aos arts. $1^{\circ}$ a $5^{\circ}$ da Constituição da República Federativa do Brasil, doutrina e jurisprudência. $6^{\text {a }}$. ed. São Paulo: Atlas, 2005, p. 138.

${ }^{416}$ In verbis: “Art. 226. A família, base da sociedade, tem especial proteção do Estado.[...]§ $7^{\circ}$ - Fundado nos princípios da dignidade da pessoa humana e da paternidade responsável, o planejamento familiar é livre decisão do casal, competindo ao Estado propiciar recursos educacionais e científicos para o exercício desse direito, vedada qualquer forma coercitiva por parte de instituições oficiais ou privadas. BRASIL. Constituição (1988). Constituição da República Federativa do Brasil. Brasília, DF: Senado, 1988.

${ }^{417}$ PIOVESAN, Flávia e PIROTTA, Wilson Ricardo Buquetti. Temas de Direitos Humanos. 4a ed. São Paulo: Saraiva, 2010, p. 317-318. Em sentido contrário, Diniz afirma que tal dispositivo constitucional não permite o aborto, mas "adotar medidas preventivas de gravidez" e que o planejamento familiar seria uma medida eficiente para diminuir os casos de aborto. DINIZ, Maria Helena. O Estado Atual do Biodireito. São Paulo: Saraiva, 2009, p. 142. 


\section{ANÁLISE DO ABORTO NO BRASIL}

Depois do estudo sobre o âmbito de proteção da vida e suas interpretações, bem como dos limites ao direito à vida em razão de outros princípios e direitos, vamos analisar o direito à vida, no caso específico do aborto, observando como é tratado pela legislação brasileira, antes de adentrarmos as principais teorias que podem ser aplicadas ao caso de aborto em decorrência de anencefalia, começando com o estudo de algumas terminologias e conceitos importantes sobre o tema.

\subsection{TERMINOLOGIAS, CONCEITOS E CLASSIFICAÇÕES}

O aborto corresponderia à "interrupção da gravidez ${ }^{418}$ antes de seu termo normal, seja ela espontânea ou provocada, tenha havido ou não expulsão do feto destruído"419 .

Explica Maria Helena Diniz que o critério médico da cronologia ${ }^{420}$ comumente adotado para diferenciar o aborto de um parto prematuro, não se aplica na esfera jurídica, "pois bastará o aniquilamento do feto em qualquer momento anterior ao fim da gestação, sem que se leve em consideração a questão de sua viabilidade" 421 para caracterizá-lo. Significa dizer, então, que, juridicamente, o aborto é a interrupção da gravidez a qualquer tempo ${ }^{422}$.

Maria Helena Diniz traz inúmeras classificações sobre o aborto. Quanto ao objeto, o aborto poderia ser ovular, embrionário ou fetal ${ }^{423}$. Ovular é o aborto ocorrido até a $8^{\text {a }}$ semana

\footnotetext{
${ }^{418}$ Para Celso Delmanto "o aborto é a interrupção do processo da gravidez, com a morte do feto". DELMANTO, Celso. Código Penal Comentado. $2^{\mathrm{a}}$ ed. ampl. e atualizada. Rio de Janeiro: Renovar, 1988, p. 239.

${ }^{419}$ DINIZ, Maria Helena. O Estado Atual do Biodireito. São Paulo: Saraiva, 2009, p. 30.

${ }^{420} \mathrm{Na}$ doutrina médica citada pela autora, o parto prematuro ocorreria após o sexto mês de gravidez, enquanto que o aborto ocorreria nos primeiros seis meses de gravidez. DINIZ, Maria Helena. O Estado Atual do Biodireito. São Paulo: Saraiva, 2009, p. 30.

${ }^{421}$ DINIZ, Maria Helena. O Estado Atual do Biodireito. São Paulo: Saraiva, 2009, p. 30.

${ }^{422}$ Vale dizer que é preciso fazer uma distinção entre o aborto e o infanticídio, neste último, o bem tutelado é a vida humana do filho durante ou logo após o parto sob influência do estado puerperal. O infanticídio não ocorre antes do parto, porque neste caso seria aborto; nem depois da ocisão logo após o parto, pois, nesse caso, seria verificado o crime de homicídio, como ensina Luis Regis Prado. PRADO, Luiz Regis. Curso de Direito Penal Brasileiro, volume 2: parte especial, arts 121 a 249, $8^{\text {a }}$ ed. rev. atual. e ampl. São Paulo: Editora Revista dos Tribunais, 2010, p. 76-77.

${ }^{423}$ DINIZ, Maria Helena. O Estado Atual do Biodireito. São Paulo: Saraiva, 2009, p. 31.
} 
de gestação ${ }^{424}$. O aborto embrionário se dá se for praticado até a $15^{\mathrm{a}}$ semana ou terceiro mês de gestação ${ }^{425}$. O aborto fetal é aquele que ocorre a partir do terceiro mês de gravidez ${ }^{426}$.

A autora ainda classifica o aborto quanto à causa, que pode ser natural ${ }^{427}$, em decorrência de doenças durante a gravidez, como diabetes entre outras, ou em razão de "defeitos estruturais do feto, embrião e ovo"428; o acidental, ocasional ou circunstancial ${ }^{429}$, provocado por "um agente externo", como, por exemplo, uma queda; e, por fim, o aborto provocado, que ocorre com a interrupção "deliberada da gestação", que, conforme ensina Maria Helena Diniz, "para atender a motivos terapêuticos, eugênicos, econômicos, morais, sociais, psicológicos etc" ${ }^{430}$.

O aborto provocado, que é o mais significativo para nosso estudo, subdivide-se em criminoso e legal. O primeiro tipo corresponde ao aborto ocorrido na forma vedada por lei, em qualquer fase da vida intrauterina, com ou sem a expulsão do "produto da concepção"431. Já o segundo abarca as situações em que o aborto ocorre com a autorização legal.

Maria Helena Diniz ainda classifica o aborto quanto ao elemento subjetivo ${ }^{432}$ : o aborto poderá ser "sofrido", quando não há o consentimento da gestante ${ }^{433}$; “consentido", quando há ${ }^{434}$; ou, ainda, "procurado", quando for praticado pela própria gestante ${ }^{435}$.

E, por fim, classifica a autora o aborto também conforme a sua finalidade, que pode ser terapêutico, sentimental, eugênico, econômico, estético e honoris causa ${ }^{436}$.

No terapêutico ${ }^{437}$ há duas modalidades: o aborto necessário ${ }^{438}$ - autorizado por lei e imprescindível para salvar a vida da mãe ${ }^{439}$; e o aborto para evitar enfermidade grave - nesta

\footnotetext{
${ }^{424}$ DINIZ, Maria Helena. O Estado Atual do Biodireito. São Paulo: Saraiva, 2009, p. 31.

${ }^{425}$ DINIZ, Maria Helena. O Estado Atual do Biodireito. São Paulo: Saraiva, 2009, p. 31.

${ }^{426}$ DINIZ, Maria Helena. O Estado Atual do Biodireito. São Paulo: Saraiva, 2009, p. 31.

${ }^{427}$ DINIZ, Maria Helena. O Estado Atual do Biodireito. São Paulo: Saraiva, 2009, p. 31.

${ }^{428}$ DINIZ, Maria Helena. O Estado Atual do Biodireito. São Paulo: Saraiva, 2009, p. 31.

${ }^{429}$ DINIZ, Maria Helena. O Estado Atual do Biodireito. São Paulo: Saraiva, 2009, p. 31.

${ }^{430}$ DINIZ, Maria Helena. O Estado Atual do Biodireito. São Paulo: Saraiva, 2009, p. 31.

${ }^{431}$ Explica ainda a autora que pode existir na forma culposa, dolosa e preterdolosa. A primeira ocorre se a interrupção não for intencional, mas houver negligência, imprudência ou imperícia do médico. Dolosa se houver intenção de destruir o feto ou, ainda, preterdolosa em que "o resultado culposo, advindo do aborto dolosamente provocado" resultar a morte ou lesão corporal de natureza grave ocasionados à gestante. DINIZ, Maria Helena. O Estado Atual do Biodireito. São Paulo: Saraiva, 2009, p. 33.

${ }_{432}$ DINIZ, Maria Helena. O Estado Atual do Biodireito. São Paulo: Saraiva, 2009, p. 32.

${ }^{433}$ DINIZ, Maria Helena. O Estado Atual do Biodireito. São Paulo: Saraiva, 2009, p. 32.

${ }^{434}$ DINIZ, Maria Helena. O Estado Atual do Biodireito. São Paulo: Saraiva, 2009, p. 32.

${ }^{435}$ DINIZ, Maria Helena. O Estado Atual do Biodireito. São Paulo: Saraiva, 2009, p. 32.

${ }^{436}$ DINIZ, Maria Helena. O Estado Atual do Biodireito. São Paulo: Saraiva, 2009, p. 32.

437 Guilherme de Souza Nucci explica que o aborto terapêutico é "uma hipótese específica do estado de necessidade. Entre dois bens que estão em conflito (vida da gestante e vida do feto ou embrião), o direito fez clara opção pela vida da mãe". NUCCI, Guilherme de Souza. Código Penal Comentado. 10ª ed. rev., atual e ampl. São Paulo: Editora Revista dos Tribunais, 2010, p. 633.
} 
hipótese, Maria Helena Diniz afirma que o aborto visa a impedir grave e iminente perigo à saúde da mãe ${ }^{440}$.

$\mathrm{O}$ aborto sentimental ${ }^{441}$ é aquele em que há autorização legal para abortar devido à gravidez ser decorrente de estupro ${ }^{442}$.

O aborto eugênico corresponde à "suspeita de que, provavelmente, o nascituro apresenta doenças congênitas, anomalias físico-mentais graves, como microcefalia, retinite pigmentosa, sífilis, mongolismo, epilepsia genuína, demência precoce, idiotia amaurótica etc" ${ }^{443}$. Para Maria Helena Diniz, o aborto eugênico serve para "aperfeiçoar a raça humana" 444 .

${ }^{438}$ Para Celso Delmanto, não deve haver outro meio de salvar a vida da gestante. DELMANTO, Celso. Código Penal Comentado. $2^{\mathrm{a}}$ ed. ampl. e atualizada. Rio de Janeiro: Renovar, 1988, p. 241. Para Guilherme de Souza Nucci é o aborto terapêutico, cf. [N.R] 436, acima.

${ }^{439}$ Neste caso, o médico pode praticar o aborto sem ou com a autorização da gestante, independentemente de autorização judicial ou policial. DINIZ, Maria Helena. O Estado Atual do Biodireito. São Paulo: Saraiva, 2009, p. 32 .

${ }^{440}$ Porém, permanece o delito penal. DINIZ, Maria Helena. O Estado Atual do Biodireito. São Paulo: Saraiva, 2009 , p. 32.

${ }^{441}$ Também denominado de ético ou humanitário. Para Celso Delmanto, não deve haver outro meio de salvar a vida da gestante. DELMANTO, Celso. Código Penal Comentado. $2^{\mathrm{a}}$ ed. ampl. e atualizada. Rio de Janeiro: Renovar, 1988, p. 241. Para Guilherme de Souza Nucci é o aborto humanitário ou piedoso "são dois valores fundamentais, mas é melhor preservar aquele já existente". NUCCI, Guilherme de Souza. Código Penal Comentado. $10^{a}$ ed. rev., atual e ampl. São Paulo: Editora Revista dos Tribunais, 2010, p.633.

${ }_{442}$ DINIZ, Maria Helena. O Estado Atual do Biodireito. São Paulo: Saraiva, 2009, p. 32.

${ }^{443}$ DINIZ, Maria Helena. O Estado Atual do Biodireito. São Paulo: Saraiva, 2009, p. 32. [N.R.] Vale dizer que o aborto eugênico pode ser considerado uma espécie, ou um exemplo, de eugenia. Explica Simon Hampton que originalmente o termo surge na metade do Século XX com o significado de "bem nascido", usado para designar pessoas de "boa linhagem" com uma conotação de saúde; mais para frente, com conotações políticas, passou a representar a opinião de que a teoria da evolução poderia ser usada para deteminar e controlar quem poderia e deveria se reproduzir. Para o autor, o nazismo, apropriou-se da Eugenia como estudo e prática da melhoria da raça humana através da reprodução seletiva controlada e o resultado foi o holocausto e outros terríveis abusos cometidos pela alemanha nazista. HAMPTON, Simon. Essencial Evolutionary Psychology. London: Sage, 2010, p. 20. Ruth Chadwick, no entanto nos lembra que "a alegação de que uma intervenção [genética] significaria eugenia de tempos em tempos é mencionada como se fosse um argumento definitivo contra a intervenção. Isso não pode ser adotado como premissa: o que exatamente é reprovável? Um aspecto é a implicação de que algumas vidas valem mais que outras. A tentativa de reduzir a incidência de problemas genéticos na população, é às vezes criticado sobre o fundamento de incorporar atitudes inapropriadas em relação às pessoas então vivas que sofrem de tais problemas. Outro é que eugenia representa interferência, aberta ou encoberta, com as liberdades individuais na área da reprodução [...] um outro aspecto problemático é o uso de técnicas de terapia genética para melhorias, ao invés de para curar doenças [...] as objeções às 'melhorias' ao invés de terapia não são claras, mas um ponto diz respeito à justiça social [...] o que é desejado e temido por alguns [...] é um livre mercado de genes [...] que poderia parecer abrir o caminho para reforçar diferenças entre os ricos e os pobres, permitindo aos ricos adquirirem genes melhores [...] alguns críticos adotam a perspectiva de que ao adotar a terapia germinativa nós perderíamos alguma coisa que é essencialmente humana. Não é sempre claro o que esta objeção significa. Ronald Dworkin em o Domínio da Vida examina a questão do que é sagrado. Ele argumenta que a noção do valor intrínseco da vida humana é bem difundido, mas que há diferentes interpretações de seu significado". CHADWICK, Ruth. In: A Companion to Bioethics. KUHSE, Helga; SINGER, Peter (Blackwell Companion to Philosophy). Massachusetts, EUA. Blackwell Publishing, 1998, p. 195-196, (tradução nossa).

${ }^{444}$ DINIZ, Maria Helena. O Estado Atual do Biodireito. São Paulo: Saraiva, 2009, p. 32. É vedada por lei, pois fere a dignidade humana especialmente porque coloca em risco a característica humana da heterogeneidade e porque, conforme Maria Helena Diniz, não há diagnóstico genético que garanta, com toda certeza, a 
O aborto econômico ocorre sob a alegação de que inexistem recursos suficientes para a manutenção do sustento da criança. Já o estético e o honoris causa correspondem, respectivamente, ao aborto praticado para não modificar o corpo da gestante e para preservar sua honra perante a sociedade ${ }^{445}$.

A partir dessas classificações, como poderíamos tratar o aborto do feto com anencefalia? Poderia ser considerado como aborto eugênico? Ou será um aborto terapêutico? É o que estudaremos mais adiante.

\subsection{LEGISLAÇÃO E DOUTRINA BRASILEIRA SOBRE ABORTO}

Após a análise do conceito e da exposição de classificações de aborto, é mister verificar como o Brasil regula a matéria.

$\mathrm{O}$ direito à vida é protegido como direito fundamental, ou seja, o artigo $5^{\circ}$ da Constituição Federal de 1988 tutela o direito à vida; mas outros dispositivos da Constituição Federal também o fazem - quando tutelam o direito à saúde (artigos 194 e 196), a proibição da pena de morte (artigo $5^{\circ}$, XLVII); e até mesmo quando garante o direto à vida da criança, do adolescente (artigo 227, caput, §1º II) e do idoso (artigo 230). A Constituição Federal tutela ainda o direito de subsistência $\left(\operatorname{artigo} 7^{\circ}\right.$ ) e a sadia qualidade de vida (artigo 225). A Constituição garante também a integridade física e psíquica do indivíduo ao vedar a prática de tortura e o tratamento degradante (artigo $5^{\circ}$, III).

No âmbito civil, o direito brasileiro protege o direito do nascituro desde a concepção (artigo $2^{\circ}$, Código Civil). A lei também estabelece parâmetros para a morte jurídica do indivíduo, considerada a partir da constatação de morte encefálica (Lei 9434 de 04 fev. 1997 alterada pela Lei 10211 de 23 mar. 2001).

$\mathrm{Na}$ esfera penal, a vida também é protegida, através do artigo 121 do Código Penal, que proíbe o homicídio. Destacamos, ainda, o artigo 123 do Código Penal, que trata do infanticídio; e os artigos 124 a 128, que tratam especificamente do aborto; além de tratados internacionais ratificados pelo Brasil e que ingressaram no ordenamento jurídico brasileiro visando à proteção do direito à vida.

transmissibilidade de deficiências físico-mentais. DINIZ, Maria Helena. O Estado Atual do Biodireito. São Paulo: Saraiva, 2009, p. 33.

${ }^{445}$ DINIZ, Maria Helena. O Estado Atual do Biodireito. São Paulo: Saraiva, 2009, p. 32. 
Dessa forma, por meio de normas constitucionais e infraconstitucionais, o ordenamento jurídico brasileiro dispõe sobre a tutela do direito à vida. A seguir, vamos, portanto, analisar as principais discussões no âmbito brasileiro acerca do tema.

\subsubsection{O aborto e a Constituição Federal}

A Constituição Federal de 1988 garante, nos termos do artigo $5^{\circ}$, caput, aos brasileiros e estrangeiros residentes no país, a inviolabilidade do direito à vida, dentre outros direitos.

Para Alexandre de Moraes, o direito à vida seria "o mais fundamental de todos os direitos, pois seu asseguramento impõe-se, já que se constitui em pré-requisito à existência e exercício de todos os demais direitos" 446 , cabendo ao estado brasileiro "assegurá-lo em sua dupla acepção, sendo a primeira relacionada ao direito de continuar vivo e a segunda de se ter a vida digna quanto à subsistência"447. Moraes afirma ainda que o direito à vida deve ser garantido levando-se em conta os princípios fundamentais elencados na Constituição Federal dentro de um "nível adequado com a condição humana"448.

Assim, admitindo-se a força normativa da Constituição Federal e o caráter vinculante dos princípios constitucionais, exige-se uma "releitura" de todos os institutos jurídicos à luz desses valores constitucionais, inclusive do direito à vida ${ }^{449}$.

Deste modo, Daniel Sarmento acredita que é na "constituição que deve ser buscado o norte para o equacionamento jurídico a ser conferido à questão da interrupção voluntária da gravidez no Brasil" ${ }^{450}$. Para tanto, o artigo $5^{\circ}$ da Constituição não pode ser interpretado sem levar em conta outros dispositivos constitucionais e legais, principalmente quando tratamos do aborto do feto anencéfalo, até mesmo porque, como vimos, o direito à vida não é absoluto.

\footnotetext{
${ }^{446}$ MORAES, Alexandre de. Direitos Humanos Fundamentais: teoria geral, comentários aos arts. $1^{\circ}$ a $5^{\circ}$ da Constituição Federal da República Federativa do Brasil, doutrina e jurisprudência. 6. ed. São Paulo:Atlas, 2005 (Coleção Temas Jurídicos:3), p. 80.

${ }^{447}$ MORAES, Alexandre de. Direitos Humanos Fundamentais: teoria geral, comentários aos arts. $1^{\circ}$ a $5^{\circ}$ da Constituição Federal da República Federativa do Brasil, doutrina e jurisprudência. 6. ed. São Paulo:Atlas, 2005 (Coleção Temas Jurídicos:3), p. 80.

${ }^{448}$ MORAES, Alexandre de. Direitos Humanos Fundamentais: teoria geral, comentários aos arts. $1^{\circ}$ a $5^{\circ}$ da Constituição Federal da República Federativa do Brasil, doutrina e jurisprudência. 6. ed. São Paulo:Atlas, 2005 (Coleção Temas Jurídicos:3), p. 80.

${ }^{449}$ SARMENTO, Daniel. Legalização do Aborto e constituição. In: SARMENTO, Daniel; PIOVESAN, Flávia (coordenadores). Nos Limites da Vida. Rio de Janeiro: Lúmen Júris, 2006, p. 23.

${ }^{450}$ SARMENTO, Daniel. Legalização do Aborto e constituição. In: SARMENTO, Daniel; PIOVESAN, Flávia (coordenadores). Nos Limites da Vida. Rio de Janeiro: Lúmen Júris, 2006, p. 25.
} 
Então, além de a Constituição Federal garantir o direito à vida, também garante uma vida digna, de modo que, como vimos, em primeiro lugar, devemos aduzir que o direito à vida deve andar de mãos dadas com o preceito da dignidade ${ }^{451}$.

Ademais, o texto constitucional também protege o direito à saúde - onde se insere o direito à saúde psíquica e física - e o direito à privacidade - o que, para muitos, englobaria a autonomia da vontade - todos regidos pelo princípio da dignidade da pessoa humana ${ }^{452}$.

Assim, diante da problemática do aborto do feto anencéfalo, temos que analisar em conjunto o direito à vida e o direito à vida digna do feto versus o direito à saúde e à integridade psíquica e física, o direito à vida digna, o direito à liberdade, à privacidade e à autonomia da gestante; bem como direito à igualdade inclusive entre os gêneros, como ressaltado nos primeiros capítulos deste trabalho.

Todavia, o texto constitucional não dispõe sobre o início da vida, cabendo às ciências médicas e biológicas determinar seu início e término, sendo certo que à ciência jurídica cabe apenas fazer seu "enquadramento legal"

Além do mais, a Constituição não faz distinção da proteção da vida intra ou extrauterina, e nem mesmo distingue a fecundação natural da artificial, fases embrionárias ou se existe ou não vida em potencial ${ }^{454}$. Apenas garante o direito à vida, e é por causa desta simplicidade $^{455}$ do texto constitucional que surgem inúmeros debates no mundo jurídico quanto ao âmbito de proteção do direito à vida, especialmente nos casos de aborto por inviabilidade extrauterina.

\subsubsection{A incorporação e hierarquia das normas de direitos humanos no Brasil}

\footnotetext{
${ }^{451}$ MORAES, Alexandre de. Direitos Humanos Fundamentais: teoria geral, comentários aos arts. $1^{\circ}$ a $5^{\circ}$ da Constituição Federal da República Federativa do Brasil, doutrina e jurisprudência. 6. ed. São Paulo:Atlas, 2005 (Coleção Temas Jurídicos:3), p. 80.

${ }^{452}$ Art. $1^{\circ}, \mathrm{Cf} / 1988$ in verbis: "A República Federativa do Brasil, formada pela união indissolúvel dos Estados e Municípios e do Distrito Federal, constitui-se em Estado Democrático de Direito e tem como fundamentos: I - a soberania; II - a cidadania; III - a dignidade da pessoa humana; IV - os valores sociais do trabalho e da livre iniciativa; V - o pluralismo político". BRASIL. Constituição da República Federativa do Brasil. Brasília, DF: Senado, 1988.

${ }^{453}$ MORAES, Alexandre de. Direitos Humanos Fundamentais: teoria geral, comentários aos arts. $1^{\circ}$ a $5^{\circ}$ da Constituição Federal da República Federativa do Brasil, doutrina e jurisprudência. 6. ed.São Paulo:Atlas, 2005 (Coleção Temas Jurídicos:3), p. 81.

${ }^{454}$ Vide, LIMA, Carolina Alves de Souza. Aborto e Anencefalia: direitos fundamentais em colisão. $1^{\text {a }}$. ed. (ano 2008), $2^{\mathrm{a}}$ reimpr. Curitiba: Juruá, 2010, p. 25.

${ }^{455}$ Daniel Sarmento afirma que o fato de a Constituição Federal não ter tratado do aborto voluntário não significa dizer que há um "indiferente constitucional”. SARMENTO, Daniel. Legalização do Aborto e constituição. In: SARMENTO, Daniel; PIOVESAN, Flávia (coordenadores). Nos Limites da Vida. Rio de Janeiro: Lúmen Júris, 2006, p. 23.
} 
Ao lado do texto constitucional, o Brasil ainda é signatário de inúmeros tratados de direitos humanos que tutelam o direito à vida, de modo que tais dispositivos também integram o ordenamento jurídico brasileiro ${ }^{456}$.

Vale dizer que, para Celso Lafer, a Constituição Federal de 1988 dita um novo rumo à sociedade brasileira, e passa a garantir direitos e estabelecer princípios gerais, consubstanciado sua posição no artigo $4^{\circ}$ do texto constitucional ${ }^{457}$, que permite uma abertura do Brasil ao mundo e a prevalência de direitos humanos com a redemocratização ${ }^{458}$, aderindo o Brasil a tais tratados de direitos humanos.

No entanto, a incorporação desses tratados no ordenamento interno brasileiro segue uma praxe, como ensina André de Carvalho Ramos, com a aprovação do tratado pelo Congresso Nacional, e, após, com a celebração do tratado pelo Presidente da República (denominada de fase do decreto legislativo) e, em seguida, com a promulgação pelo Poder Executivo (denominada a fase do decreto executivo) ${ }^{459}$.

Para Flávia Piovesan, o artigo 84, VIII ${ }^{460}$, estabelece a competência privativa do Presidente da República para celebrar tratados, convenções e atos internacionais, devendo passar pelo referendo do Congresso Nacional. Já o artigo 49, $\mathrm{I}^{461}$, dispõe sobre a competência exclusiva do Congresso Nacional para resolver em definitivo sobre tratados, acordos ou atos internacionais. Para Piovesan, há uma integração entre Poder Executivo e Legislativo, de

\footnotetext{
${ }^{456}$ Vide o artigo 3 da Declaração Universal de Direitos Humanos, o artigo 4, I, da Convenção Americana de Direitos Humanos; artigo 6, I, do Pacto Internacional de Direitos Civis e Políticos e o preâmbulo da Declaração dos Direitos da Criança.

${ }^{457}$ In verbis: Art. $4^{\circ} \mathrm{A}$ República Federativa do Brasil rege-se nas suas relações internacionais pelos seguintes princípios: I - independência nacional; II - prevalência dos direitos humanos; III - autodeterminação dos povos; IV - não-intervenção; V - igualdade entre os Estados; VI - defesa da paz; VII - solução pacífica dos conflitos; VIII - repúdio ao terrorismo e ao racismo; IX - cooperação entre os povos para o progresso da humanidade; X concessão de asilo político. Parágrafo único. A República Federativa do Brasil buscará a integração econômica, política, social e cultural dos povos da América Latina, visando à formação de uma comunidade latinoamericana de nações. BRASIL. Constituição da República Federativa do Brasil. Brasília, DF: Senado, 1988.

458 LAFER, Celso. A internacionalização dos direitos humanos: Constituição, racismo e relações internacionais. São Paulo: Manole, 2005, p. 13-14.

${ }^{459}$ CARVALHO RAMOS, André de. Responsabilidade Internacional por Violação de Direitos Humanos: seus elementos, a reparação devida e sanções possíveis - teoria e prática do direito internacional. Rio de Janeiro: Renovar, 2004, p. 118-119.

${ }^{460}$ In verbis: Art. 84. Compete privativamente ao Presidente da República: VIII - celebrar tratados, convenções e atos internacionais, sujeitos a referendo do Congresso Nacional. BRASIL. Constituição da República Federativa do Brasil. Brasília, DF: Senado, 1988.

${ }^{461}$ In verbis: "Art. 49. É da competência exclusiva do Congresso Nacional: I - resolver definitivamente sobre tratados, acordos ou atos internacionais que acarretem encargos ou compromissos gravosos ao patrimônio nacional.” BRASIL. Constituição da República Federativa do Brasil. Brasília, DF: Senado, 1988.
} 
modo que o processo de formação de tratados internacionais no Brasil constitui um ato complexo $^{462}$.

Para André de Carvalho Ramos, essa exigência aproxima a incorporação dos tratados internacionais pelo Brasil ao entendimento da corrente dualista, que primazia como o direito interno encara o direito internacional, de modo que a norma internacional somente pode ser invocada se transformada em direito interno ${ }^{463}$.

Ademais, Piovesan ensina que há uma lacuna nos dispositivos constitucionais citados acima, pois eles não tratam de um prazo para que o Presidente da República encaminhe ao Congresso o tratado assinado, bem como não estabelece prazo para o Congresso e o Presidente apreciar e promulgar o tratado, respectivamente ${ }^{464}$. Esse fato, para Piovesan, confere ampla discricionariedade ao Poder Executivo e ao Poder Legislativo, em detrimento dos compromissos assumidos pelo Brasil internacionalmente, ensejando, inclusive, responsabilização internacional do Estado ${ }^{465}$.

Flávia Piovesan reconhece que, embora não haja posição majoritária nesse sentido, os tratados de direitos humanos não precisariam passar pelo processo de incorporação legislativa, pois têm aplicação imediata por força do parágrafo $1^{\circ}$ do artigo $5^{\circ}$ da Constituição Federal, que garantiria a incorporação automática aos tratados internacionais de proteção aos direitos humanos ${ }^{466}$.

Apenas a título de exemplo de tratado em que o Brasil é parte, e que nos interessa para a temática do direito à vida, gostaríamos de mencionar como foi incorporada a nosso ordenamento a Convenção Americana de Direitos Humanos (CADH), aprovada pelas nações em 22 de novembro de 1969: O Brasil somente aderiu à CADH pelo Decreto 668 de 6 de novembro de 1992, e, posteriormente, apenas reconheceu a jurisdição obrigatória da Corte pelo Decreto Legislativo 89 de dezembro de 1998 e pelo Decreto 4463 de 11 de novembro de 2002.

Passado pelo aspecto da incorporação dos tratados, precisamos compreender qual a natureza das normas de direitos humanos no âmbito interno. Essas normas têm natureza

\footnotetext{
${ }^{462}$ PIOVESAN, Flávia. Direitos Humanos e o Direito Constitucional Internacional. $10^{\mathrm{a}}$. ed. rev., ampl. e atual. São Paulo: Saraiva, 2009, p. 48-49.

${ }^{463}$ CARVALHO RAMOS, André de. Responsabilidade Internacional por Violação de Direitos Humanos: seus elementos, a reparação devida e sanções possíveis - teoria e prática do direito internacional. Rio de Janeiro: Renovar, 2004, p. 117-118.

${ }^{464}$ PIOVESAN, Flávia. Direitos Humanos e o Direito Constitucional Internacional. $10^{\mathrm{a}}$. ed. rev., ampl. e atual. São Paulo: Saraiva, 2009, p. 50.

${ }^{465}$ PIOVESAN, Flávia. Direitos Humanos e o Direito Constitucional Internacional. $10^{a}$. ed. rev., ampl. e atual. São Paulo: Saraiva, 2009, p. 50-51.

${ }^{466}$ PIOVESAN, Flávia. Direitos Humanos e o Direito Constitucional Internacional. $10^{\mathrm{a}}$. ed. rev., ampl. e atual. São Paulo: Saraiva, 2009, p. 88-89.
} 
constitucional? Qual seria a hierarquia desses tratados de direitos humanos dos quais o Brasil faz parte, até para podermos entender eventual conflito entre tais normas de direitos humanos e a Constituição Federal brasileira ${ }^{467}$ ?

Em 2004, foi aprovada a Emenda Constitucional no 45 , que inseriu o $\S 3^{\circ}$ do artigo $5^{\circ}$ na Constituição Federal ${ }^{468}$, encerrando aparentemente alguns debates sobre a hierarquia dos tratados de direitos humanos, pois entendeu o legislador que, somente com a aprovação dos tratados de direitos humanos com o quórum diferenciado de $3 / 5$ de todos os membros de cada Casa, seriam estes tratados equiparados às emendas constitucionais.

Todavia, como ensina André de Carvalho Ramos, quando da aprovação da Emenda Constitucional $n^{\circ} 45$, havia duas posições sobre a hierarquia de tratados de Direitos Humanos: i) uma teoria afirmava que os tratados de direitos humanos que não passaram pelo rito diferenciado estabelecido no parágrafo $3^{\circ}$ do artigo $5^{\circ}$ da Constituição Federal possuem natureza de lei ordinária federal, valendo inclusive para tratados anteriores ou posteriores à Emenda Constitucional $n^{\circ} 45^{469}$; ii) outra teoria afirmava que todos os tratados de direitos humanos teriam natureza materialmente constitucional ${ }^{470}$, nos termos do $\S 2^{\circ}$ do artigo $5^{\circ}$ da Constituição Federal, e que, após a Emenda 45 de 2004, passando pelo quórum diferenciado da Emenda Constitucional, tais tratados de direitos humanos seriam, além de material, formalmente constitucionais ${ }^{471}$, compondo o então denominado "bloco de constitucionalidade" ${ }^{472}$.

\footnotetext{
${ }^{467}$ Ler interessante estudo sobre o tema. CARVALHO RAMOS, André de. A Execução das Sentenças da Corte Interamericana de Direitos Humanos no Brasil. In: CASELLA, Paulo Borba; CELLI JÚNIOR, Umberto; MEIRELLES, Elizabeth de Almeida; POLIDO, Fabrício Bertini Pasquot (orgs). Direito Internacional, Humanismo e Globalidade. São Paulo: Editora Atlas, 2008, p. 454-455; e CARVALHO RAMOS, André de. O Diálogo das Cortes: o Supremo Tribunal Federal e a Corte Interamericana de Direitos Humanos. In: JUBILUT, Liliana Lyra; AMARAL JUNIOR, Alberto do (orgs). O STF e o Direito Internacional dos Direitos Humanos. São Paulo: Quartier Latin, 2009, p. 805-850.

${ }^{468}$ Entende Carolina Lima que o $\$ 3^{\circ}$ do artigo $5^{\circ}$ da CF é inconstitucional, pois violaria o $\S 4^{\circ}$, IV, artigo 60 da $\mathrm{CF}$ e faz um tratamento diferenciado no que tange às normas de direitos humanos. LIMA, Carolina Alves de Souza. Aborto e Anencefalia: direitos fundamentais em colisão. $1^{\mathrm{a}}$. ed. (ano 2008), $2^{\mathrm{a}}$ reimpr. Curitiba: Juruá, 2010, p. 32-33. Celso Lafer considera referido parágrafo norma interpretativa "destinada a encerrar as controvérsias jurisprudenciais e doutrinárias suscitadas pelo $\S 2^{\circ}$ do art. $5^{\circ}$ ”, declarando o que já existe. LAFER, Celso. A internacionalização dos direitos humanos: Constituição, racismo e relações internacionais. São Paulo: Manole, 2005, p. 16.

${ }^{469}$ CARVALHO RAMOS, André de. A Execução das Sentenças da Corte Interamericana de Direitos Humanos no Brasil. In: CASELLA, Paulo Borba; CELLI JÚNIOR, Umberto; MEIRELLES, Elizabeth de Almeida; POLIDO, Fabrício Bertini Pasquot (orgs). Direito Internacional, Humanismo e Globalidade. São Paulo: Editora Atlas, 2008, p. 455.

${ }^{470}$ Para Flávia Piovesan, as normas de direitos humanos que não passaram pelo quórum diferenciado introduzido pela Emenda 45, antes e depois dela, têm natureza materialmente constitucional e constituem cláusulas pétreas, não podendo sequer ser objeto de deliberação para abolição. PIOVESAN, Flávia. Direitos Humanos e o Direito Constitucional Internacional. 10a . ed. rev., ampl. e atual. São Paulo: Saraiva, 2009, p. 78.

${ }^{471}$ Neste sentido, Paulo Hamilton Siqueira Júnior e Miguel Augusto Machado de Oliveira: "os tratados e convenções de direitos humanos ingressarão na categoria de norma constitucional, desde que respeitado o procedimento equivalente à emenda constitucional." SIQUEIRA JÚNIOR, Paulo Hamilton; OLIVEIRA, Miguel
} 
Diante disso, o Supremo Tribunal Federal buscou solucionar a questão atribuindo aos tratados de direitos humanos uma natureza diversa, a de supralegalidade ${ }^{473}$. Nesse sentido, o Supremo entendeu que os tratados de direitos humanos, em razão de sua natureza, não podem ser equiparados à lei infraconstitucional, e, ao mesmo tempo, não têm natureza constitucional $^{474}$, exceto se respeitado o quórum diferenciado estabelecido pelo $\S 3^{\circ}$ do artigo $5^{\circ}$ da Constituição Federal ${ }^{475}$. Deve então o Brasil cumprir internamente os compromissos assumidos internacionalmente, independentemente de se tais tratados integram o ordenamento jurídico brasileiro com status constitucional ou com natureza de supralegalidade ${ }^{476}$.

Por outro lado, ensina André de Carvalho Ramos que, no âmbito do Direito Internacional dos Direitos Humanos, as Cortes Internacionais de Direitos Humanos não têm reconhecido o "caráter jurídico" das normas de direito interno, pois o que se verifica é o cumprimento ou não dos compromissos assumidos pelos estados perante a comunidade internacional, além de o Direito Internacional possuir fontes normativas próprias ${ }^{477}$. Assim, para o autor, as normas de direito interno são consideradas "mero fato", não podendo o estado

Augusto Machado de. Direitos Humanos e Cidadania. $3^{\text {a }}$ ed. rev. e atual. São Paulo: Editora Revista dos Tribunais, 2010, p. 166.

${ }^{472}$ CARVALHO RAMOS, André de. A Execução das Sentenças da Corte Interamericana de Direitos Humanos no Brasil. In: CASELLA, Paulo Borba; CELLI JÚNIOR, Umberto; MEIRELLES, Elizabeth de Almeida; POLIDO, Fabrício Bertini Pasquot (orgs). Direito Internacional, Humanismo e Globalidade. São Paulo: Editora Atlas, 2008, p. 455. Vide, ainda, a respeito os votos dos Ministros Celso de Mello, Cezar Peluso, Eros Grau e Ellen Gracie no acórdão do Recurso Extraordinário (RE) no Supremo Tribunal Federal 466.343-SP. Celso Lafer reconhece o caráter constitucional material dos tratados internacionais de direitos humanos e que integram o bloco de constitucionalidade, definindo-o como a "somatória daquilo que se adiciona à Constituição escrita, em função dos valores e princípios nele consagrados. O bloco de constitucionalidade imprime vigor à força normativa da Constituição e é por isso parâmetro hermenêutico, de hierarquia superior, de integração, complementação e ampliação do universo dos direitos constitucionais previstos, além, de critério de preenchimento de eventuais lacunas". LAFER, Celso. A internacionalização dos direitos humanos: Constituição, racismo e relações internacionais. São Paulo: Manole, 2005, p. 17.

${ }^{473}$ Vide acórdão do Supremo Tribunal Federal Recurso Extraordinário (RE) 466.393-1 sobre prisão civil no caso de depositário infiel. Vide também interessantes comentários sobre a evolução do posicionamento do Supremo Tribunal Federal feitas por André de Carvalho Ramos. CARVALHO RAMOS, André de. A Execução das Sentenças da Corte Interamericana de Direitos Humanos no Brasil. In: CASELLA, Paulo Borba; CELLI JÚNIOR, Umberto; MEIRELLES, Elizabeth de Almeida; POLIDO, Fabrício Bertini Pasquot (orgs). Direito Internacional, Humanismo e Globalidade. São Paulo: Editora Atlas, 2008, p. 455-456.

${ }^{474}$ Vide RE 466.343-SP.

${ }^{475}$ Vide Decreto Legislativo 186 de 09 jul. 2008 que aprovou a Convenção sobre os Direitos das Pessoas com Deficiência e seu Protocolo Facultivo pelo quórum diferenciado, ingressando no ordenamento jurídico brasileiro com status de norma constitucional.

${ }^{476}$ De modo que o Brasil deverá cumprir integralmente as decisões da Corte Interamericana de Direitos Humanos. CARVALHO RAMOS, André de. A Execução das Sentenças da Corte Interamericana de Direitos Humanos no Brasil. In: CASELLA, Paulo Borba; CELLI JÚNIOR, Umberto; MEIRELLES, Elizabeth de Almeida; POLIDO, Fabrício Bertini Pasquot (orgs). Direito Internacional, Humanismo e Globalidade. São Paulo: Editora Atlas, 2008, p. 455-456

477 O Diálogo das Cortes: o Supremo Tribunal Federal e a Corte Interamericana de Direitos Humanos. In: JUBILUT, Liliana Lyra; AMARAL JUNIOR, Alberto do (orgs). O STF e o Direito Internacional dos Direitos Humanos. São Paulo: Quartier Latin, 2009, p. 817-818. 
alegar o descumprimento de um compromisso internacional assumido anteriormente em razão de uma norma interna, ainda que constitucional ${ }^{478}$.

Esse entendimento já foi defendido pela Corte Interamericana de Direitos Humanos, por exemplo. Destacamos a Opinião Consultiva 14/94 que representou um marco no que tange à relação de direito interno e direito internacional ${ }^{479}$. Tal interpretação da Corte versou essencialmente sobre a possibilidade de um Estado parte editar uma lei que viole a Convenção Americana de Direitos Humanos, em especial o artigo $4^{\circ}$, parágrafos $2^{\circ}{ }^{480}$ e $3^{\circ}{ }^{481}$ da Convenção, ao inserir nova hipótese não prevista de pena de morte. O pano de fundo foi a incorporação do artigo 140 da nova Constituição do Peru ${ }^{482}$, mediante o qual a pena de morte $^{483}$ seria ampliada para ser aplicável também nos casos de terrorismo. A Corte entendeu que o estado deve agir de boa-fé ao cumprir seus compromissos internacionais, que não pode se valer da legislação doméstica para desrespeitar tais obrigações ${ }^{484}$, e que, se o estado promulgar uma lei manifestamente contrária à Convenção - ainda que constitucional, esta lei será violadora da Convenção, o que pode dar ensejo à responsabilidade internacional do Estado no caso de violação de direitos e liberdades individuais.

\footnotetext{
478 CARVALHO RAMOS, André de. O Diálogo das Cortes: o Supremo Tribunal Federal e a Corte Interamericana de Direitos Humanos. In: JUBILUT, Liliana Lyra; AMARAL JUNIOR, Alberto do (orgs). O STF e o Direito Internacional dos Direitos Humanos. São Paulo: Quartier Latin, 2009, p. 818-819. CARVALHO RAMOS, André de. A Execução das Sentenças da Corte Interamericana de Direitos Humanos no Brasil. In: CASELLA, Paulo Borba; CELLI JÚNIOR, Umberto; MEIRELLES, Elizabeth de Almeida; POLIDO, Fabrício Bertini Pasquot (orgs). Direito Internacional, Humanismo e Globalidade. São Paulo: Editora Atlas, 2008, p. 456-457. CARVALHO RAMOS, André de. Responsabilidade Internacional por Violação de Direitos Humanos: seus elementos, a reparação devida e sanções possíveis - teoria e prática do direito internacional. Rio de Janeiro: Renovar, 2004, p. 131.

${ }^{479}$ Corte IDH. Responsabilidad Internacional por Expedición y Aplicación de Leyes Violatorias de la Convención (arts. 1 y 2 Convención Americana sobre Derechos Humanos). Opinión Consultiva OC-14/94 del 9 de diciembre de 1994. Serie A No. 14, p. 2. Vide interessante trabalho de ARAUJO, Nadia de. A Influência das Opiniões Consultivas da Corte Interamericana de Direitos Humanos no Ordenamento Jurídico Brasileiro. In: MENEZES DIREITO, Carlos Alberto, CANÇADO TRINDADE, Antonio Augusto e PEREIRA, Antonio Celso Alves (orgs). Novas Perspectivas do Direito Internacional Contemporâneo - Estudos em homenagem ao Professor Celso D. Albuquerque Mello. Rio de Janeiro: Ed. Renovar, 2008.

${ }^{480}$ In verbis: "nos países que não houverem abolido a pena de morte, esta só poderá ser imposta pelos delitos mais graves, e cumprimento de sentença final de tribunal competente e em conformidade com a lei que estabeleça tal pena, promulgada antes de haver o delito sido cometido. Tampouco se estenderá sua aplicação a delitos aos quais não se aplique atualmente” Opinión Consultiva OC-14/94 del 9 de diciembre de 1994. Serie A No. 14. p. 12 (tradução nossa).

${ }^{481}$ In verbis: "não se pode restabelecer a pena de morte nos Estados que a hajam abolido" Opinión Consultiva OC-14/94 del 9 de diciembre de 1994. Serie A No. 14. p. 12 (tradução nossa).

${ }^{482}$ http://www.tc.gob.pe/legconperu/constitucion.html>. Acesso em: 22 mai. 2009. Estabelecia o artigo 140 da nova constituição do Peru que "La pena de muerte solo puede aplicarse por el delito de traición a la pátria em caso de guerra, y el de terrorrismo, conforme a as leyes y a los tratados de los que el Peru es parte obligada."

${ }^{483}$ É importante ressaltar que o artigo 235 da constituição peruana de 1979 previa a aplicação da pena de morte unicamente nos casos de traição à pátria. Disponível em: <http://www.congreso.gob.pe/comisiones/1999/simplificacion/const/ 1979.htm >. Acesso em: 22 mai. 2009.

${ }^{484}$ Opinión Consultiva OC-14/94 del 9 de diciembre de 1994. Serie A No. 14. p. 12 (tradução nossa).
} 
Assim, no Brasil, o artigo $5^{\circ}$, caput, deve ser interpretado em conjunto com tratados de direitos humanos, em especial, com a Convenção Americana de Direitos Humanos, já incorporada no nosso plano interno ${ }^{485}$, e que garante o direito à vida, em geral, desde a concepção, bem como outros tratados de direitos humanos dos quais o Brasil faz parte.

Deste modo, vemos que é necessário analisar o direito à vida do feto, inclusive daquele acometido por anencefalia, tenho em vista também a inviabilidade de vida extrauterina, levando-se em conta a interpretação dada ao direito à vida pela Corte Interamericana de Direitos Humanos ${ }^{486}$ da qual, igualmente, o Brasil reconheceu sua jurisdição obrigatória ${ }^{487}$ e que, como vimos nos primeiros capítulos deste trabalho, tem feito uma interpretação ampliativa desse direito, alcançando vários âmbitos de proteção, inclusive abarcando a proteção de uma vida digna ${ }^{488}$.

\subsubsection{O Código Civil e o direito de personalidade}

Ao lado dessas considerações sobre a proteção do direito à vida na esfera constitucional, para que possamos compreender a proteção do referido direito internamente e seu âmbito de proteção - para daí compreender a real proteção do direito à vida no caso no

\footnotetext{
${ }^{485}$ Decreto 678 de 06 nov. 1992.

${ }^{486}$ André de Carvalho Ramos propõe um diálogo entre as Cortes, a saber: Supremo Tribunal Federal e a Corte Interamericana de Direitos Humanos, a fim de resguardar a dignidade da pessoa humana e os direitos fundamentais e uma convivência harmoniosa entre o direito internacional e o direito interno. CARVALHO RAMOS, André de. O Diálogo das Cortes: o Supremo Tribunal Federal e a Corte Interamericana de Direitos Humanos. In: JUBILUT, Liliana Lyra; AMARAL JUNIOR, Alberto do (orgs). O STF e o Direito Internacional dos Direitos Humanos. São Paulo: Quartier Latin, 2009, p. 849. CARVALHO RAMOS, André de. O impacto da Convenção Interamericana de Direitos Humanos na relação do Direito Internacional e o Direito Interno, p. 57-60. In: B. Cient. ESMPU, Brasília, a. I - no 4, p. 51-71, jul/set.2002. Vide também RE 466343, RE 349703 e HC 87585 do STF.

${ }^{487}$ Decreto Legislativo 89/98 de 03 nov. 1998 e porterior Decreto 4463 de 08 nov. 2002 que promulgou a declaração de reconhecimento da competência obrigatória da Corte.

${ }^{488}$ Cançado Trindade ensina que "dada a possível interpretação concomitante de dispositivos correspondentes ou equivalentes (um servindo de orientação a outro) de distintos tratados sobre direitos humanos, tem havido espaço para a aplicação do critério da primazia da norma mais favorável às supostas vítimas, critério este que tem encontrado apoio expresso em determinados dispositivos de tratados de direitos humanos. A escolha ou primazia do dispositivo mais favorável às supostas vítimas tem relação direta com a questão da coexistência de procedimentos distintos de petições ou reclamações de proteção dos direitos humanos, pois significativamente pode reduzir ou minimizar as possibilidades de conflito normativo; encontra-se, com efeito, em clara consonância com a tendência hodierna a nível internacional de ampliar, ao invés de restringir, a proteção dos direitos humanos" (grifo nosso). CANÇADO TRINDADE, Antonio. A Proteção Internacional dos Direitos Humanos: fundamentos jurídicos e instrumentos básicos. São Paulo: Saraiva, 1991, p. 50. Vide importante crítica de André Carvalho Ramos sobre a aplicação da norma mais favorável. CARVALHO RAMOS, André de. Teoria Geral dos Direitos Humanos na Ordem Internacional. Rio de Janeiro: Renovar, 2005, p. 106-110.
} 
feto anencéfalo no plano interno - é importante remontar as teorias que buscam explicar a partir de qual momento o indivíduo passa a ser considerado pessoa detentora de direitos no plano jurídico. Para tanto, devemos recorrer ao Direito Civil.

\subsubsection{Conceito de personalidade jurídica}

Assim como ocorre no plano constitucional, na esfera infraconstitucional também não existem definições sobre o início da vida, cuja definição dependerá do auxílio de outras disciplinas, como a biomedicina, por exemplo.

$\mathrm{Na}$ esfera do direito civil, o artigo $2^{\circ}$ do Código Civil estabelece que a personalidade civil da pessoa começa no nascimento com vida; mas a lei põe a salvo, desde a concepção, os direitos do nascituro ${ }^{489}$.

O nascituro, conforme Silmara Chinelato, é o ser já concebido e implantado no ventre materno ou in anima nobile ${ }^{490}$, e que teria, portanto, tutela jurídica, uma vez que seria reconhecida a sua personalidade jurídica, passando a ser detentor de direitos.

A personalidade jurídica não se confunde com capacidade jurídica. Conforme Chinelato, existem dois conceitos: a personalidade jurídica e a capacidade jurídica, esta como elemento daquela e que "exprime poderes ou faculdades"491. A personalidade, por seu turno, seria a "aptidão de um ente para ser titular de direitos e de obrigações",492.

\subsection{Teorias sobre a personalidade jurídica}

\footnotetext{
${ }^{489}$ Maria Helena Diniz afirma que existe tutela jurídica desde a fecundação, com base também na Lei 11.105/05, art. 6, III, 24, 25, 27, IV e artigos 124 a 128 do Código Penal. Defende, ainda, o direito ao nascer, de continuar vivo e o de subsistência, no caso de idoso, nascituro, criança, adolescente ou deficiente. DINIZ, Maria Helena. O Estado Atual do Biodireito. São Paulo: Saraiva, 2009, p. 22. Piovesan e Pirotta defendem que o direito à vida não é absoluto e que esse dispositivo garante apenas os direitos patrimoniais do nascituro no caso de sucessão ou doação, por exemplo, e alguns direitos não patrimoniais como ser sujeito passivo ou ativo em ação judicial. A eficácia de direitos, fica, no entanto condicionada ao nascimento com vida. PIOVESAN, Flávia e PIROTTA, Wilson Ricardo Buquetti. Temas de Direitos Humanos. $4^{\mathrm{a}}$. ed. São Paulo: Saraiva, 2010, p. 322.

490 ALMEIDA, Silmara J.A.Chinelato e. Tutela Civil do Nascituro. [prefácio Carlos Alberto Bittar, Mario Emílio Bigotte Chorão]. São Paulo: Saraiva, 2000, p. 15.

491 ALMEIDA, Silmara J.A.Chinelato e. Tutela Civil do Nascituro. [prefácio Carlos Alberto Bittar, Mario Emílio Bigotte Chorão]. São Paulo: Saraiva, 2000, p. 131 e 134.

492 ALMEIDA, Silmara J.A.Chinelato e. Tutela Civil do Nascituro. [prefácio Carlos Alberto Bittar, Mario Emílio Bigotte Chorão]. São Paulo: Saraiva, 2000, p. 131 e 134.
} 
No Brasil, destacam-se três teorias principais que tratam do início da personalidade jurídica: a teoria natalista, a teoria da personalidade condicional, e a teoria concepcionista ${ }^{493}$.

Silmara Chinelato ensina que a primeira teoria é, em princípio, entendida como sendo aquela que antigamente era abarcada pelo artigo $4^{\mathrm{o}}$ do Código Civil de $1816^{494}$, ou seja, a teoria de que o direito à personalidade surge com o nascimento com vida ${ }^{495}$ do feto, existindo, antes disso, a mera expectativa ${ }^{496}$ de que o feto venha a ser detentor de direitos, não gozando de direitos e obrigações, e não tendo, portanto, existência civil própria até que se separe do útero da mãe, conforme entendimento de alguns civilistas ${ }^{497}$.

Renata da Rocha atribui a existência da teoria natalista à incompreensão sobre a "autonomia biológica do concepto humano"498, atualmente comprovada em virtude dos avanços técnicos e científicos inexistentes à epoca da elaboração da teoria natalista, de modo que hoje não haveria mais razão de ser tal teoria.

Outra teoria é a da personalidade condicional, na qual se reconhece a personalidade jurídica do nascituro desde a concepção, mas a condiciona ao seu nascimento com vida ${ }^{499}$. Chinelato critica tal teoria, afirmando que as premissas que a sustentam não são coerentes. Para Chinelato, "se a personalidade é condicional, desde a concepção, a condição do nascimento - sem vida - é resolutiva, e, não suspensiva" ${ }^{\text {500 }}$. Ensina, ainda, que reconhecer a

\footnotetext{
${ }^{493}$ ALMEIDA, Silmara J.A.Chinelato e. Tutela Civil do Nascituro. [prefácio Carlos Alberto Bittar, Mario Emílio Bigotte Chorão]. São Paulo: Saraiva, 2000, p. 135-175.

${ }^{494} \mathrm{O}$ texto original corresponde ao texto atual do artigo $2^{\mathrm{o}}$ do Código Civil.

${ }^{495}$ Luísa Neto analisa o artigo 66 do Código Civil português que - semelhante ao Código Civil brasileiro reconhece a personalidade jurídica - ou capacidade para aquisição de direitos - no momento do nascimento. NETO, Luísa. O direito fundamental à disposição do próprio corpo (a relevância da vontade na configuração do seu regime). Coimbra: Coimbra Editora, 2004, p. 448. Artigo 66 do Código Civil Português:"1. A personalidade adquire-se no momento do nascimento completo e com vida. 2. Os direitos que a lei reconhece aos nascituros dependem do seu nascimento." NETO, Luísa. O direito fundamental à disposição do próprio corpo (a relevância da vontade na configuração do seu regime). Coimbra: Coimbra Editora, 2004, p. 448.

${ }^{496}$ Embora o feto tenha vida, ainda não é pessoa. SARMENTO, Daniel. Legalização do Aborto e constituição. In: SARMENTO, Daniel; PIOVESAN, Flávia (coordenadores). Nos Limites da Vida. Rio de Janeiro: Lúmen Júris, 2006, p. 31.

${ }^{497}$ Em posição contrária. ALMEIDA, Silmara J.A.Chinelato e. Tutela Civil do Nascituro. [prefácio Carlos Alberto Bittar, Mario Emílio Bigotte Chorão]. São Paulo: Saraiva, 2000, p. 175. O feto é pessoa em potencial, mas mesmo como "projeto de pessoa" recebe proteção jurídica. SARMENTO, Daniel. Legalização do Aborto e constituição. In: SARMENTO, Daniel; PIOVESAN, Flávia (coordenadores). Nos Limites da Vida. Rio de Janeiro: Lúmen Júris, 2006, p. 32.

${ }^{498}$ ROCHA, Renata da. Direito à vida e a pesquisa em células-tronco. Rio de Janeiro: Elsevier, 2008, p. 90.

${ }^{499}$ ALMEIDA, Silmara J.A.Chinelato e. Tutela Civil do Nascituro. [prefácio Carlos Alberto Bittar, Mario Emílio Bigotte Chorão]. São Paulo: Saraiva, 2000, p. 148.

${ }^{500}$ ALMEIDA, Silmara J.A.Chinelato e. Tutela Civil do Nascituro. [prefácio Carlos Alberto Bittar, Mario Emílio Bigotte Chorão]. São Paulo: Saraiva, 2000, p. 155-156.
} 
personalidade jurídica desde a concepção exigirá uma interpretação extensiva aos direitos em geral, e não somente àqueles conferidos pelo texto normativo civil ${ }^{501}$.

Por fim, a terceira teoria garante a personalidade jurídica desde a concepção, entendendo que o produto da concepção é um ser vivo, detentor de direitos ${ }^{502}$.

Renata da $\operatorname{Rocha}^{503}$ explica que a referida teoria protege a etapa inicial do desenvolvimento do embrião humano, isto é a partir da "fertilização ${ }^{504}$ do ovócito secundário pelo espermatozóide" ${ }^{, 505}$, possuindo, desde a união das células germinativas, o reconhecimento de um novo ser, com identidade própria, a partir de quando forma o embrião unicelular denominado zigoto $^{506}$.

Expõe, ainda, Renata da Rocha, as teorias genético-desenvolvimentistas referentes à vida, que se subdividem em quatro: i) teoria da nidação; ii) teoria da formação dos rudimentos do sistema nervoso, iii) teoria do pré-embrião, e iv) teoria da pessoa humana em potencial $^{507}$.

Na primeira teoria, leva-se em conta a fixação do ovo no útero da mulher denominado de nidação. Para os defensores dessa teoria, a vida começa no momento da fixação do ovo, já que não haveria possibilidade de o embrião desenvolver-se fora do útero da mulher ${ }^{508}$.

Na segunda teoria, considera-se o início da formação do córtex central, entre o $15^{\circ}$ e o $40^{\circ}$ dia do desenvolvimento embrionário, com a atividade elétrica a partir da $8^{\mathrm{a}}$ semana, o

${ }^{501}$ ALMEIDA, Silmara J.A.Chinelato e. Tutela Civil do Nascituro. [prefácio Carlos Alberto Bittar, Mario Emílio Bigotte Chorão]. São Paulo: Saraiva, 2000, p. 155-156.

${ }^{502}$ A autora explica que apesar de a personalidade jurídica existir desde a concepção, a capacidade jurídica é reduzida. ALMEIDA, Silmara J.A.Chinelato e. Tutela Civil do Nascituro. [prefácio Carlos Alberto Bittar, Mario Emílio Bigotte Chorão]. São Paulo: Saraiva, 2000, p. 168.

${ }^{503}$ ROCHA, Renata da. Direito à vida e a pesquisa em células-tronco. Rio de Janeiro: Elsevier, 2008, p. 75.

${ }^{504}$ Habermas apontando duas correntes afirma que "um lado descreve o embrião no estágio prematuro de desenvolvimento como um 'amontoado de células' e o confronta com a pessoa do recém-nascido, a quem primeiramente compete a dignidade humana no sentido estritamente moral". $\mathrm{O}$ outro lado considera a fertilização do óvulo humano como início relevante de um processo de desenvolvimento já individualizado e controlado por si próprio. Segundo esta concepção, todo exemplar biologicamente determinável da espécie deve ser considerado como uma pessoa em potencial e como um portador de direitos fundamentais. HABERMAS, Jürgen. O futuro da natureza humana: a caminho de uma eugenia liberal? Trad. Karina Jannini; revisão da tradução Eurides Avance de Souza. São Paulo: Martins Fontes, 2004, p. 43.

${ }^{505}$ Renata da Rocha apresenta uma diferença entre fertilização e concepção. A primeira situação ocorre com a travessia do espermatozóide pela película do ovo, de modo que, somente 12 horas depois ocorreria a concepção, com a efetiva união dos 'pronúcleos' dos genitores, passando a ser uma única célula. Essa distinção gera duas correntes, portanto, que defendem a partir de qual momento a vida inicia-se: singamia e cariogamia. Na primeira corrente, o início da vida ocorre exatamente na fertilização, e, na segunda, ocorre com a concepção. ROCHA, Renata da. Direito à vida e a pesquisa em células-tronco. Rio de Janeiro: Elsevier, 2008, p. 76-77.

${ }^{506}$ Somente um dos 300 a 500 espermatozóides ultrapassa a zona pulúcida. SADLER, T. W.; LANGMAN, Jan. Langman's Medical Embriology. $9^{\text {th }}$ edition. Holanda: Lippincott Williams \& Wilkins Publisher, 2003, p. 42.

${ }^{507}$ ROCHA, Renata da. Direito à vida e a pesquisa em células-tronco. Rio de Janeiro: Elsevier, 2008, p. 79-89.

${ }^{508}$ ROCHA, Renata da. Direito à vida e a pesquisa em células-tronco. Rio de Janeiro: Elsevier, 2008, p. 79. 
grau de desenvolvimento que determinaria, na visão de seus adeptos, o início da vida humana $^{509}$.

A terceira corrente - teoria do pré-embrião - sustenta que não existe um ser humano até o $14^{\circ}$ dia da gravidez, somente uma potencialidade, a capacidade, de se gerar um ${ }^{510}$.

Por fim, na teoria da pessoa humana em potencial entende-se que o embrião já possui direitos e não pode ser reconhecido como mero amontoado de células, pois as características humanas que atribuem consciência e inteligência existiriam desde a concepção ${ }^{511}$. Chinelato, por exemplo, entende que a vida inicia-se desde a concepção, com a nidação do ovo no útero da mulher, independentemente se há ou não viabilidade do feto ${ }^{512}$.

Essas teorias podem auxiliar o intérprete na análise sobre a possibilidade ou não de se abortar um feto, ou, ainda, estabelecer graus de proteção ${ }^{513}$ do direito à vida. No entanto, tais teorias podem ajudar o intérprete, mas não trazem soluções diretas. Ademais, vale lembrar que, neste trabalho, não falamos simplesmente de uma hipótese de aborto em geral, mas de um caso específico de aborto em vista de uma particular inviabilidade extrauterina do feto devido à uma específica má-formação - a anencefalia.

\subsubsection{A criminalização do aborto}

No âmbito penal, a proteção do direito à vida do feto em geral se dá com a criminalização da prática do aborto.

\footnotetext{
${ }^{509} \mathrm{Cf}$. Renata da Rocha, os defensores dessa tese entendem que o homem é um ser consciente e, somente a partir do surgimento do sistema nervoso central que possibilita isso, haveria vida. ROCHA, Renata da. Direito à vida e a pesquisa em células-tronco. Rio de Janeiro: Elsevier, 2008, p. 80-81.

510 Explica Renata da Rocha que esta teoria foi utilizada para justificar a experimentação com embriões humanos. ROCHA, Renata da. Direito à vida e a pesquisa em células-tronco. Rio de Janeiro: Elsevier, 2008, p. 81-82.

${ }_{511}$ ROCHA, Renata da. Direito à vida e a pesquisa em células-tronco. Rio de Janeiro: Elsevier, 2008, p. 89.

512 ALMEIDA, Silmara J.A.Chinelato e. Tutela Civil do Nascituro. [prefácio Carlos Alberto Bittar, Mario Emílio Bigotte Chorão]. São Paulo: Saraiva, 2000, p. 161.

${ }^{513}$ Vide críticas. ROCHA, Renata da. Direito à vida e a pesquisa em células-tronco. Rio de Janeiro: Elsevier, 2008, p. 89. No voto do Ministro Ricardo Lewandowski na Ação Direta de Inconstitucionalidade 3.510-0 que visava à declaração da incostitucionalidade do artigo $5^{\circ}$ da Lei 11.105 de 24 mar. 2005 (Lei de Biossegurança) ao analisar o termo "em geral", afirma que a vida começa desde a concepção, mas "podendo a lei do Estado signatário da Convenção deixar, eventualmente, de protegê-la, em situações excepcionais, caso outros valores estejam em jogo". Como exemplo, menciona a hipótese de exclusão de antijuridicidade do aborto necessário expresso no artigo 128, I, Código Penal. Já Daniel Sarmento defende que tal interpretação deve ser feita no Brasil. SARMENTO, Daniel. Legalização do Aborto e constituição. In: SARMENTO, Daniel; PIOVESAN, Flávia (coordenadores). Nos Limites da Vida. Rio de Janeiro: Lúmen Júris, 2006, p. 35.
} 
Ensina Luis Regis Prado que o aborto não era considerado um delito na antiguidade clássica, pois o feto era tido como "parte integrante do organismo materno" ${ }^{\natural 14}$, ficando a gestante assim autorizada a decidir sobre a continuidade ou não da gravidez. O autor explica que o aborto passou a ser entendido como uma violação ao direito de paternidade durante o reinado de Septimius Severus e, com o Cristianismo, foi equiparado ao homicídio, pois o feto passara a ser visto como um ser humano, teoria abandonada mais tarde com o iluminismo, a partir de quando passou-se a estabelecer penas mais brandas para os casos de aborto ${ }^{515}$.

Prado ensina que, no Brasil, a proibição do aborto cometido pela gestante não tinha previsão legal no Código Criminal Imperial de $1830^{516}$. Mais tarde, em 1890, o Código Penal passou a fazer distinção entre interrupção da gravidez com ou sem expulsão do feto, mas punia com penas mais leves o caso de auto-aborto em razão de ocultamento de honra própria $^{517}$.

Atualmente, o Decreto-lei 2848 de 7 de dezembro de 1940, que instituiu o Código Penal Brasileiro, protege o direito à vida através do artigo 121. O crime de aborto está previsto no artigo 124 do Código Penal, que proíbe que a conduta seja praticada pela própria gestante ou por terceiro $^{518}$, neste caso, inclusive, com ou sem a anuência da gestante. O bem jurídico protegido pelo tipo penal é a "vida do ser humano em formação"519.

\footnotetext{
${ }^{514}$ PRADO, Luiz Regis. Curso de Direito Penal Brasileiro, volume 2: parte especial, arts 121 a 249, $7^{\text {a }}$ ed. rev. atual. e ampl. São Paulo: Editora Revista dos Tribunais, 2010, p. 81.

${ }^{515}$ PRADO, Luiz Regis. Curso de Direito Penal Brasileiro, volume 2: parte especial, arts 121 a 249, $7^{\mathrm{a}}$ ed. rev. atual. e ampl. São Paulo: Editora Revista dos Tribunais, 2010, p. 103-104. Vide BITENCOURT, Cezar Roberto.Tratado de Direito Penal 2: parte especial: dos crimes contra a pessoa, $10^{\mathrm{a}}$ ed. São Paulo: Saraiva, 2010, p. 158.

${ }^{516}$ PRADO, Luiz Regis. Curso de Direito Penal Brasileiro, volume 2: parte especial, arts 121 a 249, $7^{\mathrm{a}}$ ed. rev. atual. e ampl. São Paulo: Editora Revista dos Tribunais, 2010, p. 104.

${ }^{517}$ PRADO, Luiz Regis. Curso de Direito Penal Brasileiro, volume 2: parte especial, arts 121 a 249, $7^{\text {a }}$ ed. rev. atual. e ampl. São Paulo: Editora Revista dos Tribunais, 2010, p. 104. Nesse sentido, consulte também BITENCOURT, Cezar Roberto.Tratado de Direito Penal 2: parte especial: dos crimes contra a pessoa, $10^{\mathrm{a}} \mathrm{ed}$. São Paulo: Saraiva, 2010, p. 158.

${ }^{518} \mathrm{O}$ terceiro para Guilherme de Souza Nucci é o médico, não podendo ser aplicada a analogia à enfermeira ou parteira. NUCCI, Guilherme de Souza. Código Penal Comentado. 10 ed. rev., atual e ampl. São Paulo: Editora Revista dos Tribunais, 2010, p. 633.

${ }^{519}$ PRADO, Luiz Regis. Curso de Direito Penal Brasileiro, volume 2: parte especial, arts. 121 a 249, $8^{\mathrm{a}}$ ed. rev. atual. e ampl. São Paulo: Editora Revista dos Tribunais, 2010, p. 105. Para o autor, só há o crime de aborto, se a gravidez for normal, pois em se tratando de gravidez extrauteriana (aquela desenvolvida fora do útero, como por exemplo, a tubária) ou a molar ("formação neoplasmática" incapaz de produzir uma nova vida) não haveria o crime previsto no artigo 124 do Código Penal.

Em sentido contrário, Cezar Roberto Bitencourt ensina que "o bem jurídico protegido é a vida do ser humano em formação, embora, rigorosamente falando, não se trate de crime contra a pessoa. $\mathrm{O}$ produto da concepção - feto ou embrião - não é pessoa, embora tampouco seja mera esperança de vida ou simples parte do organismo materno, como alguns doutrinadores sustentam, pois tem vida própria e recebe tratamento autônomo da ordem jurídica". BITENCOURT, Cezar Roberto.Tratado de Direito Penal 2: parte especial: dos crimes contra a pessoa, $10^{\mathrm{a}}$ ed. São Paulo: Saraiva, 2010, p. 159.
} 
O aborto caracteriza-se, portanto, em eliminar a vida do feto ${ }^{520}$ durante a gestação. Diferentemente do que ocorre, pois, no infanticídio ${ }^{521}$ e no homicídio. No primeiro caso, como ensina Luiz Regis Prado, a mãe mata o filho durante ou logo após o parto sob influência do estado puerperal, e o crime leva em conta o fator da "imediatividade", devendo ocorrer logo após o parto, nos termos da $1 \mathrm{ei}^{522}$. Se for antes do parto, trata-se de aborto; se for logo após o parto, sob influência do estado puerperal, é infanticídio; se ocorrer posteriormente, é homicídio $^{523}$.

Por essa razão, para Guilherme de Souza Nucci, é essencial estabelecer o momento exato em que a "criança deixa de ser considerada feto para ser tratada como nascente" ${ }^{\text {"524, }}$ o que ocorreria a partir da "ruptura da bolsa - parte das membranas do ovo em correspondência com o orifício uterino" ${ }^{, 525}$. Lembra ainda o autor que tal ruptura deixa o feto vulnerável "às ações violentas - por instrumentos ou pela própria mão do agente" ${ }^{, 526}$.

O Código Penal elenca duas hipóteses nas quais o aborto não é penalizado: a) quando a interrupção da gravidez for imprescindível para salvar a vida da gestante, denominado de aborto necessário ${ }^{527}$; e b) quando a gravidez for resultado de estupro e o aborto for consentido pela gestante ou representante legal ${ }^{528}$. Essas exceções legais por si só já deixam claro que a proteção conferida por nosso ordenamento à vida do feto não é absoluta.

\footnotetext{
${ }^{520}$ Para Luiz Regis Prado, o "termo inicial para a prática do delito em exame é, portanto, o começo da gravidez. Do ponto de vista biológico, o início da gravidez é marcado pela fecundação. Todavia, sob o prisma jurídico, a gestação tem início com a implantação do óvulo fecundado no endométrio, ou seja, com a sua fixação no útero materno (nidação). Destarte, o aborto tem como limite mínimo necessário para sua existência a nidação, que ocorre cerca de quatorze dias após a concepção. O termo final é o início do parto, que, conforme examinado, é marcado pelas contrações da dilatação (parto normal) ou com o início dos procedimentos cirúrgicos (v.g., cesariana)”. PRADO, Luiz Regis. Curso de Direito Penal Brasileiro, volume 2: parte especial, arts. 121 a 249 , $7^{a}$ ed. rev. atual. e ampl. São Paulo: Editora Revista dos Tribunais, 2010, p. 107-108.

${ }^{521}$ Vide evolução histórica do infanticídio. Luis Regis Prado. PRADO, Luiz Regis. Curso de Direito Penal Brasileiro, volume 2: parte especial, arts 121 a 249, $8^{\text {a }}$ ed. rev. atual. e ampl. São Paulo: Editora Revista dos Tribunais, 2010, p. 71-72. Nesse sentido, Guilherme de Souza Nucci ensina ainda que o infanticídio só passou a ser punido a partir de Constantino e Justiniano. NUCCI, Guilherme de Souza. Código Penal Comentado. 10 ed. rev., atual e ampl. São Paulo: Editora Revista dos Tribunais, 2010, p. 626.

${ }^{522}$ Ensina o autor que o Código Penal Chileno estabelece o período de 48 horas para determinar o crime de infanticídio. NUCCI, Guilherme de Souza. Código Penal Comentado. 10a ed. rev., atual e ampl. São Paulo: Editora Revista dos Tribunais, 2010, p. 634.

${ }^{523}$ PRADO, Luiz Regis. Curso de Direito Penal Brasileiro, volume 2: parte especial, arts 121 a $249,8^{\mathrm{a}}$ ed. rev. atual. e ampl. São Paulo: Editora Revista dos Tribunais, 2010, p. 76-77.

${ }^{524}$ NUCCI, Guilherme de Souza. Código Penal Comentado. 10 a ed. rev., atual e ampl. São Paulo: Editora Revista dos Tribunais, 2010, p. 627.

525 NUCCI, Guilherme de Souza. Código Penal Comentado. $10^{\mathrm{a}}$ ed. rev., atual e ampl. São Paulo: Editora Revista dos Tribunais, 2010, p. 627.

${ }^{526}$ NUCCI, Guilherme de Souza. Código Penal Comentado. $10^{\mathrm{a}}$ ed. rev., atual e ampl. São Paulo: Editora Revista dos Tribunais, 2010, p. 627.

${ }^{527}$ In verbis: Artigo 128 do Código Penal: Não se pune o aborto praticado por médico: I - se não há outro meio de salvar a vida da gestante. BRASIL. Código Penal. Decreto-Lei $n^{\circ}$ 2.848, de 7 de dezembro de 1940. Disponível em: <http://www.planalto.gov.br/ccivil_03/decreto-lei/Del2848.htm>. Acesso em: 10 jan. 2011.

528 In verbis: Artigo 128, II do Código Penal: se a gravidez resulta de estupro e o aborto é precedido de consentimento da gestante, ou, quando incapaz, de seu representante legal. BRASIL. Código Penal. Decreto-Lei
} 
No entanto, não há no Código Penal nenhuma exceção no que diz respeito ao aborto de feto anencéfalo, existindo no máximo, interpretações da doutrina e da jurisprudência autorizando sua prática. Muitos doutrinadores, no entanto, fazem uma interpretação literal do texto normativo, afirmando que o aborto de feto anencéfalo é proibido, pois a lei autoriza apenas duas exceções ao crime de aborto, o terapêutico e sentimental, comentados acima, e que qualquer situação que não se enquadre nessas duas modalidades seria considerada crime $^{529}$.

Em linha contrária, isto é, em defesa da possibilidade do aborto legal de feto anencéfalo, é possível encontrar vários argumentos na literatura jurídica. Nucci, por exemplo, invoca alguns argumentos comumente utilizados para justificar a prática do aborto nesses casos: a) a avaliação sobre a inviabilidade do feto por meio de avanços tecnológicos "antes impossível" na medicina ${ }^{530}$; b) a existência de fetos ou embriões portadores de graves anomalias que inviabilizam sua vida futura ${ }^{531}$; c) a tese da inexigibilidade de conduta diversa, tendo em vista que o Código Penal protegeria a “"vida humana' e não a falsa existência, pois o feto ou embrião só está 'vivo' por conta do organismo materno que o sustenta"532; d) a não aceitação da anencefalia por parte das gestantes, o que, para abreviar seu sofrimento, autorizaria o aborto ${ }^{533}$.

$\mathrm{n}^{\mathrm{o}}$ 2.848, de 7 de dezembro de 1940. Disponível em: <http://www.planalto.gov.br/ccivil_03/decretolei/Del2848.htm>. Acesso em: 10 jan. 2011.

${ }_{529}$ Afirma Luiz Flávio Gomes que "Nos termos dos artigos 124, 125, 126 e 127 do Código Penal, todo atentado abortivo contra o feto é crime. Apenas em duas situações é permitido o abortamento no nosso país: quando há risco para a gestante $(\mathrm{CP}$, art. 128, I: aborto necessário) ou quando a gravidez resulta de estupro (CP, art. 128, II: aborto humanitário ou sentimental). Como se vê, o aborto anencefálico (aborto de feto com crânio mal formado ou no caso de hidroanencefalia) não está expressamente autorizado. Pela letra fria da lei, constitui (constituiria) delito. De cada 10.000 nascimentos no Brasil, oito são anencefálicos. Muitas gestantes e sua família, assim como alguns médicos, mesmo correndo risco de serem processados, praticam o aborto anencefálico. Literalmente há crime. Vive-se uma situação de insegurança jurídica muito aflitiva. A exceção somente acontece quando o Judiciário, em cada caso concreto, concede autorização para o ato do abortamento". GOMES, Luiz Flávio. Aborto Anencefálico: exclusão da tipicidade material. Disponível em: <http://jus.uol.com.br/revista/texto/8561/aborto-anencefalico〉. Acesso em: 20 jan. 2011.

${ }^{530}$ NUCCI, Guilherme de Souza. Código Penal Comentado. $10^{\mathrm{a}}$ ed. rev., atual e ampl. São Paulo: Editora Revista dos Tribunais, 2010, p. 634.

${ }^{531}$ NUCCI, Guilherme de Souza. Código Penal Comentado. 10 $10^{a}$ ed. rev., atual e ampl. São Paulo: Editora Revista dos Tribunais, 2010, p. 634.

${ }_{532}$ Referida tese, para o autor, tem dois planos: "o da gestante, não suportando carregar no ventre uma criança de vida inviável; o do médico, julgando salvar a genitora do forte abalo psicológico que vem sofrendo". NUCCI, Guilherme de Souza. Código Penal Comentado. $10^{\mathrm{a}}$ ed. rev., atual e ampl. São Paulo: Editora Revista dos Tribunais, 2010, p. 634.

${ }^{533}$ NUCCI, Guilherme de Souza. Código Penal Comentado. $10^{a}$ ed. rev., atual e ampl. São Paulo: Editora Revista dos Tribunais, 2010, p. 634. 
Acrescentaríamos, ainda, outro argumento usado: a tese de inexistência de vida do feto, considerando os parâmetros determinados pela Lei 9134 de 04 de fevereiro de 1997, art. $3^{\circ}$, caput , que considera morte a paralisação da atividade cerebral $^{534}$.

Muitos doutrinadores entendem que a avaliação técnica para diagnosticar a anencefalia atualmente seria capaz de exigir do legislador - que à época da feitura de nosso Código Penal não se deparou com essa realidade - uma reformulação de postura ${ }^{535}$, admitindo nova hipótese de aborto, tendo em vista a inviabilidade absoluta da vida extrauterina do feto anencéfalo. Para Cezar Roberto Bitencourt, o legislador de 1940 não foi "radical", pois permitiu duas hipóteses de aborto e "provavelmente também teria admitido o denominado aborto anencefálico" 536 se tivesse conhecimento sobre a inviabilidade extrauterina nos casos de anencefalia na época.

Quanto à tese de inexigibilidade de conduta diversa, na verdade, existem controvérsias na doutrina acerca de sua aplicabilidade como tese autônoma no sistema penal brasileiro.

Explica Guilherme de Souza Nucci que referida tese se enquadraria normalmente como um dos elementos da culpabilidade ${ }^{537}$, embora admita que é possível usá-la em "caráter excepcional" em caso de conduta injusta cometida pelo agente e também no caso de não ser "possível aplicar outras excludentes de culpabilidade" 538.

No caso da antecipação de parto de feto anencéfalo, tal tese é aceita por Cezar Roberto Bitencourt como causa excludente de culpabilidade ${ }^{539}$, pois “outra conduta não se pode exigir de uma aflita e desesperada gestante ${ }^{, 540}$. Segue o autor asseverando que obrigar a gestante a

\footnotetext{
${ }^{534}$ Nesse sentido, BITENCOURT, Cezar Roberto.Tratado de Direito Penal 2: parte especial: dos crimes contra a pessoa, $10^{\mathrm{a}}$ ed. São Paulo: Saraiva, 2010, p. 177.

${ }_{535}$ Para Bitencourt, o texto penal "deve ser adaptado à realidade atual mediante os métodos de interpretação, dando-lhe vida e atualidade para disciplinar as relações sociais deste início de novo milênio. Com efeito, o Direito Penal não pode ficar alheio ao desenvolvimento tanto da ciência quanto dos usos e costumes, bem como da evolução histórica do pensamento, da cultura e da ética em uma sociedade em constante mutação". BITENCOURT, Cezar Roberto.Tratado de Direito Penal 2: parte especial: dos crimes contra a pessoa, $10^{\mathrm{a}}$ ed. São Paulo: Saraiva, 2010, p. 173.

${ }^{536}$ BITENCOURT, Cezar Roberto.Tratado de Direito Penal 2: parte especial: dos crimes contra a pessoa, $10^{\mathrm{a}}$ ed. São Paulo: Saraiva, 2010, p. 174.

${ }^{537}$ Nucci ensina que a culpabilidade é "um juízo de reprovação social, incidente sobre o fato e seu autor, devendo o agente ser imputável, atuar com consciência potencial de ilicitude, bem como ter a possibilidade e a exigibilidade de atuar de outro modo, seguindo as regras impostas pelo direito". NUCCI, Guilherme de Souza. Código Penal Comentado. 10 ed. rev., atual e ampl. São Paulo: Editora Revista dos Tribunais, 2010, p. 231.

${ }_{538}$ NUCCI, Guilherme de Souza. Código Penal Comentado. $10^{\mathrm{a}}$ ed. rev., atual e ampl. São Paulo: Editora Revista dos Tribunais, 2010, p. 240-241.

${ }^{539}$ A culpabilidade para o autor seria o "juízo de reprovação social" e é composto pela imputabilidade e consciência da ilicitude, isto é, considera-se culpado alguém que praticou um fato quando outra conduta lhe era exigida e, por essa razão, na tese da inexigibilidade de conduta exclui-se a culpabilidade. BITENCOURT, Cezar Roberto.Tratado de Direito Penal 2: parte especial: dos crimes contra a pessoa, $10^{\mathrm{a}}$ ed. São Paulo: Saraiva, 2010, p. 180.

${ }^{540}$ BITENCOURT, Cezar Roberto.Tratado de Direito Penal 2: parte especial: dos crimes contra a pessoa, $10^{\mathrm{a}}$ ed. São Paulo: Saraiva, 2010, p. 180.
} 
aguardar o nascimento de um bebê sem expectativa de vida é violar o princípio da dignidade humana, pois é patentemente desumano, "social e juridicamente impossível",541.

No que tange à aplicabilidade da tese, Guilherme de Souza Nucci a entende "razoável" "542, apesar de que podem existir abusos e isso deve ser evitado. Como já observamos, para Nucci, referida tese afirma que o direito penal protegeria "a vida humana e não a falsa existência, pois o feto ou embrião só está 'vivo' por conta do organismo materno que o sustenta" ${ }^{\natural 43}$, impedindo que a mulher mantenha até o final uma gravidez de "um ser que, logo ao nascer, perecerá”. Para ele, a inexigibilidade de conduta diversa seria uma causa "supralegal de exclusão da culpabilidade", admissível no nosso ordenamento - e, razoável, como vimos acima - embora fossem necessários alguns requisitos nem sempre observados.

Nucci alerta para o fato de que tal tese poderia permitir a aplicação da eugenia ${ }^{544}$, na qual se autorizaria o aborto de fetos ou embriões que não estivessem "encaixados" nos padrões determinantes da viabilidade ${ }^{545}$, e questiona qual o bem protegido nesses dois casos distintos, de um aborto em que não há viabilidade de vida extrauterina e de um aborto de um feto não adequado ao certos padrões de viabilidade: a diferença seria a existência de expectativa de vida em um caso e o nascimento com vida no outro?

Em busca de respostas, Nucci remonta os pensamentos de Nelson Hungria e Paulo José da Costa Júnior, entre outros, a fim de afirmar que o ordenamento protege a vida do feto e que anomalias que o caracterizariam como "monstruoso" não podem permitir o aborto, garantindo-lhe proteção legal. Em outras palavras, entende que a proteção da vida humana

\footnotetext{
${ }^{541}$ BITENCOURT, Cezar Roberto.Tratado de Direito Penal 2: parte especial: dos crimes contra a pessoa, $10^{\mathrm{a}}$ ed. São Paulo: Saraiva, 2010, p. 180.

${ }_{542}$ NUCCI, Guilherme de Souza. Código Penal Comentado. $10^{a}$ ed. rev., atual e ampl. São Paulo: Editora Revista dos Tribunais, 2010, p. 634.

${ }^{543}$ NUCCI, Guilherme de Souza. Código Penal Comentado. 10ª ed. rev., atual e ampl. São Paulo: Editora Revista dos Tribunais, 2010, p. 634.

${ }^{544}$ Cezar Roberto Bitencourt não equipara o aborto em decorrência da anencefalia ao aborto eugênico ou eugenésico. Esse aborto ocorreria em decorrência de "valores racistas, sexistas, étnicos". O autor defende o aborto eugenésico se valendo da teoria de excludente de culpabilidade da inexigibilidade de conduta diversa e propõe que o termo seja analisado "racionalmente, sem a indesejável e prejudicial carta de rejeição emocional" por conta do uso feito do termo na Alemanha. Além disso, considera a interrupção em caso de anencefalia como "interrupção seletiva da gestação (ISG)" em casos de anomalias fetais incompatíveis com a vida extrauterina. BITENCOURT, Cezar Roberto.Tratado de Direito Penal 2: parte especial: dos crimes contra a pessoa, $10^{\mathrm{a}}$ ed. São Paulo: Saraiva, 2010, p. 169, 174-175. Em sentido contrário, Luiz Regis Prado entende que a anencefalia seria uma das hipóteses de doenças incuráveis, embora o autor considere um fato atípico em razão da constatação da inexistência de vida e, portanto, não tipifica o crime de aborto. PRADO, Luiz Regis. Curso de Direito Penal Brasileiro, volume 2: parte especial, arts 121 a 249, $8^{\text {a }}$ ed. rev. atual. e ampl. São Paulo: Editora Revista dos Tribunais, 2010, p. 117-120. Vide também conceito de eugenia na [N.R.] 442.

${ }^{545}$ NUCCI, Guilherme de Souza. Código Penal Comentado. $10^{\mathrm{a}}$ ed. rev., atual e ampl. São Paulo: Editora Revista dos Tribunais, 2010, p.635.
} 
alcança tanto a "criança nascida quanto àquela que se encontra em gestação" 546 " "monstruosa" ou não 547 .

Salienta ainda Nucci que "a eventual curta expectativa de vida do futuro recémnascido" 548 não poderia permitir a interrupção da gravidez, pois, do mesmo modo que nosso ordenamento jurídico não aceita a eutanásia em vista da curta expectativa de um doente

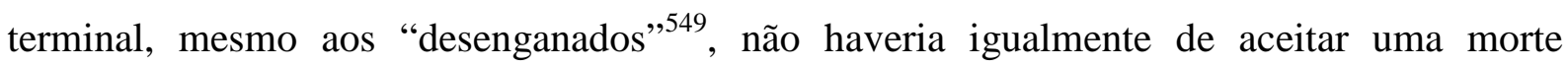
provocada por terceiros no caso do feto.

Assim, Nucci afirma que a vida deve ser protegida, independentemente de anomalias, e que a proteção à vida é extensiva ao ser em gestação e depois de seu nascimento ${ }^{550}$.

Por outro lado, há quem afirme ainda que a situação deve ser solucionada no plano da atipicidade de conduta, e não em vista de uma possível inexigibilidade de conduta diversa.

Luiz Regis Prado, por exemplo, ensina que a antecipação do parto nos casos de anencefalia "não tipifica" o delito de aborto, pois existe "um desvalor de situação ou de estado que ingressa no âmbito do risco permitido, atuando como excludente do desvalor da ação" 551 . Isto porque, para o autor, não há lesão ou perigo de lesão ao "bem jurídico tutelado, uma vez que o anencéfalo não é biologicamente capaz de concretizar-se em uma vida humana viável" ${ }^{, 552}$, isto é, a falta de viabilidade seria justificativa suficiente para afirmar a inexistência de dolo ou culpa, constituindo, portanto, o caso, verdadeiro fato atípico ${ }^{553}$.

\footnotetext{
${ }^{546}$ NUCCI, Guilherme de Souza. Código Penal Comentado. 10ª ed. rev., atual e ampl. São Paulo: Editora Revista dos Tribunais, 2010, p. 635.

${ }^{547}$ NUCCI, Guilherme de Souza. Código Penal Comentado. 10ª ed. rev., atual e ampl. São Paulo: Editora Revista dos Tribunais, 2010, p. 635.

${ }^{548}$ NUCCI, Guilherme de Souza. Código Penal Comentado. 10ª ed. rev., atual e ampl. São Paulo: Editora Revista dos Tribunais, 2010, p. 635-636.

${ }^{549}$ NUCCI, Guilherme de Souza. Código Penal Comentado. 10 a ed. rev., atual e ampl. São Paulo: Editora Revista dos Tribunais, 2010, p. 635-636.

${ }^{550}$ NUCCI, Guilherme de Souza. Código Penal Comentado. 10ª ed. rev., atual e ampl. São Paulo: Editora Revista dos Tribunais, 2010, p. 635.

${ }^{551}$ PRADO, Luiz Regis. Curso de Direito Penal Brasileiro, volume 2: parte especial, arts 121 a 249, $7^{\mathrm{a}}$ ed. rev. atual. e ampl. São Paulo: Editora Revista dos Tribunais, 2010, p. 119.

${ }^{552}$ PRADO, Luiz Regis. Curso de Direito Penal Brasileiro, volume 2: parte especial, arts 121 a 249, $7^{\mathrm{a}}$ ed. rev. atual. e ampl. São Paulo: Editora Revista dos Tribunais, 2010, p. 119.

${ }_{553}$ PRADO, Luiz Regis. Curso de Direito Penal Brasileiro, volume 2: parte especial, arts 121 a 249, $7^{\text {a }}$ ed. rev. atual. e ampl. São Paulo: Editora Revista dos Tribunais, 2010, p. 119-120. Para Luiz Flávio Gomes, o aborto anencefálico não é materialmente típico porque "no âmbito da tipicidade material, que exige três juízos valorativos distintos: $1^{\circ}$ ) juízo de desaprovação da conduta (cabe ao juiz verificar o desvalor da conduta, ou seja, se o agente, com sua conduta, criou ou incrementou um risco proibido relevante); $2^{\circ}$ ) juízo de desaprovação do resultado jurídico (isto é, desvalor do resultado que consiste na ofensa desvaliosa ao bem jurídico) e $3^{\circ}$ ) juízo de imputação objetiva do resultado (o resultado deve ser a realização do risco criado ou incrementado)" não se "tem presente a verdadeira e atual extensão do tipo penal, que abrange (a) a dimensão formal-objetiva (conduta, resultado naturalístico, nexo de causalidade e adequação típica formal à letra da lei); (b) a dimensão materialnormativa (desvalor da conduta + desvalor do resultado jurídico + imputação objetiva desse resultado) e (c) a dimensão subjetiva (nos crimes dolosos)" o aborto "elimina a dimensão material-normativa do tipo (ou seja: a tipicidade material) porque a morte, nesse caso, não é arbitrária, não é desarrazoada. Não há que se falar em resultado jurídico desvalioso nessa situação" e, portanto, para o autor o fato é atípico. GOMES, Luiz Flávio.
} 
Assim, como vimos, no caso de inexigibilidade de conduta diversa, não se poderia exigir da gestante ou médico outro comportamento senão aquele praticado no caso concreto o aborto ${ }^{554}$. Diferentemente, no plano da atipicidade, no entanto, conforme Luiz Regis Prado, o aborto do anencéfalo simplesmente não violaria o bem jurídico tutelado pelo Direito Penal em vista da falta de viabilidade do feto ${ }^{555}$.

Com relação ao outro argumento comumente utilizado sobre a proteção psíquica da gestante, Nucci também o refuta, no sentido de que não seria possível apoiar-se somente nos "abalos psicológicos" dos pais para autorizar o aborto, pois a medicina avança a cada dia, o que poderia alterar a "expectativa de vida e de cura" 556 do feto, embora não sejam raras as justificativas para permitir a prática do aborto que levam em conta o fator do sofrimento e angústia, em especial da gestante ${ }^{557}$, considerando outros valores que estão em jogo como o direito à vida do feto versus o direito à uma vida digna do feto, a saúde psíquica e física da mãe, além de sua autonomia de vontade e de sua liberdade privada de dispor do próprio corpo $^{558}$.

No entanto, a despeito de todos os argumentos apresentados, principalmente aqueles que rechaçam a prática do aborto, admite Guilherme Nucci que um feto incapaz de sobreviver fora do útero por causa de uma má-formação não tem "vida própria", já que "sobrevive à custa do organismo da gestante" ${ }^{, 559}$, e destaca que deformidades graves como, por exemplo, aquelas capazes de obstar a vida - dentre as quais se destaca a anencefalia -, seria razão "mais que suficiente para a realização do aborto, que não é baseado, porém, em características

\footnotetext{
Aborto Anencefálico: exclusão da tipicidade material. Disponível em: <http://jus.uol.com.br/revista/texto/8561/aborto-anencefalico>. Acesso em: 20 jan. 2011.

${ }^{554}$ BITENCOURT, Cezar Roberto.Tratado de Direito Penal 2: parte especial: dos crimes contra a pessoa, $10^{\mathrm{a}}$ ed. São Paulo: Saraiva, 2010, p. 180.

${ }_{555}$ PRADO, Luiz Regis. Curso de Direito Penal Brasileiro, volume 2: parte especial, arts 121 a $249,7^{\mathrm{a}} \mathrm{ed}$. rev. atual. e ampl. São Paulo: Editora Revista dos Tribunais, 2010, p. 119-120.

${ }^{556}$ NUCCI, Guilherme de Souza. Código Penal Comentado. 10 ${ }^{\mathrm{a}}$ ed. rev., atual e ampl. São Paulo: Editora Revista dos Tribunais, 2010, p. 635.

${ }_{557}$ Nesse sentido, BITENCOURT, Cezar Roberto.Tratado de Direito Penal 2: parte especial: dos crimes contra a pessoa, $10^{\mathrm{a}}$ ed. São Paulo: Saraiva, 2010, p. 171.

558 Vide BITENCOURT, Cezar Roberto.Tratado de Direito Penal 2: parte especial: dos crimes contra a pessoa, $10^{a}$ ed. São Paulo: Saraiva, 2010, p. 176, p. 181-182 e voto do Ministro Joaquim Barbosa do Supremo Tribunal Federal em Habeas Corpus 84.025-6/RJ. GOMES, JOAQUIM BARBOSA. Voto proferido pelo Ministro Joaquim Barbosa Gomes HC no 84.025/2004. In: SARMENTO, Daniel; PIOVESAN, Flávia (coordenadores). Nos Limites da Vida. Rio de Janeiro: Lúmen Júris, 2006, p. 73-92. Disponível também em: www.stf.jus.br>. Acesso em: 10 jan. 2012. Vide ainda comentários de Fernando Rey Martínez que ensina que a proibição do tratamento desumano e degradante abrange o princípio da dignidade humana, autodeterminação, liberdade ideológica e religiosa e a proteção do direito à família. REY, Fernando Martínez. Eutanasia y Derechos Fundamentales. Madrid: Centro de Estúdios Políticos Y Constitucionales, 2008, p. 82.

559 NUCCI, Guilherme de Souza. Código Penal Comentado. $10^{\mathrm{a}}$ ed. rev., atual e ampl. São Paulo: Editora Revista dos Tribunais, 2010, p. 636.
} 
monstruosas do ser em gestação, e sim na sua completa inviabilidade como pessoa, com vida autônoma, fora do útero materno" ${ }^{, 560}$.

Assim, alguns asseveram que os dispositivos do Código Penal pretendem preservar a vida em potencial e a incolumidade da gestação, o que não ocorre com o feto anencéfalo, diante do fato de que, embora "biologicamente vivo"561 - e, portanto, com alguma probabilidade de nascer com vida - não teria proteção jurídica" ${ }^{, 562}$. Desse modo, no momento em que se constatou a inviabilidade de vida extrauterina e a irreversibilidade da anencefalia, também não há que se falar em arbitrariedade ${ }^{563}$, além de deixar o feto de ser amparado pelo Código Penal.

Luiz Regis Prado entende que não se aplicaria o critério de "morte cerebral" ao feto anencéfalo, dada a inexistência de cérebro, embora ainda existam algumas funções vegetativas ${ }^{564}$. Para o autor, o critério mais adequado seria o de "morte neocortical (high brain criterion)", que é capaz de estabelecer a primazia da "consciência, afetividade e comunicação, em detrimento do aspecto biológico da vida". ${ }^{565}$ Afirma que nesses casos, "o feto não poderia

\footnotetext{
${ }^{560} \mathrm{O}$ autor cita o trabalho de José Aristodemo Pinotti que afirma ainda que a chance de um equívoco na apuração da anencefalia é praticamente inexistente quando realizado e repetido o exame com profissionais experientes e que a gestação de fetos portadores de anencefalia regularmente trazem mais risco à gestante. Vide NUCCI, Guilherme de Souza. Código Penal Comentado. 10 $0^{a}$ ed. rev., atual e ampl. São Paulo: Editora Revista dos Tribunais, 2010, p. 636. Vale mencionar ainda que a possibilidade de incidência de erro não deve ser suficiente para decidir ou não pela legalização do aborto. Conforme Fernando Rey Martínez, o risco de abusos pode ser combatido com garantias procedimentais e, inclusive a posteriori, eventuais erros não podem embasar uma proibição absoluta. REY MARTÍNEZ, Fernando. Eutanasia y Derechos Fundamentales. Madrid: Centro de Estúdios Políticos Y Constitucionales, 2008, p. 160.

${ }^{561}$ Para Luiz Regis Prado, não poderia o feto anencéfalo ser visto como "tecnicamente vivo", vez que para o autor, não há vida humana a ser protegida. PRADO, Luiz Regis. Curso de Direito Penal Brasileiro, volume 2: parte especial, arts 121 a 249, $7^{\mathrm{a}}$ ed. rev. atual. e ampl. São Paulo: Editora Revista dos Tribunais, 2010, p. 119.

${ }_{562}$ Vide voto do Ministro Joaquim Barbosa do Supremo Tribunal Federal em Habeas Corpus 84.025-6/RJ. GOMES, JOAQUIM BARBOSA. Voto proferido pelo Ministro Joaquim Barbosa Gomes HC no 84.025/2004. In: SARMENTO, Daniel; PIOVESAN, Flávia (coordenadores). Nos Limites da Vida. Rio de Janeiro: Lúmen Júris, 2006, p. 73-92. Disponível também em: www.stf.jus.br>. Acesso em: 20 jan. 2012.

563 [N.R.] Não violando, portanto, o artigo $4^{\circ}$ da Convenção Americana de Direitos Humanos.

${ }^{564}$ PRADO, Luiz Regis. Curso de Direito Penal Brasileiro, volume 2: parte especial, arts 121 a 249, $8^{\mathrm{a}}$ ed. rev. atual. e ampl. São Paulo: Editora Revista dos Tribunais, 2010, p. 119. Nesse diapasão, "o feto anencefálico conta com má formação do cérebro, mas não se pode afirmar a sua morte cerebral. Feto anencefálico tem vida cerebral. O cérebro é mal formado, mas funciona". GOMES, Luiz Flávio. Aborto Anencefálico: exclusão da tipicidade material. Disponível em: <http://jus.uol.com.br/revista/texto/8561/aborto-anencefalico>. Acesso em: 20 jan. 2011. Não existe consenso para a aplicação de diagnóstico de morte encefálica a menores de 7 anos e prematuros. Vide Resolução 1480/97 do Conselho Federal de Medicina. BRASIL. Conselho Federal de Medicina. Resolução 1480 de 21 de agosto de 1997, que define os critérios para diagnóstico de morte encefálica. Disponível em: < http://www.portalmedico.org.br/resolucoes/CFM/1997/1480_1997.htm>. Acesso em: 10 jan. 2011.

${ }^{565}$ PRADO, Luiz Regis. Curso de Direito Penal Brasileiro, volume 2: parte especial, arts 121 a 249, $8^{\text {a }}$ ed. rev. atual. e ampl. São Paulo: Editora Revista dos Tribunais, 2010, p. 119.
} 
ser considerado como "tecnicamente vivo",566, faltando a "vida humana intra-uterina a ser tutelada" ${ }^{567}$.

De outro lado, considera Cezar Roberto Bitencourt que o critério utilizado pela lei de doação de órgãos ${ }^{568}$ pode ser admitida para justificar o aborto no caso da anencefalia através de mero raciocínio lógico-jurídico ${ }^{569}$. Para o autor, o legislador brasileiro seguiu o conceito de "morte cerebral" substituindo o critério anterior da parada cardio-respiratória ${ }^{570}$ para a retirada de órgãos para transplante e, na visão dele, referida lei "não está autorizando um homicídio" ${ }^{, 571 .}$.

Tendo em vista o que foi discutido acima, seja na esfera do direito constitucional, civil ou penal, a respeito do aborto, passemos a tratar a seguir especificamente do aborto em decorrência da inviabilidade da vida extrauterina, abordando o conceito de anencefalia, os principais aspectos ético-jurídicos que o tema invoca, e como o assunto tem sido tratado pelo Poder Judiciário brasileiro.

\footnotetext{
${ }^{566}$ PRADO, Luiz Regis. Curso de Direito Penal Brasileiro, volume 2: parte especial, arts 121 a 249, $8^{\text {a }}$ ed. rev. atual. e ampl. São Paulo: Editora Revista dos Tribunais, 2010, p. 119.

${ }^{567}$ PRADO, Luiz Regis. Curso de Direito Penal Brasileiro, volume 2: parte especial, arts 121 a 249, $8^{\text {a }}$ ed. rev. atual. e ampl. São Paulo: Editora Revista dos Tribunais, 2010, p. 119. Vide interessante questionamento: "Será que "é a expectativa de trazer ao mundo um novo ser que faz projetá-lo como indivíduo independente ou é o prognóstico de existência que justifica o direito inalienável à vida"? BRASIL. Tribunal do Júri de Campo Grande/MS. Juiz Carlos Alberto Garcete da $1^{\text {a }}$ Vara.

${ }^{568}$ Artigo $3^{\circ}$, Lei 9434/97 in verbis: "A retirada post mortem de tecidos, órgãos ou partes do corpo humano destinados a transplante ou tratamento deverá ser precedida de diagnóstico de morte encefálica, constatada e registrada por dois médicos não participantes das equipes de remoção e transplante, mediante a utilização de critérios clínicos e tecnológicos definidos por resolução do Conselho Federal de Medicina". BRASIL. Lei no 9.434, de 4 de fevereiro de 1997. Dispõe sobre a remoção de órgãos, tecidos e parte do corpo humano para fins de transplante e tratamento e dá outras providências. Disponível em: < http://www.planalto.gov.br/ccivil_03/leis/L9434.htm>. Acesso em: 10 jan. 2011.

${ }^{569}$ Ensina o autor que "a simples 'morte cerebral' - que mantém os demais órgãos do corpo humano 'vivos' autoriza a extração de todos esses órgãos, imediatamente, isto é, enquanto vivos, pois mortos, de nada serviriam". BITENCOURT, Cezar Roberto.Tratado de Direito Penal 2: parte especial: dos crimes contra a pessoa, $10^{\text {a }}$ ed. São Paulo: Saraiva, 2010, p. 177.

570 Para o autor, o conceito outrora médico e agora legal, considera que a "vida não se encerra somente quando o coração deixa de bater". BITENCOURT, Cezar Roberto.Tratado de Direito Penal 2: parte especial: dos crimes contra a pessoa, 10ª ed. São Paulo: Saraiva, 2010, p. 177-178. A Resolução 1480 de 08 ago. 1997 do Conselho Federal de Medicina esclareceu que se dá a morte do indivíduo com "a parada total e irreversível das funções encefálicas" constatada pela realização de exames clínicos e complementares. Os parâmetros clínicos são "coma aperceptivo com ausência de atividade motora supra-espinal e apnéia", sendo certo que não poderão existir dúvidas sobre a "ausência de atividade elétrica cerebral ou, ausência de atividade metabólica cerebral ou, ausência de perfusão sangüínea cerebral". BRASIL. Conselho Federal de Medicina. Resolução 1480 de 21 de agosto de 1997, que define os critérios para diagnóstico de morte encefálica. Disponível em: < http://www.portalmedico.org.br/resolucoes/CFM/1997/1480_1997.htm>. Acesso em: 10 jan. 2011.

${ }^{571}$ BITENCOURT, Cezar Roberto.Tratado de Direito Penal 2: parte especial: dos crimes contra a pessoa, $10^{\mathrm{a}}$ ed. São Paulo: Saraiva, 2010, p. 177. Como veremos, é difícil determinar a morte encefálica do feto com anencefalia. Comitato nazionale per la bioetica. "Il neonato anencefalico e la donazione di organi". 21 giugno 1996. p. 16. Relatório do Comitê Nacional de Bioética Italiano - 21 de junho de 1996. Versão em português disponível em: http://www.providaanapolis.org.br/cnbport.htm>. Acesso em: 26 abr. 2011.
} 


\section{PARTE II - ABORTO DO FETO ANENCÉFALO}

\section{CONTROVÉRSIAS SOBRE A PROTEÇÃO DO DIREITO À VIDA NO CASO DE ABORTO EM DECORRÊNCIA DE INVIABILIDADE DA VIDA EXTRAUTERINA}

O conflito entre o direito ao aborto por parte da mãe, e o direito à vida do feto anencéfalo, sem dúvida é polêmica. É legal suprimir a vida de um feto anencéfalo? Em que momento o feto passa a ser detentor de direitos? Somente a vida saudável, viável e consciente ${ }^{572}$ estaria protegida? Será que admitir o aborto do feto anencéfalo seria "o começo do caminho que leva à despersonalização do homem" ${ }^{, 573}$ ? O estágio de desenvolvimento do ser humano ${ }^{574}$ deveria determinar sua proteção ou não?

\subsection{ANENCEFALIA}

O aborto do feto anencéfalo ainda suscita inúmeros debates e, para muitos autores, é uma espécie do gênero aborto eugênico ${ }^{575}$.

Maria Helena Diniz encara o aborto de feto anencéfalo como uma prática da interrupção seletiva de gravidez, verdadeira prática eugênica ${ }^{576}$, questionando, inclusive, a

\footnotetext{
${ }^{572}$ MARTINS FILHO, Ives Gandra da Silva. O direito à vida e o aborto do anencéfalo. In: MARTINS, Ives Gandra da Silva; MARTINS, Roberto Vidal da Silva; MARTINS FILHO, Ives Gandra da Silva. A Questão do Aborto: Aspectos Jurídicos Fundamentais. São Paulo: Quartier Latin, 2008, p. 118.

${ }^{573}$ MARTINS FILHO, Ives Gandra da Silva. O direito à vida e o aborto do anencéfalo. In: MARTINS, Ives Gandra da Silva; MARTINS, Roberto Vidal da Silva; MARTINS FILHO, Ives Gandra da Silva. A Questão do Aborto: Aspectos Jurídicos Fundamentais. São Paulo: Quartier Latin, 2008, p. 120.

${ }^{574}$ Ives Grandra esclarece que não há diferença da natureza do nascido e nascituro, já que ambos são seres humanos, mas de grau. MARTINS FILHO, Ives Gandra da Silva. O direito à vida e o aborto do anencéfalo. In: MARTINS, Ives Gandra da Silva; MARTINS, Roberto Vidal da Silva; MARTINS FILHO, Ives Gandra da Silva. A Questão do Aborto: Aspectos Jurídicos Fundamentais. São Paulo: Quartier Latin, 2008, p. 120.

${ }^{575}$ FUJITA, Jorge Shiguemitsu. Aborto: o cerceamento da vida de um ser humano indefeso. In: Dignidade da vida Humana. Migliore, Alfredo Domingues Barbosa [et al.] (coordenadores). São Paulo: Editora LTR, 2010, p. 82. Em sentido contrário, Cezar Roberto Bittencourt não equipara o aborto de feto anencéfalo como uma espécie de aborto eugênico. BITENCOURT, Cezar Roberto.Tratado de Direito Penal 2: parte especial: dos crimes contra a pessoa, $10^{\mathrm{a}}$ ed. São Paulo: Saraiva, 2010, p. 169, 174-175.

${ }^{576}$ DINIZ, Maria Helena. O Estado Atual do Biodireito. São Paulo: Saraiva, 2009, p. 32.Vide [N.R.] 443.
} 
possibilidade de interromper-se a gravidez no caso de uma "malformação fetal ou de patologias incompatíveis com a vida extra-uterina" ${ }^{477}$, como ocorre na anencefalia, por exemplo $^{578}$.

Para outros autores, no entanto, a anencefalia é uma doença que causa a inviabilidade absoluta da vida extrauterina do feto, constituindo, portanto, uma das doenças mais letais dentre aquelas decorrentes de defeitos $\operatorname{congênitos~}^{579} \mathrm{e}$, por essa razão, difere do aborto eugênico $^{580}$. Pelos danos e riscos à saúde envolvidos em um gestação tal, o aborto seria terapêutico $^{581}$.

Anencefalia significa literalmente "ausência de cérebro", embora nem sempre esteja caracterizada pela ausência total $^{582}$ do encéfalo ${ }^{583}$. Poderia ser conceituada como sendo uma rara $^{584}$ má-formação do tubo neural, ocorrida entre o $16^{\circ}$ e $26^{\circ}$ dias de gravidez, originada pelo não fechamento adequado do tubo neural durante a formação embrionária, o que acarreta a ausência total ou parcial "dos tecidos recobertos" 585 pela caixa ou calota craniana, bem como a ausência total ou parcial desta ${ }^{586}$.

577 DINIZ, Maria Helena. O Estado Atual do Biodireito. São Paulo: Saraiva, 2009, p. 44.
${ }^{578}$ DINIZ, Maria Helena. O Estado Atual do Biodireito. São Paulo: Saraiva, 2009, p. $44-46$.
${ }^{779}$ JAQUIER, M; KLEIN, A; BOLTSHAUSER, E. Spontaneous pregnancy outcome after prenatal diagnosis of
anencephaly. Short Comunication. In.: International Journal of Gynecology and Obstetrics (2006) 102, 99, p. 951.

${ }^{580}$ Vide: BRASIL. Supremo Tribunal Federal. Arguição de Descumprimento de Preceito Fundamental n ${ }^{\circ}$ 54-8. Petição Inicial p. 4. Disponível em: <www.stf.jus.> Acesso em: 26. abr. 2011. Vide também a assertiva de Guilherme Nucci, no sentido de que na anencefalia não há viabilidade extrauterina do feto de forma autônoma. Não se trata, para o autor, de defeitos "compatíveis com a vida". NUCCI, Guilherme de Souza. Código Penal Comentado. 10 ed. rev., atual e ampl. São Paulo: Editora Revista dos Tribunais, 2010, p. 636.

${ }^{581}$ DINIZ, Maria Helena. O Estado Atual do Biodireito. São Paulo: Saraiva, 2009, p. 32.

582 "letteralmente anencefalia significa assenza dell'encefalo. (...) Si verifica quindi, assenza degli emisferi cerebrali e dei tessuti cranici che li racchiudono, con presenza del tronco encefalico e di porzioni variabili del diencefalo. La assenza degli emisferi e del cervelletto può essere variabile, come variabile può essere il difetto della volta cranica. La superficie nervosa è coperta da un tessuto spugnoso, costituito da tessuto esposto degenerato". Comitato nazionale per la bioetica. "Il neonato anencefalico e la donazione di organi". 21 giugno 1996. p. 9. Relatório do Comitê Nacional de Bioética Italiano - 21 de junho de 1996. Versão em português disponível em: 〈http://www.providaanapolis.org.br/cnbport.htm〉. Acesso em: 26 abr. 2011.

${ }_{583}$ Encéfalo "é formado pelo cérebro, cerebelo e tronco encefálico" e cerebelo "é a grande massa encefálica situada posteriormente à ponte e ao bulbo e inferiormente à parte posterior do cérebro. Situa-se sob o tentório do cerebelo na fossa posterior do crânio. Consiste em dois hemisférios laterais unidos por uma parte intermediária estreita, o verme". MOORE, Keith L; Dalley, Arthur, F. Anatomia Orientada para Clínica. Colaboração de Anne M.R.Agur; assistência no desenvolvimento de Marion E. Moore; revisão técnica Marco Autélio Fonseca Passos; tradução Cláudia Lúcia Caetano de Araújo. Rio de Janeiro: Guanabara Koogan, 2007, p. 853.

${ }^{584}$ Por exemplo, estima-se que ocorre 1 caso a cada 1000 no mundo. OBEIDE, Nidaa et al. The Natural History of Anencephaly. Prenatal Diagnosis, 2010. 30: 357.

585 "In realtà si definisce con tale termine una rara malformazione del tubo neurale intervenuta tra il sedicesimo ed il ventiseiesimo giorno di gestazione, in cui si ha «assenza completa o parziale della volta cranica e dei tessuti sovrastanti e vario grado di malformazione e distruzione degli abbozzi di cervello esposto". Comitato nazionale per la bioetica. "Il neonato anencefalico e la donazione di organi". 21 giugno 1996. p. 9. Relatório do Comitê Nacional de Bioética Italiano - 21 de junho de 1996. Versão em português disponível em: <http://www.providaanapolis.org.br/cnbport.htm〉. Acesso em: 26 abr. 2011. Para Paulo Silveira Martins Leão Júnior, há uma "falha no processo de formação do embrião, entre o $16^{\circ}$ e $26^{\circ}$ dia de gestação, em razão da qual se verifica a ausência variável da calota craniana, dos tecidos que a ela se sobrepõem, dos hemiférios cerebrais e 
Assim, a anencefalia é um problema bem definido de um ponto de vista médico, e nem toda má-formação cerebral deve ser tratada como anencefalia ${ }^{587}$. A anencefalia é uma dentre tantas outras más-formações do encéfalo, e, além disso, a probabilidade de nascimento com vida e de vida extrauterina varia conforme a espécie de má-formação verificada e o grau desta, sendo certo que no caso específico da anencefalia estritamente definida, o feto tem uma sobrevida muito limitada ${ }^{588}$. Ao longo deste trabalho, sempre nos referiremos à anencefalia de modo preciso, conforme definida tecnicamente e exposto acima.

Além disso, outros aspectos devem ser levados em conta na análise do feto anencéfalo. A inexistência do córtex cerebral e estruturas essenciais às funções cerebrais superiores trazem um status diferenciado ao anencéfalo - não de morte cerebral, mas de ausência cerebral $^{589}$.

\subsection{PRINCIPAIS ASPECTOS ÉTICO-JURÍDICOS NO CASO DA ANENCEFALIA}

cerebelo". LEÃO JÚNIOR, Paulo Silveira Martins. O Direito Fundamental à Vida dos Embriões e Anencéfalos. In: Direito Fundamental à Vida. MARTINS, Ives Gandra da Silva (coord). São Paulo: Quartier Latin/Centro de Extensão Universitária, 2005. p. 244.

${ }_{586}^{8}$ [N.R.]Como vimos, a sua presença é variável.

587 “È questo il quadro di riferimento generale della malformazione anencefalica; non si deve tuttavia pensare che questa malformazione sia una entità strettamente definibile. L'Autore di un testo qualificato sull'anencefalia si stupisce, a ragione, della varietà di denominazioni e di classificazioni esistenti in letteratura sull'argomento. La difficoltà di classificazione si basa sul fatto che l'anencefalia non è una malformazione di tipo tutto-nulla, non è quindi o presente o assente, ma si tratta di una malformazione che passa, senza soluzione di continuità, dai quadri meno gravi ai quadri di indubitabile anencefalia. Una classificazione rigida è quindi pressoché impossibile. Alcune malformazioni del sistema nervoso centrale sono per alcuni aspetti accostabili all'anencefalia, ma da non confondere con essa. Tra queste ricordiamo: - la sindrome della banda amniotica (in cui può essere presente anencefalia associata ad amputazioni, ma raramente malformazioni di organi interni); - la iniencefalia, in cui abbiamo malformazioni gravi della colonna cervicale e malformazioni multiple; - l'encefalocele, un difetto del tubo neurale in cui una parte dell'encefalo, più o meno gravemente malformato, ernia da un difetto di chiusura del cranio. Accanto a tali malformazioni si deve ricordare anche l'idrocefalia, le cui forme più gravi possono avere significato funzionale analogo a quello dell'anencefalia; per questo motivo anche tale malformazione è spesso citata nel dibattito sul feto anencefalico". Comitato nazionale per la bioetica. "Il neonato anencefalico e la donazione di organi". 21 giugno 1996. p. 9. Relatório do Comitê Nacional de Bioética Italiano - 21 de junho de 1996. Versão em português disponível em: <http://www.providaanapolis.org.br/cnbport.htm>. Acesso em: 26 abr. 2011.

${ }^{588}$ Maria Helena Diniz aponta que $8 \%$ de fetos anencéfalos sobrevivem mais de uma semana e que $1 \%$ sobrevive de 1 a 3 meses. Entre $40 \%$ a $60 \%$ dos fetos nascem com vida. DINIZ, Maria Helena. O Estado Atual do Biodireito. São Paulo: Saraiva, 2009, p. 55. Vale mencionar aqui o caso da Menina Marcela que sobreviveu mais de um ano e oito meses, foi inicialmente diagnosticada como feto anencéfalo, mas com exames mais sofisticados verificou-se a existência de partes do cérebro, descaracterizando, para alguns, a anencefalia. Disponível em: <http://www.estadao.com.br/estadaodehoje/20080803/not_imp216662,0.php〉. Acesso em: 26 abr. 2011.

589 "Tali funzioni vengono considerate da alcuni caratteristiche dell'umanità e questa grave malformazione configurerebbe per l'anencefalico uno status particolare; non avrebbe quindi senso parlare di «morte cerebrale», ma si dovrebbe parlare di " assenza cerebrale»". Comitato nazionale per la bioetica. "Il neonato anencefalico e la donazione di organi". 21 giugno 1996. p. 16. Relatório do Comitê Nacional de Bioética Italiano - 21 de junho de 1996. Versão em português disponível em: <http://www.providaanapolis.org.br/cnbport.htm>. Acesso em: 26 abr. 2011. 
A partir da análise do conceito técnico de anencefalia, vale a pena explicitar alguns argumentos que são considerados importantes, em especial, na esfera ético-jurídica, e que podem auxiliar o intérprete na decisão, tanto para a permissão, quanto para a proibição, do aborto em casos de anencefalia.

A exemplo do que acontece com a eutanásia e outros dilemas bioéticos, o aborto "evoca um tenso conflito entre matar e a autonomia pessoal" multidisciplinar no âmbito jurídico, médico, ético, religioso etc, prejudicando uma "satisfação

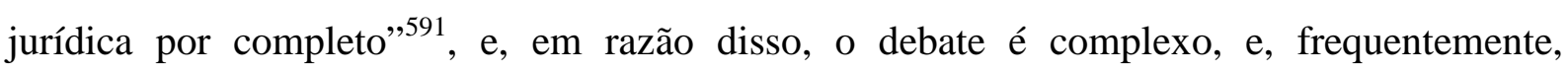
ideologizado $^{592}$. Por exemplo, em sociedades fortemente religiosas de um modo geral, muitas vezes, o debate é excessivamente permeado por valores religiosos que nem sempre correspondem aos anseios e entendimentos de uma sociedade plural e multiética ${ }^{593}$.

Especialmente na área da bioética ${ }^{594}$, existe uma grande "expectativa de que a lei reproduza o entendimento ético" 595 da sociedade, mas isso não significa dizer que as medidas legislativas devam apoiar totalmente concepções morais ou religiosas ${ }^{596}$.

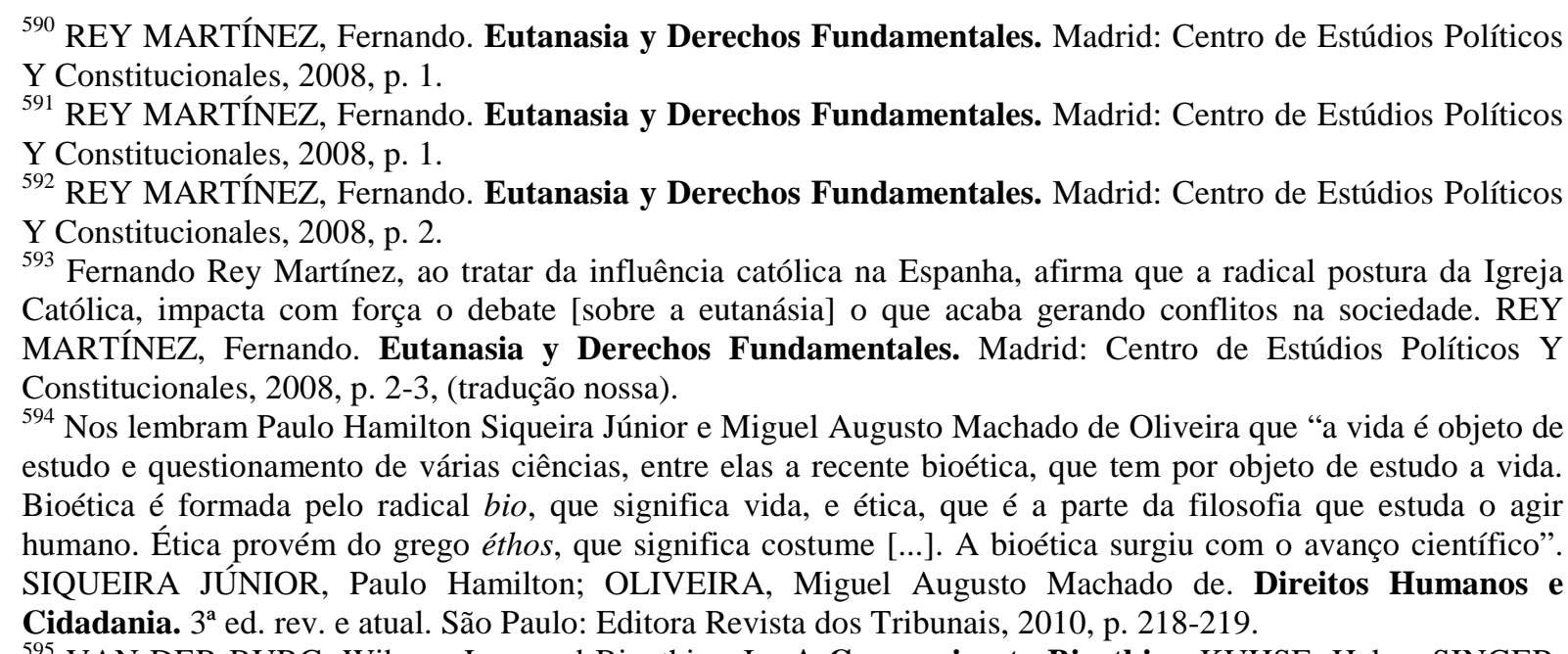
${ }_{595}$ VAN DER BURG, Wibren. Law and Bioethics. In: A Companion to Bioethics. KUHSE, Helga. SINGER, Peter. Massachusetts, EUA. Blackwell Publishing, 1998, p. 49-57. Guilherme Assis de Almeida e Eduardo C. B. Bittar ensinam que "a ciência intitulada Ética possui por objeto normas morais, enquanto a ciência entitulada Direito possui por objeto normas jurídicas. Não obstante as dificuldades que decorrem da compreensão desta decisão, é ela aceita como um ponto divisor de águas e limítrofe entre águas contíguas. Com isso, é possível divisar as preocupações jurídicas das preocupações éticas. Ética e Direito conjugam-se apesar de constituírem campos diversos de estudo, intercambiando valores e normas entre si. Dessa dialética é que ambos os fenômenos sobrevivem. Mais que tudo, há que se dizer que o tema de ética perpassa o exercício do Direito quotidianamente, pois grandes decisões que se projetam sobre a vida social passam por decisões de operadores do direito". BITTAR, Eduardo Carlos Bianca; ALMEIDA, Guilherme Assis de. Curso de Filosofia do Direito. $4^{\text {a }}$ ed. São Paulo: Atlas, 2005, p. 463.

596 "Não é necessário lembrar, no particular, a posição radical assumida pela Igreja Católica, que condena o aborto em qualquer circunstância - até mesmo naquelas hoje admitidas pela retrógrada legislação brasileira. Nem é preciso recordar que o catolicismo continua sendo a religião majoritária no país". SARMENTO, Daniel. 
Em primeiro lugar, devemos debater sobre qual o bem jurídico que deve ser protegido nos casos de anencefalia: o direito à vida do feto, o direito a uma vida digna (do feto, da gestante, ou de ambos), o direito à liberdade da gestante, o respeito à sua autonomia individual de dispor de seu próprio corpo, à sua integridade física e psíquica, ou ao seu direito à saúde e à vida?

Fernando Rey Martínez, ao tratar da eutanásia, faz uma observação sobre a autonomia individual que nos parece poder ser perfeitamente aplicável ao caso do aborto de feto anencéfalo: a descriminalização do aborto poderia ser entendida como uma maneira de reconhecer-se juridicamente a dignidade da pessoa humana pautada na autonomia individual (da gestante), o que se oporia à visão religiosa que entende a vida como dependente de Deus e, em razão disso, indisponível ${ }^{597}$.

Além disso, para Rey Martínez, a cláusula de dignidade deveria proteger o homem inclusive de definições de dignidade humana formuladas por terceiros, que podem ser válidas para quem as formulou, mas não podem ser impostas a outros que, por exemplo, não partilham os mesmos valores ${ }^{598}$.

Neste sentido, proibir a mulher de abortar sob fundamentos exclusivamente religiosos, poderia, ao menos em princípio, até estar de acordo com convicções sociais popularmente aceitas, mas não estaria de acordo com a ideia de laicidade do estado, e nem mesmo de democracia. Ao contrário, configuraria violação ao princípio da democracia que garante o pluralismo, uma vez que "o princípio básico subjacente à democracia é o de que as pessoas devem ser tratadas com igualdade" ${ }^{, 599}$. Embora a Constituição tenha abraçado o direito à liberdade de religião, adotou também o princípio da laicidade do estado. Nesse sentido, ensina Daniel Sarmento que este conceito de laicidade não apenas proíbe o estado de adotar ou apoiar uma religião oficial, mas também diz respeito à delimitação de "espaços próprios e inconfundíveis para o poder político e para a fé" ${ }^{600}$. Para o autor, a fé deve ser tratada como uma questão privada no estado laico ${ }^{601}$.

Legalização do Aborto e constituição. In: SARMENTO, Daniel; PIOVESAN, Flávia (coordenadores). Nos Limites da Vida. Rio de Janeiro: Lúmen Júris, 2006, p. 25.

${ }^{597}$ REY MARTÍNEZ, Fernando. Eutanasia y Derechos Fundamentales. Madrid: Centro de Estúdios Políticos Y Constitucionales, 2008, p. 4.

${ }_{598}^{5}$ REY MARTÍNEZ, Fernando. Eutanasia y Derechos Fundamentales. Madrid: Centro de Estúdios Políticos Y Constitucionales, 2008, p. 28.

${ }^{599}$ SARMENTO, Daniel. Legalização do Aborto e constituição. In: SARMENTO, Daniel; PIOVESAN, Flávia (coordenadores). Nos Limites da Vida. Rio de Janeiro: Lúmen Júris, 2006, p. 27.

600 "A laicidade do Estado, levada a sério, não se esgota na vedação de adoção explícita pelo governo de determinada religião, nem tampouco na proibição de apoio ou privilégio público a qualquer confissão. Ela vai além, e envolve a pretensão republicana de delimitar espaços próprios e inconfundíveis para o poder político e para a fé. No Estado laico, a fé é questão privada". SARMENTO, Daniel. Legalização do Aborto e constituição. 
Por essa razão, uma eventual autorização do aborto não deveria ser vista como um desrespeito às religiões ${ }^{602}$, mas como o pleno exercício da democracia.

Dworkin coloca em debate uma situação fática interessante: se os pais descobrem, no início da gestação, que seu feto possui uma má-formação "tão grave que sua vida após o nascimento será inevitavelmente breve e terrivelmente limitada"603, "a morte prematura passível de ser evitada é sempre, ou invariavelmente, a mais grave frustação de vida possível?" 604

Em outras palavras, Dworkin indaga se não poderia haver situações tão graves para o feto que a gestante deveria ser obrigada a abortar, na medida em que a gravidez continuada poderia trazer mais sofrimento, não só à gestante ela mesma, mas também, ao próprio feto ${ }^{605}$.

Neste sentido, é importante ressaltar que, além de existirem dificuldades de tratamento intransponíveis aos fetos acometidos de anencefalia, já que não há como impedir a evolução da doença ${ }^{606}$, há também entendimentos de que o feto possa ter um certo grau de capacidade

In: SARMENTO, Daniel; PIOVESAN, Flávia (coordenadores). Nos Limites da Vida. Rio de Janeiro: Lúmen Júris, 2006, p. 26.

${ }^{601}$ Continua o autor que "A laicidade do Estado não se compadece com o exercício da autoridade pública com fundamento em dogmas de fé - ainda que professados pela religião majoritária -, pois ela impõe aos poderes estatais uma postura de imparcialidade e equidistância em relação às diferentes crenças religiosas, cosmovisões e concepções morais que lhes são subjacentes". SARMENTO, Daniel. Legalização do Aborto e constituição. In: SARMENTO, Daniel; PIOVESAN, Flávia (coordenadores). Nos Limites da Vida. Rio de Janeiro: Lúmen Júris, 2006, p. 26.

${ }^{602}$ SARMENTO, Daniel. Legalização do Aborto e constituição. In: SARMENTO, Daniel; PIOVESAN, Flávia (coordenadores). Nos Limites da Vida. Rio de Janeiro: Lúmen Júris, 2006, p. 28.

${ }^{603}$ DWORKIN, Ronald. Domínio da Vida: aborto, eutanásia e liberdades individuais. Trad. Jefferson Luiz Camargo; rev. da tradução Silvana Vieira. São Paulo: Martins Fontes, 2003, p. 124.

${ }^{604}$ DWORKIN, Ronald. Domínio da Vida: aborto, eutanásia e liberdades individuais. Trad. Jefferson Luiz Camargo; rev. da tradução Silvana Vieira. São Paulo: Martins Fontes, 2003, p. 124.

${ }^{605}$ Friedrich Nietzsche em A Gaia Ciência trata da "Santa Crueldade" e expõe :- Um homem que tinha um recém-nascido nas mãos se aproximou de um santo. "Que devo fazer com esta criança?", perguntou. "É desgraçada, deformada e não tem vida que baste nem para morrer." "Mate-a!" gritou o santo com uma voz terrível; "E depois segure-a nos braços por três dias e três noites para criar uma lembrança para ti. Jamais voltarás a gerar um filho assim quando não é hora de procriares". Ao ouvir isso o homem se afastou, desapontado, e muitas pessoas censuraram o santo porque aconselhara crueldade; pois aconselhara o homem a matar a criança, "mas não é mais cruel deixá-la viva?", perguntou o santo homem. NIETZSCHE, Friedrich. A Gaia Ciência. Trad. Paulo César de Souza. São Paulo: Companhia das Letras, 2001, p. 103.

${ }^{606 ، ~ L a ~ d i s p o n i b i l i t a ̀ ~ d i ~ m e z z i ~ d i ~ t e r a p i a ~ i n t e n s i v a ~ a t t i ~ a l ~ s o s t e g n o ~ d e l l e ~ f u n z i o n i ~ v i t a l i ~ s u s c i t a ~ l a ~ d o m a n d a ~ s e ~ t a l i ~}$ mezzi debbano essere impiegati. Generalmente vi è accordo sul fatto che in questi casi, si debbano utilizzare solo mezzi ordinari di cura considerando che nessuna terapia, per quanto aggressiva, appare oggi in grado di modificare il decorso della malattia che risulta sempre mortale e che ha alla base l'assenza stessa delle strutture che la terapia intensiva dovrebbe momentaneamente vicariare $(37,38,39)$. Tali strutture non hanno alcuna possibilità di ripresa e ci si muoverebbe, quindi, in un campo di accanimento terapeutico privo di finalità e possibilità benefiche e, quindi, immotivato". Comitato nazionale per la bioetica. "Il neonato anencefalico e la donazione di organi". 21 giugno 1996. p. 14. Relatório do Comitê Nacional de Bioética Italiano - 21 de junho de 1996. Versão em português disponível em: 〈http://www.providaanapolis.org.br/cnbport.htm〉. Acesso em: 26 abr. 2011. 
de sentimentos, e que, portanto, possa ser afligido por dor e sofrimento ${ }^{607}$ diante da plasticidade neurológica do tronco, que existe mesmo nestes casos ${ }^{608}$.

Fernando Rey Martínez nos lembra que o direito à integridade pessoal é mais amplo que o direito à integridade física, e a proteção daquela pode, paradoxalmente, muitas vezes implicar a destruição desta ${ }^{609}$. O aborto do feto anencéfalo não seria um caso tal, em que a proteção da "integridade pessoal” do próprio feto implicaria sua própria destruição?

Socorre-nos mais uma vez Fernando Rey Martínez, que entende que, mesmo que não seja juridicamente possível exigir-se a continuidade da gravidez com base em concepções religiosas ou morais de dignidade ${ }^{610}$, também não se é possível deduzir-se deste fato que alguém que tenha graves sofrimentos tenha objetivamente uma vida indigna ${ }^{611}$, capaz até de justificar uma obrigação de dar-se morte - um verdadeiro dever de morrer - ou de abortar.

Neste sentido, vale também mencionar que considerar-se que a gravidez de um feto anencéfalo seria algo indigno é inválido, já que a mulher pode também levar até o fim sua gravidez, sem que isso viole sua dignidade ou a do feto ${ }^{612}$.

Outro aspecto bastante discutido quando se debate a possibilidade de abortar-se o feto anencéfalo é a durabilidade de sua sobrevida. Estima-se que $67 \%$ dos fetos que nascem com anencefalia morrem no período de 24 horas $^{613}$ após o nascimento, e $28 \%$ dentro de apenas uma hora após o parto. Em casos raros, os fetos anencéfalos sobrevivem mais de 10 dias.

\footnotetext{
${ }^{607}$ Para Fernando Rey Martínez, ao tratar da eutanásia, o fato de que alguém tenha graves sofrimentos não se pode deduzir que tenha uma vida indigna que justifique sua morte, pois seria possível afirmar a partir daí que todos os mesmos sofrimentos levariam "objetivamente" à uma "vida indigna", pior que a morte. REY MARTÍNEZ, Fernando. Eutanasia y Derechos Fundamentales. Madrid: Centro de Estúdios Políticos Y Constitucionales, 2008, p. 27-28.

608 "Non si tratta, ovviamente, della possibilità da parte del tronco di vicariare le funzioni della corteccia mancante, ma di ammettere che la neuroplasticità del tronco potrebbe essere sufficiente a garantire all'anencefalico, almeno nelle forme meno gravi, una qualche primitiva possibilità di coscienza. Dovrebbe, quindi, essere respinto l'assunto che l'anencefalico, in quanto privo di emisferi cerebrali non è in grado di avere coscienza e di patire sofferenza "per definizione"'. Comitato nazionale per la bioetica. "Il neonato anencefalico e la donazione di organi". 21 giugno 1996. p. 15. Relatório do Comitê Nacional de Bioética Italiano - 21 de junho de 1996. Versão em português disponível em: 〈http://www.providaanapolis.org.br/cnbport.htm>. Acesso em: 26 abr. 2011.

${ }^{609}$ REY MARTÍNEZ, Fernando. Eutanasia y Derechos Fundamentales. Madrid: Centro de Estúdios Políticos Y Constitucionales, 2008, p. 119.

${ }^{610}$ REY MARTÍNEZ, Fernando. Eutanasia y Derechos Fundamentales. Madrid: Centro de Estúdios Políticos Y Constitucionales, 2008, p. 40.

${ }^{611}$ REY MARTÍNEZ, Fernando. Eutanasia y Derechos Fundamentales. Madrid: Centro de Estúdios Políticos Y Constitucionales, 2008, p. 27-28.

${ }^{612}$ Fernando Rey Martínez afirma - quanto à eutanásia que o postulado da dignidade é discutível para justificála, pois o processo de morte não supõe em si um processo indigno. Mais uma razão porque o conceito de dignidade não é totalmente esclarecedor. REY MARTÍNEZ, Fernando. Eutanasia y Derechos Fundamentales. Madrid: Centro de Estúdios Políticos Y Constitucionales, 2008, p. 42 e 164, respectivamente.

${ }^{613} \mathrm{O}$ tempo de morte varia. OBEIDE, Nidaa et al. The Natural History of Anencephaly. Prenatal Diagnosis, 2010. 30: 357 .
} 
Somente $1 / 3$ dos fetos com anencefalia morrem ainda no útero ${ }^{614}$. Não é possível fazer intervenções terapêuticas corretivas no feto durante a gravidez, e não há tratamento para a doença após o parto ${ }^{615}$. Sem dúvida, é trágico o desenlace da doença. Mas, no entanto, a durabilidade da vida do feto não pode ser o elemento definidor de se ele deve ou não gozar de proteção à vida ${ }^{616}$.

Além disso, é possível encontrar erro no diagnóstico da anencefalia, embora esse fato seja raro, evitável, e, por si só, também não deva condicionar a prática do aborto ou sua proibição $^{617}$.

Discute-se, ainda, a possibilidade do uso de órgãos de anencéfalos para doação. De fato, tal possibilidade, somada ao fato da notória escassez de órgãos ${ }^{618}$, sugere que admitir-se a doação de órgão de anencéfalos poderia ser interessante. No entanto, ainda existem discussões éticas e dificuldades práticas para os transplantes ${ }^{619}$, principalmente porque, no caso do anencéfalo, é muito complicado constatar a morte encefálica ${ }^{620}$. Não há um conhecimento pleno da neurologia do feto ou recém-nascido que dê segurança para

\footnotetext{
${ }^{614}$ JAQUIER, M; KLEIN, A; BOLTSHAUSER, E. Spontaneous pregnancy outcome after prenatal diagnosis of anencephaly. Short Comunication. In.: International Journal of Gynecology and Obstetrics (2006) 102, 99, p. 953. Em recente estudo sobre o tema, $96 \%$ dos casos analisados foram diagnosticados fetos com anencefalia no pré-natal, com média de gravidez de 21 semanas. $27 \%$ das gestações (1/4) desenvolveram problemas no parto; $23 \%$ dos fetos morreram no útero com gestação em média de 30 semanas. A média da gestação foi de 35 semanas; $35 \%$ morreram durante o parto ainda no útero e $42 \%$ dos fetos nasceram vivos com média de 55 minutos de sobrevida, variando entre 10 minutos a 8 dias. Dos pais, somente $23 \%$ consentiram com a doação de órgãos. OBEIDE, Nidaa et al. The Natural History of Anencephaly. Prenatal Diagnosis, 2010. 30: 359.

${ }^{615}$ OBEIDE, Nidaa et al. The Natural History of Anencephaly. Prenatal Diagnosis, 2010. 30: 357.

${ }^{616}$ Comitato nazionale per la bioetica. "Il neonato anencefalico e la donazione di organi". 21 giugno 1996. p. 22. Relatório do Comitê Nacional de Bioética Italiano - 21 de junho de 1996. Versão em português disponível em: 〈http://www.providaanapolis.org.br/cnbport.htm>. Acesso em: 26 abr. 2011.

617 "Innanzitutto si è visto che la malformazione non è una entità definita, ma un continuum di gravità a cui si dovrebbero porre dei confini convenzionali. Ciò porterebbe sicuramente a difficoltà di diagnosi e possibilità di errore [...], benché la possibilità di errore non sia di per sé un elemento sufficiente a proibire una determinata pratica medica". Comitato nazionale per la bioetica. "Il neonato anencefalico e la donazione di organi". 21 giugno 1996. p. 16. Relatório do Comitê Nacional de Bioética Italiano - 21 de junho de 1996. Versão em português disponível em: 〈http://www.providaanapolis.org.br/cnbport.htm〉. Acesso em: 26 abr. 2011.

${ }^{618}$ Como vimos em nota anterior, estudo recente demonstrou que dos casos analisados, somente $23 \%$ dos pais aceitaram doar os órgãos dos fetos anencéfalos após o nascimento, o que sugere que a possibilidade do uso de órgãos de anencéfalos para doação não suprirá a demanda por tais órgãos. OBEIDE, Nidaa et al. The Natural History of Anencephaly. Prenatal Diagnosis, 2010. 30: 359.

619 "Nonostante i molti aspetti e risultati incoraggianti, l'intera materia dei trapianti infantili è ancora oggetto di discussione critica, sia per le indicazioni che per le tecniche e i risultati, a prescindere quindi dagli aspetti etici [...]. Nella valutazione si deve anche rammentare che si tratta di una chirurgia di altissimo livello tecnico organizzativo, che assai difficilmente sarà a disposizione di un numero elevato di pazienti. (Per una revisione della materia del prelievo da donatore anencefalico vedi". Comitato nazionale per la bioetica. "Il neonato anencefalico e la donazione di organi". 21 giugno 1996. p. 13. Relatório do Comitê Nacional de Bioética Italiano - 21 de junho de 1996. Versão em português disponível em: <http://www.providaanapolis.org.br/cnbport.htm>. Acesso em: 26 abr. 2011.

${ }^{620}$ Não existe consenso para a aplicação de diagnóstico de morte encefálica a menores de 7 anos e prematuros. Vide Resolução 1480/97 do Conselho Federal de Medicina.
} 
determinar a partir de qual momento seus órgãos poderiam ser retirados ${ }^{621}$, o que, por sua vez, poderia exigir até uma reavaliação do conceito de morte encefálica no caso do feto anencéfalo, admitindo-se para o caso um conceito de morte do córtex ${ }^{622}$, fato que aumenta ainda mais as controvérsias sobre o tema. E também é controverso se a definição de morte poderia ser alterada para dar-se utilidade aos órgãos do feto anencéfalo, como poderia eventualmente propor uma ética utilitarista ${ }^{623,624}$.

Tendo entendido o que é o anencéfalo e as implicações do aborto, passamos agora a discutir como este caso se reflete na colisão de direitos fundamentais entre particulares, para, na sequência, estudar a jurisprudência brasileira, inclusive a liminar da ADPF 54, onde o Supremo Tribunal Federal discutiu o assunto.

\subsection{DIREITOS FUNDAMENTAIS NAS RELAÇÕES ENTRE PARTICULARES ${ }^{625}$}

Como vimos, a autorização do aborto de feto anencéfalo encontra defensores e críticos. Aqueles que são contrários à prática sustentam basicamente que o direito à vida é indisponível e que não importa se o feto nascerá ou não com vida. O feto teria um direito subjetivo à vida, que deveria prevalecer sobre a vontade da gestante, supondo-se que ela quisesse abortar. Por

\footnotetext{
621 "Nel caso del neonato anencefalico la dimostrazione della morte cerebrale presenta notevoli difficoltà, legate alle conoscenze ancora imperfette sulla neurofisiologia neonatale in senso generale ed anche alla stessa condizione malformativa del soggetto". Comitato nazionale per la bioetica. "Il neonato anencefalico e la donazione di organi". 21 giugno 1996. p. 15. Relatório do Comitê Nacional de Bioética Italiano - 21 de junho de 1996. Versão em português disponível em: <http://www.providaanapolis.org.br/cnbport.htm>. Acesso em: 26 abr. 2011.

${ }^{622}$ Vide Comitato nazionale per la bioetica. "Il neonato anencefalico e la donazione di organi". 21 giugno 1996. p. 16-19. Relatório do Comitê Nacional de Bioética Italiano - 21 de junho de 1996. Versão em português disponível em: http://www.providaanapolis.org.br/cnbport.htm>. Acesso em: 26 abr. 2011.

${ }^{623}$ HARE, R.M. A Utilitarian Approach. In: A Companion to Bioethics. KUHSE, Helga. SINGER, Peter. Massachusetts, EUA. Blackwell Publishing, 1998, p. 80-85.

${ }^{624}$ Ainda pensando em uma ética utilitarista, interessante ressaltar o trabalho dos economistas Steven D. Levitt e Stephen J. Dubner, que sugerem que "o aborto foi um dos maiores fatores responsáveis pela diminuição da criminalidade da história americana [...]. A queda da criminalidade foi, no jargão dos economistas, 'um benefício acidental' da legalização do aborto [...]. Um estudo demonstrou que a típica criança impedida de nascer nos primeiros anos da legalização do aborto estaria 50\% mais propensa que a média a viver na pobreza; teria, igualmente, uma probabilidade $60 \%$ maior de ser criada por apenas um dos genitores. Esses dois fatores - uma infância pobre e um lar de mãe/pai solteiro - estão entre os mais fortes fatores determinantes de um futuro criminoso". LEVITT, Steven D.; DUBNER, Stephen J. Freakonomics: o lado oculto e inesperado de tudo que nos afeta. Trad. Regina Lyra; revisão técnica Ronaldo Fiani. 1. ed. rev. e atual. Rio de Janeiro: Elsevier, 2007.

${ }^{625}$ Também denominadas de relações privadas e relações interindividuais, para alguns autores. Virgílio Afonso da Silva critica essas terminologias, ensinando que a primeira excluiria relações trabalhistas e a segunda excluiria entes coletivos, adotando, portanto, relações entre particulares. SILVA, Virgílio Afonso da. A Constitucionalização do Direito: os direitos fundamentais nas relações entre particulares. $1^{\mathrm{a}}$. Edição, $2^{\mathrm{a}}$. Tiragem. São Paulo: Malheiros, p. 54.
} 
conseguinte, o direito subjetivo à vida do feto também prevaleceria caso houvesse um conflito com outros direitos que a mãe pudesse ter. Por outro lado, entre os argumentos favoráveis ao aborto, está a supremacia da individualidade e autonomia próprias, fundadas no direito da gestante de dispor do corpo.

No entanto, como se daria a interferência estatal diante das relações entre particulares, quando temos conflitos de direitos humanos - ou violação de direitos humanos - nesse contexto?

Fernando Rey Martínez afirma que o estado tem o dever de proteger a vida de seus cidadãos, mas não contra a sua autonomia e dignidade ${ }^{626}$. Como vimos, o interesse estatal de preservar a vida de seus cidadãos a todo custo e a todo tempo, é ilegítimo ${ }^{627}$, podendo, inclusive, a proteção jurídica da vida ser vista como uma barreira à autodeterminação individual $^{628}$, ao livre desenvolvimento da personalidade, e o princípio da dignidade ${ }^{629}$. Vale lembrar que Fernando Rey Martínez, concordando com Salvador Tarollo, admite ainda que a autonomia reveste-se de tal importância que influencia significativamente todos os demais direitos no ordenamento jurídico ${ }^{630}$.

Nesse sentido, Virgílio Afonso da Silva alerta para o fato de que pode existir conflito entre direitos fundamentais e direito privado, conflito este que, aparentemente, seria impossível de conciliar, tendo em vista premissas "absolutamente diversas" "631.

O autor ressalta que diante da "expansão dos direitos fundamentais"632 é possível que "quase toda relação contratual" possua direitos fundamentais que sejam "tocados" em razão das próprias características desses direitos fundamentais (tal como a inalienabilidade, entre

\footnotetext{
${ }^{626}$ REY MARTínEZ, Fernando. Eutanasia y Derechos Fundamentales. Madrid: Centro de Estúdios Políticos Y Constitucionales, 2008, p. 40.

${ }^{627}$ REY MARTÍNEZ, Fernando. Eutanasia y Derechos Fundamentales. Madrid: Centro de Estúdios Políticos Y Constitucionales, 2008, p. 124.

${ }^{628}$ Uma visão radical neste sentido é expressada de modo enfático pelos libertários americanos; por exemplo, nas palavras de Ron Paul, três vezes candidato à Presidência dos Estados Unidos pelo Libertarian Party, "Liberty means to exercise human rights in any manner a person chooses so long as it does not interfere with the exercise of the rights of others. This means, above all else, keeping government out of our lives." In: PAUL, Ron. Liberty Defined: 50 Essential Issues That Affect American Freedom. New York: Grand Cetral Publishing, 2012, p. xi.

${ }^{629}$ REY MARTÍNEZ, Fernando. Eutanasia y Derechos Fundamentales. Madrid: Centro de Estúdios Políticos Y Constitucionales, 2008, p. 83.

${ }^{630}$ REY MARTÍNEZ, Fernando. Eutanasia y Derechos Fundamentales. Madrid: Centro de Estúdios Políticos Y Constitucionales, 2008, p. 110.

${ }^{631}$ Exemplifica o autor com "autonomia privada de um lado e a inalienabilidade e a irrenunciabilidade dos direitos fundamentais, de outro". SILVA, Virgílio Afonso da. A Constitucionalização do Direito: os direitos fundamentais nas relações entre particulares. $1^{\mathrm{a}}$ edição, $2^{\mathrm{a}}$ tiragem. São Paulo: Malheiros, p. 50.

${ }^{632}$ Para o autor, "inchaço das declarações de direitos". SILVA, Virgílio Afonso da. A Constitucionalização do Direito: os direitos fundamentais nas relações entre particulares. $1^{\mathrm{a}}$ edição, $2^{\mathrm{a}}$ tiragem. São Paulo: Malheiros, p. 50. É o conceito de contorno vazios, porosidade, ambiguidade e natureza polissêmica da dignidade da pessoa humana de que trata Ingo Sarlet. SARLET, Ingo Wolfgang. A Dignidade da Pessoa Humana e os Direitos Fundamentais na Constituição Federal e 1988. São Paulo: Livraria do Advogado, 2008, p. 40.
} 
outros), o que, ao menos idealmente, só faria sentido no plano das relações verticais, isto, entre estado e indivíduos ${ }^{633}$.

Virgílio Afonso da Silva esclarece, ainda, porque - no plano horizontal (isto é, nas relações entre particulares) - , observar tais características, inviabilizaria o debate sobre o tema ${ }^{634}$, e propõe uma "mudança de paradigma" para demonstrar que as relações entre particulares podem ameaçar direitos fundamentais, mas nesses casos, "qualquer relação entre particulares significa uma relação entre dois titulares dos mesmos direitos" "635, em geral.

Essa mudança de paradigma ${ }^{636}$, portanto, leva em conta duas teorias: a) a que nega a eficácia das normas de direitos fundamentais nas relações privadas; e b) a que admite que as normas de direitos constitucionais têm eficácia plena, com base no artigo $5^{\circ}, \S 1^{\circ}$, que dispõe sobre a aplicabilidade imediata.

Aponta Virgílio Afonso da Silva, em primeiro lugar, uma recorrente confusão entre os termos "eficácia" 637 e "aplicabilidade" 638 . A primeira seria uma "forma de produção de efeitos e seu âmbito de aplicação"639, e a segunda, nos termos do artigo $5^{\circ}, \S 1^{\circ}$, diz respeito a "uma potencialidade, à capacidade de produzir efeitos desde já" ${ }^{640}$. Assim, para o autor, afirmar que os direitos fundamentais terão aplicabilidade imediata nada tem a ver com o fato de em quais

${ }^{633}$ SILVA, Virgílio Afonso da. A Constitucionalização do Direito: os direitos fundamentais nas relações entre particulares. $1^{\mathrm{a}}$ edição, $2^{\mathrm{a}}$ tiragem. São Paulo: Malheiros, p. 51.

${ }^{634}$ Explica o autor que "insistir em algumas dessas características pode impedir qualquer possibilidade de discussão sobre o tema. Isso porque, como será visto adiante, só é possível aceitar que direitos fundamentais sejam restringidos com base na autonomia da vontade se se aceitar que é possível negociá-los - ainda que isso soe como uma heresia - e até mesmo a eles renunciar - ainda que isso possa soar como impossível." SILVA, Virgílio Afonso da. A Constitucionalização do Direito: os direitos fundamentais nas relações entre particulares. $1^{\mathrm{a}}$ edição, $2^{\mathrm{a}}$ tiragem. São Paulo: Malheiros, p. 51.

${ }^{635}$ Diferentemente do que ocorre com o Estado, "que é somente destinatário dos direitos fundamentais, isto é, seu sujeito passivo, mas não é titular desses mesmos direitos". SILVA, Virgílio Afonso da. A Constitucionalização do Direito: os direitos fundamentais nas relações entre particulares. $1^{\mathrm{a}}$ edição, $2^{\mathrm{a}}$ Tiragem. São Paulo: Malheiros, p. 53.

${ }^{636}$ Daniel Sarmento defende o reconhecimento da constitucionalização do Direito Privado, deixando de ser o Direito Civil o centro da proteção dos direitos da personalidade. SARMENTO, Daniel. Direitos Fundamentais e Relações Privadas. Rio de Janeiro: Editora Lúmen Júris, 2008, p. 102-103.

${ }^{637}$ Para Virgílio Afonso da Silva, a eficácia diz respeito à propriedade de uma norma produzir efeitos jurídicos, o que não deve ser confundido com os "próprios efeitos", de modo que "é perfeitamente possível que uma norma eficaz, porque apta a produzir efeitos, não produza efeito nenhum em certos tipos de relação". SILVA, Virgílio Afonso da. A Constitucionalização do Direito: os direitos fundamentais nas relações entre particulares. $1^{\text {a }}$. Edição, 2a . Tiragem. São Paulo: Malheiros, p. 55.

${ }^{638}$ Ainda para Virgílio Afonso da Silva, a norma aplicável é aquela que não somente é dotada de eficácia capacidade de produzir efeitos -, mas, também, cujo suporte fático se conecta com os fatos de um determinado caso concreto. SILVA, Virgílio Afonso da. A Constitucionalização do Direito: os direitos fundamentais nas relações entre particulares. 1 ${ }^{\mathrm{a}}$. Edição, $2^{\mathrm{a}}$. Tiragem. São Paulo: Malheiros, p. 56.

${ }^{639}$ SILVA, Virgílio Afonso da. A Constitucionalização do Direito: os direitos fundamentais nas relações entre particulares. $1^{\mathrm{a}}$. Edição, $2^{\mathrm{a}}$. Tiragem. São Paulo: Malheiros, p. 56.

${ }^{640}$ SILVA, Virgílio Afonso da. A Constitucionalização do Direito: os direitos fundamentais nas relações entre particulares. 1 ${ }^{\mathrm{a}}$. Edição, $2^{\mathrm{a}}$. Tiragem. São Paulo: Malheiros, p. 56. 
relações jurídicas tais normas serão aplicadas ${ }^{641}$, podendo, em princípio, ser as normas de direitos fundamentais aplicadas em todas as relações jurídicas, inclusive nas relações entre particulares $^{642}$.

Alerta Virgílio Afonso da Silva que, ao "negar efeitos dos direitos fundamentais nas relações entre particulares" ${ }^{643}$, não se estaria negando, no entanto, a eficácia desses direitos, pois continuariam aptos a produzir efeitos nas relações verticais. Da mesma forma, quando afirmamos que os "direitos fundamentais produzem efeitos nas relações entre particulares"644 indiretamente, também não é negada a eficácia dessas normas, nem a produção de efeitos nas relações entre particulares, mas apenas a aplicabilidade direta dessas normas nessas relações ${ }^{645}$.

Para Virgílio Afonso da Silva, somente seria possível falar em aplicabilidade das normas de direitos fundamentais às relações entre particulares quando afirmamos que as "normas de direitos fundamentais conferem, diretamente, direitos subjetivos aos envolvidos em uma relação jurídica interprivados"646, presumindo, para o autor, que tais normas "são eficazes e produzem efeitos nesse tipo de relação, mas também que essa produção de efeitos é direta, via aplicação das normas de direitos fundamentais" ${ }^{647}$.

Por outro lado, defende Daniel Sarmento que o estado precisa intervir em determinados casos, mesmo que, com isso, a autonomia privada e individual do indivíduo seja restringida, o que é plenamente possível, dado que essa autonomia não é absoluta ${ }^{648}$. Todavia,

\footnotetext{
${ }^{641}$ SILVA, Virgílio Afonso da. A Constitucionalização do Direito: os direitos fundamentais nas relações entre particulares. 1 $^{\mathrm{a}}$. Edição, $2^{\mathrm{a}}$. Tiragem. São Paulo: Malheiros, p. 58.

${ }_{642}$ "[...]Prescrever que os direitos fundamentais têm "aplicabilidade imediata" não significa que essa aplicação deverá ocorrer em todos os tipos de relação ou que todos os tipos de relação jurídica sofrerão algum efeito das normas de direitos fundamentais. Somente se se pressupõe que direitos fundamentais devem produzir efeitos diretos - em todas as relações jurídicas possíveis é que se poderá interpretar o $\$ 1^{\circ}$ do artigo $5^{\circ}$ como aplicável de imediato - às relações particulares". SILVA, Virgílio Afonso da. A Constitucionalização do Direito: os direitos fundamentais nas relações entre particulares. $1^{\mathrm{a}}$. Edição, $2^{\mathrm{a}}$. Tiragem. São Paulo: Malheiros, p. 58.

${ }^{643}$ SILVA, Virgílio Afonso da. A Constitucionalização do Direito: os direitos fundamentais nas relações entre particulares. $1^{\mathrm{a}}$. Edição, $2^{\mathrm{a}}$. Tiragem. São Paulo: Malheiros, p. 59.

${ }^{644}$ SILVA, Virgílio Afonso da. A Constitucionalização do Direito: os direitos fundamentais nas relações entre particulares. $1^{\mathrm{a}}$. Edição, $2^{\mathrm{a}}$. Tiragem. São Paulo: Malheiros, p. 59.

${ }^{645}$ SILVA, Virgílio Afonso da. A Constitucionalização do Direito: os direitos fundamentais nas relações entre particulares. $1^{\mathrm{a}}$. Edição, $2^{\mathrm{a}}$. Tiragem. São Paulo: Malheiros, p. 59.

${ }^{646}$ SILVA, Virgílio Afonso da. A Constitucionalização do Direito: os direitos fundamentais nas relações entre particulares. $1^{\mathrm{a}}$. Edição, $2^{\mathrm{a}}$. Tiragem. São Paulo: Malheiros, p. 59.

${ }^{647}$ SILVA, Virgílio Afonso da. A Constitucionalização do Direito: os direitos fundamentais nas relações entre particulares. $1^{\mathrm{a}}$. Edição, $2^{\mathrm{a}}$. Tiragem. São Paulo: Malheiros, p. 59.

${ }^{648}$ SARMENTO, Daniel. Direitos Fundamentais e relações privadas. Rio de Janeiro: Editora Lúmen Júris, 2008, p. 155.
} 
como a autonomia individual também está ligada à dignidade da pessoa humana, restringi-la é "frustar sua possibilidade de realização existencial"649.

Para Ingo Sarlet, a eficácia dos direitos fundamentais está baseada no princípio da dignidade da pessoa humana, e vincula "diretamente" os particulares ${ }^{650}$, podendo o estado intervir nas relações entre particulares até mesmo para proteger o indivíduo de si mesmo quando atentar à sua própria dignidade ${ }^{651}$.

Em vista do exposto, resta claro que o estado tem a obrigação de regular a relação particular no caso do aborto de feto anencéfalo, em vista dos direitos fundamentais da gestante e do feto em conflito na relação.

A partir dessa análise, em que concluímos pela aplicabilidade das normas de direitos fundamentais às relações entre particulares, seguiremos para as soluções trazidas ao caso específico da legalidade ou ilegalidade do aborto do feto anencefálico no âmbito do direito brasileiro e internacional, verificando de que modo a legislação e a interpretação desta pela doutrina e jurisprudência têm mostrado o caminho para solucionar de forma mais adequada o conflito existente entre o direito à vida do feto anencéfalo e a autonomia da vontade e liberdade de dispor do próprio corpo da gestante; e também sua possível aplicação no Brasil, lembrando que validar os procedimentos e autorizar o aborto significa validar uma decisão irrevogável, uma vez que também irreversível, em razão da morte que sobrevém ao procedimento $^{652}$.

\footnotetext{
${ }^{649}$ SARMENTO, Daniel. Direitos Fundamentais e relações privadas. Rio de Janeiro: Editora Lúmen Júris, 2008, p. 155.

${ }^{650}$ SARLET, Ingo Wolfgang. A Dignidade da Pessoa Humana e os Direitos Fundamentais na Constituição Federal e 1988. São Paulo: Livraria do Advogado, 2008, p. 115.

${ }^{651}$ SARLET, Ingo Wolfgang. A Dignidade da Pessoa Humana e os Direitos Fundamentais na Constituição Federal e 1988. São Paulo: Livraria do Advogado, 2008, p. 116. Fernando Rey Martínez afirma que não existe um direito a dispor da própria vida. REY MARTÍNEZ, Fernando. Eutanasia y Derechos Fundamentales. Madrid: Centro de Estúdios Políticos Y Constitucionales, 2008, p. 118. Vale dizer ainda que Virgílio Afonso da Silva afirma que é preciso levar em conta as características de tais direitos fundamentais, e que nem sempre a possibilidade de renúncia deve ser recusada "de pronto" em vista de casos concretos cujas respostas são mais complexas do que aparentam ser, e que nem sempre a renúncia pressupõe a "abdicação definitiva e irreversível". Para o autor, é dispensável fazer uma diferenciação entre renúncia ao exercício de um direito fundamental e a renúncia geral ao direito. SILVA, Virgílio Afonso da. A Constitucionalização do Direito: os direitos fundamentais nas relações entre particulares. $1^{a}$. Edição, $2^{a}$. Tiragem. São Paulo: Malheiros, p. 61.

${ }^{652}$ REY MARTÍNEZ, Fernando. Eutanasia y Derechos Fundamentales. Madrid: Centro de Estúdios Políticos Y Constitucionales, 2008, p. 120.

${ }^{652}$ SILVA, Virgílio Afonso da. A Constitucionalização do Direito: os direitos fundamentais nas relações entre particulares. ${ }^{\mathrm{a}}$. Edição, $2^{\mathrm{a}}$. Tiragem. São Paulo: Malheiros, p. 61
} 


\section{ANÁliSE DA ARGUIÇÃO DE DESCUMPRIMENTO DE PRECEITO FUNDAMENTAL (ADPF) ${ }^{653} \mathrm{~N}^{\circ} 54^{654}$}

\subsection{PRINCIPAIS ARGUMENTOS SOBRE ANENCEFALIA NA JURISPRUDÊNCIA BRASILEIRA}

Antes de abordarmos especificamente a Arguição de Descumprimento de Preceito Fundamental $n^{\circ} 54$, vale a pena mencionar alguns argumentos que já vinham sendo aplicados pelos juízes e pelos tribunais brasileiros, inclusive pelo próprio Supremo Tribunal Federal, ao caso do aborto de feto anencéfalo.

Recentemente, inúmeras decisões vinham enfrentando o debate sobre a antecipação terapêutica do parto de feto anencéfalo, ora autorizando o aborto, ora proibindo-o. A existência de posições conflitantes aumentava ainda mais a discussão sobre o tema e trazia grande insegurança jurídica à questão ${ }^{655}$. Destacaremos algumas decisões e analisaremos os principais argumentos utilizados por nossos juízes.

Em primeira instância, destacamos a sentença proferida pelo juiz Carlos Alberto Garcete, da $1^{\mathrm{a}}$ Vara do Tribunal do Júri de Campo Grande/MS ${ }^{656}$, que autorizou a interrupção de uma gravidez de feto anencéfalo na $30^{\mathrm{a}}$ semana da gravidez. O feto acometido de anencefalia, conforme a sentença, tinha quatro camadas cardíacas atípicas, e a gestante

\footnotetext{
${ }^{653}$ Ensina André Ramos Tavares que a Arguição de Descumprimento de Preceito Fundamental é "medida própria do Brasil, de competência originária do STF, visando a realizar o controle abstrato de compatibilidade (não-descumprimento) de parcela dos atos estatais exclusivamente em relação aos preceitos constitucionais fundamentais [...]. No conceito de 'descumprimento' inclui-se toda e qualquer violação de norma constitucional [...]. O parâmetro de verificação a ser utilizado na Argüição de Descumprimento de Preceito Fundamental (ADPF) não poderá ser toda a Constituição, mas um universo bem menor, o dos preceitos fundamentais, o que a distancia, neste ponto, da ação direta de inconstitucionalidaed direta. O que é preceito? O conceito de preceito encampa tanto a figura dos princípios como a das regras". TAVARES, André Ramos. Argüição de Descumprimento de Preceito Fundamental. In: DIMOULIS, Dimitri (Coordenador Geral). TAVARES, André Ramos; DIMOULIS, Dimitri; BERCOVICI, Gilberto; SILVA, Guilherme Amorim Campos da; FRANCISCO, José Carlos; ANJOS FILHO, Robério Nunes dos; ROTHENBURG, Walter Claudius (org.). Dicionário Brasileiro de Direito Constitucional. São Paulo: Saraiva, 2007, p. 25.

${ }^{654}$ Arguição de Descumprimento de Preceito Fundamental no $54-8$, protocolada em 17 jun. 2004.

${ }^{655}$ Para Piovesan e Gonçalves, embora inúmeras decisões sobre aborto, a "maioria não incorporou debates significativos relativos ao exercício dos direitos sexuais e reprodutivos". PIOVESAN, Flávia; GONÇALVES, Tamara Amoroso. Gênero no Supremo Tribunal Federal. In SARMENTO, Daniel e SARLET, Ingo Wolfgang (coords). Direitos Fundamentais no Supremo Tribunal Federal: Balanço e Crítica. p. 379.

${ }^{656}$ BRASIL. Tribunal do Júri de Campo Grande/MS. Juiz Carlos Alberto Garcete da $1^{\text {a }}$ Vara. Disponível em: $\langle$ http://www.tjms.jus.br/webfiles/producao/GP/noticiasArquivos/201102221546061.pdf〉. Acesso em: 10 jan. 2011.
} 
justificou seu pedido no risco à sua saúde e no desgaste emocional no caso de a gravidez ser mantida $^{657}$.

O Ministério Público Estadual foi favorável ao aborto, fundamentando seu parecer na "excludente de culpabilidade",658 e na inexistência de "expectativa de vida para o feto",659.

Em sentença, o juiz afirmou que não existe direito absoluto e que os valores trazidos na Constituição Federal devem ser sopesados ${ }^{660}$. Alegou, ainda que, se de um lado há entendimentos no sentido de que o Poder Judiciário não poderia autorizar o aborto em razão da existência do cerebelo e tronco encefálico - o que possibilitaria algum tipo de atividade cerebral -, de outro, a autorização do aborto seria constitucional, pois o direito protegeria a vida humana, e não a sua falsa existência ${ }^{661}$.

Invocou também o juiz o art. $3^{\circ}$ da Lei n. 9.434, de 3 de fevereiro de 1997, que prevê a retirada post mortem de tecidos, órgãos ou partes do corpo humano para fins de transplante, desde que precedido de diagnóstico de morte encefálica ${ }^{662}$. Justificou na inviabilidade de vida extrauterina do feto o fato de a gestação neste caso acarretar um "severo desgaste emocional e físico e que apesar das alterações no corpo da mulher, são inúteis, podendo acarretar um quadro depressivo",663.

O juiz entendeu que o aborto de feto anencéfalo é "fato gerador de atipicidade penal". Para ele, o "fato encontra resposta jurídica e social para deixar de ser considerado

\footnotetext{
${ }^{657}$ BRASIL. Tribunal do Júri de Campo Grande/MS. Juiz Carlos Alberto Garcete da 1ª Vara. Disponível em: <http://www.tjms.jus.br/webfiles/producao/GP/noticiasArquivos/201102221546061.pdf>. Acesso em: 10 jan. 2011.

${ }^{658}$ BRASIL. Tribunal do Júri de Campo Grande/MS. Juiz Carlos Alberto Garcete da $1^{\text {a }}$ Vara. Disponível em: <http://www.tjms.jus.br/webfiles/producao/GP/noticiasArquivos/201102221546061.pdf>. Acesso em: 10 jan. 2011.

${ }^{659}$ BRASIL. Tribunal do Júri de Campo Grande/MS. Juiz Carlos Alberto Garcete da 1 $1^{\text {a }}$ Vara. Disponível em: <http://www.tjms.jus.br/webfiles/producao/GP/noticiasArquivos/201102221546061.pdf>. Acesso em: 10 jan. 2011.

${ }^{660}$ BRASIL. Tribunal do Júri de Campo Grande/MS. Juiz Carlos Alberto Garcete da 1ª Vara. Disponível em: <http://www.tjms.jus.br/webfiles/producao/GP/noticiasArquivos/201102221546061.pdf>. Acesso em: 10 jan. 2011.

${ }^{661}$ BRASIL. Tribunal do Júri de Campo Grande/MS. Juiz Carlos Alberto Garcete da $1^{\text {a }}$ Vara. Disponível em: <http://www.tjms.jus.br/webfiles/producao/GP/noticiasArquivos/201102221546061.pdf>. Acesso em: 10 jan. 2011.

${ }^{662}$ Como vimos, no qual o Conselho Federal de Medicina equiparou a morte encefálica à morte.

${ }^{663}$ BRASIL. Tribunal do Júri de Campo Grande/MS. Juiz Carlos Alberto Garcete da 1 ${ }^{\text {a }}$ Vara. Disponível em: <http://www.tjms.jus.br/webfiles/producao/GP/noticiasArquivos/201102221546061.pdf>. Acesso em: 10 jan. 2011.
} 
materialmente típico ou proibido" ${ }^{664}$, pois o crime não existe "se o fato não é formal e materialmente típico" ${ }^{\natural 65}$.

Ademais, entendeu o juiz ainda que o aborto do anencefálico não se enquadra na morte arbitrária prevista no art. $4^{\circ}$ da Convenção Americana de Direitos Humanos, pois inexiste vida autônoma na anencefalia ${ }^{666}$.

Finalmente, para ele, a antecipação do aborto seria permitida pela ordem constitucional, uma vez que o texto constitucional garante não só a vida, mas a vida digna ${ }^{667}$. Ressaltou o juiz que existem outros bens jurídicos em jogo na tutela constitucional ${ }^{668}$.

O tema tem sido também debatido na seara dos tribunais.

O Tribunal de Justiça de São Paulo, em 14 abr. 2011, decidiu em liminar do Mandado de Segurança $n^{\circ}$ 0019869-66.2011.8.26.0000 ${ }^{669}$ autorizar a realização do aborto de "embrião sem a ossificação da calota craniana".

A Procuradoria Geral de Justiça se manifestou pela concessão do pedido à época. $\mathrm{O}$ Tribunal de Justiça entendeu que o legislador penal não foi "radical", e que se, na época em que o Código Penal fora discutido e redatado existissem meios de confirmar patologias incompatíveis com a vida extrauterina, certamente teria descriminalizado esta modalidade de aborto $^{670}$. Além disso, entendeu o Tribunal de Justiça de São Paulo que não há "vida em curso" no anencéfalo, não podendo assim ser considerada antijurídica tal prática de aborto, tendo o feto perdido o amparo legal após comprovada sua morte encefálica ${ }^{671}$. Ademais,

${ }^{664}$ BRASIL. Tribunal do Júri de Campo Grande/MS. Juiz Carlos Alberto Garcete da 1a Vara. Disponível em: <http://www.tjms.jus.br/webfiles/producao/GP/noticiasArquivos/201102221546061.pdf>. Acesso em: 10 jan. 2011.

${ }^{665}$ BRASIL. Tribunal do Júri de Campo Grande/MS. Juiz Carlos Alberto Garcete da 1ª Vara. Disponível em: <http://www.tjms.jus.br/webfiles/producao/GP/noticiasArquivos/201102221546061.pdf>. Acesso em: 10 jan. 2011..

${ }^{666}$ BRASIL. Tribunal do Júri de Campo Grande/MS. Juiz Carlos Alberto Garcete da $1^{\text {a }}$ Vara. Disponível em: <http://www.tjms.jus.br/webfiles/producao/GP/noticiasArquivos/201102221546061.pdf>. Acesso em: 10 jan. 2011..

${ }^{667}$ BRASIL. Tribunal do Júri de Campo Grande/MS. Juiz Carlos Alberto Garcete da 1ª Vara. Disponível em: <http://www.tjms.jus.br/webfiles/producao/GP/noticiasArquivos/201102221546061.pdf>. Acesso em: 10 jan. 2011.

${ }^{668}$ BRASIL. Tribunal do Júri de Campo Grande/MS. Juiz Carlos Alberto Garcete da 1 $1^{\text {a }}$ Vara. Disponível em: <http://www.tjms.jus.br/webfiles/producao/GP/noticiasArquivos/201102221546061.pdf>. Acesso em: 10 jan. 2011.

${ }^{669}$ BRASIL. Tribunal de Justiça de São Paulo. Mandado de Segurança no 0019869-66.2011.8.26.0000. Acórdão 03511595. Disponível em: <https://esaj.tjsp.jus.br/cjsg/getArquivo.do? cdAcordao=5077560\&vlCaptcha $=$ ntnPB $>$. Acesso em: 10 jun. 2011.

${ }^{670}$ BRASIL. Tribunal de Justiça de São Paulo. Mandado de Segurança n ${ }^{\circ}$ 0019869-66.2011.8.26.0000. Acórdão 03511595. Disponível em: <https://esaj.tjsp.jus.br/cjsg/getArquivo.do? cdAcordao=5077560\&vlCaptcha $=$ ntnPB>. Acesso em: 10 jan. 2011.

${ }^{671}$ BRASIL. Tribunal de Justiça de São Paulo. Mandado de Segurança no 0019869-66.2011.8.26.0000. Acórdão 03511595. Disponível em: <https://esaj.tjsp.jus.br/cjsg/getArquivo.do? cdAcordao=5077560\&vlCaptcha $=n t n P B>$. Acesso em: 10 jan. 2011. 
considerou que a manutenção da gravidez aumentaria o risco de vida da gestante durante o pré-natal, e o sofrimento dos genitores ao longo da gravidez ${ }^{672}$.

O tema também já foi debatido incidentalmente pelo Superior Tribunal de Justiça no Habeas Corpus 32.159/RJ (acórdão 2003/0219840-5) ${ }^{673}$ e no Habeas Corpus 56.272/SP (acórdão 2006/0062671-4) ${ }^{674}$, ambos com a finalidade de pleitear a interrupção da gravidez de fetos com anomalias incompatíveis com a vida extrauterina. Destacamos o segundo caso, em que foram diagnosticados rins multicísticos e encefalocele no feto que, conforme informações apontadas no acórdão, seguramente entraria em óbito logo após o parto ${ }^{675}$.

O Ministro Relator Arnaldo Esteves Lima seguiu o voto da Ministra Laurita Vaz no Habeas Corpus anterior e entendeu que, a partir da análise do artigo 128, incisos I e II, é possível afirmar que não existe um direito absoluto à vida do feto, de modo que o legislador

\footnotetext{
${ }^{672}$ BRASIL. Tribunal de Justiça de São Paulo. Mandado de Segurança no 0019869-66.2011.8.26.0000. Acórdão 03511595. Disponível em: <https://esaj.tjsp.jus.br/cjsg/getArquivo.do? cdAcordao=5077560\&vlCaptcha $=$ ntnPB $>$. Acesso em: 10 jan. 2011.

${ }^{673}$ BRASIL. Superior Tribunal de Justiça. Habeas Corpus. Julgado em 17 fev. 2004. Trata-se de um pedido formulado pela gestante para autorizar o aborto de feto com anencefalia. Destacamos o voto da Ministra Relatora LAURITA VAZ que entendeu "independente de convicções subjetivas pessoais" necessário o exame da matéria "porque o certo ou o errado, o moral ou imoral, o humano ou desumano, enfim, o justo ou o injusto, em se tratando de atividade jurisdicional em um Estado Democrático de Direito, são aferíveis a partir do que suas Leis estabelecem", mas que o juiz não deve "ficar engessado nas letras frias da Lei" e que seja "um efetivo membro da sociedade, apto a exercer sua jurisdição com bom senso e equilíbrio, sempre buscando uma exegese consentânea com a realidade em que vive", observando os limites determinados pela lei, sob pena de agir com arbitrariedade. Para a Ministra, nosso ordenamento jurídico protege a vida e não admite a interpretação extensiva ou analogia in malam partem, prevalecendo o princípio da reserva legal. Tampouco poderia o julgador trazer novas hipóteses ao artigo 128 do Código Penal. Disponível em: <https://ww2.stj.jus.br/revistaeletronica/Abre_Documento.asp?sSeq=450912\&s Reg=200302198405\&s Data= 20040322\& formato=PDF>. Acesso em: 10 jan. 2011. Ensina José Carlos Francisco que " há reserva legalrelativa quando a Constituição empregar expressões que permitam inferir que o direito ou obrigação poderá constar da lei formalmente editada ou em ato normativo praticado por sua ordem, hipótese na qual cumpre a lei a definição dos contornos dos atos normativos secundários ou regulamentares a serem editados [...]. Impõe-se reserva absoluta de lei com o uso de expressões como 'cabe à lei regulamentar', 'a lei regulará', 'a lei disporá', 'previstas em lei', a delegação 'terá a forma de resolução do Congresso Nacional', 'a lei criará', ou 'a lei definirá'. Também serão exclusivos da lei aqueles temas indicados nos arts. 62 e 68 [da Constituição Federal] que sequer podem ser objeto de medida provisória ou de lei delegada". FRANCISCO, José Carlos. Reserva Legal. In: DIMOULIS, Dimitri (Coordenador Geral). TAVARES, André Ramos; DIMOULIS, Dimitri; BERCOVICI, Gilberto; SILVA, Guilherme Amorim Campos da; FRANCISCO, José Carlos; ANJOS FILHO, Robério Nunes dos; ROTHENBURG, Walter Claudius (org.). Dicionário Brasileiro de Direito Constitucional. São Paulo: Saraiva, 2007, p. 331.

${ }^{674}$ BRASIL. Superior Tribunal de Justiça. Habeas Corpus. Julgado em 15 mai. 2006. Disponível em: <https://ww2.stj.jus.br/revistaeletronica/Abre_Documento.asp?sSeq=622824\&s $\quad$ Reg=200600626714\&s Data $=20060515 \&$ formato=PDF $>$. Acesso em: 10 jan. 2011.

675 "Com efeito, conforme atestado pela equipe médica da Divisão de Clínica Obstretícia do Instituto Central do Hospital das Clínicas da Faculdade de Medicina da Universidade de São Paulo (HC/FMUSP), o feto apresenta quadro de RINS MULTICÍSTICOS e ENCEFALOCELE, patologia 'seguramente incompatível com a vida extrauterina', tendo em vista que, 'caso a gestação venha a prosseguir, todos os dados da literatura médica apontam para a morte do recém-nascido após o parto"”. BRASIL. Superior Tribunal de Justiça. Voto Ministro Superior Tribunal de Justiça Relator Arnaldo Esteves Lima. Habeas Corpus 56.572-SP, acórdão $\mathrm{n}^{\circ}$ 2006/0062671-4. Julgado em 15 mai. 2006. Disponível em: <https://ww2.stj.jus.br/revistaeletronica/Abre_Documento.asp?sSeq=622824\&s $\quad$ Reg=200600626714\&s Data $=20060515 \&$ formato=PDF $>$. Acesso em: 10 jan. 2011.
} 
na época do Código Penal, na segunda hipótese do aborto sentimental, visou à preservação da "honra subjetiva" ou "sanidade psicológica" da gestante em detrimento da vida em formação que carregava $^{676}$. E, por conta dessa análise, para o Ministro, seria difícil discordar da tese que afirma que o Código Penal não autorizou outra nova hipótese de aborto em caso de patologia fetal incompatível com a vida extrauterina tão-somente em decorrência da inexistência de tecnologia que confirmasse essas condições à época da elaboração da lei ${ }^{677}$.

Entendeu, portanto, o Ministro, que o legislador também protege outros "bens jurídicos essenciais", de modo que não seria possível afastar-se dos objetivos fundamentais estabelecidos no artigo $3^{\circ}$, I e IV, da Constituição Federal ${ }^{678}$.

Por fim, entendeu o Ministro Relator que a "antecipação do parto não atinge o bem juridicamente tutelado, uma vez que a morte desse feto é inevitável, em decorrência da própria patologia" ${ }^{679}$, mas julgou prejudicada a ordem impetrada, tendo em vista que a gestante encontrava-se no final da gestação.

O próprio Supremo Tribunal Federal também analisou o tema no Habeas Corpus n. $84.025-6 / \mathrm{RJ}^{680}$. O Ministro Relator Joaquim Barbosa afirmou que nos casos de anencefalia nada é possível ser feito, e que seria necessário "se preocupar com o casal, em especial com a mãe" ${ }^{681}$. Além disso, criticou o Ministro que todos os argumentos suscitados até então no caso, em que o direito da mãe de abortar fora até então negado, teriam sido em prol do feto, e não em prol dos direitos da gestante, como se os direitos do nascituro tivessem o condão de

\footnotetext{
676 BRASIL. Superior Tribunal de Justiça. Habeas Corpus. Julgado em 15 mai. 2006. Disponível em: <https://ww2.stj.jus.br/revistaeletronica/Abre_Documento. asp?sSeq=622824\&s Reg=200600626714\&s Data=20060515\&formato=PDF $>$. Acesso em: 10 jan. 2011.

677 BRASIL. Superior Tribunal de Justiça. Habeas Corpus. Julgado em 15 mai. 2006. Disponível em: <https://ww2.stj.jus.br/revistaeletronica/Abre_Documento. asp?sSeq=622824\&s Reg=200600626714\&s Data=20060515\&formato=PDF $>$. Acesso em: 10 jan. 2011.

${ }^{678}$ BRASIL. Superior Tribunal de Justiça. Voto Ministro Superior Tribunal de Justiça Relator Arnaldo Esteves Lima. Habeas Corpus 56.572-SP, acórdão no 2006/0062671-4. Julgado em 15 mai. 2006. Disponível em: <https://ww2.stj.jus.br/revistaeletronica/Abre_Documento.asp?sSeq=622824\&s Reg=200600626714\&s Data=20060515\&formato=PDF $>$. Acesso em: 10 jan. 2011.

${ }^{679}$ BRASIL. Superior Tribunal de Justiça. Voto Ministro Superior Tribunal de Justiça Relator Arnaldo Esteves Lima. Habeas Corpus 56.572-SP, acórdão no 2006/0062671-4. Julgado em 15 mai. 2006. Disponível em: <https://ww2.stj.jus.br/revistaeletronica/Abre_Documento.asp?sSeq=622824\&s $\quad$ Reg=200600626714\&s Data=20060515\&formato=PDF $>$. Acesso em: 10 jan. 2011.

${ }^{680}$ BRASIL. Supremo Tribunal Federal. Julgado em 04 mar. 2004. Caso interessante com a interposição de recursos por terceiros alheios ao processo que lhe deu origem e com decisões desencontradas nos tribunais. Disponível em: <http://redir.stf.jus.br/paginadorpub/paginador.jsp?docTP=AC\&docID=384874>. Acesso em: 10 jan. 2011. Vide também GOMES, JOAQUIM BARBOSA. Voto proferido pelo Ministro Joaquim Barbosa Gomes HC no 84.025/2004. In: SARMENTO, Daniel; PIOVESAN, Flávia (coordenadores). Nos Limites da Vida. Rio de Janeiro: Lúmen Júris, 2006, p. 73-92.

681 BRASIL. Supremo Tribunal Federal. Julgado em 04 mar. 2004. Disponível em: <http://redir.stf.jus.br/paginadorpub/paginador.jsp?docTP=AC\&docID=384874>. Acesso em: 10 jan. 2011 . Vide também GOMES, JOAQUIM BARBOSA. Voto proferido pelo Ministro Joaquim Barbosa Gomes HC $\mathrm{n}^{\mathbf{o}}$ 84.025/2004. In: SARMENTO, Daniel; PIOVESAN, Flávia (coordenadores). Nos Limites da Vida. Rio de Janeiro: Lúmen Júris, 2006, p. 73-92.
} 
excluir tais direitos, e que a decisão do Superior Tribunal de Justiça no caso, ao manter a gravidez até o fim, feriu o direito à liberdade da gestante ${ }^{682}$.

Destacou o Ministro que na literatura médica fica claro que muitos sentimentos dolorosos afligem o casal durante uma tal gravidez (culpa, frustação, choque, etc), mas que, de qualquer modo, é preciso, nos casos de feto com anencefalia, observar qual é o objeto jurídico tutelado pelos arts. 124, 125 e 126 do Código Penal. O Ministro explicou que o legislador preservou a liberdade de escolha da mulher sem levar em conta a viabilidade ou não do feto na hipótese do artigo 128, II do Código Penal ${ }^{683}$. Para ele, preservam-se ao mesmo tempo uma "vida potencial" e "incolumidade da gestação" e a autonomia da vida privada é um dos alicerces da liberdade, o que está também protegido pelo princípio constitucional da dignidade humana ${ }^{684}$.

Entendeu ainda Joaquim Barbosa que a tutela do direito à vida no caso do anencéfalo seria desproporcional, pois, se prosperasse tal tese, proteger-se-ia a liberdade sexual da mulher no caso do aborto sentimental, em que o feto pode ser viável (e em geral o é), mas não se protegeria a liberdade da mulher (autonomia, direitos reprodutivos) no caso em que a inviabilidade extrauterina é inegável ${ }^{685}$.

O Ministro ainda afirmou que o texto normativo não concede o mesmo grau de proteção à vida ao feto inviável, pois “o feto anencefálico, mesmo estando biologicamente vivo (porque feito de células e tecidos vivos), não tem proteção jurídica"686 a partir do momento em que foi diagnosticada "a irreversibilidade da anencefalia" e a "inviabilidade" do

\footnotetext{
${ }^{682}$ BRASIL. Supremo Tribunal Federal. Voto Ministro Relator Joaquim Barbosa no HC 84.025-6/RJ. p. 1-2. Disponível em: <http://redir.stf.jus.br/paginadorpub/paginador.jsp?docTP=AC\&docID=384874>. Acesso em: 10 jan. 2011.

${ }^{683}$ BRASIL. Supremo Tribunal Federal. Voto Ministro Relator Joaquim Barbosa no HC 84.025-6/RJ. p. 13-14. Disponível em: <http://redir.stf.jus.br/paginadorpub/paginador.jsp?docTP=AC\&docID=384874>. Acesso em: 10 jan. 2011.

${ }^{684}$ BRASIL. Supremo Tribunal Federal. Voto Ministro Relator Joaquim Barbosa no HC 84.025-6/RJ. p. 15. Disponível em: <http://redir.stf.jus.br/paginadorpub/paginador.jsp?docTP=AC\&docID=384874>. Acesso em: 10 jan. 2011.

${ }^{685}$ BRASIL. Supremo Tribunal Federal. Voto Ministro Relator Joaquim Barbosa no HC 84.025-6/RJ. p. 16-17. Disponível em: <http://redir.stf.jus.br/paginadorpub/paginador.jsp?docTP=AC\&docID=384874>. Acesso em: 10 jan. 2011.

${ }^{686}$ BRASIL. Supremo Tribunal Federal. Voto Ministro Relator Joaquim Barbosa no HC 84.025-6/RJ. p. 20-22. Disponível em: <http://redir.stf.jus.br/paginadorpub/paginador.jsp?docTP=AC\&docID=384874>. Acesso em: 10 jan. 2011.
} 
feto $^{687}$, de modo que, daí, “embora biologicamente vivo, [o feto] deixou de ser amparado pelo art. 124 do Código Penal”, ${ }^{688}$.

Entendeu o Ministro, por fim, tratar-se de atipicidade de conduta, tendo em vista também que o "estudo referente à medicina fetal e à terapia neo-natal"689 que orientou a tipificação do aborto em nosso Código Penal é da década de 50, justificando a lacuna do direito com relação ao feto anencéfalo ${ }^{690}$.

Analisaremos em seguida a arguição de descumprimento de preceito fundamental 54, que, depois de tramitar perante o STF por 7 anos, 9 meses, e 26 dias, finalmente foi julgada em 11 e 12 de abril de 2012, e versa exatamente sobre o feto anencefálico.

\subsection{ARGUIÇÃO DE DESCUMPRIMENTO DE PRECEITO FUNDAMENTAL (ADPF) Nº} 54

\subsubsection{Origens do caso}

O Supremo Tribunal Federal finalmente se deparou com a questão do aborto do feto anencéfalo diretamente. A Confederação Nacional dos Trabalhadores na Saúde (CNTS), na qualidade de arguente, ofereceu a Arguição de Descumprimento de Preceito Fundamental ${ }^{691}$

\footnotetext{
${ }^{687}$ BRASIL. Supremo Tribunal Federal. Voto Ministro Relator Joaquim Barbosa no HC 84.025-6/RJ. p. $20-22$. Disponível em: <http://redir.stf.jus.br/paginadorpub/paginador.jsp?docTP=AC\&docID=384874>. Acesso em: 10 jan. 2011.

${ }_{688}$ BRASIL. Supremo Tribunal Federal. Voto Ministro Relator Joaquim Barbosa no HC 84.025-6/RJ. p. $20-22$. Disponível em: <http://redir.stf.jus.br/paginadorpub/paginador.jsp?docTP=AC\&docID=384874>. Acesso em: 10 jan. 2011.

${ }^{689}$ BRASIL. Supremo Tribunal Federal. Voto Ministro Relator Joaquim Barbosa no HC 84.025-6/RJ. p. 20-22. Disponível em: <http://redir.stf.jus.br/paginadorpub/paginador.jsp?docTP=AC\&docID=384874>. Acesso em: 10 jan. 2011.

${ }^{690}$ BRASIL. Supremo Tribunal Federal. Voto Ministro Relator Joaquim Barbosa no HC 84.025-6/RJ. p 22. Disponível em: <http://redir.stf.jus.br/paginadorpub/paginador.jsp? docTP=AC\&docID=384874>. Acesso em: 10 jan. 2011. Esclareceu, por fim, o Ministro que a criança no caso em tela havia nascido e sobrevivido 7 minutos fora do útero da mãe. Voto Ministro Relator Joaquim Barbosa no HC 84.025-6/RJ. p 22. Disponível em: <http://redir.stf.jus.br/paginadorpub/paginador.jsp? docTP=AC\&docID=384874>. Acesso em: 10 jan. 2011.

${ }^{691}$ No seu livro sobre Tratado de Argüição de Descumprimento de Preceito Fundamental, André Ramos Tavares analisa a terminologia "preceito fundamental". Primeiro, traça uma diferenciação entre as normas. Adota a posição de que a norma é o gênero da qual decorrem suas espécies, regras e princípios. TAVARES, André Ramos. Tratado de Argüição de Descumprimento de Preceito Fundamental. São Paulo: Saraiva, 2001, p. 109. Aponta também três elementos importantes para diferenciar uma espécie da outra. Para o autor, deve-se levar em conta o grau de abstração, grau de aplicabilidade e balanceamento de interesses. Os princípios têm maior grau de abstração, não são aplicados de plano ao caso e permitem uma ponderação e uma coexistência
} 
perante o Supremo Tribunal Federal em 17 ago. $2004^{692}$, tendo como preceitos fundamentais pretensamente violados a dignidade da pessoa humana (artigo $1^{\circ}, \mathrm{IV}, \mathrm{CF}$ ), o direito à liberdade (artigo $5^{\circ}$, II, CF), e o direito à saúde (artigos $6^{\circ}$ e 196, CF) por conta da interpretação normalmente atribuída aos artigos 124 ao 128 do Código Penal ${ }^{693}$, que o arguente considerara equivocada.

\subsubsection{Argumentos do arguente}

A Confederação inicia sua petição inicial alegando que a proibição de antecipação terapêutica do parto de feto anencéfalo, acometido de patologia em que se verifica a inviabilidade absoluta da vida extrauteriana ${ }^{694}$, decorre de uma "interpretação específica" de dispositivos do Código Penal, ${ }^{695}$ pleiteando basicamente a inconstitucionalidade da aplicação de tais preceitos normativos contidos no Código Penal Brasileiro às gestantes e aos profissionais da saúde, com o consequente reconhecimento do "direito subjetivo da gestante" de se submeter ao procedimento médico ${ }^{696}$ sem autorização judicial prévia, fazendo, para tanto, uma interpretação conforme a Constituição Federal ${ }^{697}$.

com outros princípios. As regras, ao contrário. Nesse contexto, o autor afirma que, em princípio, preceito seria qualquer norma - pois inclui princípios e regras-, desde que "imprescindível, basilar ou inafastável", isto é, constituem a "alma da Constituição" que não precisa constar unicamente na Constituição. A noção de preceito fundamental englobaria, para o autor, as cláusulas pétreas - com a garantia da imutabilidade e os princípios sensíveis. TAVARES, André Ramos. Tratado de Argüição de Descumprimento de Preceito Fundamental. São Paulo: Saraiva, 2001, p. 109-152, em especial, 109, 110, 117, 121, 122, 134 e 136, 150 e 151.

${ }^{692}$ ADPF n ${ }^{\circ}$ 54-8. Disponível em: 〈http://www.stf.jus.br〉. Acesso em: 10 jan. 2011.

${ }^{693}$ BRASIL. Supremo Tribunal Federal. Arguição de Descumprimento de Preceito Fundamental no $54-8$. Petição Inicial, p. 9. Disponível em: <http://www.stf.jus.br>. Acesso em: 10 jan. 2011. A ADPF n 54 teve pedido para atuar como amicus curiae ANIS - Instituto de Bioética, Direitos Humanos e Gênero, associação civil com sede em Brasília. Instituto sem fins lucrativos que visa à defesa e promoção da biética, direitos humanos, liberdade de grupos vulneráveis no Brasil. BRASIL. Supremo Tribunal Federal. Arguição de Descumprimento de Preceito Fundamental no 54-8. Petição Inicial, p. 2. Disponível em: <http://www.stf.jus.br〉. Acesso em: 10 jan. 2011.

${ }^{694}$ BRASIL. Supremo Tribunal Federal. Arguição de Descumprimento de Preceito Fundamental no $54-8$. Petição Inicial, p. 2. Disponível em: 〈http://www.stf.jus.br>. Acesso em: 10 jan. 2011.

${ }^{695}$ BRASIL. Supremo Tribunal Federal. Arguição de Descumprimento de Preceito Fundamental no $54-8$. Petição Inicial, p. 2. Disponível em: <http://www.stf.jus.br>. Acesso em: 10 jan. 2011.

${ }^{696}$ BRASIL. Supremo Tribunal Federal. Arguição de Descumprimento de Preceito Fundamental no $54-8$. Petição Inicial, p. 2. Disponível em: <http://www.stf.jus.br>. Acesso em: 10 jan. 2011.

${ }^{697}$ BRASIL. Supremo Tribunal Federal. Arguição de Descumprimento de Preceito Fundamental no $54-8$. Petição Inicial, p. 2. Vide também Interpretação conforme Constituição para a Confederação seria uma "técnica de interpretação que possibilitaria a expressa exclusão de um dos sentidos possíveis da norma, para produzir um resultado que contravém a Constituição, e a afirmação de outro sentido, compatível com a Lei Maior, dentro dos limites e possibilidades oferecidas pelo texto". BRASIL. Supremo Tribunal Federal. Arguição de Descumprimento de Preceito Fundamental $\mathrm{n}^{\mathrm{o}}$ 54-8. Petição Inicial, p. 18-19. Disponível em: <http://www.stf.jus.br>. Acesso em: 10 jan. 2011. 
Em nota prévia, argumenta a parte que há um histórico internacional sobre o tema do aborto, e que não se trata de um aborto eugênico, termo este que estaria ligado ao aborto de feto detentor de anomalias que não inviabilizam sua vida extrauterina, diferentemente do que ocorre com a anencefalia ${ }^{698}$, sendo necessário, portanto, discutir a matéria tendo em conta o sofrimento da gestante e as ameaças e óbices que impedem a atuação dos profissionais da saúde neste caso ${ }^{699}$.

Alega ainda o arguente que a morte intrauterina ocorre em $65 \%$ dos casos de anencefalia $^{700}$. A anencefalia é $100 \% \mathrm{fatal}^{701}$, sem possibilidade de reverter-se o quadro ${ }^{702}$, e, por isso, é "incompatível com a vida extra-uterina" ${ }^{\natural 03}$, e não existe controvérsia a respeito na literatura e na prática médica ${ }^{704}$. Afirma ainda o arguente que a falibilidade do exame que diagnostica anomalias graves no feto, tais como a anencefalia, é "praticamente nula"705.

$\mathrm{O}$ arguente argumenta, ainda, que a saúde e a vida da gestante que carrega o feto anencéfalo ficam ameaçadas ${ }^{706}$ diante da incidência comum de óbito do feto durante a gestação, conforme indicado em parecer da Febrasgo - Federação Brasileira de Ginecologia e Obstetrícia $^{707}$. Para a Confederação, a única "indicação terapêutica médica" eficiente para o tratamento da gestante seria a antecipação do parto $^{708}$.

Assim, alega a Confederação que, no caso da anencefalia, não poderia ser aplicado o disposto no Código Penal sobre o aborto em geral, tendo em vista a inexistência do "suporte fático" exigido pelo dispositivo penal, pois a morte do feto não decorreria dos meios abortivos

\footnotetext{
${ }^{698}$ BRASIL. Supremo Tribunal Federal. Arguição de Descumprimento de Preceito Fundamental n ${ }^{\circ}$ 54-8. Petição Inicial, p. 3-4. Disponível em: 〈http://www.stf.jus.br>. Acesso em: 10 jan. 2011.

${ }^{699}$ BRASIL. Supremo Tribunal Federal. Arguição de Descumprimento de Preceito Fundamental no ${ }^{\circ}$ 54-8. Petição Inicial, p. 4. Disponível em: 〈http://www.stf.jus.br〉. Acesso em: 10 jan. 2011.

${ }^{700}$ BRASIL. Supremo Tribunal Federal. Arguição de Descumprimento de Preceito Fundamental no $54-8$. Petição Inicial, p. 5 Disponível em: 〈http://www.stf.jus.br〉. Acesso em: 10 jan. 2011.

${ }^{701}$ BRASIL. Supremo Tribunal Federal. Arguição de Descumprimento de Preceito Fundamental no 54-8. Petição Inicial, p. 5. Disponível em: 〈http://www.stf.jus.br〉. Acesso em: 10 jan. 2011.

${ }^{702}$ BRASIL. Supremo Tribunal Federal. Arguição de Descumprimento de Preceito Fundamental nº 54-8. Petição Inicial, p. 5. Disponível em: <http://www.stf.jus.br>. Acesso em: 10 jan. 2011.

${ }^{703}$ BRASIL. Supremo Tribunal Federal. Arguição de Descumprimento de Preceito Fundamental no 54-8. Petição Inicial, p. 4-5. Disponível em: 〈http://www.stf.jus.br〉. Acesso em: 10 jan. 2011.

${ }^{704}$ BRASIL. Supremo Tribunal Federal. Arguição de Descumprimento de Preceito Fundamental no $54-8$. Petição Inicial, p. 5. Disponível em: 〈http://www.stf.jus.br〉. Acesso em: 10 jan. 2011.

${ }^{705}$ BRASIL. Supremo Tribunal Federal. Arguição de Descumprimento de Preceito Fundamental no 54-8. Petição Inicial, p. 5. Disponível em: 〈http://www.stf.jus.br〉. Acesso em: 10 jan. 2011.

706 "A permanência do feto anômalo no útero da mãe é potencialmente perigosa, podendo gerar danos à saúde da mãe e até perigo de vida". BRASIL. Supremo Tribunal Federal. Arguição de Descumprimento de Preceito Fundamental no 54-8. Petição Inicial, p. 5. Disponível em: 〈http://www.stf.jus.br〉. Acesso em: 10 jan. 2011.

${ }^{707}$ BRASIL. Supremo Tribunal Federal. Arguição de Descumprimento de Preceito Fundamental no ${ }^{\circ}$ 54-8. Petição Inicial, p. 5. Disponível em: 〈http://www.stf.jus.br〉. Acesso em: 10 jan. 2011.

${ }^{708}$ BRASIL. Supremo Tribunal Federal. Arguição de Descumprimento de Preceito Fundamental $n^{\circ}$ 54-8. Petição Inicial, p. 5-6. Disponível em: 〈http://www.stf.jus.br>. Acesso em: 10 jan. 2011. Vide o parecer na íntegra juntado na Petição Inicial p. 79-81 do documento PDF. Disponível em: <http://www.stf.jus.br>. Acesso em: 10 jan. 2011.
} 
utilizados durante o procedimento de aborto, uma vez que, mesmo que a duração da gestação de 9 meses ocorra, o feto fatalmente perecerá ${ }^{709}$. Afirma também que em 1940 não existiam técnicas que pudessem demonstrar anomalias fetais que levassem à inviabilidade da vida extrauterina, daí tais anomalias não terem sido originalmente excepcionadas pelo legislador ${ }^{710}$.

Preliminarmente, a CNTS defendeu sua legitimação ativa e a pertinência temática ${ }^{711}$, alegando o cabimento da ADPF por violação a preceito fundamental ${ }^{712}$. No mérito, foram apresentados os seguintes argumentos:

i) A inexistência de potencialidade de vida extrauterina, enfraquecendo a tese de que haveria conflito entre direitos fundamentais a respeito da "potencialidade da vida do nascituro"713 e "a liberdade e autonomia individuais da gestante" ${ }^{\text {"714 }}$, requisitos exigidos simultaneamente, de modo que a gestante que optasse pela antecipação do aborto teria a salvaguarda dos direitos constitucionais que "imunizam a sua conduta da incidência da legislação ordinária repressiva" ${ }^{, 715}$.

ii) A analogia com tortura psíquica, justificada no fato de que a gestação de nove meses de um feto anencéfalo que não sobreviverá "causando dor, angústia e frustação" "716 importa a violação da dignidade da pessoa humana e "a potencial ameaça à integridade física e os danos à integridade moral e psicológica",717 com a "convivência diuturna com a triste realidade e a lembrança do feto dentro de seu corpo" ${ }^{\text {718 }}$, equipara-se à tortura. Alega, ainda, que a Constituição Federal veda todas as formas de tortura ${ }^{719}$ (artigo $5^{\circ}$, III), e que a tortura

\footnotetext{
${ }^{709}$ BRASIL. Supremo Tribunal Federal. Arguição de Descumprimento de Preceito Fundamental no $54-8$. Petição Inicial, p. 6. Disponível em: <http://www.stf.jus.br〉. Acesso em: 10 jan. 2011.

${ }^{710}$ BRASIL. Supremo Tribunal Federal. Arguição de Descumprimento de Preceito Fundamental no $54-8$. Petição Inicial, p. 6. Disponível em: <http://www.stf.jus.br〉. Acesso em: 10 jan. 2011.

${ }^{711}$ BRASIL. Supremo Tribunal Federal. Arguição de Descumprimento de Preceito Fundamental no 54-8. Petição Inicial, p. 7-8. Disponível em: <http://www.stf.jus.br>. Acesso em: 10 jan. 2011.

${ }^{712}$ BRASIL. Supremo Tribunal Federal. Arguição de Descumprimento de Preceito Fundamental no $54-8$. Petição Inicial, p. 9-13. Disponível em: 〈http://www.stf.jus.br〉. Acesso em: 10 jan. 2011.

${ }^{713}$ BRASIL. Supremo Tribunal Federal. Arguição de Descumprimento de Preceito Fundamental no 54-8. Petição Inicial, p. 13. Disponível em: 〈http://www.stf.jus.br〉. Acesso em: 10 jan. 2011.

${ }^{714}$ BRASIL. Supremo Tribunal Federal. Arguição de Descumprimento de Preceito Fundamental no $54-8$. Petição Inicial, p. 13. Disponível em: 〈http://www.stf.jus.br>. Acesso em: 10 jan. 2011.

${ }^{715}$ BRASIL. Supremo Tribunal Federal. Arguição de Descumprimento de Preceito Fundamental no 54-8. Petição Inicial, p. 14. Disponível em: 〈http://www.stf.jus.br>. Acesso em: 10 jan. 2011.

${ }^{716}$ BRASIL. Supremo Tribunal Federal. Arguição de Descumprimento de Preceito Fundamental no $54-8$. Petição Inicial, p. 14. Disponível em: 〈http://www.stf.jus.br>. Acesso em: 10 jan. 2011.

${ }^{717}$ BRASIL. Supremo Tribunal Federal. Arguição de Descumprimento de Preceito Fundamental no $54-8$. Petição Inicial, p. 14. Disponível em: 〈http://www.stf.jus.br〉. Acesso em: 10 jan. 2011.

${ }^{718}$ BRASIL. Supremo Tribunal Federal. Arguição de Descumprimento de Preceito Fundamental no $54-8$. Petição Inicial, p. 14. Disponível em: 〈http://www.stf.jus.br>. Acesso em: 10 jan. 2011.

${ }^{719}$ Como ensina Fernando Rey Martínez qualquer intervenção médica realizada contra a vontade do paciente atenta contra e lesiona a dignidade da pessoa humana, especialmente, por força do artigo 15 da Convenção Europeia de Direitos Humanos que trata da proibição de tratamento desumano e degradante. Aplicar-se-ia o
} 
consistiria na situação de intenso sofrimento físico ou mental, nos termos do artigo $1^{\circ}$ da Lei 9455 de 07 abr. $1997^{720}$, de modo que a continuidade da gravidez nos casos de feto anencéfalo violaria o princípio da dignidade da pessoa humana, em suas duas esferas ${ }^{721}$.

iii) O respeito à legalidade, liberdade e autonomia da vontade, afirmando que "tudo o que não está proibido por lei é juridicamente permitido"722, de modo que a antecipação terapêutica do parto de feto anencéfalo não está vedada pelo ordenamento jurídico e que, por essa razão, seria juridicamente permitida expressamente, diante da atipicidade da conduta ${ }^{723}$. O particular estaria protegido pela "cláusula constitucional genérica de liberdade no direito brasileiro",724 e, uma restrição à liberdade de escolha ou autonomia à vontade individual - no caso da mãe - não encontraria guarida no direito positivo, ainda menos quando se leva em consideração a existência de outros direitos em jogo ${ }^{725}$.

iv) Respeito ao direito à saúde previsto nos artigos 6º e de 196 a 200 da Constituição Federal, com base no conceito de saúde atribuído pela Organização Mundial da Saúde, que, além da ausência de doença, englobaria o "completo bem estar físico, mental e social"726 dos indivíduos.

A Confederação destaca a importância de uma interpretação conforme a Constituição, no sentido de optar-se por uma certa interpretação da norma dentre outras possíveis,

entendimento também à não intervenção médica, não realizada também contra a vontade da gestante. REY MARTÍNEZ, Fernando Martínez. Eutanasia y Derechos Fundamentales. Madrid: Centro de Estúdios Políticos Y Constitucionales, 2008, p. 26 (grifo nosso).

${ }^{720}$ BRASIL. Supremo Tribunal Federal. Arguição de Descumprimento de Preceito Fundamental no $54-8$. Petição Inicial, p. 16. Disponível em: <http://www.stf.jus.br>. Acesso em: 10 jan. 2011.

${ }^{721}$ BRASIL. Supremo Tribunal Federal. Arguição de Descumprimento de Preceito Fundamental $n^{\circ}$ 54-8. Petição Inicial, p. 15-16. Disponível em: 〈http://www.stf.jus.br〉. Acesso em: 10 jan. 2011. Para Luís Roberto Barroso, a doutrina identificou duas linhas para separar os direitos da personalidade inerentes ao princípio da dignidade da pessoa humana: uma diz respeito aos direitos de integridade física, abrangendo o direito à vida, direito à disposição do próprio corpo e o direito ao cadáver; outra trata dos direitos à integridade moral, isto é, direitos à honra, à intimidade, à liberdade, à vida privada, dentre outros. Arguição de Descumprimento de Preceito Fundamental n ${ }^{\circ}$ 54-8. Petição Inicial, p. 15. Disponível em: 〈http://www.stf.jus.br〉. Acesso em: 10 jan. 2011.

722 BRASIL. Supremo Tribunal Federal. Arguição de Descumprimento de Preceito Fundamental no ${ }^{\circ}$ 54-8. Petição Inicial, p. 17. Disponível em: 〈http://www.stf.jus.br>. Acesso em: 10 jan. 2011. Ver também a autêntica cláusula de liberdade geral: tudo o que não está proibido ou ordenado é permitido. REY MARTíNEZ, Fernando Martínez. Eutanasia y Derechos Fundamentales. Madrid: Centro de Estúdios Políticos Y Constitucionales, 2008 , p. 165.

${ }^{723}$ BRASIL. Supremo Tribunal Federal. Arguição de Descumprimento de Preceito Fundamental no 54-8. Petição Inicial, p. 17. Disponível em: <http://www.stf.jus.br>. Acesso em: 10 jan. 2011.

${ }^{724}$ BRASIL. Supremo Tribunal Federal. Arguição de Descumprimento de Preceito Fundamental no 54-8. Petição Inicial, p. 15. Disponível em: <http://www.stf.jus.br>. Acesso em: 10 jan. 2011.

${ }^{725}$ BRASIL. Supremo Tribunal Federal. Arguição de Descumprimento de Preceito Fundamental no 54-8. Petição Inicial, p. 17. Disponível em: <http://www.stf.jus.br>. Acesso em: 10 jan. 2011.

${ }^{726}$ BRASIL. Supremo Tribunal Federal. Arguição de Descumprimento de Preceito Fundamental no 54-8. Petição Inicial, p. 18. Disponível em: <http://www.stf.jus.br>. Acesso em: 10 jan. 2011. 
excluindo-se aquelas incompatíveis com a Constituição, e aceitando-se aquela que lhe seja compatível $^{727}$.

Pleiteia finalmente o arguente medida $\operatorname{liminar}^{728}$, buscando a suspensão dos processos em andamento e os efeitos das decisões que proíbam o aborto do feto anencéfalo com base nos dispositivos penais, para que a gestante possa submeter-se à antecipação do parto, e que o profissional de saúde possa realizá-la. Pleiteia, também, a inconstitucionalidade com eficácia erga omnes e efeito vinculante da interpretação dos dispositivos do Código Penal (artigos $124,126,128$, I e II) que tornam impraticável a antecipação do parto, com o reconhecimento do direito subjetivo da mulher ao aborto no caso do feto anencefálico, sem necessidade de autorização judicial para tanto ${ }^{729}$.

\subsubsection{Argumentos da Procuradoria Geral da República}

Foram abertas vistas ao Procurador-Geral da República para apresentar parecer ao caso. No parecer $n^{\circ} 3358$, o Procurador Geral da República, Claudio Fonteles, afirmou que não há que se falar em interpretação conforme à Constituição, vez que não há interpretação corretiva que deva ser feita ${ }^{730}$, e tampouco existe a possibilidade de enquadramento do aborto

\footnotetext{
${ }^{727}$ BRASIL. Supremo Tribunal Federal. Arguição de Descumprimento de Preceito Fundamental no $54-8$. Petição Inicial, p. 18-19. Disponível em: 〈http://www.stf.jus.br〉. Acesso em: 10 jan. 2011.

${ }^{728}$ Para o arguente, a violação da dignidade da pessoa humana, da legalidade, da liberdade, da autonomia da vontade e do direito à saúde configurariam a presença do fumus bonis iuris e, o periculum in mora decorreria da existência de inúmeros processos em que as gestantes pleiteiam judicialmente a possibilidade de realizar o procedimento pelo SUS ou hospitais particulares que só realizam a antecipação do parto com a devida autorização judicial - que em geral, devido a demora do trâmite processual - não ocorre. BRASIL. Supremo Tribunal Federal. Arguição de Descumprimento de Preceito Fundamental no 54-8. Decisão Liminar. Relator Ministro Marco Aurélio, p. 21-22. Disponível em: <http://www.stf.jus.br〉. Acesso em: 10 jan. 2011.

729 BRASIL. Supremo Tribunal Federal. Arguição de Descumprimento de Preceito Fundamental $\mathrm{n}^{\circ}$ 54-8. Decisão Liminar. Relator Ministro Marco Aurélio, p. 22. Disponível em: <http://www.stf.jus.br〉. Acesso em: 10 jan. 2011. O arguente alternativamente pleiteia que a presente ação seja recebida como Ação Direta de Inconstitucionalidade, caso se entenda pelo não cabimento da Arguição de Descumprimento de Preceito Fundamental, pois o que se espera é "uma interpretação conforme à Constituição" dos dispositivos constantes do Código Penal brasileiro, "sem redução de texto". BRASIL. Supremo Tribunal Federal. Arguição de Descumprimento de Preceito Fundamental $n^{\circ}$ 54-8. Decisão Liminar. Relator Ministro Marco Aurélio, p. 23. Disponível em: <http://www.stf.jus.br>. Acesso em: 10 jan. 2011.

${ }^{730}$ BRASIL. Supremo Tribunal Federal. Arguição de Descumprimento de Preceito Fundamental no $54-8$. Parecer Ministério Público Federal - emitido pelo Procurador-Geral da República Claudio Fonteles, p. 3-4, itens 7-9. Disponível em: <http://www.stf.jus.br>. Acesso em: 10 jan. 2011. Afirma que há um limite para o uso da interpretação conforme à Constituição, pois, apesar de os artigos 124 e 126 tratarem do "aborto provocado pela gestante ou com seu consentimento" e do "aborto provocado por terceiros", o caso do feto anencéfalo não se aplica às hipóteses de aborto permitidas por lei, isto é, aborto terapêutico e sentimental. BRASIL. Supremo Tribunal Federal. Arguição de Descumprimento de Preceito Fundamental no 54-8. Parecer Ministério Público
} 
do feto anencéfalo aos dispositivos penais específicos que prevêem o aborto sentimental e terapêutico $^{731}$.

Além disso, Fonteles afirmou, ainda, que o feto anencéfalo nasce com vida, que o direito à vida não está vinculado ao "tempo de duração da existência humana"732, e que relativizar "a compreensão jurídica do direito à vida",733 , baseando-se tão-somente na "dor" da gestante - que, inclusive, nem sempre corresponde à mesma da dor de todas as gestantes ${ }^{734}$ não é o certo ${ }^{735}$, devendo ser mantida a "ponderação de bens" ${ }^{\$ 736}$. Sugeriu, ademais, Fonteles, que ao se levar a gravidez do feto anencéfalo a termo, existe ainda a possibilidade de doação dos órgãos saudáveis dos anencéfalos para serem transplantados a outros bebês, o que poderia salvar vidas ${ }^{737}$.

Federal - emitido pelo Procurador-Geral da República Claudio Fonteles, p. 2-8. Disponível em: <http://www.stf.jus.br>. Acesso em: 10 jan. 2011.

${ }^{731}$ BRASIL. Supremo Tribunal Federal. Arguição de Descumprimento de Preceito Fundamental no 54-8. Parecer Ministério Público Federal - emitido pelo Procurador-Geral da República Claudio Fonteles, p. 7-8, itens 22-26. Disponível em: <http://www.stf.jus.br>. Acesso em: 10 jan. 2011. Para o Procurador-Geral, o direito à vida é um "marco primeiro, no espaço dos direitos fundamentais" e que havendo "processo de gestação" existiria "vida intra-uterina", garantida - nos termos do artigo $2^{\circ}$ do Código Civil, do artigo 41 da Convenção Americana de Direitos Humanos, do artigo $1^{\circ}$ da Convenção sobre os Direitos da Criança - a vida desde a concepção. BRASIL. Supremo Tribunal Federal. Arguição de Descumprimento de Preceito Fundamental no 54-8. Parecer Ministério Público Federal - emitido pelo Procurador-Geral da República Claudio Fonteles, p. 9-10. Disponível em: <http://www.stf.jus.br. Acesso em: 10 jan. 2011.

${ }^{732}$ BRASIL. Supremo Tribunal Federal. Arguição de Descumprimento de Preceito Fundamental no $54-8$. Parecer Ministério Público Federal - emitido pelo Procurador-Geral da República Claudio Fonteles, p. 11, item 46. Disponível em: <http://www.stf.jus.br>. Acesso em: 10 jan. 2011. Para Claudio Fonteles, portanto, o "direito à vida é a temporal". BRASIL. Supremo Tribunal Federal. Arguição de Descumprimento de Preceito Fundamental $\mathrm{n}^{\circ}$ 54-8. Parecer Ministério Público Federal - emitido pelo Procurador-Geral da República Claudio Fonteles, p. 10-11. Disponível em: 〈http://www.stf.jus.br>. Acesso em: 10 jan. 2011

${ }^{733}$ BRASIL. Supremo Tribunal Federal. Arguição de Descumprimento de Preceito Fundamental $n^{\circ}$ 54-8. Parecer Ministério Público Federal - emitido pelo Procurador-Geral da República Claudio Fonteles, p. 11, itens 50-52. Disponível em: 〈http://www.stf.jus.br〉. Acesso em: 10 jan. 2011.

${ }^{734}$ BRASIL. Supremo Tribunal Federal. Arguição de Descumprimento de Preceito Fundamental no ${ }^{\circ} 54-8$. Parecer Ministério Público Federal - emitido pelo Procurador-Geral da República Claudio Fonteles, p. 11, itens 50-52. Disponível em: <http://www.stf.jus.br>. Acesso em: 10 jan. 2011.

${ }^{735}$ BRASIL. Supremo Tribunal Federal. Arguição de Descumprimento de Preceito Fundamental no 54-8. Parecer Ministério Público Federal - emitido pelo Procurador-Geral da República Claudio Fonteles, p. 11, item 49. Disponível em: <http://www.stf.jus.br >. Acesso em: 10 jan. 2011. Para Claudio Fonteles, nem todas as mulheres grávidas "almejam livrar-se do ser humano, que existe em seus ventres maternos" e, por isso, "sofrer uma dor, mesmo que intensa, não ultrapassa o pôr cabo a uma vida, que existe, intra-uterina", com proteção normativa e que o feto não pode ser considerado uma "coisa". BRASIL. Supremo Tribunal Federal. Arguição de Descumprimento de Preceito Fundamental $\mathrm{n}^{\circ}$ 54-8. Parecer Ministério Público Federal - emitido pelo Procurador-Geral da República Claudio Fonteles, p. 11. Disponível em: 〈http://www.stf.jus.br>. Acesso em: 10 jan. 2011.

${ }_{736}$ BRASIL. Supremo Tribunal Federal. Arguição de Descumprimento de Preceito Fundamental no ${ }^{\circ}$ 54-8. Parecer Ministério Público Federal - emitido pelo Procurador-Geral da República Claudio Fonteles, p. 11, item 53. Disponível em: <http://www.stf.jus.br>. Acesso em: 10 jan. 2011.

${ }^{737}$ BRASIL. Supremo Tribunal Federal. Arguição de Descumprimento de Preceito Fundamental no 54-8. Parecer Ministério Público Federal - emitido pelo Procurador-Geral da República Claudio Fonteles, p.12, itens 55-57. Disponível em: 〈http://www.stf.jus.br>. Acesso em: 10 jan. 2011. Isso violaria o objetivo de construir uma sociedade solidária. BRASIL. Supremo Tribunal Federal. Arguição de Descumprimento de Preceito Fundamental no 54-8. Parecer Ministério Público Federal - emitido pelo Procurador-Geral da República Claudio Fonteles, p. 11-12. Disponível em: <http://www.stf.jus.br>. Acesso em 10 jan. 2011. 


\subsection{ANÁLISE DOS VOTOS DA MEDIDA LIMINAR ${ }^{738}$}

O pedido liminar da Arguição de Descumprimento de Preceito Fundamental 54 (ADPF 54) foi julgado procedente pelo Supremo Tribunal Federal em julho de 2004. A decisão da liminar foi levada à Plenário em 02 agosto de 2004, que deliberou pelo julgamento do mérito.

Posteriormente, em sessão de 20 agosto de 2004, o Plenário do Supremo Tribunal Federal, por maioria ${ }^{739}$, manteve o sobrestamento de processos e decisões não transitadas em julgado até a decisão definitiva da $\operatorname{ADPF} 54^{740}$, e revogou a segunda parte da decisão concedida na liminar, que reconhecia o direito constitucional da gestante de se submeter ao procedimento terapêutico abortivo, afirmando que a referida matéria não deve ser discutida no âmbito de medida liminar. Ademais, na ocasião, o Plenário ainda designou datas para a realização das audiências públicas, ocorridas entre agosto e setembro de 2008, tendo sido ouvidas diversas entidades, entre elas a Conferência Nacional dos Bispos do Brasil, o Conselho Federal de Medicina, o Conectas, e outros, como veremos abaixo.

Ressaltamos, adiante, alguns argumentos apontados pelos Ministros no julgamento da questão de ordem na ADPF 54-8 ${ }^{741}$. Vale dizer que, preliminarmente, muito se discutiu sobre aspectos processuais da ADPF 54. No entanto, a fim de respeitar o escopo do presente trabalho, destacaremos em nossa análise a seguir os argumentos desenvolvidos especificamente sobre o tema do aborto de feto anencéfalo.

\subsubsection{Voto do Ministro Marco Aurélio}

\footnotetext{
${ }^{738}$ [N.R.] Votos publicados no site do Supremo Tribunal Federal. Vale dizer que o voto do Ministro Celso de Mello foi cancelado e em razão disso não foi publicado no site e nem disponibilizado para análise. A informação foi fornecida pelo chefe de Gabinete Dr. Miguel Ricardo de Oliveira Piazzi, confirmada em 23 de janeiro de 2012. BRASIL. Supremo Tribunal Federal. Arguição de Descumprimento de Preceito Fundamental no $54-8$. Disponível em: <http://www.stf.jus.br>. Acesso em: 10 jan. 2011.

${ }^{739}$ Vencidos os Ministros Marco aurélio, Carlos Britto, Sepúlveda Pertence e Celso de Mello. Votos vencedores dos Ministros Nelson Jobim (presidente), Eros Grau, Carlos Velloso, Ellen Gracie, Gilmar Mendes, Cezar Peluso e Joaquim Barbosa.

${ }^{740}$ Vencido o Ministro Cezar Peluso.

${ }^{741}$ BRASIL. Supremo Tribunal Federal. Arguição de Descumprimento de Preceito Fundamental n ${ }^{\circ}$ 54-8. Medida Cautelar. Tribunal do Pleno. Julgamento em 20 out. 2004. Disponível em: 〈http://www.stf.jus.br〉. Acesso em: 10 jan. 2011.
} 
O Relator, Ministro Marco Aurélio, concedeu a liminar fundamentando-a na existência de uma "má-formação por defeito do fechamento do tubo neural durante a gestação, não apresentando o feto os hemisférios cerebrais e o córtex" $" 742$, o que acarreta a "morte intrauterina, alcançando $65 \%$ dos casos, ou a sobrevida de no máximo algumas horas após o parto" $^{, 743}$.

Além disso, o Ministro Marco Aurélio fundamentou sua decisão no risco à vida e à saúde da mulher, além da frustação e dor de se levar a termo uma gestação em que o feto não sobreviverá ${ }^{744}$.

Entendeu o Ministro também que é possível se valer dos "avanços médicos tecnológicos", que garantem que o feto anencéfalo morre ainda dentro do útero em mais de $50 \%$ dos casos, e que, se chega ao término da gestação, sua "sobrevida é diminuta, não ultrapassando período que possa ser tido como razoável, sendo nenhuma a chance de afastarem-se, na sobrevida, os efeitos da deficiência"745.

Finaliza o Ministro Marco Aurélio sua decisão reconhecendo que a manutenção da gravidez resultaria em "danos à integridade moral e psicológica [da gestante], além dos riscos físicos reconhecidos no âmbito da medicina",746, e "conflita com a dignidade humana, a legalidade, a liberdade e a autonomia da vontade" ${ }^{, 77}$, acolhendo o pedido formulado pelo autor da ADPF 54, reconhecendo o direito constitucional da gestante de submeter-se à operação terapêutica $^{748}$.

\footnotetext{
${ }^{742}$ BRASIL. Supremo Tribunal Federal. Arguição de Descumprimento de Preceito Fundamental $\mathrm{n}^{\circ}$ 54-8. Decisão Liminar. Relator Ministro Marco Aurélio, p. 1-2. Disponível em: <http://www.stf.jus.br〉. Acesso em: 10 jan. 2011.

${ }_{743}$ BRASIL. Supremo Tribunal Federal. Arguição de Descumprimento de Preceito Fundamental $\mathrm{n}^{\circ}$ 54-8. Decisão Liminar. Relator Ministro Marco Aurélio, p. 2. Disponível em: 〈http://www.stf.jus.br〉. Acesso em: 10 jan. 2011.

${ }^{744}$ BRASIL. Supremo Tribunal Federal. Arguição de Descumprimento de Preceito Fundamental ${ }^{\circ}$ 54-8. Decisão Liminar. Relator Ministro Marco Aurélio, p. 2. Disponível em: 〈http://www.stf.jus.br〉. Acesso em: 10 jan. 2011.

${ }_{745}$ BRASIL. Supremo Tribunal Federal. Arguição de Descumprimento de Preceito Fundamental $\mathrm{n}^{\circ}$ 54-8. Decisão Liminar. Relator Ministro Marco Aurélio, p. 6. Disponível em: 〈http://www.stf.jus.br〉. Acesso em: 10 jan. 2011.

${ }_{746}$ BRASIL. Supremo Tribunal Federal. Arguição de Descumprimento de Preceito Fundamental ${ }^{\circ}$ 54-8. Decisão Liminar. Relator Ministro Marco Aurélio, p. 6. Disponível em: 〈http://www.stf.jus.br>. Acesso em: 10 jan. 2011.

${ }_{747}$ BRASIL. Supremo Tribunal Federal. Arguição de Descumprimento de Preceito Fundamental no ${ }^{\circ}$ 54-8. Decisão Liminar. Relator Ministro Marco Aurélio, p. 6. Disponível em: 〈http://www.stf.jus.br>. Acesso em: 10 jan. 2011.

${ }_{748}$ BRASIL. Supremo Tribunal Federal. Arguição de Descumprimento de Preceito Fundamental no ${ }^{\circ}$ 54-8. Decisão Liminar. Relator Ministro Marco Aurélio, p. 7. Disponível em: 〈http://www.stf.jus.br>. Acesso em: 10 jan. 2011.
} 
$\mathrm{Na}$ linha dos argumentos apontados em liminar descritos acima, o Ministro Marco Aurélio confirmou sua posição quanto ao tema, admitindo a $\mathrm{ADPF}^{749}$.

\subsubsection{Voto do Ministro Carlos Ayres Britto}

O Ministro Carlos Britto debateu sobre a viabilidade da vida extrauterina do feto $^{750}$, comparando metaforicamente o feto anencéfalo à crisálida, afirmando que o "útero materno seria o casulo" 751 , e que, no caso, o que existe no útero da mulher é "algo que jamais será alguém" 752 . Seria a crisálida, que jamais virá a ser uma borboleta. E questiona: "estamos aqui discutindo sobre o direito de viver, o direito de nascer ou o direito de nascer para morrer? Existe esse direito de nascer para morrer?",753

Para o Ministro, a lei penal busca, ao proibir o aborto, impedir que "se interrompa um destino, se inviabilizasse uma trajetória mundana, se impeça alguém de ter um destino próprio extra-uterino" 754 - mas este não é o caso do anencéfalo.

Além disso, entende o Ministro Ayres Britto que cabe à mulher decidir se "continua com aquela gravidez-sacrifício ou não" ${ }^{, 755}$, e equipara o feto com anencefalia ao ser humano com vida, mas com a morte encefálica decretada ${ }^{756}$. Para o Ministro, o feto "está [apenas] aparentemente vivo, na verdade ele está ligado [à mãe] e por isso respira e por isso se

\footnotetext{
${ }^{749}$ BRASIL. Supremo Tribunal Federal. Arguição de Descumprimento de Preceito Fundamental ${ }^{\circ}$ 54-8. Medida Cautelar. Tribunal do Pleno. Julgamento em 20 out. 2004, p. 79-84. Disponível em: 〈http://www.stf.jus.br〉. Acesso em: 10 jan. 2011.

${ }^{750}$ BRASIL. Supremo Tribunal Federal. Arguição de Descumprimento de Preceito Fundamental no 54-8. Medida Cautelar. Tribunal do Pleno. Julgamento em 20 out. 2004, p. 90. Disponível em: <http://www.stf.jus.br>. Acesso em: 10 jan. 2011.

${ }^{751}$ BRASIL. Supremo Tribunal Federal. Arguição de Descumprimento de Preceito Fundamental no $54-8$. Medida Cautelar. Tribunal do Pleno. Julgamento em 20 out. 2004, p. 90. Disponível em: <http://www.stf.jus.br>. Acesso em: 10 jan. 2011.

${ }^{752}$ BRASIL. Supremo Tribunal Federal. Arguição de Descumprimento de Preceito Fundamental $\mathrm{n}^{\circ}$ 54-8. Medida Cautelar. Tribunal do Pleno. Julgamento em 20 out. 2004, p. 90. Disponível em: <http://www.stf.jus.br>. Acesso em: 10 jan. 2011.

${ }^{753}$ BRASIL. Supremo Tribunal Federal. Arguição de Descumprimento de Preceito Fundamental no 54-8. Medida Cautelar. Tribunal do Pleno. Julgamento em 20 out. 2004, p. 90-91. Disponível em: 〈http://www.stf.jus.br>. Acesso em: 10 jan. 2011.

${ }_{754}$ BRASIL. Supremo Tribunal Federal. Arguição de Descumprimento de Preceito Fundamental no 54-8. Medida Cautelar. Tribunal do Pleno. Julgamento em 20 out. 2004, p. 91. Disponível em: <http://www.stf.jus.br>. Acesso em: 10 jan. 2011.

${ }^{755}$ BRASIL. Supremo Tribunal Federal. Arguição de Descumprimento de Preceito Fundamental no ${ }^{\circ} 54-8$. Medida Cautelar. Tribunal do Pleno. Julgamento em 20 out. 2004, p. 91. Disponível em: <http://www.stf.jus.br>. Acesso em: 10 jan. 2011.

${ }^{756}$ BRASIL. Supremo Tribunal Federal. Arguição de Descumprimento de Preceito Fundamental no $54-8$. Medida Cautelar. Tribunal do Pleno. Julgamento em 20 out. 2004, p. 91. Disponível em: <http://www.stf.jus.br>. Acesso em: 10 jan. 2011.
} 
desenvolve". ${ }^{757}$ O feto "está ligado a uma UTI, chamada útero, mas a partir do momento em que se opera o desligamento do feto desses aparelhos ou dessa UTI, que se chama útero, nada mais resta, não há mais vida" ${ }^{, 758}$.

O Ministro Carlos Ayres Britto levanta alguns pontos sobre as possíveis interpretações sobre a matéria ${ }^{759}$ :

a) de que a antecipação terapêutica do aborto do feto anencéfalo é crime - neste caso, o feto estaria em um estado de latência, admitindo-se que a vida inicia-se na concepção, de modo que esse é o valor a ser ponderado em relação a outros valores alegados pela gestante;

b) de que inexiste crime de aborto em caso de gravidez de feto anencéfalo - pois o produto da concepção não possui as características da espécie humana ${ }^{760}$. A interrupção voluntária da gravidez no caso de feto anencéfalo seria "penalmente atípica", uma vez que, se a proteção penal se refere à proteção da vida em potencial, na falta dessa "potencialidade vital", não existiria o aborto de uma gravidez em "estado latente"761. Menciona, ainda, a aplicação ao anencéfalo do critério de morte encefálica da Lei 9434/97 762 ; e

c) de que os artigos 124, 126 e 128, I e II, do Código Penal, confirmam a tipicidade do crime de aborto, mas não trariam uma conduta punível no caso do anencéfalo, tendo em vista o abalo psíquico e a dor moral da gestante, valores estes que devem igualmente ser

\footnotetext{
${ }^{757}$ BRASIL. Supremo Tribunal Federal. Arguição de Descumprimento de Preceito Fundamental no ${ }^{\circ} 54-8$. Medida Cautelar. Tribunal do Pleno. Julgamento em 20 out. 2004, p. 92. Disponível em: 〈http://www.stf.jus.br>. Acesso em: 10 jan. 2011.

${ }^{758}$ BRASIL. Supremo Tribunal Federal. Arguição de Descumprimento de Preceito Fundamental no 54-8. Medida Cautelar. Tribunal do Pleno. Julgamento em 20 out. 2004, p. 92. Disponível em: <http://www.stf.jus.br>. Acesso em: 10 jan. 2011.

${ }^{759}$ BRASIL. Supremo Tribunal Federal. Arguição de Descumprimento de Preceito Fundamental no $54-8$. Medida Cautelar. Tribunal do Pleno. Julgamento em 20 out. 2004, p. 113-138. Disponível em: 〈http://www.stf.jus.br>. Acesso em: 10 jan. 2011. Disponível em: <http://redir.stf.jus.br/paginadorpub/ paginador.jsp?docTP=AC\&docID=484300>. Acesso em: 10 jan. 2011.

${ }_{760}$ Destacamos do voto do Ministro: "o crime deixa de existir se o deliberado desfazimento da gestação já não é impeditivo da transformação de algo em alguém. Se o produto da concepção traduzir em um ser a meio do caminho do humano, mas, isto sim, em um ser que de alguma forma parou a meio ciclo do humano". (negrito nosso). BRASIL. Supremo Tribunal Federal. Arguição de Descumprimento de Preceito Fundamental $\mathrm{n}^{\circ}$ 54-8. Medida Cautelar. Tribunal do Pleno. Julgamento em 20 out. 2004, p. 122. Disponível em: <http://www.stf.jus.br>. Acesso em: 10 jan. 2011. Disponível em: <http://redir.stf.jus.br/paginadorpub/ paginador.jsp?docTP=AC\&docID=484300>. Acesso em: 10 jan. 2011.

${ }^{761}$ BRASIL. Supremo Tribunal Federal. Arguição de Descumprimento de Preceito Fundamental no 54-8. Medida Cautelar. Tribunal do Pleno. Julgamento em 20 out. 2004, p. 120-121. Disponível em: 〈http://www.stf.jus.br>. Acesso em: 10 jan. 2011. Disponível em: <http://redir.stf.jus.br/paginadorpub/ paginador.jsp?docTP=AC\&docID=484300>. Acesso em: 10 jan. 2011.

${ }_{762}$ BRASIL. Supremo Tribunal Federal. Arguição de Descumprimento de Preceito Fundamental $n^{\circ}$ 54-8. Medida Cautelar. Tribunal do Pleno. Julgamento em 20 out. 2004, p. 123-124. Disponível em: http://www.stf.jus.br>. Acesso em: 10 jan. 2011. Disponível em: <http://redir.stf.jus.br/paginadorpub/ paginador.jsp?docTP=AC\&docID=484300>. Acesso em: 10 jan. 2011.
} 
tutelados $^{763}$, e que impedir a opção do aborto é um "modo cruel" de violar a integridade psíquica, moral e física da mulher ${ }^{764}$.

O Ministro Carlos Ayres Britto fez ainda uma analogia com a gravidez resultante de estupro, afirmando que a monstruosidade que se leva em conta nesta, é o ato sexual, e, na anencefalia, é todo o processo, desde a concepção até o parto ${ }^{765}$.

Por fim, seguiu Ayres Britto o voto do Ministro Marco Aurélio ${ }^{766}$.

\subsubsection{Voto do Ministro Joaquim Barbosa}

Em seu voto, o Ministro Joaquim Barbosa assinala a sua participação no HC 84.025, cujo pedido perdeu o objeto e não foi julgado pelo Supremo ${ }^{767}$. Afirma que sua posição naquela época foi no sentido de valorar o princípio da dignidade da mulher e sua autonomia privada. No entanto, reconhece que o tema é complexo ${ }^{768}$.

O Ministro reconhece a legitimidade ativa da Confederação Nacional dos Trabalhadores na Saúde, mas entende que a ADPF não pode ser usada com a finalidade de se alcançar uma interpretação conforme a Constituição ${ }^{769}$, ou, como prefere o Ministro, uma

\footnotetext{
${ }^{763}$ BRASIL. Supremo Tribunal Federal. Arguição de Descumprimento de Preceito Fundamental no $54-8$. Medida Cautelar. Tribunal do Pleno. Julgamento em 20 out. 2004, p. 124. Disponível em: <http://www.stf.jus.br>. Acesso em: 10 jan. 2011. Disponível em: <http://redir.stf.jus.br/paginadorpub/ paginador.jsp?docTP=AC\&docID=484300>. Acesso em: 10 jan. 2011.

${ }^{764}$ BRASIL. Supremo Tribunal Federal. Arguição de Descumprimento de Preceito Fundamental no ${ }^{\circ}$ 44-8. Medida Cautelar. Tribunal do Pleno. Julgamento em 20 out. 2004, p. 125-126. Disponível em: <http://www.stf.jus.br>. Acesso em: 10 jan. 2011. Disponível em: <http://redir.stf.jus.br/paginadorpub/ paginador.jsp?docTP=AC\&docID=484300>. Acesso em: 10 jan. 2011.

${ }_{765}$ BRASIL. Supremo Tribunal Federal. Arguição de Descumprimento de Preceito Fundamental no ${ }^{\circ}$ 44-8. Medida Cautelar. Tribunal do Pleno. Julgamento em 20 out. 2004, p. 126. Disponível em: <http://www.stf.jus.br>. Acesso em: 10 jan. 2011. Disponível em: <http://redir.stf.jus.br/paginadorpub/ paginador.jsp?docTP=AC\&docID=484300>. Acesso em: 10 jan. 2011.

${ }_{766}$ BRASIL. Supremo Tribunal Federal. Arguição de Descumprimento de Preceito Fundamental no ${ }^{\circ} 4-8$. Medida Cautelar. Tribunal do Pleno. Julgamento em 20 out. 2004, p. 138. Disponível em: 〈http://www.stf.jus.br>. Acesso em: 10 jan. 2011. Disponível em: <http://redir.stf.jus.br/paginadorpub/ paginador.jsp?docTP=AC\&docID=484300>. Acesso em: 10 jan. 2011.

${ }_{767}$ BRASIL. Supremo Tribunal Federal. Arguição de Descumprimento de Preceito Fundamental no ${ }^{\circ}$ 44-8. Medida Cautelar. Tribunal do Pleno. Julgamento em 20 out. 2004, p. 1, fl. 140. Disponível em: <http://www.stf.jus.br>. Acesso em: 10 jan. 2011. Disponível em: <http://redir.stf.jus.br/paginadorpub/ paginador.jsp?docTP=AC\&docID=484300>. Acesso em: 10 jan. 2011.

${ }_{768}$ BRASIL. Supremo Tribunal Federal. Arguição de Descumprimento de Preceito Fundamental no ${ }^{\circ} 4-8$. Medida Cautelar. Tribunal do Pleno. Julgamento em 20 out. 2004, p. 2, fl. 141. Disponível em: <http://www.stf.jus.br>. Acesso em: 10 jan. 2011. Disponível em: <http://redir.stf.jus.br/paginadorpub/ paginador.jsp?docTP=AC\&docID=484300>. Acesso em: 10 jan. 2011.

${ }_{769}$ BRASIL. Supremo Tribunal Federal. Arguição de Descumprimento de Preceito Fundamental no ${ }^{\circ} 4-8$. Medida Cautelar. Tribunal do Pleno. Julgamento em 20 out. 2004, p. 2, fl. 141. Disponível em: <http://www.stf.jus.br>.
} 
“declaração de constitucionalidade sob reserva de interpretação", que seria uma das formas em que se pode obter uma manifestação do órgão de cúpula ${ }^{770}$.

O Ministro entendeu que se aplica o artigo $1^{\circ}$ da Lei $9882 / 99^{771}$ ao caso, pois é patente a ameaça de lesão ou lesão se a mulher desejar interromper a gravidez de feto anencéfalo sem uma autorização judicial, enquadrando-se como conduta criminosa ${ }^{772}$. Além disso, a existência de inúmeras decisões que ora concedem, ora negam a submissão da mulher nessa situação ao procedimento de antecipação de parto, causa mais instabilidade e insegurança jurídica ${ }^{773}$, gerando uma violação à dignidade da mulher e a sua "capacidade de disposição autonômica"774.

Encerrando o voto, o Ministro Joaquim Barbosa sugere que a ADPF deve ser compreendida como um mecanismo de "alargamento da ação protetiva dos direitos fundamentais" 775 em defesa dos grupos mais vulneráveis, ou seja, daqueles que não possuem força política, econômica e social para se fazer representar e garantir a consecução efetiva de seus direitos ${ }^{776}$, decidindo pela admissão da ADPF.

Acesso em: 10 jan. 2011. Disponível em: <http://redir.stf.jus.br/paginadorpub/ paginador.jsp?docTP=AC\&docID=484300>. Acesso em: 10 jan. 2011.

${ }^{770}$ BRASIL. Supremo Tribunal Federal. Arguição de Descumprimento de Preceito Fundamental no ${ }^{\circ} 4-8$. Medida Cautelar. Tribunal do Pleno. Julgamento em 20 out. 2004, p. 3, fl. 142. Disponível em: <http://www.stf.jus.br>. Acesso em: 10 jan. 2011. Disponível em: <http://redir.stf.jus.br/paginadorpub/ paginador.jsp?docTP=AC\&docID=484300 Acesso em: 10 jan. 2011.

${ }^{771}$ BRASIL. Supremo Tribunal Federal. Arguição de Descumprimento de Preceito Fundamental no ${ }^{\circ 4-8}$. Medida Cautelar. Tribunal do Pleno. Julgamento em 20 out. 2004, p. 3, fl. 142. Disponível em: <http://www.stf.jus.br>. Acesso em: 10 jan. 2011. Disponível em: <http://redir.stf.jus.br/paginadorpub/ paginador.jsp?docTP=AC\&docID=484300>. Acesso em: 10 jan. 2011.

${ }_{772}$ BRASIL. Supremo Tribunal Federal. Arguição de Descumprimento de Preceito Fundamental no $54-8$. Medida Cautelar. Tribunal do Pleno. Julgamento em 20 out. 2004, p. 4, fl. 143. Disponível em: <http://www.stf.jus.br>. Acesso em: 10 jan. 2011. Disponível em: <http://redir.stf.jus.br/paginadorpub/ paginador.jsp?docTP=AC\&docID=484300>. Acesso em: 10 jan. 2011.Acesso em: 10 jan. 2011.

${ }^{773}$ BRASIL. Supremo Tribunal Federal. Arguição de Descumprimento de Preceito Fundamental no $54-8$. Medida Cautelar. Tribunal do Pleno. Julgamento em 20 out. 2004, p. 5, fl. 144. Disponível em: <http://www.stf.jus.br>. Acesso em: 10 jan. 2011. Disponível em: <http://redir.stf.jus.br/paginadorpub/ paginador.jsp?docTP=AC\&docID=484300>. Acesso em: 10 jan. 2011.

${ }^{774}$ BRASIL. Supremo Tribunal Federal. Arguição de Descumprimento de Preceito Fundamental no $54-8$. Medida Cautelar. Tribunal do Pleno. Julgamento em 20 out. 2004, p. 6, fl. 145. Disponível em: <http://www.stf.jus.br>. Acesso em: 10 jan. 2011. Disponível em: <http://redir.stf.jus.br/paginadorpub/ paginador.jsp?docTP=AC\&docID=484300>. Acesso em: 10 jan. 2011.

${ }^{775}$ BRASIL. Supremo Tribunal Federal. Arguição de Descumprimento de Preceito Fundamental no ${ }^{\circ} 4-8$. Medida Cautelar. Tribunal do Pleno. Julgamento em 20 out. 2004, p. 8, fl. 147. Disponível em: <http://www.stf.jus.br>. Acesso em: 10 jan. 2011. Disponível em: <http://redir.stf.jus.br/paginadorpub/ paginador.jsp?docTP=AC\&docID=484300>. Acesso em: 10 jan. 2011.

${ }_{776}$ BRASIL. Supremo Tribunal Federal. Arguição de Descumprimento de Preceito Fundamental no $54-8$. Medida Cautelar. Tribunal do Pleno. Julgamento em 20 out. 2004, p. 8-9, fl. 147-148. Disponível em: <http://www.stf.jus.br>. Acesso em: 10 jan. 2011. Disponível em: <http://redir.stf.jus.br/paginadorpub/ paginador.jsp?docTP=AC\&docID=484300>. Acesso em: 10 jan. 2011. 


\subsubsection{Voto do Ministro Nelson Jobim}

Para o Ministro Nelson Jobim, é importante que o Supremo Tribunal Federal se pronuncie sobre a questão para evitar insegurança jurídica em razão das inúmeras decisões prolatadas sobre a legalidade ou não do aborto do feto anencéfalo. Para Jobim, será preciso analisar se a interpretação do artigo 124 do Código Penal é compatível com a Constituição Federal que protege a inviolabilidade da vida, defendendo que haja, perante o STF, uma discussão definitiva sobre o tema a fim de se evitar a insegurança jurídica decorrente de decisões contraditórias, sendo, portanto, favorável à $\mathrm{ADPF}^{777}$.

\subsubsection{Voto do Ministro Sepúlveda Pertence}

O Ministro conhece da arguição e acompanha o voto do relator. Entende que uma nova Constituição e as alterações sobre os conhecimentos científicos podem contribuir para uma modificação das interpretações da lei anterior à Constituição, até então reconhecidos como indiscutíveis ${ }^{778}$.

\subsubsection{Voto do Ministro Gilmar Mendes}

Gilmar Mendes entende que a Arguição de Descumprimento de Preceito Fundamental é cabível, nos termos do artigo $1^{\circ}$ da Lei 9882/99, e quando "for relevante o fundamento da controvérsia constitucional",779, abarcará também leis pré-constitucionais, leis federais,

\footnotetext{
${ }^{777}$ BRASIL. Supremo Tribunal Federal. Arguição de Descumprimento de Preceito Fundamental no $54-8$. Medida Cautelar. Tribunal do Pleno. Julgamento em 20 out. 2004, p. 1-2, fl. 233-234. Disponível em: <http://www.stf.jus.br>. Acesso em: 10 jan. 2011. Disponível em: <http://redir.stf.jus.br/paginadorpub/ paginador.jsp?docTP=AC\&docID=484300>. Acesso em: 10 jan. 2011.

${ }_{778}$ BRASIL. Supremo Tribunal Federal. Arguição de Descumprimento de Preceito Fundamental no $54-8$. Medida Cautelar. Tribunal do Pleno. Julgamento em 20 out. 2004, p. 8-9, fl. 231-232. Disponível em: <http://www.stf.jus.br>. Acesso em: 10 jan. 2011. Disponível em: <http://redir.stf.jus.br/paginadorpub/ paginador.jsp?docTP=AC\&docID=484300>. Acesso em: 10 jan. 2011.

${ }^{779}$ BRASIL. Supremo Tribunal Federal. Arguição de Descumprimento de Preceito Fundamental no ${ }^{54-8}$. Medida Cautelar. Tribunal do Pleno. Julgamento em 20 out. 2004, p. 3, fl. 161. Disponível em: <http://www.stf.jus.br>.
} 
estaduais ou municipais ${ }^{780}$ constituindo, a ADPF, parte integrante do "sistema de controle de constitucionalidade de perfil relativamente concentrado" ${ }^{\text {781 }}$ no Supremo.

No entanto, para o Ministro, estabelecer quais os preceitos sujeitos à lesão não é fácil $^{782}$. Esses preceitos poderiam ser os direitos fundamentais previstos no artigo $5^{\circ}$ da Constituição ou os princípios sensíveis ${ }^{783}$, nos termos do artigo 34, VII, da Constituição, de modo que, para o Ministro, “a amplitude conferida às cláusulas pétreas e a ideia de unidade da Constituição" inserem boa parte das normas constitucionais nesta visão de "proteção dessas garantias"784. Essa situação pode enfraquecer a proteção exigindo-se uma interpretação restritiva $^{785}$, não das cláusulas pétreas, mas dos “princípios por elas protegidos" ${ }^{\text {"786 }}$. Significa

Acesso em: 10 jan. 2011. Disponível em: <http://redir.stf.jus.br/paginadorpub/ paginador.jsp?docTP=AC\&docID=484300>. Acesso em: 10 jan. 2011.

${ }^{780}$ BRASIL. Supremo Tribunal Federal. Arguição de Descumprimento de Preceito Fundamental $n^{\circ}$ 54-8. Medida Cautelar. Tribunal do Pleno. Julgamento em 20 out. 2004, p. 3, fl. 161. Disponível em: <http://www.stf.jus.br>. Acesso em: 10 jan. 2011. Disponível em: <http://redir.stf.jus.br/paginadorpub/ paginador.jsp?docTP=AC\&docID=484300>. Acesso em: 10 jan. 2011.

${ }^{781}$ BRASIL. Supremo Tribunal Federal. Arguição de Descumprimento de Preceito Fundamental $n^{\circ}$ 54-8. Medida Cautelar. Tribunal do Pleno. Julgamento em 20 out. 2004, p. 3, fl. 161. Disponível em: <http://www.stf.jus.br>. Acesso em: 10 jan. 2011. Disponível em: <http://redir.stf.jus.br/paginadorpub/ paginador.jsp?docTP=AC\&docID=484300>. Acesso em: 10 jan. 2011. Para o Ministro Gilmar Mendes é possível reexaminar tudo aquilo que ainda não foi analisado pelo "controle abstrato de constitucionalidade (ação direta de inconstitucionalidade e ação declaratória de constitucionalidade”. BRASIL. Supremo Tribunal Federal. Arguição de Descumprimento de Preceito Fundamental no 54-8. Medida Cautelar. Tribunal do Pleno. Julgamento em 20 out. 2004, p. 3, fl. 161. Disponível em: 〈http://www.stf.jus.br>. Acesso em: 10 jan. 2011. Disponível em: <http://redir.stf.jus.br/paginadorpub/ paginador.jsp?docTP=AC\&docID=484300>. Acesso em: 10 jan. 2011.

782 BRASIL. Supremo Tribunal Federal. Arguição de Descumprimento de Preceito Fundamental n ${ }^{\circ}$ 54-8. Medida Cautelar. Tribunal do Pleno. Julgamento em 20 out. 2004, p. 4, fl. 162. Disponível em: <http://www.stf.jus.br>. Acesso em: 10 jan. 2011. Disponível em: <http://redir.stf.jus.br/paginadorpub/ paginador.jsp?docTP=AC\&docID=484300>. Acesso em: 10 jan. 2011. Nesse sentido, André Ramos Tavares explica que os preceitos decorrentes da Constituição englobam aqueles expressos por ela (por isso diretos) e os indiretos, ou seja, aqueles "ligados à idéia central" trazida pela Constituição. TAVARES, André Ramos. Tratado de Argüição de Descumprimento de Preceito Fundamental. São Paulo: Saraiva, 2001, p. 159.

${ }^{783}$ Para André Ramos Tavares, além dos princípios expressos no ordenamento constitucional, existem os 'princípios sensíveis' que constituem “um rol de princípios (e regras, no rigor terminológico aqui adotado) aos quais a Constituição atribuiu tamanha importância que chegou a permitir que houvesse a suspensão da autonomia federativa [...]".TAVARES, André Ramos. Tratado de Argüição de Descumprimento de Preceito Fundamental. São Paulo: Saraiva, 2001, p. 150.

${ }^{784}$ BRASIL. Supremo Tribunal Federal. Arguição de Descumprimento de Preceito Fundamental no $54-8$. Medida Cautelar. Tribunal do Pleno. Julgamento em 20 out. 2004, p. 4, fl. 162. Disponível em: <http://www.stf.jus.br>. Acesso em: 10 jan. 2011. Disponível em: <http://redir.stf.jus.br/paginadorpub/ paginador.jsp?docTP=AC\&docID=484300>. Acesso em: 10 jan. 2011.

${ }^{785}$ BRASIL. Supremo Tribunal Federal. Arguição de Descumprimento de Preceito Fundamental no ${ }^{54-8}$. Medida Cautelar. Tribunal do Pleno. Julgamento em 20 out. 2004, p. 5, fl. 163. Disponível em: <http://www.stf.jus.br>. Acesso em: 10 jan. 2011. Disponível em: <http://redir.stf.jus.br/paginadorpub/ paginador.jsp?docTP=AC\&docID=484300>. Acesso em: 10 jan. 2011.

${ }^{786}$ BRASIL. Supremo Tribunal Federal. Arguição de Descumprimento de Preceito Fundamental no ${ }^{54-8}$. Medida Cautelar. Tribunal do Pleno. Julgamento em 20 out. 2004, p. 4, fl. 162. Disponível em: <http://www.stf.jus.br>. Acesso em: 10 jan. 2011. Disponível em: <http://redir.stf.jus.br/paginadorpub/ paginador.jsp?docTP=AC\&docID=484300>. Acesso em: 10 jan. 2011. Afirma o Ministro a necessidade de buscar uma interpretação restritiva da "própria garantia de eternidade sem afetar os princípios por ela protegidos". BRASIL. Supremo Tribunal Federal. Arguição de Descumprimento de Preceito Fundamental n ${ }^{\circ} 54-$ 8. Medida Cautelar. Tribunal do Pleno. Julgamento em 20 out. 2004, p. 5, fl. 163. Disponível em: 
dizer que, para Gilmar Mendes, não existe um "conteúdo específico" nas cláusulas pétreas ${ }^{787}$. Seria necessário buscar através da interpretação quais os princípios realmente protegidos por essas cláusulas $^{788}$, e, portanto, a análise da existência ou não de lesividade deve considerar as "disposições que confiram densidade normativa ou significados específicos a esse princípio" $^{789}$, e não unicamente se há violação de um princípio fundamental ${ }^{790}$.

Explica ainda o Ministro que a norma constitucional não pode ser contrariada ${ }^{791}$, mesmo quando se tratam de normas pré-constitucionais, pois o que se leva em conta não é o momento em que a lei foi editada, mas a existência de contrariedade. Não se trata de "mero conflito de normas a se resolver com a aplicação do princípio da lex posterior" ${ }^{\text {, }}{ }^{2}$, e que, com a edição da Lei 9882/99, o Supremo poderia decidir sobre qualquer conflito, com eficácia geral e efeito vinculante, envolvendo a constituição e normas pré-constitucionais ${ }^{793}$.

Ressalta o Ministro o caráter subsidiário da ADPF, isto é, ela não seria cabível se o debate for hipótese de Ação Direta de Inconstitucionalidade ou Ação Declaratória de Constitucionalidade ${ }^{794}$. Além disso, afirma que a existência de inúmeros posicionamentos

<http://www.stf.jus.br>. Acesso em: 10 jan. 2011. Disponível em: <http://redir.stf.jus.br/paginadorpub/ paginador.jsp?docTP=AC\&docID=484300>. Acesso em: 10 jan. 2011.

${ }^{787}$ BRASIL. Supremo Tribunal Federal. Arguição de Descumprimento de Preceito Fundamental no $54-8$. Medida Cautelar. Tribunal do Pleno. Julgamento em 20 out. 2004, p. 5, fl. 163. Disponível em: <http://www.stf.jus.br>. Acesso em: 10 jan. 2011. Disponível em: <http://redir.stf.jus.br/paginadorpub/ paginador.jsp?docTP=AC\&docID=484300.5>. Acesso em: 10 jan. 2011.

${ }^{788}$ BRASIL. Supremo Tribunal Federal. Arguição de Descumprimento de Preceito Fundamental no $54-8$. Medida Cautelar. Tribunal do Pleno. Julgamento em 20 out. 2004, p. 6-7. fl. 164-165. Disponível em: <http://www.stf.jus.br>. Acesso em: 10 jan. 2011. Disponível em: <http://redir.stf.jus.br/paginadorpub/ paginador.jsp?docTP=AC\&docID=484300>. Acesso em: 10 jan. 2011.

${ }^{789}$ BRASIL. Supremo Tribunal Federal. Arguição de Descumprimento de Preceito Fundamental n ${ }^{\circ}$ 54-8. Medida Cautelar. Tribunal do Pleno. Julgamento em 20 out. 2004, p. 8, fl. 166. Disponível em: <http://www.stf.jus.br>. Acesso em: 10 jan. 2011. Disponível em: <http://redir.stf.jus.br/paginadorpub/ paginador.jsp?docTP=AC\&docID=484300>. Acesso em: 10 jan. 2011.

${ }^{790}$ BRASIL. Supremo Tribunal Federal. Arguição de Descumprimento de Preceito Fundamental no ${ }^{54-8}$. Medida Cautelar. Tribunal do Pleno. Julgamento em 20 out. 2004, p. 8, fl. 166. Disponível em: <http://www.stf.jus.br>. Acesso em: 10 jan. 2011. Disponível em: <http://redir.stf.jus.br/paginadorpub/ paginador.jsp?docTP=AC\&docID=484300>. Acesso em: 10 jan. 2011.

${ }^{791}$ BRASIL. Supremo Tribunal Federal. Arguição de Descumprimento de Preceito Fundamental no $54-8$. Medida Cautelar. Tribunal do Pleno. Julgamento em 20 out. 2004, p. 9-22, especialmente, p. 22, fl. 165-178. Disponível em: <http://www.stf.jus.br>. Acesso em: 10 jan. 2011. Disponível em: <http://redir.stf.jus.br/paginadorpub/ paginador.jsp?docTP=AC\&docID=484300>. Acesso em: 10 jan. 2011.

${ }_{792}$ BRASIL. Supremo Tribunal Federal. Arguição de Descumprimento de Preceito Fundamental $n^{\circ}$ 54-8. Medida Cautelar. Tribunal do Pleno. Julgamento em 20 out. 2004, p. 23, fl. 179. Disponível em: <http://www.stf.jus.br>. Acesso em: 10 jan. 2011. Disponível em: <http://redir.stf.jus.br/paginadorpub/ paginador.jsp?docTP=AC\&docID=484300>. Acesso em: 10 jan. 2011.

${ }_{793}$ BRASIL. Supremo Tribunal Federal. Arguição de Descumprimento de Preceito Fundamental no ${ }^{\circ 4-8}$. Medida Cautelar. Tribunal do Pleno. Julgamento em 20 out. 2004, p. 23, fl. 179. Disponível em: <http://www.stf.jus.br>. Acesso em: 10 jan. 2011. Disponível em: <http://redir.stf.jus.br/paginadorpub/ paginador.jsp?docTP=AC\&docID=484300>. Acesso em: 10 jan. 2011.

${ }_{794}$ BRASIL. Supremo Tribunal Federal. Arguição de Descumprimento de Preceito Fundamental no ${ }^{\circ 4-8}$. Medida Cautelar. Tribunal do Pleno. Julgamento em 20 out. 2004, p. 28, fl. 184. Disponível em: <http://www.stf.jus.br>. Acesso em: 10 jan. 2011. Disponível em: <http://redir.stf.jus.br/paginadorpub/ paginador.jsp?docTP=AC\&docID=484300>. Acesso em: 10 jan. 2011. O Ministro esclarece que a discussão 
divergentes pode ameaçar ou lesionar um preceito fundamental ${ }^{795}$, possibilitando a propositura da ADPF para discutir essa lesividade via controle concentrado ${ }^{796}$.

Por fim, o Ministro traça o seguinte raciocínio: Se o STF tivesse de decidir um Habeas Corpus envolvendo uma gestante ou um médico, nessa circunstância, e decidisse pela concessão da medida, autorizando o aborto, o Tribunal reconheceria mais uma hipótese de aborto legal no artigo 128 do Código Penal ou a inaplicabilidade do artigo 124, também do Código Penal ${ }^{797}$. Já, se a interrupção da gestação fosse proibida, seria reconhecida em espécie a constitucionalidade da lei penal, não podendo ser admitida a interrupção no caso de feto anencéfalo $^{798}$. Em qualquer dessas situações, a decisão teria um efeito geral ${ }^{799}$. Defende por fim o Ministro pelo cabimento da $\mathrm{ADPF}^{800}$.

\subsubsection{Voto do Ministro Cezar Peluso}

sobre o controle de legitimidade do direito pré-constitucional não pode ser objeto de ADI e, por isso, é cabível a ADPF. BRASIL. Supremo Tribunal Federal. Arguição de Descumprimento de Preceito Fundamental n ${ }^{\circ}$ 54-8. Medida Cautelar. Tribunal do Pleno. Julgamento em 20 out. 2004, p. 28, fl. 184. Disponível em: <http://www.stf.jus.br>. Acesso em: 10 jan. 2011. Disponível em: <http://redir.stf.jus.br/paginadorpub/ paginador.jsp?docTP=AC\&docID=484300>. Acesso em: 10 jan. 2011.

${ }^{795}$ BRASIL. Supremo Tribunal Federal. Arguição de Descumprimento de Preceito Fundamental no 54-8. Medida Cautelar. Tribunal do Pleno. Julgamento em 20 out. 2004, p. 30, fl. 186. Disponível em: <http://www.stf.jus.br>. Acesso em: 10 jan. 2011. Disponível em: <http://redir.stf.jus.br/paginadorpub/ paginador.jsp?docTP=AC\&docID=484300>. Acesso em: 10 jan. 2011.

${ }^{796}$ BRASIL. Supremo Tribunal Federal. Arguição de Descumprimento de Preceito Fundamental no $54-8$. Medida Cautelar. Tribunal do Pleno. Julgamento em 20 out. 2004, p. 31, fl. 187. Disponível em: <http://www.stf.jus.br>. Acesso em: 10 jan. 2011. Disponível em: <http://redir.stf.jus.br/paginadorpub/ paginador.jsp?docTP=AC\&docID=484300>. Acesso em: 10 jan. 2011.

${ }^{797}$ BRASIL. Supremo Tribunal Federal. Arguição de Descumprimento de Preceito Fundamental $n^{\circ}$ 54-8. Medida Cautelar. Tribunal do Pleno. Julgamento em 20 out. 2004, p. 34, fl. 190. Disponível em: <http://www.stf.jus.br>. Acesso em: 10 jan. 2011. Disponível em: <http://redir.stf.jus.br/paginadorpub/ paginador.jsp?docTP=AC\&docID=484300>. Acesso em: 10 jan. 2011.

${ }_{798}$ BRASIL. Supremo Tribunal Federal. Arguição de Descumprimento de Preceito Fundamental no ${ }^{\circ 4-8}$. Medida Cautelar. Tribunal do Pleno. Julgamento em 20 out. 2004, p. 35, fl. 191. Disponível em: <http://www.stf.jus.br>. Acesso em: 10 jan. 2011. Disponível em: <http://redir.stf.jus.br/paginadorpub/ paginador.jsp?docTP=AC\&docID=484300>. Acesso em: 10 jan. 2011.

${ }_{799}$ BRASIL. Supremo Tribunal Federal. Arguição de Descumprimento de Preceito Fundamental no ${ }^{\circ 4-8}$. Medida Cautelar. Tribunal do Pleno. Julgamento em 20 out. 2004, p. 35, fl. 191. Disponível em: <http://www.stf.jus.br>. Acesso em: 10 jan. 2011. Disponível em: <http://redir.stf.jus.br/paginadorpub/ paginador.jsp?docTP=AC\&docID=484300>. Acesso em: 10 jan. 2011. Em razão de o tema poder ser debatido em ações individuais, cabível a ADPF para esse fim. BRASIL. Supremo Tribunal Federal. Arguição de Descumprimento de Preceito Fundamental $n^{\circ}$ 54-8. Medida Cautelar. Tribunal do Pleno. Julgamento em 20 out. 2004, p. 35, fl. 191. Disponível em: <http://www.stf.jus.br>. Acesso em: 10 jan. 2011. Disponível em: <http://redir.stf.jus.br/paginadorpub/ paginador.jsp?docTP=AC\&docID=484300>. Acesso em: 10 jan. 2011.

${ }^{800}$ BRASIL. Supremo Tribunal Federal. Arguição de Descumprimento de Preceito Fundamental no ${ }^{\circ}$ 44-8. Medida Cautelar. Tribunal do Pleno. Julgamento em 20 out. 2004, p. 36, fl. 192. Disponível em: <http://www.stf.jus.br>. Acesso em: 10 jan. 2011. Disponível em: <http://redir.stf.jus.br/paginadorpub/paginador.jsp? docTP=AC\&docID=484300>. Acesso em: 10 jan. 2011 . 
Cezar Peluso afirma, por outro lado, que a liminar ofende um valor jurídico ${ }^{801}$. Para o Ministro, a vida intrauterina é "objeto da tutela jurídico-normativa" ${ }^{\wedge 02}$, independentemente das "deformidades que o feto possa apresentar" ${ }^{803}$. Afirma, ainda, que, apesar de existirem os métodos científicos atuais, nunca se deixou de admitir a possibilidade de um feto inviável ${ }^{804}$, não se convencendo o Ministro de que o feto anencéfalo é "um condenado à morte" ${ }^{\wedge 05}$. Para ele, "todos nascemos para morrer" e não seria possível disponibilizar a outras pessoas a duração de uma vida ${ }^{806}$. Entende o Ministro que deve ser levada em consideração a integridade física e biológica do feto, e não apenas a integridade física da mulher ${ }^{807}$.

Afirma ainda o Ministro que o sofrimento faz parte da vida, e não "degrada a dignidade humana" $" 808$, de modo que o sistema jurídico somente rejeita o sofrimento causado por atos injustos ${ }^{809}$, já que não é a sua pretensão eliminar tal experiência aos homens ${ }^{810}$.

\footnotetext{
${ }^{801}$ BRASIL. Supremo Tribunal Federal. Arguição de Descumprimento de Preceito Fundamental no $54-8$. Medida Cautelar. Tribunal do Pleno. Julgamento em 20 out. 2004, p. 1, fl. 93. Disponível em: 〈http://www.stf.jus.br>. Acesso em: 10 jan. 2011.

${ }^{802}$ BRASIL. Supremo Tribunal Federal. Arguição de Descumprimento de Preceito Fundamental no $54-8$. Medida Cautelar. Tribunal do Pleno. Julgamento em 20 out. 2004, p. 1, fl. 93. Disponível em: <http://www.stf.jus.br>. Acesso em: 10 jan. 2011.

${ }^{803}$ BRASIL. Supremo Tribunal Federal. Arguição de Descumprimento de Preceito Fundamental no 54-8. Medida Cautelar. Tribunal do Pleno. Julgamento em 20 out. 2004, p. 2, fl. 94. Disponível em: 〈http://www.stf.jus.br>. Acesso em: 10 jan. 2011. Disponível em: <http://redir.stf.jus.br/paginadorpub/paginador.jsp? docTP=AC\&docID=484300>. Acesso em: 10 jan. 2011.

${ }^{804}$ BRASIL. Supremo Tribunal Federal. Arguição de Descumprimento de Preceito Fundamental no $54-8$. Medida Cautelar. Tribunal do Pleno. Julgamento em 20 out. 2004, p. 2, fl. 94. Disponível em: 〈http://www.stf.jus.br>. Acesso em: 10 jan. 2011. Disponível em: <http://redir.stf.jus.br/paginadorpub/paginador.jsp? docTP=AC\&docID=484300>. Acesso em: 10 jan. 2011.

${ }^{805}$ BRASIL. Supremo Tribunal Federal. Arguição de Descumprimento de Preceito Fundamental no $54-8$. Medida Cautelar. Tribunal do Pleno. Julgamento em 20 out. 2004, p. 2, fl. 94. Disponível em: 〈http://www.stf.jus.br>. Acesso em: 10 jan. 2011. Disponível em: <http://redir.stf.jus.br/paginadorpub/paginador.jsp? docTP=AC\&docID=484300>. Acesso em: 10 jan. 2011.

${ }^{806}$ BRASIL. Supremo Tribunal Federal. Arguição de Descumprimento de Preceito Fundamental no $54-8$. Medida Cautelar. Tribunal do Pleno. Julgamento em 20 out. 2004, p. 3-4, fl. 95-96. Disponível em: <http://www.stf.jus.br>. Acesso em: 10 jan. 2011. Disponível em: <http://redir.stf.jus.br/paginadorpub/ paginador.jsp?docTP=AC\&docID=484300>. Acesso em: 10 jan. 2011.

${ }^{807}$ BRASIL. Supremo Tribunal Federal. Arguição de Descumprimento de Preceito Fundamental no 54-8. Medida Cautelar. Tribunal do Pleno. Julgamento em 20 out. 2004, p. 3, fl. 95. Disponível em: 〈http://www.stf.jus.br>. Acesso em: 10 jan. 2011. Disponível em: <http://redir.stf.jus.br/paginadorpub/paginador.jsp? docTP=AC\&docID=484300>. Acesso em: 10 jan. 2011.

${ }^{808}$ BRASIL. Supremo Tribunal Federal. Arguição de Descumprimento de Preceito Fundamental no $54-8$. Medida Cautelar. Tribunal do Pleno. Julgamento em 20 out. 2004, p. 3, fl. 95. Disponível em: 〈http://www.stf.jus.br>. Acesso em: 10 jan. 2011. Disponível em: <http://redir.stf.jus.br/paginadorpub/paginador.jsp? docTP=AC\&docID=484300>. Acesso em: 10 jan. 2011.

${ }^{809}$ BRASIL. Supremo Tribunal Federal. Arguição de Descumprimento de Preceito Fundamental no 54-8. Medida Cautelar. Tribunal do Pleno. Julgamento em 20 out. 2004, p. 3, fl. 95. Disponível em: 〈http://www.stf.jus.br>. Acesso em: 10 jan. 2011. Disponível em: <http://redir.stf.jus.br/paginadorpub/paginador.jsp? docTP=AC\&docID=484300>. Acesso em: 10 jan. 2011.

${ }^{810}$ BRASIL. Supremo Tribunal Federal. Arguição de Descumprimento de Preceito Fundamental $\mathrm{n}^{\circ}$ 54-8. Medida Cautelar. Tribunal do Pleno. Julgamento em 20 out. 2004, p. 3-4, fl. 95-96. Disponível em: <http://www.stf.jus.br>. Acesso em: 10 jan. 2011. Disponível em: <http://redir.stf.jus.br/paginadorpub/ paginador.jsp?docTP=AC\&docID=484300>. Acesso em: 10 jan. 2011.
} 
Além disso, afirma Peluso que não há liberdade jurídica ou legalidade no caso em que a lei limita um determinado comportamento, estabelecendo-o como crime ${ }^{811}$. Outrossim, não entende ser possível aplicar analogia com o conceito de morte encefálica trazido pela lei que trata da doação de órgãos, já que o aborto não será realizado com o fim de salvar vidas ${ }^{812}$. Por fim, entende o Ministro que a gravidez por si só não traz grande risco à mulher, afastando a ofensa ao direito à saúde ${ }^{813}$.

Questiona, enfim, o Ministro, se por meio da ADPF, não se estaria buscando criar nova hipótese de excludente para o crime de aborto, negando, assim a manutenção da medida $\operatorname{liminar}^{814}$. Por fim, complementa o voto, entendendo que cabe ao Congresso Nacional debater sobre a eventual excludente de ilicitude ${ }^{815}$.

\subsubsection{Voto do Ministro Eros Grau}

Eros Grau admite que o feto, nas lições de Pontes de Miranda e conforme o artigo $2^{\circ}$ do Código Civil, é pessoa e deve ter proteção legal. Para o Ministro, durante o período em que a liminar estava em vigor, havia uma situação análoga a de como se o Direito Penal tivesse sido reescrito ${ }^{816}$ pelo Poder Judiciário, que teria criado uma nova hipótese de aborto legal ${ }^{817}$.

\footnotetext{
${ }^{811}$ BRASIL. Supremo Tribunal Federal. Arguição de Descumprimento de Preceito Fundamental no $54-8$. Medida Cautelar. Tribunal do Pleno. Julgamento em 20 out. 2004, p. 4, fl. 96. Disponível em: 〈http://www.stf.jus.br〉. Acesso em: 10 jan. 2011. Disponível em: <http://redir.stf.jus.br/paginadorpub/paginador.jsp? docTP=AC\&docID=484300>. Acesso em: 10 jan. 2011.

${ }^{812}$ BRASIL. Supremo Tribunal Federal. BRASIL. Supremo Tribunal Federal. Arguição de Descumprimento de Preceito Fundamental no 54-8. Medida Cautelar. Tribunal do Pleno. Julgamento em 20 out. 2004, p. 4, fl. 96. Disponível em: <http://www.stf.jus.br>. Acesso em: 10 jan. 2011. Disponível em: <http://redir.stf.jus.br/paginadorpub/ paginador.jsp?docTP=AC\&docID=484300>. Acesso em: 10 jan. 2011.

${ }^{813}$ BRASIL. Supremo Tribunal Federal. Arguição de Descumprimento de Preceito Fundamental no 54-8. Medida Cautelar. Tribunal do Pleno. Julgamento em 20 out. 2004, p. 4, fl. 96. Disponível em: 〈http://www.stf.jus.br>. Acesso em: 10 jan. 2011. Disponível em: <http://redir.stf.jus.br/paginadorpub/paginador.jsp? docTP=AC\&docID=484300>. Acesso em: 10 jan. 2011.

${ }^{814}$ BRASIL. Supremo Tribunal Federal. Arguição de Descumprimento de Preceito Fundamental no 54-8. Medida Cautelar. Tribunal do Pleno. Julgamento em 20 out. 2004, p. 5-6, fl. 97-98. Disponível em: <http://www.stf.jus.br>. Acesso em: 10 jan. 2011. Disponível em: <http://redir.stf.jus.br/paginadorpub/ paginador.jsp?docTP=AC\&docID=484300>. Acesso em: 10 jan. 2011.

${ }_{815}$ BRASIL. Supremo Tribunal Federal. Arguição de Descumprimento de Preceito Fundamental no 54-8. Medida Cautelar. Tribunal do Pleno. Julgamento em 20 out. 2004, p. 7, fl. 155. Disponível em: 〈http://www.stf.jus.br>. Acesso em: 10 jan. 2011. Disponível em: <http://redir.stf.jus.br/paginadorpub/paginador.jsp? docTP=AC\&docID=484300>. Acesso em: 10 jan. 2011.

${ }^{816}$ BRASIL. Supremo Tribunal Federal. Arguição de Descumprimento de Preceito Fundamental no 54-8. Medida Cautelar. Tribunal do Pleno. Julgamento em 20 out. 2004, p. 4-5, fl. 85. Disponível em: 〈http://www.stf.jus.br>. Acesso em: 10 jan. 2011.
} 
Para o Ministro, a única lógica que deve figurar no debate é a lógica jurídica, e que a liminar concedida viola a ideia de vida contida no artigo $2^{\circ}$ do Código Civil. Afirma, finalmente, que a técnica de subsunção está superada e não pode a interpretação ficar restrita a ela ${ }^{818}$, negando o referendo parcial da medida liminar.

\subsubsection{Voto da Ministra Ellen Gracie}

Para a Ministra, o que se pretende criar por meio da jurisprudência do tribunal é outra excludente de ilicitude ao aborto ${ }^{819}$, acrescentando-se "conteúdos à norma vigente" ${ }^{\text {(20 }}$, de modo que, além do aborto necessário e sentimental, seria possível outra prática de aborto - no caso em que o feto fosse anencéfalo ${ }^{821}$. Para Ellen Gracie, referida atividade, no entanto, seria de exclusividade do Poder Legislativo ${ }^{822}$.

A Ministra Ellen Gracie entendeu que cabe à sociedade se fazer representar no Congresso Nacional ${ }^{823}$ a fim de que seja sanado o "problema de saúde pública" que aflige as

\footnotetext{
${ }^{817}$ BRASIL. Supremo Tribunal Federal. Arguição de Descumprimento de Preceito Fundamental no $54-8$. Medida Cautelar. Tribunal do Pleno. Julgamento em 20 out. 2004, p. 4-5, fl. 85. Disponível em: 〈http://www.stf.jus.br〉. Acesso em: 10 jan. 2011.

${ }^{818}$ BRASIL. Supremo Tribunal Federal. Arguição de Descumprimento de Preceito Fundamental no $54-8$. Medida Cautelar. Tribunal do Pleno. Julgamento em 20 out. 2004, aditamento ao voto, p. 1, fl. 139. Disponível em: <http://www.stf.jus.br>. Acesso em: 10 jan. 2011.

${ }^{819}$ BRASIL. Supremo Tribunal Federal. Arguição de Descumprimento de Preceito Fundamental no $54-8$. Medida Cautelar. Tribunal do Pleno. Julgamento em 20 out. 2004, aditamento ao voto, p. 2, fl. 194. Disponível em: <http://www.stf.jus.br>. Acesso em: 10 jan. 2011.

${ }^{820}$ BRASIL. Supremo Tribunal Federal. Arguição de Descumprimento de Preceito Fundamental no $54-8$. Medida Cautelar. Tribunal do Pleno. Julgamento em 20 out. 2004, aditamento ao voto, p. 4, fl. 196. Disponível em: <http://www.stf.jus.br>. Acesso em: 10 jan. 2011.

${ }^{821}$ BRASIL. Supremo Tribunal Federal. Arguição de Descumprimento de Preceito Fundamental no $54-8$. Medida Cautelar. Tribunal do Pleno. Julgamento em 20 out. 2004, aditamento ao voto, p. 2-3, fl. 194-195. Disponível em: 〈http://www.stf.jus.br>. Acesso em: 10 jan. 2011.

${ }^{822}$ BRASIL. Supremo Tribunal Federal. Arguição de Descumprimento de Preceito Fundamental no ${ }^{\circ 4-8}$. Medida Cautelar. Tribunal do Pleno. Julgamento em 20 out. 2004, aditamento ao voto, p. 3, fl. 195. Disponível em: <http://www.stf.jus.br>. Acesso em: 10 jan. 2011.

${ }^{823}$ Vale lembrar o interessante artigo de José Carlos Francisco, que tratado atual "debate sobre as reais funções do Estado contemporâneo", incluindo "a separação dos poderes”. FRANCISCO, José Carlos. Estado Democrático de Direito. In: DIMOULIS, Dimitri (Coordenador Geral). TAVARES, André Ramos; DIMOULIS, Dimitri; BERCOVICI, Gilberto; SILVA, Guilherme Amorim Campos da; FRANCISCO, José Carlos; ANJOS FILHO, Robério Nunes dos; ROTHENBURG, Walter Claudius (org.). Dicionário Brasileiro de Direito Constitucional. São Paulo: Saraiva, 2007, p. 149. Complementa José Levi Mello do Amaral Júnior que "na fórmula 'separação dos poderes' o vocábulo é relativo às esferas de competência do Estado: Legislativo, Executivo e Judiciário. A ideia é conter o poder pela sua partilha e comunhão entre diferentes órgãos”. AMARAL JÚNIOR, José Levi Mello do. Poder. In: DIMOULIS, Dimitri (Coordenador Geral). TAVARES, André Ramos; DIMOULIS, Dimitri; BERCOVICI, Gilberto; SILVA, Guilherme Amorim Campos da; FRANCISCO, José Carlos; ANJOS FILHO, Robério Nunes dos; ROTHENBURG, Walter Claudius (org.). Dicionário Brasileiro de Direito Constitucional. São Paulo: Saraiva, 2007, p. 268.
} 
"mulheres das classes menos favorecidas". ${ }^{824}$ Para a Ministra, discutir o tema por meio da ADPF poderia ensejar a "ruptura de princípios basilares, como o da separação de poderes e a repartição estrita de competência ente eles" ${ }^{\$ 25}$ não conhecendo, portanto, da $\mathrm{ADPF}^{826}$.

\subsubsection{Voto do Ministro Carlos Velloso}

Afirmou o Ministro que seria possível obter a interpretação conforme a Constituição dos dispositivos do Código Penal ${ }^{827}$. Todavia, entendeu também Velloso que o Supremo acabaria trazendo mais uma hipótese de excludente de ilicitude ao realizar a interpretação conforme. ${ }^{828} \mathrm{O}$ Ministro ressalta um fato importante: na interpretação conforme, não seria possível formular uma "regulamentação legal" adequada ao caso - que só poderia partir do Congresso Nacional - como ocorre com a lei francesa que estabelece condições detalhadas para que o aborto de feto anencéfalo possa ser realizado ${ }^{829}$. Deste modo, negou Velloso a liminar da $\mathrm{ADPF}^{830}$.

\subsection{ARGUMENTOS APRESENTADOS EM AUDIÊNCIA PÚBLICA}

\footnotetext{
${ }^{824}$ BRASIL. Supremo Tribunal Federal. Arguição de Descumprimento de Preceito Fundamental no ${ }^{\text {54-8. Medida }}$ Cautelar. Tribunal do Pleno. Julgamento em 20 out. 2004, aditamento ao voto, p. 14, fl. 206. Disponível em: <http://www.stf.jus.br>. Acesso em: 10 jan. 2011.

${ }^{825}$ BRASIL. Supremo Tribunal Federal. Arguição de Descumprimento de Preceito Fundamental no ${ }^{\text {54-8. Medida }}$ Cautelar. Tribunal do Pleno. Julgamento em 20 out. 2004, aditamento ao voto, p. 15, fl. 207. Disponível em: <http://www.stf.jus.br>. Acesso em: 10 jan. 2011. Nesse sentido, Carlos Eduardo Dieder Reverbel afirma que o nosso sistema de controle de constitucionalidade "favorece o ativismo judicial" e viola a separação dos poderes, pois o juiz age como "verdadeiro legislador, e inclusive ex post facto". REVERBEL, Carlos Eduardo Dieder. Ativismo Judicial e Estado de Direito. In: AMARAL JÚNIOR, José Levi Mello do. Estado de Direito e Ativismo Judicial. São Paulo: Quartier Latin, 2010, p. 74.

${ }^{826}$ BRASIL. Supremo Tribunal Federal. Arguição de Descumprimento de Preceito Fundamental no $54-8$. Medida Cautelar. Tribunal do Pleno. Julgamento em 20 out. 2004, aditamento ao voto, p. 15, fl. 207. Disponível em: <http://www.stf.jus.br>. Acesso em: 10 jan. 2011.

${ }^{827}$ BRASIL. Supremo Tribunal Federal. Arguição de Descumprimento de Preceito Fundamental n ${ }^{\circ}$ 54-8. Medida Cautelar. Tribunal do Pleno. Julgamento em 20 out. 2004, aditamento ao voto, p. 1-5, fl. 208-212. Disponível em: 〈http://www.stf.jus.br〉. Acesso em: 10 jan. 2011.

${ }^{828}$ BRASIL. Supremo Tribunal Federal. Arguição de Descumprimento de Preceito Fundamental no ${ }^{\circ 4-8}$. Medida Cautelar. Tribunal do Pleno. Julgamento em 20 out. 2004, aditamento ao voto, p. 6, fl. 213. Disponível em: <http://www.stf.jus.br>. Acesso em: 10 jan. 2011.

${ }^{829}$ BRASIL. Supremo Tribunal Federal. Arguição de Descumprimento de Preceito Fundamental no $54-8$. Medida Cautelar. Tribunal do Pleno. Julgamento em 20 out. 2004, aditamento ao voto, p. 7, fl. 214. Disponível em: <http://www.stf.jus.br>. Acesso em: 10 jan. 2011.

${ }^{830}$ BRASIL. Supremo Tribunal Federal. Arguição de Descumprimento de Preceito Fundamental no 54-8. Medida Cautelar. Tribunal do Pleno. Julgamento em 20 out. 2004, aditamento ao voto, p. 11, fl. 218. Disponível em: <http://www.stf.jus.br>. Acesso em: 10 jan. 2011.
} 
O primeiro grupo ouvido na Audiência Pública realizada em 26 de agosto de 2008 foi composto pela Conferência Nacional dos Bispos do Brasil (CNBB), a Igreja Universal do Reino de Deus, a Associação Nacional Pró-Vida e Pró-Família, a Organização NãoGovernamental Católicas pelo Direito de Decidir, e a Associação Médico-Espírita do Brasil.

Vamos destacar alguns argumentos trazidos pelos grupos durante as audiências.

Basicamente, o representante da CNBB, Padre Luiz Antônio Bento, argumentou, sob uma perspectiva católica, em defesa da vida do feto ${ }^{831}$, defendendo que esta vida deveria ser respeitada desde a concepção em todas suas etapas de desenvolvimento ${ }^{832}$.

Para o padre Luiz Antônio Bento, "quando a vida não é respeitada no seu início, dificilmente o será em suas outras etapas" ${ }^{\Perp 833}$. Para ele, o simples fato de o feto pertencer à espécie humana já lhe garante o respeito e a tutela de sua dignidade ${ }^{834}$, que já lhe é intrínseca ${ }^{835}$, não cabendo ao estado “julgar o valor intrínseco de uma vida por suas deficiências" ${ }^{\prime 836}$. Argumenta, ainda, que a intenção do aborto do anencéfalo seria excluir o feto que não representa a perfeição, ou os padrões que a sociedade espera ${ }^{837}$. Sensibiliza-se com o sofrimento da mulher, mas essa dor não permite "o sacrifício da vida" ${ }^{838}$. Para o padre, trata-

831 "No que tange ao início da vida, o pensamento católico medieval fortemente influenciado por Tomás de Aquino, inclina-se por uma diferenciação entre o feto formado e o informe e pela visão criacionista de que a alma era infundida por Deus no feto formado. Com Pio XII, a criação da alma retrocedeu ao momento da concepção". SIQUEIRA JÚNIOR, Paulo Hamilton; OLIVEIRA, Miguel Augusto Machado de. Direitos Humanos e Cidadania. $3^{\text {a }}$ ed. rev. e atual. São Paulo: Editora Revista dos Tribunais, 2010, p. 221. Ainda sobre este assunto, vale lembrar também Paul E. Sigmund, segundo quem "Deliberate abortion of the fetus is for Aquinas equivalent to murder, but only after 'quickening' or 'ensoulment,' which Aquinas, following Aristotle, believed occured forty days after conception in the case of males, and eigthly days thereafter for females. However, contrary to what some contemporary polemicists have argued, Aquinas believed that abortion even before ensoulment was a sin, although not the sin of murder. He did not discuss the case where the mother's life is directly threatened, but given his biblically based opposition to doing evil so that good may come of it (Romans 3:8), it is unlikely that he would have approved." SIGMUND, Paul E. Law and politics. In: The Cambridge Companion to Aquinas. KRETZMANN, Norman; STUMP, Eleonor (Editors). New York, EUA. Cambridge University Press, 1993, p. 227.

${ }^{832}$ BRASIL. Supremo Tribunal Federal. Arguição de Descumprimento de Preceito Fundamental $\mathrm{n}^{\circ}$ 54-8. Audiência Pública do dia 26 ago. 2008, p. 7-8. Disponível em: 〈http://www.stf.jus.br〉. Acesso em: 10 jan. 2011. 833 BRASIL. Supremo Tribunal Federal. Arguição de Descumprimento de Preceito Fundamental $\mathrm{n}^{\circ}$ 54-8. Audiência Pública do dia 26 ago. 2008, p. 7. Disponível em: 〈http://www.stf.jus.br〉. Acesso em: 10 jan. 2011.

834 BRASIL. Supremo Tribunal Federal. Arguição de Descumprimento de Preceito Fundamental $\mathrm{n}^{\circ}$ 54-8. Audiência Pública do dia 26 ago. 2008, p. 7. Disponível em: 〈http://www.stf.jus.br〉. Acesso em: 10 jan. 2011.

835 BRASIL. Supremo Tribunal Federal. Arguição de Descumprimento de Preceito Fundamental $\mathrm{n}^{\circ}$ 54-8. Audiência Pública do dia 26 ago. 2008, p. 7. Disponível em: 〈http://www.stf.jus.br〉. Acesso em: 10 jan. 2011.

836 BRASIL. Supremo Tribunal Federal. Arguição de Descumprimento de Preceito Fundamental $\mathrm{n}^{\circ}$ 54-8. Audiência Pública do dia 26 ago. 2008, p. 8. Disponível em: 〈http://www.stf.jus.br〉. Acesso em: 10 jan. 2011.

837 BRASIL. Supremo Tribunal Federal. Arguição de Descumprimento de Preceito Fundamental $\mathrm{n}^{\circ}$ 54-8. Audiência Pública do dia 26 ago. 2008, p. 8. Disponível em: 〈http://www.stf.jus.br〉. Acesso em: 10 jan. 2011.

838 BRASIL. Supremo Tribunal Federal. Arguição de Descumprimento de Preceito Fundamental $\mathrm{n}^{\circ}$ 54-8. Audiência Pública do dia 26 ago. 2008, p. 8. Disponível em: 〈http://www.stf.jus.br〉. Acesso em: 10 jan. 2011. 
se de um aborto eugênico, uma eutanásia pré-natal ${ }^{839}$. Por fim, defende ele ainda que haveria uma consciência primitiva no feto, que este carrega "todos os dados genéticos" ${ }^{\text {" }}$ " e, como o feto pode nascer com vida, não há que se falar em "morte encefálica" 841 .

Em seguida, a Igreja Universal do Reino de Deus se manifestou, representada pelo Bispo Carlos Macedo de Oliveira, que afirmou preliminarmente que sua igreja respeita a laicidade do Estado $^{842}$ e que leva em consideração a racionalidade e a vida real ${ }^{843}$. Defendeu o Bispo o livre-arbítrio da mulher de escolher a gravidez - que nessa circunstância é muito difícil de mensurar ${ }^{844}$. Argumentou também que seria melhor aceitar essa hipótese de aborto sem "esbarrar nas radicalizações conceituais ou religiosas, até porque descriminalizar o aborto é diferente de torná-lo obrigatório" 845 , e até mesmo que uma mulher, "por questões de opção, consciência ou religiosidade, tem o direito de fazê-lo se assim desejar, ou não" ${ }^{\text {"846 }}$. Por fim, afirmou que respeita opiniões diferentes, o que é comum numa sociedade democrática, e que o "bom senso e interesse da coletividade no que tange ao bem comum" deve predominar ${ }^{847}$.

Depois, foi ouvida a Associação Nacional Pró-Vida e Pró-Família, representada pelo médico Rodolfo Acatauassú Nunes. Para ele, a anencefalia, assim como outras várias doenças congênitas, é letal ${ }^{848}$. Explicou o médico que, na anencefalia, existe uma parte do encéfalo, e que o encéfalo anterior é o mais atingido ${ }^{849}$. Por isso equivocado dizer-se que o feto não tem encéfalo ${ }^{850}$. Esclareceu o médico que a anencefalia ocorre entre o $25^{\circ}$ e o $27^{\circ}$ dias de gravidez, e que os hemisférios cerebrais podem estar totalmente ausentes, ou podem existir vestígios

839 BRASIL. Supremo Tribunal Federal. Arguição de Descumprimento de Preceito Fundamental $\mathrm{n}^{\circ}$ 54-8. Audiência Pública do dia 26 ago. 2008, p. 9. Disponível em: 〈http://www.stf.jus.br〉. Acesso em: 10 jan. 2011.

840 BRASIL. Supremo Tribunal Federal. Arguição de Descumprimento de Preceito Fundamental $\mathrm{n}^{\circ}$ 54-8. Audiência Pública do dia 26 ago. 2008, p. 10. Disponível em: 〈http://www.stf.jus.br〉. Acesso em: 10 jan. 2011.

841 BRASIL. Supremo Tribunal Federal. Arguição de Descumprimento de Preceito Fundamental $\mathrm{n}^{\circ}$ 54-8. Audiência Pública do dia 26 ago. 2008, p. 10. Disponível em: 〈http://www.stf.jus.br〉. Acesso em: 10 jan. 2011.

${ }^{842}$ BRASIL. Supremo Tribunal Federal. Arguição de Descumprimento de Preceito Fundamental $\mathrm{n}^{\circ}$ 54-8. Audiência Pública do dia 26 ago. 2008, p. 19. Disponível em: 〈http://www.stf.jus.br〉. Acesso em: 10 jan. 2011.

843 BRASIL. Supremo Tribunal Federal. Arguição de Descumprimento de Preceito Fundamental $\mathrm{n}^{\circ}$ 54-8. Audiência Pública do dia 26 ago. 2008, p. 20. Disponível em: 〈http://www.stf.jus.br〉. Acesso em: 10 jan. 2011.

844 BRASIL. Supremo Tribunal Federal. Arguição de Descumprimento de Preceito Fundamental $\mathrm{n}^{\circ}$ 54-8. Audiência Pública do dia 26 ago. 2008, p. 21. Disponível em: 〈http://www.stf.jus.br〉. Acesso em: 10 jan. 2011.

845 BRASIL. Supremo Tribunal Federal. Arguição de Descumprimento de Preceito Fundamental $\mathrm{n}^{\circ}$ 54-8. Audiência Pública do dia 26 ago. 2008, p. 21. Disponível em: 〈http://www.stf.jus.br〉. Acesso em: 10 jan. 2011.

${ }^{846}$ BRASIL. Supremo Tribunal Federal. Arguição de Descumprimento de Preceito Fundamental $\mathrm{n}^{\circ}$ 54-8. Audiência Pública do dia 26 ago. 2008, p. 21. Disponível em: <http://www.stf.jus.br〉. Acesso em: 10 jan. 2011.

847 BRASIL. Supremo Tribunal Federal. Arguição de Descumprimento de Preceito Fundamental $\mathrm{n}^{\circ}$ 54-8. Audiência Pública do dia 26 ago. 2008, p. 22. Disponível em: 〈http://www.stf.jus.br〉. Acesso em: 10 jan. 2011.

${ }_{848}$ BRASIL. Supremo Tribunal Federal. Arguição de Descumprimento de Preceito Fundamental $\mathrm{n}^{\circ}$ 54-8. Audiência Pública do dia 26 ago. 2008, p. 23. Disponível em: 〈http://www.stf.jus.br〉. Acesso em: 10 jan. 2011. 849 BRASIL. Supremo Tribunal Federal. Arguição de Descumprimento de Preceito Fundamental no $54-8$. Audiência Pública do dia 26 ago. 2008, p. 24. Disponível em: 〈http://www.stf.jus.br〉. Acesso em: 10 jan. 2011.

850 BRASIL. Supremo Tribunal Federal. Arguição de Descumprimento de Preceito Fundamental no 54-8. Audiência Pública do dia 26 ago. 2008, p. 24. Disponível em: 〈http://www.stf.jus.br〉. Acesso em: 10 jan. 2011. 
dos hemisférios cerebrais - e ainda assim a condição caracteriza a anencefalia ${ }^{851}$. O médico ainda menciona que pode o feto respirar, por exemplo, encontrando-se nos registros médicos, casos em que o feto viveu mais de um ano, e nesse caso, não houve morte encefálica ${ }^{852}$. Defende ainda o doutor que há sobrevida na anencefalia ${ }^{853}$. De acordo com o médico, dados de Pomeronce indicam que " $47 \%$ morrem no primeiro dia, $44 \%$ entre um dia e uma semana; $8 \%$ entre uma semana e um mês e $1 \%$ com cerca de três meses. Ocasionalmente de sete a dez meses foram verificadas sobrevidas $[\ldots]^{, 854}$.

Além disso, esclarece o médico que seria possível admitir "certo grau de uma consciência primitiva" ${ }^{\$ 55}$, mas não existe tecnologia para estudos mais específicos para mensurá-la ${ }^{856}$.

Também foi ouvida a socióloga Maria José Fontelas Rosado Nunes, representando a Organização Não-Governamental Católicas pelo Direito de Decidir, que realçou o "caráter laico do Estado" $" 857$, de modo que a imposição de conceitos religiosos violaria os direitos constitucionais garantidos pela Constituição Federal, num cenário democrático ${ }^{858}$. Além disso, acrescentou a socióloga que "uma legislação permissiva faculta, mas não obriga" ${ }^{\$ 59}$, o

${ }^{851}$ BRASIL. Supremo Tribunal Federal. Arguição de Descumprimento de Preceito Fundamental $\mathrm{n}^{\circ}$ 54-8. Audiência Pública do dia 26 ago. 2008, p. 25. Disponível em: 〈http://www.stf.jus.br〉. Acesso em: 10 jan. 2011.

${ }^{852}$ BRASIL. Supremo Tribunal Federal. Arguição de Descumprimento de Preceito Fundamental no ${ }^{\circ}$ 54-8. Audiência Pública do dia 26 ago. 2008, p. 26. Disponível em: 〈http://www.stf.jus.br〉. Acesso em: 10 jan. 2011.

${ }^{853}$ BRASIL. Supremo Tribunal Federal. Arguição de Descumprimento de Preceito Fundamental $\mathrm{n}^{\circ}$ 54-8. Audiência Pública do dia 26 ago. 2008, p. 27. Disponível em: 〈http://www.stf.jus.br〉. Acesso em: 10 jan. 2011. Esclarece o médico que "Não há cura no momento atual, ninguém está negando isso. Apesar de essa mortalidade ser muito elevada, algumas dessas crianças podem viver por meses ou mais raramente por um ano, mas nunca morrem, obrigatoriamente, todas elas, imediatamente após o parto". BRASIL. Supremo Tribunal Federal. Arguição de Descumprimento de Preceito Fundamental no 54-8. Audiência Pública do dia 26 ago. 2008, p. 27. Disponível em: 〈http://www.stf.jus.br〉. Acesso em: 10 jan. 2011.

${ }_{854}$ BRASIL. Supremo Tribunal Federal. Arguição de Descumprimento de Preceito Fundamental $\mathrm{n}^{\circ}$ 54-8. Audiência Pública do dia 26 ago. 2008, p. 27. Disponível em: 〈http://www.stf.jus.br〉. Acesso em: 10 jan. 2011.

${ }^{855}$ BRASIL. Supremo Tribunal Federal. Arguição de Descumprimento de Preceito Fundamental n ${ }^{\circ}$ 54-8. Audiência Pública do dia 26 ago. 2008, p. 29. Disponível em: <http://www.stf.jus.br>. Acesso em: 10 jan. 2011. O médico afirma que "A Resolução do CFM n ${ }^{\circ}$ 1752/04 autorizava a retirada de órgãos de crianças com anencefalia, classificando como inaplicáveis e desnecessários os critérios da morte encefálica. Posteriormente, em março de 2007, a Portaria $\mathrm{n}^{\circ}$ 487, do Ministério da Saúde, revendo a questão [...] resolveu: "Art. $1^{\circ}$ - A retirada de órgãos elou tecidos de neonato encefálico para fins de transplante ou tratamento deverá ser precedida de diagnóstico de parada cardíaca irreversível." (itálico do autor). BRASIL. Supremo Tribunal Federal. Arguição de Descumprimento de Preceito Fundamental no 54-8. Audiência Pública do dia 26 ago. 2008, p. 28-29. Disponível em: 〈http://www.stf.jus.br〉. Acesso em: 10 jan. 2011.

${ }^{856}$ BRASIL. Supremo Tribunal Federal. Arguição de Descumprimento de Preceito Fundamental ${ }^{\circ}$ 54-8. Audiência Pública do dia 26 ago. 2008, p. 32. Disponível em: 〈http://www.stf.jus.br〉. Acesso em: 10 jan. 2011.

${ }^{857}$ BRASIL. Supremo Tribunal Federal. Arguição de Descumprimento de Preceito Fundamental ${ }^{\circ}$ 54-8. Audiência Pública do dia 26 ago. 2008, p. 39-40. Disponível em: <http://www.stf.jus.br〉. Acesso em: 10 jan. 2011.

${ }_{858}$ BRASIL. Supremo Tribunal Federal. Arguição de Descumprimento de Preceito Fundamental $\mathrm{n}^{\circ}$ 54-8. Audiência Pública do dia 26 ago. 2008, p. 39-40. Disponível em: <http://www.stf.jus.br>. Acesso em: 10 jan. 2011.

859 BRASIL. Supremo Tribunal Federal. Arguição de Descumprimento de Preceito Fundamental $\mathrm{n}^{\circ}$ 54-8. Audiência Pública do dia 26 ago. 2008, p. 41. Disponível em: 〈http://www.stf.jus.br〉. Acesso em: 10 jan. 2011. 
que garante que pessoas que não queiram realizar o aborto possam seguir sua consciência, sem, no entanto, obrigar outros a seguir o mesmo caminho. Segundo Nunes, a manutenção forçada desse tipo de gestação desrespeita a liberdade e a dignidade da mulher, equiparandose à tortura, e transformando a mulher em "coisa". ${ }^{860}$ Por fim, a socióloga também observou o aspecto da justiça social envolvido, lembrando que a autorização do aborto do feto anencéfalo estaria "atendendo particularmente às mulheres pobres para quem a autorização judicial é condição de possibilidade de realização do procedimento médico" ${ }^{\text {"861 }}$.

Por último, foram ouvidas as médicas Marlene Rossi Severino Nobre e Irvênia Luíza de Santis Prada, representando a Associação Médico-Espírita do Brasil. Explicaram as médicas que cérebro não é sinônimo de encéfalo, que seria "a massa cerebral contida dentro da cavidade craniana" 862 no sistema nervoso formada pelo "tronco encefálico, que é sobremontado pelo cerebelo, pelo diencéfalo e pelos dois hemisférios cerebrais" ${ }^{\$ 863}$; sendo que o cérebro é formado por esses dois hemisférios ${ }^{864}$. Ensinam que o anencéfalo, dependendo do caso, pode formar o "tronco cerebral alto" ${ }^{\sharp 65}$, o que lhe permitiria o batimento cardíaco, por exemplo $^{866}$.

O tronco cerebral alto teria, para elas, "o substrato da consciência" ${ }^{867}$, mas seria dificíl mensurar tal consciência levando-se em conta apenas sua exteriorização, já que, para uma criança anencéfala, isso seria difícil ou impossível, pela inexistência frequente das "áreas nobres do córtex cerebral" 868 , ainda que exista, ao menos em tese, "substrato neural para desempenho de funções vitais e delegação com a Consciência" do anencéfalo ${ }^{869}$.

${ }^{860}$ BRASIL. Supremo Tribunal Federal. Arguição de Descumprimento de Preceito Fundamental $n^{\circ}$ 54-8. Audiência Pública do dia 26 ago. 2008, p. 42-43. Disponível em: <http://www.stf.jus.br>. Acesso em: 10 jan. 2011.

861 BRASIL. Supremo Tribunal Federal. Arguição de Descumprimento de Preceito Fundamental $\mathrm{n}^{\circ}$ 54-8. Audiência Pública do dia 26 ago. 2008, p. 44. Disponível em: 〈http://www.stf.jus.br〉. Acesso em: 10 jan. 2011.

862 BRASIL. Supremo Tribunal Federal. Arguição de Descumprimento de Preceito Fundamental $\mathrm{n}^{\circ}$ 54-8. Audiência Pública do dia 26 ago. 2008, p. 47. Disponível em: 〈http://www.stf.jus.br〉. Acesso em: 10 jan. 2011.

863 BRASIL. Supremo Tribunal Federal. Arguição de Descumprimento de Preceito Fundamental $\mathrm{n}^{\circ}$ 54-8. Audiência Pública do dia 26 ago. 2008, p. 47. Disponível em: 〈http://www.stf.jus.br〉. Acesso em: 10 jan. 2011. 864 BRASIL. Supremo Tribunal Federal. Arguição de Descumprimento de Preceito Fundamental $\mathrm{n}^{\circ}$ 54-8. Audiência Pública do dia 26 ago. 2008, p. 47. Disponível em: 〈http://www.stf.jus.br〉. Acesso em: 10 jan. 2011.

${ }^{865}$ BRASIL. Supremo Tribunal Federal. Arguição de Descumprimento de Preceito Fundamental $\mathrm{n}^{\circ}$ 54-8. Audiência Pública do dia 26 ago. 2008, p. 47. Disponível em: 〈http://www.stf.jus.br〉. Acesso em: 10 jan. 2011. 866 BRASIL. Supremo Tribunal Federal. Arguição de Descumprimento de Preceito Fundamental $\mathrm{n}^{\circ}$ 54-8. Audiência Pública do dia 26 ago. 2008, p. 47. Disponível em: 〈http://www.stf.jus.br〉. Acesso em: 10 jan. 2011. 867 BRASIL. Supremo Tribunal Federal. Arguição de Descumprimento de Preceito Fundamental $\mathrm{n}^{\circ}$ 54-8. Audiência Pública do dia 26 ago. 2008, p. 50. Disponível em: <http://www.stf.jus.br〉. Acesso em: 10 jan. 2011. 868 BRASIL. Supremo Tribunal Federal. Arguição de Descumprimento de Preceito Fundamental $\mathrm{n}^{\circ}$ 54-8. Audiência Pública do dia 26 ago. 2008, p. 51. Disponível em: <http://www.stf.jus.br〉. Acesso em: 10 jan. 2011. 869 BRASIL. Supremo Tribunal Federal. Arguição de Descumprimento de Preceito Fundamental $\mathrm{n}^{\circ}$ 54-8. Audiência Pública do dia 26 ago. 2008, p. 52. Disponível em: 〈http://www.stf.jus.br〉. Acesso em: 10 jan. 2011. 
Ainda segundo as médicas, a ciência ${ }^{870}$ teria demonstrado que a vida é um "bem outorgado" $^{871}$ e não um acaso ${ }^{872}$, e que, apesar de a anencefalia levar à morte o feto, intra ou extrauterinamente, a vida do feto deveria prevalecer sobre os outros valores em jogo ${ }^{873}$.

No segundo dia de audiência, foram ouvidos professores e cientistas. Pronunciaram-se o Conselho Federal de Medicina, a Federação Brasileira das Associações de Ginecologia e Obstetrícia, a Sociedade Brasileira de Medicina Fetal, o Deputado Federal Luiz Bassuma, Presidente da Frente Parlamentar em Defesa da Vida - Contra o Aborto, a Sociedade Brasileira de Genética Clínica, o Deputado Federal e médico José Aristodemo Pinotti, o Movimento "Brasil Sem Aborto", a Sociedade Brasileira para o Progresso da Ciência, e o ANIS - Instituto de Bioética, Direitos Humanos e Gênero.

O médico Roberto Luiz D’Ávila, representante do Conselho Federal de Medicina, explicou que nas últimas décadas a tecnologia deixou o profissional da saúde muito próximo de questões inquietantes envolvendo o início e o fim da vida ${ }^{874}$, abordando a necessidade de respeitar-se as autonomias do paciente e do médico ${ }^{875}$. Lembrou que, no caso da mulher, a gravidez é sempre um risco, e cabe ao médico atuar no sentido de proporcionar-lhes o tratamento adequado, respeitando-lhes a autonomia e dignidade ${ }^{876}$. Para D’ Ávila, o médico não deve trabalhar levando em conta as exceções, mas as regras, e a prática demonstra que poucos fetos anencefálos têm uma sobrevida significativa fora do útero ${ }^{877}$. Ressaltou o médico a dificuldade de como se orientar os médicos para que não violem a lei ou decisões

\footnotetext{
${ }^{870}$ Quanto a alegar que a Ciência estaria comprovando objetos metafísicos, vale lembrar a opinião de Nietzsche: "Knapsack of the Metaphysicians.- Those who boast so mightily of the scientificality of their metaphysics should receive no answer; it is enough to pluck at the bundle which, with a certain degree of embarrassment, they keep concealed behind their back; if one succeeds in opening it, the products of that scientificality come to light, attended by their blushes: a dear little Lord God, a nice little immortality, perhaps a certain quantity of spiritualism, and in any event a whole tangled heap of 'wretched poor sinner' and Pharisee arrogance." NIETZSCHE, Friedrich. Human, all too human. Translation: J.R. Hollingdale. Cambridge: Cambridge University Press, 2004, p. 217.

871 BRASIL. Supremo Tribunal Federal. Arguição de Descumprimento de Preceito Fundamental $\mathrm{n}^{\circ}$ 54-8. Audiência Pública do dia 26 ago. 2008, p. 54. Disponível em: 〈http://www.stf.jus.br〉. Acesso em: 10 jan. 2011.

872 BRASIL. Supremo Tribunal Federal. Arguição de Descumprimento de Preceito Fundamental $\mathrm{n}^{\circ}$ 54-8. Audiência Pública do dia 26 ago. 2008, p. 54. Disponível em: 〈http://www.stf.jus.br〉. Acesso em: 10 jan. 2011.

873 BRASIL. Supremo Tribunal Federal. Arguição de Descumprimento de Preceito Fundamental $\mathrm{n}^{\circ}$ 54-8. Audiência Pública do dia 26 ago. 2008, p. 57. Disponível em: 〈http://www.stf.jus.br〉. Acesso em: 10 jan. 2011. ${ }^{874}$ BRASIL. Supremo Tribunal Federal. Arguição de Descumprimento de Preceito Fundamental $\mathrm{n}^{\circ}$ 54-8. Audiência Pública do dia 28 ago. 2008, p. 4-5. Disponível em: 〈http://www.stf.jus.br〉. Acesso em: 10 jan. 2011. 875 BRASIL. Supremo Tribunal Federal. Arguição de Descumprimento de Preceito Fundamental $\mathrm{n}^{\circ}$ 54-8. Audiência Pública do dia 28 ago. 2008, p. 5-6. Disponível em: 〈http://www.stf.jus.br〉. Acesso em: 10 jan. 2011. ${ }^{876}$ BRASIL. Supremo Tribunal Federal. Arguição de Descumprimento de Preceito Fundamental no ${ }^{\circ}$ 54-8. Audiência Pública do dia 28 ago. 2008, p. 7-8. Disponível em: 〈http://www.stf.jus.br〉. Acesso em: 10 jan. 2011. 877 BRASIL. Supremo Tribunal Federal. Arguição de Descumprimento de Preceito Fundamental $\mathrm{n}^{\circ}$ 54-8. Audiência Pública do dia 28 ago. 2008, p. 8. Disponível em: 〈http://www.stf.jus.br〉. Acesso em: 10 jan. 2011.
} 
judiciais ${ }^{878}$, observando também que o diagnóstico da anencefalia é possível na $9^{\mathrm{a}}$ e $10^{\mathrm{a}}$ semana de gestação. Elucidou ainda o médico, que a gravidez nessas cirscuntâncias traz um risco maior de acumular-se na gestante um excesso de líquido amniótico, que, por sua vez, pode provocar na gestante toxemia gravídica, uma doença hipertensiva específica da gravidez, o que, naturalmente, também aumenta as chances de a gestante sofrer outras doenças relacionadas à hipertensão ${ }^{879}$. Para o médico, não é possível se "esperar até o terceiro trimestre para que a toxemia se manifeste e tratar a complicação com perda de tempo e com risco maior" $" 880$ para a gestante.

O outro médico ouvido, agora representando a Federação Brasileira das Associações de Ginecologia e Obstetrícia, Jorge Andalaft Neto, buscou demonstrar os riscos à saúde da mulher no caso de uma gravidez de feto anencéfalo. Os dados trazidos pelo médico mostram que, no Estado de São Paulo, de cada 619 mil partos em 2005, 604 mil partos em 2006, e 594 mil partos em $2007,88,106$, e 84 , respectivamente, foram de fetos com anencefalia ${ }^{881}$. O médico também mencionou que o diagnóstico da doença pode ser feito até a $12^{\mathrm{a}}$ semana de gestação $^{882}$, e esclareceu que, além da letalidade da doença, em geral, os fetos podem sofrer outras deformações associadas ${ }^{883}$.

Andalaft Neto ressaltou que, além dos riscos à saúde durante a gravidez que decorrem de uma gestação de feto anencéfalo, existem riscos durante o parto, a serem somados aos problemas psíquicos sofridos pelas gestantes, como quadros de depressão e stress $^{884}$. O médico apresentou dados de estudos, destacando o surgimento de pressão alta e diabetes decorrentes do excesso de líquido amniótico (polidrâmnio) que costuma ocorrer em uma gestação de feto anencéfalo, os riscos de parto prematuro ou gravidez prolongada, descolamento da placenta, falta de posicionamento correto do bebê, e óbito intrauterino, bem

${ }^{878}$ BRASIL. Supremo Tribunal Federal. Arguição de Descumprimento de Preceito Fundamental $\mathrm{n}^{\circ}$ 54-8. Audiência Pública do dia 28 ago. 2008, p. 9-10. Disponível em: 〈http://www.stf.jus.br〉. Acesso em: 10 jan. 2011.

879 BRASIL. Supremo Tribunal Federal. Arguição de Descumprimento de Preceito Fundamental $\mathrm{n}^{\circ}$ 54-8. Audiência Pública do dia 28 ago. 2008, p. 12. Disponível em: 〈http://www.stf.jus.br〉. Acesso em: 10 jan. 2011.

880 BRASIL. Supremo Tribunal Federal. Arguição de Descumprimento de Preceito Fundamental $\mathrm{n}^{\circ}$ 54-8. Audiência Pública do dia 28 ago. 2008, p. 12. Disponível em: 〈http://www.stf.jus.br〉. Acesso em: 10 jan. 2011.

881 BRASIL. Supremo Tribunal Federal. Arguição de Descumprimento de Preceito Fundamental $\mathrm{n}^{\circ}$ 54-8. Audiência Pública do dia 28 ago. 2008, p. 15. Disponível em: <http://www.stf.jus.br. Acesso em: 10 jan. 2011.

882 BRASIL. Supremo Tribunal Federal. Arguição de Descumprimento de Preceito Fundamental $\mathrm{n}^{\circ}$ 54-8. Audiência Pública do dia 28 ago. 2008, p. 16. Disponível em: 〈http://www.stf.jus.br〉. Acesso em: 10 jan. 2011.

883 BRASIL. Supremo Tribunal Federal. Arguição de Descumprimento de Preceito Fundamental $\mathrm{n}^{\circ}$ 54-8. Audiência Pública do dia 28 ago. 2008, p. 16. Disponível em: 〈http://www.stf.jus.br〉. Acesso em: 10 jan. 2011.

${ }^{884}$ BRASIL. Supremo Tribunal Federal. Arguição de Descumprimento de Preceito Fundamental $\mathrm{n}^{\circ}$ 54-8. Audiência Pública do dia 28 ago. 2008, p. 17-19. Disponível em: <http://www.stf.jus.br>. Acesso em: 10 jan. 2011. 
como a necessidade de procedimentos especiais, tais como transfusão de sangue e esterectomia e partos de emergência ${ }^{885}$.

Em seguida, foi ouvida a Sociedade Brasileira de Medicina Fetal, representada pelo doutor Heverton Neves Pettersen. Explicou o médico que "o cérebro, a coluna, o canal medular são derivados do tubo neural" parte integrante do sistema nervoso central ${ }^{886}$, e que é possível diagnosticar a anencefalia a partir da $8^{\mathrm{a}}$ semana $^{887}$. O médico afirmou que "a incidência [da anencefalia] na população mundial é em torno de 1 a cada mil nascimentos" mas o " Estado de São Paulo teve uma incidência um pouco superior: 100 casos em 600.000 nascimentos" ${ }^{889}$. Segundo Pettersen, o diagnóstico da doença hoje é de $100 \%{ }^{890}$. Ele ressaltou também as complicações decorrentes da produção em excesso de líquido amniótico, que, além dos problemas já apontados, pode também causar hidronefrose na gestante, em decorrência da compressão dos ureteres da mulher ${ }^{891}$. Pettersen demonstrou que o caso no registro médico de anencefalia, na verdade, seria um pseudo caso de anencefalia, pois existente uma pequena parte do "lóbulo temporal que faz parte dos hemisférios cerebrais" ${ }^{892}$. Para o médico, o feto anencéfalo é um "natimorto neurológico" $" 893$. Por fim, esclareceu o médico que o diagnóstico não se altera durante a gestação ${ }^{894}$, e não é possível que o encéfalo se desenvolva após a embriogênese ${ }^{895}$.

Em seguida foi ouvido o Deputado Federal Luiz Bassuma, Presidente da Frente Parlamentar em Defesa da Vida - Contra o Aborto. Para o deputado, "a vida não pode ser medida em estatística", e ressaltou que atualmente existem dois Projetos de Lei tratando do

885 BRASIL. Supremo Tribunal Federal. Arguição de Descumprimento de Preceito Fundamental $\mathrm{n}^{\circ}$ 54-8. Audiência Pública do dia 28 ago. 2008, p. 17-18. Disponível em: <http://www.stf.jus.br>. Acesso em: 10 jan. 2011.

${ }^{886}$ BRASIL. Supremo Tribunal Federal. Arguição de Descumprimento de Preceito Fundamental $\mathrm{n}^{\circ}$ 54-8. Audiência Pública do dia 28 ago. 2008, p. 23. Disponível em: 〈http://www.stf.jus.br〉. Acesso em: 10 jan. 2011.

887 BRASIL. Supremo Tribunal Federal. Arguição de Descumprimento de Preceito Fundamental $\mathrm{n}^{\circ}$ 54-8. Audiência Pública do dia 28 ago. 2008, p. 24. Disponível em: 〈http://www.stf.jus.br〉. Acesso em: 10 jan. 2011. 888 BRASIL. Supremo Tribunal Federal. Arguição de Descumprimento de Preceito Fundamental $\mathrm{n}^{\circ}$ 54-8. Audiência Pública do dia 28 ago. 2008, p. 24. Disponível em: 〈http://www.stf.jus.br〉. Acesso em: 10 jan. 2011.

889 BRASIL. Supremo Tribunal Federal. Arguição de Descumprimento de Preceito Fundamental no ${ }^{\circ}$ 54-8. Audiência Pública do dia 28 ago. 2008, p. 24. Disponível em: 〈http://www.stf.jus.br〉. Acesso em: 10 jan. 2011. 890 BRASIL. Supremo Tribunal Federal. Arguição de Descumprimento de Preceito Fundamental $\mathrm{n}^{\circ}$ 54-8. Audiência Pública do dia 28 ago. 2008, p. 27. Disponível em: 〈http://www.stf.jus.br〉. Acesso em: 10 jan. 2011.

891 BRASIL. Supremo Tribunal Federal. Arguição de Descumprimento de Preceito Fundamental $\mathrm{n}^{\circ}$ 54-8. Audiência Pública do dia 28 ago. 2008, p. 28. Disponível em: 〈http://www.stf.jus.br〉. Acesso em: 10 jan. 2011. 892 BRASIL. Supremo Tribunal Federal. Arguição de Descumprimento de Preceito Fundamental $\mathrm{n}^{\circ}$ 54-8. Audiência Pública do dia 28 ago. 2008, p. 29. Disponível em: 〈http://www.stf.jus.br〉. Acesso em: 10 jan. 2011. 893 BRASIL. Supremo Tribunal Federal. Arguição de Descumprimento de Preceito Fundamental $\mathrm{n}^{\circ}$ 54-8. Audiência Pública do dia 28 ago. 2008, p. 30. Disponível em: 〈http://www.stf.jus.br〉. Acesso em: 10 jan. 2011. 894 BRASIL. Supremo Tribunal Federal. Arguição de Descumprimento de Preceito Fundamental $\mathrm{n}^{\circ}$ 54-8. Audiência Pública do dia 28 ago. 2008, p. 31. Disponível em: <http://www.stf.jus.br〉. Acesso em: 10 jan. 2011. 895 BRASIL. Supremo Tribunal Federal. Arguição de Descumprimento de Preceito Fundamental $\mathrm{n}^{\circ}$ 54-8. Audiência Pública do dia 28 ago. 2008, p. 32. Disponível em: 〈http://www.stf.jus.br〉. Acesso em: 10 jan. 2011. 
aborto: o Projeto de Lei $n^{\circ}$ 4.403/2004, visando à legalização do aborto em geral, e o Projeto de Lei $\mathrm{n}^{\mathrm{o}} 5.364 / 2005$, buscando criminalizar o aborto no caso de estupro. Para o deputado, qualquer vida no planeta pode vir a ser "medíocre" ou "superficial", mas, no entanto, também "pode ser uma vida extraordinariamente marcante" ${ }^{896}$. Segundo Bassuma, não se pode eliminar a vida para resolver um problema ${ }^{897}$, especialmente no caso em tela, em que, segundo o deputado, seria possível fornecer-se meios para prevenir a anencefalia, como por exemplo, através do uso de ácido fólico ${ }^{898}$.

Depois manifestou-se a Sociedade Brasileira de Genética Clínica, representada pelo doutor Salmo Raskin. O pesquisador afirmou que a anencefalia ocorre frequentemente no Brasil $^{899}$. Explicou que "a neurulação é um processo embriológico fundamental que leva à formação do tubo neural [...] precursor do cérebro" ${ }^{900}$. Segundo Raskin, o tubo neural se fecha no $24^{\circ}$ dia depois da fecundação ${ }^{901}$, momento em que a mulher ainda desconhece seu estado gravídico $^{902}$, que pode ser verificado apenas quatorze semanas depois ${ }^{903}$. Se não ocorrer o fechamento do tubo, tem-se a anencefalia ${ }^{904}$. Para o pesquisador o ácido fólico reduz de $10 \mathrm{a}$ $40 \%$ dos casos de anencefalia quando administrado antes da gravidez ${ }^{905}$, mas não os elimina completamente ${ }^{906}$. Estudos demonstram que o acometimento de anencefalia na família aumenta a chance de novas ocorrências, inclusive com relação ao próprio casal que já tenha gerado um ou mais fetos anencéfalos anteriormente ${ }^{907}$. Além da forte incidência em fetos do sexo feminino, existem outros fatores que podem facilitar o aparecimento da anencefalia, tais

${ }^{896}$ BRASIL. Supremo Tribunal Federal. Arguição de Descumprimento de Preceito Fundamental no $54-8$. Audiência Pública do dia 28 ago. 2008, p. 44. Disponível em: 〈http://www.stf.jus.br〉. Acesso em: 10 jan. 2011.

897 BRASIL. Supremo Tribunal Federal. Arguição de Descumprimento de Preceito Fundamental $\mathrm{n}^{\circ}$ 54-8. Audiência Pública do dia 28 ago. 2008, p. 47. Disponível em: 〈http://www.stf.jus.br〉. Acesso em: 10 jan. 2011. 898 BRASIL. Supremo Tribunal Federal. Arguição de Descumprimento de Preceito Fundamental $\mathrm{n}^{\circ}$ 54-8. Audiência Pública do dia 28 ago. 2008, p. 47. Disponível em: 〈http://www.stf.jus.br〉. Acesso em: 10 jan. 2011.

899 BRASIL. Supremo Tribunal Federal. Arguição de Descumprimento de Preceito Fundamental no 54-8. Audiência Pública do dia 28 ago. 2008, p. 55. Disponível em: 〈http://www.stf.jus.br〉. Acesso em: 10 jan. 2011. 900 BRASIL. Supremo Tribunal Federal. Arguição de Descumprimento de Preceito Fundamental $\mathrm{n}^{\circ}$ 54-8. Audiência Pública do dia 28 ago. 2008, p. 56. Disponível em: 〈http://www.stf.jus.br〉. Acesso em: 10 jan. 2011.

901 BRASIL. Supremo Tribunal Federal. Arguição de Descumprimento de Preceito Fundamental $\mathrm{n}^{\circ}$ 54-8. Audiência Pública do dia 28 ago. 2008, p. 56. Disponível em: 〈http://www.stf.jus.br〉. Acesso em: 10 jan. 2011. 902 BRASIL. Supremo Tribunal Federal. Arguição de Descumprimento de Preceito Fundamental $\mathrm{n}^{\circ}$ 54-8. Audiência Pública do dia 28 ago. 2008, p. 57. Disponível em: 〈http://www.stf.jus.br〉. Acesso em: 10 jan. 2011.

903 BRASIL. Supremo Tribunal Federal. Arguição de Descumprimento de Preceito Fundamental $\mathrm{n}^{\circ}$ 54-8. Audiência Pública do dia 28 ago. 2008, p. 57. Disponível em: 〈http://www.stf.jus.br〉. Acesso em: 10 jan. 2011. 904 BRASIL. Supremo Tribunal Federal. Arguição de Descumprimento de Preceito Fundamental $\mathrm{n}^{\circ}$ 54-8. Audiência Pública do dia 28 ago. 2008, p. 56. Disponível em: 〈http://www.stf.jus.br〉. Acesso em: 10 jan. 2011. 905 BRASIL. Supremo Tribunal Federal. Arguição de Descumprimento de Preceito Fundamental no 54-8. Audiência Pública do dia 28 ago. 2008, p. 57. Disponível em: 〈http://www.stf.jus.br〉. Acesso em: 10 jan. 2011. 906 BRASIL. Supremo Tribunal Federal. Arguição de Descumprimento de Preceito Fundamental $\mathrm{n}^{\circ}$ 54-8. Audiência Pública do dia 28 ago. 2008, p. 57. Disponível em: 〈http://www.stf.jus.br〉. Acesso em: 10 jan. 2011. 907 BRASIL. Supremo Tribunal Federal. Arguição de Descumprimento de Preceito Fundamental $\mathrm{n}^{\circ}$ 54-8. Audiência Pública do dia 28 ago. 2008, p. 62. Disponível em: 〈http://www.stf.jus.br〉. Acesso em: 10 jan. 2011. 
como, fatores ambientais, idade e obesidade da mulher ${ }^{908}$, uso de drogas, indutores de ovulação etc ${ }^{909}$.

Ensina ainda o pesquisador que o bebê anencéfalo, depois que nasce, comumente apresenta quadros de convulsão, com exposição do "tecido neural, hemorrágico e fibrótico", falecendo horas ou dias depois do nascimento ${ }^{910}$. Em razão dessa morte rápida, normalmente fica prejudica a retirada dos órgãos ${ }^{911}$ para transplante ${ }^{912}$.

Também foi ouvido o médico, professor e deputado federal José Aristodemo Pinotti, que afirmou que o Brasil é o "quarto País em incidência de anencefalia"913, alcançando praticamente um caso a cada mil gestações ${ }^{914}$. Para ele, o diagnóstico é preciso e evidente ${ }^{915}$. $\mathrm{O}$ aborto ocorre com frequência no Brasil, e muitas mulheres - que se submetem a procedimentos abortivos ilegais - morrem ou tornam-se estéreis em consequência ${ }^{916}$. Para o professor, quando o diagnóstico é correto ${ }^{917}$, a anencefalia é letal em todos os $\operatorname{casos}^{918}$. Estima, por fim, o professor, que ocorrem entre um milhão a um milhão e meio de abortos ilegais por ano no país ${ }^{919}$.

${ }^{908}$ BRASIL. Supremo Tribunal Federal. Arguição de Descumprimento de Preceito Fundamental $\mathrm{n}^{\mathrm{o}}$ 54-8. Audiência Pública do dia 28 ago. 2008, p. 59. Disponível em: 〈http://www.stf.jus.br〉. Acesso em: 10 jan. 2011. 909 BRASIL. Supremo Tribunal Federal. Arguição de Descumprimento de Preceito Fundamental ${ }^{\circ}$ 54-8. Audiência Pública do dia 28 ago. 2008, p. 60. Disponível em: 〈http://www.stf.jus.br〉. Acesso em: 10 jan. 2011.

910 BRASIL. Supremo Tribunal Federal. Arguição de Descumprimento de Preceito Fundamental no ${ }^{\circ}$ 54-8. Audiência Pública do dia 28 ago. 2008, p. 61. Disponível em: 〈http://www.stf.jus.br〉. Acesso em: 10 jan. 2011.

911 BRASIL. Supremo Tribunal Federal. Arguição de Descumprimento de Preceito Fundamental ${ }^{\circ}$ 54-8. Audiência Pública do dia 28 ago. 2008, p. 62. Disponível em: 〈http://www.stf.jus.br〉. Acesso em: 10 jan. 2011.

912 BRASIL. Supremo Tribunal Federal. Arguição de Descumprimento de Preceito Fundamental no 54-8. Audiência Pública do dia 28 ago. 2008, p. 65. Disponível em: 〈http://www.stf.jus.br〉. Acesso em: 10 jan. 2011. $\mathrm{O}$ transplante só pode ser realizado a partir do $7^{\circ}$ dia de vida. Esse fato inviabiliza o transplante de órgãos de anencéfalos que, em geral, não sobrevivem sete dias. BRASIL. Supremo Tribunal Federal. Arguição de Descumprimento de Preceito Fundamental no 54-8. Audiência Pública do dia 28 ago. 2008, p. 66. Disponível em: 〈http://www.stf.jus.br>. Acesso em: 10 jan. 2011.

${ }_{913}$ BRASIL. Supremo Tribunal Federal. Arguição de Descumprimento de Preceito Fundamental $\mathrm{n}^{\circ}$ 54-8. Audiência Pública do dia 28 ago. 2008, p. 71. Disponível em: 〈http://www.stf.jus.br〉. Acesso em: 10 jan. 2011.

914 BRASIL. Supremo Tribunal Federal. Arguição de Descumprimento de Preceito Fundamental $n^{\circ}$ 54-8. Audiência Pública do dia 28 ago. 2008, p. 71. Disponível em: 〈http://www.stf.jus.br〉. Acesso em: 10 jan. 2011.

915 BRASIL. Supremo Tribunal Federal. Arguição de Descumprimento de Preceito Fundamental $n^{\circ}$ 54-8. Audiência Pública do dia 28 ago. 2008, p. 72-73. Disponível em: <http://www.stf.jus.br>. Acesso em: 10 jan. 2011.

916 BRASIL. Supremo Tribunal Federal. Arguição de Descumprimento de Preceito Fundamental $\mathrm{n}^{\circ}$ 54-8. Audiência Pública do dia 28 ago. 2008, p. 75. Disponível em: 〈http://www.stf.jus.br〉. Acesso em: 10 jan. 2011.

${ }^{917}$ No caso da menina Marcela, Pinotti entende ter havido um diagnóstico equivocado. BRASIL. Supremo Tribunal Federal. Arguição de Descumprimento de Preceito Fundamental no $54-8$. Audiência Pública do dia 28 ago. 2008, p. 81. Disponível em: 〈http://www.stf.jus.br>. Acesso em: 10 jan. 2011.

${ }_{918}$ BRASIL. Supremo Tribunal Federal. Arguição de Descumprimento de Preceito Fundamental $\mathrm{n}^{\circ}$ 54-8. Audiência Pública do dia 28 ago. 2008, p. 77. Disponível em: 〈http://www.stf.jus.br〉. Acesso em: 10 jan. 2011.

919 BRASIL. Supremo Tribunal Federal. Arguição de Descumprimento de Preceito Fundamental no ${ }^{\circ}$ 54-8. Audiência Pública do dia 28 ago. 2008, p. 79-80. Disponível em: 〈http://www.stf.jus.br〉. Acesso em: 10 jan. 2011. 
A professora Lenise Aparecida Martins, representante do Movimento "Brasil Sem Aborto", expôs que "cada anencéfalo tem a sua anencefalia" 920 , e que um percentual muito pequeno, em torno de um por cento, sobrevive três meses ou mais ${ }^{921}$. Para a professora, afirmar que uma vida não merece ser vivida, desembocará em uma "ética de oportunismo, de uma ética utilitarista, em lugar da ética da dignidade humana" ${ }^{922}$.

A Sociedade Brasileira para o Progresso da Ciência foi representada pelo médico Thomaz Rafael Gollop, que acrescentou a informação de que o Sistema Único de Saúde SUS, em 2007 - ano anterior às audiências públicas - realizou 2.526.284 de exames de ultrasonografia, que é capaz de diagnosticar a anencefalia ${ }^{923}$. Ensinou o professor que o sistema nervoso pode ser dividido em sistema nervoso somático, que diz respeito à vida cognitiva superior; e, o sistema nervoso visceral, que se refere à vida vegetativa ${ }^{924}$. Afirmou Gollop que, mesmo se houver existência parcial do encéfalo, o que garantiria a possibilidade de uma sobrevida maior ao anencéfalo, ainda assim, o bebê não é capaz de processar informações ${ }^{925}$. Para ele, não existe "atividade cortical" no feto anencéfalo, o que constitui uma morte cerebral. ${ }^{926}$ O médico pesquisador relatou que, entre 1989 e 2008, foram expedidos mais de cinco mil alvarás judiciais autorizando a interrupção da gestação nos casos de feto anencéfalo ${ }^{927}$. Acrescentou, por fim, mais algumas complicações comuns nesse tipo de gestação, e afirmou que o feto não teria sentimentos, pois desprovido de crânio e cérebro ${ }^{928}$.

${ }^{920}$ BRASIL. Supremo Tribunal Federal. Arguição de Descumprimento de Preceito Fundamental no $54-8$. Audiência Pública do dia 28 ago. 2008, p. 83. Disponível em: 〈http://www.stf.jus.br〉. Acesso em: 10 jan. 2011.

921 BRASIL. Supremo Tribunal Federal. Arguição de Descumprimento de Preceito Fundamental $\mathrm{n}^{\circ}$ 54-8. Audiência Pública do dia 28 ago. 2008, p. 83-84. Disponível em: <http://www.stf.jus.br>. Acesso em: 10 jan. 2011.

922 BRASIL. Supremo Tribunal Federal. Arguição de Descumprimento de Preceito Fundamental $\mathrm{n}^{\circ}$ 54-8. Audiência Pública do dia 28 ago. 2008, p. 90-91. Disponível em: <http://www.stf.jus.br>. Acesso em: 10 jan. 2011.

923 BRASIL. Supremo Tribunal Federal. Arguição de Descumprimento de Preceito Fundamental $\mathrm{n}^{\circ}$ 54-8. Audiência Pública do dia 28 ago. 2008, p. 94-95. Disponível em: <http://www.stf.jus.br>. Acesso em: 10 jan. 2011. Afirmou que no caso da Marcela a sobrevida foi em razão de uma anomalia menos grave no sistema nervoso central, a merocrania. BRASIL. Supremo Tribunal Federal. Arguição de Descumprimento de Preceito Fundamental no 54-8. Audiência Pública do dia 28 ago. 2008, p. 95. Disponível em: <http://www.stf.jus.br>. Acesso em: 10 jan. 2011.

924 BRASIL. Supremo Tribunal Federal. Arguição de Descumprimento de Preceito Fundamental no 54-8. Audiência Pública do dia 28 ago. 2008, p. 95. Disponível em: 〈http://www.stf.jus.br〉. Acesso em: 10 jan. 2011.

925 BRASIL. Supremo Tribunal Federal. Arguição de Descumprimento de Preceito Fundamental $\mathrm{n}^{\circ}$ 54-8. Audiência Pública do dia 28 ago. 2008, p. 96. Disponível em: 〈http://www.stf.jus.br〉. Acesso em: 10 jan. 2011.

926 BRASIL. Supremo Tribunal Federal. Arguição de Descumprimento de Preceito Fundamental no 54-8. Audiência Pública do dia 28 ago. 2008, p. 96. Disponível em: 〈http://www.stf.jus.br〉. Acesso em: 10 jan. 2011.

927 BRASIL. Supremo Tribunal Federal. Arguição de Descumprimento de Preceito Fundamental no 54-8. Audiência Pública do dia 28 ago. 2008, p. 100. Disponível em: <http://www.stf.jus.br>. Acesso em: 10 jan. 2011.

928 BRASIL. Supremo Tribunal Federal. Arguição de Descumprimento de Preceito Fundamental $\mathrm{n}^{\circ}$ 54-8. Audiência Pública do dia 28 ago. 2008, p. 100. Disponível em: 〈http://www.stf.jus.br〉. Acesso em: 10 jan. 2011. 
Encerrando o segundo dia de audiência, pronunciou-se o Instituto de Bioética, Direitos Humanos e Gênero - ANIS, representado pela antropóloga e professora Débora Diniz. Reforçou a antropóloga o impacto que o diagnóstico de anencefalia provoca na mulher, e equiparou a manutenção desse tipo de gestação à tortura ${ }^{929}$. Tortura pelo fato de a gestante ter que preparar o enterro e não o enxoval do bebê, tortura por esperar nove meses aguardando uma autorização judicial que não será concedida ${ }^{930}$. Para a antropóloga, a convivência com "sofrimento involuntário das mulheres" vem de encontro à democracia ${ }^{931}$.

No terceiro dia de audiência, foram ouvidos o Ministro da Saúde, José Gomes Temporão, a Escola da Gente, a Associação de Desenvolvimento da Família - ADEF, a Rede Nacional Feminista de Saúde, Direitos Sexuais e Direitos Reprodutivos, médicos especialistas e o Conselho Nacional dos Direitos da Mulher.

O Ministro da Saúde defendeu a liberdade de escolha da mulher para a antecipação do parto no caso da anencefalia, em razão do sofrimento de se levar a termo uma gravidez nestas circunstâncias, por não existir dúvidas sobre a incompatibilidade da anecenfalia com a vida extrauterina, e por força do critério de morte adotado hoje em nosso ordenamento, que considera morto o indivíduo sem atividade cerebral ${ }^{932}$, analogicamente comparado ao feto com anencefalia que, por não ter o córtex cerebral, também seria considerado natimorto. ${ }^{933}$

Além disso, esclareceu o Ministro que o Sistema Único de Saúde - SUS realiza um "diagnóstico seguro" 934 , e está equipado com aparelhos adequados para detectar a anencefalia a partir da $12^{\mathrm{a}}$ semana de gestação ${ }^{935}$, com atendimento realizado "por mais de um médico", inclusive com a repetição de exames, caso seja verificada a má-formação ${ }^{936}$. A partir desse diagnóstico, a mulher recebe um acompanhamento médico e jurídico, com informações sobre

929 BRASIL. Supremo Tribunal Federal. Arguição de Descumprimento de Preceito Fundamental $\mathrm{n}^{\circ}$ 54-8. Audiência Pública do dia 28 ago. 2008, p. 104. Disponível em: 〈http://www.stf.jus.br〉. Acesso em: 10 jan. 2011.

930 BRASIL. Supremo Tribunal Federal. Arguição de Descumprimento de Preceito Fundamental $\mathrm{n}^{\circ}$ 54-8. Audiência Pública do dia 28 ago. 2008, p. 105-107. Disponível em: 〈http://www.stf.jus.br>. Acesso em: 10 jan. 2011.

931 BRASIL. Supremo Tribunal Federal. Arguição de Descumprimento de Preceito Fundamental no 54-8. Audiência Pública do dia 28 ago. 2008, p. 110. Disponível em: 〈http://www.stf.jus.br〉. Acesso em: 10 jan. 2011.

932 BRASIL. Supremo Tribunal Federal. Arguição de Descumprimento de Preceito Fundamental $\mathrm{n}^{\circ}$ 54-8. Audiência Pública do dia 04 set. 2008, p. 5. Disponível em: <http://www.stf.jus.br>. Acesso em: 10 jan. 2011.

933 BRASIL. Supremo Tribunal Federal. Arguição de Descumprimento de Preceito Fundamental $\mathrm{n}^{\circ}$ 54-8. Audiência Pública do dia 04 set. 2008, p. 6. Disponível em: <http://www.stf.jus.br>. Acesso em: 10 jan. 2011.

934 BRASIL. Supremo Tribunal Federal. Arguição de Descumprimento de Preceito Fundamental no 54-8. Audiência Pública do dia 04 set. 2008, p. 6. Disponível em: <http://www.stf.jus.br>. Acesso em: 10 jan. 2011.

935 BRASIL. Supremo Tribunal Federal. Arguição de Descumprimento de Preceito Fundamental $\mathrm{n}^{\circ}$ 54-8. Audiência Pública do dia 04 set. 2008, p. 6-7. Disponível em: 〈http://www.stf.jus.br〉. Acesso em: 10 jan. 2011.

936 BRASIL. Supremo Tribunal Federal. Arguição de Descumprimento de Preceito Fundamental no 54-8. Audiência Pública do dia 04 set. 2008, p. 7. Disponível em: <http://www.stf.jus.br>. Acesso em: 10 jan. 2011. 
como prevenir a doença, e sobre como solicitar a interrupção da gravidez judicialmente, caso assim desejar ${ }^{937}$. Afirma, ainda o Ministro, que o estado democrático deve apoiar “a diversidade de escolhas de experiências pautadas no conjunto de possibilidades ou impossibilidades físicas, emocionais, culturais de cada mulher para lidar com a condição acima descrita". ${ }^{938}$ Por fim, para o Ministro da Saúde, a "antecipação do parto" é uma "situação limite", diferentemente do "aborto" "939, e que seria "sustentável" entendê-la como uma antecipação terapêutica no caso de anencefalia ${ }^{940}$.

Cláudia Werneck, jornalista, representando a Escola da Gente, afirmou que o tema não está vinculado à inclusão de pessoas com deficiência, mas a "direitos sexuais e reprodutivos femininos" $" 941$. Favoravelmente ao aborto do feto anencéfalo, entende Werneck que, no caso, não há confusão entre anencefalia e "síndromes genéticas e congênitas, que geram múltiplas malformações consideradas graves", mas que não são incompatíveis com a vida ${ }^{942}$, concluindo que a antecipação do parto do feto anencéfalo não configura "um ato de discriminação com base na deficiência"943 ou eugenia ${ }^{944}$.

Expõe ainda Werneck que a "humanidade" não pode ser medida em razão de "qualquer especificidade", e que os direitos previstos na Convenção Internacional dos Direitos das Pessoas com Deficiência, da ONU, "pressupõe que haja a presença de vida ainda que em forma de expectativa de vida" ${ }^{945}$. Significa dizer, para a jornalista, que é essencial que haja uma relação de um indivíduo com deficiência com o ambiente, exigindo-se, pelo menos, uma "expectativa de vida" para que os direitos e garantias passem a existir" ${ }^{946}$. Ainda segundo

937 BRASIL. Supremo Tribunal Federal. Arguição de Descumprimento de Preceito Fundamental $\mathrm{n}^{\circ}$ 54-8. Audiência Pública do dia 04 set. 2008, p. 7-8. Disponível em: 〈http://www.stf.jus.br〉. Acesso em: 10 jan. 2011. 938 BRASIL. Supremo Tribunal Federal. Arguição de Descumprimento de Preceito Fundamental no 54-8. Audiência Pública do dia 04 set. 2008, p. 9. Disponível em: <http://www.stf.jus.br>. Acesso em: 10 jan. 2011.

939 BRASIL. Supremo Tribunal Federal. Arguição de Descumprimento de Preceito Fundamental $\mathrm{n}^{\circ}$ 54-8. Audiência Pública do dia 04 set. 2008, p. 12. Disponível em: 〈http://www.stf.jus.br〉. Acesso em: 10 jan. 2011.

940 BRASIL. Supremo Tribunal Federal. Arguição de Descumprimento de Preceito Fundamental $\mathrm{n}^{\circ}$ 54-8. Audiência Pública do dia 04 set. 2008, p. 13. Disponível em: 〈http://www.stf.jus.br〉. Acesso em: 10 jan. 2011.

941 BRASIL. Supremo Tribunal Federal. Arguição de Descumprimento de Preceito Fundamental $\mathrm{n}^{\circ}$ 54-8. Audiência Pública do dia 04 set. 2008, p. 20. Disponível em: 〈http://www.stf.jus.br〉. Acesso em: 10 jan. 2011.

942 BRASIL. Supremo Tribunal Federal. Arguição de Descumprimento de Preceito Fundamental $\mathrm{n}^{\circ}$ 54-8. Audiência Pública do dia 04 set. 2008, p. 21. Disponível em: 〈http://www.stf.jus.br〉. Acesso em: 10 jan. 2011.

943 BRASIL. Supremo Tribunal Federal. Arguição de Descumprimento de Preceito Fundamental $\mathrm{n}^{\circ}$ 54-8. Audiência Pública do dia 04 set. 2008, p. 22. Disponível em: 〈http://www.stf.jus.br〉. Acesso em: 10 jan. 2011.

944 BRASIL. Supremo Tribunal Federal. Arguição de Descumprimento de Preceito Fundamental no 54-8. Audiência Pública do dia 04 set. 2008, p. 22. Disponível em: 〈http://www.stf.jus.br〉. Acesso em: 10 jan. 2011.

945 BRASIL. Supremo Tribunal Federal. Arguição de Descumprimento de Preceito Fundamental $\mathrm{n}^{\circ}$ 54-8. Audiência Pública do dia 04 set. 2008, p. 23. Disponível em: 〈http://www.stf.jus.br>. Acesso em: 10 jan. 2011.

946 BRASIL. Supremo Tribunal Federal. Arguição de Descumprimento de Preceito Fundamental no 54-8. Audiência Pública do dia 04 set. 2008, p. 25. Disponível em: 〈http://www.stf.jus.br>. Acesso em: 10 jan. 2011. 
Werneck, não se atribui um “juízo de valor” sobre a vida do feto anencéfalo, pois, neste caso, não haveria vida ${ }^{947}$.

A representante da Associação de Desenvolvimento da Família, ADEF, a médica endocrinologisla Ieda Therezinha do Nascimento Verreschi, ensina que a "perspectiva e a expectativa de vida [do feto anencéfalo] é variável" "948, devido à variação do "desenvolvimento do sistema endócrino fetal" " base do cérebro" "950 (e o feto anencéfalo pode, às vezes, ter desenvolvido a hipófise, o que poderia conferir-lhe uma sobrevida um pouco mais longa ${ }^{951}$ ). Ensina ainda a médica que entre $40 \%$ e $60 \%$ dos fetos com anencefalia nascem vivos, embora apenas $8 \%$ consigam sobreviver por algum tempo, uma vez que estejam desligados da mãe $\mathrm{e}^{952}$.

Afirma ainda Verreschi que o feto normalmente tem papel importante no "sistema de unidade fetoplacentária" "953, participando da "unidade endócrina"954 que forma com a mãe desde a concepção, ou seja, emitindo também hormônios, juntamente com a própria gestante, ao longo da gestação ${ }^{955}$. No entanto, para a médica, essa atividade não se desenvolve plenamente no caso do feto anencéfalo ${ }^{956}$ porque ele "não libera os precursores hormonais",957,

947 BRASIL. Supremo Tribunal Federal. Arguição de Descumprimento de Preceito Fundamental $\mathrm{n}^{\circ}$ 54-8. Audiência Pública do dia 04 set. 2008, p. 25-26. Disponível em: 〈http://www.stf.jus.br>. Acesso em: 10 jan. 2011.

948 BRASIL. Supremo Tribunal Federal. Arguição de Descumprimento de Preceito Fundamental $\mathrm{n}^{\circ}$ 54-8. Audiência Pública do dia 04 set. 2008, p. 35-36. Disponível em: 〈http://www.stf.jus.br>. Acesso em: 10 jan. 2011.

949 BRASIL. Supremo Tribunal Federal. Arguição de Descumprimento de Preceito Fundamental $\mathrm{n}^{\circ}$ 54-8. Audiência Pública do dia 04 set. 2008, p. 36. Disponível em: 〈http://www.stf.jus.br〉. Acesso em: 10 jan. 2011.

950 BRASIL. Supremo Tribunal Federal. Arguição de Descumprimento de Preceito Fundamental $\mathrm{n}^{\circ}$ 54-8. Audiência Pública do dia 04 set. 2008, p. 36. Disponível em: 〈http://www.stf.jus.br〉. Acesso em: 10 jan. 2011.

951 BRASIL. Supremo Tribunal Federal. Arguição de Descumprimento de Preceito Fundamental $\mathrm{n}^{\circ}$ 54-8. Audiência Pública do dia 04 set. 2008, p. 44. Disponível em: 〈http://www.stf.jus.br〉. Acesso em: 10 jan. 2011. "hipófise é um órgão que tem dupla origem: uma no sistema nervoso central e outra no sistema digestivo; um desce em direção à porção caudal do embrião e o outro sobe na porção cefálica. Esse é um conjunto em que, nos casos de anencefalia, pode-se detectar um desenvolvimento prejudicado. Então, às vezes tem um pouco mais de neuro-hipófise, às vezes tem um pouco mais de adenoipófise, e isso é um comprometimento da hipófise". BRASIL. Supremo Tribunal Federal. Arguição de Descumprimento de Preceito Fundamental no 54-8. Audiência Pública do dia 04 set. 2008, p. 43-44. Disponível em: <http://www.stf.jus.br>. Acesso em: 10 jan. 2011.

952 BRASIL. Supremo Tribunal Federal. Arguição de Descumprimento de Preceito Fundamental $\mathrm{n}^{\circ}$ 54-8. Audiência Pública do dia 04 set. 2008, p. 36. Disponível em: 〈http://www.stf.jus.br〉. Acesso em: 10 jan. 2011.

953 BRASIL. Supremo Tribunal Federal. Arguição de Descumprimento de Preceito Fundamental $\mathrm{n}^{\circ}$ 54-8. Audiência Pública do dia 04 set. 2008, p. 37. Disponível em: 〈http://www.stf.jus.br〉. Acesso em: 10 jan. 2011.

954 BRASIL. Supremo Tribunal Federal. Arguição de Descumprimento de Preceito Fundamental $\mathrm{n}^{\circ}$ 54-8. Audiência Pública do dia 04 set. 2008, p. 37. Disponível em: 〈http://www.stf.jus.br〉. Acesso em: 10 jan. 2011.

955 BRASIL. Supremo Tribunal Federal. Arguição de Descumprimento de Preceito Fundamental $n^{\circ}$ 54-8. Audiência Pública do dia 04 set. 2008, p. 37. Disponível em: 〈http://www.stf.jus.br〉. Acesso em: 10 jan. 2011.

956 BRASIL. Supremo Tribunal Federal. Arguição de Descumprimento de Preceito Fundamental $\mathrm{n}^{\circ}$ 54-8. Audiência Pública do dia 04 set. 2008, p. 37. Disponível em: 〈http://www.stf.jus.br〉. Acesso em: 10 jan. 2011.

957 BRASIL. Supremo Tribunal Federal. Arguição de Descumprimento de Preceito Fundamental $\mathrm{n}^{\circ}$ 54-8. Audiência Pública do dia 04 set. 2008, p. 37. Disponível em: 〈http://www.stf.jus.br〉. Acesso em: 10 jan. 2011. 
o que o diferencia de um ponto de vista endocrinológico de um feto normalmente desenvolvido desde o início da gestação.

A médica menciona também que há relação entre anencefalia e o "controle ambiental do uso de pesticidas" ${ }^{958}$, pois "organoclorados [que são frequentemente usados em pesticidas] dobram as chances de anencefalia" 959 .

Em seguida foi ouvida a Rede Nacional Feminista de Saúde, Direitos Sexuais e Direitos Reprodutivos, representada pela antropóloga Lia Zanotta Machado, que trouxe relatos de mulheres que passaram pela experiência de gestar um feto anencéfalo ${ }^{960}$. Para a antropóloga, as gestantes não são "depósitos"961, e não se pode obrigá-las a levar a termo tal gravidez.

Posteriormente, mais alguns especialistas foram ouvidos. A primeira deste novo grupo de especialistas ouvidos foi a médica especializada em neurologia pediátrica, Cinthia Macedo Specian, que ensinou que o tubo neural deve formar-se integralmente até o $28^{\circ}$ dia após a concepção ${ }^{962}$. No entanto, se isso não ocorrer, haverá uma falha no fechamento do tubo neural, o que pode acarretar inúmeras más-formações, inclusive a anencefalia. Para a neurologista, a anencefalia é a falha nos "segmentos cefálicos na sua porção anterior" com o desenvolvimento parcial, ou sem desenvolvimento algum, da calota craniana ${ }^{963}$, ocasionando inúmeros defeitos e degenerações na massa nervosa a partir do $24^{\circ}$ dia contado da concepção ${ }^{964}$. Para a médica, a partir da $14^{\text {a }}$ semana de gestação, é possível concluir o diagnóstico da anencefalia ${ }^{965}$.

\footnotetext{
958 BRASIL. Supremo Tribunal Federal. Arguição de Descumprimento de Preceito Fundamental $\mathrm{n}^{\circ}$ 54-8. Audiência Pública do dia 04 set. 2008, p. 38. Disponível em: 〈http://www.stf.jus.br〉. Acesso em: 10 jan. 2011. 959 BRASIL. Supremo Tribunal Federal. Arguição de Descumprimento de Preceito Fundamental no ${ }^{\circ}$ 54-8. Audiência Pública do dia 04 set. 2008, p. 38. Disponível em: 〈http://www.stf.jus.br〉. Acesso em: 10 jan. 2011. Já que para a médica podem ser considerados "desreguladores endócrinos" podendo prejudicar o desenvolvimento correto de certas glândulas. BRASIL. Supremo Tribunal Federal. Arguição de Descumprimento de Preceito Fundamental no 54-8. Audiência Pública do dia 04 set. 2008, p. 45. Disponível em: <http://www.stf.jus.br>. Acesso em: 10 jan. 2011.

960 BRASIL. Supremo Tribunal Federal. Arguição de Descumprimento de Preceito Fundamental $\mathrm{n}^{\circ}$ 54-8. Audiência Pública do dia 04 set. 2008, p. 51-52. Disponível em: <http://www.stf.jus.br>. Acesso em: 10 jan. 2011.

${ }^{961}$ BRASIL. Supremo Tribunal Federal. Arguição de Descumprimento de Preceito Fundamental $\mathrm{n}^{\circ}$ 54-8. Audiência Pública do dia 04 set. 2008, p. 54. Disponível em: 〈http://www.stf.jus.br〉. Acesso em: 10 jan. 2011.

962 BRASIL. Supremo Tribunal Federal. Arguição de Descumprimento de Preceito Fundamental $\mathrm{n}^{\circ}$ 54-8. Audiência Pública do dia 04 set. 2008, p. 72. Disponível em: <http://www.stf.jus.br〉. Acesso em: 10 jan. 2011.

963 BRASIL. Supremo Tribunal Federal. Arguição de Descumprimento de Preceito Fundamental $\mathrm{n}^{\circ}$ 54-8. Audiência Pública do dia 04 set. 2008, p. 72-73. Disponível em: <http://www.stf.jus.br>. Acesso em: 10 jan. 2011.

964 BRASIL. Supremo Tribunal Federal. Arguição de Descumprimento de Preceito Fundamental $\mathrm{n}^{\circ}$ 54-8. Audiência Pública do dia 04 set. 2008, p. 73. Disponível em: <http://www.stf.jus.br>. Acesso em: 10 jan. 2011.

965 BRASIL. Supremo Tribunal Federal. Arguição de Descumprimento de Preceito Fundamental $\mathrm{n}^{\circ}$ 54-8. Audiência Pública do dia 04 set. 2008, p. 73. Disponível em: 〈http://www.stf.jus.br〉. Acesso em: 10 jan. 2011.
} 
Esclareceu, ainda, a médica, que, para se declarar uma morte encefálica, é necessário que tenha havido uma sobrevida mínima superior a 7 dias, para que se possa identificar alguma "atividade elétrica" cerebral e seu desaparecimento. Por essa razão, não seria possível aplicar esse conceito de morte ao anencéfalo ${ }^{966}$. Em vista desta dificuldade, o exame de ultrassonagrafia e o teste de dosagem da alfa fetoproteína são indicados para auxiliar no diagnóstico de anencefalia ${ }^{967}$.

Afirmou por fim a doutora que, mesmo depois de se diagnosticar a anencefalia, seria ainda possível ocorrer um desenvolvimento de "massa rudimentar" cerebral no feto, muito embora jamais essa massa tornar-se-á um "cérebro perfeito" 968 , em relação ao que lembrounos ainda a médica que a "neurulação" no ser humano em geral segue até o início da vida adulta $^{969}$.

O segundo especialista foi o médico ginecologista Dernival da Silva Brandão, que afirmou que, na anencefalia, a abóbora craniana não existe ou existe apenas parcialmente, e "a massa encefálica [é] reduzida", admitindo-se uma gradação de seu desenvolvimento ${ }^{970}$. Segundo Brandão, a gravidez de um feto anencéfalo não traria mais riscos que uma gravidez de gêmeos. Não concorda o médico que caberia a antecipação de parto no caso do feto anencéfalo $^{971}$, pois, para ele, permitir-se o aborto terapêutico seria o início da prática da eugenia ${ }^{972}$. Por fim, para o médico, uma autorização nesse sentido influenciaria a escolha das mulheres para o aborto ${ }^{973}$.

Por fim, foi ouvida Jacqueline Pitanguy, socióloga e cientista política, representando o Conselho Nacional dos Direitos da Mulher. Argumentou a socióloga que o "conceito de vida está intimamente ligado às funções cerebrais que nos tornam seres humanos capazes de

966 BRASIL. Supremo Tribunal Federal. Arguição de Descumprimento de Preceito Fundamental no 54-8. Audiência Pública do dia 04 set. 2008, p. 75-76. Disponível em: 〈http://www.stf.jus.br>. Acesso em: 10 jan. 2011.

967 BRASIL. Supremo Tribunal Federal. Arguição de Descumprimento de Preceito Fundamental $\mathrm{n}^{\circ}$ 54-8. Audiência Pública do dia 04 set. 2008, p. 76. Disponível em: 〈http://www.stf.jus.br〉. Acesso em: 10 jan. 2011.

968 BRASIL. Supremo Tribunal Federal. Arguição de Descumprimento de Preceito Fundamental $\mathrm{n}^{\circ}$ 54-8. Audiência Pública do dia 04 set. 2008, p. 77. Disponível em: 〈http://www.stf.jus.br〉. Acesso em: 10 jan. 2011.

969 BRASIL. Supremo Tribunal Federal. Arguição de Descumprimento de Preceito Fundamental $\mathrm{n}^{\circ}$ 54-8. Audiência Pública do dia 04 set. 2008, p. 77-78. Disponível em: 〈http://www.stf.jus.br>. Acesso em: 10 jan. 2011.

970 BRASIL. Supremo Tribunal Federal. Arguição de Descumprimento de Preceito Fundamental $\mathrm{n}^{\circ}$ 54-8. Audiência Pública do dia 04 set. 2008, p. 82. Disponível em: 〈http://www.stf.jus.br〉. Acesso em: 10 jan. 2011.

971 BRASIL. Supremo Tribunal Federal. Arguição de Descumprimento de Preceito Fundamental $\mathrm{n}^{\circ}$ 54-8. Audiência Pública do dia 04 set. 2008, p. 85. Disponível em: 〈http://www.stf.jus.br〉. Acesso em: 10 jan. 2011.

972 BRASIL. Supremo Tribunal Federal. Arguição de Descumprimento de Preceito Fundamental $\mathrm{n}^{\circ}$ 54-8. Audiência Pública do dia 04 set. 2008, p. 85-86. Disponível em: 〈http://www.stf.jus.br>. Acesso em: 10 jan. 2011.

973 BRASIL. Supremo Tribunal Federal. Arguição de Descumprimento de Preceito Fundamental no 54-8. Audiência Pública do dia 04 set. 2008, p. 91. Disponível em: 〈http://www.stf.jus.br>. Acesso em: 10 jan. 2011. 
pensar, sentir, interpretar de diversas formas o mundo, sonhar, relacionar-se" ${ }^{, 974}$, e que "ausência de cérebro seria, assim, compreendida como ausência de vida"975. Defende ela o direito de a mulher decidir dar continuidade ou não à gestação ${ }^{976}$, pois a escolha se trataria de uma questão de "ética privada" 977.

No quarto dia de audiência, manifestaram-se a médica Elizabeth Kipman Cerqueira, o Conectas Direitos Humanos e Centro de Direitos Humanos, a Secretaria da Presidência da República, e a Associação Brasileira de Psiquiatria.

A ginecologista Elizabeth Kipman Cerqueira explicou que a doação de órgãos do feto anencéfalo foi proibida porque estaria provado que não seria possível declarar-se a "morte encefálica"978 do feto dentro ou fora do útero, quando há, por exemplo, "respiração espontânea"979, pois "esses sinais são de atividade cerebral"980. Ademais, acrescentou Cerqueira que o tecido nervoso continuaria progredindo, "mesmo no feto anencefálico"981. Para ela, o feto tem "curtíssimo tempo de vida, mas está vivo"982. A médica também discutiu o risco ${ }^{983}$ de uma antecipação do parto com a necessidade de internação de 3 a 11 dias devido ao uso de "ocitócicos, que provocam a contração" "984, "à ruptura uterina e à infecção"985, além dos riscos de um parto cesariano ${ }^{986}$. Os problemas decorrentes da manutenção da gravidez, por outro lado, para a ginecologista, são tratáveis e "100\% resolvidos pós-resolução

974 BRASIL. Supremo Tribunal Federal. Arguição de Descumprimento de Preceito Fundamental $n^{\circ}$ 54-8. Audiência Pública do dia 04 set. 2008, p. 96. Disponível em: 〈http://www.stf.jus.br〉. Acesso em: 10 jan. 2011.

975 BRASIL. Supremo Tribunal Federal. Arguição de Descumprimento de Preceito Fundamental $\mathrm{n}^{\circ}$ 54-8. Audiência Pública do dia 04 set. 2008, p. 96. Disponível em: 〈http://www.stf.jus.br〉. Acesso em: 10 jan. 2011.

976 BRASIL. Supremo Tribunal Federal. Arguição de Descumprimento de Preceito Fundamental $\mathrm{n}^{\circ}$ 54-8. Audiência Pública do dia 04 set. 2008, p. 97-98. Disponível em: 〈http://www.stf.jus.br>. Acesso em: 10 jan. 2011.

977 BRASIL. Supremo Tribunal Federal. Arguição de Descumprimento de Preceito Fundamental $\mathrm{n}^{\circ}$ 54-8. Audiência Pública do dia 04 set. 2008, p. 98. Disponível em: 〈http://www.stf.jus.br〉. Acesso em: 10 jan. 2011.

978 BRASIL. Supremo Tribunal Federal. Arguição de Descumprimento de Preceito Fundamental $\mathrm{n}^{\circ}$ 54-8. Audiência Pública do dia 14 set. 2008, p. 3. Disponível em: <http://www.stf.jus.br>. Acesso em: 10 jan. 2011.

979 BRASIL. Supremo Tribunal Federal. Arguição de Descumprimento de Preceito Fundamental $\mathrm{n}^{\circ}$ 54-8. Audiência Pública do dia 14 set. 2008, p. 3. Disponível em: <http://www.stf.jus.br>. Acesso em: 10 jan. 2011.

980 BRASIL. Supremo Tribunal Federal. Arguição de Descumprimento de Preceito Fundamental $\mathrm{n}^{\circ}$ 54-8. Audiência Pública do dia 14 set. 2008, p. 3. Disponível em: <http://www.stf.jus.br>. Acesso em: 10 jan. 2011.

${ }^{981}$ Por isso para a médica não houve erro no diagnóstico no Caso Marcela. BRASIL. Supremo Tribunal Federal. Arguição de Descumprimento de Preceito Fundamental no 54-8. Audiência Pública do dia 14 set. 2008 , p. 4. Disponível em: <http://www.stf.jus.br>. Acesso em: 10 jan. 2011.

982 BRASIL. Supremo Tribunal Federal. Arguição de Descumprimento de Preceito Fundamental $\mathrm{n}^{\circ}$ 54-8. Audiência Pública do dia 14 set. 2008, p. 5. Disponível em: <http://www.stf.jus.br>. Acesso em: 10 jan. 2011.

983 BRASIL. Supremo Tribunal Federal. Arguição de Descumprimento de Preceito Fundamental $\mathrm{n}^{\circ}$ 54-8. Audiência Pública do dia 14 set. 2008, p. 6. Disponível em: <http://www.stf.jus.br>. Acesso em: 10 jan. 2011.

984 BRASIL. Supremo Tribunal Federal. Arguição de Descumprimento de Preceito Fundamental no 54-8. Audiência Pública do dia 14 set. 2008, p. 6. Disponível em: <http://www.stf.jus.br>. Acesso em: 10 jan. 2011.

985 BRASIL. Supremo Tribunal Federal. Arguição de Descumprimento de Preceito Fundamental $\mathrm{n}^{\circ}$ 54-8. Audiência Pública do dia 14 set. 2008, p. 6. Disponível em: <http://www.stf.jus.br>. Acesso em: 10 jan. 2011.

986 BRASIL. Supremo Tribunal Federal. Arguição de Descumprimento de Preceito Fundamental no 54-8. Audiência Pública do dia 14 set. 2008, p. 6. Disponível em: <http://www.stf.jus.br>. Acesso em: 10 jan. 2011. 
espontânea"987. Esclarece, ainda, que a depressão da gestante surge em decorrência de se encarar a realidade, o que pode ocorrer também, inclusive, no caso de a gestante realizar o aborto $^{988}$. A ginecologista entende que se o estado liberar a realização do aborto, a primeira reação da mulher diante de uma gravidez indesejada será a de concretizá-lo ${ }^{989}$. Em razão disso, o estado seria responsável "por dar oportunidade à mulher de pensar assim" esta observação, no contexto em que foi feita, Cerqueira parece acreditar que o estado seria um bom árbitro para decidir sobre o que ou como a população estaria autorizada a pensar.

A socióloga Eleonora Menecucci de Oliveira representou a Conectas Direitos Humanos e Centro de Direitos Humanos, e ressaltou que todas as mulheres devem ter direito à saúde, com qualidade e equidade ${ }^{991}$, e também direito de informação, para que possam autonomamente decidir sobre sua vida ${ }^{992}$. A legislação atual, na visão da socióloga, impõe uma decisão às mulheres, a de não abortar, mesmo em vista dos riscos e danos relacionados a uma gestação de feto acometido por anencefalia. Se desejarem outra opção, as gestantes precisam buscar uma autorização, cujo trâmite, é muito desgastante ${ }^{993}$. Oliveira nos lembra que o tempo é um fator importante a se levar em consideração: é possível o diagnóstico com doze semanas de gestação, momento em que "não há ainda alterações gravídicas evidentes, a mulher não sente movimentação fetal e o vínculo mãe e feto ainda é incipiente" ${ }^{994}$. Para ela, a violação do direito reprodutivo consiste na impossibilidade "do exercício da escolha de interromper a gravidez"995, fato esse que gera um "grave problema de saúde pública, pois, quando as mulheres não encontram respaldo legal para interromper a gravidez, passam a

987 BRASIL. Supremo Tribunal Federal. Arguição de Descumprimento de Preceito Fundamental $\mathrm{n}^{\circ}$ 54-8. Audiência Pública do dia 14 set. 2008, p. 6. Disponível em: 〈http://www.stf.jus.br〉. Acesso em: 10 jan. 2011. Para a médica, o aborto provoca outras doenças, inclusive está ligado câncer de mama. BRASIL. Supremo Tribunal Federal. Arguição de Descumprimento de Preceito Fundamental no 54-8. Audiência Pública do dia 14 set. 2008, p. 7. Disponível em: 〈http://www.stf.jus.br>. Acesso em: 10 jan. 2011.

988 BRASIL. Supremo Tribunal Federal. Arguição de Descumprimento de Preceito Fundamental no $54-8$. Audiência Pública do dia 14 set. 2008, p. 8. Disponível em: <http://www.stf.jus.br>. Acesso em: 10 jan. 2011.

989 BRASIL. Supremo Tribunal Federal. Arguição de Descumprimento de Preceito Fundamental $\mathrm{n}^{\circ}$ 54-8. Audiência Pública do dia 14 set. 2008, p. 20. Disponível em: 〈http://www.stf.jus.br〉. Acesso em: 10 jan. 2011.

990 BRASIL. Supremo Tribunal Federal. Arguição de Descumprimento de Preceito Fundamental $\mathrm{n}^{\circ}$ 54-8. Audiência Pública do dia 14 set. 2008, p. 20. Disponível em: 〈http://www.stf.jus.br〉. Acesso em: 10 jan. 2011.

991 BRASIL. Supremo Tribunal Federal. Arguição de Descumprimento de Preceito Fundamental $\mathrm{n}^{\circ}$ 54-8. Audiência Pública do dia 14 set. 2008, p. 24. Disponível em: <http://www.stf.jus.br〉. Acesso em: 10 jan. 2011.

992 BRASIL. Supremo Tribunal Federal. Arguição de Descumprimento de Preceito Fundamental $\mathrm{n}^{\circ}$ 54-8. Audiência Pública do dia 14 set. 2008, p. 25. Disponível em: 〈http://www.stf.jus.br〉. Acesso em: 10 jan. 2011.

993 BRASIL. Supremo Tribunal Federal. Arguição de Descumprimento de Preceito Fundamental no 54-8. Audiência Pública do dia 14 set. 2008, p. 26. Disponível em: 〈http://www.stf.jus.br〉. Acesso em: 10 jan. 2011.

994 BRASIL. Supremo Tribunal Federal. Arguição de Descumprimento de Preceito Fundamental $n^{\circ}$ 54-8. Audiência Pública do dia 14 set. 2008, p. 27. Disponível em: 〈http://www.stf.jus.br〉. Acesso em: 10 jan. 2011.

995 BRASIL. Supremo Tribunal Federal. Arguição de Descumprimento de Preceito Fundamental no 54-8. Audiência Pública do dia 14 set. 2008, p. 30. Disponível em: <http://www.stf.jus.br>. Acesso em: 10 jan. 2011. 
procurar serviços clandestinos, geralmente inseguros"996. Para ela, não é possível que se atenda apenas ao desejo de uma parte das mulheres - as que não desejam antecipar a gravidez. É necessário que a lei garanta o direito de todas as mulheres poderem escolher o que parecer melhor a cada uma delas ${ }^{997}$.

Em seguida, foi ouvida a Secretaria Especial de Políticas para as Mulheres da Presidência da República, na pessoa da médica Nilcéa Freire. Ela esclareceu que, desde 2004, o Conselho Nacional dos Direitos da Mulher pronunciou-se favoravelmente à interrupção da gravidez de um feto anencéfalo ${ }^{998}$. Seria um "direito de escolha informado, mas que não está sujeito à tutela"999. Para ela, o estado teria condições de realizar a antecipação do parto ${ }^{1000}$, o que não se dá plenamente hoje em decorrência dos limites legais, que precisariam ser $\operatorname{alterados}^{1001}$.

Depois, foi ouvido o médico psiquiatra Talvane Marins de Moraes, representando a Associação Brasileira de Psiquiatria. Para o médico, a saúde “é um bem-estar Biopsicossocial" ligado à qualidade de vida ${ }^{1002}$. Ensina o psiquiatra que a a alegria e a tristeza são normais no homem, pois correspondem a "uma variação de humor" ${ }^{1003}$; o luto seria um exemplo $^{1004}$. Para Moraes, a depressão é um estado anormal ${ }^{1005}$, que exige tratamento com remédios ${ }^{1006}$. Destaca que, nesses casos, a gravidez não é indesejada, mas a antecipação do parto ocorre em razão da inviabilidade do feto ${ }^{1007}$. Para o psiquiatra, impor a manutenção da

996 BRASIL. Supremo Tribunal Federal. Arguição de Descumprimento de Preceito Fundamental no $54-8$. Audiência Pública do dia 14 set. 2008, p. 31. Disponível em: 〈http://www.stf.jus.br〉. Acesso em: 10 jan. 2011.

997 BRASIL. Supremo Tribunal Federal. Arguição de Descumprimento de Preceito Fundamental $\mathrm{n}^{\circ}$ 54-8. Audiência Pública do dia 14 set. 2008, p. 33. Disponível em: 〈http://www.stf.jus.br〉. Acesso em: 10 jan. 2011.

998 BRASIL. Supremo Tribunal Federal. Arguição de Descumprimento de Preceito Fundamental $\mathrm{n}^{\circ}$ 54-8. Audiência Pública do dia 14 set. 2008, p. 38. Disponível em: 〈http://www.stf.jus.br〉. Acesso em: 10 jan. 2011.

999 BRASIL. Supremo Tribunal Federal. Arguição de Descumprimento de Preceito Fundamental $\mathrm{n}^{\circ}$ 54-8. Audiência Pública do dia 14 set. 2008, p. 38. Disponível em: 〈http://www.stf.jus.br〉. Acesso em: 10 jan. 2011.

1000 BRASIL. Supremo Tribunal Federal. Arguição de Descumprimento de Preceito Fundamental $\mathrm{n}^{\circ}$ 54-8. Audiência Pública do dia 14 set. 2008, p. 47. Disponível em: 〈http://www.stf.jus.br>. Acesso em: 10 jan. 2011.

1001 BRASIL. Supremo Tribunal Federal. Arguição de Descumprimento de Preceito Fundamental $\mathrm{n}^{\circ}$ 54-8. Audiência Pública do dia 14 set. 2008, p. 48. Disponível em: 〈http://www.stf.jus.br>. Acesso em: 10 jan. 2011.

1002 BRASIL. Supremo Tribunal Federal. Arguição de Descumprimento de Preceito Fundamental $\mathrm{n}^{\circ}$ 54-8. Audiência Pública do dia 14 set. 2008, p. 50. Disponível em: 〈http://www.stf.jus.br〉. Acesso em: 10 jan. 2011.

1003 BRASIL. Supremo Tribunal Federal. Arguição de Descumprimento de Preceito Fundamental $\mathrm{n}^{\circ}$ 54-8. Audiência Pública do dia 14 set. 2008, p. 51. Disponível em: 〈http://www.stf.jus.br〉. Acesso em: 10 jan. 2011.

1004 BRASIL. Supremo Tribunal Federal. Arguição de Descumprimento de Preceito Fundamental $\mathrm{n}^{\circ}$ 54-8. Audiência Pública do dia 14 set. 2008, p. 52. Disponível em: 〈http://www.stf.jus.br〉. Acesso em: 10 jan. 2011.

1005 BRASIL. Supremo Tribunal Federal. Arguição de Descumprimento de Preceito Fundamental $n^{\circ}$ 54-8. Audiência Pública do dia 14 set. 2008, p. 51-52. Disponível em: 〈http://www.stf.jus.br>. Acesso em: 10 jan. 2011.

1006 BRASIL. Supremo Tribunal Federal. Arguição de Descumprimento de Preceito Fundamental no 54-8. Audiência Pública do dia 14 set. 2008, p. 52. Disponível em: <http://www.stf.jus.br>. Acesso em: 10 jan. 2011.

1007 BRASIL. Supremo Tribunal Federal. Arguição de Descumprimento de Preceito Fundamental $\mathrm{n}^{\circ}$ 54-8. Audiência Pública do dia 14 set. 2008, p. 53-54. Disponível em: <http://www.stf.jus.br>. Acesso em: 10 jan. 2011. Para o médico a nomenclatura correta seria "antecipação terapêutica do parto", vez tratar-se de natimorto. 
gravidez pode ser equiparado à tortura ${ }^{1008}$, sendo capaz de "desencadear um quadro psiquiátrico grave" ${ }^{1009}$, de depressão, "de transtorno de estresse pós-traumático e até mesmo um quadro grave de tentativa de suicídio" $" 1010$. Por fim, acrescenta que é possível fazer um eletroencefalograma do feto como mais uma forma de se diagnosticar a anencefalia ${ }^{1011}$.

\subsection{ALEGAÇÕES FINAIS DO MINISTÉRIO PÚBLICO FEDERAL, DA ADVOCACIA- GERAL DA UNIÃO E DO ARGUENTE}

Comentaremos, a seguir, as alegações finais do Ministério Público Federal, da Advocacia-Geral da União e do Arguente na ADPF, que precederam o julgamento da ação pelo Supremo Tribunal Federal.

Passamos, pois a destacar os argumentos apresentados nas alegações finais por parte da Procuradora Geral da República, Deborah Macedo Duprat de Britto Pereira, que pleiteou, nesse momento, o deferimento da ação, fundamentando-se basicamente nos debates realizados nas audiências públicas, modificando posição anteriormente defendida pelo exProcurador-Geral da República, Claudio Fonteles.

Destacou a Procuradora Geral a impossibilidade absoluta de vida extrauterina do feto anencéfalo - que normalmente falece ainda no útero, ou que tem uma sobrevida vegetativa que geralmente se extingue poucos minutos ou horas após o parto ${ }^{1012}$.

Além disso, fundamentou a Procuradora Geral a possibilidade de aborto na “impossibilidade real de transplantes de órgãos de fetos anencéfalos para terceiros" ${ }^{1013}$, vez que normalmente existem outras más-formações associadas à anencefalia, além de os órgãos

BRASIL. Supremo Tribunal Federal. Arguição de Descumprimento de Preceito Fundamental no 54-8. Audiência Pública do dia 14 set. 2008, p. 61. Disponível em: <http://www.stf.jus.br〉. Acesso em: 10 jan. 2011.

1008 BRASIL. Supremo Tribunal Federal. Arguição de Descumprimento de Preceito Fundamental $\mathrm{n}^{\circ}$ 54-8. Audiência Pública do dia 14 set. 2008, p. 63. Disponível em: 〈http://www.stf.jus.br〉. Acesso em: 10 jan. 2011.

1009 BRASIL. Supremo Tribunal Federal. Arguição de Descumprimento de Preceito Fundamental $\mathrm{n}^{\circ}$ 54-8. Audiência Pública do dia 14 set. 2008, p. 63. Disponível em: 〈http://www.stf.jus.br〉. Acesso em: 10 jan. 2011.

1010 BRASIL. Supremo Tribunal Federal. Arguição de Descumprimento de Preceito Fundamental $\mathrm{n}^{\circ}$ 54-8. Audiência Pública do dia 14 set. 2008, p. 63. Disponível em: 〈http://www.stf.jus.br〉. Acesso em: 10 jan. 2011.

1011 BRASIL. Supremo Tribunal Federal. Arguição de Descumprimento de Preceito Fundamental $\mathrm{n}^{\circ}$ 54-8. Audiência Pública do dia 14 set. 2008, p. 65. Disponível em: 〈http://www.stf.jus.br〉. Acesso em: 10 jan. 2011.

1012 BRASIL. Supremo Tribunal Federal. Arguição de Descumprimento de Preceito Fundamental $\mathrm{n}^{\circ}$ 54-8. Alegações Finais Ministério Público Federal, p.4, item 20. Disponível em: 〈http://www.stf.jus.br〉. Acesso em: 10 jan. 2011.

1013 BRASIL. Supremo Tribunal Federal. Arguição de Descumprimento de Preceito Fundamental $\mathrm{n}^{\circ}$ 54-8. Alegações Finais Ministério Público Federal, p. 5, ítens 22-23. Disponível em: 〈http://www.stf.jus.br>. Acesso em: 10 jan. 2011. 
de anencéfalos serem menores do que os normais ${ }^{1014}$. Ademais, os órgãos só poderiam ser transplantados a outro recém-nascido a partir do $7^{\circ}$ dia e inexiste na experiência médica brasileira qualquer caso de transplante nessas condições ${ }^{1015}$.

Duprat de Britto Pereira fundamentou também sua argumentação no fato de existir risco de vida e saúde à gestante, além de "abalos" de natureza psíquica ${ }^{1016}$ por ela sofridos em decorrência de uma tal gravidez. Alertou ainda a Procuradora Geral da República que os fundamentos válidos que devem ser suscitados são os de natureza jurídica, ética e científica, diante de o estado ser laico e pluralista ${ }^{1017}$. Lembrou, ainda que, no momento em que o Código Penal brasileiro foi escrito, não havia avanço científico capaz de diagnosticar a possibilidade de vida extrauterina ${ }^{1018}$, e que tal diploma também não adotou um caráter absoluto ao direito à vida ${ }^{1019}$.

Para a Procuradora Geral da República, seria possível seguir por duas direções e ainda assim decidir pela interrupção voluntária da gestação no caso de feto anencéfalo: i) vedação constitucional para tipificar uma conduta garantida como direito fundamental; e ii) atipicidade da conduta ${ }^{1020}$.

No primeiro caso, vale a necessidade de se respeitar a autodeterminação da mulher como verdadeiro reconhecimento do princípio da dignidade da pessoa humana, com liberdade de agir conforme sua vontade ${ }^{1021}$. Justifica-se, portanto, o aborto do anencéfalo no direito à

1014 BRASIL. Supremo Tribunal Federal. Arguição de Descumprimento de Preceito Fundamental $\mathrm{n}^{\circ}$ 54-8. Alegações Finais Ministério Público Federal, p. 5, ítens 22-23. Disponível em: 〈http://www.stf.jus.br>. Acesso em: 10 jan. 2011.

1015 BRASIL. Supremo Tribunal Federal. Arguição de Descumprimento de Preceito Fundamental $\mathrm{n}^{\circ}$ 54-8. Alegações Finais Ministério Público Federal, p. 5, item 24. Disponível em: 〈http://www.stf.jus.br>. Acesso em: 10 jan. 2011.

1016 BRASIL. Supremo Tribunal Federal. Arguição de Descumprimento de Preceito Fundamental no 54-8. Alegações Finais Ministério Público Federal, p. 5, item 25. Disponível em: 〈http://www.stf.jus.br>. Acesso em: 10 jan. 2011.

1017 BRASIL. Supremo Tribunal Federal. Arguição de Descumprimento de Preceito Fundamental $\mathrm{n}^{\circ}$ 54-8. Alegações Finais Ministério Público Federal, p. 5, item 26. Disponível em: 〈http://www.stf.jus.br>. Acesso em: 10 jan. 2011.

1018 BRASIL. Supremo Tribunal Federal. Arguição de Descumprimento de Preceito Fundamental $\mathrm{n}^{\circ}$ 54-8. Alegações Finais Ministério Público Federal, p. 6, ítens 29-30. Disponível em: 〈http://www.stf.jus.br>. Acesso em: 10 jan. 2011.

1019 BRASIL. Supremo Tribunal Federal. Arguição de Descumprimento de Preceito Fundamental $\mathrm{n}^{\circ}$ 54-8. Alegações Finais Ministério Público Federal, p. 6, item 31. Disponível em: 〈http://www.stf.jus.br>. Acesso em: 10 jan. 2011.

1020 BRASIL. Supremo Tribunal Federal. Arguição de Descumprimento de Preceito Fundamental $n^{\circ}$ 54-8. Alegações Finais Ministério Público Federal, p. 6, item 45. Disponível em: 〈http://www.stf.jus.br>. Acesso em: 10 jan. 2011.

1021 BRASIL. Supremo Tribunal Federal. Arguição de Descumprimento de Preceito Fundamental no 54-8. Alegações Finais Ministério Público Federal, p. 7, item 34. Disponível em: 〈http://www.stf.jus.br>. Acesso em: 10 jan. 2011. 
privacidade que abarcaria a autonomia reprodutiva, como fundamento constitucional ${ }^{1022}$, o que segue a linha do voto do Relator Ministro Joaquim Barbosa, proferido no Habeas Corpus $84.025 / 6 \mathrm{RJ}^{1023}$. Tal direito constituiria verdadeiro reconhecimento do princípio da dignidade da pessoa humana ${ }^{1024}$, afirmando ser uma "instrumentalização da mulher" 1025 a violação de seus direitos básicos ${ }^{1026}$.

Admitiu, ainda, Duprat de Britto Pereira, que "em nome de ideias religiosas ou morais"1027 é possível que decisões de se levar a termo a gravidez de um feto anencefálico sejam respeitadas individualmente, no campo da vida privada e consciência individual de cada um $^{1028}$, “mas não devem lastrear restrições heterônomas à liberdade alheia, num Estado que se pretenda Democrático de Direito" ${ }^{1029}$.

Afirmou ainda a Procuradora que a manutenção da gravidez do anencéfalo é equiparada à tortura ${ }^{1030}$, acarretando a violação da saúde física e psíquica da mulher se houver um tal prolongamento dispensável de sua angústia e sofrimento ${ }^{1031}$.

Abordou, ainda, Duprat de Britto Pereira, que a proteção progressiva do feto durante a gestação ${ }^{1032}$ não pode ser aplicada ao caso da anencefalia diante da inexistência de vida

1022 BRASIL. Supremo Tribunal Federal. Arguição de Descumprimento de Preceito Fundamental $\mathrm{n}^{\circ}$ 54-8. Alegações Finais Ministério Público Federal, p. 8, item 37. Disponível em: 〈http://www.stf.jus.br>. Acesso em: 10 jan. 2011.

${ }_{1023}$ BRASIL. Supremo Tribunal Federal. Arguição de Descumprimento de Preceito Fundamental $\mathrm{n}^{\circ}$ 54-8. Alegações Finais Ministério Público Federal, p. 7-8, ítens 34-42. Disponível em: <http://www.stf.jus.br>. Acesso em: 10 jan. 2011.

${ }^{1024}$ BRASIL. Supremo Tribunal Federal. Arguição de Descumprimento de Preceito Fundamental $\mathrm{n}^{\circ}$ 54-8. Alegações Finais Ministério Público Federal, p. 9, itens 43-44. Disponível em: <http://www.stf.jus.br>. Acesso em: 10 jan. 2011.

1025 BRASIL. Supremo Tribunal Federal. Arguição de Descumprimento de Preceito Fundamental no 54-8. Alegações Finais Ministério Público Federal, p. 9, item 45. Disponível em: <http://www.stf.jus.br〉. Acesso em: 10 jan. 2011.

${ }^{1026}$ BRASIL. Supremo Tribunal Federal. Arguição de Descumprimento de Preceito Fundamental $\mathrm{n}^{\mathrm{o}}$ 54-8. Alegações Finais Ministério Público Federal, p. 9, item 45. Disponível em: <http://www.stf.jus.br>. Acesso em: 10 jan. 2011.

${ }^{1027}$ BRASIL. Supremo Tribunal Federal. Arguição de Descumprimento de Preceito Fundamental $\mathrm{n}^{\circ}$ 54-8. Alegações Finais Ministério Público Federal, p. 9, item 45. Disponível em: <http://www.stf.jus.br>. Acesso em: 10 jan. 2011.

${ }^{1028}$ BRASIL. Supremo Tribunal Federal. Arguição de Descumprimento de Preceito Fundamental $\mathrm{n}^{\circ}$ 54-8. Alegações Finais Ministério Público Federal, p. 9, item 45. Disponível em: 〈http://www.stf.jus.br〉. Acesso em: 10 jan. 2011.

${ }^{1029}$ BRASIL. Supremo Tribunal Federal. Arguição de Descumprimento de Preceito Fundamental no ${ }^{\circ}$ 54-8. Alegações Finais Ministério Público Federal, p. 9, item 45. Disponível em: 〈http://www.stf.jus.br>. Acesso em: 10 jan. 2011.

${ }_{1030}$ BRASIL. Supremo Tribunal Federal. Arguição de Descumprimento de Preceito Fundamental no $54-8$. Alegações Finais Ministério Público Federal, p. 10, ítens 47-52. Disponível em: <http://www.stf.jus.br>. Acesso em: 10 jan. 2011.

${ }^{1031}$ BRASIL. Supremo Tribunal Federal. Arguição de Descumprimento de Preceito Fundamental $n^{\circ}$ 54-8. Alegações Finais Ministério Público Federal, p. 10-11, ítens 47-52. Disponível em: 〈http://www.stf.jus.br>. Acesso em: 10 jan. 2011.

${ }^{1032}$ A proteção é inicialmente menor, e vai aumentanto, na medida em que avança a gestação, sendo relevante determinados marcos, como a nidação - fixação do embrião no útero materno -, a formação do córtex cerebral e 
potencial do feto ${ }^{1033}$, sendo cabível à espécie a analogia de morte encefálica, nos termos do artigo $3^{\circ}$, Lei 9434/97. Afirmou também que a anencefalia não pode ser equiparada ao aborto eugênico, pois este pressupõe a viabilidade da vida extrauterina, o que não ocorre no caso do anencéfalo $^{1034}$, de modo que a antecipação do parto de feto anencéfalo constitui direito fundamental da gestante, podendo, de qualquer modo, ser mantida a gravidez nos casos em que a mulher desejar levá-la até o final ${ }^{1035}$.

Por fim, afirma a Procuradora Geral da República que a retirada do feto anencéfalo não viola o bem jurídico tutelado pelos dispositivos penais, isto é, a vida, uma vez que inexiste a continuidade da vida com o nascimento do feto ${ }^{1036}$.

A Advocacia-Geral da União - $\mathrm{AGU}^{1037}$ sustentou que as gestantes têm garantida a liberdade de escolher dar continuidade ou não à gravidez de feto anencéfalo pelas políticas públicas existentes ${ }^{1038}$, especialmente, em razão do acesso ao Sistema Único de Saúde de atendimento pré-natal e medicina diagnóstica adequados ${ }^{1039}$.

Além disso, posicionou-se a AGU no sentido de que a antecipação do parto é uma "alternativa legítima" ${ }^{, 1040}$, tendo em vista a irreversível inviabilidade da vida extrauterina e os

o momento em que se caracteriza a viabilidade de vida extra-uterina”. BRASIL. Supremo Tribunal Federal. Arguição de Descumprimento de Preceito Fundamental no 54-8. Alegações Finais Ministério Público Federal, p. 11, item 54. Disponível em: <http://www.stf.jus.br>. Acesso em: 10 jan. 2011.

1033 BRASIL. Supremo Tribunal Federal. Arguição de Descumprimento de Preceito Fundamental no 54-8. Alegações Finais Ministério Público Federal, p. 12, item 55. Disponível em: 〈http://www.stf.jus.br>. Acesso em: 10 jan. 2011.

1034 BRASIL. Supremo Tribunal Federal. Arguição de Descumprimento de Preceito Fundamental $n^{\circ}$ 54-8. Alegações Finais Ministério Público Federal, p. 13, item 59. Disponível em: 〈http://www.stf.jus.br>. Acesso em: 10 jan. 2011.

${ }^{1035}$ BRASIL. Supremo Tribunal Federal. Arguição de Descumprimento de Preceito Fundamental $\mathrm{n}^{\circ}$ 54-8. Alegações Finais Ministério Público Federal, p. 13, item 61. Disponível em: 〈http://www.stf.jus.br>. Acesso em: 10 jan. 2011.

1036 BRASIL. Supremo Tribunal Federal. Arguição de Descumprimento de Preceito Fundamental $\mathrm{n}^{\circ}$ 54-8. Alegações Finais Ministério Público Federal, p. 13-14, ítens 64-67. Disponível em: 〈http://www.stf.jus.br>. Acesso em: 10 jan. 2011.

1037 BRASIL. Supremo Tribunal Federal. Arguição de Descumprimento de Preceito Fundamental $\mathrm{n}^{\circ}$ 54-8. Alegações Finais Advocacia-Geral da União. Petição assinada pelo Advogado-Geral da União Evandro Costa Gama, pela Diretora do Departamento de controle Concentrado e Advogada-Geral Letícia de Campos Aspesi Santos e pelo Procurador Federal Gerardo Wilames Fonseca e Silva. Disponível em: <http://www.stf.jus.br〉. Acesso em: 10 jan. 2011.

1038 BRASIL. Supremo Tribunal Federal. Arguição de Descumprimento de Preceito Fundamental no 54-8. Alegações Finais Advocacia-Geral da União. Petição assinada pelo Advogado-Geral da União Evandro Costa Gama, pela Diretora do Departamento de controle Concentrado e Advogada-Geral Letícia de Campos Aspesi Santos e pelo Procurador Federal Gerardo Wilames Fonseca e Silva, p. 5-6. Disponível em:<http://www.stf.jus.br>. Acesso em: 10 jan. 2011.

1039 BRASIL. Supremo Tribunal Federal. Arguição de Descumprimento de Preceito Fundamental $\mathrm{n}^{\circ}$ 54-8. Alegações Finais Advocacia-Geral da União. Petição assinada pelo Advogado-Geral da União Evandro Costa Gama, pela Diretora do Departamento de controle Concentrado e Advogada-Geral Letícia de Campos Aspesi Santos e pelo Procurador Federal Gerardo Wilames Fonseca e Silva, p. 4. Disponível em: <http://www.stf.jus.br>. Acesso em: 10 jan. 2011.

1040 BRASIL. Supremo Tribunal Federal. Arguição de Descumprimento de Preceito Fundamental $\mathrm{n}^{\circ}$ 54-8. Alegações Finais Advocacia-Geral da União. Petição assinada pelo Advogado-Geral da União Evandro Costa 
"riscos pré-partos" 1041 no caso do feto anencéfalo, fato que vai ao encontro do "poder decisório da mulher" ${ }^{1042}$, de modo que deve ser garantido a ela o direito subjetivo ao

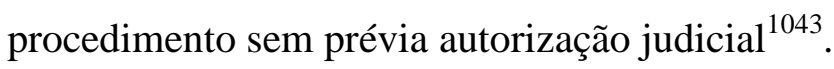

A Confederação Nacional dos Trabalhadores da Saúde - CNTS, a arguente da ADPF 54, destacou, em suas razões finais, cinco teses importantes, obtidas durante o debate público: i) a rede pública de saúde pode realizar o exame que dignostica a anencefalia, sendo certo que a anencefalia é considerada uma doença irreversível e fatal e que a rede pública tem condições de diagnosticá-la com precisão absoluta ${ }^{1044}$; ii) há um perigo maior à vida da gestante na gravidez do anencéfalo, e pode existir um dano à saúde mental da gestante ${ }^{1045}$; iii) o feto anencéfalo não é doador de órgãos, já que possui má-formações capazes de gerar rejeição ${ }^{1046}$; iv) o procedimento médico é uma antecipação de terapêutica de parto e não aborto, pois não há possibilidade de vida extrauterina ${ }^{1047}$; e v) a anencefalia não é deficiência, pois não há casos de adultos ou crianças com anencefalia ${ }^{1048}$.

Gama, pela Diretora do Departamento de controle Concentrado e Advogada-Geral Letícia de Campos Aspesi Santos e pelo Procurador Federal Gerardo Wilames Fonseca e Silva, p. 7. Disponível em: <http://www.stf.jus.br>. Acesso em: 10 jan. 2011.

1041 BRASIL. Supremo Tribunal Federal. Arguição de Descumprimento de Preceito Fundamental $\mathrm{n}^{\circ}$ 54-8. Alegações Finais Advocacia-Geral da União. Petição assinada pelo Advogado-Geral da União Evandro Costa Gama, pela Diretora do Departamento de controle Concentrado e Advogada-Geral Letícia de Campos Aspesi Santos e pelo Procurador Federal Gerardo Wilames Fonseca e Silva, p. 7. Disponível em: <http://www.stf.jus.br>. Acesso em: 10 jan. 2011.

1042 BRASIL. Supremo Tribunal Federal. Arguição de Descumprimento de Preceito Fundamental no 54-8. Alegações Finais Advocacia-Geral da União. Petição assinada pelo Advogado-Geral da União Evandro Costa Gama, pela Diretora do Departamento de controle Concentrado e Advogada-Geral Letícia de Campos Aspesi Santos e pelo Procurador Federal Gerardo Wilames Fonseca e Silva, p. 8. Disponível em: <http://www.stf.jus.br>. Acesso em: 10 jan. 2011.

1043 BRASIL. Supremo Tribunal Federal. Arguição de Descumprimento de Preceito Fundamental no 54-8. Alegações Finais Advocacia-Geral da União. Petição assinada pelo Advogado-Geral da União Evandro Costa Gama, pela Diretora do Departamento de controle Concentrado e Advogada-Geral Letícia de Campos Aspesi Santos e pelo Procurador Federal Gerardo Wilames Fonseca e Silva, p. 11. Disponível em: <http://www.stf.jus.br>. Acesso em: 10 jan. 2011.

1044 BRASIL. Supremo Tribunal Federal. Arguição de Descumprimento de Preceito Fundamental $n^{\circ}$ 54-8. Alegações Finais Confederação Nacional dos Trabalhadores da Saúde, p. 4. Disponível em: <http://www.stf.jus.br>. Acesso em: 10 jan. 2011.

1045 BRASIL. Supremo Tribunal Federal. Arguição de Descumprimento de Preceito Fundamental no 54-8. Alegações Finais Confederação Nacional dos Trabalhadores da Saúde, p. 4. Disponível em: <http://www.stf.jus.br>. Acesso em: 10 jan. 2011.

1046 BRASIL. Supremo Tribunal Federal. Arguição de Descumprimento de Preceito Fundamental no 54-8. Alegações Finais Confederação Nacional dos Trabalhadores da Saúde, p. 4. Disponível em: <http://www.stf.jus.br>. Acesso em: 10 jan. 2011.

1047 BRASIL. Supremo Tribunal Federal. Arguição de Descumprimento de Preceito Fundamental no 54-8. Alegações Finais Confederação Nacional dos Trabalhadores da Saúde, p. 4. Disponível em: <http://www.stf.jus.br>. Acesso em: 10 jan. 2011.

1048 BRASIL. Supremo Tribunal Federal. Arguição de Descumprimento de Preceito Fundamental $n^{\circ}$ 54-8. Alegações Finais Confederação Nacional dos Trabalhadores da Saúde, p. 5. Disponível em: <http://www.stf.jus.br>. Acesso em: 10 jan. 2011. 
A CNTS segue na defesa de que há atipicidade da conduta do aborto do anencéfalo $^{1049}$, porque a morte do feto não decorre de meios abortivos, uma vez que o feto, por não ter atividade cerebral, não é considerado um ser vivo ${ }^{1050}$. Seria possível, ainda, uma interpretação evolutiva do direito penal, tendo em vista a inexistência de tecnologia determinante de doenças incompatíveis com a vida do feto à epoca da lei ${ }^{1051}$, tendo inclusive o legislador naquela época já valorado o sofrimento da mãe em relação à vida do feto nos casos de aborto em decorrência de estupro ${ }^{1052}$. Por fim, reafirmou a CNTS que a dignidade da pessoa humana é violada sob o prisma da integridade física e psicológica no caso de uma gestação de feto anencéfalo, e que a gestação nessas cirscuntâncias traz um perigo maior à saúde física e psiquíca da mulher ${ }^{1053}$, reiterando o pedido de interpretação conforme à Constituição $^{1054}$.

A seguir, passamos a analisar, voto a voto, com ênfase no mérito, a tão esperada decisão do STF a respeito do caso.

\subsection{ANÁLISE DOS VOTOS NA ADPF 54 - MÉRITO ${ }^{1055}$}

A Arguição de Preceito Fundamental no 54 foi julgada pelo Supremo Tribunal Federal nas sessões dos dias 11 e 12 de abril deste ano de 2012.

\footnotetext{
1049 BRASIL. Supremo Tribunal Federal. Arguição de Descumprimento de Preceito Fundamental $\mathrm{n}^{\circ}$ 54-8. Alegações Finais Confederação Nacional dos Trabalhadores da Saúde, p. 5. Disponível em: <http://www.stf.jus.br>. Acesso em: 10 jan. 2011.

1050 BRASIL. Supremo Tribunal Federal. Arguição de Descumprimento de Preceito Fundamental no 54-8. Alegações Finais Confederação Nacional dos Trabalhadores da Saúde, p. 6. Disponível em: <http://www.stf.jus.br>. Acesso em: 10 jan. 2011.

1051 BRASIL. Supremo Tribunal Federal. Arguição de Descumprimento de Preceito Fundamental no 54-8. Alegações Finais Confederação Nacional dos Trabalhadores da Saúde, p. 6-7. Disponível em: <http://www.stf.jus.br>. Acesso em: 10 jan. 2011.

1052 BRASIL. Supremo Tribunal Federal. Arguição de Descumprimento de Preceito Fundamental $n^{\circ}$ 54-8. Alegações Finais Confederação Nacional dos Trabalhadores da Saúde, p. 7. Disponível em: <http://www.stf.jus.br>. Acesso em: 10 jan. 2011.

1053 BRASIL. Supremo Tribunal Federal. Arguição de Descumprimento de Preceito Fundamental $\mathrm{n}^{\circ}$ 54-8. Alegações Finais Confederação Nacional dos Trabalhadores da Saúde, p. 8-9. Disponível em: <http://www.stf.jus.br>. Acesso em: 10 jan. 2011.

1054 BRASIL. Supremo Tribunal Federal. Arguição de Descumprimento de Preceito Fundamental no 54-8. Alegações Finais Confederação Nacional dos Trabalhadores da Saúde, p. 9-13. Disponível em: <http://www.stf.jus.br>. Acesso em: 10 jan. 2011.

1055 [N.R.] Votos publicados no site do Supremo Tribunal Federal dos Ministros Marco Aurélio, Ricardo Lewandowski e Luiz Fux. Arguição de Descumprimento de Preceito Fundamental $n^{\circ}$ 54-8. Disponível em: <http://www.stf.jus.br>. Acesso em: 16 abr. 2012. A análise dos demais votos foram baseadas nos votos lidos durante a sessão ao vivo da TV Justiça, disponibilizadas no STF no Youtube.
} 
Nesta etapa do processo, decorridos quase 8 anos desde o início da tramitação da ação perante o STF, gostaríamos de observar preliminarmente que vários dos Ministros integrantes de nosso Supremo Tribunal Federal que participaram do julgamento de mérito diferem daqueles que votaram anteriormente, na limitar; a maioria por ter se aposentado ao longo dos anos que se foram.

Destacamos, a seguir, os principais argumentos trazidos pelos ministros no julgamento final da ADPF 54.

\subsubsection{Voto do Ministro Relator Marco Aurélio ${ }^{1056}$}

O Ministro Relator agarrou-se a alguns argumentos já indicados na análise da medida liminar, complementando-os e apontando aspectos essenciais para a análise do tema.

Entendeu o Ministro Marco Aurélio que, de acordo com os dados da OMS colhidos entre 1993 a 1998, o Brasil é o quarto país em incidência de anencefalia, tendo sido emitidas em torno de 3000 autorizações judiciais para a realização da interrupção da gravidez nesses casos até $2005^{1057}$.

Marco Aurélio enfatizou, ainda, que pretende-se, com a ADPF, tão-somente interpretar os dispositivos do Código Penal (124, 126 e 128, I e II) conforme a Constituição Federal.

Inicialmente, afastou o Ministro os termos "aborto", "aborto eugênico" ou "eugenésico", e "antecipação eugênica da gestação"1058, diante da diferenciações terminológicas que fará ao longo do voto.

Para o Ministro é evidente o conflito dos "interesses legítimos da mulher"1059 com os "interesses da sociedade que deseja proteger todos os que a integram - sejam os que

1056 Arguição de Descumprimento de Preceito Fundamental n ${ }^{\circ}$ 54-8. Voto do Ministro Relator Marco Aurélio. Disponível em: <http://www.stf.jus.br/arquivo/cms/noticiaNoticiaStf/anexo/ADPF54.pdf>. Acesso em: 16 abr. 2012.

${ }^{1057}$ Arguição de Descumprimento de Preceito Fundamental n ${ }^{\circ}$ 54-8. Voto do Ministro Relator Marco Aurélio. Disponível em: <http://www.stf.jus.br/arquivo/cms/noticiaNoticiaStf/anexo/ADPF54.pdf>. Acesso em: 16 abr. 2012, p. 31.

1058 Arguição de Descumprimento de Preceito Fundamental no 54-8. Voto do Ministro Relator Marco Aurélio. Disponível em: <http://www.stf.jus.br/arquivo/cms/noticiaNoticiaStf/anexo/ADPF54.pdf>. Acesso em: 16 abr. 2012, p. 32.

1059 Arguição de Descumprimento de Preceito Fundamental no 54-8. Voto do Ministro Relator Marco Aurélio. Disponível em: <http://www.stf.jus.br/arquivo/cms/noticiaNoticiaStf/anexo/ADPF54.pdf>. Acesso em: 16 abr. 2012, p. 33. 
nasceram, sejam os que estejam para nascer - independentemente da condição física ou viabilidade de sobrevivência" ${ }^{1060}$. No entanto, para ele, há um conflito apenas aparente, e não real, entre direitos fundamentais no caso do anecéfalo ${ }^{1061}$. Marco Aurélio entende que é necessário analisar se "há justificativa para a lei compelir a mulher a manter a gestação quando ausente a expectativa de vida para o feto" ${ }^{\text {"1062 }}$.

O Ministro Marco Aurélio abordou alguns pontos centrais da questão em seu voto. O primeiro ponto foi a análise do estado laico. Explicou o Ministro que o Brasil, já na época do Império, era um estado "relativamente tolerante"1063, pois permitia o culto não católico em ambientes domésticos e templários, ainda que não fora deles ${ }^{1064}$. A partir da transição império-república, o Brasil separou-se da igreja ${ }^{1065}$, proibindo a intervenção estatal no "exercício dos cultos religiosos"1066. Afirma o Ministro que a Constituição de 88 nos artigos $5^{\circ}$, VI e $19, \mathrm{I}^{1067}$ dedicou-se tratar desse tema adotando uma postura de "estado secular"1068 tolerante, isto é, um estado que "não é religioso, tampouco é ateu. O Estado é simplesmente neutro",1069.

Para o Ministro, na esteira de Daniel Sarmento, a laicidade estatal tem função dúplice, ora resguardando as religiões da intervenção estatal, ora protegendo o estado das "influências

${ }^{1060}$ Arguição de Descumprimento de Preceito Fundamental no 54-8. Voto do Ministro Relator Marco Aurélio. Disponível em: <http://www.stf.jus.br/arquivo/cms/noticiaNoticiaStf/anexo/ADPF54.pdf>. Acesso em: 16 abr. 2012 , p. 33.

${ }^{1061}$ Aponta os direitos em conflito: dignidade humana, usufruto da vida, liberdade, autodeterminação, saúde e o reconhecimento de direitos fundamentais e estado laico e privacidade. Arguição de Descumprimento de Preceito Fundamental $\mathrm{n}^{\mathrm{o}}$ 54-8. Voto do Ministro Relator Marco Aurélio. Disponível em: <http://www.stf.jus.br/arquivo/cms/noticiaNoticiaStf/anexo/ADPF54.pdf>. Acesso em: 16 abr. 2012, p. 33-34.

1062 Arguição de Descumprimento de Preceito Fundamental no 54-8. Voto do Ministro Relator Marco Aurélio. Disponível em: <http://www.stf.jus.br/arquivo/cms/noticiaNoticiaStf/anexo/ADPF54.pdf>. Acesso em: 16 abr. 2012, p. 33.

1063 Arguição de Descumprimento de Preceito Fundamental n ${ }^{\circ}$ 54-8. Voto do Ministro Relator Marco Aurélio. Disponível em: <http://www.stf.jus.br/arquivo/cms/noticiaNoticiaStf/anexo/ADPF54.pdf>. Acesso em: 16 abr. 2012, p. 36.

1064 Arguição de Descumprimento de Preceito Fundamental no 54-8. Voto do Ministro Relator Marco Aurélio. Disponível em: <http://www.stf.jus.br/arquivo/cms/noticiaNoticiaStf/anexo/ADPF54.pdf>. Acesso em: 16 abr. 2012, p. 36.

1065 Arguição de Descumprimento de Preceito Fundamental n ${ }^{\circ}$ 54-8. Voto do Ministro Relator Marco Aurélio. Disponível em: <http://www.stf.jus.br/arquivo/cms/noticiaNoticiaStf/anexo/ADPF54.pdf>. Acesso em: 16 abr. 2012, p. 36.

1066 Arguição de Descumprimento de Preceito Fundamental n ${ }^{\circ}$ 54-8. Voto do Ministro Relator Marco Aurélio. Disponível em: <http://www.stf.jus.br/arquivo/cms/noticiaNoticiaStf/anexo/ADPF54.pdf>. Acesso em: 16 abr. 2012, p. 37.

1067 Arguição de Descumprimento de Preceito Fundamental no 54-8. Voto do Ministro Relator Marco Aurélio. Disponível em: <http://www.stf.jus.br/arquivo/cms/noticiaNoticiaStf/anexo/ADPF54.pdf>. Acesso em: 16 abr. 2012, p. 38.

1068 Arguição de Descumprimento de Preceito Fundamental no 54-8. Voto do Ministro Relator Marco Aurélio. Disponível em: <http://www.stf.jus.br/arquivo/cms/noticiaNoticiaStf/anexo/ADPF54.pdf>. Acesso em: 16 abr. 2012 , p. 41.

1069 Arguição de Descumprimento de Preceito Fundamental no 54-8. Voto do Ministro Relator Marco Aurélio. Disponível em: <http://www.stf.jus.br/arquivo/cms/noticiaNoticiaStf/anexo/ADPF54.pdf>. Acesso em: 16 abr. 2012, p. 41. 
indevidas" das religiões ${ }^{1070}$. Na visão do Ministro, religiões "não podem guiar as decisões estatais, devendo ficar circunscritos à esfera privada"1071, e sequer podem orientar "o tratamento estatal dispensado a outros direitos fundamentais" ${ }^{\prime 1072}$.

O segundo ponto tratado pelo Ministro Marco Aurélio foi a anencefalia. Com base nas explicações científicas proferidas na audiência pública, o Ministro afirmou que o feto anencéfalo não possui as funções que "dependem do córtex e dos hemisférios cerebrais" 1073, inexistindo a "sensibilidade, mobilidade, integração de quase todas as funções corpóreas"1074, isto é, o "fenômeno da vida psíquica" $" 1075$ e do sistema nervoso central que cuida da consciência ${ }^{1076}$.

Afirmou ainda o Ministro que a anencefalia é fatal e irreversível ${ }^{1077}$, lembrando também que a morte é verificada pela "parada total e irreversível das funções encefálicas"1078 ou pela "parada irreversível das funções cardiorrespiratórias, com a finalização da atividade cardíaca e cerebral pela ausência de irrigação sanguínea" ${ }^{\text {1079 }}$, e que, no caso do anencéfalo, o próprio Conselho Federal de Medicina considerou-o natimorto (Resolução 1752/2004) ${ }^{1080}$.

${ }^{1070}$ Arguição de Descumprimento de Preceito Fundamental no 54-8. Voto do Ministro Relator Marco Aurélio. Disponível em: <http://www.stf.jus.br/arquivo/cms/noticiaNoticiaStf/anexo/ADPF54.pdf>. Acesso em: 16 abr. 2012, p. 43.

1071 Arguição de Descumprimento de Preceito Fundamental no 54-8. Voto do Ministro Relator Marco Aurélio. Disponível em: <http://www.stf.jus.br/arquivo/cms/noticiaNoticiaStf/anexo/ADPF54.pdf>. Acesso em: 16 abr. 2012, p. 44.

1072 Arguição de Descumprimento de Preceito Fundamental no 54-8. Voto do Ministro Relator Marco Aurélio. Disponível em: <http://www.stf.jus.br/arquivo/cms/noticiaNoticiaStf/anexo/ADPF54.pdf>. Acesso em: 16 abr. 2012, p. 45.

1073 Arguição de Descumprimento de Preceito Fundamental n ${ }^{\circ}$ 54-8. Voto do Ministro Relator Marco Aurélio. Disponível em: <http://www.stf.jus.br/arquivo/cms/noticiaNoticiaStf/anexo/ADPF54.pdf>. Acesso em: 16 abr. 2012, p. 47.

1074 Arguição de Descumprimento de Preceito Fundamental n ${ }^{\circ}$ 54-8. Voto do Ministro Relator Marco Aurélio. Disponível em: <http://www.stf.jus.br/arquivo/cms/noticiaNoticiaStf/anexo/ADPF54.pdf>. Acesso em: 16 abr. 2012, p. 47.

1075 Arguição de Descumprimento de Preceito Fundamental no 54-8. Voto do Ministro Relator Marco Aurélio. Disponível em: <http://www.stf.jus.br/arquivo/cms/noticiaNoticiaStf/anexo/ADPF54.pdf>. Acesso em: 16 abr. 2012, p. 47.

1076 Arguição de Descumprimento de Preceito Fundamental n ${ }^{\circ}$ 54-8. Voto do Ministro Relator Marco Aurélio. Disponível em: <http://www.stf.jus.br/arquivo/cms/noticiaNoticiaStf/anexo/ADPF54.pdf>. Acesso em: 16 abr. 2012, p. 47.

1077 Arguição de Descumprimento de Preceito Fundamental no 54-8. Voto do Ministro Relator Marco Aurélio. Disponível em: <http://www.stf.jus.br/arquivo/cms/noticiaNoticiaStf/anexo/ADPF54.pdf>. Acesso em: 16 abr. 2012, p. 47.

1078 Arguição de Descumprimento de Preceito Fundamental no 54-8. Voto do Ministro Relator Marco Aurélio. Disponível em: <http://www.stf.jus.br/arquivo/cms/noticiaNoticiaStf/anexo/ADPF54.pdf>. Acesso em: 16 abr. 2012, p. 49.

1079 Arguição de Descumprimento de Preceito Fundamental no 54-8. Voto do Ministro Relator Marco Aurélio. Disponível em: <http://www.stf.jus.br/arquivo/cms/noticiaNoticiaStf/anexo/ADPF54.pdf>. Acesso em: 16 abr. 2012, p. 50.

1080 Arguição de Descumprimento de Preceito Fundamental no 54-8. Voto do Ministro Relator Marco Aurélio. Disponível em: <http://www.stf.jus.br/arquivo/cms/noticiaNoticiaStf/anexo/ADPF54.pdf>. Acesso em: 16 abr. 2012, p. 50. 
Marco Aurélio entendeu que o anencéfalo "jamais se tornará uma pessoa"1081, e a análise de dados percentuais, ainda que um pouco controversos, demostram a inviabilidade extrauterina do feto, resistindo o anencéfalo pouco tempo fora do útero materno ${ }^{1082}$.

Para o Ministro, o aborto do feto anencéfalo não se trata de aborto eugênico, pois não há vida no feto anencéfalo ${ }^{1083}$. Não se trata também de uma deficiência com uma "sobrevida extrauterina" ${ }^{1084}$, razão pela qual não há violação dos artigos $6^{\circ}$ e 23 da Convenção sobre Direitos das Crianças das Nações Unidas ${ }^{1085}$ e dos dispositivos constitucionais que protegem a criança $^{1086}$, vez que o feto anencéfalo não virá a ser uma criança ${ }^{1087}$. O Ministro também considerou que o diagnóstico pode ser feito a partir da $12^{\mathrm{a}}$ semana por instrumentos disponíveis na rede pública de saúde ${ }^{1088}$ e é confiável ${ }^{1089}$.

Seguiu o Ministro Marco Aurélio analisando o terceiro ponto a respeito da doação de órgãos de anencéfalos, logo afastando-a por duas razões principais: evitar a coisificação da mulher, porque obrigá-la a levar a termo uma gestação somente com a finalidade meramente utilitarista de doar os órgãos de seu feto seria transformá-la num objeto ${ }^{1090}$, e pela

\footnotetext{
${ }^{1081}$ Arguição de Descumprimento de Preceito Fundamental n ${ }^{\circ}$ 54-8. Voto do Ministro Relator Marco Aurélio. Disponível em: <http://www.stf.jus.br/arquivo/cms/noticiaNoticiaStf/anexo/ADPF54.pdf>. Acesso em: 16 abr. 2012 , p. 50.

${ }^{1082}$ Arguição de Descumprimento de Preceito Fundamental no 54-8. Voto do Ministro Relator Marco Aurélio. Disponível em: <http://www.stf.jus.br/arquivo/cms/noticiaNoticiaStf/anexo/ADPF54.pdf>. Acesso em: 16 abr. 2012, p. 51-52.

${ }^{1083}$ Arguição de Descumprimento de Preceito Fundamental no 54-8. Voto do Ministro Relator Marco Aurélio. Disponível em: <http://www.stf.jus.br/arquivo/cms/noticiaNoticiaStf/anexo/ADPF54.pdf>. Acesso em: 16 abr. 2012, p. 53.

${ }_{1084}$ Arguição de Descumprimento de Preceito Fundamental n ${ }^{\circ}$ 54-8. Voto do Ministro Relator Marco Aurélio. Disponível em: <http://www.stf.jus.br/arquivo/cms/noticiaNoticiaStf/anexo/ADPF54.pdf〉. Acesso em: 16 abr. 2012 , p. 53.

${ }^{1085}$ Arguição de Descumprimento de Preceito Fundamental no 54-8. Voto do Ministro Relator Marco Aurélio. Disponível em: <http://www.stf.jus.br/arquivo/cms/noticiaNoticiaStf/anexo/ADPF54.pdf>. Acesso em: 16 abr. 2012, p. 54.

${ }^{1086}$ Arguição de Descumprimento de Preceito Fundamental no 54-8. Voto do Ministro Relator Marco Aurélio. Disponível em: <http://www.stf.jus.br/arquivo/cms/noticiaNoticiaStf/anexo/ADPF54.pdf>. Acesso em: 16 abr. 2012 , p. 55.

${ }^{1087}$ Arguição de Descumprimento de Preceito Fundamental no 54-8. Voto do Ministro Relator Marco Aurélio. Disponível em: <http://www.stf.jus.br/arquivo/cms/noticiaNoticiaStf/anexo/ADPF54.pdf>. Acesso em: 16 abr. 2012, p. 55.

${ }_{1088}$ Arguição de Descumprimento de Preceito Fundamental n ${ }^{\circ}$ 54-8. Voto do Ministro Relator Marco Aurélio. Disponível em: <http://www.stf.jus.br/arquivo/cms/noticiaNoticiaStf/anexo/ADPF54.pdf〉. Acesso em: 16 abr. 2012 , p. 55.

${ }^{1089}$ Arguição de Descumprimento de Preceito Fundamental n ${ }^{\circ}$ 54-8. Voto do Ministro Relator Marco Aurélio. Disponível em: 〈http://www.stf.jus.br/arquivo/cms/noticiaNoticiaStf/anexo/ADPF54.pdf〉. Acesso em: 16 abr. 2012, p. 55.

${ }^{1090}$ Arguição de Descumprimento de Preceito Fundamental n ${ }^{\circ}$ 54-8. Voto do Ministro Relator Marco Aurélio. Disponível em: <http://www.stf.jus.br/arquivo/cms/noticiaNoticiaStf/anexo/ADPF54.pdf>. Acesso em: 16 abr. 2012, p. 57.
} 
impossibilidade prática de se transplantar os órgãos de anencéfalos ${ }^{1091}$, seja porque são menores comparados aos de fetos normais ${ }^{1092}$, seja pela idade mínima exigida de 7 dias após o nascimento (Resolução CFM 1480/1997), normalmente não alcançada pelo feto anencéfalo $^{1093}$. Na esteira de Maíra Costa Fernandes, ainda que fosse possível aproveitar os órgãos para doação, defendeu o Ministro que o ato de doação é "intrinsecamente voluntário" 1094 , e que, mesmo com fundamento da solidariedade, o direito não obriga o sacrifício próprio para salvar a vida de outros indivíduos ${ }^{1095}$.

$\mathrm{O}$ quarto ponto analisado pelo Ministro versou sobre o pretenso direito à vida do feto anencéfalo. Para ele, o feto anecéfalo não tem vida em potencial ${ }^{1096}$, porque é "natimorto cerebral" ${ }^{\prime 1097}$. Por essa razão, o conflito dos direitos fundamentais protegidos da mulher com o direito à vida do feto anencéfalo é aparente, porque não há aborto, uma vez que não há vida a ser tutelada ${ }^{1098}$.

O Ministro defendeu ainda que o legislador do Código Penal não dispunha do conhecimento dos recursos tecnológicos capazes de diagnosticar a anencefalia ${ }^{1099}$, daí não lhe ter sido possível incluí-la no rol de excludentes legais do crime de aborto.

Marco Aurélio mencionou também o seu voto na decisão da ADI 3510, em que seria possível adotar várias linhas sobre o que seria vida e quando ela começa, destacando o voto do Ministro Ayres Britto naquela ação, de que, embora os "momentos da vida humana

${ }^{1091}$ Arguição de Descumprimento de Preceito Fundamental no 54-8. Voto do Ministro Relator Marco Aurélio. Disponível em: 〈http://www.stf.jus.br/arquivo/cms/noticiaNoticiaStf/anexo/ADPF54.pdf>. Acesso em: 16 abr. 2012 , p. 57.

1092 Arguição de Descumprimento de Preceito Fundamental no 54-8. Voto do Ministro Relator Marco Aurélio. Disponível em: 〈http://www.stf.jus.br/arquivo/cms/noticiaNoticiaStf/anexo/ADPF54.pdf>. Acesso em: 16 abr. 2012, p. 58.

1093 Arguição de Descumprimento de Preceito Fundamental no 54-8. Voto do Ministro Relator Marco Aurélio. Disponível em: 〈http://www.stf.jus.br/arquivo/cms/noticiaNoticiaStf/anexo/ADPF54.pdf>. Acesso em: 16 abr. 2012, p. 59-60.

${ }^{1094}$ Arguição de Descumprimento de Preceito Fundamental no 54-8. Voto do Ministro Relator Marco Aurélio. Disponível em: <http://www.stf.jus.br/arquivo/cms/noticiaNoticiaStf/anexo/ADPF54.pdf>. Acesso em: 16 abr. 2012 , p. 58.

1095 Arguição de Descumprimento de Preceito Fundamental no 54-8. Voto do Ministro Relator Marco Aurélio. Disponível em: <http://www.stf.jus.br/arquivo/cms/noticiaNoticiaStf/anexo/ADPF54.pdf>. Acesso em: 16 abr. 2012 , p. 58.

1096 Arguição de Descumprimento de Preceito Fundamental no 54-8. Voto do Ministro Relator Marco Aurélio. Disponível em: 〈http://www.stf.jus.br/arquivo/cms/noticiaNoticiaStf/anexo/ADPF54.pdf>. Acesso em: 16 abr. 2012 , p. 60.

1097 Arguição de Descumprimento de Preceito Fundamental no 54-8. Voto do Ministro Relator Marco Aurélio. Disponível em: 〈http://www.stf.jus.br/arquivo/cms/noticiaNoticiaStf/anexo/ADPF54.pdf>. Acesso em: 16 abr. 2012, p. 60.

1098 Arguição de Descumprimento de Preceito Fundamental no 54-8. Voto do Ministro Relator Marco Aurélio. Disponível em: <http://www.stf.jus.br/arquivo/cms/noticiaNoticiaStf/anexo/ADPF54.pdf>. Acesso em: 16 abr. 2012 , p. 60.

1099 Arguição de Descumprimento de Preceito Fundamental no 54-8. Voto do Ministro Relator Marco Aurélio. Disponível em: <http://www.stf.jus.br/arquivo/cms/noticiaNoticiaStf/anexo/ADPF54.pdf>. Acesso em: 16 abr. 2012, p. 62. 
anteriores ao nascimento devem ser objeto de proteção" ${ }^{\text {1100 }}$, o embrião não é considerado "pessoa no sentido biográfico a que se refere a Constituição" ${ }^{1101}$, existindo, portanto, a necessidade, de acordo com Marco Aurélio, de se verificar dois aspectos para tutelar-se o direito à vida: ser "indivíduo-pessoa" "1102, e ter ao menos a "potencialidade para tornar-se pessoa humana"1103.

Além disso, lembrou Marco Aurélio que, ainda que fosse admitido o direito à vida intrauterina do feto anencéfalo ${ }^{1104}$, haveria uma proteção menos intensa ${ }^{1105}$.

O Ministro ressaltou que não existe hierarquia do direito à vida em relação aos demais direitos fundamentais, mas a própria Constituição limita esse direito ao autorizar a pena de morte em caso de guerra declarada, e nas excludentes de ilicitude ou antijuridicidade no caso do aborto se a gravidez decorrer de estupro ${ }^{1106}$, por exemplo. Para o Ministro, portanto, o direito à vida comporta gradações, posição já adotada na ADI 3510 e confirmada a partir da análise das penas no caso de aborto e de homicídio, que demonstram que a proteção se amplia, conforme o desenvolvimento do indivíduo ${ }^{1107}$. Assim, se a "proteção ao feto saudável é passível de ponderação com direito da mulher, com maior razão o é eventual proteção dada ao feto anencéfalo"1108.

Por fim, o último ponto analisado pelo Ministro Marco Aurélio diz respeito ao direito à saúde, à dignidade, à liberdade, à autonomia e à privacidade da mulher. Esclareceu o

${ }^{1100}$ Arguição de Descumprimento de Preceito Fundamental no 54-8. Voto do Ministro Relator Marco Aurélio. Disponível em: <http://www.stf.jus.br/arquivo/cms/noticiaNoticiaStf/anexo/ADPF54.pdf>. Acesso em: 16 abr. 2012, p. 63.

${ }^{1101}$ Arguição de Descumprimento de Preceito Fundamental n ${ }^{\circ}$ 54-8. Voto do Ministro Relator Marco Aurélio. Disponível em: <http://www.stf.jus.br/arquivo/cms/noticiaNoticiaStf/anexo/ADPF54.pdf>. Acesso em: 16 abr. 2012, p. 64.

${ }^{1102}$ Arguição de Descumprimento de Preceito Fundamental n ${ }^{\circ}$ 54-8. Voto do Ministro Relator Marco Aurélio. Disponível em: <http://www.stf.jus.br/arquivo/cms/noticiaNoticiaStf/anexo/ADPF54.pdf>. Acesso em: 16 abr. 2012, p. 64.

1103 Arguição de Descumprimento de Preceito Fundamental no 54-8. Voto do Ministro Relator Marco Aurélio. Disponível em: <http://www.stf.jus.br/arquivo/cms/noticiaNoticiaStf/anexo/ADPF54.pdf>. Acesso em: 16 abr. 2012, p. 64.

${ }^{1104}$ Arguição de Descumprimento de Preceito Fundamental n ${ }^{\circ}$ 54-8. Voto do Ministro Relator Marco Aurélio. Disponível em: <http://www.stf.jus.br/arquivo/cms/noticiaNoticiaStf/anexo/ADPF54.pdf>. Acesso em: 16 abr. 2012, p. 65.

${ }^{1105}$ Arguição de Descumprimento de Preceito Fundamental n ${ }^{\circ}$ 54-8. Voto do Ministro Relator Marco Aurélio. Disponível em: <http://www.stf.jus.br/arquivo/cms/noticiaNoticiaStf/anexo/ADPF54.pdf>. Acesso em: 16 abr. 2012, p. 67.

${ }^{1106}$ Arguição de Descumprimento de Preceito Fundamental n ${ }^{\circ}$ 54-8. Voto do Ministro Relator Marco Aurélio. Disponível em: <http://www.stf.jus.br/arquivo/cms/noticiaNoticiaStf/anexo/ADPF54.pdf>. Acesso em: 16 abr. 2012, p. 65-66.

1107 Arguição de Descumprimento de Preceito Fundamental no 54-8. Voto do Ministro Relator Marco Aurélio. Disponível em: <http://www.stf.jus.br/arquivo/cms/noticiaNoticiaStf/anexo/ADPF54.pdf>. Acesso em: 16 abr. 2012, p. 66-67.

1108 Arguição de Descumprimento de Preceito Fundamental no 54-8. Voto do Ministro Relator Marco Aurélio. Disponível em: <http://www.stf.jus.br/arquivo/cms/noticiaNoticiaStf/anexo/ADPF54.pdf>. Acesso em: 16 abr. 2012, p. 67. 
Ministro que é assegurado à mulher o direito à saúde física e psíquica, e os direitos sexuais e reprodutivos $^{1109}$, garantindo-lhe o direito à sua integridade física, mental e moral ${ }^{1110}$.

Quanto à saúde física, o Ministro afirmou que toda gravidez traz riscos, mas esses riscos são maiores quando a gravidez for de feto anencéfalo ${ }^{1111}$. Com relação à saúde psíquica, o Ministro ressaltou que a manutenção de uma gravidez de risco poderia trazer consequências psíquicas para a mulher e para a família, decorrentes "de dor, de angústia, de impotência, de tristeza, de luto, de desespero, dada a certeza do óbito"1112, podendo caracterizar especialmente quadros de estresse, depressão e até mesmo suicídio, configurando uma verdadeira tortura ou crueldade para a mulher dar continuidade a uma gestação dessa natureza $^{1113}$.

Dessa forma, defende Marco Aurélio que cabe à mulher e não ao estado decidir sobre a manutenção ou não da gravidez de feto anencéfalo, no exercício de seu direito à privacidade ${ }^{1114}$. Ao estado cabe "informar e prestar apoio médico e psicológico à paciente, antes e depois da decisão, seja ela qual for"1115. Também não se trata de obrigá-la a antecipar o parto, mas de dá-la o direito de escolha, garantindo-lhe sua autonomia, autodeterminação e dignidade ${ }^{1116}$.

Para o Ministro, não se pode proteger apenas o feto anencéfalo nessa relação, submetendo a mulher a um sofrimento físico e psicológico desnecessário:

\footnotetext{
${ }^{1109}$ Arguição de Descumprimento de Preceito Fundamental no 54-8. Voto do Ministro Relator Marco Aurélio. Disponível em: <http://www.stf.jus.br/arquivo/cms/noticiaNoticiaStf/anexo/ADPF54.pdf>. Acesso em: 16 abr. 2012, p. 67-68.

${ }^{1110}$ Arguição de Descumprimento de Preceito Fundamental n ${ }^{\circ}$ 54-8. Voto do Ministro Relator Marco Aurélio. Disponível em: <http://www.stf.jus.br/arquivo/cms/noticiaNoticiaStf/anexo/ADPF54.pdf>. Acesso em: 16 abr. 2012, p. 77-78.

1111 Arguição de Descumprimento de Preceito Fundamental no 54-8. Voto do Ministro Relator Marco Aurélio. Disponível em: <http://www.stf.jus.br/arquivo/cms/noticiaNoticiaStf/anexo/ADPF54.pdf>. Acesso em: 16 abr. 2012, p. 68-70.

${ }^{1112}$ Arguição de Descumprimento de Preceito Fundamental n ${ }^{\circ}$ 54-8. Voto do Ministro Relator Marco Aurélio. Disponível em: <http://www.stf.jus.br/arquivo/cms/noticiaNoticiaStf/anexo/ADPF54.pdf>. Acesso em: 16 abr. 2012, p. 71.

${ }^{1113}$ Arguição de Descumprimento de Preceito Fundamental n ${ }^{\circ}$ 54-8. Voto do Ministro Relator Marco Aurélio. Disponível em: <http://www.stf.jus.br/arquivo/cms/noticiaNoticiaStf/anexo/ADPF54.pdf>. Acesso em: 16 abr. 2012, p. 72.

${ }^{1114}$ Arguição de Descumprimento de Preceito Fundamental n ${ }^{\circ}$ 54-8. Voto do Ministro Relator Marco Aurélio. Disponível em: <http://www.stf.jus.br/arquivo/cms/noticiaNoticiaStf/anexo/ADPF54.pdf>. Acesso em: 16 abr. 2012, p. 76.

1115 Arguição de Descumprimento de Preceito Fundamental no 54-8. Voto do Ministro Relator Marco Aurélio. Disponível em: <http://www.stf.jus.br/arquivo/cms/noticiaNoticiaStf/anexo/ADPF54.pdf>. Acesso em: 16 abr. 2012, p. 76.

${ }^{1116}$ Arguição de Descumprimento de Preceito Fundamental n ${ }^{\circ}$ 54-8. Voto do Ministro Relator Marco Aurélio. Disponível em: <http://www.stf.jus.br/arquivo/cms/noticiaNoticiaStf/anexo/ADPF54.pdf>. Acesso em: 16 abr. 2012, p. 76-77.
} 
o ato de obrigar a mulher a manter a gestação, colocando-a em uma espécie de cárcere privado em seu próprio corpo, desprovida do mínimo essencial de autodeterminação e liberdade, assemelha-se à tortura ou a um sacrifício que não pode ser pedido a qualquer pessoa ou dela exigido ${ }^{1117}$.

Entende o Ministro que é preciso garantir a plena liberdade de escolha na esfera privada $^{1118}$, de modo que a "incolumidade física"1119 do feto anencéfalo não pode ser preservada a qualquer custo" ${ }^{1120}$ quando for possível minimizar a dor da mulher diante da inviabilidade inevitável do feto ${ }^{1121}$.

Assim, o Ministro relator Marco Aurélio julgou a ação procedente, declarando a interpretação conforme à Constituição Federal para excluir a interrupção da gravidez de feto anencéfalo da conduta tipificada nos artigos 124, 126 e 128, I e II do Código Penal ${ }^{122}$.

\subsubsection{Voto da Ministra Rosa Weber ${ }^{1123}$}

A Ministra Rosa Weber abordou quatro argumentos principais que direcionaram seu parecer ${ }^{1124}:$ i) se a tipicidade da antecipação terapêutica do parto pode ser vista como crime de

1117 Arguição de Descumprimento de Preceito Fundamental no 54-8. Voto do Ministro Relator Marco Aurélio. Disponível em: <http://www.stf.jus.br/arquivo/cms/noticiaNoticiaStf/anexo/ADPF54.pdf>. Acesso em: 16 abr. 2012, p. 78.

1118 Arguição de Descumprimento de Preceito Fundamental no 54-8. Voto do Ministro Relator Marco Aurélio. Disponível em: <http://www.stf.jus.br/arquivo/cms/noticiaNoticiaStf/anexo/ADPF54.pdf>. Acesso em: 16 abr. 2012, p. 78.

1119 Arguição de Descumprimento de Preceito Fundamental no 54-8. Voto do Ministro Relator Marco Aurélio. Disponível em: <http://www.stf.jus.br/arquivo/cms/noticiaNoticiaStf/anexo/ADPF54.pdf>. Acesso em: 16 abr. 2012, p. 78.

${ }^{1120}$ Arguição de Descumprimento de Preceito Fundamental n ${ }^{\circ}$ 54-8. Voto do Ministro Relator Marco Aurélio. Disponível em: <http://www.stf.jus.br/arquivo/cms/noticiaNoticiaStf/anexo/ADPF54.pdf>. Acesso em: 16 abr. 2012, p. 78.

${ }^{1121}$ Arguição de Descumprimento de Preceito Fundamental n ${ }^{\circ}$ 54-8. Voto do Ministro Relator Marco Aurélio. Disponível em: <http://www.stf.jus.br/arquivo/cms/noticiaNoticiaStf/anexo/ADPF54.pdf>. Acesso em: 16 abr. 2012, p. 79.

${ }^{1122}$ Arguição de Descumprimento de Preceito Fundamental n ${ }^{\circ}$ 54-8. Voto do Ministro Relator Marco Aurélio. Disponível em: <http://www.stf.jus.br/arquivo/cms/noticiaNoticiaStf/anexo/ADPF54.pdf>. Acesso em: 16 abr. 2012, p. 80.

${ }^{1123}$ Arguição de Descumprimento de Preceito Fundamental no 54-8. Voto lido em plenário pela Ministra Rosa Weber. Disponível em: <http://www.youtube.com/watch?v=E2js96aasjY\&feature=BFa\&list=PL7655E B015996CBBE> . Acesso em: 27 abr. 2012. Vide também comentários ao voto proferido no site do STF. Disponível em:< http://www.stf.jus.br/portal/cms/verNoticiaDetalhe.asp?idConteudo=204755>. Acesso em: 27 abr. 2012.

${ }^{1124}$ Arguição de Descumprimento de Preceito Fundamental no 54-8. Voto lido em plenário pela Ministra Rosa Weber. Disponível em: <http://www.youtube.com/watch?v=E2js96aasjY\&feature=BFa\&list=PL7655E B015996CBBE> . Acesso em: 27 abr. 2012 (0:07:33- 0:07:34). 
aborto $^{1125}$; ii) se houve vontade do legislador de excluir a anencefalia do rol de excludentes para o crime de aborto $^{1126}$; iii) a ponderação dos valores em conflito: a liberdade, dignidade e saúde da mulher de um lado, e a vida do feto anencéfalo de outro; e iv) se a criminalização desse tipo de aborto, de feto anencéfalo, sem viabilidade de vida extrauterina, pode violar o direito reprodutivos da mulher.

Após tecer uma crítica sobre os conceitos fornecidos pelas ciências, a Ministra lembrou que tais conceitos não são estáveis, e que, para julgar o caso, seria válido apenas o conceito jurídico $^{1127}$.

A partir daí, Weber analisou o direito penal e civil. Em primeiro lugar, analisou as penas trazidas pelo Código Penal, destacando que crimes que versam sobre a relação entre o feto e a gestante está sujeita a penas inferiores às reservadas às relações entre dois indivíduos plenamente formados ${ }^{1128}$. Além disso, lembrou a Ministra que o direito à vida no Código Penal não é um valor único e absoluto, pois não houve interesse do legislador em proteger o feto em detrimento da mãe no caso de estupro, por exemplo ${ }^{1129}$. Para Rosa Weber, o termo vida, para o Código Penal, poderia ser substituído, conforme a linguagem do Direito Penal, pela "manutenção de sinais vitais do ser humano", sendo necessário saber quais seriam esses sinais vitais ${ }^{1130}$. Para a Ministra, não há indicação desses sinais ${ }^{1131}$.

O Código Civil também não conceitua vida, embora reconheça o interesse de protegerse o feto ${ }^{1132}$. No entanto, é necessário esclarecer que o âmbito da proteção se dá com o

${ }^{1125}$ Arguição de Descumprimento de Preceito Fundamental no 54-8. Voto lido em plenário pela Ministra Rosa Weber. Disponível em: <http://www.youtube.com/watch?v=E2js96aasjY\&feature=BFa\&list=PL7655E B015996CBBE> . Acesso em: 27 abr. 2012 (0:07:38).

${ }^{1126}$ Arguição de Descumprimento de Preceito Fundamental no 54-8. Voto lido em plenário pela Ministra Rosa Weber. Disponível em: <http://www.youtube.com/watch?v=E2js96aasjY\&feature=BFa\&list=PL7655E B015996CBBE> . Acesso em: 27 abr. 2012 (0:08:30-0:38:05).

${ }_{1127}$ Arguição de Descumprimento de Preceito Fundamental no 54-8. Voto lido em plenário pela Ministra Rosa Weber. Disponível em: <http://www.youtube.com/watch?v=E2js96aasjY\&feature=BFa\&list=PL7655E B015996CBBE> . Acesso em: 27 abr. 2012 (01439-03805).

${ }^{1128}$ Arguição de Descumprimento de Preceito Fundamental no $54-8$. Voto lido em plenário pela Ministra Rosa Weber. Disponível em: <http://www.youtube.com/watch?v=E2js96aasjY\&feature=BFa\&list=PL7655E B015996CBBE> . Acesso em: 27 abr. 2012 (0:40:01).

${ }^{1129}$ Arguição de Descumprimento de Preceito Fundamental no 54-8. Voto lido em plenário pela Ministra Rosa Weber. Disponível em: <http://www.youtube.com/watch?v=E2js96aasjY\&feature=BFa\&list=PL7655E B015996CBBE> . Acesso em: 27 abr. 2012 (0:40:30).

${ }^{1130}$ Arguição de Descumprimento de Preceito Fundamental no 54-8. Voto lido em plenário pela Ministra Rosa Weber. Disponível em: <http://www.youtube.com/watch?v=E2js96aasjY\&feature=BFa\&list=PL7655E B015996CBBE> . Acesso em: 27 abr. 2012 (0:40:46).

${ }^{1131}$ Arguição de Descumprimento de Preceito Fundamental no 54-8. Voto lido em plenário pela Ministra Rosa Weber. Disponível em: <http://www.youtube.com/watch?v=E2js96aasjY\&feature=BFa\&list=PL7655E B015996CBBE> . Acesso em: 27 abr. 2012 (0:40:54-0:41:11).

${ }^{1132}$ Arguição de Descumprimento de Preceito Fundamental no 54-8. Voto lido em plenário pela Ministra Rosa Weber. Disponível em: <http://www.youtube.com/watch?v=E2js96aasjY\&feature=BFa\&list=PL7655E B015996CBBE> . Acesso em: 27 abr. 2012 (0:44:39). 
nascimento com vida, com o início da personalidade jurídica do indivíduo ${ }^{1133}$. A Ministra busca conceitos na área de biética ${ }^{1134}$, e cita a lei de doação de órgãos (lei $\mathrm{n}^{\circ}$ 11.434/97), afirmando que o direito protege a vida, observada a existência de atividades psíquicas, e não a mera vida orgânica ou atos reflexos ${ }^{1135}$. Por outro lado, não quer dizer, na visão da Ministra que não seja possível proteger-se um organismo em funcionamento, mas essa proteção não é absoluta $^{1136}$.

Para a Ministra, a contribuição da medicina se dará com a indicação da morte cerebral que constituirá um critério seguro para determinar o conceito de vida e de morte ${ }^{1137}$. Assim como ocorreu com o embrião na análise da lei de biossegurança na ADI 3510, segundo Weber, para ser tutelado pelo direito, o organismo deve ter condições de ser pessoa, possuindo o mínimo intrínseco das capacidades humanas ${ }^{1138}$. Essa é a vida protegida pela Constituição, conforme o entendimento da Ministra ${ }^{1139}$. Portanto, para ela, a anencefalia não é compatível com o conceito de aborto ${ }^{1140}$, pois, para este existir, é necessário que exista também vida neste sentido ${ }^{1141}$. Assim, concluiu a Ministra que interrupção da gravidez de feto anencéfalo é fato atípico, e inseri-la como fato típico seria inconstitucional, já que a vida que

\footnotetext{
${ }^{1133}$ Arguição de Descumprimento de Preceito Fundamental no $54-8$. Voto lido em plenário pela Ministra Rosa Weber. Disponível em: <http://www.youtube.com/watch?v=E2js96aasjY\&feature=BFa\&list=PL7655E B015996CBBE> . Acesso em: 27 abr. 2012 (0:45:50-0:46:10).

${ }^{1134}$ Arguição de Descumprimento de Preceito Fundamental no $54-8$. Voto lido em plenário pela Ministra Rosa Weber. Disponível em: <http://www.youtube.com/watch?v=E2js96aasjY\&feature=BFa\&list=PL7655E B015996CBBE> . Acesso em: 27 abr. 2012 (0:47:10).

${ }_{1135}$ Arguição de Descumprimento de Preceito Fundamental no $54-8$. Voto lido em plenário pela Ministra Rosa Weber. Disponível em: <http://www.youtube.com/watch?v=E2js96aasjY\&feature=BFa\&list=PL7655E B015996CBBE> . Acesso em: 27 abr. 2012 (0:47:30-0:48:24).

${ }^{1136}$ Arguição de Descumprimento de Preceito Fundamental n ${ }^{\circ} 54-8$. Voto lido em plenário pela Ministra Rosa Weber. Disponível em: <http://www.youtube.com/watch?v=E2js96aasjY\&feature=BFa\&list=PL7655E B015996CBBE> . Acesso em: 27 abr. 2012 (0:48:32-0:49:25).

${ }^{1137}$ Arguição de Descumprimento de Preceito Fundamental no ${ }^{\circ} 54-8$. Voto lido em plenário pela Ministra Rosa Weber. Disponível em: <http://www.youtube.com/watch?v=E2js96aasjY\&feature=BFa\&list=PL7655E B015996CBBE> . Acesso em: 27 abr. 2012 (0:49:25-0:52:15).

${ }_{1138}$ Arguição de Descumprimento de Preceito Fundamental n ${ }^{\circ}$ 54-8. Voto lido em plenário pela Ministra Rosa Weber. Disponível em: <http://www.youtube.com/watch?v=E2js96aasjY\&feature=BFa\&list=PL7655E B015996CBBE> . Acesso em: 27 abr. 2012 (0:52:15-0:55:35).

${ }_{1139}$ Arguição de Descumprimento de Preceito Fundamental no ${ }^{\circ} 54-8$. Voto lido em plenário pela Ministra Rosa Weber. Disponível em: <http://www.youtube.com/watch?v=E2js96aasjY\&feature=BFa\&list=PL7655E B015996CBBE> . Acesso em: 27 abr. 2012 (0:57:05).

1140 Arguição de Descumprimento de Preceito Fundamental no $54-8$. Voto lido em plenário pela Ministra Rosa Weber. Disponível em: <http://www.youtube.com/watch?v=E2js96aasjY\&feature=BFa\&list=PL7655E B015996CBBE> . Acesso em: 27 abr. 2012 (0:56:34-0:56:37).

${ }^{1141}$ Arguição de Descumprimento de Preceito Fundamental no $54-8$. Voto lido em plenário pela Ministra Rosa Weber. Disponível em: <http://www.youtube.com/watch?v=E2js96aasjY\&feature=BFa\&list=PL7655E B015996CBBE> . Acesso em: 27 abr. 2012 (0:56:38-0:57:15).
} 
a Constituição protege é outra ${ }^{1142}$. Uma proibição violaria a liberdade de escolha da gestante $^{1143}$.

Quanto à vontade do legislador, a Ministra entendeu que ela não poderia violar a Constituição Federal ${ }^{1144}$, e que muitas vezes a lei é feita de forma atécnica para ser aprovada politicamente, deixando as dúvidas para serem resolvidas pelo Poder Judiciário ${ }^{1145}$.

Com relação à ponderação de valores, Rosa Weber entendeu que a técnica não mede propriamente os valores em jogo, mas, sim, os argumentos apresentados ${ }^{1146}$, pois os valores têm o mesmo peso em uma sociedade democrática ${ }^{1147}$. Caberia falar, então, para a Ministra, na proporcionalidade em sentido estrito para se justificar as restrições de um princípio em relação a outro ${ }^{1148}$. Esclareceu a Ministra que, neste caso concreto, há dúvidas sobre os direitos do feto, mas não há dúvida sobre os direitos da gestante ${ }^{1149}$. Há dúvidas também sobre a vontade do legislador. A discussão, para ela, diz respeito à possibilidade de a anencefalia estar incluída ou não no tipo penal contido nos artigos 124 e 126, e não se seria uma hipótese de excludente ${ }^{1150}$.

Por fim, quanto ao quarto ponto analisado, a respeito de encontrar-se justificada (ou não) a criminalização da conduta da gestante ${ }^{1151}$, entendeu a Ministra que é dificil valorar o

\footnotetext{
${ }^{1142}$ Arguição de Descumprimento de Preceito Fundamental no $54-8$. Voto lido em plenário pela Ministra Rosa Weber. Disponível em: <http://www.youtube.com/watch?v=E2js96aasjY\&feature=BFa\&list=PL7655E B015996CBBE> . Acesso em: 27 abr. 2012 (0:57:50).

${ }_{1143}$ Arguição de Descumprimento de Preceito Fundamental no ${ }^{\circ}$ 54-8. Voto lido em plenário pela Ministra Rosa Weber. Disponível em: <http://www.youtube.com/watch?v=E2js96aasjY\&feature=BFa\&list=PL7655E B015996CBBE> . Acesso em: 27 abr. 2012 (0:58:00-0:58:04).

1144 Arguição de Descumprimento de Preceito Fundamental no $54-8$. Voto lido em plenário pela Ministra Rosa Weber. Disponível em: <http://www.youtube.com/watch?v=E2js96aasjY\&feature=BFa\&list=PL7655E B015996CBBE> . Acesso em: 27 abr. 2012 (1:00:00-1:00:20).

${ }_{1145}$ Arguição de Descumprimento de Preceito Fundamental no $54-8$. Voto lido em plenário pela Ministra Rosa Weber. Disponível em: <http://www.youtube.com/watch?v=E2js96aasjY\&feature=BFa\&list=PL7655E B015996CBBE> . Acesso em: 27 abr. 2012 (0:59:51-0:59:59).

${ }_{1146}$ Arguição de Descumprimento de Preceito Fundamental n ${ }^{\circ} 54-8$. Voto lido em plenário pela Ministra Rosa Weber. Disponível em: <http://www.youtube.com/watch?v=E2js96aasjY\&feature=BFa\&list=PL7655E B015996CBBE> . Acesso em: 27 abr. 2012 (1:01:08-1:01:11).

1147 Arguição de Descumprimento de Preceito Fundamental n ${ }^{\circ} 54-8$. Voto lido em plenário pela Ministra Rosa Weber. Disponível em: <http://www.youtube.com/watch?v=E2js96aasjY\&feature=BFa\&list=PL7655E B015996CBBE> . Acesso em: 27 abr. 2012 (1:01:12-1:01:30).

${ }^{1148}$ Arguição de Descumprimento de Preceito Fundamental no $54-8$. Voto lido em plenário pela Ministra Rosa Weber. Disponível em: <http://www.youtube.com/watch?v=E2js96aasjY\&feature=BFa\&list=PL7655E B015996CBBE> . Acesso em: 27 abr. 2012 (1:01:31-1:02:03).

${ }_{1149}$ Arguição de Descumprimento de Preceito Fundamental no ${ }^{\circ} 54-8$. Voto lido em plenário pela Ministra Rosa Weber. Disponível em: <http://www.youtube.com/watch?v=E2js96aasjY\&feature=BFa\&list=PL7655E B015996CBBE> . Acesso em: 27 abr. 2012 (1:02:14-1:02:18).

${ }_{1150}$ Arguição de Descumprimento de Preceito Fundamental no ${ }^{\circ} 54-8$. Voto lido em plenário pela Ministra Rosa Weber. Disponível em: <http://www.youtube.com/watch?v=E2js96aasjY\&feature=BFa\&list=PL7655E B015996CBBE> . Acesso em: 27 abr. 2012 (1:2:19-1:03:10).

${ }^{1151}$ Arguição de Descumprimento de Preceito Fundamental no $54-8$. Voto lido em plenário pela Ministra Rosa Weber. Disponível em: <http://www.youtube.com/watch?v=E2js96aasjY\&feature=BFa\&list=PL7655E B015996CBBE> . Acesso em: 27 abr. 2012 (1:03:37-1:04:06).
} 
direito à vida do feto ${ }^{1152}$, pois, para tanto, seria necessário recorrer ao Direito Penal que, cada vez mais, mostra-se ineficaz para solucionar problemas concretos, causando mais custos à sociedade $^{1153}$. Além disso, para Weber, não há um interesse social de tutelar uma vida que não irá se desenvolver socialmente, violando o direito reprodutivo da mulher ${ }^{154}$. Finalizou a Ministra seu voto dizendo que aquelas mulheres que optaram por dar à luz o anencéfalo exercitaram seu direito de escolha e tiveram sua vontade respeitada ${ }^{1155}$.

\subsubsection{Voto do Ministro Joaquim Barbosa}

O Ministro Joaquim Barbosa não leu o seu voto em plenário, apenas deixando-o para juntada. Menciona, entretanto, que seu voto é o mesmo já publicado no HC 84.025/2004 ${ }^{1156}$, que já analisamos anteriormente, tendo sofrido poucas alterações.

Dessa forma, vale relembrar que, como já estudado anteriormente neste trabalho, o Ministro Joaquim Barbosa analisa dois argumentos centrais: i) se a vida do nascituro está protegido pelo Direito Penal, e, ii) se o aborto eugênico pode ser inserido em uma das hipóteses de excludente do artigo 128 do Código Penal ${ }^{1157}$.

\footnotetext{
${ }^{1152}$ Arguição de Descumprimento de Preceito Fundamental $n^{\circ}$ 54-8. Voto lido em plenário pela Ministra Rosa Weber. Disponível em: <http://www.youtube.com/watch?v=E2js96aasjY\&feature=BFa\&list=PL7655E B015996CBBE> . Acesso em: 27 abr. 2012 (1:03:55).

${ }^{1153}$ Arguição de Descumprimento de Preceito Fundamental no 54-8. Voto lido em plenário pela Ministra Rosa Weber. Disponível em: <http://www.youtube.com/watch?v=E2js96aasjY\&feature=BFa\&list=PL7655E B015996CBBE> . Acesso em: 27 abr. 2012 (1:04:26-1:05:20).

${ }_{1154}$ Arguição de Descumprimento de Preceito Fundamental no $54-8$. Voto lido em plenário pela Ministra Rosa Weber. Disponível em: <http://www.youtube.com/watch?v=E2js96aasjY\&feature=BFa\&list=PL7655E B015996CBBE> . Acesso em: 27 abr. 2012 (1:05:20-1:06:20).

${ }^{1155}$ Arguição de Descumprimento de Preceito Fundamental no $54-8$. Voto lido em plenário pela Ministra Rosa Weber. Disponível em: <http://www.youtube.com/watch?v=E2js96aasjY\&feature=BFa\&list=PL7655E B015996CBBE> . Acesso em: 27 abr. 2012 (1:06:30-1:07:24).

${ }^{1156}$ Indica em plenário que o seu voto já foi publicado na obra Nos Limites da Vida. GOMES, JOAQUIM BARBOSA. Voto proferido pelo Ministro Joaquim Barbosa Gomes HC $\mathrm{n}^{\mathrm{o}}$ 84.025/2004. In: SARMENTO, Daniel; PIOVESAN, Flávia (coordenadores). Nos Limites da Vida. Rio de Janeiro: Lúmen Júris, 2006, p. 73 92.

1157 GOMES, JOAQUIM BARBOSA. Voto proferido pelo Ministro Joaquim Barbosa Gomes $\mathrm{HC} \mathrm{n}^{\circ}$ 84.025/2004. In: SARMENTO, Daniel; PIOVESAN, Flávia (coordenadores). Nos Limites da Vida. Rio de Janeiro: Lúmen Júris, 2006, p. 89.
} 
Com relação ao primeiro aspecto, o Ministro entende que há graus de proteção da vida $^{1158}$. Faz ele uma distinção no caso do feto anencéfalo que, apesar de biologicamente vivo, não encontra amparo jurídico ${ }^{1159}$.

Já com relação ao segundo argumento central, o Ministro entendeu que o legislador não dispunha de tecnologia para diagnosticar a anencefalia e que, em razão disso, trata-se de conduta atípica ${ }^{1160}$.

Por fim, vale dizer que o Ministro entendeu que deve ser garantido o exercício dos direitos reprodutivos ligados à liberdade e autodeterminação da mulher ${ }^{1161}$.

\subsubsection{Voto do Ministro Luiz Fux ${ }^{1162}$}

O Ministro Fux inicia seu voto aguçando a imaginação do auditório, destacando a situação de casais que, ao invés de planejar como será o nascimento de seu filho, encomenda um "pequeno caixão branco"1163, sinal da tristeza de uma "mulher que, em verdade, jamais conseguirá ser mãe do filho que gestava"1164.

Para o Ministro, tal situação não é tão incomum, já que apontam os dados da Organização Mundial de Saúde (OMS) que o Brasil está em $4^{\circ}$ lugar em nascimentos de fetos anencéfalos, ficando atrás somente do México, Chile e Paraguai, com uma média de 8,6 para cada 10.000 nascimentos ${ }^{1165}$.

\footnotetext{
1158 GOMES, JOAQUIM BARBOSA. Voto proferido pelo Ministro Joaquim Barbosa Gomes $\mathrm{HC} \mathrm{n}^{\circ}$ 84.025/2004. In: SARMENTO, Daniel; PIOVESAN, Flávia (coordenadores). Nos Limites da Vida. Rio de Janeiro: Lúmen Júris, 2006, p. 90.

${ }_{1159}$ GOMES, JOAQUIM BARBOSA. Voto proferido pelo Ministro Joaquim Barbosa Gomes HC $\mathrm{n}^{\circ}$ 84.025/2004. In: SARMENTO, Daniel; PIOVESAN, Flávia (coordenadores). Nos Limites da Vida. Rio de Janeiro: Lúmen Júris, 2006, p. 90-91.

1160 GOMES, JOAQUIM BARBOSA. Voto proferido pelo Ministro Joaquim Barbosa Gomes $\mathrm{HC}^{\mathrm{0}}$ 84.025/2004. In: SARMENTO, Daniel; PIOVESAN, Flávia (coordenadores). Nos Limites da Vida. Rio de Janeiro: Lúmen Júris, 2006, p. 91.

1161 GOMES, JOAQUIM BARBOSA. Voto proferido pelo Ministro Joaquim Barbosa Gomes $\mathrm{HC} \mathrm{n}^{\circ}$ 84.025/2004. In: SARMENTO, Daniel; PIOVESAN, Flávia (coordenadores). Nos Limites da Vida. Rio de Janeiro: Lúmen Júris, 2006, p. 87-88.

${ }^{1162}$ Arguição de Descumprimento de Preceito Fundamental no 54-8. Voto do Ministro Luiz Fux. Disponível em: <http://www.stf.jus.br/arquivo/cms/noticiaNoticiaStf/anexo/ADPF54LF.pdf>. Acesso em: 16 abr. 2012.

${ }^{1163}$ Arguição de Descumprimento de Preceito Fundamental no 54-8. Voto do Ministro Luiz Fux. Disponível em: $\langle$ http://www.stf.jus.br/arquivo/cms/noticiaNoticiaStf/anexo/ADPF54LF.pdf >. Acesso em: 16 abr. 2012, p. 1.

${ }^{1164}$ Arguição de Descumprimento de Preceito Fundamental no 54-8. Voto do Ministro Luiz Fux. Disponível em: $\langle$ http://www.stf.jus.br/arquivo/cms/noticiaNoticiaStf/anexo/ADPF54LF.pdf >. Acesso em: 16 abr. 2012, p. 1.

1165 Arguição de Descumprimento de Preceito Fundamental nº 54-8. Voto do Ministro Luiz Fux. Disponível em: <http://www.stf.jus.br/arquivo/cms/noticiaNoticiaStf/anexo/ADPF54LF.pdf〉. Acesso em: 16 abr. 2012, p. 1.
} 
O Ministro entende que o Poder Judiciário deva ter uma "postura minimalista", para não buscar agir como legislador ${ }^{1166}$. Vale dizer que, para Fux, pautado na doutrina de Alexy e no Direito comparado, é preciso considerar, no entanto, "o grau de violação da dignidade da mulher" nesse caso ${ }^{1167}$.

Ressalta o Ministro que $94 \%$ dos fetos anencéfalos (de acordo com CAISM/UNICAMP - Centro de Atenção Integral à saúde da mulher - ago. 2000 e jul. 2010) morrem dentro de até 24 (vinte e quatro) horas após o parto, sendo 67\% na $1^{\text {a }}$ hora, com média de vida de 51 minutos, sem considerar aqueles fetos que morreram antes do parto, ainda na barriga da mãe ${ }^{1168}$. Além disso, destaca Fux que é possível diagnosticar a anencefalia com segurança e precisão nas primeiras cinco semanas por meio de ultrassonografia ${ }^{1169}$. Ressalta ainda o Ministro que a anencefalia é irreversível e sem cura ${ }^{1170}$.

Diante desses aspectos, entendeu o Ministro que a manutenção da gestação nessas circunstâncias é equiparável à tortura ${ }^{1171}$, apoiando-se no fato de que "a interrupção da gravidez tem o condão de diminuir o sofrimento mental da gestante" ${ }^{\text {1172 }}$. Para tanto, aponta pesquisas realizadas pelo Hospital das Clínicas da Faculdade de Medicina da Universidade de São Paulo, que indicam que $60 \%$ das mulheres, após a interrupção da gravidez, não têm qualquer constrangimento de falar sobre o ocorrido e aconselhar outras gestantes a realizar o procedimento, e 91,4\% submeteriam-se novamente ao procedimento caso a situação se repetisse $^{1173}$.

Além disso, o Ministro salienta os riscos à saúde física e vida da mulher ${ }^{1174}: 38 \%$ de fetos morrem dentro do útero ${ }^{1175}$, há um aumento excessivo do líquido amniótico ${ }^{1176}$

\footnotetext{
${ }^{1166}$ Arguição de Descumprimento de Preceito Fundamental n ${ }^{\circ}$ 54-8. Voto do Ministro Luiz Fux. Disponível em: $\langle$ http://www.stf.jus.br/arquivo/cms/noticiaNoticiaStf/anexo/ADPF54LF.pdf $>$. Acesso em: 16 abr. 2012, p. 3-4. ${ }^{1167}$ Arguição de Descumprimento de Preceito Fundamental no 54-8. Voto do Ministro Luiz Fux. Disponível em: $\langle$ http://www.stf.jus.br/arquivo/cms/noticiaNoticiaStf/anexo/ADPF54LF.pdf $>$. Acesso em: 16 abr. 2012, p. 5.

${ }_{1168}$ Arguição de Descumprimento de Preceito Fundamental n ${ }^{\circ}$ 54-8. Voto do Ministro Luiz Fux. Disponível em: $\langle$ http://www.stf.jus.br/arquivo/cms/noticiaNoticiaStf/anexo/ADPF54LF.pdf >. Acesso em: 16 abr. 2012, p. 5. ${ }_{1169}$ Arguição de Descumprimento de Preceito Fundamental no 54-8. Voto do Ministro Luiz Fux. Disponível em: $\langle$ http://www.stf.jus.br/arquivo/cms/noticiaNoticiaStf/anexo/ADPF54LF.pdf $>$. Acesso em: 16 abr. 2012, p. 6.

1170 Arguição de Descumprimento de Preceito Fundamental n 54-8. Voto do Ministro Luiz Fux. Disponível em: $\langle$ http://www.stf.jus.br/arquivo/cms/noticiaNoticiaStf/anexo/ADPF54LF.pdf >. Acesso em: 16 abr. 2012, p. 7. ${ }_{1171}$ Arguição de Descumprimento de Preceito Fundamental no 54-8. Voto do Ministro Luiz Fux. Disponível em: $<$ http://www.stf.jus.br/arquivo/cms/noticiaNoticiaStf/anexo/ADPF54LF.pdf >. Acesso em: 16 abr. 2012, p. 7.

1172 Arguição de Descumprimento de Preceito Fundamental n ${ }^{\circ}$ 54-8. Voto do Ministro Luiz Fux. Disponível em: $\langle$ http://www.stf.jus.br/arquivo/cms/noticiaNoticiaStf/anexo/ADPF54LF.pdf >. Acesso em: 16 abr. 2012, p. 7.

${ }^{1173}$ Arguição de Descumprimento de Preceito Fundamental no 54-8. Voto do Ministro Luiz Fux. Disponível em: $\langle$ http://www.stf.jus.br/arquivo/cms/noticiaNoticiaStf/anexo/ADPF54LF.pdf >. Acesso em: 16 abr. 2012, p. 8.

${ }^{1174}$ Arguição de Descumprimento de Preceito Fundamental no 54-8. Voto do Ministro Luiz Fux. Disponível em: $\langle$ http://www.stf.jus.br/arquivo/cms/noticiaNoticiaStf/anexo/ADPF54LF.pdf >. Acesso em: 16 abr. 2012, p. 9-10. 1175 Arguição de Descumprimento de Preceito Fundamental no 54-8. Voto do Ministro Luiz Fux. Disponível em: <http://www.stf.jus.br/arquivo/cms/noticiaNoticiaStf/anexo/ADPF54LF.pdf>. Acesso em: 16 abr. 2012, p. 9.
} 
(polihidrâmnio) durante a gravidez, e a ausência de pescoço e o tamanho pequeno da cabeça podem aumentar o risco no parto ${ }^{1177}$.

Em razão disso, destaca o Ministro Fux a análise da constitucionalização do Direito Penal $^{1178}$ que deveria agir na estrita necessidade para garantir a proteção dos valores ${ }^{1179}$. Para ele, o Direito Penal deve-se "sujeitar aos princípios e regras dos direitos fundamentais"1180.

Destaca Fux três premissas principais que devem orientar o direito penal ${ }^{1181}$ : i) a reserva legal e liberdade de conformação do legislador ${ }^{182}$. Conforme essa premissa, a “tipificação de condutas penais e a fixação de penas aplicáveis são matérias reservadas à lei"1183 e ao reconhecimento da liberdade de conformação do legislador, observando "as demandas sociais" 1184 e as "circunstâncias políticas e econômicas de cada época"1185. Serviria, assim, a Constituição Federal como "fonte de legitimação e de limitação do legislador"1186. ii) a premissa garantista, porque, para restringir o direito à liberdade do indivíduo, é preciso observar-se os seus direitos individuais ${ }^{1187}$, considerando-se o "princípio da razoabilidadeproporcionalidade e especialmente na dimensão da redação do excesso" ${ }^{\text {"188 }}$. iii) O dever de proteção - o Estado deve proteger os "bens jurídicos constitucionalmente relevantes, como a

Dados de 10 anos colhidos no Hospital da Mulher da UNICAMP. Disponível em: $\langle$ http://www.stf.jus.br/arquivo/cms/noticiaNoticiaStf/anexo/ADPF54LF.pdf >. Acesso em: 16 abr. 2012, p. 9.

${ }^{1176}$ Em $15 \%$ dos casos. Arguição de Descumprimento de Preceito Fundamental no 54-8. Voto do Ministro Luiz Fux. Disponível em: 〈http://www.stf.jus.br/arquivo/cms/noticiaNoticiaStf/anexo/ADPF54LF.pdf〉. Acesso em: 16 abr. 2012, p. 9.

${ }_{1177}$ Arguição de Descumprimento de Preceito Fundamental no 54-8. Voto do Ministro Luiz Fux. Disponível em: $\langle$ http://www.stf.jus.br/arquivo/cms/noticiaNoticiaStf/anexo/ADPF54LF.pdf >. Acesso em: 16 abr. 2012, p. 9.

${ }^{1178}$ Arguição de Descumprimento de Preceito Fundamental no 54-8. Voto do Ministro Luiz Fux. Disponível em: <http://www.stf.jus.br/arquivo/cms/noticiaNoticiaStf/anexo/ADPF54LF.pdf>. Acesso em: 16 abr. 2012, p. 10.

${ }^{1179}$ Arguição de Descumprimento de Preceito Fundamental no 54-8. Voto do Ministro Luiz Fux. Disponível em: $\langle$ http://www.stf.jus.br/arquivo/cms/noticiaNoticiaStf/anexo/ADPF54LF.pdf $>$. Acesso em: 16 abr. 2012, p. 1011.

${ }^{1180}$ Arguição de Descumprimento de Preceito Fundamental no 54-8. Voto do Ministro Luiz Fux. Disponível em: <http://www.stf.jus.br/arquivo/cms/noticiaNoticiaStf/anexo/ADPF54LF.pdf>. Acesso em: 16 abr. 2012, p. 11.

${ }_{1181}$ Arguição de Descumprimento de Preceito Fundamental n ${ }^{\circ}$ 54-8. Voto do Ministro Luiz Fux. Disponível em: <http://www.stf.jus.br/arquivo/cms/noticiaNoticiaStf/anexo/ADPF54LF.pdf>. Acesso em: 16 abr. 2012, p. 11.

${ }^{1182}$ Arguição de Descumprimento de Preceito Fundamental no 54-8. Voto do Ministro Luiz Fux. Disponível em: <http://www.stf.jus.br/arquivo/cms/noticiaNoticiaStf/anexo/ADPF54LF.pdf>. Acesso em: 16 abr. 2012, p. 11.

${ }^{1183}$ Arguição de Descumprimento de Preceito Fundamental no 54-8. Voto do Ministro Luiz Fux. Disponível em: <http://www.stf.jus.br/arquivo/cms/noticiaNoticiaStf/anexo/ADPF54LF.pdf>. Acesso em: 16 abr. 2012, p. 11.

${ }^{1184}$ Arguição de Descumprimento de Preceito Fundamental no 54-8. Voto do Ministro Luiz Fux. Disponível em: $<$ http://www.stf.jus.br/arquivo/cms/noticiaNoticiaStf/anexo/ADPF54LF.pdf>. Acesso em: 16 abr. 2012, p. 12.

${ }^{1185}$ Arguição de Descumprimento de Preceito Fundamental no 54-8. Voto do Ministro Luiz Fux. Disponível em: $\langle$ http://www.stf.jus.br/arquivo/cms/noticiaNoticiaStf/anexo/ADPF54LF.pdf >. Acesso em: 16 abr. 2012, p. 12.

${ }^{1186}$ Arguição de Descumprimento de Preceito Fundamental no 54-8. Voto do Ministro Luiz Fux. Disponível em: <http://www.stf.jus.br/arquivo/cms/noticiaNoticiaStf/anexo/ADPF54LF.pdf>. Acesso em: 16 abr. 2012, p. 12.

${ }_{1187}$ Arguição de Descumprimento de Preceito Fundamental no 54-8. Voto do Ministro Luiz Fux. Disponível em: $\langle\mathrm{http} / / /$ www.stf.jus.br/arquivo/cms/noticiaNoticiaStf/anexo/ADPF54LF.pdf $>$. Acesso em: 16 abr. 2012, p. 1213.

${ }^{1188}$ Arguição de Descumprimento de Preceito Fundamental no 54-8. Voto do Ministro Luiz Fux. Disponível em: <http://www.stf.jus.br/arquivo/cms/noticiaNoticiaStf/anexo/ADPF54LF.pdf>. Acesso em: 16 abr. 2012, p. 13. 
vida, a dignidade, a integridade das pessoas e a propriedade" ${ }^{1189}$, e, se não os proteger eficientemente, também viola a Constituição Federal ${ }^{1190}$.

Admite o Ministro que, em casos especiais, é preciso fazer uma leitura moral da Constituição Federal $^{1191}$, buscando a ponderação de princípios $^{1192}$. Em razão desses argumentos, entende o Ministro que o artigo 128 deve sofrer uma "reeleitura"1193, tendo em vista as "novas necessidades científicas e sociais". Acrescenta Fux que a ultrassonografia surge em 1940, razão pela qual inexistiam os meios de diagnóstico de anencefalia quando da edição do Código Penal ${ }^{1194}$, sendo possível por isso fazer uso da ferramenta aristotélica da "equidade integrativa", de forma a integrar a "omissão legislativa com aquilo que teria dito o legislador se tivesse conhecido do caso em questão"1195. Ressalta ainda o Ministro a “permissão do aborto sentimental" para corroborar tal assertiva ${ }^{196}$, de modo a demonstrar que o legislador de 1940 já tutelava a saúde psíquica da mulher, admitindo o aborto de "um feto sadio" 1197 .

Para o Ministro, o "sacrifício da penalização"1198 da gestante de feto anencéfalo não é "necessário aos fins do direito punitivo" "1199, mas é desproporcional "diante da inafastável defesa da dignidade da mulher" ${ }^{1200}$, de modo que, "ainda que não se trilhe o caminho da exclusão da antijuridicidade da conduta" ${ }^{1201}$, a gestante não deve ser punida. Para Fux, o

\footnotetext{
${ }^{1189}$ Arguição de Descumprimento de Preceito Fundamental no 54-8. Voto do Ministro Luiz Fux. Disponível em: <http://www.stf.jus.br/arquivo/cms/noticiaNoticiaStf/anexo/ADPF54LF.pdf>. Acesso em: 16 abr. 2012, p. 13. ${ }_{1190}$ Arguição de Descumprimento de Preceito Fundamental no 54-8. Voto do Ministro Luiz Fux. Disponível em: <http://www.stf.jus.br/arquivo/cms/noticiaNoticiaStf/anexo/ADPF54LF.pdf>. Acesso em: 16 abr. 2012, p. 13. ${ }^{1191}$ Arguição de Descumprimento de Preceito Fundamental no 54-8. Voto do Ministro Luiz Fux. Disponível em: <http://www.stf.jus.br/arquivo/cms/noticiaNoticiaStf/anexo/ADPF54LF.pdf>. Acesso em: 16 abr. 2012, p. 14. ${ }^{1192}$ Arguição de Descumprimento de Preceito Fundamental no 54-8. Voto do Ministro Luiz Fux. Disponível em: <http://www.stf.jus.br/arquivo/cms/noticiaNoticiaStf/anexo/ADPF54LF.pdf>. Acesso em: 16 abr. 2012, p. 14. ${ }^{1193}$ Arguição de Descumprimento de Preceito Fundamental no 54-8. Voto do Ministro Luiz Fux. Disponível em: $<$ http://www.stf.jus.br/arquivo/cms/noticiaNoticiaStf/anexo/ADPF54LF.pdf >. Acesso em: 16 abr. 2012, p. 15. ${ }_{1194}$ Arguição de Descumprimento de Preceito Fundamental no 54-8. Voto do Ministro Luiz Fux. Disponível em: <http://www.stf.jus.br/arquivo/cms/noticiaNoticiaStf/anexo/ADPF54LF.pdf>. Acesso em: 16 abr. 2012, p. 15. ${ }^{1195}$ Arguição de Descumprimento de Preceito Fundamental no 54-8. Voto do Ministro Luiz Fux. Disponível em: $<$ http://www.stf.jus.br/arquivo/cms/noticiaNoticiaStf/anexo/ADPF54LF.pdf >. Acesso em: 16 abr. 2012, p. 15. 1196 Arguição de Descumprimento de Preceito Fundamental no 54-8. Voto do Ministro Luiz Fux. Disponível em: $<$ http://www.stf.jus.br/arquivo/cms/noticiaNoticiaStf/anexo/ADPF54LF.pdf >. Acesso em: 16 abr. 2012, p. 15. ${ }^{1197}$ Arguição de Descumprimento de Preceito Fundamental no 54-8. Voto do Ministro Luiz Fux. Disponível em: $<$ http://www.stf.jus.br/arquivo/cms/noticiaNoticiaStf/anexo/ADPF54LF.pdf>. Acesso em: 16 abr. 2012, p. 15. ${ }^{1198}$ Arguição de Descumprimento de Preceito Fundamental no 54-8. Voto do Ministro Luiz Fux. Disponível em: <http://www.stf.jus.br/arquivo/cms/noticiaNoticiaStf/anexo/ADPF54LF.pdf>. Acesso em: 16 abr. 2012, p. 17. ${ }_{1199}$ Arguição de Descumprimento de Preceito Fundamental no 54-8. Voto do Ministro Luiz Fux. Disponível em: $\langle$ http://www.stf.jus.br/arquivo/cms/noticiaNoticiaStf/anexo/ADPF54LF.pdf〉. Acesso em: 16 abr. 2012, p. 17. ${ }^{1200}$ Arguição de Descumprimento de Preceito Fundamental n ${ }^{\circ}$ 54-8. Voto do Ministro Luiz Fux. Disponível em: <http://www.stf.jus.br/arquivo/cms/noticiaNoticiaStf/anexo/ADPF54LF.pdf>. Acesso em: 16 abr. 2012, p. 17. ${ }^{1201}$ Arguição de Descumprimento de Preceito Fundamental no 54-8. Voto do Ministro Luiz Fux. Disponível em: <http://www.stf.jus.br/arquivo/cms/noticiaNoticiaStf/anexo/ADPF54LF.pdf>. Acesso em: 16 abr. 2012, p. 17.
} 
perdão judicial, que exclui a punidade quando as consequências do delito atingem o próprio agente de forma tão grave que a sanção penal se torna desnecessária, bem como o critério da imprescritibilidade da pena, insculpido no artigo 59 da lei penal, revelam de forma cristalina a suma injustiça e a reprovação no teste da razoabilidade da criminalização do aborto de feto anencéfalo ${ }^{1202}$.

Continua o Ministro no sentido de que o Direito Penal deve destinar-se à punir "condutas aviltadas para a vida em comunidade"1203, o que não é o caso do aborto do feto anencéfalo. Para Fux, o caso em tela refere-se à questão de saúde pública, que atinge "em sua maioria as mulheres que compõem a parcela menos abastada da população" ${ }^{1204}$, de forma que deveria ser tratada "com uma política de assistência social eficiente"

Por fim, afirma o Ministro que não se impõe às gestantes de feto anencéfalo a realização do aborto, apenas não se deve punir aqueles que decidirem fazer o procedimento $^{1206}$. Para Fux, essas pessoas não atuam contra legem ${ }^{1207}$, não estando elas obrigadas a "assistir, durante nove meses, à missa de $7^{\circ}$ dia de um filho acometido de uma doença que o levará à morte, com grave sofrimento físico e moral para a gestante" ${ }^{\Perp 208}$.

Assim, o Ministro Fux julgou a ação procedente, conferindo interpretação conforme à Constituição Federal ao artigo 128 Código Penal, de forma a não "reconhecer o crime de aborto nas interrupção voluntária da gravidez de feto anencéfalo"1209.

\subsubsection{Voto da Ministra Cármen Lúcia ${ }^{1210}$}

\footnotetext{
${ }^{1202}$ Arguição de Descumprimento de Preceito Fundamental n ${ }^{\circ}$ 54-8. Voto do Ministro Luiz Fux. Disponível em: <http://www.stf.jus.br/arquivo/cms/noticiaNoticiaStf/anexo/ADPF54LF.pdf>. Acesso em: 16 abr. 2012, p. 1718.

${ }^{1203}$ Arguição de Descumprimento de Preceito Fundamental no 54-8. Voto do Ministro Luiz Fux. Disponível em: <http://www.stf.jus.br/arquivo/cms/noticiaNoticiaStf/anexo/ADPF54LF.pdf>. Acesso em: 16 abr. 2012, p. 18.

1204 Arguição de Descumprimento de Preceito Fundamental no 54-8. Voto do Ministro Luiz Fux. Disponível em: <http://www.stf.jus.br/arquivo/cms/noticiaNoticiaStf/anexo/ADPF54LF.pdf>. Acesso em: 16 abr. 2012, p. 18.

${ }^{1205}$ Arguição de Descumprimento de Preceito Fundamental no 54-8. Voto do Ministro Luiz Fux. Disponível em: <http://www.stf.jus.br/arquivo/cms/noticiaNoticiaStf/anexo/ADPF54LF.pdf>. Acesso em: 16 abr. 2012, p. 18.

1206 Arguição de Descumprimento de Preceito Fundamental n ${ }^{\circ}$ 54-8. Voto do Ministro Luiz Fux. Disponível em: <http://www.stf.jus.br/arquivo/cms/noticiaNoticiaStf/anexo/ADPF54LF.pdf>. Acesso em: 16 abr. 2012, p. 19.

1207 Arguição de Descumprimento de Preceito Fundamental no 54-8. Voto do Ministro Luiz Fux. Disponível em: <http://www.stf.jus.br/arquivo/cms/noticiaNoticiaStf/anexo/ADPF54LF.pdf>. Acesso em: 16 abr. 2012 , p. 19.

1208 Arguição de Descumprimento de Preceito Fundamental no 54-8. Voto do Ministro Luiz Fux. Disponível em: <http://www.stf.jus.br/arquivo/cms/noticiaNoticiaStf/anexo/ADPF54LF.pdf>. Acesso em: 16 abr. 2012, p. 19.

${ }^{1209}$ Arguição de Descumprimento de Preceito Fundamental n ${ }^{\circ}$ 54-8. Voto do Ministro Luiz Fux. Disponível em: <http://www.stf.jus.br/arquivo/cms/noticiaNoticiaStf/anexo/ADPF54LF.pdf>. Acesso em: 16 abr. 2012, p. 19.

1210 Arguição de Descumprimento de Preceito Fundamental no 54-8. Voto lido em plenário pela Ministra Cármen Lúcia. Disponível em: <http://www.youtube.com/watch?v=E2js96aasjY\&list=PL7655EB015996CBBE\&index= 2\&feature=plpp_video $>$. Acesso em: 25 abr. 2012 (2:06:25-2:19:28).
} 
A seguir, passamos a destacar do voto da Ministra Cármen Lúcia os argumentos principais que utilizou sobre o tema para fundamentar a procedência da ADPF 54.

Entendeu a Ministra que, independentemente de ser favorável ou não ao aborto do feto anencéfalo, todos prezam a vida, de acordo com os conceitos que se tem "de vida e da própria vida" ${ }^{211}$. O que resta saber, para a Ministra, é o que a Constituição valora nesta ponderação ${ }^{1212}$.

A Ministra frisou que não se trata de autorizar o aborto do feto anencéfalo, mas de verificar se os dispositivos penais que tipificam o crime de aborto também poderiam ser interpretados dessa forma no caso de feto anencéfalo ${ }^{1213}$.

Cármen Lúcia não entende que essa análise possa permitir o aborto eugenésico, pois o aborto e a eugenia são práticas proibidas. $\mathrm{O}$ aborto de feto anencéfalo versa sobre a análise de inviabilidade da vida ${ }^{1214}$.

A Ministra entende que, no caso sob análise, deve ser levada em consideração a possibilidade de escolha por parte da mulher, isto é, a liberdade de continuar ou não com a gravidez de feto anencéfalo ${ }^{1215}$.

Fundamentou seu voto nos princípios da dignidade da vida e no direito à saúde ${ }^{1216}$. Para a Ministra "o útero é o primeiro berço do ser humano"1217, e, em uma gravidez de feto anencéfalo, o "berço se tranforma num pequeno esquife, a vida se entorta"1218, pois a mulher

\footnotetext{
${ }^{1211}$ Arguição de Descumprimento de Preceito Fundamental no ${ }^{54-8}$. Voto lido em plenário pela Ministra Cármen Lúcia. Disponível em: <http://www.youtube.com/watch?v=E2js96aasjY\&list=PL7655EB015996CBBE\&index= 2\&feature=plpp_video $>$. Acesso em: 25 abr. 2012 (2:07:19).

${ }_{1212}$ Arguição de Descumprimento de Preceito Fundamental no $54-8$. Voto lido em plenário pela Ministra Cármen Lúcia. Disponível em: <http://www.youtube.com/watch?v=E2js96aasjY\&list=PL7655EB015996CBBE\&index= 2\&feature=plpp_video>. Acesso em: 25 abr. 2012 (2:07:49-2:07:51).

${ }_{1213}$ Arguição de Descumprimento de Preceito Fundamental no $54-8$. Voto lido em plenário pela Ministra Cármen Lúcia. Disponível em: <http://www.youtube.com/watch?v=E2js96aasjY\&list=PL7655EB015996CBBE\&index= 2\&feature=plpp_video>. Acesso em: 25 abr. 2012 (2:08:20).

${ }_{1214}$ Arguição de Descumprimento de Preceito Fundamental no ${ }^{\circ} 54-8$. Voto lido em plenário pela Ministra Cármen Lúcia. Disponível em: <http://www.youtube.com/watch?v=E2js96aasjY\&list=PL7655EB015996CBBE\&index= 2\&feature=plpp_video $>$. Acesso em: 25 abr. 2012 ( 2:08:35-2:09:05).

${ }^{1215}$ Arguição de Descumprimento de Preceito Fundamental no $54-8$. Voto lido em plenário pela Ministra Cármen Lúcia. Disponível em: <http://www.youtube.com/watch?v=E2js96aasjY\&list=PL7655EB015996CBBE\&index= 2\&feature=plpp_video>. Acesso em: 25 abr. 2012 (2:09:20-2:09:46).

${ }_{1216}$ Arguição de Descumprimento de Preceito Fundamental no $54-8$. Voto lido em plenário pela Ministra Cármen Lúcia. Disponível em: <http://www.youtube.com/watch?v=E2js96aasjY\&list=PL7655EB015996CBBE\&index= 2\&feature=plpp_video>. Acesso em: 25 abr. 2012 (2:09:47-2:10:06).

${ }_{1217}$ Arguição de Descumprimento de Preceito Fundamental no $54-8$. Voto lido em plenário pela Ministra Cármen Lúcia. Disponível em: <http://www.youtube.com/watch?v=E2js96aasjY\&list=PL7655EB015996CBBE\&index= 2\&feature=plpp_video>. Acesso em: 25 abr. 2012 (2:10:20).

${ }^{1218}$ Arguição de Descumprimento de Preceito Fundamental no $54-8$. Voto lido em plenário pela Ministra Cármen Lúcia. Disponível em: <http://www.youtube.com/watch?v=E2js96aasjY\&list=PL7655EB015996CBBE\&index= 2\&feature=plpp_video>. Acesso em: 25 abr. 2012 (2:10:21-2:10:33).
} 
precisa enfrentar a "morte antes mesmo da vida"1219, talvez sendo esse o fator mais importante, mais sensível à dignidade da pessoa humana ${ }^{1220}$ no caso.

A Ministra não quis abordar o argumento de se o feto é pessoa ou não ${ }^{1221}$, mas o considerou um "ser" "1222, afirmando que o caso refere-se à "uma relação de seres" 1223 .

A Ministra lembrou o luto pelo que a gestante passa ao saber que concebeu um feto anencéfalo, e que, "se puder optar" pela interrupção dessa gravidez, passa por uma espécie de "luto-libertação"1224. Assim, para ela, a escolha pelo aborto do feto anencéfalo não é uma escolha fácil ${ }^{1225}$. É a escolha do possível ${ }^{1226}$. É uma "escolha de dor" ${ }^{1227}$. É a "escolha da menor dor" ${ }^{\prime 1228}$. Para a Ministra, essa escolha se coaduna com a ideia de dignidade da vida assegurada pela Constituição ${ }^{1229}$. Por essa razão, essa conduta não é criminalizável $^{1230}$.

Para Cármen Lúcia, o avanço tecnológico trouxe dois aspectos novos ao drama da anencefalia: tanto ela antecipa o sofrimento, porque a mulher passa a saber da anencefalia

${ }^{1219}$ Arguição de Descumprimento de Preceito Fundamental n ${ }^{\text {o }}$ 54-8. Voto lido em plenário pela Ministra Cármen Lúcia. Disponível em: <http://www.youtube.com/watch?v=E2js96aasjY\&list=PL7655EB015996CBBE\&index= 2\&feature=plpp_video $>$. Acesso em: 25 abr. 2012 (2:10:48-2:10:51).

${ }^{1220}$ Arguição de Descumprimento de Preceito Fundamental $n^{\circ}$ 54-8. Voto lido em plenário pela Ministra Cármen Lúcia. Disponível em: <http://www.youtube.com/watch?v=E2js96aasjY\&list=PL7655EB015996CBBE\&index= 2\&feature=plpp_video $>$. Acesso em: 25 abr. 2012 (2:10:52-2:11:00).

${ }^{1221}$ Arguição de Descumprimento de Preceito Fundamental no 54-8. Voto lido em plenário pela Ministra Cármen Lúcia. Disponível em: <http://www.youtube.com/watch?v=E2js96aasjY\&list=PL7655EB015996CBBE\&index= 2\&feature=plpp_video $>$. Acesso em: 25 abr. 2012 (2:11:10).

${ }_{1222}$ Arguição de Descumprimento de Preceito Fundamental no 54-8. Voto lido em plenário pela Ministra Cármen Lúcia. Disponível em: <http://www.youtube.com/watch?v=E2js96aasjY\&list=PL7655EB015996CBBE\&index= 2\&feature=plpp_video $>$. Acesso em: 25 abr. 2012 (2:11:11).

${ }^{1223}$ Arguição de Descumprimento de Preceito Fundamental no 54-8. Voto lido em plenário pela Ministra Cármen Lúcia. Disponível em: <http://www.youtube.com/watch?v=E2js96aasjY\&list=PL7655EB015996CBBE\&index= 2\&feature=plpp_video $>$. Acesso em: 25 abr. 2012 (2:11:01-2:11:16).

${ }^{1224}$ Arguição de Descumprimento de Preceito Fundamental no 54-8. Voto lido em plenário pela Ministra Cármen Lúcia. Disponível em: <http://www.youtube.com/watch?v=E2js96aasjY\&list=PL7655EB015996CBBE\&index= 2\&feature=plpp_video $>$. Acesso em: 25 abr. 2012 (2:11:31).

${ }^{1225}$ Arguição de Descumprimento de Preceito Fundamental no 54-8. Voto lido em plenário pela Ministra Cármen Lúcia. Disponível em: <http://www.youtube.com/watch?v=E2js96aasjY\&list=PL7655EB015996CBBE\&index= 2\&feature=plpp_video $>$. Acesso em: 25 abr. 2012 (2:12:48-2:12:57).

${ }^{1226}$ Arguição de Descumprimento de Preceito Fundamental no $54-8$. Voto lido em plenário pela Ministra Cármen Lúcia. Disponível em: <http://www.youtube.com/watch?v=E2js96aasjY\&list=PL7655EB015996CBBE\&index= 2\&feature=plpp_video $>$. Acesso em: 25 abr. 2012 (2:13:02-2:13:04).

1227 Arguição de Descumprimento de Preceito Fundamental no 54-8. Voto lido em plenário pela Ministra Cármen Lúcia. Disponível em: <http://www.youtube.com/watch?v=E2js96aasjY\&list=PL7655EB015996CBBE\&index= 2\&feature=plpp_video $>$. Acesso em: 25 abr. 2012 (2:13:14).

${ }^{1228}$ Arguição de Descumprimento de Preceito Fundamental no 54-8. Voto lido em plenário pela Ministra Cármen Lúcia. Disponível em: <http://www.youtube.com/watch?v=E2js96aasjY\&list=PL7655EB015996CBBE\&index= 2\&feature=plpp_video $>$. Acesso em: 25 abr. 2012 (2:13:17-2:13:20).

${ }^{1229}$ Arguição de Descumprimento de Preceito Fundamental no 54-8. Voto lido em plenário pela Ministra Cármen Lúcia. Disponível em: <http://www.youtube.com/watch?v=E2js96aasjY\&list=PL7655EB015996CBBE\&index= 2\&feature=plpp_video $>$. Acesso em: 25 abr. 2012 (2:13:28-2:13:38).

${ }^{1230}$ Arguição de Descumprimento de Preceito Fundamental no 54-8. Voto lido em plenário pela Ministra Cármen Lúcia. Disponível em: <http://www.youtube.com/watch?v=E2js96aasjY\&list=PL7655EB015996CBBE\&index= 2\&feature=plpp_video $>$. Acesso em: 25 abr. 2012 (2:13:50-2:13:53). 
muito mais cedo; quanto também possibilita a formação de uma decisão da mulher a respeito $^{1231}$.

Além disso, para a Ministra, é preciso levar-se em conta também o direito do pai e da família no debate, pois todos sofrem com essa situação ${ }^{1232}$; é a dignidade de todos ${ }^{1233}$.

Aponta ainda a Ministra o direito à saúde ${ }^{1234}$. É a saúde do feto, mas também da gestante $^{1235}$, que estão em jogo, devendo ser consideradas a saúde física e psíquica ${ }^{1236}$. Para ela, "não há bem jurídico a ser tutelado com sobrevalor" ${ }^{1237}$, não existindo na norma penal o que justifique a "impossibilidade total" de a mulher escolher ${ }^{1238}$.

A mulher proibida de interromper a gravidez de feto anencéfalo, para Cármen Lúcia, tem medo do que está por vir em decorrência da anencefalia, e também devido à possibilidade de sofrer um processo criminal caso escolha por realizar um aborto ${ }^{1239}$. Além disso, a mulher nessas circunstâncias vive com vergonha de expor sua incapacidade de escolha, enfatizando a Ministra a contradição da existência dessa situação "numa sociedade que se diz uma sociedade democrática com possibilidade de garantir a liberdade para todos" ${ }^{\prime 240}$.

${ }^{1231}$ Arguição de Descumprimento de Preceito Fundamental n ${ }^{\circ}$ 54-8. Voto lido em plenário pela Ministra Cármen Lúcia. Disponível em: <http://www.youtube.com/watch?v=E2js96aasjY\&list=PL7655EB015996CBBE\&index= 2\&feature=plpp_video $>$. Acesso em: 25 abr. 2012 (2:13:58-2:14:00).

${ }_{1232}$ Arguição de Descumprimento de Preceito Fundamental no 54-8. Voto lido em plenário pela Ministra Cármen Lúcia. Disponível em: <http://www.youtube.com/watch?v=E2js96aasjY\&list=PL7655EB015996CBBE\&index= 2\&feature=plpp_video $>$. Acesso em: 25 abr. 2012 (2:14:44-2:15:30).

${ }^{1233}$ Arguição de Descumprimento de Preceito Fundamental no 54-8. Voto lido em plenário pela Ministra Cármen Lúcia. Disponível em: <http://www.youtube.com/watch?v=E2js96aasjY\&list=PL7655EB015996CBBE\&index= 2\&feature=plpp_video $>$. Acesso em: 25 abr. 2012 (2:15:36).

${ }^{1234}$ Arguição de Descumprimento de Preceito Fundamental no 54-8. Voto lido em plenário pela Ministra Cármen Lúcia. Disponível em: <http://www.youtube.com/watch?v=E2js96aasjY\&list=PL7655EB015996CBBE\&index= 2\&feature=plpp_video $>$. Acesso em: 25 abr. 2012 (2:16:08).

${ }^{1235}$ Arguição de Descumprimento de Preceito Fundamental no 54-8. Voto lido em plenário pela Ministra Cármen Lúcia. Disponível em: <http://www.youtube.com/watch?v=E2js96aasjY\&list=PL7655EB015996CBBE\&index= 2\&feature=plpp_video $>$. Acesso em: 25 abr. 2012 (2:16:14).

${ }^{1236}$ Arguição de Descumprimento de Preceito Fundamental no 54-8. Voto lido em plenário pela Ministra Cármen Lúcia. Disponível em: <http://www.youtube.com/watch?v=E2js96aasjY\&list=PL7655EB015996CBBE\&index= 2\&feature=plpp_video $>$. Acesso em: 25 abr. 2012 (2:16:30-2:16:36).

${ }^{1237}$ Arguição de Descumprimento de Preceito Fundamental no 54-8. Voto lido em plenário pela Ministra Cármen Lúcia. Disponível em: <http://www.youtube.com/watch?v=E2js96aasjY\&list=PL7655EB015996CBBE\&index= 2\&feature=plpp_video $>$. Acesso em: 25 abr. 2012 (2:16:45-2:16:49).

${ }^{1238}$ Arguição de Descumprimento de Preceito Fundamental no 54-8. Voto lido em plenário pela Ministra Cármen Lúcia. Disponível em: <http://www.youtube.com/watch?v=E2js96aasjY\&list=PL7655EB015996CBBE\&index= 2\&feature=plpp_video $>$. Acesso em: 25 abr. 2012 (2:16:55).

${ }^{1239}$ Arguição de Descumprimento de Preceito Fundamental no 54-8. Voto lido em plenário pela Ministra Cármen Lúcia. Disponível em: <http://www.youtube.com/watch?v=E2js96aasjY\&list=PL7655EB015996CBBE\&index= 2\&feature=plpp_video $>$. Acesso em: 25 abr. 2012 (2:17:14-2:17:30).

${ }^{1240}$ Arguição de Descumprimento de Preceito Fundamental n ${ }^{\circ} 54-8$. Voto lido em plenário pela Ministra Cármen Lúcia. Disponível em: <http://www.youtube.com/watch?v=E2js96aasjY\&list=PL7655EB015996CBBE\&index= 2\&feature=plpp_video $>$. Acesso em: 25 abr. 2012 (2:18:02-2:18:08). 
A Ministra entende que a excludente do artigo 128 do Código Penal abarca a vida saudável ${ }^{1241}$ para a gestante, o que inclui a vida psíquica também ${ }^{1242}$, e que o juiz, ao aplicar a lei, deve levar em conta os fins para os quais a norma se destina - e, no Brasil, todas as leis devem se destinar à dignidade da pessoa humana ${ }^{1243}$.

Finaliza a Ministra Cármen Lúcia dizendo que em uma democracia a vida "impõe respeito" 1244 e, nesse caso, o feto "não tem perspectiva de vida"1245, devendo ser levada em conta a existência de outras vidas que dependerão dessa escolha ${ }^{1246}$.

Desse modo, a Ministra Cármen Lúcia também julgou a ação procedente, conferindo interpretação conforme à Constituição Federal ao artigo 128 Código Penal, de modo que a interrupção voluntária da gravidez em caso de gestação de feto anencéfalo não tipifique o crime de aborto.

\subsubsection{Voto do Ministro Ricardo Lewandowiski ${ }^{1247}$}

O Ministro Lewandowiski afirma que as principais doutrinas penais que analisam o artigo 128 do Código Penal não permitem o aborto eugenésico, de forma que o legislador, de

\footnotetext{
${ }^{1241}$ Arguição de Descumprimento de Preceito Fundamental no $54-8$. Voto lido em plenário pela Ministra Cármen Lúcia. Disponível em: <http://www.youtube.com/watch?v=E2js96aasjY\&list=PL7655EB015996CBBE\&index= 2\&feature=plpp_video $>$. Acesso em: 25 abr. 2012 (2:18:17).

${ }_{1242}$ Arguição de Descumprimento de Preceito Fundamental no $54-8$. Voto lido em plenário pela Ministra Cármen Lúcia. Disponível em: <http://www.youtube.com/watch?v=E2js96aasjY\&list=PL7655EB015996CBBE\&index= 2\&feature=plpp_video>. Acesso em: 25 abr. 2012 (2:18:20).

${ }^{1243}$ Arguição de Descumprimento de Preceito Fundamental n ${ }^{\circ}$ 54-8. Voto lido em plenário pela Ministra Cármen Lúcia. Disponível em: <http://www.youtube.com/watch?v=E2js96aasjY\&list=PL7655EB015996CBBE\&index= 2\&feature=plpp_video $>$. Acesso em: 25 abr. 2012 (2:18:35-2:18:49).

${ }^{1244}$ Arguição de Descumprimento de Preceito Fundamental n ${ }^{\circ} 54-8$. Voto lido em plenário pela Ministra Cármen Lúcia. Disponível em: <http://www.youtube.com/watch?v=E2js96aasjY\&list=PL7655EB015996CBBE\&index= 2\&feature=plpp_video>. Acesso em: 25 abr. 2012 (2:18:52).

${ }_{1245}$ Arguição de Descumprimento de Preceito Fundamental n ${ }^{\circ} 54-8$. Voto lido em plenário pela Ministra Cármen Lúcia. Disponível em: <http://www.youtube.com/watch?v=E2js96aasjY\&list=PL7655EB015996CBBE\&index= 2\&feature=plpp_video>. Acesso em: 25 abr. 2012 (2:18:56).

${ }^{1246}$ Arguição de Descumprimento de Preceito Fundamental n ${ }^{\circ}$ 54-8. Voto lido em plenário pela Ministra Cármen Lúcia. Disponível em: <http://www.youtube.com/watch?v=E2js96aasjY\&list=PL7655EB015996CBBE\&index= 2\&feature=plpp_video $>$. Acesso em: 25 abr. 2012 (2:19:01-2:19:10).

${ }_{1247}$ Arguição de Descumprimento de Preceito Fundamental n ${ }^{\circ}$ 54-8. Voto do Ministro Ricardo Lewandowiski. Disponível em: 〈http://www.stf.jus.br/arquivo/cms/noticiaNoticiaStf/anexo/ADPF54RL.pdf>. Acesso em: 16 abr. 2012.
} 
“modo explícito e deliberado, não afastou a punibilidade da interrupção da gravidez nessas situações" $" 1248$.

Além disso, para o Ministro já existiam à época da edição da lei penal exames capazes de diagnosticar a anencefalia, como é o caso do "exame do líquido amniótico" 1249.

Enfatizou ainda Lewandowiski que o papel para alterar os dispositivos do Código Penal cabe ao Congresso Nacional, "intérprete último da vontade soberana do povo"1250, que preferiu manter "intacta"1251 a legislação penal sobre o tema.

O Ministro entendeu que a interpretação conforme "configura método preferível à pura e simples declaração de inconstitucionalidade, quando mais não seja em homenagem à vontade do legislador" ${ }^{\prime 252}$, mas, para ele, existem limites para essa interpretação: i) não pode o intérprete violar disposição literal expressa em lei ${ }^{1253}$; e, ii) não pode substitui-lo ou contrariar a vontade do legislador ${ }^{1254}$, de modo que não seria possível atribuir a um texto legal uma interpretação contra legem, mesmo sob o contexto de interpretação conforme à Constituição ${ }^{1255}$, devendo o Supremo Tribunal Federal apenas exercer o papel do "legislador

\footnotetext{
${ }^{1248}$ Arguição de Descumprimento de Preceito Fundamental n ${ }^{\circ}$ 54-8. Voto do Ministro Ricardo Lewandowiski. Disponível em: 〈http://www.stf.jus.br/arquivo/cms/noticiaNoticiaStf/anexo/ADPF54RL.pdf〉. Acesso em: 16 abr. 2012, p. 5.

${ }^{1249}$ Arguição de Descumprimento de Preceito Fundamental $\mathrm{n}^{\circ}$ 54-8. Voto do Ministro Ricardo Lewandowiski. Disponível em: 〈http://www.stf.jus.br/arquivo/cms/noticiaNoticiaStf/anexo/ADPF54RL.pdf〉. Acesso em: 16 abr. 2012, p. 6.

${ }^{1250}$ Arguição de Descumprimento de Preceito Fundamental no ${ }^{\circ}$ 54-8. Voto do Ministro Ricardo Lewandowiski. Disponível em: 〈http://www.stf.jus.br/arquivo/cms/noticiaNoticiaStf/anexo/ADPF54RL.pdf〉. Acesso em: 16 abr. 2012, p. 6 .

${ }^{1251}$ Arguição de Descumprimento de Preceito Fundamental $n^{\circ}$ 54-8. Voto do Ministro Ricardo Lewandowiski. Disponível em: 〈http://www.stf.jus.br/arquivo/cms/noticiaNoticiaStf/anexo/ADPF54RL.pdf〉. Acesso em: 16 abr. 2012, p. 6 .

${ }^{1252}$ Arguição de Descumprimento de Preceito Fundamental $n^{\circ}$ 54-8. Voto do Ministro Ricardo Lewandowiski. Disponível em: 〈http://www.stf.jus.br/arquivo/cms/noticiaNoticiaStf/anexo/ADPF54RL.pdf〉. Acesso em: 16 abr. 2012, p. 9-10.

${ }^{1253}$ Arguição de Descumprimento de Preceito Fundamental n $\mathrm{n}^{\mathrm{o}}$ 54-8. Voto do Ministro Ricardo Lewandowiski. Disponível em: 〈http://www.stf.jus.br/arquivo/cms/noticiaNoticiaStf/anexo/ADPF54RL.pdf〉. Acesso em: 16 abr. 2012, p. 11.

${ }^{1254}$ Arguição de Descumprimento de Preceito Fundamental no 54-8. Voto do Ministro Ricardo Lewandowiski. Disponível em: 〈http://www.stf.jus.br/arquivo/cms/noticiaNoticiaStf/anexo/ADPF54RL.pdf〉. Acesso em: 16 abr. 2012, p. 11.

${ }_{1255}$ Arguição de Descumprimento de Preceito Fundamental no 54-8. Voto do Ministro Ricardo Lewandowiski. Disponível em: <http://www.stf.jus.br/arquivo/cms/noticiaNoticiaStf/anexo/ADPF54RL.pdf>. Acesso em: 16 abr. 2012, p. 12.
} 
negativo" 1256 , isto é, observando o "princípio da intervenção mínima"1257, sob pena de fazer a vez do legislador positivo ${ }^{1258}$.

Entendeu ainda Lewandowiski que, tratando-se de tema extremamente polêmico ${ }^{1259} \mathrm{e}$ complexo $^{1260}$, o legislador ainda não decidiu a respeito, de modo que não foi admitida outra hipótese de aborto legal ${ }^{1261}$.

O Ministro afirmou que o direito à vida encontra-se protegido pela Constituição Federal e por tratados internacionais, em especial o artigo 4.1 do Pacto de San José, e que uma decisão que autorizasse o aborto de feto anencéfalo "teria, em tese, o condão de tornar lícita a interrupção da gestação de qualquer embrião que ostente pouca ou nenhuma expectativa de vida extra-uterina" ${ }^{\prime 262}$.

Além disso, para Lewandowiski, se admitíssemos o aborto de feto anencéfalo, existiriam outros dispositivos legais que deveriam ser declarados inconstitucionais ou ser interpretados conforme à Constituição, como é o caso do próprio artigo $2^{\circ}$ do Código Civil $^{1263}$.

Ressaltou o Ministro ainda, que a Portaria 487, de 2 de março de 2007, do Ministério da Saúde, preocupa-se com os fetos anencéfalos que, mesmo com "um sistema nervoso

\footnotetext{
${ }^{1256}$ Arguição de Descumprimento de Preceito Fundamental no 54-8. Voto do Ministro Ricardo Lewandowiski. Disponível em: <http://www.stf.jus.br/arquivo/cms/noticiaNoticiaStf/anexo/ADPF54RL.pdf〉. Acesso em: 16 abr. 2012, p. 12.

${ }^{1257}$ Arguição de Descumprimento de Preceito Fundamental $\mathrm{n}^{\circ}$ 54-8. Voto do Ministro Ricardo Lewandowiski. Disponível em: 〈http://www.stf.jus.br/arquivo/cms/noticiaNoticiaStf/anexo/ADPF54RL.pdf〉. Acesso em: 16 abr. 2012, p. 13.

${ }^{1258}$ Arguição de Descumprimento de Preceito Fundamental $\mathrm{n}^{\circ}$ 54-8. Voto do Ministro Ricardo Lewandowiski. Disponível em: <http://www.stf.jus.br/arquivo/cms/noticiaNoticiaStf/anexo/ADPF54RL.pdf>. Acesso em: 16 abr. 2012, p. 13.

${ }^{1259}$ Arguição de Descumprimento de Preceito Fundamental n $\mathrm{n}^{\circ}$ 54-8. Voto do Ministro Ricardo Lewandowiski. Disponível em: 〈http://www.stf.jus.br/arquivo/cms/noticiaNoticiaStf/anexo/ADPF54RL.pdf〉. Acesso em: 16 abr. 2012, p. 14.

${ }^{1260}$ Arguição de Descumprimento de Preceito Fundamental $n^{\circ}$ 54-8. Voto do Ministro Ricardo Lewandowiski. Disponível em: 〈http://www.stf.jus.br/arquivo/cms/noticiaNoticiaStf/anexo/ADPF54RL.pdf〉. Acesso em: 16 abr. 2012, p. 14.

${ }^{1261}$ Arguição de Descumprimento de Preceito Fundamental no $54-8$. Voto do Ministro Ricardo Lewandowiski. Disponível em: 〈http://www.stf.jus.br/arquivo/cms/noticiaNoticiaStf/anexo/ADPF54RL.pdf〉. Acesso em: 16 abr. 2012, p. 14.

${ }_{1262}$ Arguição de Descumprimento de Preceito Fundamental no 54-8. Voto do Ministro Ricardo Lewandowiski. Disponível em: 〈http://www.stf.jus.br/arquivo/cms/noticiaNoticiaStf/anexo/ADPF54RL.pdf〉. Acesso em: 16 abr. 2012, p. 15.

${ }^{1263}$ Arguição de Descumprimento de Preceito Fundamental no 54-8. Voto do Ministro Ricardo Lewandowiski. Disponível em: <http://www.stf.jus.br/arquivo/cms/noticiaNoticiaStf/anexo/ADPF54RL.pdf>. Acesso em: 16 abr. 2012, p. 17.
} 
central incompleto, sentem dor e reagem a estímulos externos" ${ }^{, 1264}$. Nessa linha, se exige a "parada cardíaca irreversível” do feto anencéfalo para retirada de órgãos para transplante ${ }^{1265}$.

Por fim, destacou o Ministro que o Congresso Nacional não está alheio ao tema ${ }^{1266}$, já que existem dois projetos de lei ${ }^{1267}$ em andamento, ambos para excluir a punibilidade da prática de aborto de feto anencéfalo ${ }^{1268}$. Ressaltou Lewandowiski que o Projeto de Lei 50/2011, inclusive, passou recentemente pela Comissão de Direitos Humanos e Legislação Participativa da Câmara Alta, e lhe foi acrescentado alguns pontos: o diagnóstico deve ser subscrito por dois médicos diversos daqueles que irão participar do procedimento, e o Conselho Federal de Medicina deverá regulamentar o procedimento $^{1269}$.

Assim, Lewandowiski considerou improcedente a ADPF 54 tendo em vista que permitir a interpretação por parte do Supremo Tribunal Federal da lei no sentido de "criar, na espécie, outra causa de exclusão de punibilidade ou, o que é ainda pior, mais uma causa de exclusão de ilicitude" ${ }^{1270}$, ultrapassaria a competência privativa do Congresso Nacional ${ }^{1271}$.

\footnotetext{
${ }^{1264}$ Arguição de Descumprimento de Preceito Fundamental $n^{\circ}$ 54-8. Voto do Ministro Ricardo Lewandowiski. Disponível em: <http://www.stf.jus.br/arquivo/cms/noticiaNoticiaStf/anexo/ADPF54RL.pdf>. Acesso em: 16 abr. 2012, p. 18.

${ }^{1265}$ Arguição de Descumprimento de Preceito Fundamental no 54-8. Voto do Ministro Ricardo Lewandowiski. Disponível em: <http://www.stf.jus.br/arquivo/cms/noticiaNoticiaStf/anexo/ADPF54RL.pdf>. Acesso em: 16 abr. 2012, p. 18-19.

${ }^{1266}$ Arguição de Descumprimento de Preceito Fundamental no 54-8. Voto do Ministro Ricardo Lewandowiski. Disponível em: 〈http://www.stf.jus.br/arquivo/cms/noticiaNoticiaStf/anexo/ADPF54RL.pdf>. Acesso em: 16 abr. 2012, p. 20.

${ }^{1267}$ Projetos 4403/2004 da Deputada Jandira Feghali e Projeto de Lei 50/2011 do Senador Mozarildo Cavalvanti. Arguição de Descumprimento de Preceito Fundamental $n^{\circ}$ 54-8. Voto do Ministro Ricardo Lewandowiski. Disponível em: 〈http://www.stf.jus.br/arquivo/cms/noticiaNoticiaStf/anexo/ADPF54RL.pdf〉. Acesso em: 16 abr. 2012, p. 21. O Ministro também nos lembra dos Projetos de Lei 183 do Senador Duciomar Costa proposto e posteriormente retirado por ele mesmo e do Projeto de Lei 227, também do Senador Mozarildo Cavalcanti, que após anos parado foi arquivado. Arguição de Descumprimento de Preceito Fundamental $\mathrm{n}^{\circ}$ 54-8. Voto do Ministro Ricardo Lewandowiski. Disponível em: <http://www.stf.jus.br/arquivo/cms/noticiaNoticiaStf/anexo/ADPF54RL.pdf>. Acesso em: 16 abr. 2012, p. 22.

${ }^{1268}$ Arguição de Descumprimento de Preceito Fundamental n ${ }^{\circ}$ 54-8. Voto do Ministro Ricardo Lewandowiski. Disponível em: <http://www.stf.jus.br/arquivo/cms/noticiaNoticiaStf/anexo/ADPF54RL.pdf>. Acesso em: 16 abr. 2012, p. 21.

${ }_{1269}$ Arguição de Descumprimento de Preceito Fundamental no 54-8. Voto do Ministro Ricardo Lewandowiski. Disponível em: <http://www.stf.jus.br/arquivo/cms/noticiaNoticiaStf/anexo/ADPF54RL.pdf>. Acesso em: 16 abr. 2012, p. 23.

${ }^{1270}$ Arguição de Descumprimento de Preceito Fundamental no 54-8. Voto do Ministro Ricardo Lewandowiski. Disponível em: <http://www.stf.jus.br/arquivo/cms/noticiaNoticiaStf/anexo/ADPF54RL.pdf〉. Acesso em: 16 abr. 2012, p. 24.

${ }^{1271}$ Arguição de Descumprimento de Preceito Fundamental no 54-8. Voto do Ministro Ricardo Lewandowiski. Disponível em: 〈http://www.stf.jus.br/arquivo/cms/noticiaNoticiaStf/anexo/ADPF54RL.pdf>. Acesso em: 16 abr. 2012, p. 24.
} 


\subsubsection{Voto do Ministro Carlos Ayres Brito ${ }^{1272}$}

O Ministro Ayres Britto iniciou seu voto lembrando que o feto anencéfalo não possui uma parte vital do cérebro sem a qual está fadado a "uma parada cárdio-respiratória" pósparto, e que, em cerca de $65 \%$ dessa espécie de gestação, a morte ocorre ainda no útero, ocasionado riscos altos à mulher ${ }^{1273}$. Brevemente, o Ministro analisou também a possibilidade de interpretação conforme a constituição, acatando-a ${ }^{1274}$.

Ayres Britto destacou três aspectos que podem ser extraídos de textos normativos consensuais em que "o aborto é uma realidade do mundo do ser transportado para o mundo do dever-ser" ${ }^{275}$, concluindo, posteriormente, que o aborto é a expulsão do produto da concepção ${ }^{1276}$. Neste sentido, concluiu também Ayres Britto que o aborto é crime tipificado pelo Código Penal ${ }^{1277}$.

Ayres Britto seguiu analisando a possibilidade de se fundamentar o início da vida, ainda que em estado latente, na concepção ${ }^{1278}$, esclarecendo que não há na Constituição Federal ou no Código Penal uma definição de vida dada pelo legislador, o que o Ministro considerou "muito estranho"1279. Enfatizou ainda o Ministro que, "quanto ao início da vida, a Constituição Federal é de um silêncio de morte" ${ }^{1280}$.

\footnotetext{
${ }^{1272}$ Arguição de Descumprimento de Preceito Fundamental no $54-8$. Voto lido em plenário pelo Ministro Ayres Brito. Disponível em: <http://www.youtube.com/watch?v=WXtDpv2VzmU\&feature=autoplay\&list $=$ PLF21CD375773F508D\&playnext=1>. Acesso em: 30 abr. 2012.

${ }^{1273}$ Arguição de Descumprimento de Preceito Fundamental no 54-8. Voto lido em plenário pelo Ministro Ayres Brito. Disponível em: <http://www.youtube.com/watch? $\mathrm{v}=\mathrm{WXtDpv} 2 \mathrm{VzmU}$ \&feature=autoplay\&list $=$ PLF21CD375773F508D\&playnext=1>. Acesso em: 30 abr. 2012. (0:05:00-0:06:49).

${ }^{1274}$ Arguição de Descumprimento de Preceito Fundamental no ${ }^{\circ}$ 54-8. Voto lido em plenário pelo Ministro Ayres Brito. Disponível em: <http://www.youtube.com/watch? $\mathrm{v}=\mathrm{WXtDpv} 2 \mathrm{VzmU}$ \&feature=autoplay\&list $=$ PLF21CD375773F508D\&playnext=1>. Acesso em: 30 abr. 2012. (0:08:00-0:09:00).

${ }^{1275}$ Arguição de Descumprimento de Preceito Fundamental no ${ }^{\circ}$ 44-8. Voto lido em plenário pelo Ministro Ayres Brito. Disponível em: <http://www.youtube.com/watch?v=WXtDpv2VzmU\&feature=autoplay\&list $=$ PLF21CD375773F508D\&playnext=1>. Acesso em: 30 abr. 2012. (0:13:31-0:13:54).

${ }^{1276}$ Arguição de Descumprimento de Preceito Fundamental no ${ }^{\circ}$ 54-8. Voto lido em plenário pelo Ministro Ayres

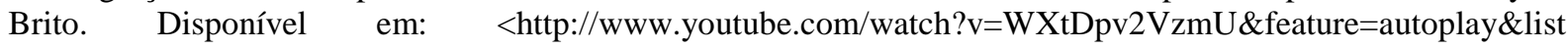
$=$ PLF21CD375773F508D\&playnext=1>. Acesso em: 30 abr. 2012. (0:14:00-0:14:39).

${ }^{1277}$ Arguição de Descumprimento de Preceito Fundamental no 54-8. Voto lido em plenário pelo Ministro Ayres Brito. Disponível em: <http://www.youtube.com/watch?v=WXtDpv2VzmU\&feature=autoplay\&list $=$ PLF21CD375773F508D\&playnext=1>. Acesso em: 30 abr. 2012. (0:14:40-0:15:31).

${ }^{1278}$ Arguição de Descumprimento de Preceito Fundamental no $54-8$. Voto lido em plenário pelo Ministro Ayres Brito. Disponível em: <http://www.youtube.com/watch? $\mathrm{v}=\mathrm{WXtDpv} 2 \mathrm{VzmU}$ \&feature=autoplay\&list $=$ PLF21CD375773F508D\&playnext=1>. Acesso em: 30 abr. 2012. (0:16:00-0:16:53).

${ }^{1279}$ Arguição de Descumprimento de Preceito Fundamental no $54-8$. Voto lido em plenário pelo Ministro Ayres Brito. Disponível em: <http://www.youtube.com/watch?v=WXtDpv2VzmU\&feature=autoplay\&list $=$ PLF21CD375773F508D\&playnext=1>. Acesso em: 30 abr. 2012.. (0:16:49-0:17:59).

${ }^{1280}$ Arguição de Descumprimento de Preceito Fundamental $\mathrm{n}^{\circ}$ 54-8. Voto lido em plenário pelo Ministro Ayres Brito. Disponível em: <http://www.youtube.com/watch?v=WXtDpv2VzmU\&feature=autoplay\&list $=$ PLF21CD375773F508D\&playnext=1>. Acesso em: 30 abr. 2012. (0:18:00-0:18:13).
} 
Para Ayres Brito, "toda vida humana começa com a fecundação do óvulo"1281; no entanto, "não é possível confundir embrião de vida humana com vida humana embrionária"1282. O zigoto se enquadraria na primeira situação, não sendo vida humana embrionária $^{1283}$, que só se desenvolve com a fecundação do zigoto dentro do útero, que se torna essencial, uma vez que o embrião não é auto-constitutivo ${ }^{1284}$.

Defendeu o Ministro então que o organismo embrionário, que está dentro do útero, por sua vez, não é propriedade da mulher, pois é detentor de direitos para o Código Civil (artigo $2^{\circ}$ ), e pelo Pacto de San José ${ }^{1285}$.

Dando continuidade a seu voto, o próximo ponto abordado por Ayres Britto foi o de que não há crime de aborto se o feto for "natimorto cerebral" "1286; isto é, se for um "ser sem viabilidade vital"1287. Neste caso, o crime não existiria por não existir no feto "uma pessoa humana $[\ldots]$ no sentido biográfico" ${ }^{288}$, segundo o Ministro.

Mais uma vez, como já o havia feito na liminar da ADPF 54, Ayres Britto comparou o feto anencéfalo com a "crisálida que jamais chegará ao estágio de borboleta"1289, e entendeu que a conduta de um aborto de feto anencéfalo seria atípica, porque a gravidez resultará em

${ }^{1281}$ Arguição de Descumprimento de Preceito Fundamental no 54-8. Voto lido em plenário pelo Ministro Ayres Brito. Disponível em: <http://www.youtube.com/watch? $\mathrm{v}=\mathrm{WXtDpv} 2 \mathrm{VzmU} \&$ feature=autoplay\&list $=$ PLF21CD375773F508D\&playnext=1>. Acesso em: 30 abr. 2012. (0:18:40-0:18:50).

1282 Arguição de Descumprimento de Preceito Fundamental no 54-8. Voto lido em plenário pelo Ministro Ayres Brito. Disponível em: <http://www.youtube.com/watch? $\mathrm{v}=\mathrm{WXtDpv} 2 \mathrm{VzmU} \&$ feature=autoplay\&list =PLF21CD375773F508D\&playnext=1>. Acesso em: 30 abr. 2012. (0:19:20-0:19:32).

${ }^{1283}$ Arguição de Descumprimento de Preceito Fundamental no 54-8. Voto lido em plenário pelo Ministro Ayres Brito. Disponível em: <http://www.youtube.com/watch? $\mathrm{v}=\mathrm{WXtDpv} 2 \mathrm{VzmU} \&$ feature=autoplay\&list $=$ PLF21CD375773F508D\&playnext=1>. Acesso em: 30 abr. 2012.. (0:19:33-0:19:37).

${ }^{1284}$ Arguição de Descumprimento de Preceito Fundamental $n^{\circ}$ 54-8. Voto lido em plenário pelo Ministro Ayres Brito. Disponível em: <http://www.youtube.com/watch?v=WXtDpv2VzmU\&feature=autoplay\&list $=$ PLF21CD375773F508D\&playnext=1>. Acesso em: 30 abr. 2012. (0:19:38-0:20:37).

${ }^{1285}$ Arguição de Descumprimento de Preceito Fundamental $n^{\circ}$ 54-8. Voto lido em plenário pelo Ministro Ayres Brito. Disponível em: <http://www.youtube.com/watch?v=WXtDpv2VzmU\&feature=autoplay\&list $=$ PLF21CD375773F508D\&playnext=1>. Acesso em: 30 abr. 2012. (0:20:38-0:21:56).

1286 Arguição de Descumprimento de Preceito Fundamental no 54-8. Voto lido em plenário pelo Ministro Ayres Brito. Disponível em: <http://www.youtube.com/watch? $\mathrm{v}=\mathrm{WXtDpv} 2 \mathrm{VzmU} \&$ feature=autoplay\&list $=$ PLF21CD375773F508D\&playnext=1>. Acesso em: 30 abr. 2012. (0:22:11-0:22:34).

${ }^{1287}$ Arguição de Descumprimento de Preceito Fundamental no 54-8. Voto lido em plenário pelo Ministro Ayres Brito. Disponível em: <http://www.youtube.com/watch? $\mathrm{v}=\mathrm{WXtDpv} 2 \mathrm{VzmU} \&$ feature=autoplay\&list =PLF21CD375773F508D\&playnext=1>. Acesso em: 30 abr. 2012. (0:22:35-0:22:39).

${ }_{1288}$ Arguição de Descumprimento de Preceito Fundamental $n^{\circ}$ 54-8. Voto lido em plenário pelo Ministro Ayres Brito. Disponível em: <http://www.youtube.com/watch?v=WXtDpv2VzmU\&feature=autoplay\&list =PLF21CD375773F508D\&playnext=1>. Acesso em: 30 abr. 2012. (0:23:18-0:23:22).

1289 Arguição de Descumprimento de Preceito Fundamental no 54-8. Voto lido em plenário pelo Ministro Ayres Brito. Disponível em: <http://www.youtube.com/watch?v=WXtDpv2VzmU\&feature=autoplay\&list =PLF21CD375773F508D\&playnext=1>. Acesso em: 30 abr. 2012. (0:24:14-0:24:18). 
um "nada"1290, o que poderia até ser chamado de aborto no sentido coloquial, mas não no sentido jurídico ${ }^{1291}$.

Ayres Britto ainda lançou mão dos critérios da morte encefálica para determinar o momento da morte ${ }^{1292}$, aproximando a anencefalia de tal conceito ${ }^{1293}$.

A seguir, o Ministro defendeu que, ainda que se considerasse o caso do aborto de anencéfalo um crime, ele não seria punível ${ }^{1294}$, porque, no caso concreto, devem-se levar em conta os riscos à saúde física e psíquica da mulher, bem como o fato de que o resultado da gravidez não será a vida ${ }^{1295}$.

Para reforçar o argumento, Britto também lembrou que o legislador não puniu o aborto no caso de gravidez decorrente de estupro, ainda que o feto fosse viável ${ }^{1296}$, pois, em vista do ato de violência do qual resulta a gravidez, negar à mulher o aborto no caso seria violar sua saúde física, psíquica e moral ${ }^{1297}$, uma verdadeira afronta ao princípio da dignidade da pessoa humana $^{1298}$.

Esclareu a seguir o Ministro que a escolha de se realizar o aborto do feto anencéfalo caberá sempre à mulher, a quem não se vai impor nenhuma conduta ${ }^{1299}$. Para ele, no entanto,

\footnotetext{
${ }^{1290}$ Arguição de Descumprimento de Preceito Fundamental $\mathrm{n}^{\circ}$ 54-8. Voto lido em plenário pelo Ministro Ayres Brito. Disponível em: <http://www.youtube.com/watch? $v=W X t D p v 2 V z m U \&$ feature=autoplay\&list $=$ PLF21CD375773F508D\&playnext=1>. Acesso em: 30 abr. 2012.. (0:24:19-0:24:37).

${ }^{1291}$ Arguição de Descumprimento de Preceito Fundamental $\mathrm{n}^{\circ}$ 54-8. Voto lido em plenário pelo Ministro Ayres Brito. Disponível em: <http://www.youtube.com/watch?v=WXtDpv2VzmU\&feature=autoplay\&list $=$ PLF21CD375773F508D\&playnext=1>. Acesso em: 30 abr. 2012. (0:25:30-0:25:42).

${ }^{1292}$ Arguição de Descumprimento de Preceito Fundamental no $54-8$. Voto lido em plenário pelo Ministro Ayres

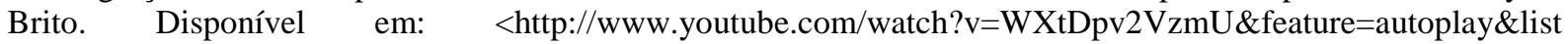
$=$ PLF21CD375773F508D\&playnext=1>. Acesso em: 30 abr. 2012. (0:27:15-0:28:39).

${ }^{1293}$ Arguição de Descumprimento de Preceito Fundamental no ${ }^{\circ}$ 54-8. Voto lido em plenário pelo Ministro Ayres

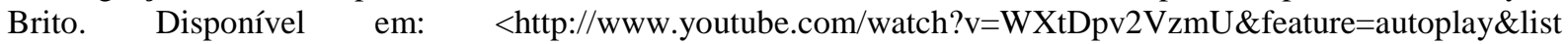
$=$ PLF21CD375773F508D\&playnext=1>. Acesso em: 30 abr. 2012. (0:32:28-0:33:52).

${ }^{1294}$ Arguição de Descumprimento de Preceito Fundamental no $54-8$. Voto lido em plenário pelo Ministro Ayres

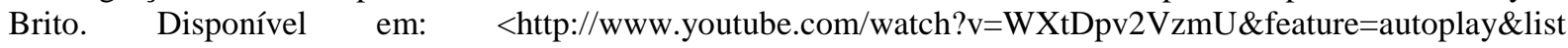
$=$ PLF21CD375773F508D\&playnext=1>. Acesso em: 30 abr. 2012.. (0:33:53-0:34:47).

${ }^{1295}$ Arguição de Descumprimento de Preceito Fundamental no $54-8$. Voto lido em plenário pelo Ministro Ayres

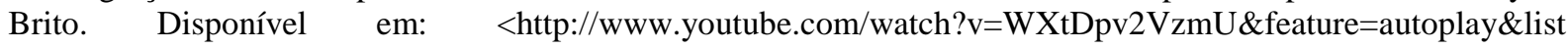
$=$ PLF21CD375773F508D\&playnext=1>. Acesso em: 30 abr. 2012. (0:34:48-0:35:54).

${ }^{1296}$ Arguição de Descumprimento de Preceito Fundamental no $54-8$. Voto lido em plenário pelo Ministro Ayres Brito. Disponível em: <http://www.youtube.com/watch?v=WXtDpv2VzmU\&feature=autoplay\&list $=$ PLF21CD375773F508D\&playnext=1>. Acesso em: 30 abr. 2012. (0:37:30-0:37:48).

${ }^{1297}$ Arguição de Descumprimento de Preceito Fundamental no $54-8$. Voto lido em plenário pelo Ministro Ayres Brito. Disponível em: <http://www.youtube.com/watch?v=WXtDpv2VzmU\&feature=autoplay\&list $=$ PLF21CD375773F508D\&playnext=1>. Acesso em: 30 abr. 2012. (0:37:49-0:39:00).

${ }^{1298}$ Arguição de Descumprimento de Preceito Fundamental no $54-8$. Voto lido em plenário pelo Ministro Ayres Brito. Disponível em: <http://www.youtube.com/watch?v=WXtDpv2VzmU\&feature=autoplay\&list $=$ PLF21CD375773F508D\&playnext=1>. Acesso em: 30 abr. 2012. (0:39:01-0:39:40).

${ }^{1299}$ Arguição de Descumprimento de Preceito Fundamental no $54-8$. Voto lido em plenário pelo Ministro Ayres Brito. Disponível em: <http://www.youtube.com/watch? $v=W X t D p v 2 V z m U \&$ feature=autoplay\&list $=$ PLF21CD375773F508D\&playnext=1>. Acesso em: 30 abr. 2012. (0:40:19-0:40:44).
} 
"gravidez é dar vida, e não morte"1300, e, de outro modo, a gravidez "não flui"1301. Por essa razão, para Ayres Britto, obrigar a mulher a levar a gravidez até o fim seria equiparável à "tortura, a tratamento cruel cruel"1302. Dar continuidade à gestação de feto anencéfalo, para o Ministro, é "martírio voluntário" ${ }^{1303}$, que a mulher pode escolher, mas ao que não pode ser obrigada ${ }^{1304}$. Para Ayres Britto, finalmente, "é melhor tirar essa plantinha do útero do que deixar cair no abismo da sepultura", e, a escolha de abortar ou não é uma decisão "sagrada" da mulher ${ }^{1305}$.

Assim, Ayres Britto seguiu o voto do Ministro Relator Marco Aurélio, dando uma interpretação conforme à Constituição Federal ao caso, considerando a interrupção da gestação do feto anencéfalo uma conduta atípica ${ }^{1306}$.

\subsubsection{Voto do Ministro Gilmar Mendes ${ }^{1307}$}

Logo no início, declarou o Ministro ser cabível a ADPF $\mathrm{n}^{\circ}$ 54, ratificando o seu posicionamento anterior, da liminar ${ }^{1308}$.

\footnotetext{
${ }^{1300}$ Arguição de Descumprimento de Preceito Fundamental no $54-8$. Voto lido em plenário pelo Ministro Ayres

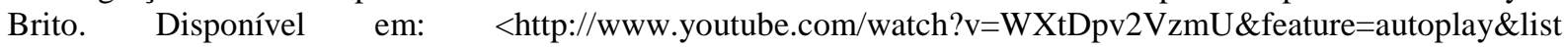
$=$ PLF21CD375773F508D\&playnext=1>. Acesso em: 30 abr. 2012. (0:42:13-0:42:18).

${ }^{1301}$ Arguição de Descumprimento de Preceito Fundamental no ${ }^{54-8}$. Voto lido em plenário pelo Ministro Ayres Brito. Disponível em: <http://www.youtube.com/watch? $\mathrm{v}=\mathrm{WXtDpv} 2 \mathrm{VzmU}$ \&feature=autoplay\&list $=$ PLF21CD375773F508D\&playnext=1>. Acesso em: 30 abr. 2012.. (0:42:19-0:43:00).

${ }^{1302}$ Arguição de Descumprimento de Preceito Fundamental no 54-8. Voto lido em plenário pelo Ministro Ayres Brito. Disponível em: <http://www.youtube.com/watch? $\mathrm{v}=\mathrm{WXtDpv} 2 \mathrm{VzmU}$ \&feature=autoplay\&list $=$ PLF21CD375773F508D\&playnext=1>. Acesso em: 30 abr. 2012.. (0:45:20-0:45:33).

${ }^{1303}$ Arguição de Descumprimento de Preceito Fundamental no $54-8$. Voto lido em plenário pelo Ministro Ayres Brito. Disponível em: <http://www.youtube.com/watch?v=WXtDpv2VzmU\&feature=autoplay\&list $=$ PLF21CD375773F508D\&playnext=1>. Acesso em: 30 abr. 2012.. (0:45:34-0:45:41).

${ }^{1304}$ Arguição de Descumprimento de Preceito Fundamental no ${ }^{\circ} 4-8$. Voto lido em plenário pelo Ministro Ayres

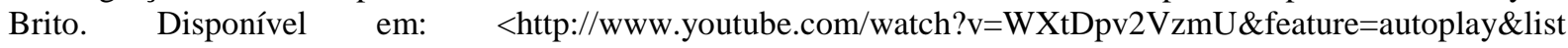
$=$ PLF21CD375773F508D\&playnext=1>. Acesso em: 30 abr. 2012. (0:45:42-0:47:10).

${ }^{1305}$ Arguição de Descumprimento de Preceito Fundamental no 54-8. Voto lido em plenário pelo Ministro Ayres Brito. Disponível em: <http://www.youtube.com/watch?v=WXtDpv2VzmU\&feature=autoplay\&list $=$ PLF21CD375773F508D\&playnext=1>. Acesso em: 30 abr. 2012. (0:48:18-0:48:20).

${ }^{1306}$ Arguição de Descumprimento de Preceito Fundamental no $54-8$. Voto lido em plenário pelo Ministro Ayres Brito. Disponível em: <http://www.youtube.com/watch?v=WXtDpv2VzmU\&feature=autoplay\&list $=$ PLF21CD375773F508D\&playnext=1>. Acesso em: 30 abr. 2012. (0:48:30-0:50:16).

${ }^{1307}$ Arguição de Descumprimento de Preceito Fundamental n ${ }^{\circ}$ 54-8. Voto lido em plenário pelo Ministro Gilmar Mendes. Disponível em: <http://www.youtube.com/watch?v=WXtDpv2VzmU\&feature=autoplay\&list $=$ PLF21CD375773F508D\&playnext=1>. Acesso em: 30 abr. 2012.

${ }^{1308}$ Arguição de Descumprimento de Preceito Fundamental n ${ }^{\circ}$ 54-8. Voto lido em plenário pelo Ministro Gilmar Mendes. Disponível em: <http://www.youtube.com/watch?v=WXtDpv2VzmU\&feature=autoplay\&list =PLF21CD375773F508D\&playnext=1>. Acesso em: 30 abr. 2012 (0:50:22-0:51:14).
} 
Na opinião do Ministro, em casos de omissão, o Supremo avançou, pois tem admitido a técnica aditiva de interpretação ${ }^{1309}$. Ademais, para Gilmar Mendes, tendo-se em vista a sensível problemática do aborto do feto anencéfalo, a decisão de cassação da liminar lhe pareceu correta ${ }^{1310}$. Relembrou ainda o Ministro o ocorrido no caso levado ao Judiciário no Rio de Janeiro, em que o feto anencéfalo nasceu antes do julgamento do processo, tendo sido declarado prejudicado o objeto da ação ${ }^{1311}$. Daí, para Gilmar Mendes a relevância da ADPF $54^{1312}$.

Iniciou o debate posicionando-se favorável à participação de entidades religiosas nos debates públicos ${ }^{1313}$ e sua habilitação como amicus curiae para consagrar a pluralidade ${ }^{1314}$, criticando a negativa do Supremo com relação a esta habilitação ${ }^{1315}$.

Com relação ao tema específico do aborto, o Ministro analisou o direito comparado e afirmou que 94 países membros da ONU autorizam esse tipo de aborto há pelo menos uma década, citando entre eles, Espanha, México, Itália e Portugal, mesmo com a existência de forte base religiosa católica nesses países ${ }^{1316}$. Salientou Gilmar Mendes que as opções desses países foram cercadas de procedimentos que garantem maior segurança no diagnóstico como, por exemplo, a exigência da confirmação do diagnóstico realizada por mais de um médico, diverso daquele que realizará o procedimento - e na formação da decisão da mulher -

${ }^{1309}$ Arguição de Descumprimento de Preceito Fundamental no 54-8. Voto lido em plenário pelo Ministro Gilmar Mendes. Disponível em: <http://www.youtube.com/watch?v=WXtDpv2VzmU\&feature=autoplay\&list =PLF21CD375773F508D\&playnext=1>. Acesso em: 30 abr. 2012 (0:52:00-0:52:47).

${ }^{1310}$ Arguição de Descumprimento de Preceito Fundamental no 54-8. Voto lido em plenário pelo Ministro Gilmar Mendes. Disponível em: <http://www.youtube.com/watch?v=WXtDpv2VzmU\&feature=autoplay\&list $=$ PLF21CD375773F508D\&playnext=1>. Acesso em: 30 abr. 2012 (0:54:01-0:54:57).

${ }^{1311}$ Arguição de Descumprimento de Preceito Fundamental no 54-8. Voto lido em plenário pelo Ministro Gilmar Mendes. Disponível em: <http://www.youtube.com/watch?v=WXtDpv2VzmU\&feature=autoplay\&list $=$ PLF21CD375773F508D\&playnext=1>. Acesso em: 30 abr. 2012 (0:54:58-0:58:18).

${ }^{1312}$ Arguição de Descumprimento de Preceito Fundamental no 54-8. Voto lido em plenário pelo Ministro Gilmar Mendes. Disponível em: <http://www.youtube.com/watch?v=WXtDpv2VzmU\&feature=autoplay\&list $=$ PLF21CD375773F508D\&playnext=1>. Acesso em: 30 abr. 2012 (0:58:19-1:00:45).

${ }^{1313}$ Arguição de Descumprimento de Preceito Fundamental no 54-8. Voto lido em plenário pelo Ministro Gilmar Mendes. Disponível em: <http://www.youtube.com/watch?v=WXtDpv2VzmU\&feature=autoplay\&list =PLF21CD375773F508D\&playnext=1>. Acesso em: 30 abr. 2012 (1:00:46-1:02:12).

${ }^{1314}$ Arguição de Descumprimento de Preceito Fundamental no 54-8. Voto lido em plenário pelo Ministro Gilmar Mendes. Disponível em: <http://www.youtube.com/watch?v=WXtDpv2VzmU\&feature=autoplay\&list =PLF21CD375773F508D\&playnext=1>. Acesso em: 30 abr. 2012 (1:02:13-1:05:05 e 1:11:01-1:12:57).

1315 Arguição de Descumprimento de Preceito Fundamental no 54-8. Voto lido em plenário pelo Ministro Gilmar Mendes. Disponível em: <http://www.youtube.com/watch?v=WXtDpv2VzmU\&feature=autoplay\&list $=$ PLF21CD375773F508D\&playnext=1>. Acesso em: 30 abr. 2012 (1:11:00-1:17:35).

${ }^{1316}$ Arguição de Descumprimento de Preceito Fundamental no 54-8. Voto lido em plenário pelo Ministro Gilmar Mendes. Disponível em: <http://www.youtube.com/watch?v=WXtDpv2VzmU\&feature=autoplay\&list $=$ PLF21CD375773F508D\&playnext=1>. Acesso em: 30 abr. 2012 (1:17:35-1:18:55). 
especialmente com o aconselhamento sobre planejamento familiar, informações detalhadas a respeito da gestação de feto com anencefalia, etc ${ }^{1317}$.

Gilmar Mendes, em seguida, destacou dois aspectos relevantes ao caso: i) a diferença entre anencefalia e morte cerebral. Para o Ministro, no primeiro caso, há algumas funções autônomas, como a respiração e o batimento cardíaco, ao passo que, na morte cerebral, essas funções dependem de aparelhos ${ }^{1318}$; e ii) entendeu o Ministro que a verificação da anencefalia ocorre a partir do final do primeiro trimestre de gravidez, isto é, seria a partir da $10^{\mathrm{a}}$ semana de gestação que o diagnóstico se daria com segurança ${ }^{1319}$. Destacou também os vários riscos comuns a esse tipo de gestação, e a inviabilidade extrauterina do feto após horas ou dias do nascimento ${ }^{1320}$.

Baseando-se nesses dois aspectos, à luz do direito brasileiro, Gilmar Mendes refutou alguns argumentos apresentados pelas partes, notadamente o que diz respeito à dignidade, afirmando que, tanto a dignidade da gestante, quanto a do feto, devem ser protegidas, pois, como já decidido na Alemanha, "a vida também passa por esse estágio fetal"1321.

Para o Ministro, a regra do Código Penal é a proibição do aborto, e a conduta analisada na ADPF 54 não versa sobre conduta atípica, pois o feto nasce com vida ${ }^{1322}$. No entanto, acredita o Ministro que a resposta ao caso pode ser extraída da interpretação do próprio dispositivo penal, em especial, a partir da análise das excludentes legais ${ }^{1323}$.

\footnotetext{
${ }^{1317}$ Arguição de Descumprimento de Preceito Fundamental nº 54-8. Voto lido em plenário pelo Ministro Gilmar Mendes. Disponível em: <http://www.youtube.com/watch?v=WXtDpv2VzmU\&feature=autoplay\&list =PLF21CD375773F508D\&playnext=1>. Acesso em: 30 abr. 2012 (1:18:56-1:29:00).

${ }^{1318}$ Arguição de Descumprimento de Preceito Fundamental n $54-8$. Voto lido em plenário pelo Ministro Gilmar Mendes. Disponível em: <http://www.youtube.com/watch?v=WXtDpv2VzmU\&feature=autoplay\&list $=$ PLF21CD375773F508D\&playnext=1>. Acesso em: 30 abr. 2012 (1:29:13-1:29:49).

${ }^{1319}$ Arguição de Descumprimento de Preceito Fundamental n ${ }^{\circ}$ 54-8. Voto lido em plenário pelo Ministro Gilmar Mendes. Disponível em: <http://www.youtube.com/watch?v=WXtDpv2VzmU\&feature=autoplay\&list $=$ PLF21CD375773F508D\&playnext=1>. Acesso em: 30 abr. 2012 (1:30:06-1:30:18).

${ }^{1320}$ Arguição de Descumprimento de Preceito Fundamental $n^{\circ} 54-8$. Voto lido em plenário pelo Ministro Gilmar Mendes. Disponível em: <http://www.youtube.com/watch?v=WXtDpv2VzmU\&feature=autoplay\&list $=$ PLF21CD375773F508D\&playnext=1>. Acesso em: 30 abr. 2012 (1:30:19-1:31:02).

${ }^{1321}$ Arguição de Descumprimento de Preceito Fundamental n ${ }^{\circ}$ 54-8. Voto lido em plenário pelo Ministro Gilmar Mendes. Disponível em: <http://www.youtube.com/watch?v=WXtDpv2VzmU\&feature=autoplay\&list $=$ PLF21CD375773F508D\&playnext=1>. Acesso em: 30 abr. 2012 (1:35:02-1:34:56).

${ }^{1322}$ Arguição de Descumprimento de Preceito Fundamental no 54-8. Voto lido em plenário pelo Ministro Gilmar Mendes. Disponível em: <http://www.youtube.com/watch?v=WXtDpv2VzmU\&feature=autoplay\&list $=$ PLF21CD375773F508D\&playnext=1>. Acesso em: 30 abr. 2012 (1:35:40-1:36:05).

${ }^{1323}$ Arguição de Descumprimento de Preceito Fundamental n ${ }^{\circ}$ 54-8. Voto lido em plenário pelo Ministro Gilmar Mendes. Disponível em: <http://www.youtube.com/watch?v=WXtDpv2VzmU\&feature=autoplay\&list =PLF21CD375773F508D\&playnext=1>. Acesso em: 30 abr. 2012 (1:36:06-1:38:07)
} 
Defendeu Gilmar Mendes que o aborto de feto anencéfalo encontra-se entre as duas excludentes já existentes ${ }^{1324}$, cabendo apenas uma interpretação evolutiva dos dispositivos legais ${ }^{1325}$. Enquanto o inciso I do artigo 128 do Código Penal protege a vida da mulher, e o inciso II do mesmo artigo protege a saúde psíquica da mulher, ainda que viável o feto ${ }^{1326}$, seria possível reconhecer que a resposta já consta da própria opção do legislador ${ }^{1327}$. Para o Ministro, os riscos desse tipo de gestação nem sempre se enquadram no risco à vida da mulher, protegido pelo inciso $\mathrm{I}^{1328}$, e, ao mesmo tempo, a situação da mulher gestante de um feto anencéfalo, que deverá conviver com o diagnóstico da inviabilidade, assemelha-se à figura da saúde psíquica protegida no inciso II do artigo 128 do Código Penal, somando-se ao fato de que no caso do feto anencéfalo, o feto é inviável ${ }^{1329}$. Assim, acredita o Ministro que o legislador não detinha o conhecimento sobre os instrumentos tecnológicos para diagnosticar a anencefalia, e, por isso, não incluiu também essa hipótese de excludente no diploma legal, podendo tal lacuna, pois, ser considerada omissão legislativa não condizente com a Constituição Federal e o próprio "espírito” do Código Penal ${ }^{1330}$.

Gilmar Mendes entendeu, portanto, que a falta de um modelo institucional adequado "contribui para a desproteção" 1331 da mulher, e que não lhe parece tolerável que se imponha à gestante a obrigação de levar uma gravidez de anencéfalo ao término, em face da inexistência de um modelo adequado, de justificativa, ou de excludente ${ }^{1332}$. A imposição da manutenção

\footnotetext{
${ }^{1324}$ Arguição de Descumprimento de Preceito Fundamental nº 54-8. Voto lido em plenário pelo Ministro Gilmar Mendes. Disponível em: <http://www.youtube.com/watch?v=WXtDpv2VzmU\&feature=autoplay\&list $=$ PLF21CD375773F508D\&playnext=1>. Acesso em: 30 abr. 2012 (1:44:56).

${ }^{1325}$ Arguição de Descumprimento de Preceito Fundamental $n^{\circ}$ 54-8. Voto lido em plenário pelo Ministro Gilmar Mendes. Disponível em: <http://www.youtube.com/watch?v=WXtDpv2VzmU\&feature=autoplay\&list =PLF21CD375773F508D\&playnext=1>. Acesso em: 30 abr. 2012 (1:38:59-1:40:18).

${ }^{1326}$ Arguição de Descumprimento de Preceito Fundamental n ${ }^{\circ} 54-8$. Voto lido em plenário pelo Ministro Gilmar Mendes. Disponível em: <http://www.youtube.com/watch?v=WXtDpv2VzmU\&feature=autoplay\&list $=$ PLF21CD375773F508D\&playnext=1>. Acesso em: 30 abr. 2012 (1:36:06-1:38:07).

${ }^{1327}$ Arguição de Descumprimento de Preceito Fundamental n ${ }^{\circ}$ 54-8. Voto lido em plenário pelo Ministro Gilmar Mendes. Disponível em: <http://www.youtube.com/watch?v=WXtDpv2VzmU\&feature=autoplay\&list $=$ PLF21CD375773F508D\&playnext=1>. Acesso em: 30 abr. 2012 (1:42:36-1:43:38).

${ }^{1328}$ Arguição de Descumprimento de Preceito Fundamental n ${ }^{\circ}$ 54-8. Voto lido em plenário pelo Ministro Gilmar Mendes. Disponível em: <http://www.youtube.com/watch?v=WXtDpv2VzmU\&feature=autoplay\&list $=$ PLF21CD375773F508D\&playnext=1>. Acesso em: 30 abr. 2012 (1:38:25).

${ }^{1329}$ Arguição de Descumprimento de Preceito Fundamental n ${ }^{\circ}$ 54-8. Voto lido em plenário pelo Ministro Gilmar Mendes. Disponível em: <http://www.youtube.com/watch?v=WXtDpv2VzmU\&feature=autoplay\&list $=$ PLF21CD375773F508D\&playnext=1>. Acesso em: 30 abr. 2012 (1:38:47-1:38:58).

${ }^{1330}$ Arguição de Descumprimento de Preceito Fundamental n ${ }^{\circ}$ 54-8. Voto lido em plenário pelo Ministro Gilmar Mendes. Disponível em: <http://www.youtube.com/watch?v=WXtDpv2VzmU\&feature=autoplay\&list $=$ PLF21CD375773F508D\&playnext=1>. Acesso em: 30 abr. 2012 (-1:43:40-1:44:56).

${ }^{1331}$ Arguição de Descumprimento de Preceito Fundamental n ${ }^{\circ}$ 54-8. Voto lido em plenário pelo Ministro Gilmar Mendes. Disponível em: <http://www.youtube.com/watch?v=WXtDpv2VzmU\&feature=autoplay\&list $=$ PLF21CD375773F508D\&playnext=1>. Acesso em: 30 abr. 2012 /91:45:54-1:46:23).

${ }^{1332}$ Arguição de Descumprimento de Preceito Fundamental n ${ }^{\circ}$ 54-8. Voto lido em plenário pelo Ministro Gilmar Mendes. Disponível em: <http://www.youtube.com/watch?v=WXtDpv2VzmU\&feature=autoplay\&list $=$ PLF21CD375773F508D\&playnext=1>. Acesso em: 30 abr. 2012 (1:44:57-1:45:28 e 1:45:54-1:46:23).
} 
da gravidez poderia ser considerada tortura física e psíquica ${ }^{1333}$. Para o Ministro, esse é um caso em que há necessidade de uma postura positiva do Poder Judiciário, diante da falta de um modelo institucional adequado, e em face da violaçao à privacidade, intimidade, e autonomia individual da mulher ${ }^{1334}$.

No entanto, alerta o Ministro, com base no direito comparado analisado, que é preciso conferir segurança, tanto no que concerne ao diagnóstico, quanto no que diz respeito à formação da decisão da mulher, cabendo ao Ministério da Saúde e ao Conselho Federal de Medicina ${ }^{1335}$ estabelecer critérios para tanto, incluindo medidas preventivas, como a adição do ácido fólico nos alimentos ou durante o período pré-gestacional - que já vem sido realizada por parte do estado brasileiro ${ }^{1336}$ - , o diagnóstico de dois ou mais médicos ${ }^{1337}$, assistência psicológica à gestante ${ }^{1338}$, etc.

Por fim, julgou Gilmar Mendes procedente a ação com efeitos aditivos, no sentido de que não seja punido o aborto de feto anencéfalo, devendo o diagnóstico ser confirmado por meio de parecer de dois médicos distintos, e que as autoridades competentes e mesmo o legislador, pronunciem-se a respeito para corrigir eventuais omissões ${ }^{1339}$.

\subsubsection{Voto do Ministro Celso de Mello ${ }^{1340}$}

\footnotetext{
${ }^{1333}$ Arguição de Descumprimento de Preceito Fundamental no 54-8. Voto lido em plenário pelo Ministro Gilmar Mendes. Disponível em: <http://www.youtube.com/watch?v=WXtDpv2VzmU\&feature=autoplay\&list =PLF21CD375773F508D\&playnext=1>. Acesso em: 30 abr. 2012 (1:45:54-1:46:23)

${ }^{1334}$ Arguição de Descumprimento de Preceito Fundamental no 54-8. Voto lido em plenário pelo Ministro Gilmar Mendes. Disponível em: <http://www.youtube.com/watch?v=WXtDpv2VzmU\&feature=autoplay\&list $=$ PLF21CD375773F508D\&playnext=1>. Acesso em: 30 abr. 2012 (1:46:24-1:47:57).

${ }^{1335}$ Arguição de Descumprimento de Preceito Fundamental no 54-8. Voto lido em plenário pelo Ministro Gilmar Mendes. Disponível em: <http://www.youtube.com/watch?v=WXtDpv2VzmU\&feature=autoplay\&list =PLF21CD375773F508D\&playnext=1>. Acesso em: 30 abr. 2012 (1:48:29-1:48:54).

${ }^{1336}$ Arguição de Descumprimento de Preceito Fundamental no ${ }^{\circ} 4-8$. Voto lido em plenário pelo Ministro Gilmar Mendes. Disponível em: <http://www.youtube.com/watch?v=WXtDpv2VzmU\&feature=autoplay\&list $=$ PLF21CD375773F508D\&playnext=1>. Acesso em: 30 abr. 2012 (1:49:13-1:50:10).

${ }^{1337}$ Arguição de Descumprimento de Preceito Fundamental no 54-8. Voto lido em plenário pelo Ministro Gilmar Mendes. Disponível em: <http://www.youtube.com/watch?v=WXtDpv2VzmU\&feature=autoplay\&list =PLF21CD375773F508D\&playnext=1>. Acesso em: 30 abr. 2012 (1:48:55-1:49:12).

${ }^{1338}$ Arguição de Descumprimento de Preceito Fundamental no 54-8. Voto lido em plenário pelo Ministro Gilmar Mendes. Disponível em: <http://www.youtube.com/watch?v=WXtDpv2VzmU\&feature=autoplay\&list =PLF21CD375773F508D\&playnext=1>. Acesso em: 30 abr. 2012 (1:50:11-1:50:43).

${ }_{1339}$ Arguição de Descumprimento de Preceito Fundamental no ${ }^{\circ}$ 54-8. Voto lido em plenário pelo Ministro Gilmar Mendes. Disponível em: <http://www.youtube.com/watch?v=WXtDpv2VzmU\&feature=autoplay\&list $=$ PLF21CD375773F508D\&playnext=1>. Acesso em: 30 abr. 2012 (1:52:53-1:53:58).

${ }^{1340}$ Arguição de Descumprimento de Preceito Fundamental $n^{\circ}$ 54-8. Voto lido em plenário pelo Ministro Celso de Mello. Disponível em: <http://www.youtube.com/watch?v=WXtDpv2VzmU\&feature=autoplay\&list $=$ PLF21CD375773F508D\&playnext=1>. Acesso em: 30 abr. 2012.
} 
O Ministro Celso de Mello entendeu tratar-se de caso extremamente relevante para determinar o "alcance e sentido da vida e da morte"1341, e que somente em um Estado laico, secular e democrático é possível tratar com dignidade as "experiências da vida"1342 numa perspectiva "emancipatória dos direitos humanos"1343.

Entendeu ainda o Ministro que o tema não é uma disputa entre Estado e Igreja ${ }^{1344}$. Para o ele, a laicidade foi a opção brasileira ${ }^{1345}$ e é o princípio fundamental do ordenamento brasileiro ${ }^{1346}$, de modo que a escolha de determinada religião recai na esfera privada ${ }^{1347}$, e "o direito não se submete à religião, embora a respeite" ${ }^{, 1348}$.

O Ministro destacou que o aborto em geral não está sendo autorizado ${ }^{1349}$, mas reconheceu o direito da mulher de escolher ou não pela interrupção da gravidez de feto anencéfalo fundamentado em seu direito reprodutivo, na liberdade, na autodeterminação, na dignidade, na autonomia pessoal e na intimidade ${ }^{1350}$.

Para o Ministro, como a Constituição não estabelece conceitos de vida e de morte, é necessário extrair esses conceitos de outros elementos ${ }^{1351}$. Cabe, na visão do Ministro, a

${ }^{1341}$ Arguição de Descumprimento de Preceito Fundamental no 54-8. Voto lido em plenário pelo Ministro Celso de Mello. Disponível em: <http://www.youtube.com/watch?v=WXtDpv2VzmU\&feature=autoplay\&list $=$ PLF21CD375773F508D\&playnext=1>. Acesso em: 30 abr. 2012 (1:57:26).

${ }^{1342}$ Arguição de Descumprimento de Preceito Fundamental no 54-8. Voto lido em plenário pelo Ministro Celso de Mello. Disponível em: <http://www.youtube.com/watch?v=WXtDpv2VzmU\&feature=autoplay\&list $=$ PLF21CD375773F508D\&playnext=1>. Acesso em: 30 abr. 2012 (1:57:35-1:57:39).

${ }^{1343}$ Arguição de Descumprimento de Preceito Fundamental $n^{\circ}$ 54-8. Voto lido em plenário pelo Ministro Celso de Mello. Disponível em: <http://www.youtube.com/watch?v=WXtDpv2VzmU\&feature=autoplay\&list $=$ PLF21CD375773F508D\&playnext=1>. Acesso em: 30 abr. 2012 (1:58:20-1:58:25).

${ }^{1344}$ Arguição de Descumprimento de Preceito Fundamental n ${ }^{\circ}$ 54-8. Voto lido em plenário pelo Ministro Celso de Mello. Disponível em: <http://www.youtube.com/watch?v=WXtDpv2VzmU\&feature=autoplay\&list $=$ PLF21CD375773F508D\&playnext=1>. Acesso em: 30 abr. 2012 (2:05:18-2:05:35).

${ }^{1345}$ Arguição de Descumprimento de Preceito Fundamental no 54-8. Voto lido em plenário pelo Ministro Celso de Mello. Disponível em: <http://www.youtube.com/watch?v=WXtDpv2VzmU\&feature=autoplay\&list $=$ PLF21CD375773F508D\&playnext=1>. Acesso em: 30 abr. 2012 (2:06:50).

${ }^{1346}$ Arguição de Descumprimento de Preceito Fundamental $n^{\circ}$ 54-8. Voto lido em plenário pelo Ministro Celso de Mello. Disponível em: <http://www.youtube.com/watch?v=WXtDpv2VzmU\&feature=autoplay\&list =PLF21CD375773F508D\&playnext=1>. Acesso em: 30 abr. 2012 (2:09:30-2:09:35).

1347 Arguição de Descumprimento de Preceito Fundamental no 54-8. Voto lido em plenário pelo Ministro Celso de Mello. Disponível em: <http://www.youtube.com/watch?v=WXtDpv2VzmU\&feature=autoplay\&list $=$ PLF21CD375773F508D\&playnext=1>. Acesso em: 30 abr. 2012 (2:10:47-2:10:53).

${ }^{1348}$ Arguição de Descumprimento de Preceito Fundamental no 54-8. Voto lido em plenário pelo Ministro Celso de Mello. Disponível em: <http://www.youtube.com/watch?v=WXtDpv2VzmU\&feature=autoplay\&list $=$ PLF21CD375773F508D\&playnext=1>. Acesso em: 30 abr. 2012 (2:11:50-2:11:54).

${ }^{1349}$ Arguição de Descumprimento de Preceito Fundamental no 54-8. Voto lido em plenário pelo Ministro Celso de Mello. Disponível em: <http://www.youtube.com/watch?v=WXtDpv2VzmU\&feature=autoplay\&list =PLF21CD375773F508D\&playnext=1>. Acesso em: 30 abr. 2012 (2:17:05-2:17:12).

${ }^{1350}$ Arguição de Descumprimento de Preceito Fundamental $n^{\circ}$ 54-8. Voto lido em plenário pelo Ministro Celso de Mello. Disponível em: <http://www.youtube.com/watch?v=WXtDpv2VzmU\&feature=autoplay\&list $=$ PLF21CD375773F508D\&playnext=1>. Acesso em: 30 abr. 2012 (2:15:20-2:16:13).

1351 Arguição de Descumprimento de Preceito Fundamental no 54-8. Voto lido em plenário pelo Ministro Celso de Mello. Disponível em: <http://www.youtube.com/watch?v=WXtDpv2VzmU\&feature=autoplay\&list =PLF21CD375773F508D\&playnext=1>. Acesso em: 30 abr. 2012 (2:20:21-2:21:10). 
ponderação de valores ${ }^{1352}$, destacando que o direito à sexualidade e fecundidade foi reconhecido como direitos humanos básicos ${ }^{1353}$ em tratados e conferências internacionais ${ }^{1354}$.

Afirmou ainda o Ministro que as mulheres têm conquistado seus direitos ao longo da história ${ }^{1355}$, e que a elas é reconhecida a igualdade no exercício desses direitos ${ }^{1356}$, direitos esses universais e indivisíveis ${ }^{1357}$.

Reconheceu o Ministro também, por outro lado, a sacralidade e inviolabilidade do direito à vida ${ }^{1358}$, destacando que o valor da pessoa humana e a sua dignidade constituem valores fundantes do estado ${ }^{1359}$.

Defendeu o Ministro que interrupção terapêutica de parto não é aborto ${ }^{1360}$. No caso do feto anencéfalo, a sua vida intrauterina está apenas em funcionamento porque ligada ao corpo da mulher ${ }^{1361}$. Para ele, se não há vida a ser protegida, nada justifica a limitação dos direitos da mulher e a aplicação da norma penal poderia ser considerada inconstitucional ${ }^{1362}$.

\footnotetext{
${ }^{1352}$ Arguição de Descumprimento de Preceito Fundamental no $54-8$. Voto lido em plenário pelo Ministro Celso de Mello. Disponível em: <http://www.youtube.com/watch?v=WXtDpv2VzmU\&feature=autoplay\&list $=$ PLF21CD375773F508D\&playnext=1>. Acesso em: 30 abr. 2012 (2:21:35-2:21:50).

${ }^{1353}$ Arguição de Descumprimento de Preceito Fundamental no $54-8$. Voto lido em plenário pelo Ministro Celso de Mello. Disponível em: <http://www.youtube.com/watch?v=WXtDpv2VzmU\&feature=autoplay\&list $=$ PLF21CD375773F508D\&playnext=1>. Acesso em: 30 abr. 2012 (2:25:00-2:25:50).

${ }^{1354}$ Arguição de Descumprimento de Preceito Fundamental $n^{\circ}$ 54-8. Voto lido em plenário pelo Ministro Celso de Mello. Disponível em: <http://www.youtube.com/watch?v=WXtDpv2VzmU\&feature=autoplay\&list $=$ PLF21CD375773F508D\&playnext=1>. Acesso em: 30 abr. 2012 (2:24:14).

${ }^{1355}$ Arguição de Descumprimento de Preceito Fundamental $n^{\circ}$ 54-8. Voto lido em plenário pelo Ministro Celso de Mello. Disponível em: <http://www.youtube.com/watch? $v=W X t D p v 2 V z m U \&$ feature=autoplay\&list $=$ PLF21CD375773F508D\&playnext=1>. Acesso em: 30 abr. 2012 (2:24:50).

${ }^{1356}$ Arguição de Descumprimento de Preceito Fundamental no ${ }^{\circ}$ 44-8. Voto lido em plenário pelo Ministro Celso

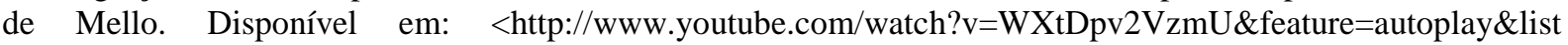
$=$ PLF21CD375773F508D\&playnext=1>. Acesso em: 30 abr. 2012 (2:27:10-2:30:45).

${ }^{1357}$ Arguição de Descumprimento de Preceito Fundamental no $54-8$. Voto lido em plenário pelo Ministro Celso de Mello. Disponível em: <http://www.youtube.com/watch?v=WXtDpv2VzmU\&feature=autoplay\&list $=$ PLF21CD375773F508D\&playnext=1>. Acesso em: 30 abr. 2012 (2:26:32-2:26:40).

${ }^{1358}$ Arguição de Descumprimento de Preceito Fundamental no $54-8$. Voto lido em plenário pelo Ministro Celso de Mello. Disponível em: <http://www.youtube.com/watch?v=WXtDpv2VzmU\&feature=autoplay\&list $=$ PLF21CD375773F508D\&playnext=1>. Acesso em: 30 abr. 2012 (2:32:22-2:32:28).

${ }^{1359}$ Arguição de Descumprimento de Preceito Fundamental no ${ }^{\circ}$ 44-8. Voto lido em plenário pelo Ministro Celso de Mello. Disponível em: <http://www.youtube.com/watch? $v=W X t D p v 2 V z m U \&$ feature=autoplay\&list $=$ PLF21CD375773F508D\&playnext=1>. Acesso em: 30 abr. 2012 (2:32:44-2:33:20).

${ }^{1360}$ Arguição de Descumprimento de Preceito Fundamental $n^{\circ}$ 54-8. Voto lido em plenário pelo Ministro Celso

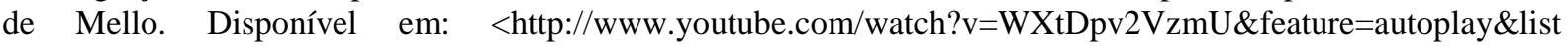
$=$ PLF21CD375773F508D\&playnext=1>. Acesso em: 30 abr. 2012 (2:17:30-2:17:46).

${ }^{1361}$ Arguição de Descumprimento de Preceito Fundamental no $54-8$. Voto lido em plenário pelo Ministro Celso de Mello. Disponível em: <http://www.youtube.com/watch?v=WXtDpv2VzmU\&feature=autoplay\&list $=$ PLF21CD375773F508D\&playnext=1>. Acesso em: 30 abr. 2012 (2:19:17-2:19:37).

${ }^{1362}$ Arguição de Descumprimento de Preceito Fundamental no $54-8$. Voto lido em plenário pelo Ministro Celso de Mello. Disponível em: <http://www.youtube.com/watch?v=WXtDpv2VzmU\&feature=autoplay\&list $=$ PLF21CD375773F508D\&playnext=1>. Acesso em: 30 abr. 2012 (2:19:40-2:20:07).
} 
O Ministro acredita que cabe ao Supremo extrair a máxima eficácia dos direitos ${ }^{1363}$, e que hoje existe uma nova perspectiva do Direito Internacional que considera a dimensão subjetiva da pessoa humana, tendo a dignidade como valor essencial do ordenamento jurídico $^{1364}$.

O Ministro entendeu ainda que não há graus de anencefalia e que pensar nesses graus de anencefalia seria algo incompatível com o que se tem tratado na ADPF n ${ }^{\circ} 54^{1365}$.

Continuou Celso de Mello sua análise sobre o início da vida abordando as teorias desde Aristóteles até São Tomás de Aquino, destacando que, inexistindo consenso a respeito do tema dentro da própria igreja, o Papa Pio IX decidiu que a vida se daria no momento da concepção $^{1366}$.

No entanto, o Ministro partiu do conceito de morte para encontrar um conceito de vida. A ausência de atividade cerebral, que conceitua a morte, serve de parâmetro para definir o que é vida ${ }^{1367}$. A contrario sensu, para Celso de Mello, a vida começa com os primeiros sinais da atividade cerebral, embora tenha também relembrado o Ministro a existência de inúmeras correntes científicas que tentam explicar a partir de que momento a vida começaria $^{1368}$.

O Ministro Celso de Mello debateu uma nova vertente sobre uma das dimensões do princípio da proporcionalidade, afirmando que a proteção insuficiente ou deficiente de um direito fundamental também permitiriam a aplicação desse princípio - e não apenas a proibição do excesso - pois, tratar-se-iam de direitos fundamentais da mesma estatura a

\footnotetext{
${ }^{1363}$ Arguição de Descumprimento de Preceito Fundamental no $54-8$. Voto lido em plenário pelo Ministro Celso de Mello. Disponível em: <http://www.youtube.com/watch? $v=W X t D p v 2 V z m U \&$ feature=autoplay\&list $=$ PLF21CD375773F508D\&playnext=1>. Acesso em: 30 abr. 2012 (2:34:58-2:35:10).

${ }^{1364}$ Arguição de Descumprimento de Preceito Fundamental no $54-8$. Voto lido em plenário pelo Ministro Celso de Mello. Disponível em: <http://www.youtube.com/watch? $v=W X t D p v 2 V z m U \&$ feature=autoplay\&list $=$ PLF21CD375773F508D\&playnext=1>. Acesso em: 30 abr. 2012 (2:35:40-2:36:23).

${ }^{1365}$ Arguição de Descumprimento de Preceito Fundamental n ${ }^{\circ}$ 54-8. Voto lido em plenário pelo Ministro Celso de Mello. Disponível em: <http://www.youtube.com/watch?v=WXtDpv2VzmU\&feature=autoplay\&list $=$ PLF21CD375773F508D\&playnext=1>. Acesso em: 30 abr. 2012 (0:04:50-0:04:57).

${ }^{1366}$ Arguição de Descumprimento de Preceito Fundamental $\mathrm{n}^{\circ}$ 54-8. Voto lido em plenário pelo Ministro Celso de Mello. Disponível em: <http://www.youtube.com/watch?v=WXtDpv2VzmU\&feature=autoplay\&list $=$ PLF21CD375773F508D\&playnext=1>. Acesso em: 30 abr. 2012 (0:05:00-0:10:05).

${ }_{1367}$ Arguição de Descumprimento de Preceito Fundamental $n^{\circ}$ 54-8. Voto lido em plenário pelo Ministro Celso de Mello. Disponível em: <http://www.youtube.com/watch?v=WXtDpv2VzmU\&feature=autoplay\&list $=$ PLF21CD375773F508D\&playnext=1>. Acesso em: 30 abr. 2012 (0:10:40-0:11:00).

${ }^{1368}$ Arguição de Descumprimento de Preceito Fundamental no 54-8. Voto lido em plenário pelo Ministro Celso de Mello. Disponível em: <http://www.youtube.com/watch?v=WXtDpv2VzmU\&feature=autoplay\&list $=$ PLF21CD375773F508D\&playnext=1>. Acesso em: 30 abr. 2012 (0:11:00-0:11:25).
} 
outros que estariam sujeitos à teoria da "ponderação concreta"1369. Assim, para o Ministro, mesmo em se tratando de direito à vida, é possível a ponderação ${ }^{1370}$.

O Ministro também se valeu da interpretação hermenêutica debatida pela Comissão Interamericana de Direitos Humanos no caso Baby Boy (Resolução 23/81). Nesse caso, a Comissão interpreta a cláusula "em geral" constante do artigo 4.1 da Convenção Americana de Direitos Humanos ${ }^{1371}$ e entende que se não existisse tal dispositivo, a interpretação seria totalmente diferente, admitindo-se a proteção do direito à vida de forma absoluta desde a concepção, o que não é caso.

O Ministro também analisou a anencefalia do ponto de vista do Direito Penal ${ }^{1372}$. Entendeu ele que não existe no feto anencéfalo um "organismo cuja integridade deva ser protegida pela legislação penal"1373, pois é considerado um "natimorto", conforme a Resolução 1752/04 editada pelo Conselho Federal de Medicina, não existindo, portanto, “objeto material do tipo penal" ${ }^{1374}$. Assim, para o Ministro, não há aborto no caso do anencéfalo: A interrupção voluntária da gestação de feto anencéfalo é fato atípico e não se trata de mais uma hipótese de excludente ${ }^{1375}$. Ainda que a conduta fosse considerada típica, não há "delituosidade". Trata-se, para o Ministro, de "causa supralegal de exclusão de culpabilidade" ${ }^{1376}$, isto é, não há qualquer fundamento que sustente a obrigatoriedade da

\footnotetext{
${ }^{1369}$ Arguição de Descumprimento de Preceito Fundamental no 54-8. Voto lido em plenário pelo Ministro Celso de Mello. Disponível em: <http://www.youtube.com/watch?v=WXtDpv2VzmU\&feature=autoplay\&list =PLF21CD375773F508D\&playnext=1>. Acesso em: 30 abr. 2012 (0:16:10-0:17:30).

${ }^{1370}$ Arguição de Descumprimento de Preceito Fundamental no 54-8. Voto lido em plenário pelo Ministro Celso de Mello. Disponível em: <http://www.youtube.com/watch?v=WXtDpv2VzmU\&feature=autoplay\&list $=$ PLF21CD375773F508D\&playnext=1>. Acesso em: 30 abr. 2012 (0:22:50).

${ }^{1371}$ Arguição de Descumprimento de Preceito Fundamental $n^{\circ}$ 54-8. Voto lido em plenário pelo Ministro Celso de Mello. Disponível em: <http://www.youtube.com/watch?v=WXtDpv2VzmU\&feature=autoplay\&list $=$ PLF21CD375773F508D\&playnext=1>. Acesso em: 30 abr. 2012 (0:24:30—0:29:25).

${ }^{1372}$ Arguição de Descumprimento de Preceito Fundamental $n^{\circ}$ 54-8. Voto lido em plenário pelo Ministro Celso de Mello. Disponível em: <http://www.youtube.com/watch?v=WXtDpv2VzmU\&feature=autoplay\&list $=$ PLF21CD375773F508D\&playnext=1>. Acesso em: 30 abr. 2012 (0:29:26-0:29:55).

${ }^{1373}$ Arguição de Descumprimento de Preceito Fundamental no 54-8. Voto lido em plenário pelo Ministro Celso de Mello. Disponível em: <http://www.youtube.com/watch?v=WXtDpv2VzmU\&feature=autoplay\&list $=$ PLF21CD375773F508D\&playnext=1>. Acesso em: 30 abr. 2012 (0:29:55-0:30:35).

${ }^{1374}$ Arguição de Descumprimento de Preceito Fundamental no 54-8. Voto lido em plenário pelo Ministro Celso de Mello. Disponível em: <http://www.youtube.com/watch?v=WXtDpv2VzmU\&feature=autoplay\&list =PLF21CD375773F508D\&playnext=1>. Acesso em: 30 abr. 2012 (0:30:55).

${ }^{1375}$ Arguição de Descumprimento de Preceito Fundamental $n^{\circ}$ 54-8. Voto lido em plenário pelo Ministro Celso de Mello. Disponível em: <http://www.youtube.com/watch?v=WXtDpv2VzmU\&feature=autoplay\&list =PLF21CD375773F508D\&playnext=1>. Acesso em: 30 abr. 2012 (0:47:25).

${ }^{1376}$ Arguição de Descumprimento de Preceito Fundamental $n^{\circ}$ 54-8. Voto lido em plenário pelo Ministro Celso de Mello. Disponível em: <http://www.youtube.com/watch?v=WXtDpv2VzmU\&feature=autoplay\&list $=$ PLF21CD375773F508D\&playnext=1>. Acesso em: 30 abr. 2012 (0:48:55-0:49:04).
} 
manutenção da gravidez ${ }^{1377}$, configurando inexigibilidade de conduta diversa, descaracterizando a delituosidade da conduta.

Por fim, julga procedente a ação para dar interpretação conforme à Constituição aos artigos 124, 126 e 128, I e II d Código Penal ${ }^{1378}$.

\subsubsection{Voto do Ministro Cezar Peluso ${ }^{1379}$}

Para o Ministro, o caso do aborto do feto anencéfalo é importante para estabelecer-se o "conceito de vida e sua tutela normativa" ${ }^{1380}$. Em primeiro lugar, entendeu o Ministro que existe uma profunda diferença entre este caso, de aborto de anencéfalo, e o das célulastronco ${ }^{1381}$, uma vez que este envolvia embriões excedentes, que jamais seriam implantados no útero $^{1382}$, restando afastada qualquer concepção de vida humana do caso, pois inexistente o "processo vital" que, segundo Peluso, caracterizaria a vida ${ }^{1383}$.

Segundo Peluso, pois, a vida é um processo ${ }^{1384}$, entendida como uma "sessão contínua de mudanças", que não decorre de um conceito jurídico que serve para "eventos operacionais de acordo com diretriz unitária de movimentação autônoma"1385. Para o Ministro, "não há

1377 Arguição de Descumprimento de Preceito Fundamental no 54-8. Voto lido em plenário pelo Ministro Celso de Mello. Disponível em: <http://www.youtube.com/watch?v=WXtDpv2VzmU\&feature=autoplay\&list $=$ PLF21CD375773F508D\&playnext=1>. Acesso em: 30 abr. 2012. (0:50:33).

${ }^{1378}$ O Ministro considera relevante a susgestão do Ministro Gilmar Mendes de exigir que médico diferente daquele que fará o procedimento avalie a condição de anencefalia do feto e que o Ministério da Saúde e o Conselho Federal de Medicina regulem a matéria. (0:54:11).

1379 Arguição de Descumprimento de Preceito Fundamental no 54-8. Voto lido em plenário pelo Ministro Cezar Peluso. Disponível em: <http://www.youtube.com/watch?v=1Bh_d4D56jI\&list=PLF21CD375773F508D \&index=1\&feature=plpp_video $>$. Acesso em: 30 abr. 2012.

1380 Arguição de Descumprimento de Preceito Fundamental no $54-8$. Voto lido em plenário pelo Ministro Cezar Peluso. Disponível em: <http://www.youtube.com/watch?v=1Bh_d4D56jI\&list=PLF21CD375773F508D \&index $=1 \&$ feature=plpp_video $>$. Acesso em: 02 mai. 2012 (1:01:30-1:01:39).

${ }^{1381}$ Arguição de Descumprimento de Preceito Fundamental $\mathrm{n}^{\circ}$ 54-8. Voto lido em plenário pelo Ministro Cezar Peluso. Disponível em: <http://www.youtube.com/watch?v=1Bh_d4D56jI\&list=PLF21CD375773F508D \&index=1\&feature=plpp_video $>$. Acesso em: 02 mai. 2012 (1:04:00-1:04:05).

${ }^{1382}$ Arguição de Descumprimento de Preceito Fundamental no 54-8. Voto lido em plenário pelo Ministro Cezar Peluso. Disponível em: <http://www.youtube.com/watch?v=1Bh_d4D56jI\&list=PLF21CD375773F508D \&index=1\&feature=plpp_video $>$. Acesso em: 02 mai. 2012 (1:04:07-1:04:14).

${ }_{1383}$ Arguição de Descumprimento de Preceito Fundamental no 54-8. Voto lido em plenário pelo Ministro Cezar Peluso. Disponível em: <http://www.youtube.com/watch?v=1Bh_d4D56jI\&list=PLF21CD375773F508D \&index=1\&feature=plpp_video $>$. Acesso em: 02 mai. 2012 (1:04:15-1:04:30).

${ }^{1384}$ Arguição de Descumprimento de Preceito Fundamental $n^{\circ}$ 54-8. Voto lido em plenário pelo Ministro Cezar Peluso. Disponível em: <http://www.youtube.com/watch?v=1Bh_d4D56jI\&list=PLF21CD375773F508D \&index=1\&feature=plpp_video $>$. Acesso em: 02 mai. 2012 (1:04:35-1:04:38).

${ }^{1385}$ Arguição de Descumprimento de Preceito Fundamental $n^{\circ}$ 54-8. Voto lido em plenário pelo Ministro Cezar Peluso. Disponível em: <http://www.youtube.com/watch?v=1Bh_d4D56jI\&list=PLF21CD375773F508D \&index=1\&feature=plpp_video $>$. Acesso em: 02 mai. 2012 (1:05:59-1:06:09). 
vida no ser que não tenha, ou ainda não tenha, a capacidade de mover-se por si mesmo" "1386, que seria o caso dos embriões excedentes do caso das células-tronco.

Para Peluso, entretanto, os fetos anencéfalos, com exceção daqueles que efetivamente morreram, têm essa capacidade de movimento autônomo "vinculado ao processo contínuo da vida" ${ }^{1387}$, e a própria morte encefálica pressupõe a existência de vida ${ }^{1388}$.

Segundo o Ministro, no caso da ADI 3510, seu voto seguiu no sentido de se identificar a "ausência de vida no material embrionário congelado"1389, ainda que goze de "dignidade constitucional própria" ${ }^{1390}$, o que é uma situação diversa da do aborto do feto anencéfalo ${ }^{1391}$.

Ademais, para Peluso, o conceito de morte trazido pela Lei 9.474 tem apenas uma função "operacional” para fins de transplante de órgãos ${ }^{1392}$, e, segundo ele, não é possível aplicar-se tal conceito no caso do anencéfalo ${ }^{1393}$.

Lembrou-nos o Ministro ainda de que a morte é irreversível, e, com base nisso, entendeu ele que o resultado da audiência pública da ADPF 54 teria sido "contraditório"1394. Para Peluso, o próprio termo "anencefalia" induz a erro, pois sugere completa ausência de cérebro, quando, na verdade, a ausência é de apenas "uma parte do encefalo"1395.

\footnotetext{
${ }^{1386}$ Arguição de Descumprimento de Preceito Fundamental n ${ }^{\circ}$ 54-8. Voto lido em plenário pelo Ministro Cezar Peluso. Disponível em: <http://www.youtube.com/watch?v=1Bh_d4D56jI\&list=PLF21CD375773F508D \&index=1\&feature=plpp_video $>$. Acesso em: 02 mai. 2012 (1:06:25-1:06:32).

${ }_{1387}$ Arguição de Descumprimento de Preceito Fundamental $n^{\circ}$ 54-8. Voto lido em plenário pelo Ministro Cezar Peluso. Disponível em: <http://www.youtube.com/watch?v=1Bh_d4D56jI\&list=PLF21CD375773F508D \&index=1\&feature=plpp_video $>$. Acesso em: 02 mai. 2012 (1:07:55-1:08:00).

${ }^{1388}$ Arguição de Descumprimento de Preceito Fundamental no ${ }^{54-8}$. Voto lido em plenário pelo Ministro Cezar Peluso. Disponível em: <http://www.youtube.com/watch?v=1Bh_d4D56jI\&list=PLF21CD375773F508D \&index=1\&feature=plpp_video $>$. Acesso em: 02 mai. 2012 (1:08:15-1:08:31).

${ }_{1389}$ Arguição de Descumprimento de Preceito Fundamental no ${ }^{\circ} 54-8$. Voto lido em plenário pelo Ministro Cezar Peluso. Disponível em: <http://www.youtube.com/watch?v=1Bh_d4D56jI\&list=PLF21CD375773F508D \&index=1\&feature=plpp_video $>$. Acesso em: 02 mai. 2012 (1:08:35-1:08:50).

${ }_{1390}$ Arguição de Descumprimento de Preceito Fundamental no ${ }^{\circ}$ 54-8. Voto lido em plenário pelo Ministro Cezar Peluso. Disponível em: <http://www.youtube.com/watch?v=1Bh_d4D56jI\&list=PLF21CD375773F508D \&index=1\&feature=plpp_video $>$. Acesso em: 02 mai. 2012 (1:08:35-1:08:50).

${ }^{1391}$ Arguição de Descumprimento de Preceito Fundamental no ${ }^{\circ}$ 54-8. Voto lido em plenário pelo Ministro Cezar Peluso. Disponível em: <http://www.youtube.com/watch?v=1Bh_d4D56jI\&list=PLF21CD375773F508D \&index=1\&feature=plpp_video $>$. Acesso em: 02 mai. 2012 (1:08:51-1:09:11).

${ }^{1392}$ Arguição de Descumprimento de Preceito Fundamental no ${ }^{54-8}$. Voto lido em plenário pelo Ministro Cezar Peluso. Disponível em: <http://www.youtube.com/watch?v=1Bh_d4D56jI\&list=PLF21CD375773F508D \&index=1\&feature=plpp_video $>$. Acesso em: 02 mai. 2012 (1:09:35-1:09:59).

${ }^{1393}$ Arguição de Descumprimento de Preceito Fundamental no ${ }^{54-8}$. Voto lido em plenário pelo Ministro Cezar Peluso. Disponível em: <http://www.youtube.com/watch?v=1Bh_d4D56jI\&list=PLF21CD375773F508D \&index $=1$ \&feature=plpp_video $>$. Acesso em: 02 mai. 2012 (1:10:20-1:10:44).

${ }_{1394}$ Arguição de Descumprimento de Preceito Fundamental $n^{\circ}$ 54-8. Voto lido em plenário pelo Ministro Cezar Peluso. Disponível em: <http://www.youtube.com/watch?v=1Bh_d4D56jI\&list=PLF21CD375773F508D \&index=1\&feature=plpp_video $>$. Acesso em: 02 mai. 2012 (1:10:44-1:10:47).

${ }^{1395}$ Arguição de Descumprimento de Preceito Fundamental $n^{\circ}$ 54-8. Voto lido em plenário pelo Ministro Cezar Peluso. Disponível em: <http://www.youtube.com/watch?v=1Bh_d4D56jI\&list=PLF21CD375773F508D \&index $=1 \&$ feature=plpp_video $>$. Acesso em: 02 mai. 2012 (1:11:12-1:11:38).
} 
Dando continuidade a seu raciocínio, concluiu, então, o Ministro, que a morte encefálica para fins de transplante é uma interrupção do "ciclo vital que chega ao seu termo" 1396 , enquanto que a "anencefalia integra, ainda que brevemente, o processo contínuo e progressivo que chamamos vida" ${ }^{\text {1397, }}$ e, portanto, não pode ser interrompida ${ }^{1398}$.

Além disso, o Ministro defendeu que o fundamento do aborto e da morte encefálica para transplante de órgãos são diversos ${ }^{1399}$ : no caso de transplantes, a morte encefálica é declarada visando-se a "salvar a vida alheia"1400; enquanto que, por outro lado, "ninguém sustenta a possibilidade de fazer aborto para salvar vida alheia" ${ }^{1401}$ no caso do anencéfalo ${ }^{1402}$.

A seguir, Peluso questionou a alusão à liberdade, autonomia e autodeterminação para justificar o aborto do anencéfalo, bem como o argumento de que se a lei não impõe ou não proíbe determinada conduta, como a interrupção da gravidez específica do feto anencéfalo, ela não seria proibida ${ }^{1403}$. Para ele, tal tipo de raciocínio simplesmente não se aplica no Direito Penal ${ }^{1404}$.

\footnotetext{
${ }^{1396}$ Arguição de Descumprimento de Preceito Fundamental no $54-8$. Voto lido em plenário pelo Ministro Cezar Peluso. Disponível em: <http://www.youtube.com/watch?v=1Bh_d4D56jI\&list=PLF21CD375773F508D \&index=1\&feature=plpp_video $>$. Acesso em: 02 mai. 2012 (1:11:46-1:12:04).

${ }^{1397}$ Arguição de Descumprimento de Preceito Fundamental no ${ }^{\circ}$ 54-8. Voto lido em plenário pelo Ministro Cezar Peluso. Disponível em: <http://www.youtube.com/watch?v=1Bh_d4D56jI\&list=PLF21CD375773F508D \&index=1\&feature=plpp_video $>$. Acesso em: 02 mai. 2012 (1:12:05-1:12:14).

${ }^{1398}$ Arguição de Descumprimento de Preceito Fundamental no ${ }^{54-8}$. Voto lido em plenário pelo Ministro Cezar Peluso. Disponível em: <http://www.youtube.com/watch?v=1Bh_d4D56jI\&list=PLF21CD375773F508D \&index=1\&feature=plpp_video $>$. Acesso em: 02 mai. 2012 (1:12:15-1:12:29).

1399 Arguição de Descumprimento de Preceito Fundamental no $54-8$. Voto lido em plenário pelo Ministro Cezar Peluso. Disponível em: <http://www.youtube.com/watch?v=1Bh_d4D56jI\&list=PLF21CD375773F508D \&index $=1$ \& feature=plpp_video $>$. Acesso em: 02 mai. 2012 (1:13:05-1:13:23).

${ }^{1400}$ Arguição de Descumprimento de Preceito Fundamental no ${ }^{54-8}$. Voto lido em plenário pelo Ministro Cezar Peluso. Disponível em: <http://www.youtube.com/watch?v=1Bh_d4D56jI\&list=PLF21CD375773F508D \&index=1\&feature=plpp_video $>$. Acesso em: 02 mai. 2012 (1:12:50-1:12:54).

${ }^{1401}$ Arguição de Descumprimento de Preceito Fundamental no ${ }^{5} 4-8$. Voto lido em plenário pelo Ministro Cezar Peluso. Disponível em: <http://www.youtube.com/watch?v=1Bh_d4D56jI\&list=PLF21CD375773F508D \&index=1\&feature=plpp_video $>$. Acesso em: 02 mai. 2012 (1:13:00-1:13:04).

${ }_{1402}$ Vale lembrar aqui Supiot: "o sentido da vida não reside em nossos órgãos [...]. Recusar compreendê-lo, identificar a razão à explicação científica ou o Direito à regulação biológica só pode escancarar as válvulas da loucura ou da violência mortal". SUPIOT, Alain. Homus juridicus: Ensaio sobre a função antropológica do Direito. Trad. Maria Ermantina de Almeida Prado Galvão. São Paulo: Martins Fontes, 2007, p. XIV.

${ }_{1403}$ Arguição de Descumprimento de Preceito Fundamental no $54-8$. Voto lido em plenário pelo Ministro Cezar Peluso. Disponível em: <http://www.youtube.com/watch?v=1Bh_d4D56jI\&list=PLF21CD375773F508D \&index=1\&feature=plpp_video $>$. Acesso em: 02 mai. 2012 (1:13:24-1:14:04).

${ }^{1404}$ Arguição de Descumprimento de Preceito Fundamental $n^{\circ}$ 54-8. Voto lido em plenário pelo Ministro Cezar Peluso. Disponível em: <http://www.youtube.com/watch?v=1Bh_d4D56jI\&list=PLF21CD375773F508D \&index=1\&feature=plpp_video $>$. Acesso em: 02 mai. 2012 (1:14:04-1:14:09).
} 
Peluso também questionou a necessidade de se existir uma potencialidade de vida extrauterina para se configurar o aborto ${ }^{1405}$. Para o Ministro não há dúvida de que essa potencialidade não é necessária para que a conduta viole a lei ${ }^{1406}$.

Finalmente, quanto ao apelo à liberdade, autonomia e autodeterminação, para o Ministro, tais valores não podem ser usados de modo preordenado a se acobertar "o cometimento de um crime"1407.

Para Peluso, no aborto do anencéfalo, aplica-se uma "pena capital" ao feto ${ }^{1408}$, sem reconhecer-lhe ética ou juridicamente a dignidade ${ }^{1409}$, o que é atentatório a um mundo diverso e plural ${ }^{1410}$; é reduzir o feto à "condição de lixo, imprestável ou incômoda"1411; uma pena de morte decretada pelo mais forte ao mais fraco ${ }^{1412}$.

Ademais, agrega o Ministro que a alcunha de "mostruosidade" não descaracteriza a proteção jurídica do feto anencéfalo, pois ele pertence à categoria humana ${ }^{1413}$. Para Cezar Peluso, a liberdade de crença aliada à autonomia individual, "adulteradas"1414 para justificar determinadas condutas, poderiam ensejar inclusive a autorização de condutas "satânicas" com

\footnotetext{
${ }^{1405}$ Arguição de Descumprimento de Preceito Fundamental no $54-8$. Voto lido em plenário pelo Ministro Cezar Peluso. Disponível em: <http://www.youtube.com/watch?v=1Bh_d4D56jI\&list=PLF21CD375773F508D \&index=1\&feature=plpp_video $>$. Acesso em: 02 mai. 2012 (1:14:25-1:14:33).

${ }^{1406}$ Arguição de Descumprimento de Preceito Fundamental $n^{\circ}$ 54-8. Voto lido em plenário pelo Ministro Cezar Peluso. Disponível em: <http://www.youtube.com/watch?v=1Bh_d4D56jI\&list=PLF21CD375773F508D \&index $=1$ \&feature=plpp_video $>$. Acesso em: 02 mai. 2012 (1:14:34-1:14:56).

${ }_{1407}$ Arguição de Descumprimento de Preceito Fundamental no 54-8. Voto lido em plenário pelo Ministro Cezar Peluso. Disponível em: <http://www.youtube.com/watch?v=1Bh_d4D56jI\&list=PLF21CD375773F508D \&index=1\&feature=plpp_video $>$. Acesso em: 02 mai. 2012 (1:14: 56-1:15:30).

${ }_{1408}$ Arguição de Descumprimento de Preceito Fundamental $n^{\circ}$ 54-8. Voto lido em plenário pelo Ministro Cezar Peluso. Disponível em: <http://www.youtube.com/watch?v=1Bh_d4D56jI\&list=PLF21CD375773F508D \&index=1\&feature=plpp_video $>$. Acesso em: 02 mai. 2012 (1:15:40-1:15:45).

${ }_{1409}$ Arguição de Descumprimento de Preceito Fundamental $n^{\circ}$ 54-8. Voto lido em plenário pelo Ministro Cezar Peluso. Disponível em: <http://www.youtube.com/watch?v=1Bh_d4D56jI\&list=PLF21CD375773F508D \&index=1\&feature=plpp_video $>$. Acesso em: 02 mai. 2012 (1:16:14-1:16:17).

${ }_{1410}$ Arguição de Descumprimento de Preceito Fundamental $n^{\circ}$ 54-8. Voto lido em plenário pelo Ministro Cezar Peluso. Disponível em: <http://www.youtube.com/watch?v=1Bh_d4D56jI\&list=PLF21CD375773F508D \&index=1\&feature=plpp_video $>$. Acesso em: 02 mai. 2012 (1:15:47-1:15:51).

${ }^{1411}$ Arguição de Descumprimento de Preceito Fundamental no ${ }^{5} 4-8$. Voto lido em plenário pelo Ministro Cezar Peluso. Disponível em: <http://www.youtube.com/watch?v=1Bh_d4D56jI\&list=PLF21CD375773F508D \&index=1\&feature=plpp_video $>$. Acesso em: 02 mai. 2012 (1:16:04-1:16:14).

${ }_{1412}$ Arguição de Descumprimento de Preceito Fundamental $n^{\circ}$ 54-8. Voto lido em plenário pelo Ministro Cezar Peluso. Disponível em: <http://www.youtube.com/watch?v=1Bh_d4D56jI\&list=PLF21CD375773F508D \&index=1\&feature=plpp_video $>$. Acesso em: 30 abr. 2012 (1:16:43-1:17:17).

${ }_{1413}$ Arguição de Descumprimento de Preceito Fundamental $n^{\circ}$ 54-8. Voto lido em plenário pelo Ministro Cezar Peluso. Disponível em: <http://www.youtube.com/watch?v=1Bh_d4D56jI\&list=PLF21CD375773F508D \&index=1\&feature=plpp_video $>$. Acesso em: 30 abr. 2012 (1:17:18-1:17:57).

${ }^{1414}$ Arguição de Descumprimento de Preceito Fundamental no ${ }^{\circ}$ 54-8. Voto lido em plenário pelo Ministro Cezar Peluso. Disponível em: <http://www.youtube.com/watch?v=1Bh_d4D56jI\&list=PLF21CD375773F508D \&index=1\&feature=plpp_video>. Acesso em: 30 abr. 2012 (1:19:37-1:19:39).
} 
"sacrifícios humanos"1415. Para o Ministro, nos dois casos, a "agressão do valor constitucional da vida" que se discute é a mesma ${ }^{1416}$.

Ainda para o Ministro, a tipicidade de conduta se enquadra nas disposições legais que tratam do aborto ${ }^{1417}$, pois, se assim não o fosse, seria possível, a partir dessa interpretação, ser aplicada em caso de "assassinatos de bebês anencéfalos recém-nascidos" 1418 com os mesmos fundamentos de saúde psíquica da mãe, mudando-se apenas o "momento da execução"1419.

Rechaça também o Ministro o argumento de que a vida de um feto teria menos valor que a vida de um adulto ${ }^{1420}$, pois, para ele, o valor da vida intrauterina, ainda que como projeto de vida, também está protegida pela lei, e o feto é bem jurídico que merece proteção jurídica $^{1421}$, independentemente de deformidade que possa apresentar ainda no útero, pois sua dignidade já está tutelada ${ }^{1422}$.

Para o Ministro, a possibilidade de dispor do feto anencéfalo o transformaria em coisa $^{1423}$, mas o "ser humano é sujeito de direito"1424. Ainda que não tenha personalidade jurídica, o feto - "anencéfalo ou não"1425 - tem garantido seus direitos, de acordo com o

${ }^{1415}$ Arguição de Descumprimento de Preceito Fundamental n ${ }^{\circ}$ 54-8. Voto lido em plenário pelo Ministro Cezar Peluso. Disponível em: <http://www.youtube.com/watch?v=1Bh_d4D56jI\&list=PLF21CD375773F508D \&index=1\&feature=plpp_video $>$. Acesso em: 30 abr. 2012 (1:17:58-1:19:16).

${ }^{1416}$ Arguição de Descumprimento de Preceito Fundamental no 54-8. Voto lido em plenário pelo Ministro Cezar Peluso. Disponível em: <http://www.youtube.com/watch?v=1Bh_d4D56jI\&list=PLF21CD375773F508D \&index=1\&feature=plpp_video $>$. Acesso em: 30 abr. 2012 1:19:48-1:19:51).

1417 Arguição de Descumprimento de Preceito Fundamental $n^{\circ}$ 54-8. Voto lido em plenário pelo Ministro Cezar Peluso. Disponível em: <http://www.youtube.com/watch?v=1Bh_d4D56jI\&list=PLF21CD375773F508D \&index=1\&feature=plpp_video $>$. Acesso em: 30 abr. 2012 (1:22:50-1:23:10).

1418 Arguição de Descumprimento de Preceito Fundamental no 54-8. Voto lido em plenário pelo Ministro Cezar Peluso. Disponível em: <http://www.youtube.com/watch?v=1Bh_d4D56jI\&list=PLF21CD375773F508D \&index=1\&feature=plpp_video $>$. Acesso em: 30 abr. 2012 (1:23:17-1:23:28).

1419 Arguição de Descumprimento de Preceito Fundamental no 54-8. Voto lido em plenário pelo Ministro Cezar Peluso. Disponível em: <http://www.youtube.com/watch?v=1Bh_d4D56jI\&list=PLF21CD375773F508D \&index=1\&feature=plpp_video >. Acesso em: 30 abr. 2012 (1:23:29-1:23:54). Vide também 1:40:00-1:40:11.

${ }_{1420}$ Arguição de Descumprimento de Preceito Fundamental no 54-8. Voto lido em plenário pelo Ministro Cezar Peluso. Disponível em: <http://www.youtube.com/watch?v=1Bh_d4D56jI\&list=PLF21CD375773F508D \&index=1\&feature=plpp_video $>$. Acesso em: 30 abr. 2012 (1:25:10-1:25:16).

${ }^{1421}$ Arguição de Descumprimento de Preceito Fundamental $\mathrm{n}^{\circ}$ 54-8. Voto lido em plenário pelo Ministro Cezar Peluso. Disponível em: <http://www.youtube.com/watch?v=1Bh_d4D56jI\&list=PLF21CD375773F508D \&index=1\&feature=plpp_video $>$. Acesso em: 30 abr. 2012 (1:27:17-1:25:54).

${ }^{1422}$ Arguição de Descumprimento de Preceito Fundamental no 54-8. Voto lido em plenário pelo Ministro Cezar Peluso. Disponível em: <http://www.youtube.com/watch?v=1Bh_d4D56jI\&list=PLF21CD375773F508D \&index=1\&feature=plpp_video $>$. Acesso em: 30 abr. 2012 (1:25:23-1:26:11).

${ }^{1423}$ Arguição de Descumprimento de Preceito Fundamental no 54-8. Voto lido em plenário pelo Ministro Cezar Peluso. Disponível em: <http://www.youtube.com/watch?v=1Bh_d4D56jI\&list=PLF21CD375773F508D \&index=1\&feature=plpp_video>. Acesso em: 30 abr. 2012 (1:26:30).

${ }^{1424}$ Arguição de Descumprimento de Preceito Fundamental $n^{\circ}$ 54-8. Voto lido em plenário pelo Ministro Cezar Peluso. Disponível em: <http://www.youtube.com/watch?v=1Bh_d4D56jI\&list=PLF21CD375773F508D \&index=1\&feature=plpp_video>. Acesso em: 30 abr. 2012 (1:26:46).

${ }^{1425}$ Arguição de Descumprimento de Preceito Fundamental $n^{\circ}$ 54-8. Voto lido em plenário pelo Ministro Cezar Peluso. Disponível em: <http://www.youtube.com/watch?v=1Bh_d4D56jI\&list=PLF21CD375773F508D \&index=1\&feature=plpp_video $>$. Acesso em: 30 abr. 2012 (1:27:02-1:27:04). 
Código Civil ${ }^{1426}$. Não se trata, para o Ministro, de "capacidade de exercício desses direitos" $" 1427$, mas de "capacidade passiva"1428, uma vez que o direito o "reconhece como sujeito de direito enquanto portador de vida" ${ }^{1429}$. Assim, para Cezar Peluso, o feto é "sujeito de direito", nem coisa, nem objeto de direito alheio"1430.

O Ministro entende que o direito reconhece o "valor supremo da vida humana", que dar-se a morte não está legitimado ${ }^{1432}$, mesmo que haja uma breve duração da vida ${ }^{1433}$. Para Peluso, é preciso confrontar ainda a situação do anencéfalo com a eugenia e com situações semelhantes de angústia e dor ${ }^{1434}$. A dignidade é intrínsica à vida humana, e "anterior ao próprio ordenamento" ${ }^{1435}$. Para o Ministro, o direito à vida não pode ser relativizado $^{1436}$.

Para Peluso, a vida humana é "fundante e inegociável"1437, não comportando "margem para transigência"1438. A "curta potencialidade ou perspectiva de vida"1439 não é razão

${ }^{1426}$ Arguição de Descumprimento de Preceito Fundamental no $54-8$. Voto lido em plenário pelo Ministro Cezar Peluso. Disponível em: <http://www.youtube.com/watch?v=1Bh_d4D56jI\&list=PLF21CD375773F508D \&index $=1 \&$ feature=plpp_video $>$. Acesso em: 30 abr. 2012 (1:26:54-1:28:02).

${ }_{1427}$ Arguição de Descumprimento de Preceito Fundamental no ${ }^{54-8}$. Voto lido em plenário pelo Ministro Cezar Peluso. Disponível em: <http://www.youtube.com/watch?v=1Bh_d4D56jI\&list=PLF21CD375773F508D \&index=1\&feature=plpp_video $>$. Acesso em: 30 abr. 2012 (1:28:03-1:28:05).

${ }^{1428}$ Arguição de Descumprimento de Preceito Fundamental $n^{\circ}$ 54-8. Voto lido em plenário pelo Ministro Cezar Peluso. Disponível em: <http://www.youtube.com/watch?v=1Bh_d4D56jI\&list=PLF21CD375773F508D \&index $=1$ \&feature=plpp_video $>$. Acesso em: 30 abr. 2012 (1:28:11).

${ }_{1429}$ Arguição de Descumprimento de Preceito Fundamental no $54-8$. Voto lido em plenário pelo Ministro Cezar Peluso. Disponível em: <http://www.youtube.com/watch?v=1Bh_d4D56jI\&list=PLF21CD375773F508D \&index $=1$ \&feature=plpp_video $>$. Acesso em: 30 abr. 2012 (1:28:21).

${ }^{1430}$ Arguição de Descumprimento de Preceito Fundamental $n^{\circ}$ 54-8. Voto lido em plenário pelo Ministro Cezar Peluso. Disponível em: <http://www.youtube.com/watch?v=1Bh_d4D56jI\&list=PLF21CD375773F508D \&index=1\&feature=plpp_video>. Acesso em: 30 abr. 2012 (1:28:22-1:28:30).

${ }^{1431}$ Arguição de Descumprimento de Preceito Fundamental no ${ }^{54-8}$. Voto lido em plenário pelo Ministro Cezar Peluso. Disponível em: <http://www.youtube.com/watch?v=1Bh_d4D56jI\&list=PLF21CD375773F508D \&index=1\&feature=plpp_video $>$. Acesso em: 30 abr. 2012 (1:29:38-1:29:48).

${ }_{1432}$ Arguição de Descumprimento de Preceito Fundamental no ${ }^{\circ}$ 54-8. Voto lido em plenário pelo Ministro Cezar Peluso. Disponível em: <http://www.youtube.com/watch?v=1Bh_d4D56jI\&list=PLF21CD375773F508D \&index $=1 \&$ feature=plpp_video $>$. Acesso em: 30 abr. 2012 (1:30:08).

${ }^{1433}$ Arguição de Descumprimento de Preceito Fundamental $n^{\circ}$ 54-8. Voto lido em plenário pelo Ministro Cezar Peluso. Disponível em: <http://www.youtube.com/watch?v=1Bh_d4D56jI\&list=PLF21CD375773F508D \&index=1\&feature=plpp_video $>$. Acesso em: 30 abr. 2012 (1:29:45-1:30:09).

${ }^{1434}$ Arguição de Descumprimento de Preceito Fundamental no ${ }^{54-8}$. Voto lido em plenário pelo Ministro Cezar Peluso. Disponível em: <http://www.youtube.com/watch?v=1Bh_d4D56jI\&list=PLF21CD375773F508D \&index=1\&feature=plpp_video $>$. Acesso em: 30 abr. 2012 (1:30:10-1:30:26).

${ }_{1435}$ Arguição de Descumprimento de Preceito Fundamental no ${ }^{\circ}$ 54-8. Voto lido em plenário pelo Ministro Cezar Peluso. Disponível em: <http://www.youtube.com/watch?v=1Bh_d4D56jI\&list=PLF21CD375773F508D \&index=1\&feature=plpp_video $>$. Acesso em: 30 abr. 2012 (1:30:27-1:30:33).

${ }_{1436}$ Arguição de Descumprimento de Preceito Fundamental no ${ }^{\circ}$ 54-8. Voto lido em plenário pelo Ministro Cezar Peluso. Disponível em: <http://www.youtube.com/watch?v=1Bh_d4D56jI\&list=PLF21CD375773F508D \&index=1\&feature=plpp_video $>$. Acesso em: 30 abr. 2012 (1:30:34-1:30:42).

${ }^{1437}$ Arguição de Descumprimento de Preceito Fundamental $n^{\circ}$ 54-8. Voto lido em plenário pelo Ministro Cezar Peluso. Disponível em: <http://www.youtube.com/watch?v=1Bh_d4D56jI\&list=PLF21CD375773F508D \&index=1\&feature=plpp_video>. Acesso em: 30 abr. 2012 (1:30:44-1:31:01). 
suficiente para deixar de autorizar sua manutenção. Para ele, a dignidade humana não se “decompõe", ainda que o cérebro do feto seja incompleto ${ }^{1440}$. A curta duração da vida também não autoriza a "antecipação terapêutica da morte"1441. A vida é valor supremo, pressuposto de outros "bens materiais e imateriais" "1442. Para o Ministro, o feto goza de igual proteção de um adulto, criança ou outro feto sem deformidade ${ }^{1443}$.

Peluso também defende que o aborto de feto anencéfalo não se aproxima da eutanásia $^{1444}$, e também poderia justicar outras práticas abortivas, seja em razão de outras anomalias, seja por razões sociais ou até mesmo econômicas ${ }^{1445}$, pois, segundo o Ministro, para o direito, essas outras situações é que seriam análogas ao aborto do feto anencéfalo ${ }^{1446}$.

Para o Ministro, feto não é coisa e não importa seu "grau de inviabilidade extrauterina" 1447 ou "prognóstico" de vida, de modo que não pode ser descartado como se fosse "material genético congelado"1448.

O aborto do feto anencéfalo está intimamente ligado ao conceito de inviabilidade, mas, para o Ministro, a apuração da anencefalia ainda é muito difícil de ser verificada com

${ }^{1438}$ Arguição de Descumprimento de Preceito Fundamental n ${ }^{\circ}$ 54-8. Voto lido em plenário pelo Ministro Cezar Peluso. Disponível em: <http://www.youtube.com/watch?v=1Bh_d4D56jI\&list=PLF21CD375773F508D \&index $=1 \&$ feature=plpp_video $>$. Acesso em: 30 abr. 2012 (1:31:02-1:31:05).

1439 Arguição de Descumprimento de Preceito Fundamental $n^{\circ}$ 54-8. Voto lido em plenário pelo Ministro Cezar Peluso. Disponível em: <http://www.youtube.com/watch?v=1Bh_d4D56jI\&list=PLF21CD375773F508D \&index $=1 \&$ feature=plpp_video $>$. Acesso em: 30 abr. 2012 (1:31:10-1:31:24).

${ }^{1440}$ Arguição de Descumprimento de Preceito Fundamental $n^{\circ}$ 54-8. Voto lido em plenário pelo Ministro Cezar Peluso. Disponível em: <http://www.youtube.com/watch?v=1Bh_d4D56jI\&list=PLF21CD375773F508D \&index=1\&feature=plpp_video $>$. Acesso em: 30 abr. 2012 (1:31:25-1:31:46).

${ }^{1441}$ Arguição de Descumprimento de Preceito Fundamental n ${ }^{\circ}$ 54-8. Voto lido em plenário pelo Ministro Cezar Peluso. Disponível em: <http://www.youtube.com/watch?v=1Bh_d4D56jI\&list=PLF21CD375773F508D \&index=1\&feature=plpp_video $>$. Acesso em: 30 abr. 2012 (1:32:27-1:32:55).

${ }_{1442}$ Arguição de Descumprimento de Preceito Fundamental no 54-8. Voto lido em plenário pelo Ministro Cezar Peluso. Disponível em: <http://www.youtube.com/watch?v=1Bh_d4D56jI\&list=PLF21CD375773F508D \&index $=1 \&$ feature=plpp_video $>$. Acesso em: 30 abr. 2012 (1:33:00-1:33:44).

${ }^{1443}$ Arguição de Descumprimento de Preceito Fundamental $\mathrm{n}^{\circ}$ 54-8. Voto lido em plenário pelo Ministro Cezar Peluso. Disponível em: <http://www.youtube.com/watch?v=1Bh_d4D56jI\&list=PLF21CD375773F508D \&inde $=1 \&$ feature=plpp_video $>$. Acesso em: 30 abr. 2012 (1:34:00-1:34:23).

${ }^{1444}$ Arguição de Descumprimento de Preceito Fundamental $n^{\circ}$ 54-8. Voto lido em plenário pelo Ministro Cezar Peluso. Disponível em: <http://www.youtube.com/watch?v=1Bh_d4D56jI\&list=PLF21CD375773F508D \&index=1\&feature=plpp_video $>$. Acesso em: 30 abr. 2012 (1:35:30-1:35:36).

1445 Arguição de Descumprimento de Preceito Fundamental no 54-8. Voto lido em plenário pelo Ministro Cezar Peluso. Disponível em: <http://www.youtube.com/watch?v=1Bh_d4D56jI\&list=PLF21CD375773F508D \&index=1\&feature=plpp_video $>$. Acesso em: 30 abr. 2012 (1:37:20-1:37:22).

${ }_{1446}$ Arguição de Descumprimento de Preceito Fundamental no 54-8. Voto lido em plenário pelo Ministro Cezar Peluso. Disponível em: <http://www.youtube.com/watch?v=1Bh_d4D56jI\&list=PLF21CD375773F508D \&index=1\&feature=plpp_video $>$. Acesso em: 30 abr. 2012 (1:37:42-1:37:44).

${ }^{1447}$ Arguição de Descumprimento de Preceito Fundamental $n^{\circ}$ 54-8. Voto lido em plenário pelo Ministro Cezar Peluso. Disponível em: <http://www.youtube.com/watch?v=1Bh_d4D56jI\&list=PLF21CD375773F508D \&index=1\&feature=plpp_video $>$. Acesso em: 30 abr. 2012 (1:40:50-1:41:14).

${ }^{1448}$ Arguição de Descumprimento de Preceito Fundamental $n^{\circ}$ 54-8. Voto lido em plenário pelo Ministro Cezar Peluso. Disponível em: <http://www.youtube.com/watch?v=1Bh_d4D56jI\&list=PLF21CD375773F508D \&index=1\&feature=plpp_video $>$. Acesso em: 30 abr. 2012 (1:41:14). 
segurança ${ }^{1449}$, pois, como se depreendeu dos debates com especialistas, não haveria instrumentos para diferenciar a meroencefalia mais grave da anencefalia ${ }^{1450}$.

Para o Ministro, é preciso ter cautela no uso dessas "verdades provisórias"1451 trazidas pela ciência, incapaz de trazer conceitos exatos ${ }^{1452}$, devendo o intérprete se basear na “dignidade e incolumidade da vida humana" ${ }^{1453}$. No caso da Marcela, mesmo com a criança com quase um ano e com exames de tomografia, não houve consenso entre os especialistas para afirmar o diagnóstico de anencefalia, quiçá o diagnóstico de anencefalia via ultrassonografia do feto ainda no útero ${ }^{1454}$.

Criticou, ainda, Peluso, o argumento de analogia à tortura, decorrente da imposição à mulher de se levar a gestação até o fim, tratada como conduta que poderia ser evitada ${ }^{1455}$. Para Peluso, não se trata de uma conduta que possa ser evitada ${ }^{1456}$. A lei não autoriza outra conduta, que seria, inclusive, tipificada em lei como crime ${ }^{1457}$.

Além disso, para Peluso, não é possível erradicar o sofrimento da vida humana, pois este lhe seria "inerente"1458. Ademais, o sofrimento não diminui a dignidade ${ }^{1459}$. O Ministro

${ }^{1449}$ Arguição de Descumprimento de Preceito Fundamental n ${ }^{\circ}$ 54-8. Voto lido em plenário pelo Ministro Cezar Peluso. Disponível em: <http://www.youtube.com/watch?v=1Bh_d4D56jI\&list=PLF21CD375773F508D \&index=1\&feature=plpp_video $>$. Acesso em: 30 abr. 2012 (1:41:14-1:41:55).

${ }^{1450}$ Arguição de Descumprimento de Preceito Fundamental $n^{\circ}$ 54-8. Voto lido em plenário pelo Ministro Cezar Peluso. Disponível em: <http://www.youtube.com/watch?v=1Bh_d4D56jI\&list=PLF21CD375773F508D \&index $=1 \&$ feature=plpp_video $>$. Acesso em: 30 abr. 2012 (1:41:56-1:42:43).

${ }^{1451}$ Arguição de Descumprimento de Preceito Fundamental $\mathrm{n}^{\circ}$ 54-8. Voto lido em plenário pelo Ministro Cezar Peluso. Disponível em: <http://www.youtube.com/watch?v=1Bh_d4D56jI\&list=PLF21CD375773F508D \&index=1\&feature=plpp_video $>$. Acesso em: 30 abr. 2012 (1:43:57-1:44:00).

${ }^{1452}$ Arguição de Descumprimento de Preceito Fundamental $n^{\circ}$ 54-8. Voto lido em plenário pelo Ministro Cezar Peluso. Disponível em: <http://www.youtube.com/watch?v=1Bh_d4D56jI\&list=PLF21CD375773F508D \&index=1\&feature=plpp_video $>$. Acesso em: 30 abr. 2012 (1:44:01-1:44:40).

${ }^{1453}$ Arguição de Descumprimento de Preceito Fundamental no 54-8. Voto lido em plenário pelo Ministro Cezar Peluso. Disponível em: <http://www.youtube.com/watch?v=1Bh_d4D56jI\&list=PLF21CD375773F508D \&index $=1 \&$ feature=plpp_video $>$. Acesso em: 30 abr. 2012 (1:44:41-1:46:45).

${ }^{1454}$ Arguição de Descumprimento de Preceito Fundamental $n^{\circ}$ 54-8. Voto lido em plenário pelo Ministro Cezar Peluso. Disponível em: <http://www.youtube.com/watch?v=1Bh_d4D56jI\&list=PLF21CD375773F508D \&index=1\&feature=plpp_video $>$. Acesso em: 30 abr. 2012 (1:46:46-1:48:24).

${ }^{1455}$ Arguição de Descumprimento de Preceito Fundamental $\mathrm{n}^{\circ}$ 54-8. Voto lido em plenário pelo Ministro Cezar Peluso. Disponível em: <http://www.youtube.com/watch?v=1Bh_d4D56jI\&list=PLF21CD375773F508D \&index=1\&feature=plpp_video $>$. Acesso em: 30 abr. 2012 (1:50:30-1:51:19).

${ }^{1456}$ Arguição de Descumprimento de Preceito Fundamental no 54-8. Voto lido em plenário pelo Ministro Cezar Peluso. Disponível em: <http://www.youtube.com/watch?v=1Bh_d4D56jI\&list=PLF21CD375773F508D \&index=1\&feature=plpp_video $>$. Acesso em: 30 abr. 2012 (1:51:20-1:51:21).

${ }^{1457}$ Arguição de Descumprimento de Preceito Fundamental no 54-8. Voto lido em plenário pelo Ministro Cezar Peluso. Disponível em: <http://www.youtube.com/watch?v=1Bh_d4D56jI\&list=PLF21CD375773F508D \&index=1\&feature=plpp_video $>$. Acesso em: 30 abr. 2012 (1:51:22-1:51:55).

${ }_{1458}$ Arguição de Descumprimento de Preceito Fundamental $\mathrm{n}^{\circ}$ 54-8. Voto lido em plenário pelo Ministro Cezar Peluso. Disponível em: <http://www.youtube.com/watch?v=1Bh_d4D56jI\&list=PLF21CD375773F508D \&index=1\&feature=plpp_video $>$. Acesso em: 30 abr. 2012 (1:53:08-1:53:10).

${ }^{1459}$ Arguição de Descumprimento de Preceito Fundamental $\mathrm{n}^{\circ}$ 54-8. Voto lido em plenário pelo Ministro Cezar Peluso. Disponível em: <http://www.youtube.com/watch?v=1Bh_d4D56jI\&list=PLF21CD375773F508D \&index=1\&feature=plpp_video $>$. Acesso em: 30 abr. 2012 (1:53:10-1:53:14). 
considera uma "atitude egocêntrica" $" 1460$ por parte da mulher se abster de seu sofrimento eliminando-lhe a causa, isto é, o feto ${ }^{1461}$. A vida, para o Ministro, não pode ser suprimida por uma dor, ainda que legítima ${ }^{1462}$. Diferentemente do que ocorre no caso do estupro, em que a mulher é vítima de um crime violento e engravida à força ${ }^{1463}$, o feto anencéfalo decorre de um infortúnio, porém fruto da liberdade sexual do casal ${ }^{1464}$.

Com relação ao argumento de que a gravidez de feto anencéfalo traz mais risco à mulher, defendeu o Ministro que toda a gravidez é perigosa, e que, com esse critério, seria o caso, então, de proibir qualquer gravidez ${ }^{1465}$.

Por fim, entendeu o Ministro que caberia ao Poder Legislativo traçar hipóteses de excludentes de punibilidade ${ }^{1466}$, não podendo o Judiciário assumir a responsabilidade que cabe ao Congresso Nacional ${ }^{1467}$.

Deste modo, julgou Peluso totalmente improcedente a ação ${ }^{1468}$.

\subsubsection{O Ministro Dias Toffoli}

\footnotetext{
${ }^{1460}$ Arguição de Descumprimento de Preceito Fundamental no ${ }^{54-8}$. Voto lido em plenário pelo Ministro Cezar Peluso. Disponível em: <http://www.youtube.com/watch?v=1Bh_d4D56jI\&list=PLF21CD375773F508D \&index $=1$ \&feature=plpp_video $>$. Acesso em: 30 abr. 2012 (1:56:22).

${ }^{1461}$ Arguição de Descumprimento de Preceito Fundamental no $54-8$. Voto lido em plenário pelo Ministro Cezar Peluso. Disponível em: <http://www.youtube.com/watch?v=1Bh_d4D56jI\&list=PLF21CD375773F508D \&index=1\&feature=plpp_video $>$. Acesso em: 30 abr. 2012 (1:56:23-1:56:27).

${ }_{1462}$ Arguição de Descumprimento de Preceito Fundamental no ${ }^{\circ}$ 54-8. Voto lido em plenário pelo Ministro Cezar Peluso. Disponível em: <http://www.youtube.com/watch?v=1Bh_d4D56jI\&list=PLF21CD375773F508D \&index=1\&feature=plpp_video $>$. Acesso em: 30 abr. 2012 (1:58:28-1:58:36).

${ }^{1463}$ Arguição de Descumprimento de Preceito Fundamental $n^{\circ}$ 54-8. Voto lido em plenário pelo Ministro Cezar Peluso. Disponível em: <http://www.youtube.com/watch?v=1Bh_d4D56jI\&list=PLF21CD375773F508D \&index=1\&feature=plpp_video $>$. Acesso em: 30 abr. 2012 (1:59:25-2:00:08).

${ }^{1464}$ Arguição de Descumprimento de Preceito Fundamental no $54-8$. Voto lido em plenário pelo Ministro Cezar Peluso. Disponível em: <http://www.youtube.com/watch?v=1Bh_d4D56jI\&list=PLF21CD375773F508D \&index=1\&feature=plpp_video $>$. Acesso em: 30 abr. 2012 (2:00:09-2:00:14).

${ }^{1465}$ Arguição de Descumprimento de Preceito Fundamental no $54-8$. Voto lido em plenário pelo Ministro Cezar Peluso. Disponível em: <http://www.youtube.com/watch?v=1Bh_d4D56jI\&list=PLF21CD375773F508D \&index=1\&feature=plpp_video $>$. Acesso em: 30 abr. 2012 (2:06:30-2:07:17).

${ }_{1466}$ Arguição de Descumprimento de Preceito Fundamental $\mathrm{n}^{\circ}$ 54-8. Voto lido em plenário pelo Ministro Cezar Peluso. Disponível em: <http://www.youtube.com/watch?v=1Bh_d4D56jI\&list=PLF21CD375773F508D \&index=1\&feature=plpp_video $>$. Acesso em: 30 abr. 2012 (2:07:37-2:07-39).

1467 Arguição de Descumprimento de Preceito Fundamental $n^{\circ}$ 54-8. Voto lido em plenário pelo Ministro Cezar Peluso. Disponível em: <http://www.youtube.com/watch?v=1Bh_d4D56jI\&list=PLF21CD375773F508D \&index=1\&feature=plpp_video $>$. Acesso em: 30 abr. 2012 (2:09:27-2:09:47).

${ }_{1468}$ Arguição de Descumprimento de Preceito Fundamental no $54-8$. Voto lido em plenário pelo Ministro Cezar Peluso. Disponível em: <http://www.youtube.com/watch?v=1Bh_d4D56jI\&list=PLF21CD375773F508D \&index=1\&feature=plpp_video $>$. Acesso em: 30 abr. 2012 (2:11:11-2:11:12).
} 
O Ministro Dias Toffoli se absteve de julgar a ADPF 54, declarando-se impedido em vista de ter participado do processo anteriormente como representante da Advogacia Geral da União.

\subsubsection{Decisão da ADPF 54}

Deste modo, em decisão histórica, em 11 e 12 de abril de 2012, depois de quase 8 anos de tramitação, o Supremo Tribunal Federal, através da maioria de seus Ministros, declarou a inconstitucionalidade da interpretação de que o aborto de feto anencéfalo seria conduta tipificada nos termos do Código Penal brasileiro.

Por 8 votos a 2, prevaleceu o entendimento de que, conforme a Constituição Federal, não é crime interromper a gravidez em caso de anencefalia. Neste sentido, votaram os Ministros Ayres Britto, Cármen Lúcia, Celso de Mello, Gilmar Mendes, Joaquim Barbosa, Luiz Fux, Marco Aurélio, e Rosa Weber; restando vencidos os Ministros Cezar Peluso e Ricardo Lewandowski; e sendo que o Ministro Dias Toffoli declarou-se impedido e não julgou.

A seguir, a partir da análise dos argumentos trazidos pelas partes e dos argumentos usados pelo Supremo Tribunal Federal, encerraremos nosso trabalho na Parte III, procurando sugerir modelos de interpretação constitucional cabíveis ao caso.

No entanto, antes de adentrar esta parte final do trabalho, vamos ainda estudar como o aborto tem sido tratado no direito comparado, a fim de colocar nosso direito em perspectiva e poder melhor refletir sobre o assunto, e, em seguida, analisar as teorias aplicáveis sobre a restrição do direito à vida para, munidos destes estudos, poder enfrentar o desafio das interpretações constitucionais cabíveis no Brasil ao aborto do feto anencéfalo, e distinguir se algum dos modelos propostos cobriria a decisão a que o STF efetivamente chegou. 


\section{O ABORTO NO DIREITO COMPARADO}

\subsection{DIREITO COMPARADO}

Diversos são os documentos que nos remetem à proteção internacional do direito à vida, inclusive muitos deles já foram discutidos na Parte I do presente trabalho.

No que tange especificamente ao aborto, e mais especificamente ao aborto de feto anencéfalo, muito pouco podemos acrescentar, uma vez que, na ausência de norma específica sobre o caso, sua proibição ou autorização decorrerá da construção de argumentos válidos em face do ordenamento jurídico envolvido, observando o sentido e o alcance da norma que será crucial para autorizar ou não o aborto.

Ensina Daniel Sarmento que, a partir da década de 60, houve uma inclinação mundial em favor de se descriminalizar o aborto, especialmente, diante do "processo de emancipação da mulher e o avanço na laicização dos Estados"1469.

Por essa razão, é interessante analisar como o direito interno de alguns países cuidam do direito à vida e como regulam o aborto. Selecionamos alguns estados ${ }^{1470}$ em especial,

\footnotetext{
1469 SARMENTO, Daniel. Legalização do Aborto e constituição. In: SARMENTO, Daniel; PIOVESAN, Flávia (coordenadores). Nos Limites da Vida. Rio de Janeiro: Lúmen Júris, 2006, p. 7.

${ }^{1470}$ Interessante mencionar o relatório do Comitê de Direitos Humanos que traz o caso de Karen Noelia Llantoy Huamán v. Peru Comunication 1153/2003 de 22 de novembro de 2005. Karen engravidou aos 17 anos e descobriu que o feto era anencéfalo, mesmo com recomendação médica para realizá-lo, o aborto foi negado pelo diretor do hospital que justificou que a lei peruana somente permitia o aborto para salvar a vida e preservar a saúde da gestante. O bebê nasceu três semanas depois da data prevista e sobreviveu por quatro dias. Karen alegou que a lei peruana não prevê o aborto nessa situação e sequer dispõe de meios céleres para autorizar o procedimento judicialmente (violando os artigos $2^{\circ}, 6^{\circ}, 7^{\circ}$ e 17 do Pacto Internacional sobre os Direitos Civis e Políticos). Alegou, ainda, que a norma não deve ser interpretada restritivamente, pois deixa somente duas opções para a gestante de realizar um aborto clandestino ou levar a gravidez até o final com riscos físicos e psíquicos, de modo que a gravidez poderia ser considerada um tratamento cruel e desumano, tendo sido violada também sua vida privada, pois não poderia decidir sobre a sua vida reprodutiva. O estado peruano não se manifestou a respeito. O Comitê atribui um peso às alegações da autora, tendo em vista a inexistência de defesa por parte do estado, e decidiu que o estado do Peru violou os artigos $2^{\circ}$ da Pacto Internacional sobre os Direitos Civis e Políticos, $7^{\circ}, 17$ e 24 do Pacto, negando-se a analisar eventual violação ao artigo $6^{\circ}$. Basicamente, o Comitê destacou que o artigo $7^{\circ}$ protege a dor física e mental e que a menor teve de suportar as deformidades do feto e o fato de que morreria logo, fatos que causaram muita angústia e sofrimento ao lhe ser negado o aborto terapêutico, conforme relatórios médicos que comprovaram a profunda depressão que acometia a autora. Além disso, negar a cirurgia é uma intervenção à vida privada da mulher, tendo sido violado também o artigo 17 da Convenção. Tratando-se de menor, o artigo 24 também foi violado, pois lhe foi negado um tratamento especial necessário diante de sua vulnerabilidade. O voto dissidente de Hipólito Solari Yrigoyen também é relevante. Afirma o membro do Comitê que o artigo $6^{\circ}$ também foi violado porque mesmo com exames demonstrando a inviabilidade do feto e os riscos de se manter a gravidez, o diretor do hospital, unilateralmente, interpretou o procedimento como aborto voluntário e não terapêutico, impedindo a interrupção da gravidez. Para Hipólito
} 
diante da relevância de sua legislação ou jurisprudência ou, ainda, porque serviram de paradigma, tendo sido mencionados e analisados pela doutrina e tribunais internacionais de Direitos Humanos.

\subsubsection{América do Norte}

\subsubsection{Estados Unidos}

Como ensina Daniel Sarmento, nos Estados Unidos o aborto em geral é permitido no primeiro trimestre de gravidez ${ }^{1471}$, exceto se comprovada a viabilidade fetal extrauterina ${ }^{1472}$. No segundo trimestre de gravidez, os estados poderiam regular o direito ao aborto para proteger a saúde da mulher; e, somente a partir do terceiro trimestre de gestação, os estados poderiam proibir o aborto (exceto no caso de perigo à vida ou à saúde da mulher, em que a vida potencial do feto não prevalece) ${ }^{1473}$.

$\mathrm{O}$ autor esclarece ainda que a proteção dos direitos reprodutivos da mulher ficou parcialmente comprometida com a sentença da Suprema Corte americana no caso Harris v. Macrae, de 1980, que desobrigou os estados de realizar abortos na rede pública de saúde ou arcar com as despesas ${ }^{1474}$.

Solari, colocar a vida de alguém em perigo e não tão somente tirar a vida de alguém, viola o artigo $6^{\circ}$ do Pacto. Disponível em: <http://www.ccprcentre.org/doc/ICCPR/AR/A_61_40_vol.II_E.pdf>. Acesso em: 10 dez. 2011.

${ }^{1471}$ SARMENTO, Daniel. Legalização do Aborto e constituição. In: SARMENTO, Daniel; PIOVESAN, Flávia (coordenadores). Nos Limites da Vida. Rio de Janeiro: Lúmen Júris, 2006, p. 8. Steinbock afirma que menos que 1.5 por cento dos abortos ocorridos nos Estados Unidos ultrapassam a $20^{a}$ semana de gestação. A maior parte ocorre até a $12^{\mathrm{a}}$ semana: "(Fewer than 1.5 per cent of all abortions in the United States take place after twenty weeks; most are done within twelve weeks.)". STEINBOCK, Bonnie. Mother-fetus conflict. In: A Companion to Bioethics. KUHSE, Helga. SINGER, Peter (Blackwell Companion to Philosophy). Massachusetts, EUA. Blackwell Publishing, 1998, p. 135-145.

${ }^{1472}$ SARMENTO, Daniel. Legalização do Aborto e constituição. In: SARMENTO, Daniel; PIOVESAN, Flávia (coordenadores). Nos Limites da Vida. Rio de Janeiro: Lúmen Júris, 2006, p. 9. Vide: EUA. Supreme Court of United State. Caso Planned Parenthood v. Casey, 505, U.S. 833 (1992).

${ }^{1473}$ SARMENTO, Daniel. Legalização do Aborto e constituição. In: SARMENTO, Daniel; PIOVESAN, Flávia (coordenadores). Nos Limites da Vida. Rio de Janeiro: Lúmen Júris, 2006, p. 8-9.

${ }^{1474} \mathrm{O}$ autor salienta que a postura da Suprema Corte atende à ideia americana de que os direitos fundamentais são "exclusivamente direitos de defesa contra o Estado que não conferem ao cidadão a possibilidade de reclamações efetivas dos poderes públicos em seu favor". SARMENTO, Daniel. Legalização do Aborto e constituição. In: SARMENTO, Daniel; PIOVESAN, Flávia (coordenadores). Nos Limites da Vida. Rio de Janeiro: Lúmen Júris, 2006, p. 10. 
É interessante abordar a decisão da Suprema Corte no caso Roe v. Wade, que é o leading case da legalização do aborto nos Estados Unidos, e conhecer um pouco mais sobre os argumentos usados pelo tribunal americano no caso.

\subsection{Caso Roe v. Wade}

A célebre decisão do caso Roe v. Wade é de suma importância para os estudiosos sobre o aborto há 38 anos, e, apesar de também ter defensores, até hoje sofre críticas quanto ao conteúdo e forma do julgamento ${ }^{1475}$. A Suprema Corte entendeu que os estados da união norte-americana não podem proibir a prática do aborto nos três primeiros meses de gestação, mas podem regulá-lo do quarto ao sexto mês de gestação, quando a saúde da mulher estiver em risco, e somente podem proibir o aborto nos três últimos meses da gravidez, quando o feto se torna viável ${ }^{1476}$.

A Suprema Corte norte-americana determinou neste caso que a cláusula de "due process" da Constituição dos Estados Unidos protege um direito fundamental ao aborto ${ }^{1477}$. Para tanto, em primeiro lugar, a Corte concluiu que o direito de restar-se livre da intervenção do estado ${ }^{1478}$, intervenção esta profundamente indesejada em assuntos tão pessoais quanto o de ter uma criança, inclui um direito fundamental ao aborto.

A seguir, em segundo lugar, a Corte questionou se a restrição a esse direito poderia ser justificada sob o teste de "strict scrutiny" como necessário para promover um interesse estatal importante (“compelling”), e concluiu que apenas quando o feto chega a um certo estágio de viabilidade o interesse do Estado em sua vida efetivamente passa por esse teste e se torna “compelling",1479.

\footnotetext{
1475 DWORKIN, Ronald. Domínio da Vida: aborto, eutanásia e liberdades individuais. Trad. Jefferson Luiz Camargo; rev. da tradução Silvana Vieira. São Paulo: Martins Fontes, 2003, p. 141-142.

${ }^{1476}$ DWORKIN, Ronald. Domínio da Vida: aborto, eutanásia e liberdades individuais. Trad. Jefferson Luiz Camargo; rev. da tradução Silvana Vieira. São Paulo: Martins Fontes, 2003, p. 142 e 235.

${ }^{1477}$ FALLON JR, Richard H. The Dynamic Constitution. New York: Cambrigde University Press, 2004, p. 144.

${ }^{1478}$ Conhecido como o "direito de ser deixado sozinho, em paz" constituindo no sentido nuclear da privacidade. NETO, Luísa. O direito fundamental à disposição do próprio corpo (a relevância da vontade na configuração do seu regime). Coimbra: Coimbra Editora, 2004, p. 510-511.

${ }^{1479}$ FALLON JR, Richard H. The Dynamic Constitution. New York: Cambrigde University Press, 2004, p. 144. Ensina Dworkin que a interpretação da Constituição Americana segue no sentido de limitar o poder de o estado prejudicar seus cidadãos. Para tanto, é preciso fazer dois testes de constitucionalidade: cláusula de "processo legal justo" ("due process", no original) contido na $14^{a}$ Emenda: o estado poderia limitar a liberdade do indivíduo, se existir alguma justificativa racional para tal, mas Dworkin entende tratar-se de uma "restrição
} 
A decisão da Corte tem sido criticada ${ }^{1480}$ por parte da doutrina norte-americana pelas duas conclusões acima. Para os críticos, a Corte omitiu o ponto moralmente mais relevante da questão: o de que o aborto envolve a destruição de um feto humano. Além disso, o estado deveria, para os críticos, ter interesse em preservar a vida fetal a partir da concepção, também sob argumentos de ordem moral ${ }^{1481}$.

Para Richard Fallon, foi surpreendente que sete ministros de uma Suprema Corte particularmente conservadora, como a que presidiu Roe v. Wade, tenham aprovado o direito ao aborto ${ }^{1482}$. Isto tem sido atribuído ao fato de que mesmo os ministros mais conservadores da Suprema Corte na ocasião eram de orientação secular ${ }^{1483}$. Da perspectiva dos ministros, a decisão pareceu um compromisso razoável, que protegeria o direito da mulher de controlar seu corpo até o momento de viabilidade fetal, mas também permitiria ao estado proteger o feto daí por diante. Os ministros - talvez até ingenuamente - não imaginaram que tal compromisso que lhes pareceu tão judicioso e balanceado fosse gerar tanta controvérsia pública $^{1484}$.

Para Richard Posner, a decisão foi pragmática, e a Suprema Corte dos Estados Unidos tem uma histórica inclinação a sê-lo ${ }^{1485}$. No entanto, para ele, a verdade é que Roe v. Wade atribuiu um valor menor à vida fetal que ao interesse da mulher de controlar sua atividade reprodutória ${ }^{1486}$. Como o Ministro White, no voto dissidente do caso análogo Doe v. Bolton declarou, "a [Suprema] Corte aparentemente dá mais valor à conveniência da mãe grávida do que a existência e desenvolvimento da vida que ela carrega" 1487 .

\footnotetext{
muito frágil". Além disso, a Constituição escolheria determinadas liberdades, exigindo uma "razão inexorável" para restringi-las, pois transformadas em direitos constitucionais especifícos. DWORKIN, Ronald. Domínio da Vida: aborto, eutanásia e liberdades individuais. Trad. Jefferson Luiz Camargo; rev. da tradução Silvana Vieira. São Paulo: Martins Fontes, 2003, p. 144-145.

${ }^{1480}$ Dworkin destaca entre as principais críticas feitas à decisão americana que a Corte tomou uma decisão política, pois não cabia a ela decidir esse assunto em julgamento, pois de competência das assembleias legislativas. DWORKIN, Ronald. Domínio da Vida: aborto, eutanásia e liberdades individuais. Trad. Jefferson Luiz Camargo; rev. da tradução Silvana Vieira. São Paulo: Martins Fontes, 2003, p. 141-142.

${ }^{1481}$ FALLON JR, Richard H. The Dynamic Constitution. New York: Cambrigde University Press, 2004, p. 144.

${ }^{1482}$ FALLON JR, Richard H. The Dynamic Constitution. New York: Cambrigde University Press, 2004, p. 144.

${ }^{1483}$ FALLON JR, Richard H. The Dynamic Constitution. New York: Cambrigde University Press, 2004, p. 145. Nesse sentido, Ronald Dworkin. DWORKIN, Ronald. Domínio da Vida: aborto, eutanásia e liberdades individuais. Trad. Jefferson Luiz Camargo; rev. da tradução Silvana Vieira. São Paulo: Martins Fontes, 2003, p. 225 .

${ }^{1484}$ FALLON JR, Richard H. The Dynamic Constitution. New York: Cambrigde University Press, 2004, p. 145.

${ }^{1485}$ POSNER, Richard A. Law, pragmatism, and democracy. Cambrigde-MA: Harvard University Press, 2005 , p. 125.

${ }^{1486}$ POSNER, Richard A. Law, pragmatism, and democracy. Cambrigde-MA: Harvard University Press, 2005, p. 124.

${ }^{1487}$ EUA. Supreme Court of United State. Doe v. Bolton, 410 U.S. 179, 222 (1973) (Tradução nossa).
} 
Robert McCloskey, em seu clássico livro “The American Supreme Court”, afirma que em Roe v. Wade a Corte demonstrou-se surpreendentemente inclinada a encontrar na constituição direitos que não estavam expressos no texto. Isso porque, no caso do aborto, o direito de abortar tinha amplo suporte das elites políticas e culturais, as quais a própria Corte pertencia $^{1488}$. Quando a Suprema Corte fundamentou a decisão no direito de privacidade das mulheres, a discussão rapidamente entrou no debate político da função e direitos da mulher e no impacto que um direito ao aborto teria na possibilidade de as mulheres entrarem na força de trabalho.

$\mathrm{Na}$ análise de Dworkin sobre o voto, a Suprema Corte norte-americana fundou-se na autonomia da mulher em administrar seu próprio corpo, pois, para o autor, seria uma espécie de escravidão da mulher manter uma gravidez indesejada ${ }^{1489}$.

Além disso, Dworkin explica que o sofrimento gerado às mulheres em decorrência da criminalização do aborto as impulsionava a agir contrariamente à lei, colocando em risco a própria vida ou sua saúde ao submeter-se a abortos clandestinos ${ }^{1490}$.

Ademais, para Dworkin, os argumentos para autorizar o aborto observaram as diretrizes constitucionais americanas, de modo que a restrição à liberdade individual não poderia ser arbitrada por parte do estado ${ }^{1491}$. Para o filósofo, a Constituição Americana seleciona algumas liberdades e "as transforma em direitos constitucionais específicos que o Estado não pode restringir ou revogar a menos que tenha uma razão muito forte para fazê10,1492 .

\footnotetext{
${ }^{1488}$ MCCLOSKEY Robert. The American Supreme Court. Chicago: The University of Chicago Press, 2a edição, 1994, p. 166-167.

1489 “'[...]. Uma mulher forçada a ter uma criança que não deseja porque não pode fazer um aborto seguro pouco depois de ter engravidado não é dona de seu próprio corpo, pois a lei lhe impõe uma espécie de escravidão. Além do mais, isso é só o começo. Para muitas mulheres, ter filhos indesejados significa a destruição de suas próprias vidas, porque elas próprias não deixaram de ser crianças, porque não mais poderão trabalhar, estudar ou viver de acordo com o que consideram importante, ou porque não têm condições financeiras de manter os filhos. (Sem dúvida, esses diferentes tipos de prejuízo serão multiplicados e intensificados se na origem da gravidez estiver um incesto ou estupro, ou se a criança nascer com graves deficiências físicas ou mentais)" ${ }^{\text {"1489 }}$. DWORKIN, Ronald. Domínio da Vida: aborto, eutanásia e liberdades individuais. Trad. Jefferson Luiz Camargo; rev. da tradução Silvana Vieira. São Paulo: Martins Fontes, 2003, p. 143

${ }^{1490}$ DWORKIN, Ronald. Domínio da Vida: aborto, eutanásia e liberdades individuais. Trad. Jefferson Luiz Camargo; rev. da tradução Silvana Vieira. São Paulo: Martins Fontes, 2003, p. 143-144. Para o autor, a adoção não resolveria o problema, pois geraria um sofrimento terrível entregar um filho nessa situação. DWORKIN, Ronald. Domínio da Vida: aborto, eutanásia e liberdades individuais. Trad. Jefferson Luiz Camargo; rev. da tradução Silvana Vieira. São Paulo: Martins Fontes, 2003, p. 143.

${ }^{1491}$ Para Dworkin, é uma restrição frágil. DWORKIN, Ronald. Domínio da Vida: aborto, eutanásia e liberdades individuais. Trad. Jefferson Luiz Camargo; rev. da tradução Silvana Vieira. São Paulo: Martins Fontes, 2003, p. 144.

${ }^{1492}$ DWORKIN, Ronald. Domínio da Vida: aborto, eutanásia e liberdades individuais. Trad. Jefferson Luiz Camargo; rev. da tradução Silvana Vieira. São Paulo: Martins Fontes, 2003, p. 144-145.
} 
$\mathrm{O}$ argumento seguinte era o de que o direito à privacidade da mulher de procriar incluiria o direito ao aborto, e que não existiria, por exemplo, uma forte razão que se contrapusesse a isso até o sexto mês da gestação ${ }^{1493}$. Dworkin segue entendendo que a decisão Roe v. Wade manteve-se coerente com os casos anteriormente julgados pela Suprema Corte, pelos quais se garantia o direito à mulher de conceber ou não filhos, o que, consequentemente, determinaria a escolha de decidir sobre tê-los ou não. Esse argumento foi pautado no direito constitucional específico da mulher de decidir sobre "questões de procriação" "1494, verificandose, portanto, a possibilidade de a mulher decidir sobre suas relações sexuais e sobre as alterações em seu próprio corpo, comuns durante uma gravidez, protegendo, assim, a Suprema Corte, a integridade física da mulher ${ }^{1495}$. Daí, porque, para Dworkin, a decisão sobre o aborto está na esfera privada ${ }^{1496}$.

Outro aspecto interessante suscitado por Dworkin é que a criminalização do aborto normalmente é justificada na proteção à vida humana, e, daí, para o autor, é importante estabelecer qual a responsabilidade do estado na proteção do direito à vida: se é independente ou derivativa. No primeiro caso, o estado poderia proibir o aborto e proteger a vida simplesmente pelo valor intrínseco dela (ou seja, a vida teria um valor em si mesma) ${ }^{1497}$, como vimos na primeira parte deste trabalho. Já, no segundo caso, o feto teria direitos a partir da concepção, devendo o estado proteger seus interesses como o faz de todos os indivíduos (ou seja, o feto seria sujeito de vários direitos, e o estado, por isso, teria a responsabilidade de protegê-los como o faz em relação às pessoas em geral) ${ }^{1498}$.

\footnotetext{
${ }^{1493}$ Dworkin esclarece que, por outro lado, analisando o voto dissidente do Juiz Rehnquist, negou-se às mulheres esse direito, afirmando-se existir apenas um "interesse de liberdade". Para Rehnquist, entretanto, esse "interesse seria forte o bastante para tornar inconstitucional qualquer lei que proíba o aborto quando necessário para salvar a vida da mãe". DWORKIN, Ronald. Domínio da Vida: aborto, eutanásia e liberdades individuais. Trad. Jefferson Luiz Camargo; rev. da tradução Silvana Vieira. São Paulo: Martins Fontes, 2003, p. 145-146.

${ }_{1494}$ DWORKIN, Ronald. Domínio da Vida: aborto, eutanásia e liberdades individuais. Trad. Jefferson Luiz Camargo; rev. da tradução Silvana Vieira. São Paulo: Martins Fontes, 2003, p. 146-147.

${ }^{1495}$ DWORKIN, Ronald. Domínio da Vida: aborto, eutanásia e liberdades individuais. Trad. Jefferson Luiz Camargo; rev. da tradução Silvana Vieira. São Paulo: Martins Fontes, 2003, p. 147. Dworkin trata da difícil constatação ao estabelecer diferenças entre aborto e medidas contraceptivas, já que estas podem atuar como abortíferos de tal forma que "é evidente, portanto, que o tribunal não pode sustentar que o direito da mulher a controlar seu papel na procriação termina com a fertilização, se não permitir que os Estados proíbam a venda desses contraceptivos" (Caso Griswold $v$. Connecticut de 1968). No entanto, Dworkin aduz que há diferenças entre pôr fim a vida do feto e impedir que a vida se inicie. DWORKIN, Ronald. Domínio da Vida: aborto, eutanásia e liberdades individuais. Trad. Jefferson Luiz Camargo; rev. da tradução Silvana Vieira. São Paulo: Martins Fontes, 2003, p. 148.

${ }^{1496}$ DWORKIN, Ronald. Domínio da Vida: aborto, eutanásia e liberdades individuais. Trad. Jefferson Luiz Camargo; rev. da tradução Silvana Vieira. São Paulo: Martins Fontes, 2003, p. 147.

${ }^{1497}$ DWORKIN, Ronald. Domínio da Vida: aborto, eutanásia e liberdades individuais. Trad. Jefferson Luiz Camargo; rev. da tradução Silvana Vieira. São Paulo: Martins Fontes, 2003, p. 149.

${ }^{1498}$ No entanto, Dworkin afirma que essas responsabilidades podem entrar em conflito quando temos, por exemplo, um caso de Eutanásia. Por essa razão, é necessário, na concepção de Dworkin, verificar se o estado tem a responsabilidade derivativa ou independente, pois esta última autorizaria o governo impedir que um indivíduo
} 
Dworkin também se questionou se existiria na constituição americana um direito constitucional ao aborto ${ }^{1499}$. Afirma que a decisão de fazer um aborto não diz respeito somente à mulher (ou ainda, extensivamente, ao pai), pois as "decisões individuais afetam valores coletivamente compartilhados" $" 1500$. No entanto, indaga Dworkin se a comunidade política, para proteger a "santidade ou a inviolabilidade da vida humana", poderia exigir que as pessoas reconhecessem esses valores em suas decisões particulares ${ }^{1501}$. Seria tal estado digno ${ }^{1502}$

Para responder à questão, Dworkin faz a seguinte analogia inversa: Se entendêssemos que a "santidade da vida" seria violada com a manutenção da gravidez de um feto com máformação, seria correto impor às mulheres interromper a gravidez por ser esta a vontade da maioria, "mesmo contrariando suas convicções religiosas ou éticas"? ${ }^{1503}$ Parece ao filósofo restar pouca dúvida de que esta situação hipotética seria absurda. Afirma ele, então, que o contrário ocorre quando o aborto é proibido (ou seja, o estado, neste caso, obriga a mulher a continuar a gravidez contra suas convicções), e, em vista do que concluímos com a analogia inversa, devemos compreender que o "estado insulta com igual violência a dignidade de uma mulher grávida quando a força a fazer a escolha oposta" ${ }^{\text {1504 }}$. Para Dworkin, o fato de ser uma escolha da maioria não é justificativa suficiente, nem para proibir o aborto, nem para exigi$10^{1505}$.

Entende Dworkin que as "convicções sobre o valor intrínseco da vida humana são religiosas"1506, e, em razão disso, um estado que proíbe o aborto "se compromete com uma interpretação polêmica da santidade da vida e, por esse motivo, restringe a liberdade ao impor

pratique a eutanásia, simplesmente para garantir o valor intrínseco da vida em qualquer situação, ainda que existam motivos para a pessoa escolher a morte. DWORKIN, Ronald. Domínio da Vida: aborto, eutanásia e liberdades individuais. Trad. Jefferson Luiz Camargo; rev. da tradução Silvana Vieira. São Paulo: Martins Fontes, 2003, p. 149-150.

1499 DWORKIN, Ronald. Domínio da Vida: aborto, eutanásia e liberdades individuais. Trad. Jefferson Luiz Camargo; rev. da tradução Silvana Vieira. São Paulo: Martins Fontes, 2003, p. 206 e 209.

1500 DWORKIN, Ronald. Domínio da Vida: aborto, eutanásia e liberdades individuais. Trad. Jefferson Luiz Camargo; rev. da tradução Silvana Vieira. São Paulo: Martins Fontes, 2003, p. 209.

${ }^{1501}$ DWORKIN, Ronald. Domínio da Vida: aborto, eutanásia e liberdades individuais. Trad. Jefferson Luiz Camargo; rev. da tradução Silvana Vieira. São Paulo: Martins Fontes, 2003, p. 209-210.

${ }^{1502}$ DWORKIN, Ronald. Domínio da Vida: aborto, eutanásia e liberdades individuais. Trad. Jefferson Luiz Camargo; rev. da tradução Silvana Vieira. São Paulo: Martins Fontes, 2003, p. 163.

${ }^{1503}$ DWORKIN, Ronald. Domínio da Vida: aborto, eutanásia e liberdades individuais. Trad. Jefferson Luiz Camargo; rev. da tradução Silvana Vieira. São Paulo: Martins Fontes, 2003, p. 222.

${ }^{1504}$ DWORKIN, Ronald. Domínio da Vida: aborto, eutanásia e liberdades individuais. Trad. Jefferson Luiz Camargo; rev. da tradução Silvana Vieira. São Paulo: Martins Fontes, 2003, p. 223.

1505 DWORKIN, Ronald. Domínio da Vida: aborto, eutanásia e liberdades individuais. Trad. Jefferson Luiz Camargo; rev. da tradução Silvana Vieira. São Paulo: Martins Fontes, 2003, p. 223.

${ }^{1506}$ DWORKIN, Ronald. Domínio da Vida: aborto, eutanásia e liberdades individuais. Trad. Jefferson Luiz Camargo; rev. da tradução Silvana Vieira. São Paulo: Martins Fontes, 2003, p. 231. 
uma postura essencialmente religiosa em detrimento de outras" ${ }^{\text {1507 }}$. Para Dworkin, o direito da mulher de decidir pelo aborto (ou não) é um direito em consonância com a "dignidade humana individual", ou seja, é o "direito moral" e a "responsabilidade moral" que pertence exclusivamente a cada indivíduo de se questionar "sobre o significado e o valor de suas próprias vidas"1508. Assim, Dworkin vê o direito de escolher o aborto como decorrente do direito à autonomia procriadora individual, fundamentado na constituição americana ${ }^{1509}$, e qualquer impedimento ao livre exercício desse direito é indevido, ${ }^{1510}$ de modo que restrições ou a proibição seriam medidas inconstitucionais ${ }^{1511}$.

Além disso, esclarece Dworkin que, no caso Roe v. Wade, foi necessário estabelecerse uma posição constitucional quanto à personalidade jurídica do feto ${ }^{1512}$, já que a própria constituição americana garante direitos iguais às pessoas. Em vista da decisão, a personalidade jurídica foi negada ao feto pela Suprema Corte, o que tem sido confirmado nas leis que se seguiram ${ }^{1513}$, pois, se tal personalidade tivesse sido admitida, para Dworkin, ainda que a gravidez causasse risco à vida da mulher, não poderia ser autorizado o aborto ${ }^{1514}$.

1507 DWORKIN, Ronald. Domínio da Vida: aborto, eutanásia e liberdades individuais. Trad. Jefferson Luiz Camargo; rev. da tradução Silvana Vieira. São Paulo: Martins Fontes, 2003, p. 230-231.

1508 DWORKIN, Ronald. Domínio da Vida: aborto, eutanásia e liberdades individuais. Trad. Jefferson Luiz Camargo; rev. da tradução Silvana Vieira. São Paulo: Martins Fontes, 2003, p. 233.

1509 DWORKIN, Ronald. Domínio da Vida: aborto, eutanásia e liberdades individuais. Trad. Jefferson Luiz Camargo; rev. da tradução Silvana Vieira. São Paulo: Martins Fontes, 2003, p. 232.

${ }^{1510}$ DWORKIN, Ronald. Domínio da Vida: aborto, eutanásia e liberdades individuais. Trad. Jefferson Luiz Camargo; rev. da tradução Silvana Vieira. São Paulo: Martins Fontes, 2003, p. 242.

${ }^{1511}$ DWORKIN, Ronald. Domínio da Vida: aborto, eutanásia e liberdades individuais. Trad. Jefferson Luiz Camargo; rev. da tradução Silvana Vieira. São Paulo: Martins Fontes, 2003, p. 214. Outra coisa é exigir do estado o financiamento do aborto, mas no caso de um aborto em que as mulheres precisem fazer, o não financiamento é equiparado à coerção. DWORKIN, Ronald. Domínio da Vida: aborto, eutanásia e liberdades individuais. Trad. Jefferson Luiz Camargo; rev. da tradução Silvana Vieira. São Paulo: Martins Fontes, 2003 , p. 244 e 246

${ }^{1512}$ Afirma Dworkin que "a questão preliminar que Blackmun teve de decidir é diferente da questão de se o feto tem direitos morais, ou se tem interesses que seria moralmente condenável violar ou ignorar". Para o autor, o feto teria um direito moral à vida na perspectiva teológica, mas que para quase todos que defendem isso, também entendem que o argumento não é fundamental para a discussão constitucional, em razão da separação da Igreja e do estado. DWORKIN, Ronald. Domínio da Vida: aborto, eutanásia e liberdades individuais. Trad. Jefferson Luiz Camargo; rev. da tradução Silvana Vieira. São Paulo: Martins Fontes, 2003, p. 151.

${ }^{1513}$ DWORKIN, Ronald. Domínio da Vida: aborto, eutanásia e liberdades individuais. Trad. Jefferson Luiz Camargo; rev. da tradução Silvana Vieira. São Paulo: Martins Fontes, 2003, p. 154-155.

${ }^{1514}$ DWORKIN, Ronald. Domínio da Vida: aborto, eutanásia e liberdades individuais. Trad. Jefferson Luiz Camargo; rev. da tradução Silvana Vieira. São Paulo: Martins Fontes, 2003, p. 154-155. Vale dizer que Dworkin critica a posição dos críticos que defendem aos estados instituírem livremente sobre o aborto, pois para o autor se o feto for considerado pessoa, os estados não podem, mas devem proibir o aborto. Em razão disso, para Dworkin, "aqueles que dizem que o Supremo Tribunal deveria deixar que os Estados decidam a questão do aborto ao sabor de suas tendências políticas, estão na verdade admitindo que o feto não é uma pessoa constitucional". DWORKIN, Ronald. Domínio da Vida: aborto, eutanásia e liberdades individuais. Trad. Jefferson Luiz Camargo; rev. da tradução Silvana Vieira. São Paulo: Martins Fontes, 2003, p. 152 e 154 . Vale dizer, ainda, que Dworkin aponta um aspecto importante quando se atribui ao feto um status de pessoa. O autor afirma que uma lei que protege a grávida de eventual crime, não atribui automaticamente o status de pessoa ao feto porque ao se atribuir esse caráter ao feto, estaria autorizado também a diminuição de outros direitos constitucionais. Assim, por exemplo, se fosse reconhecido esse caráter de pessoa a uma árvore, garantindo-lhe 
Vale dizer ainda que, para o autor, a lógica que protege a mulher grávida não é a mesma que atribui status de pessoa ao feto ${ }^{1515}$, e, portanto, legislações que protegem o feto em razão da gravidez não estão automaticamente transformando-o em sujeito de direitos.

Afirma Dworkin, ainda, que admitir o aborto no caso de fetos inviáveis não provoca necessariamente uma cultura de insensibilização. Dworkin ensina que sociedades europeias em que o aborto é permitido no primeiro trimestre têm se mostrado muito menos violentas do que outras sociedades em que o aborto é proibido ${ }^{1516}$.

Finalmente, sobre a possibilidade de a lei exigir um período de quarentena para que as gestantes que desejam realizar abortos reflitam sobre a decisão, Dworkin alerta que proibir o aborto por um determinado período para reflexão, em geral, não mudaria a opinião das mulheres, mas, no entanto, prejudicaria aquelas mais pobres, que moram longe dos centros hospitalares, pois são estas mulheres que, provavelmente, optariam por não realizar o aborto não por terem mudado sua convicção a respeito, mas, simplesmente, em razão da dificuldade de acesso aos hospitais ${ }^{1517}$. Sumarizando, nos Estados Unidos o direito ao aborto é visto como um direito fundamental da mulher, e não pode ser proibido, de modo algum, nos três primeiros meses de gestação. Do quarto ao sexto mês, os estados da união podem regulamentá-lo, sem proibi-lo; e, somente a partir dos três últimos meses de gravidez, podem proibi-lo, em razão do grau de desenvolvimento a que chega o feto ${ }^{1518}$.

\subsubsection{Europa}

\subsubsection{Inglaterra}

\footnotetext{
igualmente o direito à vida, poderia ser proibida a publicação de livros, mesmo existindo a liberdade de expressão. DWORKIN, Ronald. Domínio da Vida: aborto, eutanásia e liberdades individuais. Trad. Jefferson Luiz Camargo; rev. da tradução Silvana Vieira. São Paulo: Martins Fontes, 2003, p. 157-158.

1515 DWORKIN, Ronald. Domínio da Vida: aborto, eutanásia e liberdades individuais. Trad. Jefferson Luiz Camargo; rev. da tradução Silvana Vieira. São Paulo: Martins Fontes, 2003, p. 157.

${ }^{1516}$ DWORKIN, Ronald. Domínio da Vida: aborto, eutanásia e liberdades individuais. Trad. Jefferson Luiz Camargo; rev. da tradução Silvana Vieira. São Paulo: Martins Fontes, 2003, p. 161.

1517 DWORKIN, Ronald. Domínio da Vida: aborto, eutanásia e liberdades individuais. Trad. Jefferson Luiz Camargo; rev. da tradução Silvana Vieira. São Paulo: Martins Fontes, 2003, p. 242-243.

1518 DWORKIN, Ronald. Domínio da Vida: aborto, eutanásia e liberdades individuais. Trad. Jefferson Luiz Camargo; rev. da tradução Silvana Vieira. São Paulo: Martins Fontes, 2003, p. 142 e 235.
} 
$\mathrm{Na}$ Inglaterra, o aborto é permitido nas primeiras 24 semanas de gestação por razões sociais e econômicas da gestante; e, além deste período, a qualquer tempo, mas apenas em caso de a gravidez envolver risco à vida ou à saúde física ou mental da gestante, e em caso de risco de má-formação do feto que poderia fazer com que, se a criança viesse a nascer, sofresse de graves deficiências físicas ou mentais, sendo, em qualquer caso, exigido um certificado emitido por dois médicos atestando a razão que justifica o aborto ${ }^{1519}$.

\subsubsection{Espanha}

Na Espanha, permite-se o aborto, inclusive em caso de crimes sexuais, até 14 semanas. Em caso de risco à saúde e à vida da mulher, o aborto pode ser realizado a qualquer tempo; e, em caso de má-formação do feto, até 22 semanas. Neste último caso, são também necessárias duas opiniões médicas corroborando a má-formação ${ }^{1520}$.

Daniel Sarmento salienta que, na Espanha, em 1985, um projeto de lei aprovado autorizou o aborto nos moldes citados acima, mas foi impugnado porque não estabelecia um segundo diagnóstico feito por médico diverso daquele que realizaria o procedimento cirúrgico $^{1521}$. Essa impugnação deu origem à decisão STC 53/1985 do Tribunal Constitucional Espanhol, que comentaremos abaixo.

\footnotetext{
1519 Dispõe o "Abortion Act of 1967" do Reino Unido, em seu Artigo $1^{\text {o }}$ - Section 1: Medical termination of pregnancy. (1) Subject to the provisions of this section, a person shall not be guilty of an offence under the law relating to abortion when a pregnancy is terminated by a registered medical practitioner if two registered medical practitioners are of the opinion, formed in good faith-..(a) that the pregnancy has not exceeded its twenty-fourth week and that the continuance of the pregnancy would involve risk, greater than if the pregnancy were terminated, of injury to the physical or mental health of the pregnant woman or any existing children of her family; or (b) that the termination is necessary to prevent grave permanent injury to the physical or mental health of the pregnant woman; or $(c)$ that the continuance of the pregnancy would involve risk to the life of the pregnant woman, greater than if the pregnancy were terminated; or $(d)$ that there is a substantial risk that if the child were born it would suffer from such physical or mental abnormalities as to be seriously handicapped. (2) In determining whether the continuance of a pregnancy would involve such risk of injury to health as is mentioned in paragraph (a) or (b) of subsection (1) of this section, account may be taken of the pregnant woman's actual or reasonably foreseeable environment. Disponível em: <http://www.legislation.gov.uk/ukpga/1967/87/section/1>. Acesso em: 22 fev. 2012. A respeito do aborto na Inglaterra, vide também: NETO, Luísa. $\mathbf{O}$ direito fundamental à disposição do próprio corpo (a relevância da vontade na configuração do seu regime). Coimbra: Coimbra Editora, 2004, p. 618.

${ }^{1520}$ NETO, Luísa. O direito fundamental à disposição do próprio corpo (a relevância da vontade na configuração do seu regime). Coimbra: Coimbra Editora, 2004, p. 617.

${ }^{1521}$ SARMENTO, Daniel. Legalização do Aborto e constituição. In: SARMENTO, Daniel; PIOVESAN, Flávia (coordenadores). Nos Limites da Vida. Rio de Janeiro: Lúmen Júris, 2006, p. 19.
} 
Um novo projeto de lei corrigiu as falhas do anterior ${ }^{1522}$ e prevaleceu até julho de 2010, quando uma nova lei sobre o tema entrou em vigor na Espanha ${ }^{1523}$.

Atualmente, como exposto acima, a lei espanhola autoriza o aborto até 14 semanas de gestação, e até 22 semanas para os casos de risco à saúde ou à vida da gestante, e, ainda, no caso de má-formação do feto.

Destacamos que a lei espanhola autoriza o aborto, no momento do diagnóstico, nos casos de anomalias fetais incompatíveis com a vida, e no caso de enfermidade extremamente grave e incurável. Nos casos em que a causa da interrupção for médica, será necessário um (ou conforme o caso, dois) parecer emitido por médicos distintos daquele que fará o aborto.

O novo texto normativo ampliou o tempo em que originalmente era possível praticarse o aborto, de 12 semanas para 14 semanas, e também autorizou o aborto para jovens entre 16 e 18 anos de idade ${ }^{1524}$.

Tendo em vista a relevância do debate desenvolvido pelo Tribunal Constitucional Espanhol sobre o aborto em 1985, vale a pena discorrer sobre os argumentos usados pelo Tribunal por ocasião da decisão STC 53-1985, ainda que atualmente a lei a tenha suplantado no plano normativo espanhol.

Em meados da década de 80, três decisões do Tribunal Constitucional Espanhol abordaram a temática da descriminalização do aborto na Espanha: a STC 75/1984 de 27 de junho, a STC 53 de 11 de abril de 1985, e a STC 70/1985 ${ }^{1525}$ de 31 de maio do mesmo ano.

\footnotetext{
${ }^{1522}$ SARMENTO, Daniel. Legalização do Aborto e constituição. In: SARMENTO, Daniel; PIOVESAN, Flávia (coordenadores). Nos Limites da Vida. Rio de Janeiro: Lúmen Júris, 2006, p. 20.

${ }^{1523}$ ESPANHA. Ley Orgánica 02/2010 de 03 de marzo de 2010. Entrou em vigor em 05 jul. 2010.

${ }^{1524}$ In verbis: Artículo 14. Interrupción del embarazo a petición de la mujer. Podrá interrumpirse el embarazo dentro de las primeras catorce semanas de gestación a petición de la embarazada, siempre que concurran los requisitos siguientes: a) Que se haya informado a la mujer embarazada sobre los derechos, prestaciones y ayudas públicas de apoyo a la maternidad, en los términos que se establecen en los apartados 2 y 4 del artículo 17 de esta Ley. b) Que haya transcurrido un plazo de al menos tres días, desde la información mencionada en el párrafo anterior y la realización de la intervención. Artículo 15. Interrupción por causas médicas. Excepcionalmente, podrá interrumpirse el embarazo por causas médicas cuando concurra alguna de las circunstancias siguientes: a) Que no se superen las veintidós semanas de gestación y siempre que exista grave riesgo para la vida o la salud de la embarazada y así conste en un dictamen emitido con anterioridad a la intervención por un médico o médica especialista distinto del que la practique o dirija. En caso de urgencia por riesgo vital para la gestante podrá prescindirse del dictamen. b) Que no se superen las veintidós semanas de gestación y siempre que exista riesgo de graves anomalías en el feto y así conste en un dictamen emitido con anterioridad a la intervención por dos médicos especialistas distintos del que la practique o dirija. c) Cuando se detecten anomalías fetales incompatibles con la vida y así conste en un dictamen emitido con anterioridad por un médico o médica especialista, distinto del que practique la intervención, o cuando se detecte en el feto una enfermedad extremadamente grave e incurable en el momento del diagnóstico y así lo confirme un comité clínico. (negrito nosso)

${ }^{1525} \mathrm{Na}$ sentença STC 70/1985, o Tribunal Constitucional Espanhol começara a desenvolver o entendimento constitucional espanhol quanto ao aborto ao afirmar que existe um limite para a proteção da vida intrauterina em relação aos direitos da mulher à liberdade pessoal e intimidade.
} 
A STC 53-1985 tornou-se a mais célebre decisão sobre o aborto na Espanha por enfrentar direta e corajosamente a questão da personalidade do feto humano, e concluiu que o feto é um objeto jurídico constitucionalmente protegido pelo artigo 15 da Constituição Espanhola, mas que, a despeito disso, não é considerado pessoa.

Assim, o tribunal espanhol deixou claro que, embora exista uma proteção constitucional do nascituro desde a gestação como parte do bloco de constitucionalidade, o que garante a proteção constitucional da vida desde o momento de sua existência, não lhe foi reconhecida a personalidade, de modo que o feto e o embrião não são titulares do direito à vida.

\subsubsection{Irlanda}

Como veremos a seguir, ao analisar a decisão da Corte Europeia de Direitos Humanos, o aborto na Irlanda é proibido, mas muitas mulheres irlandesas acabam fazendo o aborto na Inglaterra ${ }^{1526}$. A discussão da lei irlandesa é mais rica e interessante no contexto da análise da Corte Europeia, daí a analisarmos adiante.

É interessante notar que a Irlanda tem um alto índice de fetos com defeitos no tubo neural comparado com o de outros países europeus ${ }^{1527}$.

\subsection{INTERPRETAÇÃO DOS TRIBUNAIS INTERNACIONAIS A RESPEITO DO ABORTO}

\subsubsection{A Corte Europeia de Direitos Humanos e o aborto ${ }^{1528}$}

\footnotetext{
${ }^{1526}$ NETO, Luísa. O direito fundamental à disposição do próprio corpo (a relevância da vontade na configuração do seu regime). Coimbra: Coimbra Editora, 2004, p. 619.

${ }^{1527}$ OBEIDE, Nidaa et al. The Natural History of Anencephaly. Prenatal Diagnosis, 2010. 30, p. 357. Recente estudo demonstrou que 6,41 de cada 10.000 das gestações correspondem à gestação de feto anencéfalo na Irlanda. OBEIDE, Nidaa et al. The Natural History of Anencephaly. Prenatal Diagnosis, 2010. 30, p. 359.

${ }^{1528}$ Vale lembrar algumas interpretações relevantes que tratam especificamente a respeito do aborto. Destacamos a interpretação feita pela Comissão Européia de Direitos Humanos no caso X contra Reino Unido que restringiuse ao termo contido no artigo $2^{\circ}$ da Convenção Européia "toda pessoa", isto é, se o feto poderia ser compreendido como uma pessoa protegida pelo artigo, pois, para a Comissão, nem mesmo a Convenção determina o momento que essa proteção do direito à vida começa, e tampouco quando ela termina. Para a Comissão, a proteção da vida contida no artigo $2^{\circ}$ da Convenção européia não abarca o feto e tampouco
} 
A Convenção Europeia de Direitos Humanos (CEDH) tem dois dispositivos importantes no que se refere à proteção e respeito ao direito à vida, englobando, inclusive aspectos sobre a vida privada e familiar.

$\mathrm{O}$ artigo $2^{\circ}$ da Convenção $\mathrm{EDH}^{1529}$ estabelece que o direito à vida de qualquer pessoa é garantido em lei, e que ninguém poderá ser intencionalmente privado desta.

Ao lado desse artigo, mais adiante, o artigo 8 da $\mathrm{CEDH}^{1530}$ estabelece que qualquer um tem direito ao respeito de sua vida privada e familiar, sendo possível existir limites se houver previsão legal, ou quando seja necessária para a segurança nacional, para a segurança pública, para o bem-estar econômico do país, para a defesa da ordem e a prevenção das infrações penais, para a proteção da saúde ou da moral, ou para a proteção dos direitos e das liberdades de terceiros ${ }^{1531}$.

Daniel Sarmento esclarece que, na década de 80, a Comissão entendeu que o artigo $8^{\circ}$ da Convenção Europeia usava o termo "pessoa" garantindo o direito à vida somente aos

garantiria um caráter absoluto do direito à vida ao feto, estando os direitos do feto limitados pelos direitos e interesses da mãe. O entendimento também não segue no sentido de limitar à questão tão somente na esfera da vida privada, mas considerar todos os direitos em jogo. Luísa Neto explica que apesar de dispositivos internacionais que garantem a proteção da vida (Cita o artigo $3^{\circ}$ da DUDH, $6^{\circ}$ do PIDCP, $2^{\circ}$ CEDH e Convenção para Repressão do Crime de Genocídio de 1.12.48), tal direito não é definido, como se verifica nas decisões emitidas pela Comissão dos Direitos do Homem, no caso Paton v. Reino Unido (N.R. o caso também é conhecido como X v. Reino Unido mencionado). NETO, Luísa. O direito fundamental à disposição do próprio corpo (a relevância da vontade na configuração do seu regime). Coimbra: Coimbra Editora, 2004, p. 448. Luísa Neto explica ainda que "[...] quanto aos que por contrato dispõem do próprio corpo, em termos de renúncia genérica e não especificamente abrangida por casos de legítima defesa ou estado de necessidade, nem o direito internacional nem o direito nacional obriga a evitar que estranhos percam a vida". NETO, Luísa. O direito fundamental à disposição do próprio corpo (a relevância da vontade na configuração do seu regime). Coimbra: Coimbra Editora, 2004, p. 448. Vide também REY MARTÍNEZ, Fernando. La Protección Jurídica de La Vida: Un Derecho em Transformación Y Expansión (art. 2 CEDH y Protocolos $6^{\circ}$ y $13^{\circ}$ ). In: GARCIA ROCA, Javier e SANTOLAYA, Pablo (coords). La Europa de Los Derechos: El Convenio Europeo de Derechos Humanos. Madrid: Centro de Estúdios Políticos Y Constitucionales, 2005, p. 85.

${ }^{1529}$ In verbis: 1 . O direito de qualquer pessoa à vida é protegido pela lei. Ninguém poderá ser intencionalmente privado da vida, salvo em execução de uma sentença capital pronunciada por um tribunal, no caso de o crime ser punido com esta pena pela lei. 2. Não haverá violação do presente artigo quando a morte resulte de recurso à força, tornado absolutamente necessário: a) Para assegurar a defesa de qualquer pessoa contra uma violência ilegal; b) Para efectuar uma detenção legal ou para impedir a evasão de uma pessoa detida legalmente; e c) Para reprimir, em conformidade com a lei, uma revolta ou uma insurreição.

${ }^{1530}$ In verbis: 1. Qualquer pessoa tem direito ao respeito da sua vida privada e familiar, do seu domicílio e da sua correspondência. 2. Não pode haver ingerência da autoridade pública no exercício deste direito senão quando esta ingerência estiver prevista na lei e constituir uma providência que, numa sociedade democrática, seja necessária para a segurança nacional, para a segurança pública, para o bem-estar económico do país, a defesa da ordem e a prevenção das infracções penais, a protecção da saúde ou da moral, ou a protecção dos direitos e das liberdades de terceiros.

${ }^{1531}$ Vide artigo $8^{\circ}$ da CEDH. 
“indivíduos já nascidos”, e que o aborto ocorrido no início da gravidez deveria ser ponderado em respeito ao direito à saúde e vida privada da mulher ${ }^{1532}$.

Em 1992, a Corte Europeia, em um caso envolvendo a Irlanda, decidiu que a vida intrauterina não poderia ser protegida com igual intensidade atribuída à vida de alguém já nascido $^{1533}$.

Para Jan Kratochvil, os diplomas internacionais não resolvem os dois problemas principais sobre o tema do aborto: se o feto tem direito à vida e quais direitos prevalecem quando existirem conflitos entre direitos protetivos ao feto e direitos das gestantes. ${ }^{1534}$

No primeiro caso, para o autor, não há uma resposta clara dada pela Corte Europeia ou por outros órgãos de Direitos Humanos ${ }^{1535}$ ao problema.

No segundo caso, há muitas situações em que o direito à vida, liberdade de tratamento desumano, direito à privacidade foram considerados violados na hipótese de proibição ao aborto $^{1536}$.

Para Kratochvil, a Comissão de Direitos Humanos tende muito mais a proteger os direitos da gestante do que os dos fetos, e a leitura por eles atribuída à Convenção demandaria que os estados descriminalizassem a maior parte de abortos, mas, ao mesmo tempo, sem favorecer a prática de aborto incondicionalmente ${ }^{1537}$.

Segundo Kratochvil , a Corte Europeia pacificou o entendimento de que a vida da mãe estaria protegida pelo artigo $2^{\circ}$ no caso de a gravidez colocar em risco sua vida ${ }^{1538}$. Já com relação às outras circunstâncias, a jurisprudência da Corte não é clara ${ }^{1539}$.

\footnotetext{
${ }^{1532}$ SARMENTO, Daniel. Legalização do Aborto e constituição. In: SARMENTO, Daniel; PIOVESAN, Flávia (coordenadores). Nos Limites da Vida. Rio de Janeiro: Lúmen Júris, 2006, p. 21.

${ }^{1533}$ SARMENTO, Daniel. Legalização do Aborto e constituição. In: SARMENTO, Daniel; PIOVESAN, Flávia (coordenadores). Nos Limites da Vida. Rio de Janeiro: Lúmen Júris, 2006, p. 22.

${ }^{1534}$ KRATOCHVIL, Jan. The Rigth to Life in the Perspective of The Human Rights Committee and the European Court of Human Rights. Disponível em: 〈http://ssm.com/abstract=951225, p. 23>. Acesso em: 10 jun. 2011.

${ }^{1535}$ KRATOCHVIL, Jan. The Rigth to Life in the Perspective of The Human Rights Committee and the European Court of Human Rights. Disponível em: 〈http://ssm.com/abstract=951225, p. 23>. Acesso em: 10 jun. 2011.

${ }^{1536}$ KRATOCHVIL, Jan. The Rigth to Life in the Perspective of The Human Rights Committee and the European Court of Human Rights. Disponível em: <http://ssm.com/abstract=951225, p. 24>. Acesso em: 10 jun. 2011.

${ }^{1537}$ KRATOCHVIL, Jan. The Rigth to Life in the Perspective of The Human Rights Committee and the European Court of Human Rights. Disponível em: <http://ssm.com/abstract=951225, p. 24>. Acesso em: 10 jun. 2011.

${ }^{1538}$ Autor exemplifica com o caso X v. United Kigdom, 8416/78. KRATOCHVIL, Jan. The Rigth to Life in the Perspective of The Human Rights Committee and the European Court of Human Rights. Disponível em:http://ssm.com/abstract=951225, p. 24>. Acesso em: 10 jun. 2011.

${ }^{1539}$ KRATOCHVIL, Jan. The Rigth to Life in the Perspective of The Human Rights Committee and the European Court of Human Rights. Disponível em: 〈http://ssm.com/abstract=951225, p. 25>. Acesso em: 10 jun. 2011.
} 
Kratochvil afirma que a Corte entendeu que o direito à saúde da mãe pode ser violado quando uma lei é muito rígida em favor do feto (totalmente contra o aborto, por exemplo) ${ }^{1540}$, mas ainda não existe um sedimentação do entendimento da Corte nesse sentido.

Critica, ainda, Jan Kratochvil a inexistência de jurisprudência e dispositivos internacionais mais claros a respeito do tema, bem como a falta de um padrão universal adotado pelos estados, de modo que a decisão no sentido de se uma lei que proíbe o aborto viola ou não os direitos da mulher recai na margem nacional adotada em cada estado ${ }^{1541}$.

Em 2010, uma nova decisão da Corte Europeia de Direitos Humanos tratou do tema, trazendo à baila argumentos interessantes, como veremos a seguir.

\subsubsection{Caso A, B e C v. Irlanda}

Em recente decisão da Corte Europeia de Direitos Humanos foi discutida a possibilidade de aborto em duas situações à luz do artigo $8^{\circ}$ da Convenção Europeia de Direitos Humanos (caso A, B e C v. Irlanda).

A principal demanda (com relação à dois requerentes) versava sobre a proibição do aborto em caso de saúde e bem-estar na Irlanda. Com relação à terceira requerente, a discussão versava sobre a falha de uma implementação efetiva do direito constitucional ao aborto na Irlanda em caso de risco à vida da mulher ${ }^{1542}$, único caso em que o aborto é legal na Irlanda.

Os fatos trazidos pela Corte possuem traços semelhantes: uma das mulheres envolvidas na demanda, (A), residente na Irlanda, viajou para a Inglaterra em 28 de fevereiro de 2005 para realizar um aborto não permitido na Irlanda, a nove semanas e meia de uma

\footnotetext{
${ }^{1540}$ O autor cita o caso Open Door and Dublin Well Woman Centre em que a Corte entendeu que uma lei contrária ao aborto poderia ser desproporcional. KRATOCHVIL, Jan. The Rigth to Life in the Perspective of The Human Rights Committee and the European Court of Human Rights. Disponível em: $\langle$ http://ssm.com/abstract=951225, p. 25>. Acesso em:10 jun. 2011. Por outro lado, indica a decisão no caso Brügemmann and Scheuten em que a Comissão entendeu que nem toda a regulamentação proibitiva de aborto, constitui uma interferência à vida privada da mulher. KRATOCHVIL, Jan. The Rigth to Life in the Perspective of The Human Rights Committee and the European Court of Human Rights. Disponível em: <http://ssm.com/abstract=951225, p. 25>. Acesso em: 10 jun. 2011.

${ }^{1541}$ KRATOCHVIL, Jan. The Rigth to Life in the Perspective of The Human Rights Committee and the European Court of Human Rights. Disponível em: 〈http://ssm.com/abstract=951225, p. 25>. Acesso em: 10 jun. 2011.

${ }^{1542}$ ECHR. Case A, B e C v. Ireland. Aplication no. 25579/05. Julgamento 16 dez. 2010. Parágrafo 2 (Tradução nossa).
} 
gravide $^{1543}$ inesperada, diante da possibilidade de infertilidade de seu parceiro ${ }^{1544}$. Na época, estava desempregada, solteira e vivendo na pobreza (ou miséria), com quatro outros filhos pequenos que estavam sob a custódia da assistência social em vista de problemas decorrentes de seus antecendentes de alcoolismo ${ }^{1545}$. Além disso, a gestante sofria de depressão ${ }^{1546}$. Em vista destas circunstâncias, a gestante entendeu que o aborto seria a decisão mais correta para ela $^{1547}$. Depois de realizar o aborto na Inglaterra; mais especificamente, no dia seguinte ao aborto, (A) retornou à Irlanda, com náuseas, sangramentos e dores, decorrentes de complicações após o aborto a que se submeteu ${ }^{1548}$.

A outra requerente, também residente na Irlanda, grávida de sete semanas, (B), em 17 de janeiro de 2005, viajou, também para a Inglaterra para realizar o aborto, acreditando que sua situação não se enquadrava nas hipóteses de excludentes do crime de aborto na Irlanda ${ }^{1549}$. A gravidez indesejada ocorrera mesmo com uso da pílula-do-dia-seguinte. Médicos já a haviam alertado sobre o risco de que viesse a sofrer uma gravidez "ectópica", mas esse fato não poderia ser diagnosticado antes de 6-10 semanas de gravidez. ${ }^{1550}$ Ela esperou várias semanas até que conseguisse arcar com as despesas da viagem e, mesmo com a confirmação de que não se tratava de uma gravidez "ectópica"1551, (B) realizou o aborto na Inglaterra. Chegou na noite anterior ao procedimento, e permaneceu na Inglaterra na noite do

${ }^{1543}$ ECHR. Case A, B e C v. Ireland. Aplication no. 25579/05. Julgamento 16 dez. 2010. Parágrafos 13-14 (tradução nossa).

${ }^{1544}$ ECHR. Case A, B e C v. Ireland. Aplication no. 25579/05. Julgamento 16 dez. 2010. Parágrafo 14 (tradução nossa).

${ }^{1545}$ ECHR. Case A, B e C v. Ireland. Aplication no. 25579/05. Julgamento 16 dez. 2010. Parágrafo 14 (tradução nossa). No ano anterior à gravidez, (A) manteve-se sóbria e vinha tentando conseguir a guarda de seus filhos. Somente depois que ingressou com o pedido à Corte, (A) recuperou a guarda de dois filhos e outros dois continuam em tratamento. ECHR. Case A, B e C v. Ireland. Aplication no. 25579/05. Julgamento 16 dez. 2010. Parágrafo 17 (tradução nossa).

${ }^{1546}$ ECHR. Case A, B e C v. Ireland. Aplication no. 25579/05. Julgamento 16 dez. 2010. Parágrafo 14 (tradução nossa).

${ }^{1547}$ ECHR. Case A, B e C v. Ireland. Aplication no. 25579/05. Julgamento 16 dez. 2010. Parágrafos 16-17 (tradução nossa). (A) entendia que a gravidez em 2005 não era a melhor opção para ela, diante de inúmeros problemas. Depois de ingressar com o pedido à Corte, (A) ficou novamente grávida e deu à luz a outro bebê. ECHR. Case A, B e C v. Ireland. Aplication no. 25579/05. Julgamento 16 dez. 2010. Parágrafo 17 (tradução nossa).

${ }^{1548}$ ECHR. Case A, B e C v. Ireland. Aplication no. 25579/05. Julgamento 16 dez. 2010. Parágrafo 16 (tradução nossa).

${ }^{1549}$ ECHR. Case A, B e C v. Ireland. Aplication no. 25579/05. Julgamento 16 dez. 2010. Parágrafos 18-19 (tradução nossa).

${ }^{1550}$ ECHR. Case A, B e C v. Ireland. Aplication no. 25579/05. Julgamento 16 dez. 2010. Parágrafo 19 (tradução nossa).

${ }^{1551}$ ECHR. Case A, B e C v. Ireland. Aplication no. 25579/05. Julgamento 16 dez. 2010. Parágrafo 19 (tradução nossa). 
aborto, e depois retornou para a Irlanda. Todavia, posteriormente, também teve complicações decorrentes do aborto ${ }^{1552}$.

A última das recorrentes, (C), também residente na Irlanda, buscou o aborto na Inglaterra em 3 de março de 2005, acreditando não ser possível fazer valer seu direito ao aborto $^{1553}$. A recorrente estava no primeiro trimestre de gravide ${ }^{1554}$. Ela havia feito sessões de quimioterapia durante três anos como tratamento de um câncer raro e, ao perguntar ao médico sobre as implicações de uma gravidez neste contexto, o médico lhe havia respondido que não seria possível prever se haveria ou não danos ao feto, ou qual o impacto da gravidez ou da suspensão da quimioterapia no câncer, e que poderia ser perigoso ao feto se a quimioterapia fosse realizada, especialmente nos três primeiros meses da gravidez ${ }^{1555}$.

Alegou a requerente que, durante uma série de testes para o câncer - todos contraindicados durante a gestação, descobriu que estava grávida. Ademais, alegou que consultou também o médico geral responsável a respeito de seu caso, mas que não recebeu informações suficientes com relação ao impacto da gravidez na sua saúde e vida, nem dos testes conduzidos anteriormente no feto ${ }^{1556}$. Ela, então, teria consultado os riscos pela internet e daí decidido fazer um aborto induzido (já que estava no início da gravidez), por meio de pílulas, mas, acreditando que não conseguiria acesso a essas pílulas legalmente na Irlanda ${ }^{1557}$, acabou aguardando oito semanas para que o aborto cirúrgico fosse possível ${ }^{1558}$, na Inglaterra. Ao retornar para Irlanda, sofreu complicações devido à um aborto incompleto, com hemorragia e infecção ${ }^{1559}$.

A Corte Europeia de Direitos Humanos analisou o pedido das requerentes à luz do artigo $8^{\circ}$ da Convenção Europeia de Direitos Humanos. A Corte entendeu que os principais pontos levantados pelas requerentes foram que o artigo $8^{\circ}$ foi violado no que tange às restrições de aborto na Irlanda, visto que não seria possível abortar em razão de saúde ou

1552 ECHR. Case A, B e C v. Ireland. Aplication no. 25579/05. Julgamento 16 dez. 2010. Parágrafos 20-21 (tradução nossa).

${ }^{1553}$ ECHR. Case A, B e C v. Ireland. Aplication no. 25579/05. Julgamento 16 dez. 2010. Parágrafo 22 (tradução nossa).

${ }^{1554}$ ECHR. Case A, B e C v. Ireland. Aplication no. 25579/05. Julgamento 16 dez. 2010. Parágrafo 22 (tradução nossa).

${ }^{1555}$ ECHR. Case A, B e C v. Ireland. Aplication no. 25579/05. Julgamento 16 dez. 2010. Parágrafo 23 (tradução nossa).

${ }^{1556}$ ECHR. Case A, B e C v. Ireland. Aplication no. 25579/05. Julgamento 16 dez. 2010. Parágrafo 24 (tradução nossa).

${ }^{1557}$ ECHR. Case A, B e C v. Ireland. Aplication no. 25579/05. Julgamento 16 dez. 2010. Parágrafo 25 (tradução nossa).

${ }^{1558}$ ECHR. Case A, B e C v. Ireland. Aplication no. 25579/05. Julgamento 16 dez. 2010. Parágrafo 26 (tradução nossa).

${ }^{1559}$ ECHR. Case A, B e C v. Ireland. Aplication no. 25579/05. Julgamento 16 dez. 2010. Parágrafo 26 (tradução nossa). 
bem-estar ${ }^{1560}$, bem como - no caso da demandante C - por força da falta de qualquer legislação de implementação do artigo 40.3 .3 da Constituição Irlandesa ${ }^{1561}$, que tem sido entendido no sentido de se conferir autorização de aborto em caso de risco à vida da gestante.

Alegaram as requerentes que a aplicação das restrições interferia intimamente em suas vidas familiares e privadas, bem como em sua integridade psíquica ${ }^{1562}$. Alegaram, ainda, que o debate não versava diretamente a respeito da lei irlandesa, mas em relação ao modo como o estado irlandês interpretava a lei, de maneira muito restritiva ${ }^{1563}$. Afirmaram, ainda, que as mulheres irlandesas viajavam para abortar de qualquer modo, de maneira que o estado tampouco mantinha de forma legítima a proteção do direito à vida do feto ${ }^{1564}$. Alegaram que a proteção da vida do feto - exceto em casos em que a vida da mãe esteja em risco - não refletia a posição do povo irlandês e era desproporcionalmente rígida ${ }^{1565}$.

O estado se defendeu basicamente fazendo uso da margem de apreciação ${ }^{1566}$ para proteger a vida do feto ${ }^{1567}$, alegando que a proteção da vida do nascituro estava fundada em "profundos valores morais" da sociedade irlandesa ${ }^{1568}$. O governo admitiu que não existia

\footnotetext{
${ }^{1560}$ ECHR. Case A, B e C v. Ireland. Aplication no. 25579/05. Julgamento 16 dez. 2010. Parágrafo 32 (tradução nossa).

${ }^{1561}$ ECHR. Case A, B e C v. Ireland. Aplication no. 25579/05. Julgamento 16 dez. 2010. Parágrafo 44 (tradução nossa).

${ }^{1562}$ ECHR. Case A, B e C v. Ireland. Aplication no. 25579/05. Julgamento 16 dez. 2010. Parágrafo 168 (tradução nossa).

${ }^{1563}$ ECHR. Case A, B e C v. Ireland. Aplication no. 25579/05. Julgamento 16 dez. 2010. Parágrafo 137 (tradução nossa).

${ }^{1564}$ ECHR. Case A, B e C v. Ireland. Aplication no. 25579/05. Julgamento 16 dez. 2010. Parágrafo 170 (tradução nossa).

${ }^{1565}$ ECHR. Case A, B e C v. Ireland. Aplication no. 25579/05. Julgamento 16 dez. 2010. Parágrafos 170-171 (tradução nossa).

${ }^{1566}$ André de Carvalho Ramos explica que a teoria da margem de apreciação baseia-se na "subsidiariedade da jurisdição internacional e prega que determinadas questões polêmicas relacionadas com as restrições estatais a direitos protegidos devem ser discutidas e dirimidas pelas comunidades nacionais, não podendo o juiz internacional apreciá-las". CARVALHO RAMOS, André de. Teoria Geral dos Direitos Humanos na Ordem Internacional. Rio de Janeiro: Renovar, 2005, p. 110. Ensina ainda o autor que a teoria da margem de apreciação nacional decorre da enorme "confiança nos Estados europeus, que seriam todos democráticos e defensores de direitos humanos". CARVALHO RAMOS, André de. Teoria Geral dos Direitos Humanos na Ordem Internacional. Rio de Janeiro: Renovar, 2005, p. 117. Para muitos, no entanto, a aplicação dessa teoria poderia fazer com que o estado deixasse de assegurar os direitos humanos, ensejando a possibilidade de se relativizar os direitos humanos. CARVALHO RAMOS, André de. Teoria Geral dos Direitos Humanos na Ordem Internacional. Rio de Janeiro: Renovar, 2005, p. 116-117. André de Carvalho Ramos entende que a margem de apreciação nacional é verdadeiro "disfarce teórico para o relativismo no campo dos direitos humanos”. CARVALHO RAMOS, André de. Teoria Geral dos Direitos Humanos na Ordem Internacional. Rio de Janeiro: Renovar, 2005, p. 183. Ler sobre universalidade e relativismo: CARVALHO RAMOS, André de. Avanços e Recuos: a universalidade dos Direitos Humanos no século XXI. In: Direitos Humanos em Concreto. COSTA, Paulo Sérgio Weyl A. (Coord.) Curitiba: Juruá, 2008.

${ }^{1567}$ ECHR. Case A, B e C v. Ireland. Aplication no. 25579/05. Julgamento 16 dez. 2010. Parágrafos 137 e 172 (tradução nossa).

${ }^{1568}$ ECHR. Case A, B e C v. Ireland. Aplication no. 25579/05. Julgamento 16 dez. 2010. Parágrafo 180 (tradução nossa).
} 
nenhuma proposta em curso na Irlanda para se debater o aborto ${ }^{1569}$, mas que referendos em 1983, 1992 e 2002 deixaram clara a opinião contrária ao aborto do povo irlandês ${ }^{1570}$. O estado também afirmou que a proteção da vida do feto não dependia de mero consenso sobre quando a vida começa, mas de "equilíbrio" e legitimidade de escolha ${ }^{1571}$.

A Corte iniciou a análise abordando o consenso europeu a respeito da permissão do aborto. O consenso europeu atual era claramente favorável à extensão do direito ao aborto na Irlanda. Mesmo sem haver um consenso sobre a definição do início da vida, haveria um consenso sobre os "standards" mínimos para os serviços de aborto preservando a saúde e bem-estar da mulher ${ }^{1572}$. Segundo a Corte, tal “consenso" é possível de ser verificado na medida em que, dos 47 estados europeus sujeitos à jurisdição da Corte, 31 permitem o aborto no primeiro trimestre; e 42 dos 47 estados permitem o aborto se a saúde da mulher estiver em risco. Ademais, 32 estados dos 47 permitem o término da gravidez em caso de anormalidade fetal, estando a Irlanda entre os quatro estados que possuem regras penais mais restritivas em caso de aborto (juntamente com Malta, São Marino e Andorra) ${ }^{1573}$.

Com relação ao artigo $2^{\circ}$ da Convenção Europeia de Direitos Humanos, a Corte entendeu que a Irlanda teria um direito soberano para estabelecer quando a vida começa a ser protegida e, com base nesse direito à vida, os direitos à privacidade e integridade física deveriam ser medidos ${ }^{1574}$, pois tais direitos também não são absolutos ${ }^{1575}$, assim como, a gravidez não deve ser analisada exclusivamente na esfera privada ${ }^{1576}$. A Corte reconheceu que não há hierarquia formal entre direito à vida e direito à saúde, devendo ambos direitos ser protegidos pelo estado $^{1577}$.

\footnotetext{
${ }^{1569}$ ECHR. Case A, B e C v. Ireland. Aplication no. 25579/05. Julgamento 16 dez. 2010. Parágrafo 180 (tradução nossa).

${ }^{1570}$ ECHR. Case A, B e C v. Ireland. Aplication no. 25579/05. Julgamento 16 dez. 2010. Parágrafo 183 (tradução nossa).

${ }^{1571}$ ECHR. Case A, B e C v. Ireland. Aplication no. 25579/05. Julgamento 16 dez. 2010. Parágrafo 186 (tradução nossa).

${ }^{1572}$ ECHR. Case A, B e C v. Ireland. Aplication no. 25579/05. Julgamento 16 dez. 2010. Parágrafo 175 (tradução nossa).

${ }^{1573}$ ECHR. Case A, B e C v. Ireland. Aplication no. 25579/05. Julgamento 16 dez. 2010. Parágrafo 175 (tradução nossa).

${ }^{1574}$ ECHR. Case A, B e C v. Ireland. Aplication no. 25579/05. Julgamento 16 dez. 2010. Parágrafo 197 (tradução nossa).

${ }^{1575}$ ECHR. Case A, B e C v. Ireland. Aplication no. 25579/05. Julgamento 16 dez. 2010. Parágrafo 199 (tradução nossa).

${ }^{1576}$ ECHR. Case A, B e C v. Ireland. Aplication no. 25579/05. Julgamento 16 dez. 2010. Parágrafo 199 (tradução nossa).

${ }^{1577}$ ECHR. Case A, B e C v. Ireland. Aplication no. 25579/05. Julgamento 16 dez. 2010. Parágrafo 209 (tradução nossa).
} 
A Corte afirmou, ainda, que o significado de vida privada contido no artigo $8^{\circ}$ da Convenção é amplo e engloba o direito à autonomia e desenvolvimento pessoal ${ }^{1578}$. Isso alcança, para a Corte, matérias envolvendo identificação de gênero, orientação sexual e vida sexual $^{1579}$. Além disso, englobaria a integridade física e psíquica do indivíduo ${ }^{1580}$.

É possível admitir, para a Corte, que a interrupção da gravidez "toca a esfera da vida privada da mulher" ${ }^{1581}$, mas também enfatiza que o artigo $8^{\circ}$ não pode ser interpretado no sentido de que a gravidez e sua terminação pertencem unicamente à vida privada da mulher ${ }^{1582}$. Para a Corte, quando a mulher está grávida, cria-se uma ligação com o feto em desenvolvimento $^{1583}$, de modo que o direito ao respeito da vida privada da mulher deve ser pesado em relação a outros direitos e liberdades, inclusive quanto aos direitos do nascituro ${ }^{1584}$. $\mathrm{O}$ artigo $8^{\circ}$ também não poderia ser interpretado no sentido de conceder um direito ao aborto, para a Corte. ${ }^{1585}$

Com relação às duas primeiras requerentes dos casos acima, a Corte entendeu que existem obrigações positivas inerentes ao efetivo respeito à vida privada, e que a proibição do aborto no caso de risco de saúde e bem-estar seria equiparado a uma interferência do estado no direito ao respeito pela vida privada da mulher ${ }^{1586}$. Portanto, o aspecto que deve ser analisado é se a proibição do aborto é uma intervenção indevida por parte do estado ${ }^{1587}$, ou se a interferência estatal é legítima ${ }^{1588}$.

Considerou a Corte que a proteção do feto nesses casos decorrera de uma escolha moral de reconhecer-se a qualidade de pessoa ao feto ${ }^{1589}$. E, no entanto, a Corte não considera

\footnotetext{
1578 (Tradução nossa). A Corte cita o caso Pretty v. The United Kingdom vide §61. Parágrafo 212.

1579 ECHR. Case A, B e C v. Ireland. Aplication no. 25579/05. Julgamento 16 dez. 2010. Parágrafo 212 (tradução nossa).

1580 ECHR. Case A, B e C v. Ireland. Aplication no. 25579/05. Julgamento 16 dez. 2010. Parágrafo 212 (tradução nossa).

${ }^{1581}$ ECHR. Case A, B e C v. Ireland. Aplication no. 25579/05. Julgamento 16 dez. 2010. Parágrafo 213 (tradução nossa).

1582 ECHR. Case A, B e C v. Ireland. Aplication no. 25579/05. Julgamento 16 dez. 2010. Parágrafo 213 (tradução nossa).

${ }^{1583}$ ECHR. Case A, B e C v. Ireland. Aplication no. 25579/05. Julgamento 16 dez. 2010. Parágrafo 213 (tradução nossa).

${ }^{1584}$ ECHR. Case A, B e C v. Ireland. Aplication no. 25579/05. Julgamento 16 dez. 2010. Parágrafo 213 (tradução nossa). Vide casos Tysiac v. Poland §106 e Vo v. France, §76-82.

1585 ECHR. Case A, B e C v. Ireland. Aplication no. 25579/05. Julgamento 16 dez. 2010. Parágrafo 214 (tradução nossa).

1586 ECHR. Case A, B e C v. Ireland. Aplication no. 25579/05. Julgamento 16 dez. 2010. Parágrafo 216 (tradução nossa).

${ }^{1587}$ ECHR. Case A, B e C v. Ireland. Aplication no. 25579/05. Julgamento 16 dez. 2010. Parágrafo 216 (tradução nossa).

${ }^{1588}$ ECHR. Case A, B e C v. Ireland. Aplication no. 25579/05. Julgamento 16 dez. 2010. Parágrafos 217 e 221 (tradução nossa).

${ }^{1589}$ ECHR. Case A, B e C v. Ireland. Aplication no. 25579/05. Julgamento 16 dez. 2010. Parágrafos 223-227 (tradução nossa).
} 
que esses aspectos morais decorrentes de crenças religiosas ou outras sejam determinantes para se estabelecer restrições ao aborto ${ }^{1590}$.

A Corte entendeu que o uso da margem de apreciação deve ser limitado nos casos em que uma faceta importante para a existência de um indivíduo ou de identidade está em jogo, embora não haja consenso sobre qual a importância que deva ser dada aos interesses em discussão ${ }^{1591}$. Se, de um lado, ampliar a margem de apreciação seria conceder ao estado irlandês o direito de determinar um certo equilíbrio local (isto é, irlandês) para o direito à vida dos nascituros, por outro, a situação implica também os direitos conflitantes das mulheres envolvidas, e a Irlanda precisaria também respeitar sua vida privada ${ }^{1592}$.

A Corte entendeu que a Irlanda é o único estado sob sua jurisdição que permite o aborto apenas quando há risco à vida da mãe, mas que as recorrentes A e B poderiam ter obtido um aborto legal em cerca de 30 estados, e a Recorrente C, em 40 estados. Afirmou, ainda, que a tendência internacional é de ampliar o acesso ao aborto ${ }^{1593}$, embora isso por si só não deva restringir a margem de apreciação da Irlanda. Finalmente, a Corte entendeu que, apesar de a Irlanda proibir o aborto, permite que as mulheres viajem para outros estados para fazê-lo legalmente, e que tem medidas para garantir o tratamento médico e cuidados pósaborto às pacientes ${ }^{1594}$.

Em vista do exposto, no caso das recorrentes A e B, a Corte entendeu que não houve violação ao artigo $8^{\circ}$ da Convenção Europeia de Direitos Humanos por parte da Irlanda, afirmando que o país não excedeu a margem de apreciação aplicável ao caso, com base nas opiniões morais profundas do povo irlandês quanto à natureza da vida, e em virtude da consequente proteção a ser acordada ao direito à vida do feto ${ }^{1595}$.

Com relação à terceira requerente, vale dizer que o objeto da demanda versava sobre a falha na implementação do Artigo 40.3.3 por parte do estado irlandês de introduzir modos de se efetivar a modalidade de aborto legal em razão do risco à vida e à gravidez da mulher ${ }^{1596}$.

\footnotetext{
${ }^{1590}$ ECHR. Case A, B e C v. Ireland. Aplication no. 25579/05. Julgamento 16 dez. 2010. Parágrafo 228 (tradução nossa).

${ }^{1591}$ ECHR. Case A, B e C v. Ireland. Aplication no. 25579/05. Julgamento 16 dez. 2010. Parágrafo 232 (tradução nossa).

${ }^{1592}$ ECHR. Case A, B e C v. Ireland. Aplication no. 25579/05. Julgamento 16 dez. 2010. Parágrafo 234 (tradução nossa).

${ }^{1593}$ ECHR. Case A, B e C v. Ireland. Aplication no. 25579/05. Julgamento 16 dez. 2010. Parágrafo 235 (tradução nossa).

${ }^{1594}$ ECHR. Case A, B e C v. Ireland. Aplication no. 25579/05. Julgamento 16 dez. 2010. Parágrafo 239 (tradução nossa).

${ }^{1595}$ ECHR. Case A, B e C v. Ireland. Aplication no. 25579/05. Julgamento 16 dez. 2010. Parágrafo 241 (tradução nossa).

${ }^{1596}$ ECHR. Case A, B e C v. Ireland. Aplication no. 25579/05. Julgamento 16 dez. 2010. Parágrafos 243-250 (tradução nossa).
} 
Neste caso, a Corte conclui que houve violação ao artigo $8^{\circ}$ da $\mathrm{CEDH}$, rejeitando o argumento do estado da Irlanda de que a recorrente não teria conseguido esgotar internamente ${ }^{1597}$ a questão $^{1598}$. Além do mais, o estado não teria cumprido suas obrigações positivas, ou seja, não garantira o respeito à vida privada da terceira recorrente em razão da ausência de qualquer regulamentação que possibilitasse a ela um aborto legal na Irlanda ${ }^{1599}$, em especial, em razão do risco à sua vida e à do feto.

Merecem destaque alguns argumentos contidos nos votos concorrentes e dissidentes da Corte.

Em voto concorrente com a decisão da Corte, o Juiz López Guerra considerou que os estados têm direito à margem de apreciação para regulamentar o aborto ${ }^{1600}$, mas que devem ser levados em consideração também "o grau de intensidade e gravidade do perigo para a saúde da mulher" ${ }^{1601}$, bem como seu bem-estar. Para o juiz, a Corte limitou-se a analisar se a lei irlandesa era compatível com o artigo $8^{\circ}$ da $\mathrm{CEDH}^{1602}$, ao invés de analisar o caso concreto em si, ou seja, declarar qual a gravidade do perigo para a saúde da gestante nessas situações específicas $^{1603}$, e se esse fato diminuiria a margem de apreciação do estado para com casos semelhantes ${ }^{1604}$.

Já o voto concorrente do Juiz Geoghegan Finlay aponta a questão de se a Corte deveria ou não levar em conta o consenso em relação aos estados que permitem o aborto para analisar se foi alcançado um "justo equilíbrio" entre o direito à vida do feto e os direitos de (A) e $(\mathrm{B})^{1605}$ na Irlanda. Respondendo à indagação, para ele, o consenso nos demais estados

\footnotetext{
${ }^{1597}$ Conforme ensina Guilherme Assis de Almeida "no DIDH, vigora a regra do esgotamento dos recursos internos, ou seja, qualquer denúncia sobre violação de direitos humanos só será apreciada pelas instâncias internacionais, depois de esgotadas todas as medidas judiciais cabíveis no plano interno, ou a existência de fortes indícios de que tais medidas não serão eficazes". ALMEIDA, Guilherme Assis de. Direitos humanos e nãoviolência. São Paulo: Atlas, 2001, p. 64.

${ }^{1598}$ ECHR. Case A, B e C v. Ireland. Aplication no. 25579/05. Julgamento 16 dez. 2010. Parágrafo 267 (tradução nossa).

${ }^{1599}$ ECHR. Case A, B e C v. Ireland. Aplication no. 25579/05. Julgamento 16 dez. 2010. Parágrafo 267, p. 49 (tradução nossa).

${ }^{1600}$ ECHR. Case A, B e C v. Ireland. Aplication no. 25579/05. Julgamento 16 dez. 2010. Parágrafos 1-3 (tradução nossa). Voto Concorrente do Juiz López Guerra.

${ }^{1601}$ ECHR. Case A, B e C v. Ireland. Aplication no. 25579/05. Julgamento 16 dez. 2010. Parágrafo 3 (tradução nossa). Voto Concorrente do Juiz López Guerra.

${ }^{1602}$ ECHR. Case A, B e C v. Ireland. Aplication no. 25579/05. Julgamento 16 dez. 2010. Parágrafo 4 (tradução nossa). Voto Concorrente do Juiz López Guerra.

${ }^{1603}$ ECHR. Case A, B e C v. Ireland. Aplication no. 25579/05. Julgamento 16 dez. 2010. Parágrafos 4-5 (tradução nossa). Voto Concorrente do Juiz López Guerra.

${ }^{1604}$ ECHR. Case A, B e C v. Ireland. Aplication no. 25579/05. Julgamento 16 dez. 2010. Parágrafo 5 (tradução nossa). Voto Concorrente do Juiz López Guerra.

${ }^{1605}$ ECHR. Case A, B e C v. Ireland. Aplication no. 25579/05. Julgamento 16 dez. 2010. Parágrafos 3-5 (tradução nossa). Voto Concorrente do Juiz Geoghegan Finlay.
} 
contratantes não poderia ser apresentado para diminuir a margem de apreciação nacional da Irlanda ${ }^{1606}$.

Por fim, vejamos o voto conjunto parcialmente dissidente dos juízes Christos Rozakis, Françoise Tulkens, Elisabet Fura, Päivi Hirvelä, Giorgio Malinverni, e Mihai Poalelungi ${ }^{1607}$.

Entenderam os juízes que o direito à vida da mãe e do feto é desigual ${ }^{1608}$. Para eles, houve uma confusão a respeito de que determinar o momento em que a vida se inicia ficaria no âmbito da margem de apreciação de cada estado ${ }^{1609}$. Além disso, entenderam os juízes que, para se verificar se um estado violou o direito à vida privada, seria preciso analisar dois aspectos: Se existe consenso europeu a favor do aborto, e a sanção prevista no caso de abortos realizados para proteger a saúde ou bem-estar da mulher na Irlanda ${ }^{1610}$. Para os juízes, por um lado, esse consenso diz respeito à tentativa de harmonização da proteção dos direitos humanos $^{1611}$. Essa harmonização, por outro lado, deve ser limitada ${ }^{1612}$, assim como o é a margem de apreciação ${ }^{1613}$.

Por fim, discordaram os juízes do argumento de que a possibilidade de sair do país para fazer um aborto garante o direito à vida privada, e de que isso seria suficiente para se tratar o aborto no país de acordo com as concepções morais do povo irlandês ${ }^{1614}$. Para eles, a Corte não enfrentou diretamente o problema da interferência do estado na vida privada das

\footnotetext{
${ }^{1606}$ ECHR. Case A, B e C v. Ireland. Aplication no. 25579/05. Julgamento 16 dez. 2010. Parágrafos 9-10 (tradução nossa). Voto Concorrente do Juiz Geoghegan Finlay.

1607 (Tradução nossa). ECHR. Case A, B e C v. Ireland. Aplication no. 25579/05. Julgamento 16 dez. 2010. Parágrafos 9-10 (tradução nossa). Voto em conjunto Parcialmente Dissidente dos Juízes Christos Rozakis, Françoise Tulkens, Elisabet Fura, Päivi Hirvelä, Giorgio Malinverni e Mihai Poalelungi.

${ }^{1608}$ ECHR. Case A, B e C v. Ireland. Aplication no. 25579/05. Julgamento 16 dez. 2010. Parágrafo 2 (tradução nossa). Voto em conjunto Parcialmente Dissidente dos Juízes Christos Rozakis, Françoise Tulkens, Elisabet Fura, Päivi Hirvelä, Giorgio Malinverni e Mihai Poalelungi.

${ }^{1609}$ ECHR. Case A, B e C v. Ireland. Aplication no. 25579/05. Julgamento 16 dez. 2010. Parágrafos 2-3 (tradução nossa). Voto em conjunto Parcialmente Dissidente dos Juízes Christos Rozakis, Françoise Tulkens, Elisabet Fura, Päivi Hirvelä, Giorgio Malinverni e Mihai Poalelungi.

${ }^{1610}$ ECHR. Case A, B e C v. Ireland. Aplication no. 25579/05. Julgamento 16 dez. 2010. Parágrafo 3 (tradução nossa). Voto em conjunto Parcialmente Dissidente dos Juízes Christos Rozakis, Françoise Tulkens, Elisabet Fura, Päivi Hirvelä, Giorgio Malinverni e Mihai Poalelungi.

${ }^{1611}$ ECHR. Case A, B e C v. Ireland. Aplication no. 25579/05. Julgamento 16 dez. 2010. Parágrafo 5 (tradução nossa). Voto em conjunto Parcialmente Dissidente dos Juízes Christos Rozakis, Françoise Tulkens, Elisabet Fura, Päivi Hirvelä, Giorgio Malinverni e Mihai Poalelungi.

1612 (Tradução nossa). ECHR. Case A, B e C v. Ireland. Aplication no. 25579/05. Julgamento 16 dez. 2010. Parágrafo 5 (tradução nossa). Voto em conjunto Parcialmente Dissidente dos Juízes Christos Rozakis, Françoise Tulkens, Elisabet Fura, Päivi Hirvelä, Giorgio Malinverni e Mihai Poalelungi.

${ }^{1613}$ ECHR. Case A, B e C v. Ireland. Aplication no. 25579/05. Julgamento 16 dez. 2010. Parágrafo 5 (tradução nossa). Voto em conjunto Parcialmente Dissidente dos Juízes Christos Rozakis, Françoise Tulkens, Elisabet Fura, Päivi Hirvelä, Giorgio Malinverni e Mihai Poalelungi.

${ }^{1614}$ ECHR. Case A, B e C v. Ireland. Aplication no. 25579/05. Julgamento 16 dez. 2010. Parágrafo 6-7 (tradução nossa). Voto em conjunto Parcialmente Dissidente dos Juízes Christos Rozakis, Françoise Tulkens, Elisabet Fura, Päivi Hirvelä, Giorgio Malinverni e Mihai Poalelungi.
} 
recorrentes ${ }^{1615}$, e, pela primeira vez, ignorou o consenso europeu, permitindo que as concepções morais irlandesas se sobrepusessem a ele ${ }^{1616}$.

\subsubsection{A Corte Interamericana de Direitos Humanos e o aborto}

$\mathrm{Na}$ Corte Interamericana, o sentido de vida vem sendo construído como vimos em detalhes na Parte I deste trabalho.

No entanto, a Corte Interamericana ainda não tem decisões especificamente versando sobre o aborto, ou sobre o aborto do feto anencéfalo ${ }^{1617}$.

Com relação ao aborto, vale mencionar novamente que, como vimos na Parte I deste trabalho, o artigo $4^{\circ}$, I, da Convenção Americana de Direitos Humanos, afirma que "toda pessoa tem direito que se respeite sua vida. Esse direito deve ser protegido pela lei e, em geral, desde a concepção"1618. Daniel Sarmento ensina, entretanto, que a disposição "em geral" deve ser entendida como um princípio e não uma regra, pois não teria havido intenção

\footnotetext{
${ }^{1615}$ ECHR. Case A, B e C v. Ireland. Aplication no. 25579/05. Julgamento 16 dez. 2010. Parágrafo 8 (tradução nossa). Voto em conjunto Parcialmente Dissidente dos Juízes Christos Rozakis, Françoise Tulkens, Elisabet Fura, Päivi Hirvelä, Giorgio Malinverni e Mihai Poalelungi.

${ }^{1616}$ ECHR. Case A, B e C v. Ireland. Aplication no. 25579/05. Julgamento 16 dez. 2010. Parágrafo 9 (tradução nossa). Voto em conjunto Parcialmente Dissidente dos Juízes Christos Rozakis, Françoise Tulkens, Elisabet Fura, Päivi Hirvelä, Giorgio Malinverni e Mihai Poalelungi.

1617 Vide Caso Baby-Boy citado pelo Ministro Celso de Mello em seu voto na Ação Direta de Inconstitucionalidade 3.510-0. Ação Declaratória de Inconstitucionalidade (ADI 3510-0), p. 35-36, fl. 588-589. Disponível em: 〈http://www.stf.jus.br〉. Acesso em: 10 jan. 2012. O caso Baby-Boy (Resolução 23/81 - Caso 2141 de 06 mar. 1981), como foi conhecido, foi interposto por Christian S. White y Gary K. Potter à Comissão Interamericana de Direitos Humanos contra os Estados Unidos da América e o Estado de Massachusetts. A vítima - Baby-Boy (nome atribuído ao feto) - foi morta por um processo abortivo. Buscou-se a condenação do estado americano pela violação dos direitos consagrados na Declaração dos Direitos e Deveres do Homem, especialmente, do direito à vida contido no artigo $1^{\circ}$, por permitir o aborto, notadamente, após a sentença no caso Roe v. Wade. A Comissão, entretanto, entendeu que os Estados Unidos não violaram o direito à vida disposto no DUDH. Incidentalmente, interpretou o artigo $4^{\circ}$ da Convenção Americana de Direitos Humanos entendendo que a leitura do direito à vida contido ali deve ser realizada levando-se em conta a cláusula "em geral", de modo que as "implicações jurídicas da cláusula 'em geral, desde o momento da concepção' são substancialmente diferentes da cláusula mais curta 'desde o momento da concepção', inexistindo, portanto, o carácter de proteção absoluta a esse direito. Disponível em: 〈http://www.cidh.org/annualrep/80.81sp/estadosunidos2141.htm>. Acesso em: 10 jan. 2012. Vide especialmente os parágrafos 30 e 19 (tradução nossa).

${ }^{1618}$ No voto do Ministro Ricardo Lewandowski na Ação Direta de Inconstitucionalidade 3.510-0 que visava a declaração da incostitucionalidade do artigo $5^{\circ}$ da Lei 11.105 de 24 mar. 2005 (Lei de Biossegurança) ao analisar o termo "em geral", afirma que a vida começa desde a concepção, mas "podendo a lei do Estado signatário da Convenção deixar, eventualmente, de protegê-la, em situações excepcionais, caso outros valores estejam em jogo". Como exemplo, menciona a hipótese de exclusão de antijuridicidade do aborto necessário expresso no artigo 128, I, Código Penal. SARMENTO, Daniel. Legalização do Aborto e constituição. In: SARMENTO, Daniel; PIOVESAN, Flávia (coordenadores). Nos Limites da Vida. Rio de Janeiro: Lúmen Júris, 2006, p. 35.
} 
de "conferir à vida intra-uterina uma proteção absoluta"1619, cabendo, nesse caso, a relativização do direito à vida ${ }^{1620}$.

Em vista da ausência de casos abordando especificamente o aborto, seria prematuro opinar com relação ao caminho que a Corte Interamericana deve seguir com relação ao tema. No futuro, devemos ter a oportunidade de constatar se a Corte Interamericana seguirá a tendência da Corte Europeia, e o quão importante serão as influências culturais que seguramente se farão sentir no debate, notadamente, a do catolicismo, sempre muito forte no ocidente, especialmente na parte "latina" da América; dos Estados Unidos, em vista de sua inegável influência econômica, política e cultural em níveis mundial e regional; da Europa, de onde provém originalmente muitos dos povos que hoje habitam as Américas, e nossa eterna fonte de inspiração jurídica por afinidade histórica e também cultural; e da crescente laicização das sociedades no mundo moderno - que, atualmente, vêm também enfrentando a resistência de um verdadeiro renascimento da religiosidade popular, inclusive de fundamentalismos.

O que fica claro, entretanto, das análises, tanto de nosso direito pátrio, quanto do direito comparado, de outros países e internacionais, é que o aborto envolve direitos conflitantes - especialmente, direitos vários que a gestante possa ter, e o direito à vida - que alguns defendem haver, outros que não - do feto.

A seguir, pois, passaremos a estudar as teorias que normalmente se aplicam para restringir direitos fundamentais, com ênfase justamente no direito à vida, em mais um passo necessário rumo à conclusão de nosso trabalho.

\footnotetext{
${ }^{1619}$ SARMENTO, Daniel. Legalização do Aborto e constituição. In: SARMENTO, Daniel; PIOVESAN, Flávia (coordenadores). Nos Limites da Vida. Rio de Janeiro: Lúmen Júris, 2006, p. 35. Ensina ainda Fábio Konder Comparato: "Ao dispor o artigo $4^{\circ}$ [da $\left.\mathrm{CADH}\right]$ que o direito à vida deve ser protegido pela lei desde o momento da concepção, vedou em princípio a legalização do aborto. Digo 'em princípio', porque a cláusula em geral, constante dessa disposição, parece abrir a possibilidade do estabelecimento de exceções à regra [...]. Uma exceção eticamente admissível a essa regra geral proibitiva parece ser a da obtenção de embriões clonados para tratamento de doenças neurodegenerativas do próprio sujeito [...]".COMPARATO, Fabio Konder. A Afirmação Histórica dos Direitos Humanos. 5. ed.rev. e atual. São Paulo: Saraiva, 2007, p. 369.

${ }^{1620}$ SARMENTO, Daniel. Legalização do Aborto e constituição. In: SARMENTO, Daniel; PIOVESAN, Flávia (coordenadores). Nos Limites da Vida. Rio de Janeiro: Lúmen Júris, 2006, p. 35.
} 


\section{TEORIAS APLICADAS SOBRE RESTRIÇÃO AO DIREITO À VIDA}

\subsection{CONFLITOS E LIMITES DE DIREITOS FUNDAMENTAIS}

Como vimos, no caso do direito à vida, encarado como princípio, é possível pensar em outros direitos fundamentais que se lhe podem vir a colidir. E, nesses casos, como superar tais conflitos? Aplicando-se a norma mais favorável? Mais favorável a quem? O critério da proporcionalidade é suficiente?

Norberto Bobbio questiona o valor absoluto de um direito fundamental. Afirma o autor que "dois direitos fundamentais, mas antinômicos, não podem ter, um e outro, um fundamento absoluto, ou seja, um fundamento que torne um direito e o seu oposto, ambos, inquestionáveis e irresistíveis" ${ }^{\text {"1621 }}$, e que considerá-los dessa maneira é uma ilusão ${ }^{1622}$; daí porque, para o autor, os direitos fundamentais são relativos, pois "a tutela deles encontra, em certo ponto, um limite insuperável na tutela de um direito igualmente fundamental"1623.

Nessa linha, ensina Jane Reis Gonçalves Pereira que "a assertiva de que os direitos fundamentais não são absolutos soa natural e lógica" ${ }^{\text {"1624 }}$, e, para ela, a justificativa decorre da necessária harmonização entre direitos e valores consagrados por determinada ordem jurídica $^{1625}$, observando-se dois fatores ${ }^{1626}$ : i) a universalidade dos direitos fundamentais; e, ii) a constitucionalização do conjunto de direitos fundamentais. O primeiro denota que a coexistência desses direitos é necessária, já que a todos se atribui a titularidade desses

\footnotetext{
${ }^{1621}$ BOBBIO, Norberto. A Era dos Direitos. Tradução Carlos Nelson Coutinho. Apresentação de Celso Lafer. $6^{\mathrm{a}}$ reimpressão. Rio de Janeiro: Elsevier, 2004, p. 21.

${ }^{1622}$ BOBBIO, Norberto. A Era dos Direitos. Tradução Carlos Nelson Coutinho. Apresentação de Celso Lafer. $6^{\text {a }}$ reimpressão. Rio de Janeiro: Elsevier, 2004, p. 22.

${ }^{1623}$ BOBBIO, Norberto. A Era dos Direitos. Tradução Carlos Nelson Coutinho. Apresentação de Celso Lafer. $6^{\text {a }}$ reimpressão. Rio de Janeiro: Elsevier, 2004, p. 41. Para Bobbio, "é sempre uma questão de opinião estabelecer qual o ponto em que um termina e o outro começa, a delimitação do âmbito de um direito fundamental do homem é extremamente variável e não pode ser estabelecida de uma vez por todas". BOBBIO, Norberto. A Era dos Direitos. Tradução Carlos Nelson Coutinho. Apresentação de Celso Lafer. $6^{a}$ reimpressão. Rio de Janeiro: Elsevier, 2004, p. 41

1624 PEREIRA, Jane Reis Gonçalves. Interpretação Constitucional e Direitos Fundamentais: uma contribuição ao estudo das restrições aos direitos fundamentais na perspectiva da teoria dos princípios. Rio de Janeiro: Renovar, 2006, p. 132.

1625 PEREIRA, Jane Reis Gonçalves. Interpretação Constitucional e Direitos Fundamentais: uma contribuição ao estudo das restrições aos direitos fundamentais na perspectiva da teoria dos princípios. Rio de Janeiro: Renovar, 2006, p. 133.

1626 PEREIRA, Jane Reis Gonçalves. Interpretação Constitucional e Direitos Fundamentais: uma contribuição ao estudo das restrições aos direitos fundamentais na perspectiva da teoria dos princípios. Rio de Janeiro: Renovar, 2006, p. 133.
} 
direitos, e somente seria possível essa coexistência se os direitos estiverem devidamente "harmonizados" "1627. O segundo corresponderia à ideia de que os direitos fundamentais estão "constitucionalizados como um conjunto, e não isoladamente" ${ }^{, 1628}$, de forma que precisam ser harmonizados levando-se em conta "outros direitos e bens protegidos pela Constituição Federal"1629. Daí a necessidade de uma "acomodação hermenêutica" ${ }^{1630}$ : um princípio deve "ceder, parcial ou totalmente, em favor do outro"1631.

Explica ainda Golçalves Pereira que alguns direitos já trazem limites inerentes que decorrem de sua própria natureza ${ }^{1632}$, enquanto que outros exigem uma "densificação de seu conteúdo e a regulação ou detalhamento das condições e formas de seu exercício" "1633, pois são tratados de forma ampla ${ }^{1634}$.

Além de constituírem verdadeiros "objetos de limitação"1635, os direitos fundamentais também constituiriam "limites ao estado" "1636, como se atuassem em uma via de mão dupla ${ }^{1637}$,

1627 PEREIRA, Jane Reis Gonçalves. Interpretação Constitucional e Direitos Fundamentais: uma contribuição ao estudo das restrições aos direitos fundamentais na perspectiva da teoria dos princípios. Rio de Janeiro: Renovar, 2006, p. 133.

1628 PEREIRA, Jane Reis Gonçalves. Interpretação Constitucional e Direitos Fundamentais: uma contribuição ao estudo das restrições aos direitos fundamentais na perspectiva da teoria dos princípios. Rio de Janeiro: Renovar, 2006, p. 133.

1629 PEREIRA, Jane Reis Gonçalves. Interpretação Constitucional e Direitos Fundamentais: uma contribuição ao estudo das restrições aos direitos fundamentais na perspectiva da teoria dos princípios. Rio de Janeiro: Renovar, 2006, p. 133.

1630 PEREIRA, Jane Reis Gonçalves. Interpretação Constitucional e Direitos Fundamentais: uma contribuição ao estudo das restrições aos direitos fundamentais na perspectiva da teoria dos princípios. Rio de Janeiro: Renovar, 2006, p. 134.

1631 PEREIRA, Jane Reis Gonçalves. Interpretação Constitucional e Direitos Fundamentais: uma contribuição ao estudo das restrições aos direitos fundamentais na perspectiva da teoria dos princípios. Rio de Janeiro: Renovar, 2006, p. 134.

1632 PEREIRA, Jane Reis Gonçalves. Interpretação Constitucional e Direitos Fundamentais: uma contribuição ao estudo das restrições aos direitos fundamentais na perspectiva da teoria dos princípios. Rio de Janeiro: Renovar, 2006, p. 134.

1633 PEREIRA, Jane Reis Gonçalves. Interpretação Constitucional e Direitos Fundamentais: uma contribuição ao estudo das restrições aos direitos fundamentais na perspectiva da teoria dos princípios. Rio de Janeiro: Renovar, 2006, p. 134.

${ }^{1634}$ Para a autora, tratados de "modo sintético e aberto". PEREIRA, Jane Reis Gonçalves. Interpretação Constitucional e Direitos Fundamentais: uma contribuição ao estudo das restrições aos direitos fundamentais na perspectiva da teoria dos princípios. Rio de Janeiro: Renovar, 2006, p. 134.

1635 PEREIRA, Jane Reis Gonçalves. Interpretação Constitucional e Direitos Fundamentais: uma contribuição ao estudo das restrições aos direitos fundamentais na perspectiva da teoria dos princípios. Rio de Janeiro: Renovar, 2006, p. 136.

1636 PEREIRA, Jane Reis Gonçalves. Interpretação Constitucional e Direitos Fundamentais: uma contribuição ao estudo das restrições aos direitos fundamentais na perspectiva da teoria dos princípios. Rio de Janeiro: Renovar, 2006, p. 136.

1637 Para a autora constitui verdadeiro "paradoxo". PEREIRA, Jane Reis Gonçalves. Interpretação Constitucional e Direitos Fundamentais: uma contribuição ao estudo das restrições aos direitos fundamentais na perspectiva da teoria dos princípios. Rio de Janeiro: Renovar, 2006, p. 136. 
ora como comandos para determinar a ação estatal ${ }^{1638}$, ora como comandos de limites para o exercício de outros direitos.

Ainda para Jane Reis Gonçalves Pereira, embora muitas terminologias sejam adotadas pela doutrina, os limites dos direitos fundamentais, em princípio, têm dois sentidos diversos: i) o de constrição; e ii) o de contorno ${ }^{1639}$. A constrição ou limitação corresponderiam a uma “diminuição da esfera máxima de indicidência do direito"1640, e o contorno (configuração, conformação, delimitação ou regulação) corresponderia à “densificação do conteúdo normativo do direito" ${ }^{, 1641}$, por meio do qual poderiam ser apontadas medidas para que o direito possa ser assegurado, ou especificações para seu exercício, por exemplo ${ }^{1642}$.

Vamos a seguir estudar as principais teorias doutrinárias que tratam da restrição de direitos fundamentais. Buscaremos entender se seria possível restringir o direito à vida do feto anencéfalo, e quais teorias poderiam ser aplicadas para justificar essa restrição.

\subsection{TEORIA INTERNA}

Ensina Virgílio Afonso da Silva que a teoria interna ${ }^{1643}$ se funda na ideia de que o processo de definição dos limites de cada direito é algo interno dele ${ }^{1644}$; daí falamos em

1638 A autora afirma que nesse caso, a "atividade de conformação dos direitos fundamentais operada pelo legislador também está sujeita à limitações", constituindo o "limite dos limites". PEREIRA, Jane Reis Gonçalves. Interpretação Constitucional e Direitos Fundamentais: uma contribuição ao estudo das restrições aos direitos fundamentais na perspectiva da teoria dos princípios. Rio de Janeiro: Renovar, 2006, p. 135.

${ }^{1639}$ Para a autora: "de um lado, corresponde à idéia de constrição; e, de outro, relaciona-se à noção de contorno ou alcance máximo de alguma coisa". PEREIRA, Jane Reis Gonçalves. Interpretação Constitucional e Direitos Fundamentais: uma contribuição ao estudo das restrições aos direitos fundamentais na perspectiva da teoria dos princípios. Rio de Janeiro: Renovar, 2006, p. 137.

1640 PEREIRA, Jane Reis Gonçalves. Interpretação Constitucional e Direitos Fundamentais: uma contribuição ao estudo das restrições aos direitos fundamentais na perspectiva da teoria dos princípios. Rio de Janeiro: Renovar, 2006, p. 138

1641 PEREIRA, Jane Reis Gonçalves. Interpretação Constitucional e Direitos Fundamentais: uma contribuição ao estudo das restrições aos direitos fundamentais na perspectiva da teoria dos princípios. Rio de Janeiro: Renovar, 2006, p. 138

1642 PEREIRA, Jane Reis Gonçalves. Interpretação Constitucional e Direitos Fundamentais: uma contribuição ao estudo das restrições aos direitos fundamentais na perspectiva da teoria dos princípios. Rio de Janeiro: Renovar, 2006, p. 138.

${ }^{1643}$ Não sendo admitida restrições externas a esses direitos. PEREIRA, Jane Reis Gonçalves. Interpretação Constitucional e Direitos Fundamentais: uma contribuição ao estudo das restrições aos direitos fundamentais na perspectiva da teoria dos princípios. Rio de Janeiro: Renovar, 2006, p. 140.

1644 Também denominado de concepção estrita do conteúdo dos direitos. PEREIRA, Jane Reis Gonçalves. Interpretação Constitucional e Direitos Fundamentais: uma contribuição ao estudo das restrições aos direitos fundamentais na perspectiva da teoria dos princípios. Rio de Janeiro: Renovar, 2006, p. 140. 
limites imanentes ${ }^{1645}$. Esses limites internos, imanentes, não sofrem influência de aspectos externos, e tampouco emergem devido a conflitos com outros direitos ${ }^{1646}$.

Jane Reis Gonçalves Pereira explica que os direitos fundamentais, na teoria interna, só podem ser "delimitados", e não limitados, se o texto constitucional nada dispuser nesse sentido $^{1647}$. Assim, a atividade interpretativa ou legislativa não poderia restringir os direitos fundamentais. $\mathrm{Na}$ atividade interpretativa, o conflito de direitos e seu eventual sopesamento não seriam possíveis; e na, atividade legislativa, poder-se-ia apenas "detalhar suas formas de exercício dentro do âmbito de seu conteúdo constitucionalmente previsto"1648. Deste modo, para a autora, a interpretação do direito seria feita em uma etapa só, pois não seria necessária a "harmonização com outros direitos ou bens"1649.

Por isso que, para Virgílio Afonso da Silva, esse sistema é próprio das regras cujos conteúdos normativos se valem de uma situação fática previamente determinada, razão pela qual não podem ser sopesadas ${ }^{1650}$. O direito garantido precisa ser definitivo e não prima facie, como explica o autor. Ou o direito subjetivo existe ou não existe e, se existir, poderá ser "naturalmente exercido no âmbito de seus limites"1651.

Explica Jane Reis que os defensores dessa teoria buscam uma "maior segurança e previsibilidade à atividade hermenêutica" ${ }^{1652}$. Além disso, entende que a teoria interna evitaria "falsos casos constitucionais"; ou seja, um direito não poderia ser protegido se estivesse além

${ }^{1645}$ SILVA, Virgílio Afonso da. Direitos Fundamentais: conteúdo essencial, restrições e eficácia. São Paulo: Malheiros, 2009, p. 128.

${ }^{1646}$ SILVA, Virgílio Afonso da. Direitos Fundamentais: conteúdo essencial, restrições e eficácia. São Paulo: Malheiros, 2009, p. 128.

1647 PEREIRA, Jane Reis Gonçalves. Interpretação Constitucional e Direitos Fundamentais: uma contribuição ao estudo das restrições aos direitos fundamentais na perspectiva da teoria dos princípios. Rio de Janeiro: Renovar, 2006, p. 140.

${ }_{1648}$ PEREIRA, Jane Reis Gonçalves. Interpretação Constitucional e Direitos Fundamentais: uma contribuição ao estudo das restrições aos direitos fundamentais na perspectiva da teoria dos princípios. Rio de Janeiro: Renovar, 2006, p. 141.

1649 PEREIRA, Jane Reis Gonçalves. Interpretação Constitucional e Direitos Fundamentais: uma contribuição ao estudo das restrições aos direitos fundamentais na perspectiva da teoria dos princípios. Rio de Janeiro: Renovar, 2006, p. 142. A autora exemplifica o estudo no caso de liberdade de expressão que não poderia ser limitada pelo direito à honra ou imagem, pois "as condutas humanas são ou não protegidas pelo direito". PEREIRA, Jane Reis Gonçalves. Interpretação Constitucional e Direitos Fundamentais: uma contribuição ao estudo das restrições aos direitos fundamentais na perspectiva da teoria dos princípios. Rio de Janeiro: Renovar, 2006, p. 142-143.

${ }^{1650}$ SILVA, Virgílio Afonso da. Direitos Fundamentais: conteúdo essencial, restrições e eficácia. São Paulo: Malheiros, 2009, p. 129.

${ }^{1651}$ SILVA, Virgílio Afonso da. Direitos Fundamentais: conteúdo essencial, restrições e eficácia. São Paulo: Malheiros, 2009, p. 130.

1652 PEREIRA, Jane Reis Gonçalves. Interpretação Constitucional e Direitos Fundamentais: uma contribuição ao estudo das restrições aos direitos fundamentais na perspectiva da teoria dos princípios. Rio de Janeiro: Renovar, 2006, p. 144. 
da esfera de proteção da Constituição Federal, o que evitaria a "inflação de direitos fundamentais"1653 e o consequente "enfraquecimento de sua força vinculante" ${ }^{\text {"1654 }}$.

Portanto, ressaltemos que, segundo a teoria interna, cada direito encontraria restrições internamente, conhecidos como limites imanentes.

\subsubsection{Limites imanentes}

Esse fundamento - que visa a justificar que o limite interno decorre do próprio direito fundamental - consagra a ideia de que os direitos fundamentais não são absolutos e seus limites são definidos pela Constituição, implícita ou expressamente ${ }^{1655}$. Os limites, na verdade, decorreriam da "própria essência dos direitos fundamentais". ${ }^{1656}$ Assim, por exemplo, não seria possível sacrificar seres humanos no exercício de sua liberdade religiosa, pois tal conduta encontraria seus próprios limites, implícitos ou explícitos, no texto constitucional $^{1657}$.

1653 PEREIRA, Jane Reis Gonçalves. Interpretação Constitucional e Direitos Fundamentais: uma contribuição ao estudo das restrições aos direitos fundamentais na perspectiva da teoria dos princípios. Rio de Janeiro: Renovar, 2006, p. 144.

1654 PEREIRA, Jane Reis Gonçalves. Interpretação Constitucional e Direitos Fundamentais: uma contribuição ao estudo das restrições aos direitos fundamentais na perspectiva da teoria dos princípios. Rio de Janeiro: Renovar, 2006, p. 144.

${ }^{1655}$ Vide exemplos trazidos por Virgílio Afonso da Silva ao analisar a jurisprudência do Supremo Tribunal Federal a respeito do tema, embora para o autor, não exista uma "linha jurisprudencial coerente " no Supremo Tribunal Federal a respeito. SILVA, Virgílio Afonso da. Direitos Fundamentais: conteúdo essencial, restrições e eficácia. São Paulo: Malheiros, 2009, p. 131.

${ }^{1656}$ SILVA, Virgílio Afonso da. Direitos Fundamentais: conteúdo essencial, restrições e eficácia. São Paulo: Malheiros, 2009, p. 132.

${ }^{1657} \mathrm{O}$ autor traz diversos exemplos desenvolvidos por José Carlos Vieira de Andrade a respeito do tema. Ler mais a respeito. SILVA, Virgílio Afonso da. Direitos Fundamentais: conteúdo essencial, restrições e eficácia. São Paulo: Malheiros, 2009, p. 132-133. Jane ensina que a concepção de Vieira de Andrade conjuga aspectos das teorias interna e externa. Para ela, Vieira de Andrade admite a irrestringibilidade abstrata e restringibilidade concreta, de modo que seria possível aplicar a ponderação "para restringir direitos sujeitos à reserva legal" pelo legislador ou "para solucionar conflitos concretos entre direitos e bens constitucionais" pelo Judiciário, de forma que tais direitos fundamentais "são irrestringíveis no plano abstrato, pelo legislador, mas são restringíveis no plano concreto, pela atuação judicial". Vale dizer que para o direito fundamental sujeito à reserva legal, se admite a ponderação e para os demais caberia a "harmonização legislativa" para que o juiz possa solucionar o caso concreto. PEREIRA, Jane Reis Gonçalves. Interpretação Constitucional e Direitos Fundamentais: uma contribuição ao estudo das restrições aos direitos fundamentais na perspectiva da teoria dos princípios. Rio de Janeiro: Renovar, 2006, p. 155-157. Jane Reis apresenta críticas à essa tese, afirmando a dificuldade em estabelecer leis "harmonizadoras", sem criar "restrições recíprocas". PEREIRA, Jane Reis Gonçalves. Interpretação Constitucional e Direitos Fundamentais: uma contribuição ao estudo das restrições aos direitos fundamentais na perspectiva da teoria dos princípios. Rio de Janeiro: Renovar, 2006, p. 157-158. A autora lembra que essas restrições somente seriam possíveis para Vieira de Andrade, se autorizadas pela Constituição Federal. PEREIRA, Jane Reis Gonçalves. Interpretação Constitucional e Direitos Fundamentais: uma 
Extraímos, portanto, dos ensinamentos de Virgílio Afonso da Silva, a diferença entre limites imanentes e restrições a direitos fundamentais que decorrem do conflito entre tais direitos: no primeiro caso, o direito fundamental possui limites próprios que estão expressa ou implicitamente previstos, mas que precisam ser declarados; já, no caso de restrições dos direitos fundamentais diante do conflito entre direitos fundamentais, podem surgir novas restrições a esses direitos, que decorrem de outros direitos, e não de seus próprios limites ${ }^{1658}$. Virgílio Afonso da Silva trata da ideia da "proibição por mera não-proteção"1659 . Isso significa que determinada conduta seria proibida não por existir uma proibição ou restrição imposta, mas simplesmente porque o direito em questão não comporta aquela conduta. Em outras palavras, a proibição existe porque o direito não protege determinada conduta, não a abrange ${ }^{1660}$, e, ainda que venha a existir uma imposição legal restringindo-a, tal restrição não seria uma verdadeira limitação, pois não ultrapassaria "os limites dessa liberdade" ${ }^{\text {"1661 }}$.

No entanto, a dificuldade está em demarcar o que está de fato ${ }^{1662}$ ou não protegido, em se tratando de "suporte fático restrito aos direitos fundamentais"1663, lembrando, como o fez

contribuição ao estudo das restrições aos direitos fundamentais na perspectiva da teoria dos princípios. Rio de Janeiro: Renovar, 2006, p. 155.

1658 SILVA, Virgílio Afonso da. Direitos Fundamentais: conteúdo essencial, restrições e eficácia. São Paulo: Malheiros, 2009, p. 132.

1659 SILVA, Virgílio Afonso da. Direitos Fundamentais: conteúdo essencial, restrições e eficácia. São Paulo: Malheiros, 2009, p. 133.

${ }^{1660}$ SILVA, Virgílio Afonso da. Direitos Fundamentais: conteúdo essencial, restrições e eficácia. São Paulo: Malheiros, 2009, p. 133.

${ }^{1661}$ SILVA, Virgílio Afonso da. Direitos Fundamentais: conteúdo essencial, restrições e eficácia. São Paulo: Malheiros, 2009, p. 133.

1662 Virgílio Afonso da Silva traz como um dos argumentos favoráveis à teoria interna aquela desenvolvida por Peter Häberle que aproxima as ideias de limite imanente e de conteúdo essencial de direitos fundamentais, também denominada pelo autor de teoria institucional de direitos fundamentais. SILVA, Virgílio Afonso da. Direitos Fundamentais: conteúdo essencial, restrições e eficácia. São Paulo: Malheiros, 2009, p. 134. Vide também: PEREIRA, Jane Reis Gonçalves. Interpretação Constitucional e Direitos Fundamentais: uma contribuição ao estudo das restrições aos direitos fundamentais na perspectiva da teoria dos princípios. Rio de Janeiro: Renovar, 2006, p. 152-155. Virgílio Afonso da Silva explica que Häberle buscou desenvolver sua teoria no "conceito de instituição" de Maurice Hauriou. SILVA, Virgílio Afonso da. Direitos Fundamentais: conteúdo essencial, restrições e eficácia. São Paulo: Malheiros, 2009, p. 134.

1663 SILVA, Virgílio Afonso da. Direitos Fundamentais: conteúdo essencial, restrições e eficácia. São Paulo: Malheiros, 2009, p. 133. Virgílio Afonso da Silva também traça diferenças entre o suporte fático restrito e suporte fático amplo em relação à teoria interna e externa e que a tendência é considerá-las mais no sentido suporte fático restrito/teoria interna e suporte fático amplo/teoria externa. Afirma, ainda, o autor que não existe uma dicotomia necessária entre as teorias. SILVA, Virgílio Afonso da. Direitos Fundamentais: conteúdo essencial, restrições e eficácia. São Paulo: Malheiros, 2009, p. 158-159. Afirma, ainda, que a teoria de Pieroth e Schlink é diferente da teoria de Robert Alexy. Para aquele "o âmbito de proteção do direito fundamental não pode ser feita de forma isolada, sem uma análise sistemática de outros direitos fundamentais e de outras disposições constitucionais", enquanto que para Robert Alexy "toda ação, estado ou posição jurídica que tenha alguma caracterísitca que, isoladamente considerada, faça parte do 'âmbito temático' de determinado direito fundamental deve ser considerada como abrangida por seu âmbito de proteção, independentemente da consideração de outras variáveis". SILVA, Virgílio Afonso da. Direitos Fundamentais: conteúdo essencial, restrições e eficácia. São Paulo: Malheiros, 2009, p. 161. Para o autor, a teoria de Pieroth e Schlink está ligada à teoria externa com um suporte fático restrito, admitindo uma exclusão a priori de determinada conduta. Essa 
Virgílio Afonso da Silva, que admitir a teoria dos limites imanentes importa a exclusão total do conceito de sopesamento ${ }^{1664}$.

\subsection{TEORIA EXTERNA ${ }^{1665}$}

A teoria externa leva em consideração a existência do direito propriamente dito e suas restrições. As restrições, portanto, dizem respeito ao exercício do direito, e não ao seu conteúdo, fato que pode ser sopesado, observando critérios específicos de proporcionalidade, e também subcritérios de adequação, necessidade e proporcionalidade propriamente ditos ${ }^{1666}$. Além disso, esta teoria sustenta que, ainda que um direito seja restringido por outro, ele não perde sua validade, constituindo o que tratamos acima de prima facie ${ }^{1667}$.

Conforme ensina Jane Reis Gonçalves Pereira, existe uma diferença entre a simples "delimitação de conteúdo", defendida na teoria interna, e a "restrição de direitos fundamentais" ${ }^{1668}$. Nesta última, a interpretação se dá em dois momentos ${ }^{1669}$ : i) a verificação do "conteúdo do direitos" ${ }^{1670}$ que diz respeito à observação exclusivamente do que está sendo protegido por determinado direito fundamental, de forma abragente ${ }^{1671}$; e ii) em seguida, a

teoria opõe-se à posição defendida pelo autor. SILVA, Virgílio Afonso da. Direitos Fundamentais: conteúdo essencial, restrições e eficácia. São Paulo: Malheiros, 2009, p. 161-164.

${ }^{1664}$ SILVA, Virgílio Afonso da. Direitos Fundamentais: conteúdo essencial, restrições e eficácia. São Paulo: Malheiros, 2009, p. 133. Vide també PEREIRA, Jane Reis Gonçalves. Interpretação Constitucional e Direitos Fundamentais: uma contribuição ao estudo das restrições aos direitos fundamentais na perspectiva da teoria dos princípios. Rio de Janeiro: Renovar, 2006, p. 152.

1665 Ou concepção ampla. PEREIRA, Jane Reis Gonçalves. Interpretação Constitucional e Direitos Fundamentais: uma contribuição ao estudo das restrições aos direitos fundamentais na perspectiva da teoria dos princípios. Rio de Janeiro: Renovar, 2006, p. 146.

1666 SILVA, Virgílio Afonso da. Direitos Fundamentais: conteúdo essencial, restrições e eficácia. São Paulo: Malheiros, 2009, p. 138.

${ }^{1667}$ SILVA, Virgílio Afonso da. Direitos Fundamentais: conteúdo essencial, restrições e eficácia. São Paulo: Malheiros, 2009, p. 138-139.

1668 PEREIRA, Jane Reis Gonçalves. Interpretação Constitucional e Direitos Fundamentais: uma contribuição ao estudo das restrições aos direitos fundamentais na perspectiva da teoria dos princípios. Rio de Janeiro: Renovar, 2006, p. 146.

${ }^{1669}$ Segundo a autora, o primeiro momento se encontraria o "conteúdo inicialmente protegido" para, em seguida, após analisar os demais direitos que fazem fronteira com o direito analisado, encontrar o "conteúdo definitivamente protegido". PEREIRA, Jane Reis Gonçalves. Interpretação Constitucional e Direitos Fundamentais: uma contribuição ao estudo das restrições aos direitos fundamentais na perspectiva da teoria dos princípios. Rio de Janeiro: Renovar, 2006, p. 147.

1670 PEREIRA, Jane Reis Gonçalves. Interpretação Constitucional e Direitos Fundamentais: uma contribuição ao estudo das restrições aos direitos fundamentais na perspectiva da teoria dos princípios. Rio de Janeiro: Renovar, 2006, p. 146.

1671 PEREIRA, Jane Reis Gonçalves. Interpretação Constitucional e Direitos Fundamentais: uma contribuição ao estudo das restrições aos direitos fundamentais na perspectiva da teoria dos princípios. Rio de Janeiro: Renovar, 2006, p. 147. 
identificação dos limites externos que surgem da harmonização com outros direitos fundamentais $^{1672}$.

Significa dizer que, depois de verificado a priori o que está sendo protegido, é preciso conciliar o que foi verificado com outros direitos também a priori protegidos, e, finalmente, encontrar o que está sendo protegido efetivamente ${ }^{1673}$.

Dessa maneira, como ensina Virgílio Afonso da Silva, a relação entre esta teoria e os direitos fundamentais não poderia ser mais próxima, pois os "direitos fundamentais são garantidos por uma norma que consagra um direito prima facie ${ }^{\Perp 1674}$. Para o autor, o princípio $^{1675}$ é ilimitado, e, diante de sua carga expansiva, pode colidir com outros direitos. Daí, é crucial a distinção na teoria externa entre prima facie e direito definitivo, uma vez que este último será efetivamente definido na teoria externa a partir do sopesamento realizado em relação às condições fáticas e jurídicas existentes ${ }^{1676}$.

Assim, como vimos, o princípio abarca uma ideia de "mandamento de otimização", com um conteúdo prima facie ilimitado, até mesmo em razão de sua carga expansiva ${ }^{1677}$. No entanto, dois aspectos são levados em consideração por Virgílio Afonso da Silva: i) os direitos fundamentais não são absolutos; e ii) a restrição do princípio decorre da existência de outros princípios $^{1678}$.

1672 PEREIRA, Jane Reis Gonçalves. Interpretação Constitucional e Direitos Fundamentais: uma contribuição ao estudo das restrições aos direitos fundamentais na perspectiva da teoria dos princípios. Rio de Janeiro: Renovar, 2006, p. 146.

1673 PEREIRA, Jane Reis Gonçalves. Interpretação Constitucional e Direitos Fundamentais: uma contribuição ao estudo das restrições aos direitos fundamentais na perspectiva da teoria dos princípios. Rio de Janeiro: Renovar, 2006, p. 147.

${ }^{1674}$ SILVA, Virgílio Afonso da. Direitos Fundamentais: conteúdo essencial, restrições e eficácia. São Paulo: Malheiros, 2009, p. 139.

${ }^{1675}$ Para Jane Reis Gonçalves Pereira "Em síntese esquemática, a teoria externa preceitua que: i) os direitos fundamentais são princípios, veiculando comandos prima facie; ii) os direitos fundamentais são restringíveis; iii) as restrições aos direitos fundamentais são motivadas pela existência de conflitos entre estes e outros direitos e bens constitucionais; iv) a legitimidade constitucional da restrição é de ser examinada mediante um juízo de ponderação, que irá sopesar os direitos e bens em conflito, através da aplicação do princípio da proporcionalidade". PEREIRA, Jane Reis Gonçalves. Interpretação Constitucional e Direitos Fundamentais: uma contribuição ao estudo das restrições aos direitos fundamentais na perspectiva da teoria dos princípios. Rio de Janeiro: Renovar, 2006, p. 152.

${ }^{1676}$ SILVA, Virgílio Afonso da. Direitos Fundamentais: conteúdo essencial, restrições e eficácia. São Paulo: Malheiros, 2009, p. 140. Vide [N.R.] 1721 sobre o caso Open Door and Dublin Well Woman v. Ireland, também citado por Jane Reis Gonçalves Pereira. PEREIRA, Jane Reis Gonçalves. Interpretação Constitucional e Direitos Fundamentais: uma contribuição ao estudo das restrições aos direitos fundamentais na perspectiva da teoria dos princípios. Rio de Janeiro: Renovar, 2006, p. 150.

1677 De acordo com Virgílio Afonso da Silva. SILVA, Virgílio Afonso da. Direitos Fundamentais: conteúdo essencial, restrições e eficácia. São Paulo: Malheiros, 2009, p. 140.

1678 SILVA, Virgílio Afonso da. Direitos Fundamentais: conteúdo essencial, restrições e eficácia. São Paulo: Malheiros, 2009, p. 140. 
Para Virgílio Afonso da Silva, entretanto, a restrição da qual estamos tratando poderia ocorrer não somente pela existência de princípios, como também por meio de regras ${ }^{1679}$. A primeira situação importa uma restrição material e outra formal ${ }^{1680}$.

A restrição material decorre da restrição em decorrência da existência de um ou mais princípios colidentes, exigindo-se a limitação de pelo menos um deles para solucionar o problema.

Na restrição formal, por outro lado, a limitação pode decorrer da existência de uma regra, ou porque não houve uma ponderação feita pelo legislador ${ }^{1681}$, fato que exigirá do intérprete judicial uma manifestação sobre qual princípio prevalerá ${ }^{1682}$.

Quanto à restrição decorrente de regras, vale dizer que, conforme elucida Virgílio Afonso da Silva, a restrição tem origem na legislação infraconstitucional, isto é, a existência de uma regra na esfera infraconstitucional pode limitar uma conduta prima facie garantida constitucionalmente ${ }^{1683}$, ou permitir uma "ação estatal cujo efeito é a restrição da proteção que um direito fundamental prima facie garantida" 1684 .

Várias críticas são feitas à teoria externa ${ }^{1685}$. Virgílio Afonso da Silva aponta seis críticas principais: i) a da contradição lógica; ii) da ilusão desonesta; iii) da racionalidade; iv) da segurança jurídica ${ }^{1686}$; v) da inflação judiciária; e vi) dos direitos irreais ${ }^{1687}$.

A primeira crítica, contradição lógica, se refere à limitação total ou parcial do exercício de um direito garantido integralmente ${ }^{1688}$. O autor defende que esse raciocício é

\footnotetext{
${ }^{1679}$ Nesse sentido. PEREIRA, Jane Reis Gonçalves. Interpretação Constitucional e Direitos Fundamentais: uma contribuição ao estudo das restrições aos direitos fundamentais na perspectiva da teoria dos princípios. Rio de Janeiro: Renovar, 2006, p. 151.

${ }^{1680}$ SILVA, Virgílio Afonso da. Direitos Fundamentais: conteúdo essencial, restrições e eficácia. São Paulo: Malheiros, 2009, p. 142.

${ }^{1681}$ SILVA, Virgílio Afonso da. Direitos Fundamentais: conteúdo essencial, restrições e eficácia. São Paulo: Malheiros, 2009, p. 142-143.

${ }^{1682}$ SILVA, Virgílio Afonso da. Direitos Fundamentais: conteúdo essencial, restrições e eficácia. São Paulo: Malheiros, 2009, p. 143.

${ }_{1683}$ SILVA, Virgílio Afonso da. Direitos Fundamentais: conteúdo essencial, restrições e eficácia. São Paulo: Malheiros, 2009, p. 141.

${ }^{1684}$ SILVA, Virgílio Afonso da. Direitos Fundamentais: conteúdo essencial, restrições e eficácia. São Paulo: Malheiros, 2009, p. 141.

1685 Jane Reis Gonçalves Pereira aponta, ainda, que a "multiplicação desordenada de conflito entre os direitos fundamentais" pode levar ao "enfraquecimento" desses direitos, pois como inexistem critérios para orientar a interpretação, o intérprete não saberia objetivamente identificar quais princípios deveriam prevalecer em relação a outros. PEREIRA, Jane Reis Gonçalves. Interpretação Constitucional e Direitos Fundamentais: uma contribuição ao estudo das restrições aos direitos fundamentais na perspectiva da teoria dos princípios. Rio de Janeiro: Renovar, 2006, p. 158.

${ }_{1686}$ Além da segurança jurídica, poderia comprometer a "legitimidade democrática das decisões". PEREIRA, Jane Reis Gonçalves. Interpretação Constitucional e Direitos Fundamentais: uma contribuição ao estudo das restrições aos direitos fundamentais na perspectiva da teoria dos princípios. Rio de Janeiro: Renovar, 2006, p. 159.

${ }^{1687}$ SILVA, Virgílio Afonso da. Direitos Fundamentais: conteúdo essencial, restrições e eficácia. São Paulo: Malheiros, 2009, p. 143-156.
} 
próprio das regras e, portanto, da teoria interna, mas não é adequado quando se trata da teoria externa. Na teoria externa, tem-se os princípios que comportariam a noção de que, apesar de um direito ser garantido integralmente, ele pode não ser necessariamente exercitado na sua integralidade, ${ }^{1689}$ em razão da existência de outros direitos e da necessidade de harmonização entre todos eles.

Com relação à segunda crítica, de ilusão desonesta, Virgílio Afonso da Silva concorda com a posição doutrinária que afirma que um direito prima facie não fundamenta necessariamente a garantia desse direito, mas "uma pretensão a um sopesamento entre princípios" ${ }^{1690}$, pois, em geral, é preciso analisar-se todos os princípios colidentes que estão em jogo e o peso que receberão no caso em estudo ${ }^{1691}$. O direito seria, portanto, ilusório, porque não estaria garantido sem que se analisassem também todos outros princípios que lhe pudessem ser colidentes.

Com relação à crítica da racionalidade, em razão de inexistirem critérios para o sopesamento, o mesmo poderia ser considerado uma "decisionismo disfarçado"1692. Para o autor, entretanto, é impossível evitar certo grau de subjetividade ao intérprete e ao aplicador do direito ${ }^{1693}$, já que, no direito, não se é possível garantir uma resposta única e correta objetivamente $^{1694}$. Até nos sistemas aparentemente mais objetivos é difícil aplicar o direito de maneira totalmente objetiva ${ }^{1695}$.

Essa situação de subjetividade leva à construção das duas outras críticas à teoria externa, a da (in) segurança jurídica, e a da inflação judiciária (esta última em razão das inúmeras possibilidades de colisão entre direitos fundamentais, aumentando significativamente as demandas judiciais) ${ }^{1696}$. A solução proposta por Virgílio Afonso da

\footnotetext{
1688 SILVA, Virgílio Afonso da. Direitos Fundamentais: conteúdo essencial, restrições e eficácia. São Paulo: Malheiros, 2009, p. 144.

1689 SILVA, Virgílio Afonso da. Direitos Fundamentais: conteúdo essencial, restrições e eficácia. São Paulo: Malheiros, 2009, p. 145.

1690 SILVA, Virgílio Afonso da. Direitos Fundamentais: conteúdo essencial, restrições e eficácia. São Paulo: Malheiros, 2009, p. 146.

${ }^{1691}$ SILVA, Virgílio Afonso da. Direitos Fundamentais: conteúdo essencial, restrições e eficácia. São Paulo: Malheiros, 2009, p. 146.

1692 SILVA, Virgílio Afonso da. Direitos Fundamentais: conteúdo essencial, restrições e eficácia. São Paulo: Malheiros, 2009, p. 147.

1693 SILVA, Virgílio Afonso da. Direitos Fundamentais: conteúdo essencial, restrições e eficácia. São Paulo: Malheiros, 2009, p. 147.

${ }^{1694}$ SILVA, Virgílio Afonso da. Direitos Fundamentais: conteúdo essencial, restrições e eficácia. São Paulo: Malheiros, 2009, p. 147.

1695 SILVA, Virgílio Afonso da. Direitos Fundamentais: conteúdo essencial, restrições e eficácia. São Paulo: Malheiros, 2009, p. 147.

1696 SILVA, Virgílio Afonso da. Direitos Fundamentais: conteúdo essencial, restrições e eficácia. São Paulo: Malheiros, 2009, p. 148-153.
} 
Silva para essas duas críticas, basicamente, seria traçar "parâmetros" para direcionar a interpretação do direito ${ }^{1697}$ e exigir do Poder Judicário decisões coerentes ${ }^{1698}$.

Por fim, com relação à crítica sobre direitos irreais, explica Virgílio Afonso da Silva que o direito poderia abarcar situações ilícitas ou imorais, mesmo que isso parecesse incoerente a priori. $\mathrm{O}$ autor exemplifica falando do direito à liberdade de expressão, que, em princípio, admitiria a proteção do direito à calúnia ${ }^{1699}$. Por outro lado, admitir-se uma restrição prima facie a esse direito implicaria declarar-lhe limites imanentes, o que não se compatibilizaria com a teoria externa ${ }^{1700}$.

A diferença fundamental, enfim, entre a interpretação da teoria externa e da interna nestes casos estaria no fato de que, para esta, o direito encontra limites que lhe são internos, enquanto que, para aquela, o direito só seria limitado em razão da colisão com outros direitos fundamentais $^{1701}$, ou seja, após realizado um sopesamento ${ }^{1702}$.

\subsubsection{Sopesamento}

Como ensina Robert Alexy, o sopesamento é possível quando apurado um conflito entre princípios. No caso do direito à vida, diante de sua carga expansiva, bem como de sua natureza, é inegável os inúmeros conflitos que podem advir de sua análise.

Como vimos, o sopesamento pode ser realizado na teoria externa, pois essa teoria admite a possibilidade de restrição de direitos por fatores externos, alheios ao conteúdo interno do próprio direito em si.

Conforme ensina Virgílio, a maioria das restrições a direitos fundamentais são feitas por meio de regras, comumente presentes no texto constitucional ${ }^{1703}$. Isso ocorre, como

\footnotetext{
${ }^{1697}$ SILVA, Virgílio Afonso da. Direitos Fundamentais: conteúdo essencial, restrições e eficácia. São Paulo: Malheiros, 2009, p. 148.

${ }^{1698}$ SILVA, Virgílio Afonso da. Direitos Fundamentais: conteúdo essencial, restrições e eficácia. São Paulo: Malheiros, 2009, p. 151-153.

${ }^{1699}$ SILVA, Virgílio Afonso da. Direitos Fundamentais: conteúdo essencial, restrições e eficácia. São Paulo: Malheiros, 2009, p. 153.

${ }^{1700}$ SILVA, Virgílio Afonso da. Direitos Fundamentais: conteúdo essencial, restrições e eficácia. São Paulo: Malheiros, 2009, p. 154.

${ }^{1701}$ SILVA, Virgílio Afonso da. Direitos Fundamentais: conteúdo essencial, restrições e eficácia. São Paulo: Malheiros, 2009, p. 155.

${ }^{1702}$ SILVA, Virgílio Afonso da. Direitos Fundamentais: conteúdo essencial, restrições e eficácia. São Paulo: Malheiros, 2009, p. 156.

${ }^{1703}$ SILVA, Virgílio Afonso da. Direitos Fundamentais: conteúdo essencial, restrições e eficácia. São Paulo: Malheiros, 2009, p. 178.
} 
explica o autor, quando o intérprete precisa fazer um sopesamento entre dois ou mais princípios, cujo resultado é trazido pela lei infraconstitucional ${ }^{1704}$.

Se, no processo de constitucionalidade do dispositivo infraconstitucional, existir uma restrição a um direito fundamental, aplica-se a regra de proporcionalidade para resolver o conflito $^{1705}$.

No entanto, se não houver uma lei infraconstitucional que venha a restringir um direito fundamental para resolver um conflito, isto é, se existir uma lacuna a respeito da solução de um conflito entre princípios, aplica-se o sopesamento para verificar qual - ou quais - o princípio aplicável para solucionar o caso concreto ${ }^{1706}$.

\subsubsection{Proporcionalidade}

Como vimos, a proporcionalidade será aplicada se existir uma lei infraconstitucional que venha a restringir a aplicação de determinado direito fundamental prevista no texto normativo constitucional porque, se não houver regra a ser adotada, não será possível contrapô-la em relação às medidas de adequação, necessidade e proporcionalidade em sentido estrito.

André de Carvalho Ramos ensina que esse princípio ${ }^{1707}$ é uma "técnica de controle do poder estatal" 1708 , e que "consiste na aferição da idoneidade, necessidade e equilíbrio da

\footnotetext{
${ }^{1704}$ SILVA, Virgílio Afonso da. Direitos Fundamentais: conteúdo essencial, restrições e eficácia. São Paulo: Malheiros, 2009, p. 178-179.

${ }^{1705}$ SILVA, Virgílio Afonso da. Direitos Fundamentais: conteúdo essencial, restrições e eficácia. São Paulo: Malheiros, 2009, p. 179.

${ }^{1706}$ SILVA, Virgílio Afonso da. Direitos Fundamentais: conteúdo essencial, restrições e eficácia. São Paulo: Malheiros, 2009, p. 179.

${ }^{1707}$ Virgílio Afonso da Silva trata como regra. SILVA, Virgílio Afonso da. Direitos Fundamentais: conteúdo essencial, restrições e eficácia. São Paulo: Malheiros, 2009, p. 167-169. Não pode ser considerado princípio na teoria de Robert Alexy. SILVA, Virgílio Afonso da. O Proporcional e o Razoável. São Paulo: Revista dos Tribunais 798 (2002): 23-50, especialmente, p. 25-27. Nesse sentido, para Walter Claudius Rothenburg, a proporcionalidade não é um princípio, mas um critério. Para o autor, há três aspectos que devem ser considerados: i) em razão do conteúdo, pois a proporcionalidade não diz respeito a valores, mas a como certas normas devem ser aplicadas; ii) em razão do objeto: a proporcionalidade diz respeito "indiretamente ao comportamento", pois diretamente ligada às normas e iii) em razão da pertinência, a proporcionionalidade é uma regra de interpretação/aplicação do direito. ROTHENBURG, Walter Claudius. Princípio da Proporcionalidade. In: LOPES, Maria Elisabeth de Castro; OLIVEIRA NETO, Olavo de. (coord). Princípios Processuais Civis na Constituição. Rio de Janeiro: Elsevier, 2008, p. 292-294.

${ }^{1708}$ CARVALHO RAMOS, André de. Teoria Geral dos Direitos Humanos na Ordem Internacional. Rio de Janeiro: Renovar, 2005, p. 136.
} 
intervenção estatal em determinado direito fundamental" ${ }^{1709}$, mas entende que deve ser aplicado com moderação e justiça, ainda quando usado para resguardar outro direito fundamental ${ }^{1710}$.

Essa regra da proporcionalidade pressupõe a análise de três medidas ${ }^{1711}$, como ensina Virgílio Afonso da Silva: i) A medida adotada pelo estado é adequada para alcançar ${ }^{1712} \mathrm{o}$ objetivo da lei? ii) A medida é necessária? iii) A medida é proporcional em sentido estrito? ${ }^{1713}$ - isto é, há "ponderação entre a finalidade perseguida e os meios adotados para sua consecução"1714?

Essas medidas visam a evitar arbitrariedade ${ }^{1715}$, tornando o sistema mais transparente ${ }^{1716}$.

A primeira medida visa ao combate de medidas inadequadas, inúteis ${ }^{1717}$, e seu fim deve ser também constitucionalmente legítimo ${ }^{1718}$.

${ }^{1709}$ CARVALHO RAMOS, André de. Teoria Geral dos Direitos Humanos na Ordem Internacional. Rio de Janeiro: Renovar, 2005, p. 136.

${ }_{1710}$ CARVALHO RAMOS, André de. Teoria Geral dos Direitos Humanos na Ordem Internacional. Rio de Janeiro: Renovar, 2005, p. 137.

${ }^{1711}$ Para Virgílio Afonso da Silva as "sub-regras relacionam-se de forma subsidiária entre si”, de modo que não é necessário que o juiz as examine sempre quando o ato for abusivo. SILVA, Virgílio Afonso da. O Proporcional e o Razoável. São Paulo: Revista dos Tribunais 798 (2002): 23-50, especialmente, p. 34-35.

${ }^{1712}$ Virgílio Afonso da Silva explica que o significado correto do termo em alemão é fomentar e não alcançar. Assim, para o autor, não basta alcançar o fim pretendido, mas também como o objetivo é fomentado, "ainda que o objetivo não seja completamente realizado". SILVA, Virgílio Afonso da. O Proporcional e o Razoável. São Paulo: Revista dos Tribunais 798 (2002): 23-50, especialmente, p. 36-37.

${ }^{1713}$ SILVA, Virgílio Afonso da. Direitos Fundamentais: conteúdo essencial, restrições e eficácia. São Paulo: Malheiros, 2009, p. 179.

${ }^{1714}$ CARVALHO RAMOS, André de. Teoria Geral dos Direitos Humanos na Ordem Internacional. Rio de Janeiro: Renovar, 2005, p. 137.

${ }_{1715}$ Uma das críticas desse sistema é exatamente a possibilidade de arbitrariedade por parte do intérprete. SILVA, Virgílio Afonso da. Direitos Fundamentais: conteúdo essencial, restrições e eficácia. São Paulo: Malheiros, 2009, p. 148.

${ }^{1716}$ CARVALHO RAMOS, André de. Teoria Geral dos Direitos Humanos na Ordem Internacional. Rio de Janeiro: Renovar, 2005, p. 137.

${ }^{1717}$ CARVALHO RAMOS, André de. Teoria Geral dos Direitos Humanos na Ordem Internacional. Rio de Janeiro: Renovar, 2005, p. 137-138. André de Carvalho Ramos trata da faceta negativa do critério da proporcionalidade, como, no caso da exigência do diploma de jornalista, antes do RE 511.961-SP. Vide importantes comentários feitos na nova edição da obra. CARVALHO RAMOS, André de. Teoria Geral dos Direitos Humanos na Ordem Internacional. 2 ed. São Paulo: Saraiva, 2012, p. 172-173.

${ }_{1718}$ SILVA, Virgílio Afonso da. Direitos Fundamentais: conteúdo essencial, restrições e eficácia. São Paulo: Malheiros, 2009, p. 169-170. Ensina Walter Claudius Rothenburg que esse momento configura "a capacidade de proporcionar, ou pelo menos contribuir para, o objetivo pretendido. Não se exige aptidão para alcançar efetivamente os objetivos previstos [...], bastando a possibilidade de promover ou fomentar o objetivo, ou seja, a provável idoneidade da restrição para proporcionar a finalidade almejada”. ROTHENBURG, Walter Claudius. Princípio da Proporcionalidade. In: LOPES, Maria Elisabeth de Castro; OLIVEIRA NETO, Olavo de. (coord). Princípios Processuais Civis na Constituição. Rio de Janeiro: Elsevier, 2008, p. 295. No caso Cicarelli analisado pelo autor, a adequação autorizaria a ideia de que "a proibição de veiculação das cenas de sexo entre os namorados (esse o meio, restritivo dos direitos de informação e comunicação) mostrar-se-ia hábil a protegerlhes a privacidade (esse o fim)". ROTHENBURG, Walter Claudius. Princípio da Proporcionalidade. In: LOPES, Maria Elisabeth de Castro; OLIVEIRA NETO, Olavo de. (coord). Princípios Processuais Civis na Constituição. Rio de Janeiro: Elsevier, 2008, p. 295. 
A segunda medida refere-se àquela menos gravosa ${ }^{1719}$, e não necessariamente à uma medida de urgência que deva ser realizada. Para Virgilío trata-se de um exame comparativo, diferente da primeira medida, cujo critério é absoluto - decorrente de uma relação de meio e fim $^{1720}$. Nessa medida, compara-se verificando a "eficiência" da medida e o "grau de restrição ao direito fundamental" em jogo ${ }^{1721}$. Para André de Carvalho Ramos, é a análise da medida menos gravosa ou restrita dentre aquelas que poderão ser aplicadas ${ }^{1722}$.

A última medida trata da proporcionalidade em sentido estrito ${ }^{1723}$, e leva em consideração o equilíbrio alcançado entre as vantagens na aplicação de determinada medida, e o sacrifício decorrente da restrição de certo direito fundamental ${ }^{1724}$. Como ensina André de

${ }^{1719}$ CARVALHO RAMOS, André de. Teoria Geral dos Direitos Humanos na Ordem Internacional. Rio de Janeiro: Renovar, 2005, p. 139. Ensina Virgílio Afonso da Silva que "um ato estatal que limita um direito fundamental é somente necessário caso a realização do objetivo perseguido não possa ser promovida, com a mesma intensidade, por meio de outro ato que limite, em menor medida, o direito fundamental atingido". SILVA, Virgílio Afonso da. O Proporcional e o Razoável. São Paulo: Revista dos Tribunais 798 (2002): 23-50, especialmente, p. 38 .

${ }^{1720}$ SILVA, Virgílio Afonso da. Direitos Fundamentais: conteúdo essencial, restrições e eficácia. São Paulo: Malheiros, 2009, p. 170-171.

${ }^{1721}$ SILVA, Virgílio Afonso da. Direitos Fundamentais: conteúdo essencial, restrições e eficácia. São Paulo: Malheiros, 2009, p. 171.

${ }^{1722}$ CARVALHO RAMOS, André de. Teoria Geral dos Direitos Humanos na Ordem Internacional. Rio de Janeiro: Renovar, 2005, p. 138-139. CARVALHO RAMOS, André de. Teoria Geral dos Direitos Humanos na Ordem Internacional. 2 ed. São Paulo: Saraiva, 2012, p. 174-175. Para Walter Claudius Rothenburg, a necessidade refere-se à ideia de que "o meio utilizado deve trazer o menor sacrifício possível para alcançar com semelhante eficácia o objetivo pretendido". Para o autor, a verificação da "necessidade do meio em relação ao fim" não é fácil, pois exige "a menor restrição ao direito e a maior eficácia de resultado". ROTHENBURG, Walter Claudius. Princípio da Proporcionalidade. In: LOPES, Maria Elisabeth de Castro; OLIVEIRA NETO, Olavo de. (coord). Princípios Processuais Civis na Constituição. Rio de Janeiro: Elsevier, 2008, p. 297. A título de curiosidade, no caso Cicarelli "os provedores de internet que armazenavam as imagens foram instados a tirá-las de veiculação, mas afirmaram que não havia como fazê-lo, porque inúmeras e diversas fontes reinseriam as imagens em circulação. Portanto, a retirada dos próprios provedores seria a única alternativa vislumbrada (daí por que não se poder pretender um sacrifício menor) para obter o resultado com semelhante grau de eficácia." ROTHENBURG, Walter Claudius. Princípio da Proporcionalidade. In: LOPES, Maria Elisabeth de Castro; OLIVEIRA NETO, Olavo de. (coord). Princípios Processuais Civis na Constituição. Rio de Janeiro: Elsevier, 2008, p. 297-298.

${ }^{1723}$ No caso Cicarelli, de acordo com Walter Rothenburg, esse aspecto levaria à análise "sobre o grau de afronta ao direito de privacidade das pessoas envolvidas (invasão de privacidade em grau máximo, por revelar cenas de sexo) é suportável em relação ao grau de restrição do direito à expressão e informação pública (restrição também em grau máximo, pois significaria a proibição de divulgação das cenas mediante a suspensão de exibição dos próprios provedores)". ROTHENBURG, Walter Claudius. Princípio da Proporcionalidade. In: LOPES, Maria Elisabeth de Castro; OLIVEIRA NETO, Olavo de. (coord). Princípios Processuais Civis na Constituição. Rio de Janeiro: Elsevier, 2008, p. 299-300.

${ }^{1724}$ CARVALHO RAMOS, André de. Teoria Geral dos Direitos Humanos na Ordem Internacional. Rio de Janeiro: Renovar, 2005, p. 139-140. Virgílio Afonso da Silva entende que essa medida "consiste em um sopesamento entre a intensidade da restrição ao direito fundamental atingido e a importância da realização do direito fundamental que com ele colide e que fundamenta a adoção da medida restritiva". SILVA, Virgílio Afonso da. O Proporcional e o Razoável. São Paulo: Revista dos Tribunais 798 (2002): 23-50, especialmente, p. 40. O autor exemplifica indicando uma situação de restrição de direitos fundamentais para o combate da Aids: "se para combater a disseminação da Aids, o Estado decidisse que todos os cidadãos devessem fazer exame para detectar uma possível infecção pelo HIV e, além disso, prescrevesse que todos os infectados fossem encarcerados, estaríamos diante da seguinte situação: a medida seria, sem dúvida, adequada e necessária - nos termos previstos pela regra da proporcionalidade -, já que promove a realização do fim almejado e, embora seja fácil imaginar medidas alternativas que restrinjam menos a liberdade e a dignidade dos cidadãos, nenhuma 
Carvalho Ramos, é preciso verificar "a proporcionalidade entre a restrição de um direito (meio) e o benefício de outro (finalidade) ${ }^{{ }^{1725}}$, especialmente diante do fato da eficácia irradiante dos direitos humanos, e diante do fato de que nesses casos é totalmente ineficaz tentar aplicar a norma mais favorável ao indivíduo ${ }^{1726}$, pois frequentemente existem indivíduos com interesses divergentes no caso concreto ${ }^{1727}$.

Virgílio Afonso da Silva ensina que essa técnica constitui um "sopesamento entre os direitos envolvidos", com o objetivo de evitar-se a desproporção exagerada de "que medidas estatais, embora adequadas e necessárias, restrinjam direitos fundamentais além daquilo que a realização do objetivo perseguido seja capaz de justificar" ${ }^{, 1728}$.

Alerta o autor para as diferenças entre proporcionalidade e sopesamento. Em um caso em que se discute a constitucionalidade de lei que limita direitos fundamentais, deve-se recorrer à regra da proporcionalidade, ${ }^{1729}$ verificar-se se a lei é adequada para alcançar seus objetivos, e se não há outra opção mais eficaz e menos onerosa, e, por fim, "se há um equilíbrio entre a restrição de um direito e a realização de outro" ${ }^{1730}$. Nesse caso, deve existir

dessas alternativas teria a mesma eficácia da medida citada. Somente o sopesamento que a proporcionalidade em sentido estrito exige é capaz de evitar que esse tipo de medidas descabidas seja considerado proporcional, visto que, após ponderação racional, não há como não decidir pela liberdade e dignidade humana (art. $5^{\circ}$ e $1^{\circ}$, III), ainda que isso possa, em tese, implicar um nível menor de proteção à saúde pública (art. $\left.6^{\circ}\right)^{\prime}$. SILVA, Virgílio Afonso da. O Proporcional e o Razoável. São Paulo: Revista dos Tribunais 798 (2002): 23-50, especialmente, p. 40-41.

${ }^{1725}$ CARVALHO RAMOS, André de. Teoria Geral dos Direitos Humanos na Ordem Internacional. Rio de Janeiro: Renovar, 2005, p. 141.

${ }^{1726}$ Nesse sentido, André de Carvalho Ramos. CARVALHO RAMOS, André de. Teoria Geral dos Direitos Humanos na Ordem Internacional. Rio de Janeiro: Renovar, 2005, p. 141.

1727 Walter Claudius Rothenburg traz um exemplo interessante envolvendo o direito fundamental à saúde trabalhando todas as medidas. Ensina que um indivíduo pleiteia ao Estado uma cirurgia ortopédica e que há três possibilidades: "cirurgia, de resultado mais imediato, mas alto custo; a fisioterapia, de resultado mais demorado, mas de baixo custo; tratamento analgésico, de resultado imediato e baixíssimo custo, mas que oferece apenas um paliativo. A avaliação médica é de que o problema ainda não é muito grave e pode ser contornado por algum tempo com o emprego paliativo" [...] embora não muito eficiente, pois "o problema tende a agravar-se e pode atingir, em alguns anos, gravidade tal que somente a cirurgia poderá corrigi-lo". [...] a "fisioterapia intensa poderá resolvê-lo, com alguma demora" e a cirurgia "é igualmente eficiente desde logo". O paliativo não é adequado, a cirurgia não é necessária, "pois existe outro meio relativamente menos gravoso (a fisioterapia, que demanda mais tempo, porém compromete menos recursos públicos sempre escassos e potencialmente faltantes a outras pessoas em situação de maior gravidade, e submete o paciente a um desconforto suportável) e com eficiência (benefício) equiparável". O resultado proporcionalmente indicado é a fisioterapia. O autor alerta que mesmo essa análise envolve ponderações. ROTHENBURG, Walter Claudius. Princípio da Proporcionalidade. In: LOPES, Maria Elisabeth de Castro; OLIVEIRA NETO, Olavo de. (coord). Princípios Processuais Civis na Constituição. Rio de Janeiro: Elsevier, 2008, p. 312-313.

${ }^{1728}$ SILVA, Virgílio Afonso da. Direitos Fundamentais: conteúdo essencial, restrições e eficácia. São Paulo: Malheiros, 2009, p. 175.

${ }^{1729}$ SILVA, Virgílio Afonso da. Direitos Fundamentais: conteúdo essencial, restrições e eficácia. São Paulo: Malheiros, 2009, p. 179.

${ }^{1730}$ SILVA, Virgílio Afonso da. Direitos Fundamentais: conteúdo essencial, restrições e eficácia. São Paulo: Malheiros, 2009, p. 179. 
uma "medida concreta que será testada" $" 1731$. Por outro lado, se não existir uma lei que trate do conflito entre dois princípios, será necessário realizar a ponderação entre eles ${ }^{1732}$.

No caso do direito à vida, é óbvia a existência de conflitos reais ou potenciais entre direitos fundamentais, especialmente do direito à vida com o direito à autonomia individual, à liberdade e à dignidade ${ }^{1733}$.

$\mathrm{O}$ caso específico sobre o direito à vida do feto anencéfalo e os direitos fundamentais da gestante tem uma configuração complexa. Ao mesmo tempo em que uma lei infraconstitucional procura limitar o exercício de direitos fundamentais da mulher, procura ela também garantir o direito à vida do feto, o que entra em conflito com outros princípios.

Virgílio Afonso da Silva entende que uma situação como essa é mesmo perfeitamente possível de ocorrer. Para solucioná-la, além da aplicação da técnica de sopesamento, poderse-ia admitir a regra da proporcionalidade, conforme a complexidade do tema ${ }^{1734}$.

\subsection{CONTEÚDO ESSENCIAL}

Esclarece Virgílio Afonso da Silva que a restrição a um direito fundamental deve passar pelo teste da proporcionalidade, mas questiona se seria possível, em um caso concreto, que uma restrição a determinado direito fundamental passasse pelo teste e, posteriormente, fosse declarado inconstitucional porque esvaziara o conteúdo essencial do direito fundamental restringido ${ }^{1735}$. Em se tratando do direito à vida, por exemplo, o tema fica particularmente complexo. Aceitar a pena de morte, por exemplo, esvaziaria por completo o conteúdo essencial do direito à vida.

\footnotetext{
${ }^{1731}$ SILVA, Virgílio Afonso da. Direitos Fundamentais: conteúdo essencial, restrições e eficácia. São Paulo: Malheiros, 2009, p. 179.

${ }^{1732}$ SILVA, Virgílio Afonso da. Direitos Fundamentais: conteúdo essencial, restrições e eficácia. São Paulo: Malheiros, 2009, p. 179.

${ }^{1733}$ Carolina Alves de Souza Lima entende que no caso de aborto de feto anencéfalo, a adequação e a necessidade referem-se ao aborto como "único meio idôneo" para poder "preservar a saúde e a liberdade de autonomia da mulher" - objetivo visado. "Se ele é necessário é porque, nesse caso, é adequado". LIMA, Carolina Alves de Souza. Aborto e Anencefalia: direitos fundamentais em colisão. $1^{\mathrm{a}}$.ed. (ano 2008), $2^{\mathrm{a}}$ reimpr. Curitiba: Juruá, 2010, p. 156-157. Já no que se refere à terceira medida, o "processo de ponderação, avalia-se a importância de realizar cada um dos direitos em conflito". LIMA, Carolina Alves de Souza. Aborto e Anencefalia: direitos fundamentais em colisão. $1^{a}$.ed. (ano 2008), $2^{a}$ reimpr. Curitiba: Juruá, 2010, p. 158.

${ }^{1734}$ SILVA, Virgílio Afonso da. Direitos Fundamentais: conteúdo essencial, restrições e eficácia. São Paulo: Malheiros, 2009, p. 182.

${ }^{1735}$ SILVA, Virgílio Afonso da. Direitos Fundamentais: conteúdo essencial, restrições e eficácia. São Paulo: Malheiros, 2009, p. 181-182.
} 
Um exemplo interessante trazido por Virgílio Afonso da Silva decorre do argumento formulado pelo Ministro Celso de Mello no caso Ellwanger ${ }^{1736}$, que posteriormente se repetiu também no voto proferido na ADI $3510-0$ sobre células-tronco ${ }^{1737}$. Para o Ministro, a ponderação não poderia esvaziar o conteúdo essencial dos direitos fundamentais, principalmente em se tratando do direito à vida ${ }^{1738}$. Por essa razão, Virgílio Afonso da Silva explica que o Ministro "faz menção a um método (ponderação) de resolução de colisões entre direitos fundamentais (princípios) que deve levar em consideração o contexto completo do

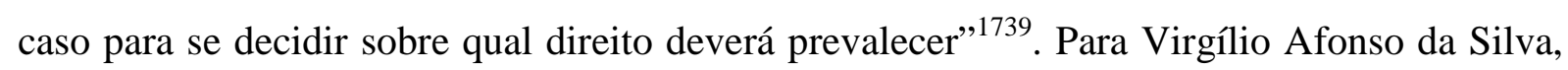
em algumas situações, poderá aplicar-se a regra da "ponderação ou sopesamento" 1740 e a regra da proporcionalidade, desde que não se esvazie o conteúdo essencial do direito fundamental em análise ${ }^{1741}$. Haveria, portanto, para o Virgílio Afonso da Silva, duas garantias: a proporcionalidade e o conteúdo essencial ${ }^{1742}$.

Ensina ainda Virgílio Afonso da Silva que, para definir o conteúdo essencial, é preciso observar duas dimensões, uma objetiva, e uma subjetiva ${ }^{1743}$.

A dimensão objetiva tem o fim de analisar se a proteção do conteúdo essencial de um determinado direito fundamental "implica proibir restrições à eficácia desse direito que o tornem sem significado para todos os indivíduos ou para boa parte deles" ${ }^{\text {"1744 }}$. Entretanto, Virgílio Afonso da Silva entende que através dessa análise não se agrega nenhuma outra

\footnotetext{
${ }^{1736}$ Vide HC 82.424. Vide importante parecer emitido por Celso Lafer no caso Ellwanger. LAFER, Celso. A Internacionalização dos Direitos Humanos: Constituição, racismo e relações internacionais. São Paulo: Manole, 2005, p. 33-88.

${ }^{1737}$ SILVA, Virgílio Afonso da. Direitos Fundamentais: conteúdo essencial, restrições e eficácia. São Paulo: Malheiros, 2009, p. 182 e 200.Vide também voto do Ministro Celso de Mello. Ação Declaratória de Inconstitucionalidade (ADI 3510-0), p. 32-33, fl. 585-586. Disponível em: 〈http://www.stf.jus.br>. Acesso em: 10 jan. 2012.

${ }^{1738}$ SILVA, Virgílio Afonso da. Direitos Fundamentais: conteúdo essencial, restrições e eficácia. São Paulo: Malheiros, 2009, p. 182 e 200.Vide também voto do Ministro Celso de Mello na ADI 3510-0. Ação Declaratória de Inconstitucionalidade (ADI 3510-0), p. 32-33, fl. 585-586. Disponível em: <http://www.stf.jus.br>. Acesso em: 10 jan. 2012.

${ }^{1739}$ SILVA, Virgílio Afonso da. Direitos Fundamentais: conteúdo essencial, restrições e eficácia. São Paulo: Malheiros, 2009, p. 182 e 200.

${ }^{1740}$ SILVA, Virgílio Afonso da. Direitos Fundamentais: conteúdo essencial, restrições e eficácia. São Paulo: Malheiros, 2009, p. 182 e 200.

${ }^{1741}$ SILVA, Virgílio Afonso da. Direitos Fundamentais: conteúdo essencial, restrições e eficácia. São Paulo: Malheiros, 2009, p. 182 e 200.

${ }^{1742}$ SILVA, Virgílio Afonso da. Direitos Fundamentais: conteúdo essencial, restrições e eficácia. São Paulo: Malheiros, 2009, p. 200.

${ }^{1743}$ SILVA, Virgílio Afonso da. Direitos Fundamentais: conteúdo essencial, restrições e eficácia. São Paulo: Malheiros, 2009, p. 185.

${ }^{1744}$ SILVA, Virgílio Afonso da. Direitos Fundamentais: conteúdo essencial, restrições e eficácia. São Paulo: Malheiros, 2009, p. 185.
} 
proteção a direitos fundamentais no ordenamento além daquelas naturalmente alcançadas pelas cláusulas pétreas ${ }^{1745}$.

A dimensão subjetiva visa a proteger os direitos fundamentais de uma "restrição excessiva", e verificar se tais direitos protegem as "condutas ou posições jurídicas individuais" $" 1746$.

Passando a restrição do direito à vida pelo teste da proporcionalidade, poderia ser tal restrição considerada inconstitucional? Virgílio Afonso da Silva entende que não ${ }^{1747}$, e, justifica sua posição na diferença entre conteúdo essencial relativo e absoluto.

\subsubsection{Conteúdo essencial relativo}

Virgílio Afonso da Silva afirma que existem direitos fundamentais que não possuem contornos definidos, e que podem variar conforme o caso concreto, tendo em vista os demais direitos fundamentais envolvidos ${ }^{1748}$, consagrando assim um caráter relativizado desse direito.

O autor aproxima a noção de conteúdo essencial relativo e proporcionalidade ${ }^{1749}$, defendendo que é possível não esvaziar o conteúdo essencial de um direito fundamental, ainda que nada reste desse direito a ser aplicado diante de sua restrição e da proteção de outros bens jurídicos ${ }^{1750}$.

\footnotetext{
${ }^{1745}$ SILVA, Virgílio Afonso da. Direitos Fundamentais: conteúdo essencial, restrições e eficácia. São Paulo: Malheiros, 2009, p. 186.

${ }^{1746}$ SILVA, Virgílio Afonso da. Direitos Fundamentais: conteúdo essencial, restrições e eficácia. São Paulo: Malheiros, 2009, p. 186. Para Virgílio Afonso da Silva é possível que uma restrição a direito fundamental não viole a dimensão objetiva, mas poderia violar a dimensão subjetiva do conteúdo essencial daquele direito. Podemos extrair um exemplo exposto pelo autor: pena de morte no Brasil em caso de guerra. Nesse caso, todo o conteúdo essencial de dimensão subjetiva é eliminado, mas o mesmo não ocorre com o conteúdo da dimensão objetiva. Por isso, o autor defende a proteção, mesmo nesses casos, da dimensão individual. SILVA, Virgílio Afonso da. Direitos Fundamentais: conteúdo essencial, restrições e eficácia. São Paulo: Malheiros, 2009, p. 186-187.

${ }^{1747}$ SILVA, Virgílio Afonso da. Direitos Fundamentais: conteúdo essencial, restrições e eficácia. São Paulo: Malheiros, 2009, p. 206-207.

${ }^{1748} \mathrm{O}$ autor aponta a existência de críticas, mas entende que essa teoria indica a direção correta. SILVA, Virgílio Afonso da. Direitos Fundamentais: conteúdo essencial, restrições e eficácia. São Paulo: Malheiros, 2009, p. 196.

${ }^{1749}$ SILVA, Virgílio Afonso da. Direitos Fundamentais: conteúdo essencial, restrições e eficácia. São Paulo: Malheiros, 2009, p. 200.

${ }^{1750}$ SILVA, Virgílio Afonso da. Direitos Fundamentais: conteúdo essencial, restrições e eficácia. São Paulo: Malheiros, 2009, p. 196-197.
} 
Por esta razão, para o autor, se a restrição de um direito fundamental passar pelo teste da proporcionalidade, não terá seu conteúdo essencial atacado ${ }^{1751}$, desde que a restrição seja justificada $^{1752}$, sendo necessária a dupla garantia da proporcionalidade e do conteúdo essencial $^{1753}$.

\subsubsection{Conteúdo essencial absoluto}

A teoria do conteúdo essencial absoluto dos direitos fundamentais defende a existência de um núcleo desses direitos que se lhes constitui um limite absoluto que nenhuma restrição pode ultrapassar ${ }^{1754}$, muito embora vários doutrinadores entendam que não existe um núcleo imutável ${ }^{1755}$, mesmo que seja absoluto. Tal núcleo seria uma "barreira intransponível"1756 ${ }^{\text {. No }}$ entanto, é difícil afirmar o que faz parte ou não desse conteúdo ${ }^{1757}$.

Virgílio Afonso da Silva aponta duas espécies de conteúdo essencial absoluto, o dinâmico, e o estático.

Na primeira espécie, a do conteúdo essencial absoluto dinâmico, não se fala em “imutabilidade", e o conteúdo pode ser alterado com o tempo ${ }^{1758}$.

A segunda espécie, a do conteúdo essencial absoluto estático, atribui-se ao conteúdo absoluto a intangibilidade e a imutabilidade ${ }^{1759}$. Para o autor, isso não proibiria uma mudança

${ }^{1751}$ SILVA, Virgílio Afonso da. Direitos Fundamentais: conteúdo essencial, restrições e eficácia. São Paulo: Malheiros, 2009, p. 197.

${ }^{1752}$ SILVA, Virgílio Afonso da. Direitos Fundamentais: conteúdo essencial, restrições e eficácia. São Paulo: Malheiros, 2009, p. 198.

1753 SILVA, Virgílio Afonso da. Direitos Fundamentais: conteúdo essencial, restrições e eficácia. São Paulo: Malheiros, 2009, p. 200.

${ }^{1754}$ SILVA, Virgílio Afonso da. Direitos Fundamentais: conteúdo essencial, restrições e eficácia. São Paulo: Malheiros, 2009, p. 187.

${ }^{1755}$ Conteúdo essencial absoluto-dinâmico. Há aqueles que entendem existir um conteúdo essencial além de intangível, imutável, denominado pela doutrina de conteúdo essencial absoluto-estático. Nesse caso, há quem admita a existência de um núcleo estático, imutável que pode ser mais abrangente ou menos, podendo ser até mais flexível. SILVA, Virgílio Afonso da. Direitos Fundamentais: conteúdo essencial, restrições e eficácia. São Paulo: Malheiros, 2009, p. 188-191.

1756 SILVA, Virgílio Afonso da. Direitos Fundamentais: conteúdo essencial, restrições e eficácia. São Paulo: Malheiros, 2009, p. 187.

1757 SILVA, Virgílio Afonso da. Direitos Fundamentais: conteúdo essencial, restrições e eficácia. São Paulo: Malheiros, 2009, p. 187.

1758 SILVA, Virgílio Afonso da. Direitos Fundamentais: conteúdo essencial, restrições e eficácia. São Paulo: Malheiros, 2009, p. 188. O conteúdo é absoluto porque não pode ser relativizado, conforme o autor. SILVA, Virgílio Afonso da. Direitos Fundamentais: conteúdo essencial, restrições e eficácia. São Paulo: Malheiros, 2009, p. 188.

1759 SILVA, Virgílio Afonso da. Direitos Fundamentais: conteúdo essencial, restrições e eficácia. São Paulo: Malheiros, 2009, p. 189. 
do "conteúdo total" do direito, porque isso dependeria ainda de se saber se o tal conteúdo é restrito ou não ${ }^{1760}$. Naturalmente, quanto maior a extensão desse núcleo “imutável”, nesse modelo estático, menor a capacidade de interpretação sobre o direito em questão ${ }^{1761}$.

Ainda no contexto desta análise, interessante o raciocínio utilizado por Virgílio Afonso da Silva para analisar a dignidade da pessoa humana, e também muito útil para este trabalho.

A dignidade poderia ser observada sob duas óticas relevantes: i) dignidade como conteúdo essencial de todos os direitos fundamentais; e ii) dignidade como conteúdo essencial absoluto $^{1762}$.

Se a dignidade for entendida como conteúdo essencial de todos os direitos, teríamos que admitir que somente a dignidade teria um núcleo absoluto, enquanto os demais direitos teriam um núcleo relativo ${ }^{1763}$.

Por outro lado, se a dignidade for compreendida como conteúdo absoluto, seria possível atribuir-lhe característica de regra e princípio ${ }^{1764}$. Assim, conforme ensina Virgílio Afonso da Silva, a parte da dignidade que se revelasse como regra não aceitaria uma ponderação, ao passo que, a parte que fosse princípio, $\operatorname{sim}^{1765}$.

Além disso, seria possível imaginar-se a "hipertrofia da dignidade e da consequente absolutização de todos os direitos fundamentais", como ensina, Virgílio Afonso da Silva ${ }^{1766}$.

Assim, diante dos aspectos analisados acerca das restrições dos direitos fundamentais, em se tratando do direito à vida, concluímos que, em caso de conflito com outros direitos, entendidos como princípios, necessário se faz respeitar a proporcionalidade e lançar mão do sopesamento, levando em consideração as peculiaridades do caso concreto, especialmente

${ }^{1760}$ SILVA, Virgílio Afonso da. Direitos Fundamentais: conteúdo essencial, restrições e eficácia. São Paulo: Malheiros, 2009, p. 190.

${ }^{1761}$ SILVA, Virgílio Afonso da. Direitos Fundamentais: conteúdo essencial, restrições e eficácia. São Paulo: Malheiros, 2009, p. 191.

${ }^{1762}$ SILVA, Virgílio Afonso da. Direitos Fundamentais: conteúdo essencial, restrições e eficácia. São Paulo: Malheiros, 2009, p. 192.

${ }^{1763}$ SILVA, Virgílio Afonso da. Direitos Fundamentais: conteúdo essencial, restrições e eficácia. São Paulo: Malheiros, 2009, p. 192.

${ }^{1764}$ Virgílio Afonso da Silva recorre à Robert Alexy nesse aspecto. SILVA, Virgílio Afonso da. Direitos Fundamentais: conteúdo essencial, restrições e eficácia. São Paulo: Malheiros, 2009, p. 201.

${ }^{1765}$ SILVA, Virgílio Afonso da. Direitos Fundamentais: conteúdo essencial, restrições e eficácia. São Paulo: Malheiros, 2009, p. 201. Entende o autor que a dignidade "tende a ter um conteúdo essencial relativo", seguindo o caminho de boa parte dos princípios, exceto aqueles em que o texto constitucional proíbe a ponderação. Virgílio Afonso exemplifica com o artigo $5^{\circ}$, III, da Constituição Federal que veda a tortura e o tratamento degradante. SILVA, Virgílio Afonso da. Direitos Fundamentais: conteúdo essencial, restrições e eficácia. São Paulo: Malheiros, 2009, p. 202.

${ }^{1766}$ SILVA, Virgílio Afonso da. Direitos Fundamentais: conteúdo essencial, restrições e eficácia. São Paulo: Malheiros, 2009, p. 193. O autor critica a "banalização do uso da garantia da dignidade da pessoa humana" no Brasil. SILVA, Virgílio Afonso da. Direitos Fundamentais: conteúdo essencial, restrições e eficácia. São Paulo: Malheiros, 2009, p. 193. 
porque o direito à vida deve ser cumprido na maior medida possível, e só pode ser restringido em casos específicos.

A seguir, munidos deste embasamento teórico, vamos finalmente propor quatro modelos possíveis de interpretação constitucional ao caso específico do aborto do feto anencéfalo no Brasil, e sugerir qual deles nos parece mais plausível em vista do contexto normativo e jurisprudencial em que estamos imersos, levando em conta, especialmente, a recente decisão do STF sobre o tema. 


\section{PARTE III - O ABORTO DO FETO ANENCÉFALO E O TRATAMENTO CONSTITUCIONAL ADEQUADO}

\section{QUATRO MODELOS POSSÍVEIS DE INTERPRETAÇÃO DA CONSTITUIÇÃO FEDERAL BRASILEIRA}

Diante de tudo o que foi tratado, pretendemos, inspirados na linha adotada por Fernando Rey Martínez ao tratar da eutanásia na Espanha ${ }^{1767}$, apresentar alguns modelos de interpretação possíveis da nossa Constituição Federal no que tange aos conflitos suscitados pelo aborto do feto anencéfalo.

Os modelos interpretativos que vamos propor podem ser analisados a partir de várias regras e princípios que são encontrados no texto constitucional, não se limitando apenas ao artigo $5^{\circ}$ da Constituição Federal. A abertura dos termos constitucionais e legais aplicáveis acaba fazendo com que surjam mais controvérsias, diferentemente do que ocorreria se o texto contivesse termos precisos ${ }^{1768}$.

Podemos extrair do texto constitucional diversas disposições que são pertinentes a nossa matéria. $\mathrm{O}$ direito à vida, o direito à liberdade, o direito à liberdade ideológica e religiosa, o direito à integridade física e psíquica, o direito à saúde física e psíquica, a proibição de tratamento desumano e degradante, o princípio da autodeterminação, o da autonomia da vontade, os direitos reprodutivos e sexuais, o direito à família, o direito à dignidade da pessoa humana, o direito à vida digna ou com qualidade de vida, e, ainda, o direito à igualdade ${ }^{1769}$. Para concluirmos pela autorização ou não do aborto, é necessário avaliar o direito à vida em conjunto com todos os demais direitos indicados, além de

\footnotetext{
${ }^{1767}$ REY MARTÍNEZ, Fernando. Eutanasia y Derechos Fundamentales. Madrid: Centro de Estúdios Políticos Y Constitucionales, 2008, p. 12.

${ }^{1768}$ Nesse sentido Fernando Rey Martínez afirma que a interpretação será construída e não encontrada no texto constitucional espanhol. A mesma coisa é aplicada ao caso em tela. REY MARTíNEZ, Fernando. Eutanasia y Derechos Fundamentales. Madrid: Centro de Estúdios Políticos Y Constitucionales, 2008, p. 81. Ao analisar a Constituição Americana, Dworkin traz duas leituras possíveis: i) constituição de detalhes, "mas segura, porém mais "mundana"" ou ii) constituição de princípios, "mais grandiosa, mas talvez mais perigosa". DWORKIN, Ronald. Domínio da Vida: aborto, eutanásia e liberdades individuais. Trad. Jefferson Luiz Camargo; rev. da tradução Silvana Vieira. São Paulo: Martins Fontes, 2003, p. 170.

${ }^{1769}$ Vale dizer que proibir o aborto de feto anencéfalo e permitir outras situações de aborto, como por exemplo estupro e risco à vida da mãe, causa, no mínimo, uma violação ao princípio da igualdade perante à lei. REY MARTÍNEZ, Fernando. Eutanasia y Derechos Fundamentales. Madrid: Centro de Estúdios Políticos Y Constitucionales, 2008, p. 121-122.
} 
considerar a interpretação que se lhes tem sido conferida pela doutrina e jurisprudência nacional e internacional. Não está em jogo somente o direito à vida do feto ou o direito à vida em geral que a Constituição brasileira garante. Em jogo estão também outros direitos, tanto previstos na Constituição, quanto em tratados internacionais dos quais o Brasil é parte.

Em especial, o conflito entre a liberdade e a vida não é de fácil solução.

Por um lado, precisamos ter em mente que a vida é um bem jurídico que deve ser protegido independentemente da vontade de seu titular, pois, além de ter uma dimensão individual, também tem uma coletiva ${ }^{1770}$, pela importância que tem a vida para a coletividade. Neste sentido, ensina Fernando Rey Martínez, a respeito da vida, que

ao mesmo tempo em que transforma em problemática sua adição à categoria clássica de direito subjetivo, [e] explicita a importância da sua dimensão objetiva ou extraindividual, [a vida] se trataria de um bem indisponível por sua direta conexão com a mesma conservação do núcleo social; mas isso não quer dizer, entendo, que a vida humana seja um bem jurídico exclusivo da comunidade (...). A vida não é um bem exclusivamente social, mas também não é exclusivamente individual ${ }^{1771}$.

É interessante observar que, neste mesmo sentido, seguiu o Ministro Lewandowski em seu voto na Ação Declaratória de Inconstitucionalidade (ADI) 3510-0, que versou sobre a constitucionalidade de se realizar pesquisas com células-tronco, ao afirmar que o direito à vida deve ser entendido como um bem coletivo, ou seja, um direito comum a todos ${ }^{1772}$.

Por outro lado, a liberdade é um dos fundamentos mais importantes da democracia. Ainda na esteira de Rey Martínez, não podemos nos esquecer de que, em vista da importância que tem a cláusula geral de liberdade, e da interpretação amplamente aceita nas democracias de que, de um modo geral, o que não está proibido ou ordenado é permitido, a inexistência de proibições explícitas no texto constitucional devem também ser levadas em conta no momento da aplicação do direito ${ }^{1773}$. Deste modo, assim como, para Rey Martínez, a ausência

\footnotetext{
${ }^{1770}$ Nesse sentido, voto do Ministro Joaquim barbosa na Ação Declaratória de Inconstitucionalidade (ADI 35100), p. 4. O Supremo Tribunal Federal enfrentou a questão proferindo sua decisão em maio de 2008, aprovando o uso de células-tronco embrionárias nas pesquisas científicas e declarando, assim, constitucional o artigo $5^{\circ}$ da Lei 11.105/05. Disponível em: <http://www.stf.jus.br>. Acesso em: 10 jan. 2012. Vide também Ronald Dworking a respeito. DWORKIN, Ronald. Domínio da Vida: aborto, eutanásia e liberdades individuais. Trad. Jefferson Luiz Camargo; rev. da tradução Silvana Vieira. São Paulo: Martins Fontes, 2003, p. 209.

${ }^{1771}$ REY MARTÍNEZ, Fernando. Eutanasia y Derechos Fundamentales. Madrid: Centro de Estúdios Políticos Y Constitucionales, 2008, p. 155, (tradução nossa)..

1772 BRASIL. Supremo Tribunal Federal. Ação Declaratória de Inconstitucionalidade (ADI 3510-0), p. 23-24. Disponível em: <http://www.stf.jus.br>. Acesso em: 10 jan. 2012.

${ }^{1773}$ Luísa Neto entende que, no caso do aborto, não existindo uma "proibição total ao aborto", igualmente não existe o "reconhecimento constitucional de um direito ao aborto". NETO, Luísa. O direito fundamental à disposição do próprio corpo (a relevância da vontade na configuração do seu regime). Coimbra: Coimbra Editora, 2004, p. 450.
} 
de uma proibição da eutanásia na Espanha poderia ser entendida como um silêncio eloquente, que a autoriza ${ }^{1774}$, a ausência de uma proibição expressa do aborto do feto anencéfalo no Brasil também o poderia. Resta patente, pois, a enorme tensão entre o direito à vida e à liberdade no caso em tela.

Em vista das considerações acima e das formidáveis dificuldades e indagações que o tema nos apresenta, ainda inspirados em Rey Martínez, a fim de facilitar a análise e compreensão do caso do aborto do feto anencéfalo no Brasil, especialmente em vista dos conflitos de princípios e direitos suscitados pela questão, gostaríamos de sugerir quatro modelos interpretativos do direito constitucional brasileiro possíveis de serem aplicados ao aborto do feto anencéfalo em nosso país, deduzidos de argumentos jurídicos válidos à luz de nossa Constituição: i) o modelo da proibição absoluta; ii) o modelo da livre-disposição; iii) o modelo da liberdade limitada; e iv) o modelo da exceção permitida.

Posteriormente, discutiremos também se seria possível interpretar-se a decisão do STF sobre o caso como estando coberta por algum desses modelos.

\subsection{O MODELO DE INTERPRETAÇÃO CONSTITUCIONAL DA PROIBIÇÃO ABSOLUTA DO ABORTO DO ANENCEFÁLICO}

O primeiro modelo de interpretação constitucional proposto defende que a proteção à vida conferida pelo artigo $5^{\circ}$ do texto constitucional deve ser interpretada do modo mais amplo possível, que a proibição do aborto, assim, deve ser entendida de modo absoluto, abarcando a proteção à vida do ser humano desde a concepção, independentemente de existir ou não má-formação fetal, risco à saúde ou mesmo à vida da mãe, etc.

Esse modelo de interpretação se fundamenta principalmente em preceitos religiosos, de predominância católica, que pressupõem que a vida é uma dádiva divina e, por isso, absolutamente indisponível ${ }^{1775}$.

Neste modelo, aplicar-se a sanção penal ao aborto do feto anencefálico não seria apenas e tão-somente totalmente de acordo com a proteção constitucional da vida, mas

\footnotetext{
${ }^{1774}$ REY MARTÍNEZ, Fernando. Eutanasia y Derechos Fundamentales. Madrid: Centro de Estúdios Políticos Y Constitucionales, 2008, p. 166.

${ }^{1775}$ REY MARTÍNEZ, Fernando. Eutanasia y Derechos Fundamentales. Madrid: Centro de Estúdios Políticos Y Constitucionales, 2008, p. 84.
} 
também, uma eventual descriminalização seria inconstitucional ${ }^{1776}$. Segundo esta interpretação, inclusive, até mesmo as formas de aborto já permitidas pelo Código Penal seriam inconstitucionais.

A proteção da vida neste modelo seria a proteção da vida como valor abstrato ${ }^{1777}$, a qualquer custo $^{1778}$. A vida seria indisponível e teria um valor em si mesma ${ }^{1779}$ - ainda que à beira da extinção, ainda que não haja vida extrauterina ou que haja vida por poucos minutos, ainda que a vida seja breve e consumida por sofrimentos atrozes e incuráveis, ainda que esta vida violente de modo cruel e desumano a saúde física e psíquica da mulher, sua liberdade no sentido mais amplo, sua dignidade, e qualquer outro direito que possa ter.

De um modo geral, o voto do Ministro Peluso na ADPF 54 se encaixa neste modelo interpretativo. Neste sentido, vale lembrar que, inter alia, Peluso expressamente defendeu que a vida é o valor supremo, pressuposto de todos outros "bens materiais e imateriais" "1780, "fundante e inegociável"1781, e que, portanto, não admite "margem para transigência" "1782, de modo que, para ele, o direito à vida não pode ser relativizado ${ }^{1783}$.

\subsection{O MODELO DE INTERPRETAÇÃO CONSTITUCIONAL DA LIVRE DISPOSIÇÃO}

\footnotetext{
${ }^{1776}$ REY MARTÍNEZ, Fernando. Eutanasia y Derechos Fundamentales. Madrid: Centro de Estúdios Políticos Y Constitucionales, 2008, p. 84.

${ }^{1777}$ REY MARTÍNEZ, Fernando. Eutanasia y Derechos Fundamentales. Madrid: Centro de Estúdios Políticos Y Constitucionales, 2008, p. 41.

1778 Parece-nos que esta teoria está bem alinhada à posição apresentada por Dworkin sobre a santidade e sacralidade da vida.

${ }^{1779}$ Luísa Neto comenta que uma interpretação da vida humana "enquanto valor em si" implicaria, além da atribuição de um valor absoluto à vida, também uma proibição ao suicídio, o direito a uma vida digna, a condições mínimas de subsistência, etc, e que, em vista disso, tal direito acabaria funcionando como a matriz originária dos principais direitos sociais. NETO, Luísa. $\mathbf{O}$ direito fundamental à disposição do próprio corpo (a relevância da vontade na configuração do seu regime). Coimbra: Coimbra Editora, 2004, p. 450.

${ }^{1780}$ BRASIL. Supremo Tribunal Federal. Arguição de Descumprimento de Preceito Fundamental $n^{\circ}$ 54-8. Voto lido em plenário pelo Ministro Cezar Peluso. Disponível em: <http://www.youtube.com/watch?v=1Bh_d4D56jI\&list=PLF21CD375773F508D\&index=1\&feature=plpp_vide o>. Acesso em: 30 abr. 2012 (1:33:00-1:33:44).

${ }^{1781}$ BRASIL. Supremo Tribunal Federal. Arguição de Descumprimento de Preceito Fundamental $n^{\circ}$ 54-8. Voto lido em plenário pelo Ministro Cezar Peluso. Disponível em: <http://www.youtube.com/ watch?v=1Bh_d4D56jI\&list=PLF21CD375773F508D\&index=1\&feature=plpp_video $>$. Acesso em: 30 abr. 2012 (1:30:44-1:31:01).

1782 BRASIL. Supremo Tribunal Federal. Arguição de Descumprimento de Preceito Fundamental $n^{\circ}$ 54-8. Voto lido em plenário pelo Ministro Cezar Peluso. Disponível em: <http://www.youtube.com/ watch?v=1Bh_d4D56jI\&list=PLF21CD375773F508D\&index=1\&feature=plpp_video >. Acesso em: 30 abr. 2012 (1:31:02-1:31:05).

1783 BRASIL. Supremo Tribunal Federal. Arguição de Descumprimento de Preceito Fundamental $n^{\circ}$ 54-8. Voto lido em plenário pelo Ministro Cezar Peluso. Disponível em: <http://www.youtube.com/ watch?v=1Bh_d4D56jI\&list=PLF21CD375773F508D\&index=1\&feature=plpp_video $>$. Acesso em: 30 abr. 2012 (1:30:34-1:30:42).
} 
No segundo modelo de interpretação constitucional proposto, o da livre disposição, compreende-se o direito a realizar o aborto como um direito fundamental da mulher de dispor do próprio corpo ${ }^{1784}$.

As premissas que fundamentam este modelo são totalmente diferentes das do modelo anterior. Aqui não existe uma obrigação de se levar a gravidez de um feto anencéfalo até o final, pois o direito à vida não é absoluto e deve ser considerado em relação aos demais princípios constitucionais como, por exemplo, o princípio da autodeterminação, do livre desenvolvimento da personalidade, da liberdade, da dignidade humana, da integridade física e psíquica, da proteção contra tratamento desumano e degradante, da liberdade religiosa e ideológica, do direito à saúde, e outros.

Neste modelo de interpretação constitucional, o aborto - inclusive de fetos perfeitos seria o exercício legítimo de direitos fundamentais da mulher e, neste caso, a criminalização do aborto é que seria considerada inconstitucional. O direito ao aborto seria deduzido do texto constitucional através da interpretação de que os princípios que lhe seriam mais favoráveis, mencionados acima, seriam absolutos ou, no mínimo, quase absolutos - e, certamente, mais importantes do que o direito à vida ou à proteção do feto, que seriam relativizados.

Vale lembrar, como bem o fez Rey Martínez quando tratou da eutanásia ${ }^{1785}$, que, neste modelo, mesmo a mulher podendo decidir pelo aborto, ela não estaria obrigada a realizá-lo, e a lei poderia, inclusive, estabelecer alguns limites procedimentais para salvaguardar a autonomia da mulher, garantindo a manifestação de seu consentimento livre ${ }^{1786}$. Rey Martínez nos lembra também de que o fato de que juridicamente é possível fazer alguma coisa não significa obrigatoriamente dizer que seja conveniente ${ }^{1787}$ à sociedade fazê-lo ${ }^{1788}$.

Enfim, segundo este modelo de interpretação constitucional, não seria constitucionalmente permitido ao estado de modo algum proibir o aborto do feto anencefálico

\footnotetext{
${ }^{1784}$ Carolina Alves de Souza Lima entende que o aborto no caso de feto anencéfalo deve ser considerado um exercício regular do direito e, para ela, trata-se de um direito constitucional da gestante interromper a gravidez. LIMA, Carolina Alves de Souza. Aborto e Anencefalia: direitos fundamentais em colisão. $1^{a}$.ed. (ano 2008), $2^{\mathrm{a}}$ reimpr. Curitiba: Juruá, 2010, p. 165-166.

${ }^{1785}$ REY MARTÍNEZ, Fernando. Eutanasia y Derechos Fundamentales. Madrid: Centro de Estúdios Políticos Y Constitucionales, 2008, p. 85.

${ }^{1786}$ REY MARTÍNEZ, Fernando. Eutanasia y Derechos Fundamentales. Madrid: Centro de Estúdios Políticos Y Constitucionales, 2008, p. 85.

${ }^{1787}$ De modo semelhante, mas não idêntico, vale lembrar o famoso brocardo, "Non omne quod licet honestum est", ou seja, "nem tudo o que é lícito é honesto"; bem como o texto bíblico da primeira epístola de Paulo aos coríntios, "Todas as coisas me são lícitas, mas nem todas as coisas convêm; todas as coisas me são lícitas, mas nem todas as coisas edificam." (I Coríntios, 10:23).

${ }_{1788}$ REY MARTÍNEZ, Fernando. Eutanasia y Derechos Fundamentales. Madrid: Centro de Estúdios Políticos Y Constitucionales, 2008, p. 88.
} 
(ou do feto perfeito!), na medida em que o direito fundamental da mulher de dispor de seu corpo seria mais importante do que qualquer direito de proteção que o feto pudesse ter.

No julgamento da ADPF 54, nenhum Ministro optou de modo claro por este modelo de interpretação constitucional, nem mesmo as Ministras.

\subsection{O MODELO DE INTERPRETAÇÃO CONSTITUCIONAL DO ABORTO DO FETO ANENCÉFALO COMO LIBERDADE LIMITADA}

O terceiro modelo, denominado modelo da liberdade limitada, considera o aborto como liberdade constitucional que pode ser legislativamente limitada, configurando, de certo modo, uma subespécie do segundo modelo, que parte da liberdade como direito fundamental prevalente. Porém, este modelo é mais rigorosamente articulado tecnicamente, e não aceita a liberdade de abortar da mulher como absoluta, admitindo-lhe possíveis limites implementáveis através da lei. E, no entanto, tal lei não poderia restringir o direito da mulher arbitrariamente.

Neste modelo, não se deduz da Constituição um direito ao aborto, mas a cláusula geral de liberdade ampara muitas condutas que não receberam expressa proteção como direitos fundamentais, e proíbe o poder público de impor limitações irrazoáveis, arbitrárias e irracionais $^{1789}$.

Neste contexto, depreender-se-ia do direito fundamental à liberdade um direito constitucionalmente protegido ao aborto em geral, e ao aborto do feto anencéfalo em particular, e simplesmente proibir-se o aborto em qualquer circunstância seria inconstitucional porque caracterizaria uma restrição arbitrária à liberdade.

No entanto, uma proibição que não caracterizasse tal restrição arbitrária, seria constitucionalmente aceitável - mas dependeria da ação do legislador. Ou seja, para este modelo de interpretação, a Constituição seria a priori permissiva quanto a qualquer forma de aborto, até que a lei o proibisse de modo que não fosse arbitrário. Parece-nos que a Constituição dos Estados Unidos tem sido interpretada conforme este modelo.

Neste contexto, vê-se que proibir o aborto do feto anencéfalo seria um verdadeiro desafio ao legislador, em vista da premissa de que a Constituição privilegiaria a liberdade da

\footnotetext{
${ }^{1789}$ REY MARTÍNEZ, Fernando. Eutanasia y Derechos Fundamentales. Madrid: Centro de Estúdios Políticos
} Y Constitucionales, 2008, p. 86. 
mulher, e, portanto, o legislador, se quisesse realmente proibir o aborto do feto anencéfalo, teria que apresentar uma mui persuasiva fundamentação para justificar tal restrição à liberdade da gestante.

Em conclusão, segundo este modelo de interpretação, o legislador poderia, atendendo a interesses públicos, limitar a liberdade constitucional ao aborto, inclusive ao aborto do feto anencéfalo, mas a condição para se entender a constitucionalidade dessa limitação seria sua razoabilidade. Limitações irrazoáveis, arbitrárias e irracionais seriam inconstitucionais.

Nenhum dos votos dos Ministros do STF na ADPF 54 foi total e consistentemente articulado a partir deste modelo de interpretação constitucional. No entanto, a argumentação de que a liberdade só poderia ser restringida em vista de fundamentos importantes foi usada em partes de diversos votos. Neste sentido, Marco Aurélio defendeu a necessidade de se analisar se "há justificativa para a lei compelir a mulher a manter a gestação quando ausente a expectativa de vida para o feto" ${ }^{\text {1790, }}$, e que cabe à mulher decidir sobre a manutenção ou não da gravidez de feto anencéfalo no exercício de seu direito à privacidade ${ }^{1791}$. Também Rosa Weber mencionou em seu voto que uma proibição a se abortar o feto anencéfalo violaria a liberdade de escolha da gestante ${ }^{1792}$, e Joaquim Barbosa entendeu que deve ser garantido o exercício dos direitos reprodutivos ligados à liberdade e autodeterminação da mulher ${ }^{1793}$.

\subsection{O MODELO DE INTERPRETAÇÃO CONSTITUCIONAL DA EXCEÇÃO PERMITIDA AO ABORTO DO FETO ANENCÉFALO}

O quarto e último modelo de interpretação constitucional - o modelo da exceção permitida - entenderia que o aborto constitui uma exceção legítima à proteção geral do Estado à vida sob certas condições.

\footnotetext{
${ }^{1790}$ Arguição de Descumprimento de Preceito Fundamental no 54-8. Voto do Ministro Relator Marco Aurélio. Disponível em: <http://www.stf.jus.br/arquivo/cms/noticiaNoticiaStf/anexo/ADPF54.pdf>. Acesso em: 16 abr. 2012, p. 33.

${ }^{1791}$ Arguição de Descumprimento de Preceito Fundamental n ${ }^{\circ}$ 54-8. Voto do Ministro Relator Marco Aurélio. Disponível em: <http://www.stf.jus.br/arquivo/cms/noticiaNoticiaStf/anexo/ADPF54.pdf>. Acesso em: 16 abr. 2012, p. 76.

1792 Arguição de Descumprimento de Preceito Fundamental n ${ }^{\circ}$ 54-8. Voto lido em plenário pela Ministra Rosa Weber. Disponível em: <http://www.youtube.com/watch?v=E2js96aasjY\&feature=BFa\&list=PL7655E B015996CBBE> . Acesso em: 27 abr. 2012 (0:58:00-0:58:04).

1793 GOMES, JOAQUIM BARBOSA. Voto proferido pelo Ministro Joaquim Barbosa Gomes HC $\mathrm{n}^{\circ}$ 84.025/2004. In: SARMENTO, Daniel; PIOVESAN, Flávia (coordenadores). Nos Limites da Vida. Rio de Janeiro: Lúmen Júris, 2006, p. 87-88.
} 
Assim como no modelo de interpretação anterior, seria aceitável o aborto, e a descriminalização ocorreria sob certas condições. No entanto, este modelo se alicerça em bases teóricas distintas do modelo anterior ${ }^{1794}$ : O terceiro modelo, do aborto do feto anencéfalo como liberdade limitável, se origina de uma concepção ideológica que é favorável ao fenômeno da liberdade; por outro lado, este quarto modelo entende que o aborto é uma exceção ao direito à vida, e, por isso, apesar de permitido, deve ser interpretado restritivamente.

Em outras palavras, no modelo da exceção permitida, o direito à vida em geral é a regra, mas, excepcionalmente, ele pode ser limitado, sendo que as exceções ao direito geral devem, por sua vez, ser interpretadas restritivamente.

E, no entanto, isso não quer dizer que essas exceções possam ser, por sua vez, interpretadas restritivamente de modo arbitrário. Também neste modelo de interpretação constitucional, apesar da primazia geral do direito à vida, o legislador e o intérprete do direito não gozam de uma liberdade absoluta para restringir a liberdade das pessoas, pois, sempre que a liberdade individual for restringida, será preciso que a restrição se fundamente nos princípios da adequação, da necessidade e da proporcionalidade em sentido estrito, a fim de se evitar com isso arbitrariedades por parte do estado ${ }^{1795}$.

Os Ministros do STF, no julgamento de mérito da ADPF 54, parecem, de um modo geral, ter partido da primazia do direito à vida, para então o relativizar no conflito com outros direitos. No entanto, com a exceção de Peluso, nenhum Ministro defendeu expressamente a primazia da vida em seu voto. A posição de destaque a que foi alçado o direito à vida decorre

\footnotetext{
${ }^{1794}$ REY MARTÍNEZ, Fernando. Eutanasia y Derechos Fundamentales. Madrid: Centro de Estúdios Políticos Y Constitucionales, 2008, p. 87.

1795 No mesmo sentido em relação à eutanásia em face da Constituição Espanhola, ver REY MARTÍNEZ, Fernando. Eutanasia y Derechos Fundamentales. Madrid: Centro de Estúdios Políticos Y Constitucionales, 2008 , p. 166. A respeito da possibilidade de aplicar a regra da proporcionalidade, vide item 4.3.2. Além disso, na ADI 3510-0, o Ministro Gilmar Mendes explica que na doutrina alemã, "o ato não será adequado quando não proteja o direito fundamental de maneira ótima; não será necessário na hipótese de existirem medidas alternativas que favoreçam ainda mais a realização do direito fundamental; e violará o subprincípio da proporcionalidade em sentido estrito se o grau de satisfação do fim legislativo é inferior ao grau em que não se realiza o direito fundamental de proteção". Essa descrição refere-se ao princípio da proporcionalidade de excesso. Já o princípio da proporcionalidade como proibição de proteção deficiente refere-se à obrigação de o Estado tomar as medidas legais e materiais para efetivar a proteção adequada. Para o Ministro, no caso das células-tronco, a lei de biossegurança não estaria de acordo com esse último princípio. Ação Declaratória de Inconstitucionalidade (ADI 3510-0), p. 14-15. Disponível em: 〈http://www.stf.jus.br〉. Acesso em: 10 jan. 2012. Também no voto proferido na ADI 3510-0, a Ministra Ellen Gracie afirma que não há ofensa à vida ou à dignidade humana na utilização de "pré-embriões inviáveis ou congelados" Para ela, a Lei de Biossegurnaça trata do pré-embrião, ou seja, uma "massa indiferenciada de células da qual um ser humano pode ou não emergir", e não do conceito de embrião propriamente dito, isto é, uma "unidade biológica detentora de vida humana individualizada", que surge após o $14^{\circ}$ dia. Por fim, a Ministra destaca buscar o "resultado de maior alcance com o mínimo de sacrifício possível", de modo que seria melhor aproveitar a utilidade dos embriões do que simplesmente descartá-los. Ação Declaratória de Inconstitucionalidade (ADI 3510-0), p. 3 e 6. Disponível em: 〈http://www.stf.jus.br>. Acesso em: 10 jan. 2012.
} 
da leitura completa dos votos dos Ministros, que, implicitamente, reconhecem sua primazia ao contrapô-lo com os outros direitos em conflito, e, inclusive, a fim de justificar sua relativização, chegam a negar que o conceito jurídico de vida se aplique ao feto anencéfalo.

Neste sentido, apesar de defender que não existiria hierarquia do direito à vida em relação aos demais direitos fundamentais ${ }^{1796}$, o Ministro Marco Aurélio parece reconhecer, ainda que indiretamente, a primazia do direito à vida, procurando, para resolver o caso, afastar sua aplicabilidade ${ }^{1797}$, argumentando que não há vida ${ }^{1798}$ e nem mesmo vida em potencial ${ }^{1799}$ no feto anencéfalo, sendo que o próprio Conselho Federal de Medicina considerou o anencéfalo natimorto $^{1800}$.

Também Rosa Weber parece partir da primazia da vida ao analisar a possibilidade do aborto do feto anencéfalo. Defende a Ministra que, para ser tutelado, o organismo deve ter condições de ser pessoa, possuindo o mínimo intrínseco das capacidades humanas ${ }^{1801}$, e que é essa a vida protegida pela Constituição ${ }^{1802}$, de modo que, para ela, a anencefalia não seria sequer compatível com o conceito de aborto ${ }^{1803}$, pois, para caracterizá-lo, seria necessário que houvesse também vida neste sentido ${ }^{1804}$, o que não ocorre no feto anencéfalo.

\footnotetext{
1796 Arguição de Descumprimento de Preceito Fundamental no 54-8. Voto do Ministro Relator Marco Aurélio. Disponível em: <http://www.stf.jus.br/arquivo/cms/noticiaNoticiaStf/anexo/ADPF54.pdf>. Acesso em: 16 abr. 2012, p. 65-66.

1797 Arguição de Descumprimento de Preceito Fundamental no 54-8. Voto do Ministro Relator Marco Aurélio. Disponível em: <http://www.stf.jus.br/arquivo/cms/noticiaNoticiaStf/anexo/ADPF54.pdf>. Acesso em: 16 abr. 2012, p. 60.

1798 Arguição de Descumprimento de Preceito Fundamental n ${ }^{\circ}$ 54-8. Voto do Ministro Relator Marco Aurélio. Disponível em: <http://www.stf.jus.br/arquivo/cms/noticiaNoticiaStf/anexo/ADPF54.pdf>. Acesso em: 16 abr. 2012, p. 53.

1799 Arguição de Descumprimento de Preceito Fundamental no 54-8. Voto do Ministro Relator Marco Aurélio. Disponível em: <http://www.stf.jus.br/arquivo/cms/noticiaNoticiaStf/anexo/ADPF54.pdf>. Acesso em: 16 abr. 2012, p. 60.

1800 Arguição de Descumprimento de Preceito Fundamental n ${ }^{\circ}$ 54-8. Voto do Ministro Relator Marco Aurélio. Disponível em: <http://www.stf.jus.br/arquivo/cms/noticiaNoticiaStf/anexo/ADPF54.pdf>. Acesso em: 16 abr. 2012, p. 50.

${ }^{1801}$ Arguição de Descumprimento de Preceito Fundamental no 54-8. Voto lido em plenário pela Ministra Rosa Weber. Disponível em: <http://www.youtube.com/watch?v=E2js96aasjY\&feature=BFa\&list=PL7655E B015996CBBE> . Acesso em: 27 abr. 2012 (0:52:15-0:55:35).

${ }_{1802}$ Arguição de Descumprimento de Preceito Fundamental no 54-8. Voto lido em plenário pela Ministra Rosa Weber. Disponível em: <http://www.youtube.com/watch?v=E2js96aasjY\&feature=BFa\&list=PL7655E B015996CBBE> . Acesso em: 27 abr. 2012 (0:57:05).

${ }^{1803}$ Arguição de Descumprimento de Preceito Fundamental n ${ }^{\circ}$ 54-8. Voto lido em plenário pela Ministra Rosa Weber. Disponível em: <http://www.youtube.com/watch?v=E2js96aasjY\&feature=BFa\&list=PL7655E B015996CBBE> . Acesso em: 27 abr. 2012 (0:56:34-0:56:37).

${ }^{1804}$ Arguição de Descumprimento de Preceito Fundamental n ${ }^{\circ}$ 54-8. Voto lido em plenário pela Ministra Rosa Weber. Disponível em: <http://www.youtube.com/watch?v=E2js96aasjY\&feature=BFa\&list=PL7655E B015996CBBE> . Acesso em: 27 abr. 2012 (0:56:38-0:57:15).
} 
Joaquim Barbosa também parece ter reconhecido a primazia do direito à vida em relação aos outros direitos, mas entendeu que há graus de proteção da vida ${ }^{1805}$, concluindo que o feto anencéfalo, apesar de biologicamente vivo, não encontraria amparo jurídico em decorrência da precariedade de sua condição ${ }^{1806}$.

Cármen Lúcia mais claramente parece partir da primazia do direito à vida no estado de direito, ao afirmar, logo de início, que, independentemente de ser favorável ou não ao aborto do feto anencéfalo, todos prezam a vida, e que a vida "impõe respeito" em uma democracia ${ }^{1807}$, para, posteriormente, relativizar o direito à vida de acordo com os conceitos “de vida e da própria vida" ${ }^{1808}$, conforme a Constituição ${ }^{1809}$, levando-se em conta no caso em tela que o feto anencéfalo "não tem perspectiva de vida" 1810 .

Ayres Britto também parece acolher a primazia da vida, ainda que indiretamente, para justificar seu voto no sentido de que não há crime de aborto se o feto for "natimorto cerebral" ${ }^{1811}$. Para o Ministro, ainda que a vida goze de proteção, o feto anencéfalo seria um "ser sem viabilidade vital" ${ }^{\text {"1812, }}$ e, portanto, não existiria no feto "uma pessoa humana [...] no sentido biográfico"1813, o que justificaria que seu direito à vida fosse relativizado.

Também Celso de Mello, apesar do destaque dado em seu voto aos direitos da mulher, seu direito reprodutivo, direito à liberdade, autodeterminação, dignidade, autonomia pessoal e

1805 GOMES, JOAQUIM BARBOSA. Voto proferido pelo Ministro Joaquim Barbosa Gomes HC $\mathrm{n}^{\circ}$ 84.025/2004. In: SARMENTO, Daniel; PIOVESAN, Flávia (coordenadores). Nos Limites da Vida. Rio de Janeiro: Lúmen Júris, 2006, p. 90.

1806 GOMES, JOAQUIM BARBOSA. Voto proferido pelo Ministro Joaquim Barbosa Gomes HC $\mathrm{n}^{\circ}$ 84.025/2004. In: SARMENTO, Daniel; PIOVESAN, Flávia (coordenadores). Nos Limites da Vida. Rio de Janeiro: Lúmen Júris, 2006, p. 90-91.

${ }^{1807}$ Arguição de Descumprimento de Preceito Fundamental no 54-8. Voto lido em plenário pela Ministra Cármen Lúcia. Disponível em: <http://www.youtube.com/watch?v=E2js96aasjY\&list=PL7655EB015996CBBE\&index= 2\&feature=plpp_video $>$. Acesso em: 25 abr. 2012 (2:18:52).

${ }^{1808}$ Arguição de Descumprimento de Preceito Fundamental n ${ }^{\circ}$ 54-8. Voto lido em plenário pela Ministra Cármen Lúcia. Disponível em: <http://www.youtube.com/watch?v=E2js96aasjY\&list=PL7655EB015996CBBE\&index= 2\&feature=plpp_video $>$. Acesso em: 25 abr. 2012 (2:07:19).

${ }^{1809}$ Arguição de Descumprimento de Preceito Fundamental no 54-8. Voto lido em plenário pela Ministra Cármen Lúcia. Disponível em: <http://www.youtube.com/watch?v=E2js96aasjY\&list=PL7655EB015996CBBE\&index= 2\&feature=plpp_video $>$. Acesso em: 25 abr. 2012 (2:07:49-2:07:51).

${ }^{1810}$ Arguição de Descumprimento de Preceito Fundamental no $54-8$. Voto lido em plenário pela Ministra Cármen Lúcia. Disponível em: <http://www.youtube.com/watch?v=E2js96aasjY\&list=PL7655EB015996CBBE\&index= 2\&feature=plpp_video $>$. Acesso em: 25 abr. 2012 (2:18:56).

${ }^{1811}$ Arguição de Descumprimento de Preceito Fundamental no 54-8. Voto lido em plenário pelo Ministro Ayres Brito. Disponível em: <http://www.youtube.com/watch? $\mathrm{v}=\mathrm{WXtDpv} 2 \mathrm{VzmU} \&$ feature=autoplay\&list =PLF21CD375773F508D\&playnext=1>. Acesso em: 30 abr. 2012. (0:22:11-0:22:34).

${ }_{1812}$ Arguição de Descumprimento de Preceito Fundamental $n^{\circ}$ 54-8. Voto lido em plenário pelo Ministro Ayres Brito. Disponível em: <http://www.youtube.com/watch?v=WXtDpv2VzmU\&feature=autoplay\&list =PLF21CD375773F508D\&playnext=1>. Acesso em: 30 abr. 2012. (0:22:35-0:22:39).

${ }^{1813}$ Arguição de Descumprimento de Preceito Fundamental $n^{\circ}$ 54-8. Voto lido em plenário pelo Ministro Ayres Brito. Disponível em: <http://www.youtube.com/watch?v=WXtDpv2VzmU\&feature=autoplay\&list =PLF21CD375773F508D\&playnext=1>. Acesso em: 30 abr. 2012. (0:23:18-0:23:22). 
intimidade ${ }^{1814}$, ressaltou a sacralidade e inviolabilidade do direito à vida ${ }^{1815}$, alçando-o a condição privilegiada em relação aos outros direitos, destacando o valor da pessoa humana e a sua dignidade como valores fundantes do estado ${ }^{1816}$, e concluiu que o feto anencéfalo não estaria vivo no sentido jurídido e que, portanto, uma vez que não há vida a ser protegida, nada justificaria a limitação dos direitos da mulher ${ }^{1817}$.

A argumentação dos votos de Cármen Lúcia e Celso de Mello brevemente comentada acima nos parece particularmente importante por deixar claro o padrão de argumentação que encontramos nos votos da maioria dos Ministros: De um modo geral, eles implicitamente reconhecem a primazia do direito à vida sobre os demais direitos constitucionais, e sentem a necessidade de relativizá-lo no conflito com os outros direitos envolvidos no caso do anencéfalo. Porém, o direito à vida é tão poderoso, que é preciso justificar muito bem sua relativização, mesmo em face de outros direitos absolutamente fundamentais, como são a liberdade, a autodeterminação, a dignidade, e o direito à saúde. Assim, o argumento de que o feto anencéfalo não teria vida no sentido jurídico passa a ser utilizado seguidamente pelos Ministros que, deste modo, afastam sua aplicabilidade ao caso sem realmente sopesar e ponderar os direitos em jogo. O que, no entanto, deixa patente a primazia do direito à vida no modelo brasileiro de interpretação constitucional - tão importante é o direito à vida, que o principal modo de "relativizá-lo" encontrado pelos Ministros é negar a própria existência da vida (jurídica) do anencéfalo.

Tornaremos a analisar os principais argumentos usados na ADPF 54 com relação ao modelo de interpretação constitucional adotado no Brasil pelo STF sobre o aborto do feto anencéfalo de modo mais sistematizado no capítulo 2.3, abaixo.

\footnotetext{
1814 BRASIL. Supremo Tribunal Federal. Arguição de Descumprimento de Preceito Fundamental $\mathrm{n}^{\circ}$ 54-8. Voto lido em plenário pelo Ministro Celso de Mello. Disponível em: $<$ http://www.youtube.com/watch?v=WXtDpv2VzmU\&feature=autoplay\&list $=$ PLF21CD375773F508D\&playnext=1>. Acesso em: 30 abr. 2012 (2:15:20-2:16:13).

${ }^{1815}$ Arguição de Descumprimento de Preceito Fundamental no 54-8. Voto lido em plenário pelo Ministro Celso de Mello. Disponível em: <http://www.youtube.com/watch?v=WXtDpv2VzmU\&feature=autoplay\&list =PLF21CD375773F508D\&playnext=1>. Acesso em: 30 abr. 2012 (2:32:22-2:32:28).

${ }^{1816}$ Arguição de Descumprimento de Preceito Fundamental $n^{\circ}$ 54-8. Voto lido em plenário pelo Ministro Celso de Mello. Disponível em: <http://www.youtube.com/watch?v=WXtDpv2VzmU\&feature=autoplay\&list $=$ PLF21CD375773F508D\&playnext=1>. Acesso em: 30 abr. 2012 (2:32:44-2:33:20).

${ }^{1817}$ Arguição de Descumprimento de Preceito Fundamental $n^{\circ}$ 54-8. Voto lido em plenário pelo Ministro Celso de Mello. Disponível em: <http://www.youtube.com/watch?v=WXtDpv2VzmU\&feature=autoplay\&list $=$ PLF21CD375773F508D\&playnext=1>. Acesso em: 30 abr. 2012 (2:19:40-2:20:07).
} 


\section{O MODELO DE INTERPRETAÇÃO CONSTITUCIONAL MAIS ADEQUADO À REALIDADE JURÍDICA BRASILEIRA: UMA TENTATIVA DE DEFINIÇÃO}

\subsection{MODELOS A PRIORI INADEQUADOS À REALIDADE JURÍDICA ATUAL DO BRASIL}

Apesar de que em tese os quatro modelos de interpretação constitucional propostos seriam possíveis, podemos dizer que, no direito brasileiro atual, a priori, o aborto claramente não é totalmente proibido, pois, como vimos, existem hipóteses legais permitindo sua prática, inclusive o caso analisado neste trabalho, o da gestação de feto anencéfalo ${ }^{1818}$ - apesar de que a argumentação do Ministro Peluso na $\mathrm{ADPF} 54$, de que o direito à vida não poderia ser relativizado $^{1819}$, possa sugerir o contrário.

Nosso direito, por outro lado, tampouco ampara o aborto de forma geralizada - ao contrário, também como já analisado, a regra geral de nosso sistema é a de que o aborto é proibido, ainda que não absolutamente ${ }^{1820}$.

A posição brasileira está, pois, em algum ponto intermediário deste continuum, cujos extremos são, de um lado, a proibição do aborto, e, do outro, sua autorização - ambas, $\operatorname{absolutas}^{1821}$.

Em vista desses fatos, descartamos, pois, a possibilidade de que o modelo de interpretação constitucional brasileiro a ser adotado venha a ser o da proibição absoluta ou o da livre disposição, e enfocaremos, então, nossa análise, nos dois modelos restantes: O da liberdade limitada e o da exceção permitida.

A fim de procurar melhor identificar qual desses dois modelos de interpretação constitucional seria mais adequado à realidade brasileira, passamos, a seguir, a revisar os

\footnotetext{
${ }^{1818}$ Vide especiamente capítulo 3.4.2 da primeira parte deste trabalho.

1819 Arguição de Descumprimento de Preceito Fundamental no 54-8. Voto lido em plenário pelo Ministro Cezar Peluso. Disponível em: <http://www.youtube.com/watch?v=1Bh_d4D56jI\&list=PLF21CD375773F508D \&index=1\&feature=plpp_video $>$. Acesso em: 30 abr. 2012 (1:30:34-1:30:42).

${ }^{1820}$ Vide especialmente o capítulo 1 da terceira parte deste trabalho.

${ }^{1821}$ Entende Luísa Neto, analisando o tema em relação a Portugal, que, no caso do aborto, também não existe em seu país uma "proibição total ao aborto", nem um "reconhecimento constitucional de um direito ao aborto". In NETO, Luísa. O direito fundamental à disposição do próprio corpo (a relevância da vontade na configuração do seu regime). Coimbra: Coimbra Editora, 2004, p. 450.
} 
argumentos indicados pelo Supremo Tribunal Federal sobre o tema ${ }^{1822}$, tendo como base, principalmente, os votos dos Ministros na decisão da ADPF 54 e em sua liminar, já amplamente analisadas neste trabalho ${ }^{1823}$; e os votos dos Ministros na Ação Declaratória de Inconstitucionalidade (ADI) 3510-0, que também já foi julgada pelo STF, e que versou sobre a possibilidade de pesquisas com células-tronco, assunto que traz muitas analogias válidas para o caso do aborto do feto anencéfalo. Em nossa análise, levaremos em conta também, sempre que necessário, os principais argumentos doutrinários aplicáveis.

Vale dizer que o modo de atuação do STF não permite uma opção clara por um dos modelos sugeridos. Como afirma Conrado Hübner Mendes, é difícil encontrar uma posição que se possa atribuir ao Supremo Tribunal Federal, cujas decisões correspondem a "um diálogo de surdos"1824. Para Hübner, os votos dos Ministros "nem sequer conversam entre si", impedindo uma "opinião institucional coesa", capaz de orientar e fortalecer "a linguagem dos direitos fundamentais" $" 1825$.

Por essa razão, nos resta a tentativa de buscar nos argumentos isolados dos Ministros um caminho que nos leve em direção a um dos modelos interpretativos propostos, e que nos permita identificar o que chamaremos de interpretação brasileira.

\subsection{O FETO ANENCÉFALO E O PAPEL DO JUDICIÁRIO}

Antes de partir propriamente para a análise de qual dos modelos de interpretação constitucional seria mais adequado ao Brasil, gostaríamos de, brevemente, discutir o papel do Judiciário em face dos desafios trazidos pelo mundo moderno, o avanço da ciência, e as espectativas da sociedade.

Como o Ministro Sepúlveda Pertence nos lembrou em seu voto da liminar da ADPF 54, novas interpretações judiciais podem surgir a partir de novos conhecimentos científicos, e

\footnotetext{
${ }^{1822}$ Como afirma Dworkin, não se busca uniformidade, mas a integridade do direito nas decisões tomadas pelos juízes. DWORKIN, Ronald. Domínio da Vida: aborto, eutanásia e liberdades individuais. Trad. Jefferson Luiz Camargo; rev. da tradução Silvana Vieira. São Paulo: Martins Fontes, 2003, p. 204-205.

${ }^{1823}$ E alguns argumentos desenvolvidos na ADI 3510 que podem servir de parâmetro. O Supremo Tribunal Federal enfrentou a questão proferindo sua decisão em maio de 2008, aprovando o uso de células-tronco embrionárias nas pesquisas científicas e declarando, assim, constitucional o artigo $5^{\circ}$ da Lei 11.105/05. Disponível em: 〈http://www.stf.jus.br〉. Acesso em: 10 jan. 2012.

${ }^{1824}$ HÜBNER MENDES, Conrado. Onze Ilhas. Disponível em: <http://www.osconstitucionalistas.com.br/onzeilhas >. Acesso em: 5 jun. 2012.

${ }^{1825}$ HÜBNER MENDES, Conrado. Onze Ilhas. Disponível em: <http://www.osconstitucionalistas.com.br/onzeilhas >. Acesso em: 5 jun. 2012.
} 
o que era indiscutível até então, pode ser reanalisado através de um novo olhar ${ }^{1826}$. O problema do feto anencéfalo é um exemplo disso, já que seu dignóstico só é possível hoje graças ao avanço constante da medicina e das ciências.

Por sua vez, especificamente com relação ao feto anencéfalo, alerta o Ministro Joaquim Barbosa que a violação ao direito da mulher é patente, e a existência de inúmeras decisões contraditórias acaba por violar mais ainda o direito da gestante ${ }^{1827}$. Qual o papel do Judiciário em vista deste desafio?

Entendeu o Ministro que a ADPF não deveria buscar uma interpretação conforme ${ }^{1828}$ ou a "declaração de constitucionalidade sob reserva de interpretação" ${ }^{1829}$, que seria uma das formas em que se pode obter uma manifestação do órgão de cúpula ${ }^{1830}$.

No entanto, entendeu ele também que a ADPF deve ser compreendida como um mecanismo de "alargamento da ação protetiva dos direitos fundamentais" "1831, em defesa dos mais vulneráveis ${ }^{1832}$.

Mas será isso mesmo? Para responder essa questão, é preciso ter em mente qual o papel desempenhado pelo Supremo Tribunal Federal hoje na sociedade, já que, como afirmam

${ }^{1826}$ BRASIL. Supremo Tribunal Federal. Arguição de Descumprimento de Preceito Fundamental $\mathrm{n}^{\circ}$ 54-8. Medida Cautelar. Tribunal do Pleno. Julgamento em 20 out. 2004, p. 8, fl. 234. Disponível em: <http://www.stf.jus.br>. Acesso em: 10 jan. 2012. Disponível em: <http://redir.stf.jus.br/paginadorpub/ paginador.jsp?docTP=AC\&docID=484300>. Acesso em: 10 jan. 2012.

${ }_{1827}$ BRASIL. Supremo Tribunal Federal. Arguição de Descumprimento de Preceito Fundamental $\mathrm{n}^{\circ}$ 54-8. Medida Cautelar. Tribunal do Pleno. Julgamento em 20 out. 2004, p. 3-4, fl. 142-143. Disponível em: <http://www.stf.jus.br>. Acesso em: 10 jan. 2012.

1828 BRASIL. Supremo Tribunal Federal. Arguição de Descumprimento de Preceito Fundamental $\mathrm{n}^{\circ}$ 54-8. Medida Cautelar. Tribunal do Pleno. Julgamento em 20 out. 2004, p. 2, fl. 141. Disponível em: <http://www.stf.jus.br>. Acesso em: 10 jan. 2012. Disponível em: <http://redir.stf.jus.br/paginadorpub/ paginador.jsp?docTP=AC\&docID=484300> Acesso em: 10 jan. 2012.

${ }_{1829}$ BRASIL. Supremo Tribunal Federal. Arguição de Descumprimento de Preceito Fundamental $\mathrm{n}^{\circ}$ 54-8. Medida Cautelar. Tribunal do Pleno. Julgamento em 20 out. 2004, p. 3, fl. 142. Disponível em: <http://www.stf.jus.br>. Acesso em: 10 jan. 2012.

Disponível em: <http://redir.stf.jus.br/paginadorpub/ paginador.jsp?docTP=AC\&docID=484300>. Acesso em: 10 jan. 2012.

${ }^{1830}$ BRASIL. Supremo Tribunal Federal. Arguição de Descumprimento de Preceito Fundamental $\mathrm{n}^{\circ}$ 54-8. Medida Cautelar. Tribunal do Pleno. Julgamento em 20 out. 2004, p. 3, fl. 142. Disponível em: <http://www.stf.jus.br>. Acesso em: 10 jan. 2012.

Disponível em: <http://redir.stf.jus.br/paginadorpub/ paginador.jsp?docTP=AC\&docID=484300>. Acesso em: 10 jan. 2012.

${ }_{1831}$ BRASIL. Supremo Tribunal Federal. Arguição de Descumprimento de Preceito Fundamental $\mathrm{n}^{\circ}$ 54-8. Medida Cautelar. Tribunal do Pleno. Julgamento em 20 out. 2004, p. 8, fl. 147. Disponível em: <http://www.stf.jus.br>. Acesso em: 10 jan. 2012.

Disponível em: <http://redir.stf.jus.br/paginadorpub/ paginador.jsp?docTP=AC\&docID=484300>. Acesso em: 10 jan. 2012.

${ }^{1832}$ BRASIL. Supremo Tribunal Federal. Arguição de Descumprimento de Preceito Fundamental $\mathrm{n}^{\circ}$ 54-8. Medida Cautelar. Tribunal do Pleno. Julgamento em 20 out. 2004, p. 8, fl. 147. Disponível em: <http://www.stf.jus.br>. Acesso em: 10 jan. 2012.

Disponível em: <http://redir.stf.jus.br/paginadorpub/ paginador.jsp?docTP=AC\&docID=484300>. Acesso em: 10 jan. 2012. 
Flávia Piovesan e Tamara Amoroso Gonçalves, a "arena jurisdicional"1833 tem sido o verdadeiro "foco" das estratégias dos movimentos sociais feministas ${ }^{1834}$, e não mais o Executivo e o Legislativo.

Na opinião de Piovesan e Amoroso Gonçalves, o papel das Cortes Constitucionais seria o de desenvolver "a cultura e a consciência de direitos e a supremacia constitucional, tendo seus julgados o impacto de transformar legislações e políticas públicas, contribuindo para o avanço na proteção dos direitos humanos"1835.

Alexandre de Moraes, por sua vez, entende que o Poder Judiciário pode interferir ${ }^{1836}$, excepcionalmente e de forma "minimalista" por meio de método de interpretação ampliativa, denominada de ativismo judicial ${ }^{1837}$, quando se verificar a "gravidade dos casos concretos colocados e em defesa da supremacia dos direitos fundamentais" ${ }^{1838}$. Destaca Moraes que,

1833 PIOVESAN, Flávia; GONÇALVES, Tamara Amoroso. Gênero no Supremo Tribunal Federal. In: SARMENTO, Daniel e SARLET, Ingo Wolfgang (coords). Direitos Fundamentais no Supremo Tribunal Federal: Balanço e Crítica, p. 389.

1834 PIOVESAN, Flávia; GONÇALVES, Tamara Amoroso. Gênero no Supremo Tribunal Federal. In: SARMENTO, Daniel e SARLET, Ingo Wolfgang (coords). Direitos Fundamentais no Supremo Tribunal Federal: Balanço e Crítica, p. 389.

1835 PIOVESAN, Flávia; GONÇALVES, Tamara Amoroso. Gênero no Supremo Tribunal Federal. In: SARMENTO, Daniel e SARLET, Ingo Wolfgang (coords). Direitos Fundamentais no Supremo Tribunal Federal: Balanço e Crítica, p. 390.

${ }^{1836}$ Afirma Alexandre de Moraes que com o "fortalecimento do Poder Judiciário e da Jurisdição Constitucional pela Constituição Federal de 1988, principalmente pelos complexos mecanismos de controle de constitucionalidade e pelo vigor dos efeitos de suas decisões, em especial os efeitos erga omnes e vinculantes, somados à inércia dos Poderes Políticos em efetivar totalmente as normas constitucionais, vem permitindo que novas técnicas interpretativas ampliem a atuação jurisdicional em assuntos tracidionalmente de alçadas dos Poderes Legislativo e Executivo". MORAES, Alexandre de. Direitos Humanos Fundamentais: teoria geral, comentários aos arts. $1^{\circ}$ a $5^{\circ}$ da Constituição Federal da República Federativa do Brasil, doutrina e jurisprudência. 9. ed. São Paulo: Atlas, 2011, p. 39.

1837 Alexandre de Moraes destaca a dificuldade de conceituar a expressão. MORAES, Alexandre de. Direitos Humanos Fundamentais: teoria geral, comentários aos arts. $1^{\circ}$ a $5^{\circ}$ da Constituição Federal da República Federativa do Brasil, doutrina e jurisprudência. 9. ed. São Paulo: Atlas, 2011, p. 39. Luís Roberto Barroso ensina que a judicialização, isto é, a "transferência de poder para juízes e tribunais" para decidir questões de grande "repercussão política ou social" tem três causas principais: a redemocratização do Brasil, abrangência da Constituição Federal e o controle de constitucionalidade brasileiro. BARROSO, Luís Roberto. Judicialização, Ativismo Judicial e Legitimidade Democrática. Disponível em: <http://www.conjur.com.br/2008-dez22/judicializacao_ativismo_legitimidade_democratica>, p. 2-3. Acesso em: 10 jan. 2012. Para o autor, a judicialização e o ativismo judicial são parentes. No entanto, enquanto a judicialização é um "fato que decorre do sistema constitucional adotado pelo Brasil, o ativismo é "uma atitude, a escolha de um modo específico e proativo de interpretar a Constituição, expandindo o seu sentido e alcance. Normalmente ele se instala em situações de retração do Poder Legislativo, de um certo descolamento entre a classe política e a sociedade civil, impedindo que as demandas sociais sejam atendidas de maneira efetiva". BARROSO, Luís Roberto. Judicialização, Ativismo Judicial e Legitimidade Democrática. Disponível em: <http://www.conjur.com.br/2008-dez-22/judicializacao_ativismo_legitimidade_democratica>, p. 5. Acesso em: 10 jan. 2012.

${ }^{1838}$ MORAES, Alexandre de. Direitos Humanos Fundamentais: teoria geral, comentários aos arts. $1^{\circ}$ a $5^{\circ}$ da Constituição Federal da República Federativa do Brasil, doutrina e jurisprudência. 9. ed. São Paulo: Atlas, 2011, p. 41. Para o autor é essencial “o bom-senso entre a 'passividade judicial' e o 'pragmatismo jurídico', entre 'o respeito à tradicional formulação das regras de freios e contrapesos da Separação de Poderes' e 'a necessidade de garantir às normas constitucionais à máxima efetividade"'. Para Alexandre de Moraes, o Supremo deve se valer do ativismo judicial de forma "clara e fundamentada, de maneira a balizar o excessivo subjetivismo, permitindo 
muitos direitos fundamentais foram efetivados por meio dessa prática. Dentre eles, por exemplo, "o reconhecimento do direito constitucional ao aborto, como projeção do direito à privacidade" no caso Roe v. Wade ${ }^{1839}$.

A "face positiva" do ativismo judicial, como ensina Luís Roberto Barroso, é a possibilidade de o Poder Judiciário atender "a demandas da sociedade que não puderam ser satisfeitas pelo parlamento". 1840

Explica Luís Barroso que o Poder Judiciário passa a participar intensamente "na concretização dos valores e fins constitucionais" $" 1841$, o que pode ocorrer: i) aplicando-se a Constituição em casos não contemplados expressamente e sem atuação do legislador; ${ }^{1842}$ ii) declarando-se a inconstitucionalidade de atos normativos fundados "em critérios menos rígidos que os de patente e ostensiva violação da Constituição"1843; e, iii) estabelecendo-se procedimentos ou os recusando, em relação especialmente à políticas públicas ${ }^{1844}$. Destaca Barroso, quanto a esta última conduta do Judiciário, o exemplo de distribuição de medicamentos, em que o juiz age diretamente sobre as politícas, determinando a entrega de

a análise crítica da opção tomada, com o desenvolvimento de técnicas de autocontenção judicial, principalmente, afastando sua aplicação em questões estritamente políticas, e, basicamente, com a utilização minimalista desse método decisório, ou seja, somente interferindo excepcionalmente de forma ativista, mediante a gravidade de casos concretos colocados e em defesa da supremacia dos Direitos Fundamentais". MORAES, Alexandre de. Direitos Humanos Fundamentais: teoria geral, comentários aos arts. $1^{\circ}$ a $5^{\circ}$ da Constituição Federal da República Federativa do Brasil, doutrina e jurisprudência. 9. ed. São Paulo: Atlas, 2011, p. 41. Luís Roberto Barroso explica que "o ativismo judicial, até aqui, tem sido parte da solução, e não do problema. Mas ele é um antibiótico poderoso, cujo uso deve ser eventual e controlado. Em dose excessiva, há risco de se morrer da cura. A expansão do Judiciário não deve desviar a atenção da real disfunção que aflige a democracia brasileira: a crise de representatividade, legitimidade e funcionalidade do Poder Legislativo. Precisamos de reforma política. E essa não pode ser feita por juízes." BARROSO, Luís Roberto. Judicialização, Ativismo Judicial e Legitimidade Democrática. Disponível em: <http://www.conjur.com.br/2008-dez22/judicializacao_ativismo_legitimidade_democratica>, p. 15. Acesso em: 10 jan. 2012.

${ }^{1839}$ MORAES, Alexandre de. Direitos Humanos Fundamentais: teoria geral, comentários aos arts. $1^{\circ}$ a $5^{\circ}$ da Constituição Federal da República Federativa do Brasil, doutrina e jurisprudência. 9.ed. São Paulo: Atlas, 2011, p. 40. Luís Roberto Barroso cita também Brown v. Board of Education, Griswold v. Connecticut, envolvendo negros e direito à privacidade respectivamente, entre outros casos americanos clássicos que inspiraram a prática no Brasil. BARROSO, Luís Roberto. Judicialização, Ativismo Judicial e Legitimidade Democrática. Disponível em: <http://www.conjur.com.br/2008-dez-22/judicializacao_ativismo_legitimidade_democratica〉, p. 5-6. Acesso em: 10 jan. 2012.

${ }^{1840}$ BARROSO, Luís Roberto. Judicialização, Ativismo Judicial e Legitimidade Democrática. Disponível em: <http://www.conjur.com.br/2008-dez-22/judicializacao_ativismo_legitimidade_democratica>, p. 7. Acesso em: 10 jan. 2012.

${ }^{1841}$ BARROSO, Luís Roberto. Judicialização, Ativismo Judicial e Legitimidade Democrática. Disponível em: <http://www.conjur.com.br/2008-dez-22/judicializacao_ativismo_legitimidade_democratica〉, p. 5. Acesso em: 10 jan. 2012.

${ }^{1842}$ BARROSO, Luís Roberto. Judicialização, Ativismo Judicial e Legitimidade Democrática. Disponível em: <http://www.conjur.com.br/2008-dez-22/judicializacao_ativismo_legitimidade_democratica>, p. 5. Acesso em: 10 jan. 2012.

1843 BARROSO, Luís Roberto. Judicialização, Ativismo Judicial e Legitimidade Democrática. Disponível em: <http://www.conjur.com.br/2008-dez-22/judicializacao_ativismo_legitimidade_democratica〉, p. 5. Acesso em: 10 jan. 2012.

${ }^{1844}$ BARROSO, Luís Roberto. Judicialização, Ativismo Judicial e Legitimidade Democrática. Disponível em: <http://www.conjur.com.br/2008-dez-22/judicializacao_ativismo_legitimidade_democratica>, p. 5. Acesso em: 10 jan. 2012. 
medicamentos, terapias, e procedimentos a priori não disponibilizados pelo estado para tratamento de certas doenças, muito embora isso possa comprometer a manutenção de tais políticas públicas ou dos recursos públicos ${ }^{1845}$.

Em sentido contrário ao ativismo judicial, vale lembrar Elival da Silva Ramos, que defende que uma análise das decisões mais recentes do Supremo Tribunal Federal sugere um aumento irrazoável desse ativismo ${ }^{1846}$, em grande parte causado por "ineficiência dos Poderes representativos na adoção das providências normativas adequadas à concretização do projeto social-democrátio desenhado na Carta de $1988^{" 1847}$. Para o autor, o atual ativismo judicial em voga no Brasil, especialmente no STF, leva a uma "principiologização do direito", que "valendo-se dos contornos menos nítidos das normas-princípio e potencializando-lhes os efeitos do que seria lícito fazer" abre "as portas do sistema jurídico ao subjetivismo de decisões judiciais", deixando de "concretizar a Constituição" para "construí-la, ao sabor das preferências axiológicas de seus prolatores" 1848 .

Até o momento, o Projeto de Lei do Senado 50/2011, que descriminaliza o aborto de feto anencéfalo quando precedido de consentimento da gestante (ou de seu representante legal, no caso de gestante incapaz), segue tramitando no Congresso Nacional, mas não tem previsão para ser votado, sendo que, desde 24 de maio último, aguarda a designação de um Relator para a Comissão de Assuntos Sociais do Senado, que deverá revisá-lo ${ }^{1849}$. Mas o fato de não existir claramente uma regulamentação no caso do aborto, não exclui o papel importante que tem sido exercido pelo Poder Judiciário na proteção de direitos fundamentais. Ao contrário, a lacuna na regulamentação ressalta a importância das cortes na análise dos casos concretos, em especial, a do STF.

${ }^{1845}$ BARROSO, Luís Roberto. Judicialização, Ativismo Judicial e Legitimidade Democrática. Disponível em: <http://www.conjur.com.br/2008-dez-22/judicializacao_ativismo_legitimidade_democratica〉, p. 13. Acesso em: 10 jan. 2012. O autor critica os impactos dessas decisões, propondo a cautela contra esses "riscos sistêmicos". BARROSO, Luís Roberto. Judicialização, Ativismo Judicial e Legitimidade Democrática. Disponível em: 〈http://www.conjur.com.br/2008-dez-22/judicializacao_ativismo_legitimidade_democratica〉, p. 13. Acesso em: 10 jan. 2012.

${ }_{1846}$ Marcos Paulo Veríssimo afirma que, embora a competência do Supremo Tribunal originalmente fosse solidificar a interpretação da Constituição como "órgão responsável" pela "guarda da Constituição", tem alcançado papel importante na "política" brasileira, decidindo temas relevantes na seara política, como, por exemplo, a constitutucionalidade da Lei de Biossegurança, debatida na ADI 3.510. VERISSIMO, Marcos Paulo. A constituição de 1988, vinte anos depois: suprema corte e ativismo judicial "à brasileira". Rev. direito GV [online]. 2008, vol.4, n.2, p. 407-440. ISSN 1808-2432, p. 3-4, 6 e 8. O autor analisa estatisticamente o aumento significativo dos julgamentos proferidos pela Corte Constitucional nos últimos anos. A essa atividade incessante do Supremo, o autor denomina "ativismo à brasileira". VERISSIMO, Marcos Paulo. A constituição de 1988, vinte anos depois: suprema corte e ativismo judicial "à brasileira". Rev. direito GV [online]. 2008, vol.4, n.2, pp. 407-440. ISSN 1808-2432, p. 9.

${ }^{1847}$ RAMOS, Elival da Silva. Ativismo Judicial: Parâmetros dogmáticos. São Paulo: Saraiva, 2010, p. 314.

${ }_{1848}$ RAMOS, Elival da Silva. Ativismo Judicial: Parâmetros dogmáticos. São Paulo: Saraiva, 2010, p. 314.

1849 A tramitação do Projeto de Lei do Senado 50/2011 pode ser acompanhada e está disponível em: $\langle$ http://www.senado.gov.br/atividade/materia/detalhes.asp?p_cod_mate=99165>. Acesso em 5 de junho de 2012. 
É interessante lembrar que Dworkin, ao tratar do drama constitucional e as teorias de interpretação da constituição americana, criticou a posição de Scalia de que o direito ao aborto não deveria existir nos Estados Unidos porque não fora expressante escrito na Constituição Americana ${ }^{1850}$. Certamente, a função da mais alta corte de um país precisa ir muito além de ler o que já está explícito na letra da constituição ${ }^{1851}$.

Assim, neste contexto de efetivação dos direitos humanos, devemos repensar esses argumentos a respeito do papel do Judiciário, tanto no caso do aborto do feto anencéfalo, quanto em outros casos envolvendo direitos humanos e fundamentais. Precisamos entender que o Poder Judiciário passou a exercer um papel importante de afirmação dos direitos humanos, inclusive das mulheres ${ }^{1852}$, e que, com base neste novo papel que tem assumido, tem também feito uma nova leitura dos direitos expressamente consagrados pela Constituição, como pudemos ver, inclusive, no julgamento final da ADPF 54.

\subsection{DISCUSSÃO SOBRE DECISÕES E OS PRINCIPAIS MODELOS DE INTERPRETAÇÃO}

Como vimos, é razoavelmente tênue a diferença entre os modelos de interpretação constitucional da liberdade limitada e da exceção permitida ao aborto do feto anencéfalo.

Para distinguir qual modelo melhor se adapta ao Brasil, pergunta-se: É possível depreender-se de nossa Constituição Federal um verdadeiro direito da mulher ao aborto do feto anencéfalo, direito este que decorre de outros direitos, especialmente do direito à liberdade, e não que pode ser limitado de forma arbitrária - ainda que possa ser limitado? Ou o direito à vida em geral é a regra de nossa Constituição Federal, e, apenas excepcionalmente, ele pode ser restringido?

A pergunta encerra a resposta de qual o modelo mais adequado ao Brasil. E, no entanto, chegar a ela é muito difícil, ainda mais se levarmos em conta que, faticamente, ambos

\footnotetext{
${ }^{1850}$ DWORKIN, Ronald. Domínio da Vida: aborto, eutanásia e liberdades individuais. Trad. Jefferson Luiz Camargo; rev. da tradução Silvana Vieira. São Paulo: Martins Fontes, 2003, p. 200.

${ }^{1851}$ DWORKIN, Ronald. Domínio da Vida: aborto, eutanásia e liberdades individuais. Trad. Jefferson Luiz Camargo; rev. da tradução Silvana Vieira. São Paulo: Martins Fontes, 2003, p. 200.

1852 PIOVESAN, Flávia; GONÇALVES, Tamara Amoroso. Gênero no Supremo Tribunal Federal. In: SARMENTO, Daniel e SARLET, Ingo Wolfgang (coords). Direitos Fundamentais no Supremo Tribunal Federal: Balanço e Crítica. p. 390.
} 
modelos provavelmente conduzem o intérprete à mesma conclusão no caso prático - a autorização do aborto do anencéfalo.

Para enfrentar a questão, vejamos os principais argumentos que o STF tem usado com relação ao direito à vida do feto ou embrião humano, e com relação aos direitos que podem com ele colidir.

\subsubsection{Argumentos no sentido de que o direito à vida não é absoluto}

Conforme já exposto neste trabalho, o Ministro Relator Marco Aurélio concedeu a liminar na ADPF 54 levando em conta a existência de risco à vida e à saúde da mulher, além da frustação e dor de se levar a termo uma gestação em que o feto não sobreviverá ${ }^{1853}$, entendendo que a manutenção da gravidez violaria sua integridade moral e psicológica, além da saúde física da mulher ${ }^{1854}$.

Ademais, argumentou Marco Aurélio na decisão da ADPF 54 que, ainda que fosse admitido um direito à vida intrauterina do feto anencéfalo ${ }^{1855}$, esta vida gozaria de uma proteção menos intensa ${ }^{1856}$, uma vez que direito à vida comportaria gradações, posição já adotada pelo Ministro na ADI 3510 e confirmada a partir de suas análises dos casos de aborto e de homicídio, que, para ele, demonstram que a proteção à vida se alarga com o desenvolvimento do indivíduo ${ }^{1857}$.

Admite, portanto, o Ministro, que proibir o aborto da gestação de um feto anencéfalo geraria um conflito com outros direitos e princípios protegidos constitucionalmente, tais

1853 BRASIL. Supremo Tribunal Federal. Arguição de Descumprimento de Preceito Fundamental $n^{\circ}$ 54-8. Decisão Liminar. Relator Ministro Marco Aurélio, p. 2. Disponível em: 〈http://www.stf.jus.br>. Acesso em: 10 jan. 2012.

1854 BRASIL. Supremo Tribunal Federal. Arguição de Descumprimento de Preceito Fundamental no $54-8$. Decisão Liminar. Relator Ministro Marco Aurélio, p. 6. Disponível em: <http://www.stf.jus.br〉. Acesso em: 10 jan. 2012.

${ }_{1855}$ Arguição de Descumprimento de Preceito Fundamental n ${ }^{\circ}$ 54-8. Voto do Ministro Relator Marco Aurélio. Disponível em: <http://www.stf.jus.br/arquivo/cms/noticiaNoticiaStf/anexo/ADPF54.pdf>. Acesso em: 16 abr. 2012, p. 65.

${ }^{1856}$ Arguição de Descumprimento de Preceito Fundamental no 54-8. Voto do Ministro Relator Marco Aurélio. Disponível em: <http://www.stf.jus.br/arquivo/cms/noticiaNoticiaStf/anexo/ADPF54.pdf>. Acesso em: 16 abr. 2012, p. 67.

${ }^{1857}$ Arguição de Descumprimento de Preceito Fundamental no 54-8. Voto do Ministro Relator Marco Aurélio. Disponível em: <http://www.stf.jus.br/arquivo/cms/noticiaNoticiaStf/anexo/ADPF54.pdf>. Acesso em: 16 abr. 2012, p. 66-67. 
como, o princípio da dignidade humana, o direito à liberdade e à autonomia da vontade ${ }^{1858}$. Assim, a proibição ao aborto não pode ser reconhecida como constitucionalmente válida na sua totalidade, de forma absoluta - como já não o é -, pois encontra limites em razão da existência de outros direitos e princípios.

Para corroborar esse entendimento, destacamos também, o voto da Ministra Cármen Lúcia no recente julgamento do STF sobre pesquisa com células-tronco, cujo raciocínio e lógica foram mantidos no voto de mérito da ADPF 54. Defendeu a Ministra no caso da pesquisa com células-tronco que o direito à vida não é absoluto no Brasil, exemplificado na existência da previsão expressa e lícita de aborto em certas circunstâncias ${ }^{1859}$. Para a Ministra, é, pois, necessária a ponderação do direito à vida com os demais direitos constitucionalmente garantidos ${ }^{1860}$. Afirma Cármen Lúcia que "a Constituição garante não apenas o direito à vida, mas assegura a liberdade para que o ser humano dela disponha"1861.

Agregou a Ministra a esse argumento que o princípio da dignidade da pessoa humana transcendeu o indivíduo e "a intangibilidade e a indisponibilidade da vida passaram a considerar cada um e todos" 1862 , já que esse princípio não "permite desconhecer o que a liberdade pode possibilitar em termos de dignificação do homem"1863. E, para ilustrar sua argumentação, invocou a Ministra especificamente o exemplo do aborto conforme disposição do artigo 128, I e II, do Código Penal brasileiro, afirmando que a Constituição Federal somente reconhece a inviolabilidade do direito à vida em análise conjunta com outros direitos fundamentais que o tornam efetivo ${ }^{1864}$. Para Cármen Lúcia, é o viver digno que cabe ao estado oferecer $^{1865}$.

${ }^{1858}$ BRASIL. Supremo Tribunal Federal. Arguição de Descumprimento de Preceito Fundamental $\mathrm{n}^{\circ}$ 54-8. Decisão Liminar. Relator Ministro Marco Aurélio, p. 6. Disponível em: <http://www.stf.jus.br>. Acesso em: 10 jan. 2012.

${ }_{1859}$ BRASIL. Supremo Tribunal Federal. Ação Declaratória de Inconstitucionalidade (ADI 3510-0), p. 14. Disponível em: 〈http://www.stf.jus.br〉. Acesso em: 10 jan. 2012.

${ }_{1860}$ BRASIL. Supremo Tribunal Federal. Ação Declaratória de Inconstitucionalidade (ADI 3510-0), p. 15. Disponível em: 〈http://www.stf.jus.br〉. Acesso em: 10 jan. 2012.Embora a Ministra faça a distinção entre os temas, só o aduz para "demarcar o estatuto jurídico constitucional do direito à vida". Ação Declaratória de Inconstitucionalidade (ADI 3510-0), p.16. Disponível em: 〈http://www.stf.jus.br〉. Acesso em: 10 jan. 2012.

${ }^{1861}$ Afirmando, para tanto, pela liberdade de pesquisa com células-tronco. BRASIL. Supremo Tribunal Federal. Ação Declaratória de Inconstitucionalidade (ADI 3510-0), p.17. Disponível em: <http://www.stf.jus.br>. Acesso em: 10 jan. 2012.

${ }^{1862}$ BRASIL. Supremo Tribunal Federal. Ação Declaratória de Inconstitucionalidade (ADI 3510-0), p. 34-35. Disponível em: <http://www.stf.jus.br>. Acesso em: 10 jan. 2012.

${ }_{1863}$ BRASIL. Supremo Tribunal Federal. Ação Declaratória de Inconstitucionalidade (ADI 3510-0), p. 36. Disponível em: <http://www.stf.jus.br>. Acesso em: 10 jan. 2012.

${ }^{1864}$ BRASIL. Supremo Tribunal Federal. Ação Declaratória de Inconstitucionalidade (ADI 3510-0), p. 16. Disponível em: <http://www.stf.jus.br>. Acesso em: 10 jan. 2012.

${ }_{1865}$ BRASIL. Supremo Tribunal Federal. Ação Declaratória de Inconstitucionalidade (ADI 3510-0), p. 41. Disponível em: <http://www.stf.jus.br>. Acesso em: 10 jan. 2012. 
O Ministro Celso de Mello também defendeu argumento semelhante ao de Cármen Lúcia, ao tratar das células-tronco. Também para o Ministro, o direito à vida não seria absoluto, inexistindo quaisquer dispositivos no direito brasileiro e internacional nesse sentido $^{1866}$, razão pela qual, o direito à vida comportaria ponderação ${ }^{1867}$, admitindo inclusive cláusulas permissivas de aborto ${ }^{1868}$. Vale dizer que o Ministro Celso de Mello, apesar de defender a sacralidade e a inviolabilidade da vida ${ }^{1869}$ como verdadeiro núcleo fundante e eticamente legítimo do ordenamento jurídico ${ }^{1870}$, admite também ele que a laicidade representa a liberdade de religião e a igualdade de crença, estando garantida a liberdade de consciência e culto, bem como o respeito ao pluralismo da sociedade brasileira ${ }^{1871}$. Ademais, para o Ministro, é fundamental que efetivamente exista vida para que seja tutelada ${ }^{1872}$. Constatada sua inexistência, não há que se falar em proteção ${ }^{1873}$. No mérito da ADPF 54, Celso de Mello também admitiu a possibilidade de ponderação do direito à vida ${ }^{1874}$, inclusive lembrando-nos da interpretação hermenêutica da Comissão Interamericana de Direitos Humanos no caso Baby Boy (Resolução 23/81) ${ }^{1875}$, que já analisamos.

Também Joaquim Barbosa entendeu que há graus de proteção da vida ${ }^{1876}$, indicando, inclusive, que, apesar de biologicamente vivo, o feto anencéfalo não encontra amparo jurídico $^{1877}$.

${ }^{1866}$ BRASIL. Supremo Tribunal Federal. Ação Declaratória de Inconstitucionalidade (ADI 3510-0), p. 34-36. Disponível em: <http://www.stf.jus.br>. Acesso em: 10 jan. 2012.

${ }^{1867}$ BRASIL. Supremo Tribunal Federal. Ação Declaratória de Inconstitucionalidade (ADI 3510-0), p. 34. Disponível em: 〈http://www.stf.jus.br>. Acesso em: 10 jan. 2012.

${ }_{1868}$ BRASIL. Supremo Tribunal Federal. Ação Declaratória de Inconstitucionalidade (ADI 3510-0), p. 34-36. Disponível em: <http://www.stf.jus.br>. Acesso em: 10 jan. 2012.

${ }_{1869}$ BRASIL. Supremo Tribunal Federal. Ação Declaratória de Inconstitucionalidade (ADI 3510-0), p. 3. Disponível em: 〈http://www.stf.jus.br〉. Acesso em: 10 jan. 2012.

${ }^{1870}$ BRASIL. Supremo Tribunal Federal. Ação Declaratória de Inconstitucionalidade (ADI 3510-0), p. 4. Disponível em: <http://www.stf.jus.br〉. Acesso em: 10 jan. 2012.

${ }_{1871}$ BRASIL. Supremo Tribunal Federal. Ação Declaratória de Inconstitucionalidade (ADI 3510-0), p. 6. Disponível em: <http://www.stf.jus.br>. Acesso em: 10 jan. 2012.

${ }^{1872}$ BRASIL. Supremo Tribunal Federal. Ação Declaratória de Inconstitucionalidade (ADI 3510-0), p. 16. Disponível em: <http://www.stf.jus.br>. Acesso em: 10 jan. 2012.

${ }_{1873}$ Arguição de Descumprimento de Preceito Fundamental no $54-8$. Voto lido em plenário pelo Ministro Celso de Mello. Disponível em: <http://www.youtube.com/watch?v=WXtDpv2VzmU\&feature=autoplay\&list $=$ PLF21CD375773F508D\&playnext=1>. Acesso em: 30 abr. 2012 (2:32:22-2:32:28).

${ }^{1874}$ Arguição de Descumprimento de Preceito Fundamental $\mathrm{n}^{\circ}$ 54-8. Voto lido em plenário pelo Ministro Celso de Mello. Disponível em: <http://www.youtube.com/watch?v=WXtDpv2VzmU\&feature=autoplay\&list $=$ PLF21CD375773F508D\&playnext=1>. Acesso em: 30 abr. 2012 (0:22:50).

${ }^{1875}$ Arguição de Descumprimento de Preceito Fundamental no $54-8$. Voto lido em plenário pelo Ministro Celso de Mello. Disponível em: <http://www.youtube.com/watch?v=WXtDpv2VzmU\&feature=autoplay\&list $=$ PLF21CD375773F508D\&playnext=1>. Acesso em: 30 abr. 2012 (0:24:30—0:29:25).

1876 GOMES, JOAQUIM BARBOSA. Voto proferido pelo Ministro Joaquim Barbosa Gomes $\mathrm{HC} \mathrm{n}^{\mathrm{o}}$ 84.025/2004. In: SARMENTO, Daniel; PIOVESAN, Flávia (coordenadores). Nos Limites da Vida. Rio de Janeiro: Lúmen Júris, 2006, p. 90. Vale dizer que, embora não disponível o voto o Ministro Joaquim Barbosa na ADPF 54, remeteu-se ele à decisão publicada anteriormente no HC 84.025/2004. 
Também Rosa Weber parece partir da premissa da primazia da vida e relativizá-la ${ }^{1878}$, ainda que a Ministra também tenha afirmado, expressamente, que valores (vida, liberdade) têm o mesmo peso em uma sociedade democrática ${ }^{1879}$.

Parece-nos que as argumentações de Marco Aurélio, Cármen Lúcia, Celso de Mello, Joaquim Barbosa, e Rosa Weber expostas acima, sugerem a prevalência do modelo de interpretação constitucional do direito ao aborto do feto anencéfalo como uma exceção permitida ao direito à vida. Afinal, os Ministros parecem partir do direito à vida como primário, para, em seguida, sopesá-lo no conflito com outros direitos, como vimos no primeiro capítulo dessa terceira parte do trabalho.

\subsubsection{Argumentos envolvendo a brevidade da vida do feto}

Como vimos, o Ministro Marco Aurélio concedeu a liminar na ADPF 54, baseada na existência de uma má-formação fetal ${ }^{1880}$, o que, segundo ele, acarreta a morte intra-uterina em $65 \%$ dos casos de anencefalia, ou uma sobrevida de poucas horas após o parto" ${ }^{\text {1881, }}$, sem chance de sobrevivência nesse pequeno período sem "os efeitos da deficiência"1882.

Nessa esteira, acrescentou o Ministro Ayres Britto, ainda na liminar da ADPF 54, que o feto anencéfalo e a viabilidade da sua vida extrauterina ${ }^{1883}$ poderiam ser comparados à

1877 GOMES, JOAQUIM BARBOSA. Voto proferido pelo Ministro Joaquim Barbosa Gomes HC $\mathrm{n}^{\circ}$ 84.025/2004. In: SARMENTO, Daniel; PIOVESAN, Flávia (coordenadores). Nos Limites da Vida. Rio de Janeiro: Lúmen Júris, 2006, p. 90-91.

${ }_{1878}$ Arguição de Descumprimento de Preceito Fundamental no 54-8. Voto lido em plenário pela Ministra Rosa Weber. Disponível em: <http://www.youtube.com/watch?v=E2js96aasjY\&feature=BFa\&list=PL7655E B015996CBBE> . Acesso em: 27 abr. 2012 (0:57:50).

1879 Arguição de Descumprimento de Preceito Fundamental no 54-8. Voto lido em plenário pela Ministra Rosa Weber. Disponível em: <http://www.youtube.com/watch?v=E2js96aasjY\&feature=BFa\&list=PL7655E B015996CBBE> . Acesso em: 27 abr. 2012 (1:01:12-1:01:30).

1880 BRASIL. Supremo Tribunal Federal. Arguição de Descumprimento de Preceito Fundamental $\mathrm{n}^{\circ}$ 54-8. Decisão Liminar. Relator Ministro Marco Aurélio, p. 1-2. Disponível em: <http://www.stf.jus.br〉. Acesso em: 10 jan. 2012.

${ }^{1881}$ BRASIL. Supremo Tribunal Federal. Arguição de Descumprimento de Preceito Fundamental $\mathrm{n}^{\circ}$ 54-8. Decisão Liminar. Relator Ministro Marco Aurélio, p. 2. Disponível em: <http://www.stf.jus.br〉. Acesso em: 10 jan. 2012.

${ }_{1882}$ BRASIL. Supremo Tribunal Federal. Arguição de Descumprimento de Preceito Fundamental $n^{\circ}$ 54-8. Decisão Liminar. Relator Ministro Marco Aurélio, p. 6. Disponível em: 〈http://www.stf.jus.br>. Acesso em: 10 jan. 2012.

${ }_{1883}$ BRASIL. Supremo Tribunal Federal. Arguição de Descumprimento de Preceito Fundamental $\mathrm{n}^{\circ}$ 54-8. Medida Cautelar. Tribunal do Pleno. Julgamento em 20 out. 2004, p. 90. Disponível em: 〈http://www.stf.jus.br>. Acesso em: 10 jan. 2012. 
crisálida. O útero seria o "casulo"1884, que contém "algo que jamais será alguém"1885. E questionou ainda Britto: "estamos aqui discutindo sobre o direito de viver, o direito de nascer ou o direito de nascer para morrer? Existe esse direito de nascer para morrer?"1886 Para o Ministro, a proibição ao aborto em geral teria o objetivo de impedir que um destino extrauterino seja ceifado ${ }^{1887}$ - mas não é essa a situação do anencéfalo, conforme o Ministro.

Além disso, entendeu o Ministro Ayres Britto que cabe à mulher decidir se "continua com aquela gravidez-sacrifício ou não" ${ }^{1888}$, e equiparou o feto com anencefalia ao ser humano com vida, mas com a morte encefálica decretada ${ }^{1889}$. Para o Ministro, o feto "está [apenas] aparentemente vivo, na verdade ele está ligado e por isso respira e por isso se desenvolve". ${ }^{1890}$ O feto "está ligado a uma UTI, chamada útero, mas a partir do momento em que se opera o desligamento do feto desses aparelhos ou dessa UTI, que se chama útero, nada mais resta, não há mais vida"1891.

Também o Ministro Fux analisou o impacto da brevidade da vida extrauterina do anencéfalo $^{1892}$, e Rosa Weber defendeu que não há um interesse social de tutelar uma vida que não irá se desenvolver socialmente, violando o direito reprodutivo da mulher ${ }^{1893}$.

As argumentações acima, per se, não jogam luz diretamente sobre qual modelo de interpretação seria o mais adequado, porque procuram justificar o aborto meramente com base

1884 BRASIL. Supremo Tribunal Federal. Arguição de Descumprimento de Preceito Fundamental $\mathrm{n}^{\circ}$ 54-8. Medida Cautelar. Tribunal do Pleno. Julgamento em 20 out. 2004, p. 90. Disponível em: <http://www.stf.jus.br>. Acesso em: 10 jan. 2012.

1885 BRASIL. Supremo Tribunal Federal. Arguição de Descumprimento de Preceito Fundamental $\mathrm{n}^{\circ}$ 54-8. Medida Cautelar. Tribunal do Pleno. Julgamento em 20 out. 2004, p. 90. Disponível em: <http://www.stf.jus.br>. Acesso em: 10 jan. 2012.

1886 BRASIL. Supremo Tribunal Federal. Arguição de Descumprimento de Preceito Fundamental $\mathrm{n}^{\circ}$ 54-8. Medida Cautelar. Tribunal do Pleno. Julgamento em 20 out. 2004, p. 90-91. Disponível em: <http://www.stf.jus.br>. Acesso em: 10 jan. 2012.

1887 BRASIL. Supremo Tribunal Federal. Arguição de Descumprimento de Preceito Fundamental $\mathrm{n}^{\circ}$ 54-8. Medida Cautelar. Tribunal do Pleno. Julgamento em 20 out. 2004, p. 91. Disponível em: <http://www.stf.jus.br>. Acesso em: 10 jan. 2012.

1888 BRASIL. Supremo Tribunal Federal. Arguição de Descumprimento de Preceito Fundamental $\mathrm{n}^{\circ}$ 54-8. Medida Cautelar. Tribunal do Pleno. Julgamento em 20 out. 2004, p. 91. Disponível em: 〈http://www.stf.jus.br〉. Acesso em: 10 jan. 2012.

1889 BRASIL. Supremo Tribunal Federal. Arguição de Descumprimento de Preceito Fundamental $\mathrm{n}^{\circ}$ 54-8. Medida Cautelar. Tribunal do Pleno. Julgamento em 20 out. 2004, p. 91. Disponível em: 〈http://www.stf.jus.br〉. Acesso em: 10 jan. 2012.

1890 BRASIL. Supremo Tribunal Federal. Arguição de Descumprimento de Preceito Fundamental $\mathrm{n}^{\circ}$ 54-8. Medida Cautelar. Tribunal do Pleno. Julgamento em 20 out. 2004, p. 92. Disponível em: 〈http://www.stf.jus.br>. Acesso em: 10 jan. 2012.

1891 BRASIL. Supremo Tribunal Federal. Arguição de Descumprimento de Preceito Fundamental no 54-8. Medida Cautelar. Tribunal do Pleno. Julgamento em 20 out. 2004, p. 92. Disponível em: 〈http://www.stf.jus.br>. Acesso em: 10 jan. 2012.

1892 Arguição de Descumprimento de Preceito Fundamental no 54-8. Voto do Ministro Luiz Fux. Disponível em: <http://www.stf.jus.br/arquivo/cms/noticiaNoticiaStf/anexo/ADPF54LF.pdf>. Acesso em: 16 abr. 2012, p. 5.

1893 Arguição de Descumprimento de Preceito Fundamental no 54-8. Voto lido em plenário pela Ministra Rosa Weber. Disponível em: <http://www.youtube.com/watch?v=E2js96aasjY\&feature=BFa\&list=PL7655E B015996CBBE> . Acesso em: 27 abr. 2012 (1:05:20-1:06:20). 
em fatos, não normas ou interpretações normativas - sugerindo que uma vida tão breve quanto a do anencéfalo não gozaria de uma proteção plena, ou até mesmo negando que o feto anencefálico esteja vivo, com base em que estaria em uma situação análoga à de morte cerebral. Indiretamente, entretanto, se a brevidade da vida é um fundamento válido para se relativizar a proteção à própria vida, podemos interpretar que também estes argumentos podem ser entendidos como em favor do modelo de interpretação constitucional do direito ao aborto do feto anencéfalo como uma exceção permitida ao direito à vida, na medida em que, ainda que de um modo oblíquo, partam da primazia da vida e a relativizem por sua brevidade.

\subsubsection{Argumentos envolvendo o estado, a igreja, e valores}

O âmbito de proteção do direito à vida também deve ser analisado na ótica de um estado democrático de direito e de um estado laico. Muitos Ministros mencionaram este aspecto, mas especialmente os Ministros Joaquim Barbosa ${ }^{1894}$ e Celso de Mello ${ }^{1895}$ enfatizaram a separação do estado e da igreja.

Vale lembrar, ainda, os ensinamentos de Daniel Sarmento que, como vimos, afirma que a proibição do aborto não se coaduna com a ideia de laicidade do estado e com a ideia de democracia, pois não se teria um tratamento isonômico entre os indivíduos ${ }^{1896}$. O estado, na visão do autor, deve manter-se imparcial e equidistante diante das diversas religiões, ainda que uma delas represente a posição majoritária da sociedade. ${ }^{1897,1898}$

\footnotetext{
1894 BRASIL. Supremo Tribunal Federal. Ação Declaratória de Inconstitucionalidade (ADI 3510-0), p. 5. Disponível em: <http://www.stf.jus.br>. Acesso em: 10 jan. 2012.

${ }^{1895}$ Arguição de Descumprimento de Preceito Fundamental no $54-8$. Voto lido em plenário pelo Ministro Celso de Mello. Disponível em: <http://www.youtube.com/watch?v=WXtDpv2VzmU\&feature=autoplay\&list =PLF21CD375773F508D\&playnext=1>. Acesso em: 30 abr. 2012 (2:11:50-2:11:54).

${ }^{1896}$ SARMENTO, Daniel. Legalização do Aborto e constituição. In: SARMENTO, Daniel; PIOVESAN, Flavia (coordenadores). Nos Limites da Vida. Rio de Janeiro: Lúmen Júris, 2006, p. 27.

${ }^{1897}$ SARMENTO, Daniel. Legalização do Aborto e constituição. In: SARMENTO, Daniel; PIOVESAN, Flavia (coordenadores). Nos Limites da Vida. Rio de Janeiro: Lúmen Júris, 2006, p. 26.

${ }^{1898}$ Em sentido contrário, Alain Supiot: "Os debates atuais sobre a bioética ganhariam muito em abrir-se a essa história de nossa concepção de ser humano, que é uma parte da história do Ocidente cristão. Essa concepção, da qual somos herdeiros, é a da imago Dei, do homem concebido à imagem de Deus e como tal chamado a se tornar senhor da natureza [...]. Mas, concebido à imagem de Deus, o homem não é Deus. Sua dignidade particular procede não de si mesmo, mas de seu Criador, e ele a partilha com todos os outros homens". SUPIOT, Alain. Homus juridicus: Ensaio sobre a função antropológica do Direito. Trad. Maria Ermantina de Almeida Prado Galvão. São Paulo: Martins Fontes, 2007, p. 15.
} 
Também neste sentido, lembramo-nos da ideia de Dworkin, de que o estado não deve adotar um conceito de vida com uma conotação religiosa ${ }^{1899}$. O estado tem o dever de observar a coexistência de vários direitos, fato que, por si só, já impediria uma proteção absoluta à vida, pois precisaria garantir também uma liberdade de escolha ao indivíduo como exercício democrático ${ }^{1900}$.

Neste contexto, lembramo-nos de mais uma pergunta de Dworkin: Se o estado entendesse que é seu dever proteger a vida poderia ele - o estado - impor valores à todos? Seria possível impor a toda a sociedade brasileira que o valor da vida deve transcender outros direitos? ${ }^{1901}$ Parece que o Ministro Joaquim Barbosa responde à indagação ao admitir que não é possível. Para ele, "ninguém poderá obrigá-los a agir diferente de seus valores, inclusive com relação em que momento a vida começa"1902.

Também o Ministro Marco Aurélio, na decisão da ADPF 54, enfatizou que o estado brasileiro é laico e, assim, não pode fazer política pública apenas com base em valores religiosos, inclusive fazendo um histórico a respeito da tolerância religiosa e laicidade do Brasil $^{1903}$.

Como não dizem respeito à posição do direito à vida com relação aos outros direitos em conflito no caso, esses argumentos da laicidade do estado, e até mesmo de que o estado não poderia nos impor valores, também não nos parecem iluminar um particular modelo de interpretação constitucional adequado ao caso do aborto do anencéfalo, ainda que sejam muito interessantes e importantes na solução do caso prático. Tais argumentos dizem respeito, primordialmente, ao papel do estado e a sua separação da igreja.

\subsubsection{Argumentos envolvendo a personalidade do feto}

\footnotetext{
${ }^{1899}$ Como ensina Dworkin, vide item 3.1.1.1.1.

1900 Voto Joaquim Barbosa. BRASIL. Supremo Tribunal Federal. Ação Declaratória de Inconstitucionalidade (ADI 3510-0), p. 6-7. Disponível em: 〈http://www.stf.jus.br>. Acesso em: 10 jan. 2012.

${ }^{1901}$ Para Alain Supiot, "nenhum Estado, nem sequer aqueles que se proclamam absolutamente laicos, poderia manter-se sem mobilizar um certo número de crenças fundamentais”. SUPIOT, Alain. Homus juridicus: Ensaio sobre a função antropológica do Direito. Trad. Maria Ermantina de Almeida Prado Galvão. São Paulo: Martins Fontes, 2007, p. XVIII. "Os Estados, assim como as pessoas, continuam a ser sustentados por certezas indemonstráveis, por verdadeiras crenças, que não procedem de uma livre escolha, pois elas participam da identidade deles”. SUPIOT, Alain. Homus juridicus: Ensaio sobre a função antropológica do Direito. Trad. Maria Ermantina de Almeida Prado Galvão. São Paulo: Martins Fontes, 2007, p. XVI.

1902 BRASIL. Supremo Tribunal Federal. Ação Declaratória de Inconstitucionalidade (ADI 3510-0), p. 8. Disponível em: <http://www.stf.jus.br>. Acesso em: 10 jan. 2012.

1903 Arguição de Descumprimento de Preceito Fundamental no 54-8. Voto do Ministro Relator Marco Aurélio. Disponível em: <http://www.stf.jus.br/arquivo/cms/noticiaNoticiaStf/anexo/ADPF54.pdf>. Acesso em: 16 abr. 2012, p. 41.
} 
Afastando a possibilidade de que o embrião humano fosse titular de um direito subjetivo à vida, o Ministro Marco Aurélio, no voto sobre a pesquisa com células-tronco (ADI 3510-0), reconheceu a possibilidade de que a personalidade do feto se dê apenas com o nascimento com vida, existindo controvérsia quanto a se a Constituição Federal protege a vida de forma geral, inclusive a vida uterina ${ }^{1904}$, não podendo a mulher ser vista em hipótese nenhuma como uma mera "incubadora"1905.

Nessa linha, referente ao mesmo tema, o Ministro Carlos Ayres Britto reiterou na ADI 3510-0 a ideia de que se pode extrair da Constituição Federal diversos termos que denotam a necessária existência de "alguém"1906, de uma "pessoa completa""1907, para se falar em proteção. Afirmou o Ministro que é importante saber quais "momentos dessa vida estão validamente protegidos pelo Direito Constitucional e em que medida ${ }^{1908}$ ". É o que se denominaria, para ele, "tutela jurídica proporcional". ${ }^{1909}$ Para o Ministro, a proibição do aborto não reconhece a existência de duas pessoas, ${ }^{1910}$ pois se assim o fosse, as hipóteses legais para o aborto seriam inconstitucionais ${ }^{1911}$. O Ministro afirma ainda que existem duas realidades a serem consideradas: A da "vida intra-uterina e o da vida para além dos escaninhos do útero materno" 1912 , levando-se em conta que o feto precisa da mãe para manterse vivo ${ }^{1913}$. Por fim, reconheceu o Ministro que a "vida humana já rematadamente adornada

1904 BRASIL. Supremo Tribunal Federal. Ação Declaratória de Inconstitucionalidade (ADI 3510-0), p. 9. Disponível em: <http://www.stf.jus.br>. Acesso em: 10 jan. 2012.

1905 BRASIL. Supremo Tribunal Federal. Ação Declaratória de Inconstitucionalidade (ADI 3510-0), p. 9. Disponível em: <http://www.stf.jus.br>. Acesso em: 10 jan. 2012. Essa viabilidade decorreria da gestação humana. Ação Declaratória de Inconstitucionalidade (ADI 3510-0), p. 9. Disponível em: <http://www.stf.jus.br>. Acesso em: 10 jan. 2012.

1906 BRASIL. Supremo Tribunal Federal. Ação Declaratória de Inconstitucionalidade (ADI 3510-0), p. 13. Disponível em: <http://www.stf.jus.br>. Acesso em: 10 jan. 2012. Vale a pena recordar a posição do Ministro no voto da liminar na ADPF 54 em que útero seria o casulo que contém "algo que jamais será alguém". Vide [N.R.] 933.

1907 BRASIL. Supremo Tribunal Federal. Ação Declaratória de Inconstitucionalidade (ADI 3510-0), p. 13. Disponível em: <http://www.stf.jus.br>. Acesso em: 10 jan. 2012.

1908 Voto proferido na Ação Declaratória de Inconstitucionalidade (ADI 3510-0), p. 26. Disponível em: <http://www.stf.jus.br>. Acesso em: 10 jan. 2012.

1909 BRASIL. Supremo Tribunal Federal. Ação Declaratória de Inconstitucionalidade (ADI 3510-0), p. 15. Disponível em: <http://www.stf.jus.br>. Acesso em: 10 jan. 2012.

${ }_{1910}$ BRASIL. Supremo Tribunal Federal. Ação Declaratória de Inconstitucionalidade (ADI 3510-0), p. 18. Disponível em: <http://www.stf.jus.br>. Acesso em: 10 jan. 2012.

1911 BRASIL. Supremo Tribunal Federal. Ação Declaratória de Inconstitucionalidade (ADI 3510-0), p. 19. Disponível em: <http://www.stf.jus.br>. Acesso em: 10 jan. 2012.

1912 BRASIL. Supremo Tribunal Federal. Ação Declaratória de Inconstitucionalidade (ADI 3510-0), p. 23. Disponível em: <http://www.stf.jus.br>. Acesso em: 10 jan. 2012.

1913 BRASIL. Supremo Tribunal Federal. Ação Declaratória de Inconstitucionalidade (ADI 3510-0), p. 38. Disponível em: <http://www.stf.jus.br>. Acesso em: 10 jan. 2012. 
com o atributo da personalidade civil é o fenômeno que transcorre entre o nascimento com vida e a morte cerebral" ${ }^{\prime 1914}$.

Assim, restou clara na ADI 3510-0 a posição dos Ministros Marco Aurélio e Ayres Britto de que a personalidade do feto inicia-se com o nascimento com vida, e não na concepção. Na decisão da ADPF 54, inclusive, Marco Aurélio enfatizou que o anencéfalo “jamais se tornará uma pessoa",1915, e Joaquim Barbosa concluiu que o feto anencéfalo, apesar de biologicamente vivo, não tem amparo jurídico ${ }^{1916}$.

Rosa Weber, também no mérito da ADPF 54, afirmou claramente que o âmbito da proteção à vida do ser humano se dá com o nascimento com vida, com o início da personalidade jurídica do indivíduo ${ }^{1917}$.

Para Celso de Mello, a ausência de atividade cerebral, que conceitua a morte, serve de parâmetro para definir o que é vida ${ }^{1918}$, e, portanto, a contrario sensu, a vida começaria apenas com os primeiros sinais da atividade cerebral ${ }^{1919}$. O Ministro também defendeu que o anencéfalo seria um "natimorto", conforme a Resolução 1252/04 do Conselho Federal de Medicina $^{1920}$.

Entretanto, estes argumentos, ainda que interessantes também, não iluminam o modelo de interpretação mais adequado ao Brasil, porque versam sobre a partir de quando ${ }^{1921}$, e até

1914 BRASIL. Supremo Tribunal Federal. Ação Declaratória de Inconstitucionalidade (ADI 3510-0), p. 56. Disponível em: <http://www.stf.jus.br>. Acesso em: 10 jan. 2012.

${ }^{1915}$ Arguição de Descumprimento de Preceito Fundamental n ${ }^{\circ}$ 54-8. Voto do Ministro Relator Marco Aurélio. Disponível em: <http://www.stf.jus.br/arquivo/cms/noticiaNoticiaStf/anexo/ADPF54.pdf>. Acesso em: 16 abr. 2012, p. 50.

1916 GOMES, JOAQUIM BARBOSA. Voto proferido pelo Ministro Joaquim Barbosa Gomes HC $\mathrm{n}^{\circ}$ 84.025/2004. In: SARMENTO, Daniel; PIOVESAN, Flávia (coordenadores). Nos Limites da Vida. Rio de Janeiro: Lúmen Júris, 2006, p. 90-91.

1917 Arguição de Descumprimento de Preceito Fundamental no 54-8. Voto lido em plenário pela Ministra Rosa Weber. Disponível em: <http://www.youtube.com/watch?v=E2js96aasjY\&feature=BFa\&list=PL7655E B015996CBBE> . Acesso em: 27 abr. 2012 (0:45:50-0:46:10).

${ }^{1918}$ Arguição de Descumprimento de Preceito Fundamental no 54-8. Voto lido em plenário pelo Ministro Celso de Mello. Disponível em: <http://www.youtube.com/watch?v=WXtDpv2VzmU\&feature=autoplay\&list =PLF21CD375773F508D\&playnext=1>. Acesso em: 30 abr. 2012 (0:10:40-0:11:00).

1919 Arguição de Descumprimento de Preceito Fundamental no 54-8. Voto lido em plenário pelo Ministro Celso de Mello. Disponível em: <http://www.youtube.com/watch?v=WXtDpv2VzmU\&feature=autoplay\&list $=$ PLF21CD375773F508D\&playnext=1>. Acesso em: 30 abr. 2012 (0:11:00-0:11:25).

${ }^{1920}$ Arguição de Descumprimento de Preceito Fundamental no 54-8. Voto lido em plenário pelo Ministro Celso de Mello. Disponível em: <http://www.youtube.com/watch?v=WXtDpv2VzmU\&feature=autoplay\&list $=$ PLF21CD375773F508D\&playnext=1>. Acesso em: 30 abr. 2012 (0:30:55).

${ }^{1921}$ Supiot, entretanto, nos lembra de que "a personalidade jurídica não é decerto um fato de natureza; é certa representação do homem, que postula a unidade de sua carne e de seu espírito e que proíbe reduzi-lo a um ser biológico ou um ser mental [...]. Essa proibição é que é de fato visada pelos que hoje procuram desqualificar o sujeito de direito para poder apreender o ser humano como uma simples unidade de conta e tratá-lo como gado ou, o que equivale ao mesmo, como pura abstração”. SUPIOT, Alain. Homus juridicus: Ensaio sobre a função antropológica do Direito. Trad. Maria Ermantina de Almeida Prado Galvão. São Paulo: Martins Fontes, 2007, p. XI. 
onde, existe personalidade - mas não entram na seara de se, no Brasil, deve-se partir da interpretação constitucional da primazia da vida ou da liberdade.

\subsubsection{Argumentos sobre a vida na concepção e o Pacto de San José}

Por outro lado, o Ministro Lewandowski, também no voto das células-tronco, tratou da tese de que a vida inicia-se quando da concepção, defendendo que esta teoria deveria prevalecer, vez que foi adotada pelo Pacto de San José, já ratificado pelo Brasil, e que, portanto, ingressou no ordenamento jurídico brasileiro como "regra de caráter supralegal", independentemente de se a vida começou no útero ou fora dele, devendo o embrião, em qualquer estágio, ser tratado dignamente. ${ }^{1923}$ Todavia, o Ministro ressaltou também que, em circunstâncias especiais, o estado poderá deixar de protegê-lo, quando outros valores precisarem ser protegidos ${ }^{1924}$. Assim, apesar de reconhecer que a vida inicia se na concepção, o Ministro Lewandowski entendeu que, em alguns casos, o estado pode deixar de protegê-lo. Seria o caso do aborto do feto anencéfalo? Como vimos, para Lewandowski, não ${ }^{1925}$.

É interessente fazer uma releitura desse voto observando o texto da Convenção Americana de Direitos Humanos (Pacto de San Jose), citado pelo próprio Ministro Lewandowski.

A Convenção deve ser interpretada observando todos os termos contidos na norma ${ }^{1926}$, como vimos na primeira parte deste trabalho. A cláusula "em geral" desde a concepção ${ }^{1927}$, contida no texto normativo internacional, permite, por um lado, verificar que o direito à vida não é um direito absoluto, podendo o estado deixar de protegê-lo quando existirem outros direitos que também precisam ser protegidos. Por outro lado, no entanto, tampouco existiria

\footnotetext{
${ }^{1922}$ BRASIL. Supremo Tribunal Federal. Ação Declaratória de Inconstitucionalidade (ADI 3510-0), p. $20-21$. Disponível em: <http://www.stf.jus.br>. Acesso em: 10 jan. 2012.

${ }^{1923}$ BRASIL. Supremo Tribunal Federal. Ação Declaratória de Inconstitucionalidade (ADI 3510-0), p. 23. Disponível em: <http://www.stf.jus.br>. Acesso em: 10 jan. 2012.

1924 BRASIL. Supremo Tribunal Federal. Ação Declaratória de Inconstitucionalidade (ADI 3510-0), p. 22-23. Disponível em: <http://www.stf.jus.br>. Acesso em: 10 jan. 2012.

${ }^{1925}$ Arguição de Descumprimento de Preceito Fundamental no 54-8. Voto do Ministro Ricardo Lewandowiski. Disponível em: <http://www.stf.jus.br/arquivo/cms/noticiaNoticiaStf/anexo/ADPF54RL.pdf>. Acesso em: 16 abr. 2012, p. 24.

${ }^{1926}$ R. Limongi França traz as regras de Direito Civil consolidadas por Carlos de Carvalho, artigo 62, §1 $1^{\text {": "No }}$ texto da Lei se entende não haver frase ou palavra inútil, supérflua ou sem efeito". FRANÇA, R. Limongi. Hermenêutica Jurídica; atualização de Antônio de S. Limongi França; prefácio de Giselda M.F. Novaes Hironaka. São Paulo: Revista dos Tribunais, p. 36.

${ }^{1927}$ Vide comentários 3.2.2 na segunda parte do trabalho.
} 
um direito subjetivo ao aborto, justamente porque em geral o direito à vida deve ser protegido desde a concepção. O direito à vida deveria ser protegido em grande medida, mas também devem ser protegidos outros direitos colidentes, admitindo, portanto, o Pacto, uma proteção gradual desse direito em relação aos demais.

Os argumentos acima, do Ministro Lewandoswski (ainda que ele tenha se posicionado contra o aborto do anencéfalo na decisão da ADPF 54), bem como a interpretação do Pacto de San José, parecem favorecer que o modelo adequado de interpretação constitucional no Brasil seria, mais uma vez, o da exceção permitida. O direito à vida é "geral”, a permissão ao aborto seria, então, excepcional.

\subsubsection{Argumentos sobre a vida e personalidade a partir da fecundação}

Na ADI 3510-0, o Ministro Cezar Peluso, por sua vez, não concordou com uma gradação da proteção da vida ${ }^{1928}$, e afirmou que a vida se inicia na fecundação ${ }^{1929}$, de modo que, para ele, a vida intrauterina é "um valor constitucional proeminente"1930.

Também neste sentido, Eros Grau defendeu, na liminar da ADPF 54, que o feto, nas lições de Pontes de Miranda, e conforme o artigo $2^{\circ}$ do Código Civil, seria pessoa, e deveria ter proteção legal ${ }^{1931}$. Para o Ministro, durante o período em que a liminar autorizando o aborto de fetos anencefálicos estava em vigor, foi como se o Direito Penal tivesse sido

${ }^{1928}$ BRASIL. Supremo Tribunal Federal. Ação Declaratória de Inconstitucionalidade (ADI 3510-0), p. 7. Disponível em: <http://www.stf.jus.br>. Acesso em: 10 jan. 2012.

${ }^{1929}$ BRASIL. Supremo Tribunal Federal. Ação Declaratória de Inconstitucionalidade (ADI 3510-0), p. 15. Disponível em: <http://www.stf.jus.br>. Acesso em: 10 jan. 2012. O voto do Ministro Cezar Peluzo decidiu pela constitucionalidade da Lei de Biossegurança e atribuiu interpretação conforme à Constituição Federal. Afirma que a pesquisa com células-tronco adultas não exclui a pesquisa com as células-tronco embrionárias, e que a ausência da Lei de Biossegurança estimularia a comercialização de órgãos e não o contrário. Poderia estimular também a experimentação inadequada com o uso de embriões. Defende, ainda, que o embrião congelado "participa, em grau primitivo, dos requisitos da proteção à dignidade humana deste [...] e que o embrião já possui "atributo de humanidade", afirmando que a vida começaria na concepção. Ação Declaratória de Inconstitucionalidade (ADI 3510-0), respectivamente p. 3, 7-8, 9, 11 e 41, 12 e 13. Disponível em: <http://www.stf.jus.br〉. Acesso em: 10 jan. 2012. Por fim, para o Ministro Peluzo, a proteção dos embriões decorre da Constituição Federal - em menor grau, entretanto. Com base nisso, a lei resguarda a dignidade aos embriões estabelecendo medidas para efetivar essa proteção. Ação Declaratória de Inconstitucionalidade (ADI 3510-0), p. 36, 38-40. Disponível em: <http://www.stf.jus.br>. Acesso em: 10 jan. 2012.

${ }_{1930}$ BRASIL. Supremo Tribunal Federal. Ação Declaratória de Inconstitucionalidade (ADI 3510-0), p. 7-15. Disponível em: 〈http://www.stf.jus.br>. Acesso em: 10 jan. 2012.

${ }^{1931}$ BRASIL. Supremo Tribunal Federal. Arguição de Descumprimento de Preceito Fundamental ${ }^{\circ}$ 54-8. Medida Cautelar. Tribunal do Pleno. Julgamento em 20 out. 2004, p. 4-5, fl. 85. Disponível em: <http://www.stf.jus.br〉. Acesso em: 10 jan. 2012. 
reescrito ${ }^{1932}$ pelo Poder Judiciário, que criara uma nova hipótese de aborto legal ${ }^{1933}$. Para o Ministro, a liminar concedida violou a ideia de vida contida no artigo $2^{\circ}$ do Código Civil ${ }^{1934}$.

Estes argumentos de Peluso e Eros Grau são interessantes porque contrastam fortemente com argumentos de outros ministros, e parecem até sugerir que a interpretação do direito à vida absoluto, que havíamos descartado no início desta parte do trabalho, lhes pareceria ser a mais adequada.

E, no entanto, como já vimos, é fato que, atualmente, o direito à vida não é entendido de forma absoluta segundo a Constituição.

\subsubsection{Argumentos envolvendo morte encefálica}

Já Celso de Mello reconheceu na ADI 3510-0 os argumentos da morte encefálica como critério demarcatório para o término da vida ${ }^{1935}$. Arguiu o Ministro Lewandowski, também neste sentido, que, utilizando o mesmo raciocínio aplicado ao caso de morte encefálica, em que a lei encerra a personalidade jurídica, não tendo sido formadas as terminações nervosas no embrião, não há pessoa humana ${ }^{1936}$. A analogia de morte encefálica também já foi admitida pelo Ministro Carlos Britto na liminar da ADPF $54^{1937}$. Sem vida, não há personalidade, e, como nos ensinou Dworkin, atribuir ou não personalidade ao feto, ou admitir-lhe gradações dessa personalidade, seria essencial para reconhecer-lhe um direito

1932 BRASIL. Supremo Tribunal Federal. Arguição de Descumprimento de Preceito Fundamental $\mathrm{n}^{\circ}$ 54-8. Medida Cautelar. Tribunal do Pleno. Julgamento em 20 out. 2004, p. 4-5, fl. 85. Disponível em: <http://www.stf.jus.br>. Acesso em: 10 jan. 2012. O Ministro Eros Grau reconheceu o caráter de pessoa ao embrião, desde que formado no ventre materno. Ação Declaratória de Inconstitucionalidade (ADI 3510-0), p. 5. Disponível em: <http://www.stf.jus.br>. Acesso em: 10 jan. 2012.

1933 BRASIL. Supremo Tribunal Federal. Arguição de Descumprimento de Preceito Fundamental $n^{\circ}$ 54-8. Medida Cautelar. Tribunal do Pleno. Julgamento em 20 out. 2004, p. 4-5, fl. 85. Disponível em: <http://www.stf.jus.br>. Acesso em: 10 jan. 2012.

1934 Afirma, finalmente, que a técnica de subsunção está superada e não pode a interpretação ficar restrita a ela, negando o referendo parcial da medida liminar. Arguição de Descumprimento de Preceito Fundamental $n^{\circ}$ 54-8. Medida Cautelar. Tribunal do Pleno. Julgamento em 20 out. 2004, aditamento ao voto, p. 1, fl. 139. Disponível em: <http://www.stf.jus.br>. Acesso em: 10 jan. 2012.

${ }^{1935}$ BRASIL. Supremo Tribunal Federal. Ação Declaratória de Inconstitucionalidade (ADI 3510-0), p. 27-28. Disponível em: <http://www.stf.jus.br>. Acesso em: 10 jan. 2012.

${ }_{1936}$ BRASIL. Supremo Tribunal Federal. Ação Declaratória de Inconstitucionalidade (ADI 3510-0), p. 47-48. Disponível em: <http://www.stf.jus.br>. Acesso em: 10 jan. 2012.

1937 BRASIL. Supremo Tribunal Federal. Arguição de Descumprimento de Preceito Fundamental $n^{\circ}$ 54-8. Medida Cautelar. Tribunal do Pleno. Julgamento em 20 out. 2004, p. 91. Disponível em: 〈http://www.stf.jus.br>. Acesso em: 10 jan. 2012. 
subjetivo à vida ${ }^{1938}$. No entanto, ainda na ADI 3510-0, o Ministro Celso de Mello manifestou uma preocupação muito relevante com relação ao fato de que a ponderação do direito à vida não poderia ser tal que esvaziasse seu conteúdo essencial ${ }^{1939}$, como vimos. Também Rosa Weber, na ADPF 54, citou a lei de doação de órgãos e afirmou que o direito protege a vida, observada a existência de atividades psíquicas - o que não se dá em caso de morte encefálica - , e não a mera vida orgânica ou atos reflexos ${ }^{1940}$.

Mais uma vez, estamos diante de argumentos que se propõem factuais ou, pelo menos, semi-factuais - de que o feto anencéfalo já estaria morto por analogia à morte encefálica, e que, por isso, não sopesam princípios e direitos, o que seria necessário para avaliarmos qual modelo de interpretação constitucional seria aplicável.

\subsubsection{A análise penal de Carlos Ayres Britto}

Pareceu-nos particularmente enriquecedora a análise trazida pelo Ministro Carlos Ayres Britto à liminar da ADPF 54. Afirmou o Ministro em seu voto que são possíveis algumas interpretações penais no caso do aborto do feto anencéfalo ${ }^{1941}$ : a) de que a antecipação terapêutica do aborto do feto anencéfalo é crime, pois há vida desde a concepção; b) de que inexiste crime de aborto em caso de gravidez de feto anencéfalo - pois não existem as características da espécie humana ${ }^{1942}$, ou em razão do critério da morte encefálica da Lei

1938 DWORKIN, Ronald. Domínio da Vida: aborto, eutanásia e liberdades individuais. Trad. Jefferson Luiz Camargo; rev. da tradução Silvana Vieira. São Paulo: Martins Fontes, 2003, p. 154-155.

1939 Ação Declaratória de Inconstitucionalidade (ADI 3510-0), p. 33. Disponível em: 〈http://www.stf.jus.br>. Acesso em: 10 jan. 2012. Nesse sentido, vide comentário de Virgílio Afonso da Silva. SILVA, Virgílio Afonso da. Direitos Fundamentais: conteúdo essencial, restrições e eficácia. São Paulo: Malheiros, 2009, p. 182 e 200. 1940 Arguição de Descumprimento de Preceito Fundamental no 54-8. Voto lido em plenário pela Ministra Rosa Weber. Disponível em: <http://www.youtube.com/watch?v=E2js96aasjY\&feature=BFa\&list=PL7655E B015996CBBE> . Acesso em: 27 abr. 2012 (0:47:30-0:48:24).

1941 Arguição de Descumprimento de Preceito Fundamental no 54-8. Medida Cautelar. Tribunal do Pleno. Julgamento em 20 out. 2004, p. 113-138. Disponível em: 〈http://www.stf.jus.br〉. Acesso em: 10 jan. 2012. Disponível em: <http://redir.stf.jus.br/paginadorpub/ paginador.jsp?docTP=AC\&docID=484300>. Acesso em: 10 jan. 2012.

1942 Destacamos do voto do Ministro: “o crime deixa de existir se o deliberado desfazimento da gestação já não é impeditivo da transformação de algo em alguém. Se o produto da concepção traduzir em um ser a meio do caminho do humano, mas, isto sim, em um ser que de alguma forma parou a meio ciclo do humano". BRASIL. Supremo Tribunal Federal. Arguição de Descumprimento de Preceito Fundamental no 54-8. Medida Cautelar. Tribunal do Pleno. Julgamento em 20 out. 2004, p. 122. Disponível em: <http://www.stf.jus.br>. Acesso em: 10 jan. 2012. Disponível em: <http://redir.stf.jus.br/paginadorpub/ paginador.jsp?docTP=AC\&docID=484300> . Acesso em: 10 jan. 2012 . 
9434/97 $7^{1943}$, tratando-se de conduta "penalmente atípica" "1944; e c) de que os artigos 124, 126 e 128, I e II, do Código Penal, estabelecem a tipicidade do crime de aborto, mas a conduta não seria punível, em razão da existência de direitos da gestante igualmente tutelados ${ }^{1945}$, equiparando-se a manutenção da gravidez à crueldade contra a mulher ${ }^{1946}$. No caso da gravidez resultante de estupro, a monstruosidade é o ato sexual contra a vontade da mulher, e, na anencefalia, é todo o processo, desde a concepção até o parto ${ }^{1947}$.

Eis que a interpretação sugerida pelo Ministro em "a", acima, está de acordo com o modelo da proibição absoluta.

A interpretação "b" consegue, na verdade, evitar uma interpretação constitucional do assunto, já que, tanto inexistir características da espécie humana no feto anencéfalo, quanto o feto anencéfalo já estar morto (em ambos os casos, por não ter encéfalo), seriam aspectos de natureza interpretativa factual, não normativa. E, no entanto, ambas sugestões nos parecem mais ficções jurídicas do que interpretações científicas de fatos objetivos.

Finalmente, a interpretação "c", que acaba por autorizar o aborto do feto anencéfalo em razão de direitos da gestante, se encaixaria melhor no modelo da exceção permitida do que no modelo da liberdade limitada. Afinal, em nenhum momento o Ministro sugere que exista um direito ao aborto decorrente da liberdade, que poderia ser limitado apenas em alguns casos "razoáveis". Ao contrário: fica claro que o aborto é, em geral, proibido em nosso ordenamento - não se questiona a constitucionalidade da proibição geral do Código Penal; ou seja, a vida tem primazia - e, no entanto, essa proteção é que tem que ceder, excepcionalmente, em casos específicos de colisão com direitos outros, da própria gestante, como vemos nos casos excepcionais de risco à sua própria vida, e no caso da gravidez decorrente de estupro.

\footnotetext{
${ }^{1943}$ Arguição de Descumprimento de Preceito Fundamental $n^{\circ}$ 54-8. Medida Cautelar. Tribunal do Pleno. Julgamento em 20 out. 2004, p. 123-124. Disponível em: 〈http://www.stf.jus.br〉. Acesso em: 10 jan. 2012. Disponível em: <http://redir.stf.jus.br/paginadorpub/ paginador.jsp?docTP=AC\&docID=484300>. Acesso em: 10 jan. 2012.

${ }^{1944}$ Arguição de Descumprimento de Preceito Fundamental $n^{\circ}$ 54-8. Medida Cautelar. Tribunal do Pleno. Julgamento em 20 out. 2004, p. 120-121. Disponível em: 〈http://www.stf.jus.br〉. Acesso em: 10 jan. 2012. Disponível em: <http://redir.stf.jus.br/paginadorpub/ paginador.jsp?docTP=AC\&docID=484300>. Acesso em: 10 jan. 2012.

${ }^{1945}$ Arguição de Descumprimento de Preceito Fundamental $\mathrm{n}^{\circ}$ 54-8. Medida Cautelar. Tribunal do Pleno. Julgamento em 20 out. 2004, p. 124. Disponível em: 〈http://www.stf.jus.br〉. Acesso em: 10 jan. 2012. Disponível em: <http://redir.stf.jus.br/paginadorpub/ paginador.jsp?docTP=AC\&docID=484300>. Acesso em: 10 jan. 2012.

${ }^{1946}$ Arguição de Descumprimento de Preceito Fundamental $n^{\circ}$ 54-8. Medida Cautelar. Tribunal do Pleno. Julgamento em 20 out. 2004, p. 125-126. Disponível em: <http://www.stf.jus.br. Acesso em: 10 jan. 2012. Disponível em: <http://redir.stf.jus.br/paginadorpub/ paginador.jsp?docTP=AC\&docID=484300>. Acesso em: 10 jan. 2012.

${ }^{1947}$ Arguição de Descumprimento de Preceito Fundamental $\mathrm{n}^{\circ}$ 54-8. Medida Cautelar. Tribunal do Pleno. Julgamento em 20 out. 2004, p. 126. Disponível em: 〈http://www.stf.jus.br〉. Acesso em: 10 jan. 2012. Disponível em: <http://redir.stf.jus.br/paginadorpub/ paginador.jsp?docTP=AC\&docID=484300>. Acesso em: 10 jan. 2012.
} 


\subsubsection{Argumentos invocando a iniciativa do Poder Legislativo}

Para a Ministra Ellen Gracie ${ }^{1948}$, ao julgar a liminar da ADPF 54, uma nova hipótese de aborto seria ato de competência exclusiva do Poder Legislativo, e somente a sociedade poderia exigir de seus representantes uma solução para esse "problema de saúde pública" que aflige particularmente as "mulheres das classes menos favorecidas"1949.

Lembremo-nos ainda do alerta formulado pelo Ministro Carlos Velloso, na liminar da ADPF 54, de que a interpretação conforme não permitiria criar uma "regulamentação legal" adequada, com todas condições para realização do aborto do feto anencéfalo, e que tal iniciativa deveria ser do Legislativo ${ }^{1950}$.

Em vista do disposto acima, vemos que também as argumentações de Ellen Grace e Carlos Velloso parecem fortalecer nossa impressão de que o modelo de interpretação constitucional aplicável ao Brasil seria o da exceção permitida. Para ambos, na ausência de lei específica autorizando mais uma hipótese de aborto, deve prevalecer a vida. Ou seja, mais uma vez, o direito à vida é a regra de nosso ordenamento; o aborto é a exceção. Gracie, particularmente, deixa claro que o aborto pode ser autorizado, e que talvez até fosse o mais adequado para atender às expectativas da sociedade e da saúde pública - mas, no entanto, tal exceção precisa ser aprovada pelo Legislativo. Para eles, no silêncio da lei, em nosso direito, deveria prevalecer o direito à vida; ao contrário do modelo da liberdade limitada, em que, no silêncio "eloquente" do Legislador, deveria prevalecer a liberdade de escolha da gestante.

Vale lembrar que, na ADPF 54, também o Ministro Lewandowiski enfatizou que o papel para alterar os dispositivos do Código Penal deveria caber ao Congresso Nacional, e não ao $\mathrm{STF}^{1951}$, opinião também manifestada por Cezar Peluso ${ }^{1952}$.

1948 BRASIL. Supremo Tribunal Federal. Arguição de Descumprimento de Preceito Fundamental no 54-8. Medida Cautelar. Tribunal do Pleno. Julgamento em 20 out. 2004, aditamento ao voto, p. 3, fl. 195. Disponível em: 〈http://www.stf.jus.br>. Acesso em: 10 jan. 2012.

1949 BRASIL. Supremo Tribunal Federal. Arguição de Descumprimento de Preceito Fundamental no 54-8. Medida Cautelar. Tribunal do Pleno. Julgamento em 20 out. 2004, aditamento ao voto, p. 14, fl. 206. Disponível em: 〈http://www.stf.jus.br>. Acesso em: 10 jan. 2012.

1950 BRASIL. Supremo Tribunal Federal. Arguição de Descumprimento de Preceito Fundamental $n^{\circ}$ 54-8. Medida Cautelar. Tribunal do Pleno. Julgamento em 20 out. 2004, aditamentoe ao voto, p. 7, fl. 214. Disponível em: 〈http://www.stf.jus.br>. Acesso em: 10 jan. 2012.

${ }^{1951}$ Arguição de Descumprimento de Preceito Fundamental no 54-8. Voto do Ministro Ricardo Lewandowiski. Disponível em: <http://www.stf.jus.br/arquivo/cms/noticiaNoticiaStf/anexo/ADPF54RL.pdf>. Acesso em: 16 abr. 2012, p. 6. 


\subsubsection{Conclusão sobre o modelo de interpretação constitucional aplicável ao Brasil}

Em vista do exposto acima, parece-nos que, no Brasil, a interpretação constitucional dada ao caso do aborto do feto anencéfalo se encaixa no quarto modelo sugerido - o do direito ao aborto do feto anencéfalo como uma exceção permitida pelo sistema.

Em outras palavras, diferentemente do que ocorre nos Estados Unidos, onde o princípio da liberdade parece ter primazia sobre a vida do feto ${ }^{1953}$, no Brasil, parte-se de um direito geral à vida que pode ser, excepcionalmente, limitado em certas circunstâncias.

A crítica que fica à decisão é no sentido de que a atuação do STF, pautada nas posições individuais isoladas de cada um de seus Ministros, que não dialogam entre si, torna difícil a aferição precisa de um modelo de interpretação constitucional sobre a relação do direito à vida com outros direitos fundamentais em caso de conflito. Como vimos, um dos principais argumentos dos Ministros no mérito da ADPF 54 foi que não haveria vida no sentido jurídico no feto anencéfalo, argumento este que evita um verdadeiro sopesamento dos direitos fundamentais em conflito no caso, e por conseguinte, acaba gerando insegurança jurídica sobre qual seria a resposta, no futuro, de um questionamento à constitucionalidade de uma lei penal descriminalizadora do aborto de modo mais amplo, como seria o caso do atual anteprojeto de novo Código Penal proposto pela Comissão de Juristas do Senado ${ }^{1954}$.

1952 Arguição de Descumprimento de Preceito Fundamental no 54-8. Voto lido em plenário pelo Ministro Cezar Peluso. Disponível em: <http://www.youtube.com/watch?v=1Bh_d4D56jI\&list=PLF21CD375773F508D \&index=1\&feature=plpp_video $>$. Acesso em: 30 abr. 2012 (2:09:27-2:09:47).

${ }^{1953}$ Interessantemente, Alain Supiot nos lembra de que, "em terras de common law [...] o Direito [o sistema de regras] procede dos direitos [individuais, subjetivos], e não o contrário" como, segundo o mesmo autor, ocorre nos países da Europa continental, do qual o Brasil segue a tradição jurídica. Neste sentido, é curioso notar que, realmente, tanto nos Estados Unidos, quanto na Inglaterra, os mais importantes expoentes do common law hoje, o princípio da liberdade parece ter primazia sobre a vida do feto, o que se coaduna bem com a ideia de um sistema de Direito que emerge de direitos individuais, na medida em que o corpo das leis foi se formando historicamente a partir das decisões de casos individuais julgados pelas cortes, como aponta Supiot. SUPIOT, Alain. Homus juridicus: Ensaio sobre a função antropológica do Direito. Trad. Maria Ermantina de Almeida Prado Galvão. São Paulo: Martins Fontes, 2007, p. XXVI.

${ }^{1954}$ LEMOS, Iara. Anteprojeto de novo Código Penal vai prever possibilidade de aborto. Disponível em: <http://g1.globo.com/politica/noticia/2012/03/anteprojeto-de-novo-codigo-penal-vai-prever-possibilidade-deaborto.html>. Acesso em 5 jun. 2012. Destacamos da nova redação proposta pela Comissão de Juristas do Senado, in verbis: Art. 128. Não há crime de aborto: I - se houver risco à vida ou à saúde da gestante. II - se a gravidez resulta de violação da dignidade sexual, ou do emprego não consentido de técnica de reprodução assistida; III - se comprovada a anencefalia ou quando o feto padecer de graves e incuráveis anomalias que inviabilizem a vida independente, em ambos os casos atestado por dois médicos. IV - se por vontade da gestante até a $12^{\mathrm{a}}$ semana da gestação, quando o médico constatar que a mulher não apresenta condições psicológicas de 


\section{SOBRE A POSSIBILIDADE DE SE CONDICIONAR O ABORTO DO FETO ANENCÉFALO A FIM DE GARANTIR DIREITOS}

Tendo chegado a uma conclusão quanto ao modelo de interpretação constitucional aparentemente adotado no caso do aborto do feto anencéfalo no Brasil, a título de sugestão, gostaríamos de manifestar nosso entendimento de que tal exceção permitida poderia ser, ainda, condicionada, através da implementação de algumas medidas protetivas para aumentarse a certeza de que todos os direitos previstos na Constituição e envolvidos no caso tenham maiores possibilidades de ser efetivamente amparados. O modo mais adequado de se implantar essas medidas seria, claro, através do Poder Legislativo.

Como sabemos, a descriminalização do aborto não é um processo fácil, e, muito menos, isento de riscos - tanto para a mãe, quando para o feto. Existem muitas dificuldades a serem transpostas, até porque a medida do aborto é irrevogável, pois irreversível, uma vez que implica a morte do feto ${ }^{1955}$.

A fim de se evitar abusos, seria conveniente revestir a autorização legal do aborto do feto anencefálico com a carapaça protetora de mecanismos de controle e garantia ${ }^{1956}$.

arcar com a maternidade. Parágrafo único. Nos casos dos incisos II e III, e da segunda parte do inciso I, o aborto deve ser precedido de consentimento da gestante, ou quando menor, incapaz ou impossibilitada de consentir, de seu representante legal, do cônjuge ou de seu companheiro. Disponível em: <http://www.prr3.mpf.gov.br/component/option,com_remository/Itemid,68/func,select/id,334/orderby,6/>.

Acesso em: 07 jun. 2012. É interessante frisar que a proposta amplia a situação prevista no Código Penal atual, abarcando também a possibilidade de aborto no caso de a gravidez colocar em risco a saúde da gestante. Permite também, no inciso III, o aborto no caso de o feto ser acometido de anencefalia ou se acometido de anomalia grave e incurável "que inviabilizem a vida independente" (negrito nosso). Parece-nos que esse inciso permitiria uma interpretação extensiva, abarcando anomalias tão graves como a anencefalia, mas diferentes dela. Já, na hipótese prevista no inciso IV, o aborto seria permitido até a $12^{\mathrm{a}}$ semana de gestação, ampliando o leque de situações em que a mulher poderia exercer sua liberdade de escolha, inclusive em razão de dificuldades sociais e econômicas, como já ocorre em alguns países, pois tais situações violam também a integridade psíquica da mãe.

${ }^{1955}$ REY MARTÍNEZ, Fernando. Eutanasia y Derechos Fundamentales. Madrid: Centro de Estúdios Políticos Y Constitucionales, 2008, p. 118.

1955 SILVA, Virgílio Afonso da. A Constitucionalização do Direito: os direitos fundamentais nas relações entre particulares. $1^{\text {a }}$. Edição, 2a . Tiragem. São Paulo: Malheiros, p. 120.

${ }^{1956}$ Vide Projeto de Lei do Senado Federal 50/2011, cujo texto aprovado pela Comissão de Direitos Humanos e Legislação Participativa prevê a necessidade de parecer atestando a anencefalia elaborado por três médicos distintos daqueles que participarão da interrupção da gravidez com o consentimento expresso da gestante. Os critérios para o diagnóstico deverão ser estabelecidos por meio de Resolução do Conselho Federal de Medicina, e já foram definidos na Resolução 1.989, de 10 de maio de 2012. Destacamos que o diagnóstico de anencefalia deverá ser realizado por dois médicos, a partir da $12^{\mathrm{a}}$ semana de gestação, e a interrupção deverá ocorrer em hospital que tenha estrutura para realizar a cirurgia e atender eventuais complicações. Ademais, a gestante deverá ser informada dos riscos de sua escolha. Disponível em: <http://www.portalmedico.org.br/resolucoes/CFM/2012/1989_2012.pdf>. Acesso em: 07 jun. 2012. 
Em primeiro lugar, seria importante considerar como se dará a recomendação médica ao paciente, pois, diante de uma situação extremamente delicada como essa, o médico pode influenciar o paciente, levando-o a adotar suas recomendações não por sua livre e própria convicção, mas em razão de sua vulnerabilidade ${ }^{1957}$. Naturalmente, isso pode e deve ser minimizado.

É preciso também verificar se a paciente não será pressionada a fazer o aborto do feto anencéfalo diante de seu contexto econômico, uma vez que poderá ser mais barato para as partes ou até para o estado realizar o aborto do que esperar pelo ciclo normal da gravidez ${ }^{1958}$.

Além disso, será preciso examinar e acompanhar eventual processo depressivo da paciente e familiares em vista da enfermidade, porque uma pessoa deprimida também se coloca em uma posição de extrema de vulnerabilidade ${ }^{1959}$.

Erros médicos, que podem dizer respeito ao diagnóstico ou ao prognóstico ${ }^{1960}$, também precisam ser minimizados.

Outro aspecto importante a se levar em conta é o de que, com a descriminalização de um fato, o sentido de gravidade que revestia o ato proibido vai perdendo, com o tempo, a "aura" de gravidade que tem junto à sociedade, o que também dá margem a abusos pelas partes ou profissionais da saúde ${ }^{1961}$.

Ademais, vale lembrar que a legalização do aborto do feto anencéfalo pode vir a criar um sentimento de obrigação de fazê-lo para a gestante, transmitindo uma ideia de que o aborto é socialmente desejado, exercendo sobre a grávida uma pressão para que faça o aborto, especialmente quando se tratar de uma gestante mais vulnerável ${ }^{1962}$.

É certo que sempre poderão existir abusos, mas isso poderá ser minimizado com garantias procedimentais e de controle ${ }^{1963}$, que deverão ser considerados pelo legislador, especialmente quando existir conflitos entre direitos fundamentais. É neste sentido que tecemos as sugestões a seguir.

\footnotetext{
${ }^{1957}$ REY MARTÍNEZ, Fernando. Eutanasia y Derechos Fundamentales. Madrid: Centro de Estúdios Políticos Y Constitucionales, 2008, p. 177.

1958 Nesse sentido ao tratar da eutanásia. REY MARTÍNEZ, Fernando. Eutanasia y Derechos Fundamentales. Madrid: Centro de Estúdios Políticos Y Constitucionales, 2008, p. 178.

${ }^{1959}$ REY MARTÍNEZ, Fernando. Eutanasia y Derechos Fundamentales. Madrid: Centro de Estúdios Políticos Y Constitucionales, 2008, p. 178.

${ }^{1960}$ REY MARTÍNEZ, Fernando. Eutanasia y Derechos Fundamentales. Madrid: Centro de Estúdios Políticos Y Constitucionales, 2008, p. 180.

${ }^{1961}$ REY MARTÍNEZ, Fernando. Eutanasia y Derechos Fundamentales. Madrid: Centro de Estúdios Políticos Y Constitucionales, 2008, p. 180.

1962 Neste sentido, quando à eutanásia, ver REY MARTÍNEZ, Fernando. Eutanasia y Derechos Fundamentales. Madrid: Centro de Estúdios Políticos Y Constitucionales, 2008, p. 189.

1963 REY MARTÍNEZ, Fernando. Eutanasia y Derechos Fundamentales. Madrid: Centro de Estúdios Políticos Y Constitucionales, 2008, p. 58.
} 
Os procedimentos de controle e garantia devem ocorrer em dois momentos: (i) procedimentos preventivos, desde o momento em que for constatada a anencefalia, até o efetivo aborto, caso essa seja a escolha da paciente, e (ii) procedimentos corretivos, $a$ posteriori, para verificar-se ex post a legalidade de todo o processo, identificando e punindo eventuais erros ou abusos.

O primeiro cuidado necessário é o devido acompanhamento psicológico para auxiliar a gestante e familiares nessa decisão de abortar ou não. Independentemente de sua decisão, o acompanhamento com profissionais minimizará o desconforto ou o sentido de obrigação legal ou pressão social que eventualmente poderiam influenciar a gestante.

O aborto não poderá ser realizado se a mulher estiver fortemente influenciada pela depressão ou alguma desordem psicológica de natureza grave, daí mais uma vez a necessidade de um acompanhamento do profissional.

O médico que fará o procedimento do aborto não deve ser o mesmo médico que diagnosticou a anencefalia, necessitando a gestante de um acompanhamento por dois médicos e dois diagnósticos, como tem sido feito em outros países, como vimos ao longo deste trabalho.

Poderíamos pensar também na necessidade de se exigir a expressa manifestação da vontade da gestante com testemunhas que pudessem reproduzir judicialmente a intenção da gestante de passar pelo procedimento. Outrossim, a gestante e familiares deveriam ser exaustivamente informados sobre os riscos de continuar a gravidez e de abortar, recebendo dos profissionais da saúde o diagnóstico, prognóstico e alternativas para que a gestante e seus familiares possam decidir de forma clara e consciente. Vale dizer que, uma vez que a gestante passasse por todo esse procedimento, seria possível desistir e não fazer o aborto, a qualquer tempo ${ }^{1964}$. Além disso, uma lei que viesse autorizar o aborto de feto anencéfalo deveria exigir alguns cuidados adicionais em que somente as gestantes maiores, ou menores com autorização de seu represente legal, poderiam fazer o aborto.

Por fim, como bem aponta Fernando Rey Martínez para o caso da eutanásia, nenhum profissional da saúde seria obrigado por lei a realizar o aborto, observando o direito de objeção de consciência do profissional ${ }^{1965}$.

Após o aborto, seria necessário verificar se o feto era de fato anencéfalo por um terceiro independente, tecnicamente qualificado para o diagnóstico, evitando assim que a

${ }^{1964}$ REY MARTÍNEZ, Fernando. Eutanasia y Derechos Fundamentales. Madrid: Centro de Estúdios Políticos Y Constitucionales, 2008, p. 71.

${ }^{1965}$ REY MARTÍNEZ, Fernando. Eutanasia y Derechos Fundamentales. Madrid: Centro de Estúdios Políticos Y Constitucionales, 2008, p. 71. 
gestante seja enganada pelo profissional da saúde, e evitando também o conluio entre as partes a fim de realizar um aborto diverso daquele autorizado pela lei, ou ainda, em razão de tráfico de órgãos.

A verificação a posteriori seria realizada pelo órgão público, especialmente encarregado de verificar se todas as medidas prescritas foram observadas.

Essas condições, em princípio, responderiam às principais preocupações que têm sido suscitadas a respeito do caso pelas partes interessadas, cientistas, profissionais, e pela sociedade civil.

O direito à informação da gestante dos riscos pela manutenção da gravidez ou pelo aborto, o respeito à escolha, o acompanhamento durante e após o parto - seja no caso da manutenção da gravidez ou no caso da antecipação do parto -, protegeriam o direito à liberdade da mulher, sua autonomia reprodutiva, e seu direito à privacidade, além do direito à saúde física e psíquica.

A fiscalização para que os abusos fossem evitados daria maior segurança para as partes envolvidas e para a sociedade, de modo que o estado cumpriria seu dever de proteger a saúde pública, sua obrigação de criar políticas públicas garantindo maior efetividade aos direitos fundamentais da gestante, e seu dever de preservar a liberdade, autonomia e privacidade da mulher, restringindo o direito à vida o menos possível, apenas diante de situações cuidadosamente analisadas e sopesadas, o que é absolutamente essencial para o funcionamento de um estado democrático de direito que garanta à todos o pluralismo, a laicidade do estado, a igualdade de gêneros, e a convivência harmoniosa dos direitos fundamentais. 


\section{CONCLUSÃO}

Neste trabalho, analisamos o aborto do feto anencéfalo à luz do ordenamento jurídico brasileiro, levando em consideração também a tutela do direito à vida em face do Direito Internacional dos Direitos Humanos.

Ao longo do trabalho, traçamos um arcabouço teórico sobre o direito à vida, abordando o conceito de vida, os diversos sentidos atribuídos ao direito à vida, suas dimensões vertical e horizontal, e objetiva e subjetiva; apontando possíveis interpretações que podem ser aplicadas para compreensão de uma restrição ou limitação da vida ou do direito à vida, especialmente quando se tem em jogo outros direitos fundamentais.

Vimos que o direito à vida tem grande importância e destaque entre os direitos fundamentais, até mesmo por ser pressuposto de todos outros direitos; mas que, apesar disso, não é, nem poderia ser, absoluto. Assim, tratamos das principais teorias aplicadas com relação às restrições ao direito à vida, analisando os critérios e circunstâncias em que o direito à vida poderia ser restringido ou limitado, demonstrando a possibilidade e a existência de gradações dessa proteção quando se tem outros direitos fundamentais envolvidos.

Buscamos uma teoria capaz de auxiliar o intérprete quando houver conflito entre a proteção do direito à vida de um lado, e a liberdade, a dignidade, e outros princípios e direitos fundamentais conflitantes, de outro, e lançamos mão, para enfrentar a questão, das concepções aplicáveis aos direitos fundamentais de limites imanentes, sopesamento e proporcionalidade.

Como o direito à vida e os direitos humanos e fundamentais têm sido fortemente definidos e implementados pelo Direito Internacional dos Direitos Humanos, nosso estudo conduziu-nos a ele, e abordamos como se dá a incorporação de tratados internacionais no ordenamento jurídico brasileiro, com especial atenção aos tratados internacionais de direitos humanos. Vimos como, a partir da emenda constitucional 45, os tratados internacionais podem vir a adquirir status constitucional em certas circunstâncias, e que, acima disso, o Brasil precisa cumprir os tratados internacionais com os que se compromete.

Analisamos também o tratamento que o aborto em geral recebe no Brasil, estudando como a legislação e a doutrina têm debatido e entendido o tema. Lembramos que o aborto envolve relações entre particulares, e refletimos sobre as implicações disso em um estado democrático de direito. Vimos que, apesar de ser função do estado democrático de direito 
garantir, entre outros direitos, a liberdade, em vista da importância do valor que tem a vida, não só para o indivíduo, mas também para a coletividade, tem o estado a obrigação de defendê-la, e um verdadeiro e legítimo interesse em regulamentar o aborto, mesmo sendo este, a priori, um assunto de natureza privada, envolvendo primordialmente interesses particulares, e, geralmente, relações entre particulares.

Explicamos o que é a anencefalia de um ponto de vista médico-científico, para ter uma base sólida sobre a qual refletir a respeito do problema, e traçamos e analisamos, então, as mais relevantes controvérsias sobre a proteção do direito à vida no caso de aborto do feto anencéfalo. Analisamos como tem sido tratada na prática a situação do aborto do feto anencéfalo no Brasil, abordando especialmente as decisões e a jurisprudência a respeito.

Elencamos as principais doutrinas e soluções adotadas no plano internacional com relação ao aborto, para ajudar a embasar o estudo deste tema em nosso direito interno. Além disso, destacamos as normas estrangeiras e internacionais que têm sido invocadas e estudadas com relação à proteção dos direitos em conflito no caso, especialmente o direito à vida, à dignidade, à vida digna, à liberdade, à saúde, à autonomia, à igualdade, e aos direitos reprodutivos e sexuais, através de um estudo de direito comparado das legislações de alguns países onde a discussão está particularmente desenvolvida, e da interpretação dos tribunais internacionais de direitos humanos sobre a matéria, com especial ênfase no Sistema Interamericano de Proteção aos Direitos Humanos, do qual o Brasil faz parte, confrontando as referidas legislações, doutrinas e jurisprudências com o ordenamento jurídico brasileiro. Também lançamos mão do estudo de grandes pensadores do direito contemporâneo para nos auxiliar em nossas análises, notadamente, André de Carvalho Ramos, Fernando Rey Martínez, Jürgen Habermas, Robert Alexy, e Ronald Dworkin.

Por fim, aplicamos as análises teóricas e estudos doutrinários e jurisprudenciais desenvolvidos ao caso concreto de aborto do anencéfalo, conforme julgado pelo Supremo Tribunal Federal na Arguição de Preceito Fundamental (ADPF) 54. Vimos em detalhes todos argumentos apresentados, a favor e contra o aborto do anencéfalo, no escopo da ADPF 54. Analisamos e refletimos sobre todos argumentos apresentados em audiência sobre o caso. Notamos, de modo muito vívido, as dificuldades que a situação envolve, os impactos da decisão na sociedade, e o quanto o debate desperta verdadeira comoção social em função dos valores que implica. Tendo em vista que a decisão final sobre a constitucionalidade do aborto do anencéfalo coube ao nosso Supremo Tribunal Federal, e a importância da decisão sobre a sociedade, discutimos o papel que cabe ao Judiciário em um estado democrático de direito, especialmente com relação à efetivação dos direitos humanos. 
Propusemos, então, quatro modelos de interpretação constitucional sobre o caso do aborto do feto anencéfalo, explicando as diferenças e consequências de uma eventual adoção de cada um desses modelos pelo Supremo Tribunal Federal.

Cada um dos modelos de interpretação constitucional propostos se alicerça na prevalência de premissas e valores diversos: Os dois primeiros modelos, de interpretações absolutas, "radicais", foram propostos, analisados, e descartados. O modelo da proibição absoluta interpreta a Constituição Federal como garantindo o direito à vida absolutamente; e, por outro lado, o modelo da livre disposição defende que a Constituição garante a liberdade da mãe de dispor do próprio corpo mais do que vida do feto, também de modo absoluto. Em razão da análise desenvolvida no trabalho, tais modelos de interpretação foram descartados, servindo, no entanto, como tipos ideais extremos de um continuum em meio ao qual está o modelo intepretativo mais possível.

Neste continuum, analisamos o modelo da liberdade limitada, e o modelo da exceção permitida. Ainda que ambos modelos interpretativos da Constituição Federal levem à mesma conclusão, especialmente no caso do anencéfalo - a saber, uma autorização do aborto - eles partem de premissas diversas: Aquele, da liberdade da mãe; este, da primazia da vida. No modelo da liberdade limitada, a Constituição garante um direito geral de liberdade, que só pode ser restringido de modo que não seja arbitrário. No modelo da exceção permitida, a Constituição garante em geral a vida, e é esse direito à vida que só pode ser limitado em situações razoáveis.

Realizamos um teste de consistência da aplicabilidade desses modelos, com vistas a selecionar qual seria provavelmente o adotado pelo Supremo Tribunal Federal na interpretação constitucional brasileira, através de uma análise detalhada dos principais argumentos aplicáveis ao caso, que o próprio Supremo Tribunal Federal efetivamente utilizou no julgamento da ADPF 54 e de sua liminar, e no julgamento da Ação Direta de Inconstitucionalidade (ADI) 3510, que versou sobre a constitucionalidade de se realizar pesquisas com células-tronco embrionárias humanas. Concluímos pelo modelo da exceção permitida, em vista das evidências apresentadas de que, no Brasil, a análise constitucional parte do pressuposto de que o direito à vida em geral deve ter primazia sobre os demais, podendo, apenas excepcionalmente, ser limitado, e de modo que seja razoável e proporcional em vista das circunstâncias fáticas.

Finalmente, discutimos ainda quais medidas o Poder Legislativo poderia vir a tomar para contribuir com uma solução satisfatória ao tema do aborto do anencéfalo, levantando os principais desafios - normalmente, de natureza factual - que devem ser enfrentados em razão 
de uma eventual legalização, e sugerindo meios de se proteger a sociedade em vista do aborto do anencefálico com instrumentos capazes de garantir a maior efetivação possível de todos direitos fundamentais em conflito no caso.

Gostaríamos de mencionar também nesta conclusão o quanto é importante pensarmos sobre o papel que o Supremo Tribunal Federal teve ao decidir sobre a possibilidade da antecipação da gravidez em caso de feto anencéfalo. Como vimos, o assunto está longe de ser fácil e exigiu uma grande ponderação do STF sobre relevantes temas que a análise do direito à vida, especialmente quando em conflito com outros direitos fundamentais, suscita.

Ao lado e além de temas polêmicos como o do anencéfalo, que envolvem a percepção da sociedade sobre o que é vida, sobre a "sacralidade" da vida, sobre a liberdade, a dignidade, a saúde, e até a vida digna, o Supremo enfrentará as inúmeras reivindicações dos movimentos feministas pela liberdade à autonomia reprodutiva e sexual da mulher, pela autodeterminação, e pela igualdade de gênero. O Poder Judiciário passa, assim, a exercer um papel chave na luta pela afirmação dos direitos das mulheres.

Além disso, é mister uma mudança de paradigmas da efetivação de direitos fundamentais também sob a ótica do direito internacional. A experiência observada em outros países e as respostas contidas nas decisões proferidas nos tribunais de proteção de direitos humanos e nos dispositivos normativos de direito internacional assinalam a necessidade de se buscar a plena autonomia dos direitos sexuais e reprodutivos de ambos os gêneros, com vistas a diminuir insistentes discriminações e posturas sexistas.

O direito da população à saúde sexual e reprodutiva exige do estado duas condutas: uma, intervencionista, criando instrumentos de acesso à informação, exames, acompanhamento médico e psicológico; e outra, não-intervencionista, envolvendo a liberdade de escolha, garantindo-se o direito à privacidade, autonomia reprodutiva e autodeterminação, entre outros direitos.

Essa nova perspectiva do direito e da função do Judiciário decorre também do fato de que os direitos humanos precisam ser repensados com base em sociedades pluralistas, democráticas e igualitárias, pautadas na convivência harmoniosa dos direitos fundamentais como imperativo para se fazer valer o princípio da dignidade da pessoa humana e, em maior medida, de se fazer justiça.

Se, por um lado, a decisão da ADPF 54 foi importante no sentido de responder a um anseio concreto, urgente e dramático da sociedade; por outro, é necessário lembrar que os Ministros do Supremo Tribunal Federal decidiram a questão com base em suas posições individuais e isoladas sobre o tema, sem dialogar uns com os outros, e sem enfrentar 
diretamente a indagação do valor do direito à vida em relação aos outros direitos fundamentais em conflito no caso.

Essa situação gera graves dúvidas com relação à posição de nosso Supremo Tribunal Federal, não só quanto à possibilidade da relativização do direito à vida em nosso ordenamento, mas também em relação ao sopesamento do direito à vida com outros direitos, o que, por sua vez, exacerba a insegurança jurídica sobre qual seria a posição do Supremo quanto a outras questões importantes de direitos humanos e fundamentais que devem emergir nos próximos anos, notadamente, quanto à eventual constitucionalidade de uma lei penal descriminalizadora do aborto, a exemplo do disposto no anteprojeto de novo Código Penal proposto pela Comissão de Juristas do Senado.

Com relação ao aborto do feto anencéfalo, os argumentos apresentados pelos Ministros nos levam a crer que foi adotado o quarto modelo de interpretação constitucional o da exceção permitida -, em que o direito à vida é a regra, podendo ser relativizado desde que justificado.

No entanto, acreditamos que, cedo ou tarde, o STF enfrentará a nova questão do aborto em geral. Como vimos, nosso Supremo Tribunal Federal deve iniciar sua análise a partir de uma interpretação constitucional baseada na primazia relativa do direito à vida mas, além disso, pouco podemos prever sobre qual seria a posição final que o Supremo teria sobre o caso. 


\section{REFERÊNCIAS}

ACCIOLY, Hildebrando; G. E. do Nascimento e Silva e; CASELLA, Paulo Borba. Manual de Direito Internacional Público. 18 ed., de acordo com o Decreto 7030, de 14-12-2009, e a Lei 12.134, 18-12-2009. São Paulo: Saraiva, 2010.

ALEXY, Robert. Teoria dos Direitos Fundamentais. Tradução de Virgílio Afonso da Silva. São Paulo: Malheiros, 2008.

ALMEIDA, Guilherme Assis de. Direitos humanos e não-violência. São Paulo: Atlas, 2001

ALMEIDA, Silmara J.A.Chinelato e. Tutela Civil do Nascituro. [prefácio Carlos Alberto Bittar, Mario Emílio Bigotte Chorão]. São Paulo: Saraiva, 2000.

AMARAL JÚNIOR, José Levi Mello do. Poder. In: DIMOULIS, Dimitri (Coordenador Geral). TAVARES, André Ramos; DIMOULIS, Dimitri; BERCOVICI, Gilberto; SILVA, Guilherme Amorim Campos da; FRANCISCO, José Carlos; ANJOS FILHO, Robério Nunes dos; ROTHENBURG, Walter Claudius (org.). Dicionário Brasileiro de Direito Constitucional. São Paulo: Saraiva, 2007, p. 267-269.

ARAUJO, Nadia de. A Influência das Opiniões Consultivas da Corte Interamericana de Direitos Humanos no Ordenamento Jurídico Brasileiro. In: MENEZES DIREITO, Carlos Alberto, CANÇADO TRINDADE, Antonio Augusto e PEREIRA, Antonio Celso Alves (orgs). Novas Perspectivas do Direito Internacional Contemporâneo - Estudos em homenagem ao Professor Celso D. Albuquerque Mello. Rio de Janeiro: Ed. Renovar, 2008.

BARROSO, Luís Roberto. Judicialização, Ativismo Judicial e Legitimidade Democrática. Disponível em: <http://www. conjur.com.br/2008 -dez-22/judicializacao _ativismo_ legitimidade_democratica, p. 5-18>. Acesso em: 10 jan. 2012.

BITENCOURT, Cezar Roberto.Tratado de Direito Penal 2: parte especial: dos crimes contra a pessoa, 10ª ed. São Paulo: Saraiva, 2010.

BITTAR, Eduardo Carlos Bianca; ALMEIDA, Guilherme Assis de. Curso de Filosofia do Direito. $4^{\mathrm{a}}$ ed. São Paulo: Atlas, 2005.

BOBBIO, Norberto. A Era dos Direitos. Tradução Carlos Nelson Coutinho. Apresentação de Celso Lafer. 6a reimpressão. Rio de Janeiro: Elsevier, 2004. 
CANÇADO TRINDADE, Antonio Augusto. A Humanização do Direito Internacional. Belo Horizonte: Del Rey, 2006.

Tratado de Direito Internacional de Direitos Humanos. Vol. I e II, Porto Alegre: Sérgio Antônio Fabris Editor, 2003.

O Sistema Interamericano de Direitos Humanos no limiar do novo século: recomendações para o fortalecimento de seu mecanismo de proteção. In: GOMES, Flávio; PIOVESAN, Flávia (coords.). O Sistema Interamericano de Proteção dos Direitos Humanos e o Direito Brasileiro. São Paulo: Editora Revista dos Tribunais, 2000.

A Proteção Internacional dos Direitos Humanos: fundamentos jurídicos e instrumentos básicos. São Paulo: Saraiva, 1991.

CARVALHO RAMOS, André de. Teoria Geral dos Direitos Humanos na Ordem Internacional. Rio de Janeiro: Renovar, 2005.

Teoria Geral dos Direitos Humanos na Ordem Internacional. 2. ed. São Paulo: Saraiva, 2012.

Direitos Humanos em Juízo: comentários aos casos contenciosos e consultivos da Corte Interamericana de Direitos Humanos e estudo da implementação dessas decisões no Direito Brasileiro. São Paulo: Max Limonad, 2001.

Responsabilidade Internacional por Violação de Direitos Humanos: seus elementos, a reparação devida e sanções possíveis: teoria e prática do direito internacional. Rio de Janeiro: Renovar, 2004.

Processo Internacional de Direitos Humanos: análise dos sistemas de apuração de violações dos direitos humanos e a implementação das decisões no Brasil. Rio de Janeiro: Renovar, 2002.

Processo Internacional de Direitos Humanos: análise dos sistemas de apuração de violações dos direitos humanos e a implementação das decisões no Brasil. 2. ed. São Paulo: Saraiva, 2012. 
O Impacto da Convenção Americana de Direitos Humanos na Relação do Direito Internacional com o Direito Interno. In: Boletim Cientifico da Escola Superior do Ministério Público da União, ano I, número 4, p. 51-71, jul/set. 2002.

\section{Responsabilidade Internacional do Estado por Violação de Direitos Humanos.} In: R.CEJ, Brasília, n. 29, p. 53-63, abr/jun 2005.

Tratados Internacionais: novos espaços de atuação do Ministério Público. In: Boletim Cientifico da Escola Superior do Ministério Público da União, ano II, número 7, p. 81-100, abr/jun. 2003.

O Diálogo das Cortes: o Supremo Tribunal Federal e a Corte Interamericana de Direitos Humanos. In: JUBILUT, Liliana Lyra; AMARAL JUNIOR, Alberto do (orgs). O STF e o Direito Internacional dos Direitos Humanos. São Paulo: Quartier Latin, 2009, p. 805-850.

. A Execução das Sentenças da Corte Interamericana de Direitos Humanos no Brasil. In: CASELLA, Paulo Borba; CELLI JÚNIOR, Umberto; MEIRELLES, Elizabeth de Almeida; POLIDO, Fabrício Bertini Pasquot (orgs). Direito Internacional, Humanismo e Globalidade. São Paulo: Editora Atlas, 2008, p. 451-468.

Avanços e Recuos: a universalidade dos Direitos Humanos no século XXI. In: Direitos Humanos em Concreto. COSTA, Paulo Sérgio Weyl A. (Coord.) Curitiba: Juruá, 2008.

O direito à vida e a pena de morte. In: PETERKE, Sven (coord). Manual prático de direitos humanos internacionais. Brasília: Escola Superior do Ministério Público da União, 2009, p. 221-252.

A ADPF 153 e a Corte Interamericana de Direitos Humanos. In: GOMES, Luiz Flávio; MAZZUOLI, Valério de Oliveira (Orgs.). Crimes da Ditadura Militar: uma análise à luz da jurisprudência atual da Corte Interamericana de Direito Humanos: Argentina, Brasil, Chile, Uruguais. São Paulo: Editora Revistas dos Tribunais, 2011.

CASSESE, Antonio. International Law. New York: Oxford University Press, 2005.

CASTRO, Carlos Roberto Siqueira. Extensão dos direitos e deveres fundamentais às relações privadas. In: ROCHA, João Carlos de Carvalho; PARREIRAS, Tarcísio Humberto; GAZETTA, Henrique. Direitos Humanos: Desafios Humanitários Contemporâneos: 10 anos do Estatuto dos Refugiados (L. 9474 de 22 jul. 1997). Belo Horizonte: Del Rey, 2008. 
CHADWICK, Ruth. Gene Therapy. In: A Companion to Bioethics. KUHSE, Helga; SINGER, Peter (Blackwell Companion to Philosophy). Massachusetts, EUA. Blackwell Publishing, 1998, p. 189-197.

CHINELATO, Silmara Juny de Abreu. Comentários ao Código Civil, V. 18. São Paulo: Saraiva, 2004.

CHINELATO, Silmara Juny de Abreu; BITTAR, Carlos Eduardo Bianca (org). Estudo de Direito de Autor, Direito de Personalidade, Direito do Consumidor e Danos Morais. Rio de Janeiro: Forense universitária, 2002.

CLAPHAM, Andrew; MARKS, Susan. International Human Rights Lexicon. New York: Oxford University Press, 2005.

Comitato nazionale per la bioetica. "Il neonato anencefalico e la donazione di organi". 21 giugno 1996. p. 9. Relatório do Comitê Nacional de Bioética Italiano - 21 de junho de 1996. Versão em português: http://www.providaanapolis.org.br/cnbport.htm>. Acesso em 26 abr. 2011.

COMPARATO, Fábio Konder. A Afirmação Histórica dos Direitos Humanos. 5. ed.rev. e atual. São Paulo: Saraiva, 2007.

Ética: direito, moral e religião no mundo moderno. São Paulo: Companhia das Letras, 2006.

Fundamento dos Direitos Humanos. Instituto de Estudos avançados da Universidade de São Paulo, 1997. Disponível www.iea.usp.br/artigos.

DALLARI, Pedro B. A Constituição e Tratados Internacionais. São Paulo: Saraiva, 2003.

Delmanto, Celso. Código Penal Comentado. $2^{\text {a }}$ ed. Ampl. e atualizada. Rio de Janeiro: Renovar, 1988.

DIMOULIS, Dimitri; Vida (Direito à) DIMOULIS, Dimitri (Coordenador Geral). TAVARES, André Ramos; DIMOULIS, Dimitri; BERCOVICI, Gilberto; SILVA, Guilherme Amorim Campos da; FRANCISCO, José Carlos; ANJOS FILHO, Robério Nunes dos; ROTHENBURG, Walter Claudius (org.). Dicionário Brasileiro de Direito Constitucional. São Paulo: Saraiva, 2007, p. 397-399. 
DIMOULIS, Dimitri; MARTINS, Leonardo. Teoria Geral dos Direitos Fundamentais. $2^{\mathrm{a}}$. ed.rev., atual. E ampl. São Paulo: Editora Revista dos Tribunais, 2009.

DINIZ, Debora e MEDEIROS, Marcelo. Aborto no Brasil: uma pesquisa domiciliar com técnica de urna. Associação Brasileira de Pós-Graduação em Saúde Coletiva versão impressa ISSN 1413-8123 Ciência \& saúde coletiva. Vol.15 supl.1. Rio de Janeiro jun. 2010. Disponível em: <http://dx.doi.org/10.1590/S1413-81232010000700002>. Acesso em 10 jan. 2012. Texto integral disponível em: <http://www.scielo.br/scielo.php?script=sci_arttext\&pid=S1413- $\quad 81232010000700002$ \&lng=pt\&nrm =iso> . Acesso em: 10 jan. 2012.

DINIZ, Geilza Fátima Cavalcanti. Aspectos Jurídicos da Clonagem Reprodutiva de Seres Humanos. $2^{a}$. ed. Curitiba: Juruá, 2008.Fica?

DINIZ, Maria Helena. O Estado Atual do Biodireito. São Paulo: Saraiva, 2009.

DWORKIN, RONALD. Domínio da Vida: aborto, eutanásia e liberdades individuais. Trad. Jefferson Luiz Camargo; revisão da tradução Silvana Vieira. São Paulo: Martins Fontes, 2003. (justiça e direito).

Levando os Direitos a Sério. Trad. Jefferson Luiz Camargo; 2a . ed. São Paulo: Martins Fontes, 2007. (justiça e direito).

Uma questão de Princípio. Trad. Luís Carlos Borges; (revisão técnica Gildo Sá Leitão Rios; revisão da tradução Silvana Vieira) 2a . ed. São Paulo: Martins Fontes, 2005. (justiça e direito).

FALLON JR, Richard H. The Dynamic Constitution. New York: Cambrigde University Press, 2004.

FARIA, José Eduardo. Direitos Humanos, Direitos Sociais e Justiça. São Paulo, Malheiros, 2005.

FERREIRA, Aurélio Buarque de Holanda. Miniaurélio Eletrônico versão 5.12. 6a. edição, revista e atualizada, do Minidicionário Aurélio, da Língua Portuguesa. Edição eletrônica autorizada à Positivo Informática Ltda.XXX: Editora Positivo, 2004. 
FERREIRA FILHO, Manoel Gonçalves. Direitos humanos fundamentais. São Paulo: Saraiva, 2008.

FRANCISCO, José Carlos. Estado Democrático de Direito. In: DIMOULIS, Dimitri (Coordenador Geral). TAVARES, André Ramos; DIMOULIS, Dimitri; BERCOVICI, Gilberto; SILVA, Guilherme Amorim Campos da; FRANCISCO, José Carlos; ANJOS FILHO, Robério Nunes dos; ROTHENBURG, Walter Claudius (org.). Dicionário Brasileiro de Direito Constitucional. São Paulo: Saraiva, 2007, p. 148-149.

FRANÇA, R. Limongi. Hermenêutica Jurídica; atualização de Antônio de S. Limongi França; prefácio de Giselda M.F. Novaes Hironaka. São Paulo: Revista dos Tribunais

FREEMAN, Katherine. The Unborn Child and the European Convention Of Human Rights: to whom does “every one's right to life' belong? Atlanta: Emory International Law Review, 1994 Fall; 8(2):615-650.

FUJITA, Jorge Shiguemitsu. Aborto: o cerceamento da vida de um ser humano indefeso. In: Dignidade da vida Humana. Migliore, Alfredo Domingues Barbosa [et al.] (Coords.). São Paulo: Editora LTR, 2010.

FUKUYAMA, Francis. Nosso Futuro Pós-humano: conseqüências da revolução da biotecnologia. Trad. Maria Luiza X. de A. Borges. Rio de Janeiro: Rocco, 2003.

GARCIA ROCA, Javier. La Interpretación constitucional de uma declaración internacional, el Convenio Europeo de Derechos Humanos, y bases para uma globalización de los derechos In: GARCIA ROCA, Javier e SANTOLAYA, Pablo (coords). La Europa de Los Derechos: El Convenio Europeo de Derechos Humanos. Madrid: Centro de Estúdios Políticos Y Constitucionales, 2005, p. 139-182.

GOMES, JOAQUIM BARBOSA. Voto proferido pelo Ministro Joaquim Barbosa Gomes HC $n^{\circ}$ 84.025/2004. In: SARMENTO, Daniel; PIOVESAN, Flávia (coordenadores). Nos Limites da Vida. Rio de Janeiro: Lúmen Júris, 2006, p. 73-92.

GOMES, Luiz Flávio. Aborto Anencefálico: exclusão da tipicidade material. Disponível em: <http://jus.uol.com.br/revista/texto/8561/aborto-anencefalico>. Acesso em 20 jan. 2011.

HABERMAS, Jürgen. O Futuro da Natureza Humana: a caminho de uma eugenia liberal? Trad. Karina Jannini; ver. trad. Eurides Avance de Souza. São Paulo: Martins Fontes, 2004. 
HALL, Zach W. The Intersection of Science, Politics, Culture, and Law. Minnesota Journal ol Law, Science \& Technology, 2009. 10 Minn. J. L. Sci. \& Tech.1.

HAMMERSCHMIDT, Denise. Intimidade Genética \& Direitos da Personalidade. São Paulo: Juruá, 2008.

HAMPTON, Simon. Essencial Evolutionary Psychology. London: Sage, 2010

HARE, R.M. A Utilitarian Approach. In: A Companion to Bioethics. KUHSE, Helga. SINGER, Peter (Blackwell Companion to Philosophy). Massachusetts, EUA. Blackwell Publishing, 1998, p. 80-85.

HÜBNER MENDES, Conrado. Onze Ilhas. Disponível em: <http://www.osconstitucionalistas.com.br/onze-ilhas >. Acesso em: 5 jun. 2012.

JAQUIER, M; KLEIN, A; BOLTSHAUSER, E. Spontaneous pregnancy outcome after prenatal diagnosis of anencephaly. Short Comunication. In.: International Journal of Gynecology and Obstetrics (2006) 102, 99, p. 951-953.

KANT, I. Foundation of the Methaphysics of Morals. Translation: Robert Paul Wolff. In: Ethical Theories. New York: Prentice Hall; 1950.

KRATOCHVIL, Jan. The Rigth to Life in the Perspective of The Human Rights Committee and the European Court of Human Rights. Disponível em: <http://ssm.com/abstract=951225>. Acesso em: 10 jun. 2011.

LAFER, Celso. A Internacionalização dos Direitos Humanos: constituição, racismo e relações internacionais. São Paulo: Manole, 2005.

A Reconstrução dos Direitos Humanos: um diálogo com o pensamento de Hannah Arendt. São Paulo: Companhia das Letras, 1988.

Declaração Universal dos Direitos Humanos (1948) in MAGNOLI, Demetrio (organizador). História da Paz. São Paulo: Contexto, 2008, pp. 297-329.

LEÃO JÚNIOR, Paulo Silveira Martins. O Direito Fundamental à Vida ds Emrbiões e Anencéfalos. In: Direito Fundamental à Vida. MARTINS, Ives Gandra da Silva (coord). São Paulo: Quartier Latin/Centro de Extensão Universitária, 2005. p. 215- 258. 
LEMOS, Iara. Anteprojeto de novo Código Penal vai prever possibilidade de aborto. Disponível em: <http://g1.globo.com/politica/noticia/2012/03/anteprojeto-de-novo-codigopenal-vai-prever-possibilidade-de-aborto.html>. Acesso em 5 jun. 2012.

LEVITT, Steven D.; DUBNER, Stephen J. Freakonomics: o lado oculto e inesperado de tudo que nos afeta. Trad. Regina Lyra; revisão técnica Ronaldo Fiani. 1. ed. rev. e atual. Rio de Janeiro: Elsevier, 2007.

LEWANDOWSKI, Enrique Ricardo. Proteção dos Direitos Humanos na Ordem Interna e Internacional. Rio de Janeiro: Forense, 1984.

LIMA, Carolina Alves de Souza. Aborto e Anencefalia: direitos fundamentais em colisão. $1^{\text {a }}$ ed. (ano 2008), 2a reimpr. Curitiba: Juruá, 2010.

MALINOWSKI, Michael J.; RAO, Radhika. Legal History and Legal Theory: Legal Limitations on Genetic Research and the Commercialization of its Results. The American Society of Comparative Law, Inc., 2006. The American Journal of Comparative Law. 54 Am. J.Comp. L. 45.

MARKS, Susan; CLAPHAM, Andrew. International Human Rights Lexicon. New York: Oxford, 2005.

MARTINS, Ives Gandra da Silva (Coord). Direito Fundamental à Vida. São Paulo: Quartier Latin, 2005.

MARTINS FILHO, Ives Gandra da Silva. O direito à vida e o aborto do anencéfalo. In: MARTINS, Ives Gandra da Silva; MARTINS, Roberto Vidal da Silva; MARTINS FILHO, Ives Gandra da Silva. A Questão do Aborto: Aspectos Jurídicos Fundamentais. São Paulo: Quartier Latin, 2008, p. 115-127.

MAUÉS, Antonio Moreira. O Direito à Vida na Jurisprudência da Corte Interamericana de Direitos Humanos. In: Direitos Humanos em Concreto. COSTA, Paulo Sérgio Weyl A. (Coord.) Curitiba: Juruá, 2008.

MCCLOSKEY Robert. The American Supreme Court. Chicago: The University of Chicago Press, 2a edição, 1994. 
MEDINA, Andrés Forero; GAITÁN, Pedro Afonso Sandoval. La defensa de La vida humana em Colômbia. P\&B, Vol. 9. Revista n 1 (24), p. 43-71, 2005.

MOORE, Keith L; Dalley, Arthur, F. Anatomia Orientada para Clínica. Colaboração de Anne M.R.Agur; assistência no desenvolvimento de Marion E. Moore; revisão técnica Marco Autélio Fonseca Passos; tradução Cláudia Lúcia Caetano de Araújo. Rio de Janeiro: Guanabara Koogan, 2007.

MORAES, Alexandre de. Direito Constitucional. 7. ed. revista, ampliada e atualizada com $E C n^{\circ}$ 24/99. São Paulo: Atlas, 2000.

Direitos Humanos Fundamentais: teoria geral, comentários aos arts. $1^{\circ}$ a $5^{\circ}$ da Constituição Federal da República Federativa do Brasil, doutrina e jurisprudência. 6. ed. São Paulo:Atlas, 2005 (Coleção Temas Jurídicos:3).

Direitos Humanos Fundamentais: teoria geral, comentários aos arts. $1^{\circ}$ a $5^{\circ}$ da Constituição Federal da República Federativa do Brasil, doutrina e jurisprudência. 9. ed. São Paulo:Atlas, 2011.

MORENO, Gasparini Denise. Direitos Humanos Fundamentais: teoria geral, comentários aos arts. $1^{\circ}$ a $5^{\circ}$ da Constituição da República Federativa do Brasil, doutrina e jurisprudência. 6 ed. São Paulo: Atlas, 2005 (Coleção Temas Jurídicos; 3).

NETO, Luísa. O direito fundamental à disposição do próprio corpo (a relevância da vontade na configuração do seu regime). Coimbra: Coimbra Editora, 2004.

NIETZSCHE, Friedrich. O Crepúsculo dos ídolos - ou como se filosofa com um martelo. Tradução de Paulo César de Souza. São Paulo: Companhia das Letras, 2006.

Human, all too human. Translation: J.R. Hollingdale. Cambridge: Cambridge University Press, 2004. 2001.

A Gaia Ciência. Trad. Paulo César de Souza. São Paulo: Companhia das Letras,

NUCCI, Guilherme de Souza. Código Penal Comentado. 10 ed. rev., atual e ampl. São Paulo: Editora Revista dos Tribunais, 2010. 
OBEIDE, Nidaa et al. The Natural History of Anencephaly. Prenatal Diagnosis, 2010. 30: 357-360.

PAUL, Ron. Liberty Defined: 50 Essential Issues That Affect American Freedom. New York: Grand Cetral Publishing, 2012.

PASQUALUCCI, Jo M. The Right to a Dignified Life (Vida Digna): The Integration of Economic and Social Rights with Civil and Political Rights in the Inter-American Human Rights System. In: Hastings College of the Law Hastings International and Comparative Law Review, 2008. 31 Hastings Int'l \& Comp. L. Rev. 1

PEREIRA, Jane Reis Gonçalves. Interpretação Constitucional e Direitos Fundamentais: uma contribuição ao estudo das restrições aos direitos fundamentais na perspectiva da teoria dos princípios. Rio de Janeiro: Renovar, 2006.

PERRONE-MOISÉS, Cláudia. Direitos Humanos e Desenvolvimento: A Contribuição das Nações Unidas. PERRONE-MOISÉS, Cláudia. (Org.); AMARAL JUNIOR, A. (Org.). O Cinqüentenário da Declaração Universal dos Direitos do Homem. São Paulo: EDUSP, 1999, p. 179-269.

PIOVESAN, Flávia. Direitos Humanos e a Justiça Internacional: um estudo comparativo dos sistemas regionais europeu, interamericano e africano. São Paulo: Saraiva, 2006.

Direitos Humanos e o Direito Constitucional Internacional. $10^{\text {a }}$. ed. rev., ampl. e atual. São Paulo: Saraiva, 2009.

PIOVESAN, Flávia e GONÇALVES, Tamara Amoroso. Gênero no Supremo Tribunal Federal. In SARMENTO, Daniel e SARLET, Ingo Wolfgang (coords). Direitos Fundamentais no Supremo Tribunal Federal: Balanço e Crítica. p. 367-390.

PIOVESAN, Flávia e PIROTTA, Wilson Ricardo Buquetti. Temas de Direitos Humanos. $4^{\text {a }}$. ed. São Paulo: Saraiva, 2010, p. 306-336.

POSNER, RICHARD A. Law, pragmatism, and democracy. Cambrigde-MA: Harvard University Press, 2005.

PRADO, Luiz Regis. Curso de Direito Penal Brasileiro, volume 2: parte especial, arts 121 a 249, $8^{\text {a }}$ ed. rev. atual. e ampl. São Paulo: Editora Revista dos Tribunais, 2010, p. 39-77. 
RAMOS, Elival da Silva. Ativismo Judicial: Parâmetros dogmáticos. São Paulo: Saraiva, 2010.

REVERBEL, Carlos Eduardo Dieder. Ativismo Judicial e Estado de Direito. In: AMARAL JÚNIOR, José Levi Mello do. Estado de Direito e Ativismo Judicial. São Paulo: Quartier Latin, 2010.

REY MARTÍNEZ, Fernando. La Protección Jurídica de La Vida: Un Derecho em Transformación Y Expansión (art. 2 CEDH y Protocolos $6^{\circ}$ y 13\%). In: GARCIA ROCA, Javier e SANTOLAYA, Pablo (coords). La Europa de Los Derechos: El Convenio Europeo de Derechos Humanos. Madrid: Centro de Estúdios Políticos Y Constitucionales, 2005.

Eutanasia y Derechos Fundamentales. Madrid: Centro de Estúdios Políticos Y Constitucionales, 2008.

El Debate de La Eutanásia Y El Suicídio Asistido em Perspectiva Comparada. Garantias de Procedimiento a tener em cuenta ante su eventual despenalización en España. In: UNED. Revista de Direito Político, no 71-72, enero-agosto, 2008, p. 439-477.

ROCHA, Renata da. Direito à Vida e a Pesquisa com Células-tronco. Rio de Janeiro: Elsevier, 2008.

RODRIGUES, Renata Cenedesi Bom Costa. El Nuevo Concepto del Derecho a la vida en la Jurisprudencia de la Corte Interamericana de Derechos Humanos. p. 91. Disponível em: 〈http://www.idpc.es/archivo/1213281758FCI9RCB.pdf>. Acesso em: 10 out. 2010.

ROTHENBURG, Walter Claudius. Princípio da Proporcionalidade. In: LOPES, Maria Elisabeth de Castro; OLIVEIRA NETO, Olavo de. (coords). Princípios Processuais Civis na Constituição. Rio de Janeiro: Elsevier, 2008, p. 283-319.

SADLER, T. W.; LANGMAN, Jan. Langman's Medical Embriology. $9^{\text {th }}$ edition. Holanda: Lippincott Williams \& Wilkins Publisher, 2003.

SAGAN, Carl. Bilhões e bilhões: reflexões sobre vida e morte na virada do milênio. Tradução Rosaura Eichemberg. São Paulo: Companhia das Letras, 1998.

SARLET, Ingo Wolfgang. A Dignidade da Pessoa Humana e os Direitos Fundamentais na Constituição Federal e 1988. São Paulo: Livraria do Advogado, 2008. 
A Eficácia dos Direitos Fundamentais. Porto Alegre: Livraria do Advogado, 2007.

SARMENTO, Daniel; PIOVESAN, Flávia (coordenadores). Nos Limites da Vida. Rio de Janeiro: Lúmen Júris, 2006.

SARMENTO, Daniel. Direitos Fundamentais e Relações Privadas. $2^{\mathrm{a}}$. Ed., $2^{\mathrm{a}}$. tiragem. Rio de Janeiro: Editora Lumen Júris, 2008.

SHAW, Malcom N. Internacional Law. Cambridge: Cambridge University Press, 2003.

SCHWABE, Jürgen. Cinqüenta Anos de Jurisprudência do Tribunal Constitucional Federal Alemão. MARTINS, Leonardo (org. e introd). Trad. Beatriz Hennig et al. $1^{\mathrm{a}}$ edição. Uruguai: Fundación KONRAD-ADENAUER URUGUAY, 2005. Disponível em: <http://www.bibliojuridica.org/libros/5/2241/13.pdfISBN: $9974-7942-1-8>, \quad$ p.265-347. Acesso em: 01 jan. 2011.

SEGRE, Marco; GUZ, Gabriela. Início da vida e células-tronco embrionárias. Disponível em: <http://www.jornaldaciencia.org.br/Detalhe.jsp?id=29790> Acesso em: 04 mai. 2011.

SIGMUND, Paul E. Law and politics. In: The Cambridge Companion to Aquinas. KRETZMANN, Norman; STUMP, Eleonor (Editors). New York, EUA. Cambridge University Press, 1993, p. 217-231.

SILVA, José Afonso da. Curso de Direito Constitucional Positivo. 29a edição. São Paulo: Malheiros, 2007.

Aplicabilidade das Normas Constitucionais. $7^{\mathrm{a}}$. ed, $1^{\mathrm{a}}$. tiragem, São Paulo: Malheiros, 2007.

SILVA, Virgílio Afonso da. Direitos Fundamentais: conteúdo essencial, restrições e eficácia. São Paulo: Malheiros, 2009.

.A Constitucionalização do Direito: os direitos fundamentais nas relações entre particulares. $1^{\mathrm{a}}$. Edição, 2a . Tiragem. São Paulo: Malheiros.

O Proporcional e o Razoável. São Paulo: Revista dos Tribunais 798 (2002): 23-50. 
SILVEIRA, Vladmir Oliveira da; ROCASOLANO, Maria Mendez. Direitos humanos: conceitos, significados e funções. São Paulo: Saraiva, 2010.

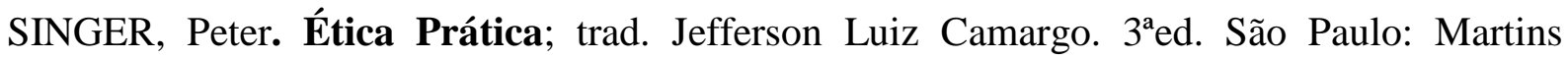
Fontes, 2002.

Writings on an Ethical Life. New York:HarperCollins Publishers Inc., 2000.

SIQUEIRA JÚNIOR, Paulo Hamilton; OLIVEIRA, Miguel Augusto Machado de. Direitos Humanos e Cidadania. $3^{a}$ ed. rev. e atual. São Paulo: Editora Revista dos Tribunais, 2010.

STEINBOCK, Bonnie. Mother-fetus conflict. In: A Companion to Bioethics. KUHSE, Helga. SINGER, Peter (Blackwell Companion to Philosophy). Massachusetts, EUA. Blackwell Publishing, 1998, p. 135-145.

SUPIOT, Alain. Homus juridicus: Ensaio sobre a função antropológica do Direito. Trad. Maria Ermantina de Almeida Prado Galvão. São Paulo: Martins Fontes, 2007.

TAVARES, André Ramos. Tratado de Arguiição de Descumprimento de Preceito Fundamental. São Paulo: Saraiva, 2001.

Direito Constitucional Econômico. $3^{\mathrm{a}}$ ed. Rio de Janeiro: Forense; São Paulo: Método, 2011.

Ação Direta de Inconstitucionalidade. In: DIMOULIS, Dimitri (Coordenador Geral). TAVARES, André Ramos; DIMOULIS, Dimitri; BERCOVICI, Gilberto; SILVA, Guilherme Amorim Campos da; FRANCISCO, José Carlos; ANJOS FILHO, Robério Nunes dos; ROTHENBURG, Walter Claudius (org.). Dicionário Brasileiro de Direito Constitucional. São Paulo: Saraiva, 2007, p. 5-8.

Argüição de Descumprimento de Preceito Fundamental. In: DIMOULIS, Dimitri (Coordenador Geral). TAVARES, André Ramos; DIMOULIS, Dimitri; BERCOVICI, Gilberto; SILVA, Guilherme Amorim Campos da; FRANCISCO, José Carlos; ANJOS FILHO, Robério Nunes dos; ROTHENBURG, Walter Claudius (org.). Dicionário Brasileiro de Direito Constitucional. São Paulo: Saraiva, 2007, p. 25-26.

Interpretação Constitucional. In: DIMOULIS, Dimitri (Coordenador Geral). TAVARES, André Ramos; DIMOULIS, Dimitri; BERCOVICI, Gilberto; SILVA, Guilherme Amorim Campos da; FRANCISCO, José Carlos; ANJOS FILHO, Robério Nunes dos; 
ROTHENBURG, Walter Claudius (org.). Dicionário Brasileiro de Direito Constitucional. São Paulo: Saraiva, 2007, p. 194-196.

VAN DER BURG, Wibren. Law and Bioethics. In: A Companion to Bioethics. KUHSE, Helga. SINGER, Peter. Massachusetts, EUA. Blackwell Publishing, 1998, p. 49-57.

VERÍSSIMO, Marcos Paulo. A constituição de 1988, vinte anos depois: suprema corte e ativismo judicial "à brasileira". Rev. direito GV [online]. 2008, vol.4, n.2, p. 407-440. ISSN 1808-2432. 